\title{
THE COPPER DEPOSITS OF MICHIGAN
}

BY

\author{
B. S. BUTLER and W. S. BURBANK
}

IN COLLABORATION WITH

T. M. BRODERICK, L. C. GRATON, C. D. HOHL, CHARLES PAน́CACHE

M. J. SCHOLZ, ALFRED WANDKE, and R. C. WELLS

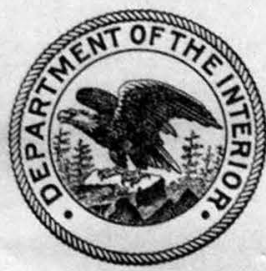


U. S. GEOLUGILIAL SUIEVE,

MAY 141929

\section{BRAH I}

ADDITIONAL COPIES

OF THIS PUBLICATION MAY BE PROCURED FROM

THE SUPERINTENDENT OF DOCUMENTS

U.S.GOVERNMENT PRNTING OFFICE

WASHINGTON, D. C.

$\$ 2.50$ PER COPY 


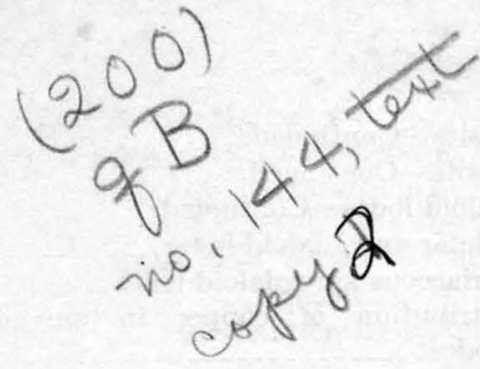

Outline of report

Geology

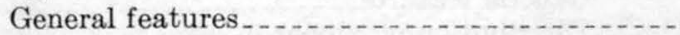

Lava tops or amygdaloids . . . . . . . . . . . .

Oxidation of lavas _......

Copper in trap . .

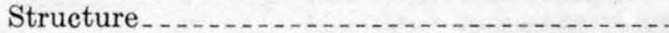

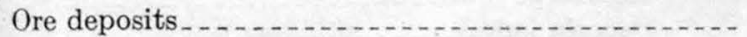

Conglomerate lodes... . . . . . .

Amygdaloid lodes. ......................

Ore shoots _ . . .

Mineralized fissures . . . . . .

Changes with depth.

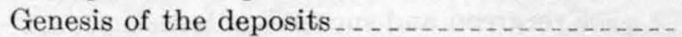

Part 1. General features.

Introduction

Field work and authorship...............

Scope of report

Acknowledgments_............

Previous investigation

Bibliography

Geography_.

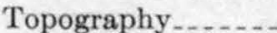

Climate.

Industries . . . . . .

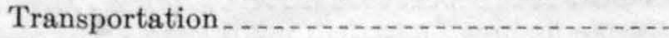

Power...

Physiography _...

Bedrock geology
Broader relations

Location and extent....................

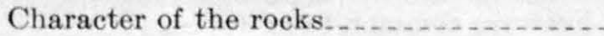

Stratigraphy _._.

Maps and sections ...........

Age and relations _.....................

General character and distribution.......

Sediments_................................

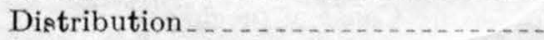

General character.................

Conglomerate . ...................

Felsite conglomerate...........

Extent and thickness of beds..........................

Vertical distribution.......

Character of material ......

Character of beds...........

Character of underlying bed.

Source of material ........

Manner of deposition.......

Amygdaloidal conglomerate......

Relation to felsite conglomerate.

Origin ................

Sandstone and shale .................

Ash and tuff.

\section{CONTENTS}

Page

XI

$\mathrm{XI}$

XI

XI

$\mathrm{XI}$

XI

$\mathrm{XI}$

XII

XII

XII

XII

XII

XI

$\mathrm{XI}$

1

1

1

2

2

3

14

14

14

14

15

15

15

16

16

16

16

16

17

17

17

17

18

18

18

18

18

18

18

18

19

19

19

20

20

20

20

21

21
Part 1. General features-Continued.

Page

Bedrock geology - Continued.

Stratigraphy-Continued.

Igneous rocks

Extrusive rocks

Distribution ......................

Extent of beds...................

Thickness....................

Composition of flows...........

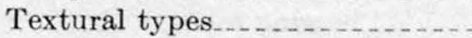

Ophite.................

Porphyrites ...............

Glomeroporphyrites .........

Melaphyre.

Relation of texture to composition 24

Distribution of the different rocks..................... 24

Character of eruptive rocks .... $\quad 25$

Location of volcanic vents _..... $\quad 26$

Amygdaloids . . . . . 26

Trap__._.

Bottom amygdaloid layer_..... $\quad 27$

The lava tops_............... 27

Varieties.............. 27

Smooth tops_............. 28

Fragmental or brecciated tops.

Character

Origin_.

"Scoriaceous tops"

Alteration

Alteration of traps $\quad 34$

Alteration of the lava tops...... 34

Red color of amygdaloid tops _... $\quad 34$

Statement of the problem ... 34

Red tops of unaltered western flows

Oxidation in smooth-top flows of

Keweenawan series.

Oxidation and eoncentration in brecciated-top flows

Mineralogic features.

Cause of iron oxidation and centration

Modern weathering ........

Independent solutions .......

Surface weathering immediately after extrusion....

Hydrothermal alteration ....

Atmospheric oxidation of hot tops.

Magmatic processes........ Magmatic segregation . Fumarolic alteration ... Action of gases from the flows. 
Part 1. General features-Continued.

Bedrock geology-Continued.

Stratigraphy-Continued.

Igneous rocks-Continued.

Copper content of the basalts......

Intrusive rocks _...

Quartz porphyry and felsite.....

Basic dikes_.......................

Age of intrusive rocks ..........

Structure - .

Folds_.

Age and cause of folding and faulting ....

Mineralogy _...........

Rock-forming period

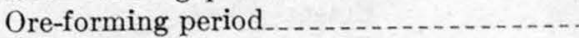

Period of weathering

Minerals of the Keweenawan copper-

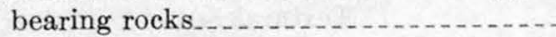

Native metals ..........................

Sulphides_...

Arsenides _.......

Haloids_...

Carbonates_

Silicates.

Phosphates

Sulphates_._. _...

Molybdates and tungstates.........

Hydrocarbon

Part 2. Ore deposits

History -

Production.

Operating practice

Mining-

Development_...

Stoping . . . .

Open stope

Room and pillar.

Shrinkage stope......................

Horizontal cut and fill ...............

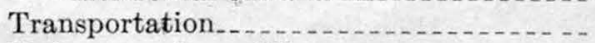

Underground conditions ....................

Milling

Smelting - .

Copper deposits

Principal types

Distribution in the Keweenawan series.......

Conglomerate lodes. .....................

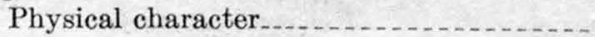

Iron content . .

Mineralization _.............................

Mineralogy _... . . .

Rock alteration .......................

Distribution of copper in the lode........

General controls

Richness in relation to depth.......

Sandstone and shale lodes.

General relations

Mineralization and rock alteration

Amygdaloid lodes......................

Types of amygdaloid

Brecciated amygdaloid lodes...........

Physical character.................

Iron content

Mineralization

Mineralogy

Rock alteration
Page Part 2. Ore deposits-Continued.

Copper deposits-Continued.

Amygdaloid lodes-Continued.

Cellular amygdaloid lodes.

Scoriaceous amygdaloid lodes

Distribution of copper in amygdaloid lodes

Distribution of shoots in the lodes

Distribution of copper in the shoots

Richness in relation to depth

Fissure deposits

General features.

Distribution of copper in veins

Has there been enrichment of the deposits?

No evidence that the lodes are poor at the surface and richer below

Kearsarge lode.

Osceola lode

Calumet \& Hecla conglomerate

Pewabic amygdaloid lodes

Atlantic lode

Isle Royale lode.

Baltic lode

Evergreen and succeeding lodes

Nonesuch lode.

Veins

No evidence of leaching and removal of copper near the surface

No evidence of enrichment at the salt-water horizon

Summary and conclusions....................

Persistence with depth

Conditions determining position of ore shoots

Permeability of rock.

Barriers of relatively impermeable rock

Fault barrier

Folds.

Strike fissures

Cross fissures

Influence of thick flows

Chemical composition

Similar origin of all types

Features common to all types.

Single period of mineralization

Hypotheses of origin

Source of copper.-.

Mode of transportation

Cause of precipitation

Chloride water conception $\ldots$

Mine waters

Deposition by ascending solutions

Source of the copper

Direction of movement of the solutions

Means of access of the solutions

Ascent from contacts of the Duluth gabbro ..............

Ascent from the Keweenaw fault -

Gradual accumulation in permeable channelways ..........

Causes and conditions of precipitation

Precipitation by reducing action of ferrous iron

Precipitation in consequence of saturation ..................

Precipitation by oxidation ...... Presence of sulphides 
Part 2. Ore deposits-Continued.

Genesis of the deposits-Continued.

Hypotheses of origin-Continued.

Deposition by ascending solutions-Con.

Causes and conditions of precipitation-Continued.

Precipitation by oxidation-Con. Presence of an oxidizing Destruction of oxidizing agent-bleaching .........

Presence of sulphates.......

Chemistry of the deposition of native copper from ascending solutions, by R. C. Wells

Deposition by cooling ...............

Deposition by relief of pressure .........

Deposition by fractional oxidation of copper sulphide.

Deposition by dilution . . . . . . . . . . .

Deposition by reduction of acidity -

Conclusions _........

Summary of genesis .......

Source of copper

Transportation

Cause of deposition

Other related deposits ..........

Coro Coro, Bolivia

Triassic of New Jersey _.........

Triassic of Connecticut

Cape d'Or, Nova Scotia_... . . . . . . . . . 143

Oberstein, Germany .................. 143

Commander Island, Russia _. . . . . _..... 143

Faroe Islands _. _ . 143

Sao Paulo, Brazil _.......... 143

Upper Serbia _.......

White River, Alaska_.

Copper River district, Alaska_..._..... 144

Nova Zembla, Russia_................ 144

Zwickau, Saxony _........... 144

Algodones, Chile

Comobabi Mountains, Arizona _........ 144

Permian "Red Beds" of the Southwest... 144

Montana_ _ 145

Aretic Canada

Applieation of geology to mining _...

Likelihood of finding new ore bodies ........ 146

Conditions of exploration _.............. 146

Drift covering _._. 146

Distribution of deposits _...

Grade of ore $\ldots 146$

Size of deposit and grade of ore $\ldots . . . . .147$

Size and grade necessary for success_..... 147

Exploration of lodes__._.

Character of amygdaloid lodes ........ 148

Conglomerates................ 149

Mineralogy as a guide in exploration and development._._. 149 Mineralogic guides in amygdaloids _ $\quad 149$ Mineralogic guides in conglomerates_ 150 Mineralogic guides in fissures ....... 150

Ore shoots _ _ _ _ 150

Extent of lodes

Barriers . . . 150

Barriers in the lode itself ......... 150

Folds _... 150
Part 2. Ore deposits - Continued.

Application of geology to mining-Continued.

Ore shoots-Continued.

Barriers-Continued. Page

Faults _...

Fissure deposits_................. 150

Geologic distribution _... 151

Geographic distribution ........... 151

Relation to present surface $\ldots \ldots \ldots 1$

Exploration _..._.

Stages_._.

Geologic reconnaissance_........... 151

Location of favorable lodes.......... 151

Search for ore shoots _............ 151

Development of prospects_......... 151

Extension of ore shoots _........ 151

Methods of exploration

Examination of surface

Trenches and pits............... 152

Diamond drilling ................. 152

Churn drilling _................. 153

Underground opening _.......... 153

Other methods ................. 153

Application of methods ............... 153

Surface examination _..._.......... 153

Trenching ...................... 153

Diamond drilling _............... 153

Underground exploration _..._.

Depth _..................... 154

Horizontal versus vertical exploration

Transverse versus longitudinal exploration _._.......... 155

Prospecting fissures_._....... 155

Equipment for prospecting _..._. 155

Suggestions for future geologic work in the Copper

Range _... 155

Geophysical methods applied to exploration and geologic mapping, by T. M. Broderick and C. D. Hohl.

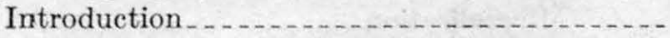

Use of geophysieal methods.........

Principles of geophysical methods........

The three fundamentally different appliea-

tions of geophysics........

Direct application of geophysics to copper finding-

Existing conditions

Electrical methods _..........

Direct conductivity and resistance methods . . . . .

Spontaneous polarization

Equipotential lines...............

Inductive methods _...........

Conclusions ............

Indirect application of geophysics to copper finding.

Application of geophysical methods to geologic mapping -

Early geologic work

Ideal conditions for magnetic work....... Magnetic contrasts in rocks ........ Simplicity of geologic structure ...... Numerous geologic checks available.Favorable geographic and topographic conditions 
Part 2. Ore deposits-Continued.

Geophysical methods applied, etc.-Continued.

Application of geophysical methods, etc.-Con.

Theory and practice of magnetic surveying-

Fundamental principles..

Instruments.

Plotting of results

History of work in the Lake Superior Keweenawan rocks .........................

Early observations

Recent work .............................

Recent work within the copper district. . -

Work prior to 1925

Work in 1925

Work in 1926.

Results_.

Determination of strike

Tracing beds at specific horizons.....

Location of faults, folds, and fissures

Other relations of magnetic features

to geologic features.

Persistence of magnetic features.....

Magnetic correlations ...............

Present attitude toward magnetic surveying -.

Part 3. Detailed description of lodes and fissures

Nonesuch lode

Stratigraphic occurrence

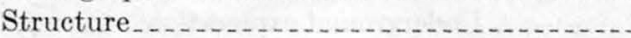

Mineralization

Ore minerals _...

Favorable conditions....................

Influence of shale beds . . . . . . . . . . .

Influence of fissures ...............

Mineralogic and textural influences

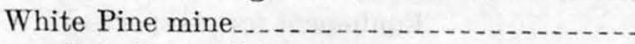

Location and topography _.............

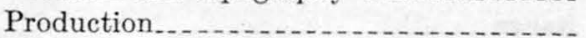

Rocks...

Structure _... _..

Mineralization

White Pine Extension 174

White Pine Extension mine_................. 174

Nonesuch mine

Onondaga exploration _.................. 175

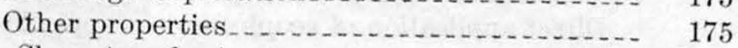

Lake Shore trap horizon $\ldots \ldots \ldots \ldots$

Ashbed amygdaloid $\ldots$

Production _. _ .

Character of rock

Mineralization

Developments.............. 176

Copper Falls mine $\ldots \ldots$

Arnold mine $\ldots \ldots$

Phoenix mine

Hancock mine

Atlantic mine

Lodes of the Hancock mine

Pewabic amygdaloid lodes_...

Location and production............... 178

Character of flows _................ 178

$\begin{array}{ll}\text { Character of amygdaloids_............. } & 178\end{array}$

Mineralization ...

$\begin{array}{ll}\text { Rock alteration } & 179\end{array}$

Mineralization in different lodes_.......... 180

"Main" branch.

Pewabic Far West lodes............... 180

Fissures or "crossings" ................ 180

Faults_.

Franklin Jr. mine.....

Rhode Island mine $\ldots$
Part 3. Detailed description of lodes and fissures-Con. Allouez conglomerate ("Albany \& Boston").......

Production.

Character of conglomerate

Franklin Jr, mine-

Rhode Island mine.

Allouez mine

Delaware -

Lodes in Cliff mine

Calumet \& Hecla conglomerate lode

Location and extent.

Production.

Composition

Iron oxide of the felsites and quartz porphyries of Keweenaw Point.

Iron oxides in the Calumet \& Hecla

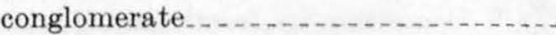

Changes in the iron oxides during mineralization

Thickness.

Texture

Hanging wall

Footwall

Structure.

Faults.

Fissures and joints

Alteration ......

Mineralization.

Character.

Minerals.

Distribution of the copper

Influence of faults and fissures.

Mineralization of the walls.

Change in grade of ore

Map showing "copper per unit area of lode"

Cause of convergence of solutions and influence of barriers ...........

Copper boulders and skulls...........

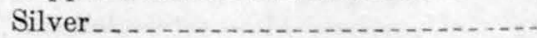

Osceola lode.

History and production

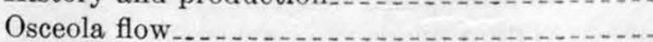

Character of the Osceola amygdaloid .........

Thickness.

Hanging wall

Structure

Alteration and mineralization of the lode-co

Oxidation..........

Alteration and mineralization later than oxidation

Distribution of copper in the lode

Distribution through thickness of the lode

Distribution in the plane of the lode......

Variation in copper content with depth......

Changes in method of mining.

Kearsarge lode

History and production

Kearsarge flow.

Extent and criteria for recognition.......

Thickness.

Character of Kearsarge

General features.

Local observations.

Structure

Allouez anticline.

Faults and fissures 
Part 3. Detailed description of lodes and fissures - Con. Kearsarge lode-Continued.

Alteration and mineralization

Oxidation 198

Alteration accompanying mineralization - 198

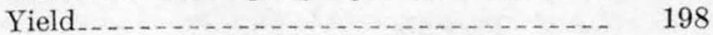

$\begin{array}{ll}\text { Probable causes of rich and poor ground ..... } & 199\end{array}$

Character of rock . .

Influence of structure and texture ...... 200

Structure

Texture ............. 200

Influence of fissures on the lode ....... 201

Conditions favorable to mineralization in the known productive portion of the Kearsarge lode.

Effect of depth on the copper content of the lode.

Mayflower-Old Colony mine

Structure

Developments...................................

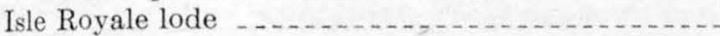

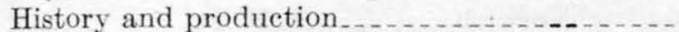

Extent and correlation .....................

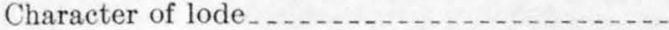

Fragmental zone.........................

Banded amygdaloid ....................

Foot inclusion zone.....................

Vein trap

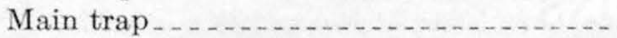

Hanging-wall trap ........................

Distribution of types ................. 205

Structure $\ldots 206$

Isle Royale syncline $\ldots \ldots \ldots$

Faults_....................... 206

Fissures_.......................... 207

Rock alteration and ore deposition .......... 208

First period .......................... 208

Second period ......................... 208

Chemistry of ore deposition ......... 210

Arcadian lode _................. 211

New Arcadian lode............................ 211

Winona lode_........... 211

Production and character ............... 211

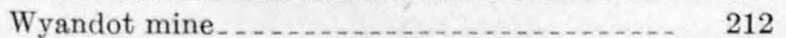

Elm River mine........................... 212

Cherokee mine . . . . . . . . . . 212

Wyandot No. 8 lode................. 212

Evergreen and succeeding lodes_............... 212

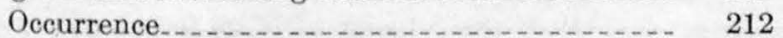

Production

Character of flows . . ...................... 213

Structure _. _...

Character of amygdaloids................ 213

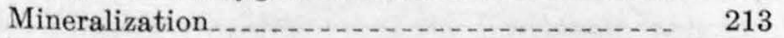

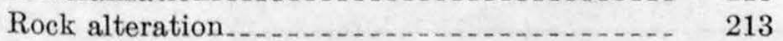

Relation of mineralization to character of lode_ 213

Butler lode ................................... 214

Mass mine............. 214

Lithologic character............. 214

Structure _...

Mineralization_..... 214

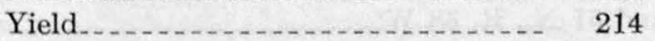

Adventure mine. . . . . . . . . . . . . . . 214

South Lake mine.................... 214

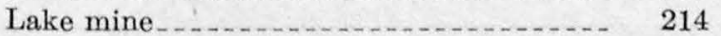

North Lake mine. . . . . 214

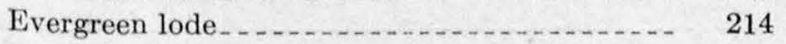

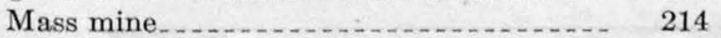

Adventure mine.
Part 3. Detailed description of lodes and fissures-Con. Page Evergreen and succeeding lodes-Continued.

Evergreen lode-Continued.

South Lake mine . . _........ 215

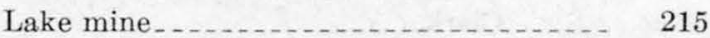

North Lake mine . . . . . . . 215

Knowlton lode_.................. 215

Mass mine _.................. 215

Adventure mine . . . . . . . 215

Lake mine _. _...

Michigan mine . .

Ogima lode_...

Other lodes . . . . . . . . . . . . 216

Forest ("Victoria") lode_..._. _............... 216

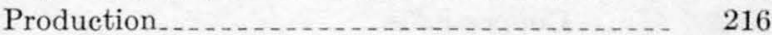

Geologic horizon .................... 216

Character of amygdaloid _........... 216

Mineralization ............... 216

Extent of development. ................. 216

Lake lode_...

Production _........................ 216

Location

Structure _.......................... 217

Correlation _...

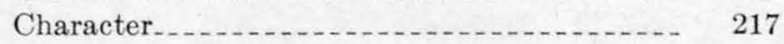

Algomah lode_...

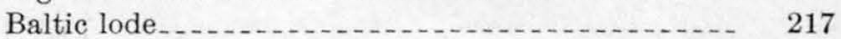

History and production................ 217

Extent and correlation .................. 218

Baltic flow ...

Structure_...

Folds . .

Cross faults and slips ............... 218

Strike fissures . . . . . . . 219

Character of Baltic amygdaloid............. 219

Oxidation . . . . . . . . 219

Mineralization ...................... 219

Minerals_..._. 219

Rock alteration ...................... 220

Relation of mineralization to character of lode

Results of operation ................... 220

Baltic West lode....................... 221

Relation of fissure mineralization and lode mineralization .......................... 221

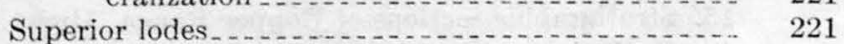

Occurrence...................... 221

Production ................................ 221

Character ....... 222

Mineralization ............................ 222

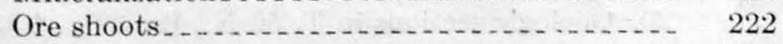

Isle Royale................................... 222

Felsite of Indiuna mine ...................... 222

Development............................ 222

Mineralization ......................... 222

Fissure deposits . . . .

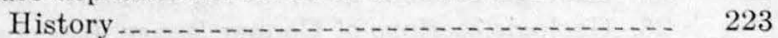

Producticn ... . .

Distribution .......................... 223

Distribution of copper in the fissures......... 223

State of division of copper............. 225

Exploration of fissures................... 225

Incentive to exploration . . . . .

General features of exploration......... 225

Method of exploration............... 226

Suggested explorations _.............. 226

Fissure mines and prospects of Keweenaw and Ontonagon Counties...............

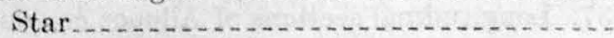

0

20

21

(1)

1

2

(2)

5

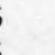

5

(1)

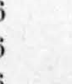

(8)


Part 3. Detailed description of lodes and fissures - Con. Page Fissure deposits-Continued.

Fissure mines and prospects of Keweenaw and Ontonagon Counties-Continued.

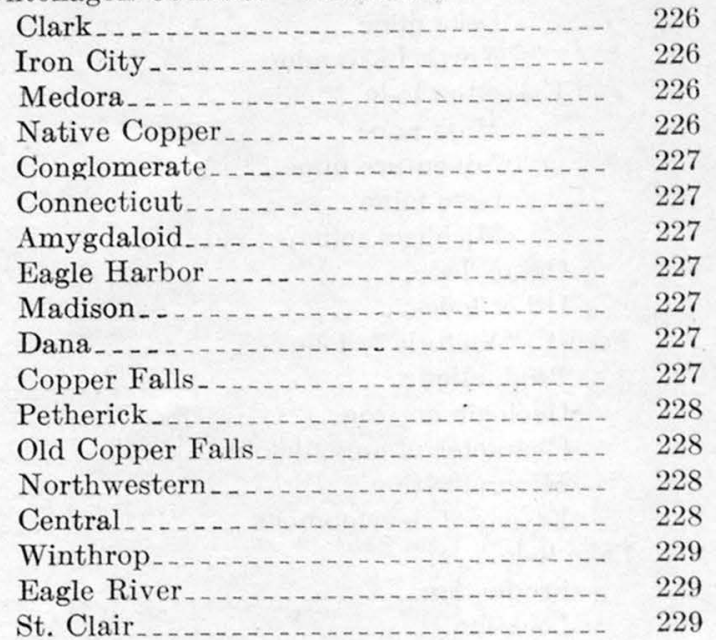

Part 3. Detailed description of lodes and fissures - Con. Fissure deposits-Continued.

Fissure mines and prospects of Keweenaw and Ontonagon Counties-Continued.

Bay State

Phoenix . . . . .

Phoenix fissure.

Robbins or West.

Old Phoenix.

Vaughnsville.

Cliff

North Cliff

North American

Albion-Manhattan

Mohawk.

Fulton.

Arsenide

Minesota and Branch fissures and Calico lode

Norwich

Index

\section{ILLUSTRATIONS}

Plate 1. Implements used by early Indians in mining copper and tools made from copper

2. General geologic map and sections of the Keweenawan and associated rocks in the Lake Superior copper district

3. Map of Copper Range of Michigan

4. Topographic map of central portion of Copper Range from Painesdale to Cliff, Mich.

5. Geologic map of Copper Range, Mich., from Keweenaw Point to Mount Houghton

6. Geologic map of Copper Range from Mount Houghton to Delaware

7. Geologic map of Copper Range from Copper Falls to Gratiot_

8. Geologie map of Copper Range from Gratiot to LaSalle_.

9. Geologic map of Copper Range from LaSalle to Atlantic..

10. Geologic map of Copper Range from Atlantic to Challenge

11. Geologic map of Copper Range from Challenge to Winona

12. Geologic map of Copper Range from Winona to Adventure

13. Geologic map of Copper Range from Adventure to Victoria

14. General geologic map from Presque Isle River to Victoria mine, Mich

15. Stratigraphic sections of Copper Range, Mich.

16. Geologic sections in T. 58 N., Rs. 28 and 29 W.

17. Manitou and North Cliff geologic sections

18. Geologic sections in Tps. 57 and 58 N., Rs. 31 and $32 \mathrm{~W}$

19. Geologic sections in Tps. 56 and 57 N., R. 32 W.

20. Geologic sections in T. 56 N., Rs. 32 and 33 W.

21. Geologic sections in T. 56 N., R. $33 \mathrm{~W}$

22. Geologic sections in Tps. 55 and 56 N., R. 33 W.

23. Geologic sections in Quincy mine, T. 55 N., R. 34 W.

24. Geologic sections in Tps. 54 and 55 N., R. 34 W.

25. Geologic sections in T. 53 N., R. 35 W., and T. 54 N., R. 34 W

26. Geologic sections of Copper Range diamond-drill holes, T. 53 N., R. 35 W

27. Geologic sections in T. 52 N., R. 36 W., and T. 53 N., R. 35 W.

28. Geologic sections in Elm River \& Contact Copper Co.'s mines, T. 52 N., R. 36 W.

29. Geologic sections in T. 52 N., R. 36 W., and T. 51 N., R. 37 W.

30. Geologic sections in T. 51 N., R. 37 W., and Tps. 50 and 51 N., R. 38 W.

31. Geologic sections in T. 50 N., Rs. 38 and 39 W., and T. 51 N., R. 38 W

32. Geologic sections in T. 49 N., Rs. 40,41 , and $42 \mathrm{~W}$

33. Maps of White Pine mine

34. Longitudinal sections of Ashbed lode.

35. Longitudinal sections of Hancock lode

36. Longitudinal sections of Pewabic lode.

37. Longitudinal sections of Allouez conglomerate and Keweenaw mine

In pocket. In pocket. In pocket In pocket. In pocket In pocket. In pocket. In pocket In pocket. In pocket. In pocket In pocket In pocket. In pocket. In pocket. In pocket. In pocket. In pocket. In pocket. In pocket. In pocket. In pocket. In pocket. In pocket. In pocket. In pocket. In pocket. In pocket. In pocket. In pocket. In pocket. In pocket. In pocket. In pocket. In pocket. In pocket, 
Plate 38. Longitudinal sections of Calumet \& Hecla conglomerate

39. Longitudinal sections of Osceola lode

In pocket.

40. Longitudinal section of Kearsarge lode.

In pocket.

41. Longitudinal sections of Isle Royale lode

In pocket.

42. Longitudinal sections of Old Arcadian and Winona lodes

In pocket.

43. Longitudinal sections of Knowlton lode

In pocket.

In pocket.

44. Longitudinal sections of Ogima lode _... In pocket

45. Longitudinal sections of Butler and Ogima lodes .

46. Longitudinal sections of Evergreen lode

47. Longitudinal section of Forest lode, Evergreen mine.... In pocket.

48. Longitudinal sections of Superior and Lake lodes _... In pocket.

49. Longitudinal sections of Baltic and Baltic West lodes _... In pocket.

50. Sections showing development along fissures from Ahmeek mine to Pennsylvania mine ............... In pocket.

51. Sections showing development along Mass fissure, Ahmeek mine

52. Development of Minesota fissure and associated lodes of Michigan mine _........................... In pocket.

53. Ridges produced by resistant flows

54. $A$, Douglass Houghton Falls; $B$, Drill cores improperly stored; $C$, Glaciated surface showing resistance of amygdular inclusions.

55. Texture of sedimentary rocks as shown in diamond-drill cores.

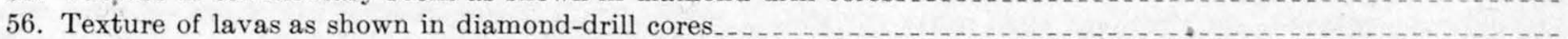

57. Texture of lavas as shown in microseopic sections

58. Texture of flow tops as seen in lodes

59. Texture of flow tops as seen in specimens

60. Texture of flow tops as seen in diamond-drill cores

61. Texture of flow tops as seen in thin sections

62. Iron oxides in flow tops as seen in polished sections

63. Iron oxides in rocks as seen in polished sections

64. Alteration and replacement of minerals

65. Alteration and replacement of minerals

66. $A$, Porcelanic datolite inclosing copper; $B$, Mammillary surface of porcelanic datolite.

67. $A$, Intergrowth of copper and silver; $B$, Fissure breccia partly replaced by datolite; $C$, Native silver on native copper

68. Relation of sulphides and other minerals

69. Sulphide veins

70. Arsenides of copper

71. Quartz arsenide vein, Ahmeek mine

72. Texture and alteration of Calumet \& Hecla conglomerate lode

73. Bleaching of amygdaloid lodes associated with copper and sulphide

74. A, No. 2 shaft house, Quincy mine; $B$, Shaft houses, Baltic mine; $C$, View looking north from Isle Royale mine to Quincy Hill over Portage Lake.

75. $A$, Shafts on Kearsarge lode; $B$, Shafts on Winona lode; $C$, North Bluff and shafts and dumps of Calico and Minesota lodes, Michigan mine; D, Calumet, showing shafts on Calumet \& Hecla conglomerate and Osceola amygdaloid.

Figure 1. Variation in thickness of Kearsarge flow

2. Change in iron in lava top at Twin Falls, Idaho

3. Iron content of smooth-top flow

4. Iron content of Kearsarge flow

5. Gains and losses in constituents in oxidized tops, as compared with trap portions of flows

6. Change in character and content of iron in different parts of lava flows

7. Stability relation for the equation $\mathrm{Fe}_{3} \mathrm{O}_{4}+\mathrm{CO} \rightleftarrows 3 \mathrm{FeO}+\mathrm{CO}_{2-}$

8. Geologic section from Vermilion Lake, Ontario, to Calumet, Mich

9. Possible development of the Keweenaw fault.

10. Possible development of the Keweenaw fault

11. Paragenesis of minerals of Michigan copper deposits

12. Production of copper by Michigan mines, $1855-1925$, and yield per ton, $1906-1925$

13. Production and dividends of Michigan copper mines, to end of 1925 , by lodes.

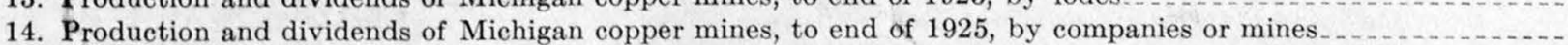

15. Variation in copper content per foot of depth, Calumet \& Hecla mine

16. Influence of varying permeability of rock on flow of solutions and formation of ore shoots

17. Change in iron content in bleached rock associated with copper

18. Composition of bleached and unbleached rock

17
36
36
36
36
36
36
36
36
36
37
52





\section{OUTLINE OF REPORT}

The copper district of Keweenaw Point, in the northern peninsula of Michigan, is the second largest producer of copper in the world. The output of the district since 1845 has been more than $7,500,000,000$ pounds and showed a rather steady and consistent increase from the beginning of production to the end of the World War in 1918, since which there has been a marked decrease.

\section{GEOLOGY}

General features.- In Keweenawan time a series of basaltic flows accumulated to a depth of thousands of feet. Interbedded with the flows are felsite conglomerates. In the lower part of the series the conglomerates are rather abundant and thick; in the middle part they are relatively few and thin but persist for long distances; in the upper part they make up the bulk of the rock.

Intruded into and probably also interbedded with the basalts and conglomerates are siliceous, felsitic, and porphyritic rocks of similar composition to the material that makes up the conglomerates.

The location of the fissures from which the igneous material, both extrusive and intrusive, presumably came is unknown, but there are some reasons for supposing that they were situated toward the center of the Lake Superior structural basin, under the present lake, and that the flow outward from them was in a direction opposite to the present dip of the beds. Probably the felsite bodies from which the conglomerates were derived lay in the same-direction as the fissures, and the material was carried down the same slopes as the lavas. Both the flows and the sediments are believed to have accumulated on a land surface, though probably some, especially of the later sediments, were laid down in bodies of water.

The flows range in thickness from a few feet to 1,300 feet and in extent along the strike from a few hundred feet to at least 40 miles. Nearly all of them are basaltic, but there are differences in composition, expressed in textural differences, which make it possible to divide the flows into several general groups.

The intrusive rocks are mainly siliceous felsites or porphyries, but there are some, like those of Mount Bohemia and others toward the Michigan-Wisconsin boundary, that approach the Duluth gabbro in composition and texture, and these and the felsite also were probably derived from the same source as that rock.

Lava tops or amygdaloids. - The dense rock that forms the greater part of most of the thick flows is commonly called "trap"; it is everywhere overlain by more open-textured material, which is known as "amygdaloid." The cellular tops were formed by the action of gas which was contained in the lava and was liberated during the progress of flow and consolidation. Part of this gas escaped from the surface, and part was caught as bubbles in the viscous top of the lava and thus formed a cellular mass which was later converted into amygdaloid by the filling of the vesicles. Several types of top are recognized. The most common is the cellular top, which was produced by the simple freezing in of individual bubbles of gas. Coalescing amygdaloid has resulted when many bubbles collected into an irregular layer of gas separated by material in which cavities were relatively few. This gave long connected passages in the tops. Fragmental top is due to the breaking up of the cellular top, during solidification and flow, into angular fragments which became so jumbled as to form an irregular hummocky surface. Where the fragments are piled above the general surface they also sink into the flow, so that lava top of this kind varies abruptly and irregularly in thickness. Scoriaceous top results from a working over of any of the other types by the process of erosion and sedimentation. It very commonly underlies felsite conglomerate but occurs also where there is little or no felsite sediment.

From comparison with other regions it is thought that the different types have resulted from different conditions of the lava as it reached the surface. Lava that issued at a high temperature and had a low gas content produced cellular top. Lava that issued at a low temperature and had a high gas content produced fragmental top. Coalescing top was formed on lava intermediate between the other two.

Oxidation of lavas.-The tops of nearly all the flows are distinctly red, and the fragmental tops are decidedly red. Chemical analyses show that there is in general a steady decrease in the proportion of ferric iron and an increase in ferrous iron from the top of a flow nearly to the bottom. In the fragmental flows there is also more total iron in the top - as much as 40 per cent more than in the compact portion of the flow.

It is thought that the oxidation and concentration of the iron were accomplished in large part by the gases given off by the lava during solidification. The evidence indicates that at the temperature at which the lavas emerged the inclosed gases were either neutral or reducing in their action on ferric oxide, but as they cooled in their ascent through the flow they became strongly oxidizing toward ferrous oxide.

Copper in trap.-An examination of the freshest traps confirms previous observations that they contain copper in small amount. Both native copper and ehalcopyrite are present. It seems probable that at least a part of the copper is a primary constituent of the traps.

Structure.-The Michigan copper region is on the southern rim of the Lake Superior syncline or basin, which was probably formed during Keweenawan time. The early Keweenawan rocks of Keweenaw Point dip steeply and the later ones progressively less steeply northwestward, toward the center of the basin. Transverse to the general strike of the Lake Superior syncline are anticlines and synclines that pitch down the dip of the larger fold; among the folds are the Keweenaw anticline, the Ontonagon syncline, and the Bessemer anticline. On these broader anticlines and synclines are several subordinate folds of similar trend, such as the Allouez anticline, the Isle Royale syncline, and the Baltic and Mass anticlines.

The greatest fault of the region is the Keweenaw fault, which bounds the copper-bearing series on the south from the end of Keweenaw Point to Lake Gogebic. This is a reverse fault of northwesterly dip, along which the basaltic series has been thrust over the "Eastern" (Cambrian) sandstone. The dip of the fault is nearly parallel to the flows, and it also follows the major anticlinal and synclinal structure of the rocks. Many branch faults and fissures are associated with the Keweenaw fault. Relatively small transverse faults and fissures are also present around the crests of the anticlines. The movement on the Keweenaw fault probably did not begin till late Keweena- 
wan time, and much of it occurred after the "Eastern" sandstone was deposited. The transverse folding and faulting probably followed the Keweenaw faulting and preceded the period of mineralization.

\section{ORE DEPOSITS}

The copper deposits are of two main classes - lode deposits and fissure deposits. ${ }^{1}$ The lode deposits consist of conglomerate lodes, which are mineralized beds of felsite conglomerate interbedded with the lava flows, and amygdaloid lodes, which are the mineralized vesicular or brecciated tops of the lava flows. The fissure deposits are veins along fractures that are in part parallel and in part transverse to the beds; all of them are of narrow tabular form.

The commercially important known deposits with one exception are confined to the portion of the Keweenawan series composed predominantly of lava flows. They are distributed through most of that portion of the series. The more productive lodes, from the base upward, are the Baltic amygdaloid, Isle Royale amygdaloid, Kearsarge amygdaloid, Osceola amygdaloid, Calumet \& Hecla conglomerate, Allouez conglomerate, Pewabic amygdaloid, and Ashbed amygdaloid. The Nonesuch lode, named for the formation that contains it, is in the upper sedimentary portion of the series. The fissure deposits are in the same portion of the series as most of the lodes.

Conglomerate lodes.- Only two of the conglomerate beds have been extensively explored, the Calumet \& Hecla and the Allouez. The Calumet \& Hecla conglomerate over most of its known extent is a sandy or "scoriaceous" bed with a little felsite sand at the top. At Calumet it opens into a well-developed felsite conglomerate lens that increases in thickness and extent with increased depth. The Allouez conglomerate is thicker and more persistent than the Calumet \& Hecla but in places is represented only by a clay seam. The valuable mineralized portion of the Calumet \& Hecla conglomerate is confined to the conglomerate lens, and the copper content decreases abruptly where the conglomerate changes to sand. The copper occurs as native metal and mainly replaces the finer matrix of the conglomerate. The common minerals associated with the copper are feldspar and epidote, mainly deposited earlier than the copper, and quartz and calcite, contemporaneous with the copper. Zeolites are conspicuously absent. The characteristic rock alteration effected by the ore-bearing solutions was the removal of hematite, with a resultant bleaching of the lode from brown to pinkish.

Amygdaloid lodes.-All but two of the largely productive amygdaloid lodes, as well as most of those that have given some encouragement, are of the fragmental type. One, the Pewabic, is mainly of the coalescing type, though in part it is fragmental, and the Ashbed is mainly a "scoriaceous" lode, though locally fragmental. No mines have been found in the cellular amygdaloids, which are by far the most abundant.

A greater, variety of minerals is associated with the copper in the amygdaloid lodes than in the conglomerates. Chlorite, feldspar, epidote, and pumpellyite are the abundant minerals that mainly preceded the copper in deposition. Abundant quartz and calcite and some prehnite and datolite were locally deposited with the copper; the zeolites laumontite and analcite, together with saponite and other minerals in small amount, were deposited later than the copper. Sericite was deposited apparently both with and later than the copper.

The rock alteration effected during the formation of the amygdaloid lodes was of two types - a removal of hematite similar to that in the conglomerate, and a partial removal of the iron of hematite and a partial chemical reduction of ferric oxide

1 The terms "lode" and "fissure" are here applied according to local usage; for definitions see section on ore deposits, p. 101. to ferrous oxide and recombination to form ferrous and ferric compounds such as pumpellyite, chlorite, and epidote.

Ore shoots. - The minable copper occurs in shoots, of which many are large but all far less extensive than the lodes that contain them. The ore of the shoots was deposited in the more permeable parts of the lodes by solutions whose movement was directed by barriers of relatively impermeable material. Two types of environment have most commonly favored the formation of shoots - a "bed," conglomerate or amygdaloid, that is prevailingly impermeable but contains permeable portions of great downward extension, like the Calumet \& Hecla conglomerate shoot and the Kearsarge amygdaloid shoot, and a "bed," such as the Osceola amygdaloid, that is prevailingly permeable but contains impermeable streaks which cause a concentration of solutions beneath them.

Mineralized fissures.-Most of the veins in the north end of the district are in cross fissures on the Keweenaw and Allouez anticlines. The mineralization of the fissures has occurred near the intersections with strong amygdaloids and under the "slide" at the base of the Greenstone flow.

The fissures at the south end of the district are mainly strike fissures dipping more steeply than the beds; they also are mineralized near the intersection with strong conglomerates or amygdaloids.

Changes with depth.-All the larger known ore shoots have had as rich ore at some place near their outcrop as at any greater depth. Any changes in grade to the present depth of development may be attributed more to changes in the character of the lode rock than to distance from the outcrop. Decrease in grade in the fissures and possibly in some of the lodes may be due mainly to depth.

Genesis of the deposits.-Two differing explanations of the genesis of the deposits have been advanced. One assumes that they are due to descending solutions, that the copper was derived from the lavas or from overlying beds, and that reaction of the oxidized copper-bearing solutions with the ferrous iron of the lavas produced metallic copper and ferric compounds. The other assumes that they were formed by ascending potential sulphide-bearing solutions which derived their copper from an igneous source, and that the reaction of these solutions with the ferric iron of the rocks resulted in the oxidation of the solutions, the reduction of the ferric iron, and the precipitation of native copper.

The theory of deposition by descending waters appears untenable for several reasons. There is, in the first place, no adequate source of the copper, for although copper is present in the traps there is no evidence of its removal. It is difficult, also, to believe that gravity circulation could have been adequate to form the deposits, for the gravity circulation of solutions in the deep levels of the mines is almost nil, and many of the deposits are on the under sides of impermeable barriers. The deposits, moreover, were formed in beds rich in ferric iron and poor in ferrous iron. The ferric iron was partly removed and partly reduced to the ferrous state - a reaction which does not seem likely to occur in the presence of oxidized solutions.

In the ascensional hypothesis it is assumed that the copper solutions originated in the underlying Duluth gabbro and that they either entered the lode-forming layers directly where the downward extensions of these layers were in contact with the magma or passed from the magma to the places of deposition by way of fissures. Solutions thus originating must have been highly heated, in the early stages gaseous, and under great pressure, and they could therefore easily make their way along fissures and permeable layers.

The principal facts that cause the authors to favor this hypothesis are that the solutions became concentrated and deposited ore on the under sides of barriers and that they were reducing in character-they carried sulphides, and they deposited native copper in beds rich in ferric iron, which they partly reduced or removed. 


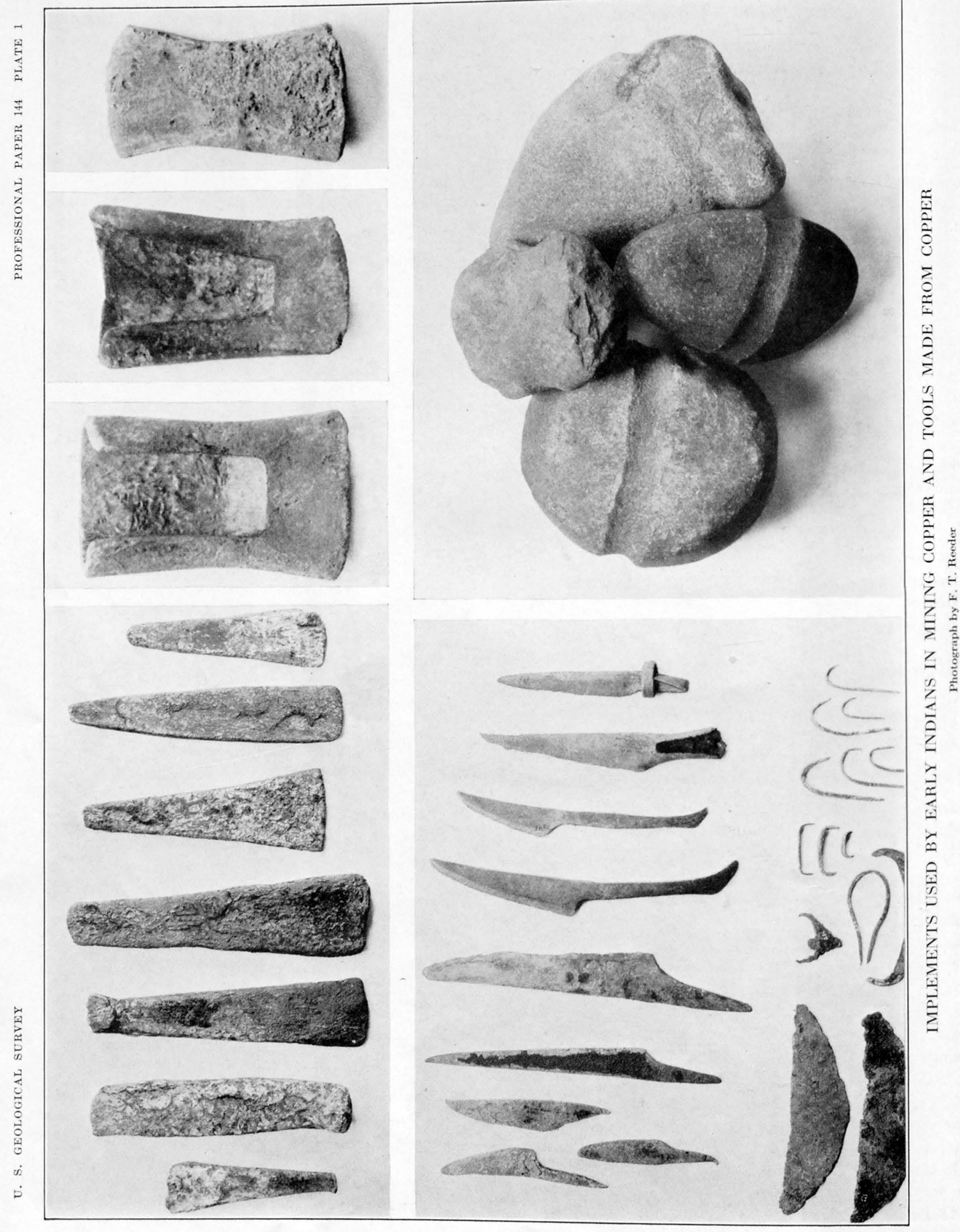




\title{
THE COPPER DEPOSITS OF MICHIGAN
}

\author{
By B. S. Butler and W. S. Burbank
}

In collaboration with T. M. Broderick, L. C. Graton, C. D. Hohl, Charles Palache, M. J. Scholz, Alfred Wandke, and R. C. WELLS

\section{PART 1. GENERAL FEATURES}

\section{INTRODUCTION}

\section{FIELD WORK AND AUTHORSHIP}

The field work on which this report is based was begun in the spring of 1920 by the Calumet \& Hecla Consolidated Copper Co. under the supervision of Prof. L. C. Graton. The work done under these conditions was continued till the spring of 1924. T. M. Broderick, B. S. Butler, C. D. Hohl, and Alfred Wandke were engaged in the survey for the greater part or all of the period; Prof. Charles Palache for the summers of 1920 and 1921. Professor Graton spent each summer and short periods at other seasons in the district.

Messrs. Broderick, Butler, and Hohl worked mainly on the general field problems, Professor Palache gave special attention to mineralogy, and Mr. Wandke worked partly in the field but gave special attention to the petrographic and mineralogic studies in the laboratory. Robert Hoffman spent the summer of 1920 and E. R. Lovell the summer of 1921 in the work. By a cooperative arrangement between Harvard University, the National Research Council, and the United States Geological Survey, R. C. Wells at the same time made a study of the chemistry of the formation of native copper. The chemists of the Calumet \& Hecla Co. contributed analyses and other chemical data, especially in the early stages of the investigation. Augustus Locke was in frequent consultation with the other workers, and short periods were spent on the work by J. Volney Lewis, William Burns, and G. N. Bjorge. W. O. Hotchkiss and H. R. Aldrich, who have been working on the geology of the Keweenawan rocks for the Wisconsin Geological and Natural History Survey, visited the district and made interesting contributions to the discussion of the broader relations of the Keweenawan. Prof. A. C. Lane likewise gave the benefit of his long experience in the district.

On the completion of the Calumet \& Hecla investigation in the spring of 1924, an arrangement had been made by the United States Geological Survey after consultation with the other companies of the district, by which the general geologic results of the Calumet \& Hecla study were turned over to the Geological Survey, which extended the study throughout the productive part of the district. Mr. Butler, reappointed on the Geological Survey, and W. S. Burbank were assigned to this work, which was carried on till August, 1925. A large part of this field work was done in association with the geological department of the Calumet \& Hecla Co.

During the last few years certain electrical methods of prospecting have been tried in the district with indifferent results, and in connection with this work Messrs. Broderick and Hohl started dip-needle surveys, which were successful in indicating the trend of different formations on the bedrock surface beneath the extensive covering of glacial drift. The results obtained were of such general interest that these gentlemen have kindly prepared a chapter on "geophysical methods applied to exploration and geologic mapping," which has been incorporated in this report.

Miss Marie J. Scholz compiled most of the statistical data for both the Calumet \& Hecla Consolidated Copper Co. and the Geological Survey and did most of the clerical work on the report. The drafting of the surface map and considerable of the other drafting was done by Carlos V. Rawlings.

The general features of the geology and the occurrence of the copper and much of the detail for the north end of the district, as presented in this report, were mainly worked out during the Calumet \& Hecla investigation by the men engaged in that work. The names of all these men appear in the title-page with the addition of W. S. Burbank. The report as it now stands was prepared by B.S. Butler and W.S. Burbank.

\section{SCOPE OF REPORT}

The difficulty and high cost of obtaining geologic data in this generally drift-covered district has made it desirable to collect and to put on record all such data that are available. Field observations have therefore been presented in the text and on the maps and sections in greater detail than has been customary in reports of this character. The attempt has been 
made also to show on the maps all known developments in the district, with the hope that this would promote the most effective planning of future developments. ${ }^{1}$ The facts of the occurrence of copper have been set forth as they have been ascertained, and a general discussion of the origin of the ores is given. The attempt has been made to keep fact and speculation distinct, and it is hoped that the reader will draw his own conclusions from the facts rather than unqualifiedly accept those here presented. In the section on the application of geology to mining are described methods in the search for ore deposits that seem to give most promise of success.

\section{ACKNOWLEDGMENTS}

It is hardly necessary to say that any geologic report on an old district is likely to be but one of a series each based on the data accumulated by many others in addition to the authors, up to the time that it was made. This report is no exception to the rule and contains much information derived from earlier reports. The last general account of the region, however, was written about 15 years ago, and the mining developments that have been carried on, at times very actively, during the period that has since elapsed have added greatly to the body of geologic fact that was then available.

The main sources of information, apart from the work of the authors, have been the reports of the Michigan Geological Survey, previous reports by the United States Geological Survey, and the data accumulated by the operating companies. The Michigan Geological Survey generously furnished all material in its possession. All the mining companies of the district gave that hearty cooperation which was essential to the success of the report and without the assurance of which the survey would not have been undertaken. The help given by the different companies has, of course, not been equal. Those who had much gave much; some had little and could give no more than they had. The Calumet \& Hecla Consolidated Copper Co. made the outstanding contribution, starting the work, and paying for a large part of it; and without this cooperation the report by the Geological Survey would not have been undertaken. Whatever of usefulness comes to the district from this report should be largely credited to that company.

Acknowledgment to individuals who have published the results of their investigations is made under the heading "Previous investigations." Acknowledgment to individuals for the data coming from companies is not easy, because information on any one topic has usually been accumulated over a long period and has been gathered by several individuals. The authors trust that they will be pardoned, therefore, if they do not try to accredit each borrowed fact to its original

isee note on p. 233. author but merge their acknowledgments of indebted. ness in one expression of most cordial thanks to the officials of the companies. Several engineers of the district, especially Mr. R. R. Seeber and Mr. Herman Fesing, have furnished data for companies with which they were formerly connected but which at the time of the investigation were not operating. Mr. A. H. Meuche contributed many data on the south end of the district collected both while he was a member of the Michigan Geological Survey and later. Chemists of the Calumet \& Hecla Co. have helped both by their interest and by analyses. For analyses the authors are indebted to Messrs. W. F. Hillenbrand and $\mathrm{H}$. C. Kenney.

In addition to the acknowledgments for contributions to the report, the authors wish to express appreciation for courtesies extended, especially by the Calumet \& Hecla Co., to the Geological Survey and to them personally, which added much to the convenience and effectiveness of the work.

To Mr. F. C. Calkins, of the Geological Survey, the authors are indebted for a critical reading of the report, which resulted in many helpful suggestions.

\section{PREVIOUS INVESTIGATIONS}

Few other districts of the country have received such numerous and repeated examinations by geologists and engineers as have been made in the copper country of Michigan. Altogether a vast amount of information has been assembled regarding this district. Of that which has been published, most has been afforded by the State surveys of Michigan, Wisconsin, and Minnesota and by the United States Geological Survey. All known publications on the geology of the district are listed in the bibliography, but the contributions of several groups of workers are of so outstanding importance as to deserve special mention.

Douglass Houghton, ${ }^{1 \mathrm{a}}$ in 1841 , first brought the district effectively to the attention of mining men. His valuable work was terminated in its midst four years later by his death.

The next general report was made by Raphael Pumpelly and his associate, A. R. Marvine, ${ }^{2}$ who laid the foundation for the systematic study of the stratigraphy of the district, studied the mineralogy of the deposits in detail, and set up a theory of the deposition of the ores that for 50 years has exerted a controlling influence on geologic thought regarding the district. The value of Pumpelly's pioneer work in mineralogy and rock alteration is too well recognized to need extended comment.

The work of R. D. Irving ${ }^{3}$ and his associates gave a broad view of the copper-bearing rocks and their stratigraphic and structural relations and added much

ia Houghton, Douglass, Michigan State Geologist [Fourth] Ann. Rept.: Michigan H. R. Doc. 27, 1841 .

2 Míchigan Geol. Survey, vol. 1, pt. 2, 1873.

Irving, R. D., The copper-bearing rocks of Lake Superior: U. S. Geol. Survey Mon. 5, 1883. 
to the knowledge of the mineralogy and petrography of these formations.

L. L. Hubbard, ${ }^{4}$ as State geologist, contributed especially to our knowledge of the felsite masses and the general structure in the north end of the district, and later, as an operator, he was successful in applying geology to the location of profitable lodes, notably in the Champion mine.

The final report by A. C. Lane, ${ }^{5}$ as State geologist, brought together the results of years of study by himself and other members of the Michigan Geological Survey. This report is the great storehouse of fact concerning the stratigraphy of the district. In it is presented a theory of the origin of the copper deposits considerably modifying that set forth by Pumpelly. The value of this report is too well known to require comment.

Van Hise and Leith, ${ }^{6}$ in their monograph on Lake Superior geology, made evident the setting of the copper district in the larger province. They definitely broke away from the Pumpelly theory of formation of the ores.

Many others have contributed to our knowledge of the district, as will appear in the following pages and as can be seen by consulting the bibliography. Some of them, notably Prof. A. E. Seaman, have made a far more extensive and intimate study of the district than the bibliography would indicate.

\section{BIBLIOGRAPHY}

[See also p. 233]

Ackermann, Hermann W.

Die Kupferführenden Schichten am Lake Superior: Naturw. Gesell. Isis Dresden Sitzungsber. 1875, pp. 101-105, 1876.

Agassiz, Alexander.

On the position of the sandstone of the southern slope of a portion of Keweenaw Point, Lake Superior: Boston Soc. Nat. Hist. Proc., vol. 11, pp. 244-246, 1867.

On underground temperatures at great depth: Am. Jour. Sci., 3d ser., vol. 50, pp. 503-504, 1895.

Agassiz, George Russell.

Alexander Agassiz, 1835-1910: Letters and publications of Alexander Agassiz, with a sketch of his life and work, Boston and New York, Houghton Mifflin Co., 1913.

Agassiz, Lours.

Lake Superior; its physical characters, vegetation, and animals, Boston, 428 pp., 1850.

On Marcou's "Geology of North America": Am. Jour. Sci., 2d ser., vol. 27, pp. 134-137, 1859.

ALDRICH, H. R.

Magnetic surveying on the copper-bearing rocks of Wisconsin: Econ. Geology, vol. 18, pp. 562-574, 1923.

Allen, Rolland Craten.

Progress of the geological survey of Michigan; geology and topography: Michigan Acad. Sci. Rept. 13, pp.69-78, 1911.

(and Ruthven, A. G.) Progress of the geological and biological survey of Michigan: Michigan Acad. Sci. Rept. 14, pp. 33-36, 1912.

'Hubbard, L. L., Michigan Geol. Survey, vol. 6, 1898.

'Lane, A. C., The Keweenaw series of Michigan: Michigan Geol, and Biol. Survey Pub. 6, 2 vols., 1911.

- Van Hise, C. R., and Leith, C. K., The geology of the Lake Superior region:

U. S. Geol. Survey Mon. 52, 1911 .
Allen, Rolland Craten-Continued.

(and others) Mineral resources of Michigan, with statistical tables of production and value of mineral products for 1910 and prior years: Michigan Geol. Survey Pub. 8 (Geol. ser. 6), 465 pp., 1912.

Biennial report of the director: Michigan Geol. Survey Pub. 17 (Geol. ser. 14), 104 pp., map, 1914.

(and Barrett, L. P.) A revision of the sequence and structure of the pre-Keweenawan formations of the eastern Gogebic iron range of Michigan: Michigan Geol. Survey Pub. 18 (Geol. ser. 15), pp. 33-61, map, 1915; [in part], Jour. Geology, vol. 23, pp. 689-703, map, 1915.

(and Barrett, L. P.) Contributions to the pre-Cambrian geology of northern Michigan and Wisconsin: Michigan Geol. Survey Pub. 18 (Geol. ser. 15), pp. 13-164, maps, 1915.

(and Smith, R. A., and Barrett, L. P.) Geological map of Michigan, scale 1:750,000: Michigan Geol. Survey Pub. 23, 1916.

Mineral resources of Michigan, with statistical tables of production and value of mineral products for 1912 and prior years: Michigan Geol. Survey Pub. 13 (Geol. ser. 10), 255 pp., 1913. Idem for 1913, Pub. 16 (Geol. ser. 13), 150 pp., 1914; for 1914, Pub. 19 (Geol. ser. 16), 359 pp., 1915; for 1915, Pub. 21 (Geol. ser. 17), 402 pp., map, 1916; for 1916, Pub. 24 (Geol. ser. 20), 291 pp., 1917; for 1917, Pub. 27 (Geol. ser. 22), 225 pp., map, 1918; for 1918, Pub. 29 (Geol. ser. 24), 214 pp., 4 figs., 1920.

ANONYMOUS.

The silver of the Lake Superior mineral region: Min. Mag., vol. 1, pp. 447-454, 1853.

Barnes, George Orville.

Field notes . . . on the Ontonagon district [Lake Superior region]: 31st Cong., 1st sess., S. Ex. Doc. 1, pt. 3, and H. Ex. Doc. 5, pt. 3, pp. 627-636, 1849.

Barrett, L. P. (See Allen, R. C., and Smith, R. A.)

Batermann, Hilary.

Remarks on the copper mines of the State of Michigan: Geol. Soc. London Quart. Jour., vol. 22, pp. 448-463, 1866; abstract, Geol. Mag., vol. 3, pp. 225-226, 1866.

BAYField, H. W.

Outlines of the geology of Lake Superior: Quebec Lit. and Hist. Soc. Trans., vol. 1, pp. 1-43, 1829.

Bayley, William Shirley.

Basic massive rocks: Jour. Geology, vol. 1, pp. 433-456, 587-596, 1893.

The Sturgeon River tongue [Michigan]: U. S. Geol. Survey Mon. 36, pp. 458-487, 1899; Nineteenth Ann. Rept., pt. 3, pp. 146-151, 1899.

BelL, Robert.

Geology of Lakes Superior and Nipigon: Canada Geol. Survey Rept. Progress for 1866-1869, pp. 313-364, 1870.

Report on the country north of Lake Superior, between the Nipigon and Michipicoten Rivers: Canada Geol. Survey Rept. Progress for 1870-1871, pp. 322-351, 1872.

Report on the country between Lake Superior and Lake Winnipeg: Canada Geol. Survey Rept. Progress for 1872-1873, pp. 87-111, 1873.

The mineral region of Lake Superior: Canadian Naturalist and Geologist, 2d ser., vol. 7, pp. 49-51, 1875.

Report on an exploration in 1875, between James Bay and Lakes Superior and Huron: Canada Geol. Survey Rept. Progress for 1875-1876, pp. 294-342, 1877.

Report on geological researches north of Lake Huron and east of Lake Superior: Canada Geol. Survey Rept. Progress for 1876-1877, pp. 193-220, 1878. 
Benedict, C. H.

(and Kenny, H. C.) Ammonia leaching of Calumet \& Hecla tailings: Am. Inst. Min. Eng. Trans., vol. 70, pp. 595-610, 1924.

Calumet \& Hecla reclamation plant: Lake Superior Min. Inst. Bull., 1925.

Berkey, Charles Peter.

The occurrence of datolite on the north shore of Lake Superior [abstract]: Minnesota Acad. Nat. Sci. Bull, vol. 4 , pp. $42-43,1896$.

The occurrence of copper minerals in hematite ore, Montana mine, Soudan, Minn.: Lake Superior Min. Inst. Proc., vol. 4, pp. 73-79, 1896; Minnesota Univ. Eng. Year Book, vol. 5, pp. 110-117, 1897.

On the occurrence of native copper and other copper minerals in the hematite ore of the Montana mine, Soudan, Minn. [abstract]: Science, new ser., vol. 6, pp. 363-364, 1897.

Bigsby, JoHn Jeremiah

Notes on the geography and geology of Lake Superior: Quart. Jour. Sci., vol. 18, pp. 1-34, 228-269, 1824-25; abstract, Bull. sei. nat., Paris, vol. 7, pp. 8-13, 1826.

On the physical geography, geology, and commercial resources of Lake Superior: Edinburgh New Philos. Jour., vol. 53, pp. 55-62, 1852.

Blake, WiLliam P.

Review of a portion of the geological map of the United States and British provinces, by Jules Marcou: Am. Jour. Sci., 2d ser., vol. 22 , pp. 383-388, 1856 .

BLANDY, JoHN F.

Topography with especial reference to the Lake Superior copper district: Am. Inst. Min. Eng. Trans., vol. 1, pp. $75-82,1873$.

The origin of the native copper in the Michigan deposits: Eng. and Min. Jour., vol. 70, pp. 278-279, 1900.

(See also Williams, C. P.)

BоoтH, JoHN C.

(and Hulburt, E. J.) Geological and topographical map of the mineral district of Lake Superior, Mich., New York, 1855.

Borie, Jules.

Notice sur le lac Supérieur et ses mines de cuivre de la rive américaine: Soc. ind. min. Bull., vol. 6, pp. 233-284, 1860 ; vol. 7, pp. 185-251, 1861; vol. 8, pp. 270-271, 1862; Allgem. Berg- u. hüttenm. Zeitung, vol. 4, pp. 448-450, 457-460, 469-471, 1862.

Bradish, Alva.

Memoir of Douglass Houghton, first State geologist of Michigan; with an appendix containing reports or abstracts of the first geological survey, and a chronological statement of the progress of geological exploration in Michigan, 302 pp., Detroit, 1889.

Brauns, R.

Native copper in basalt: Zeitschr. Kryst. Min., 1911, p. 493; Centralbl. Mineralogie, 1908, pp. 705-709.

Bringmade, Robert Bruce.

The Michigan copper mines and methods: Min. World, vol. 32 , pp. 549-552, 1910.

Bristol, T. W. (See Houghton, Jacob, jr.)

Broderick, Thomas Monteith.

The relation of the titaniferous magnetites of northeastern Minnesota to the Duluth gabbro: Econ. Geology, vol. 12, pp. 663-696, 1917.

Brooks, Thomas Benton.

On the youngest Huronian rocks south of Lake Superior, and the age of the copper-bearing series: Am. Jour. Sci., 3 d ser., vol. 11 , pp. 206-211, 1876.

Classified list of the rocks observed in the Huronian series south of Lake Superior: Am. Jour. Sci., 3d ser., vol. 12, pp. 194-204, 1876.
Brooks, Thomas Benton-Continued.

(and Pumpelly, R.) On the age of the copper-bearing rocks of Lake Superior: Am. Jour. Sci., 3d ser., vol. 3, pp. $428-432,1872$.

(and Julien, A. A.) Lithology [of the Upper Peninsula]: Michigan Geol. Survey, vol. 2, pp. 199-212, 1873.

Brodghton, Samuel H.

Remarks on the mining interest and details of the geology of Ontonagon County [Mich.], 24 pp., map, Philadelphia, 1863.

Burt, William A.

Topography and geology of the survey of a district of township lines, south of Lake Superior, 1845: 29th Cong., 1st sess., S. Ex. Doc. 357, pp. 2-19, 1846.

Geological report of survey [in Lake Superior region]: 31st Cong., 1st sess., S. Ex. Doc. 1, pt. 3, and H. Ex. Doc. 5, pt. 3 , pp. $811-832,842-875,933-935$, maps, 1849.

Callender, John A.

The Lake Superior copper mines: Min. Mag,, vol. 2, pp. 249-253, 1854.

Campbell, J. B.

[Lake Superior region]: 28th Cong., spec. sess., S. Ex. Doc. 175 , pp. 4-8, 1845

Case, Ermine Cowles.

(and Robinson, W. I.) The geology of Limestone Mountain and Sherman Hill, in Houghton County, Mich.: Michigan Geol. Survey Pub. 18 (Geol. ser. 15), pp. 165181, 1915: Jour. Geology, vol. 23, pp. 256-260, 1915.

Chamberlin, Thomas Chrowder.

The copper-bearing series of Lake Superior: Science, vol. 1, pp. 453-455, 1883.

(and Strong, Moses) Geology of the upper St. Croix district: Geology of Wisconsin, vol. 3, pp. 363-428, 1880 .

(See also Irving, Roland Duer.)

Clarke, Robert E.

Notes from the copper region [Lake Superior]: Harpers Mag., vol. 6, pp. 433-448, 577-588, 1853.

Clements, Julius Morgan.

A contribution to the study of contact metamorphism: Am. Jour. Sci., 4th ser., vol. 7, pp. 81-91, 1899.

Cordier, Louis.

Note sur une masse de cuivre natif provenant des rives du lac Supérieur aux Etats-Unis d'Amérique: Compt. Rend., vol. 28 , pp. 161-162, 1849.

Corey, G. W.

The Nonesuch sandstone [Porcupine district, Mich.]: Eng. and Min. Jour., vol. 82, p. 778, 1906.

Credner, Hermann.

Die Gliederung der eozoischen (vorsilurischen) Formationsgruppe Nord Amerikas: Zeitschr. ges. Naturwiss., Band 32 , pp. $353-405,1868$.

Die vorsilurischen Gebilde der "Obern Halbinsel von Michigan" in Nord Amerika: Deutsch. geol. Gesell. Zeitschr., Band 21, pp. 516-554, 1869.

Beschreibung einiger charakteristischer Vorkommen des gediegenen Kupfers auf Keweenaw Point am Oberen See Nord-Amerika's: Neues Jahrb., 1869, pp. 1-14.

Gewaltige Kupfermassen am Lake Superior: Neues Jahrb., 1870 , p. 86.

Ueber Nordamerikanische Schieferporphyroide: Jahrb. Mineralogie, 1870, pp. 970-984.

Elemente der Geologie, 4th ed., 726 pp., 1878.

Crooks, H. F. (See Savage, T. E.)

DAwson, JoHN W.

On the geological structure and mineral deposits of the promontory of Mamainse, Lake Superior: Canadian Naturalist, vol. 2, pp. 1-12, 1857.

Deroux, H.

Die Kupfergruben des Oberen See's Lake Superior: Berg- u. hüttenm. Zeitung, vol. 20, pp. 305-307, 329-331, 1861. 
DESOR, ÉDOUARD.

[On the clay and drift deposits in the vicinity of Lake Superior]: Boston Soc. Nat. Hist. Proc., vol. 3, pp. 235236,1850 .

[On the sand dunes of Lake Superior]: Boston Soc. Nat. Hist. Proc., vol. 3, p. 207, 1850; vol. 4, pp. 41-42, 1851.

$[\mathrm{On}$ the origin of some of the elements of the so-called Tertiary or drift of Lake Superior]: Boston Soc. Nat. Hist. Proc., vol. 4, pp. 28-29, 1851.

On the Silurian rocks of the Lake Superior land district: Am. Assoc. Adv. Sci. Proc. 5th meeting, pp. 64, 65, 1851.

On the superficial deposits of this district, in Foster, J. W., and Whitney, J. D., Report on the geology of the Lake Superior land district, pt. 2: 32d Cong., spec. sess., S. Ex. Doc. 41, pp. 232-270, 1851; in part, Am. Jour. Sci., 2 d ser., vol. 13, pp. 93-109, 1852.

Dickenson, George J.

[Report on Isle Royale]: 31st Cong., 1st sess., S. Ex. Doc. 1, pt. 3, and H. Ex. Doc. 5, pt. 3, pp. 503-506, 1849.

DiefFenbach, Otto.

Bemerkungen über den Kupferbergbau in den Vereinigten Staaten von Nordamerika: Berg- u. hüttenm. Zeitung, Band 17 , pp. $47-48,66-68,75-76,1858$.

Dovglass, James.

The native copper mines of Lake Superior: Quart. Jour. Sci., vol. 11, pp. 162-180, 1874; Canadian Naturalist, new ser., vol. 7, pp. 318-336, 1874.

The copper resources of the United States: Sci. Am. Suppl. vol. 34, pp. 14183-14186, 1893.

Duparc, Louis.

Note sur la région cuprifère de l'extrémité nord-est de la péninsule de Keweenaw (Lac Supérieur): Arch. sci. phys. nat., 4th ser., vol. 10, pp. 518-538, 1900.

Dupee, J. A.

[On copper deposits of Keweenaw Point, Lake Superior]: Boston Soc. Nat. Hist. Proc., vol. 5, pp. 279-280, 1856.

Dutron, T. R.

Observations on the basaltic formation on the northern shore of Lake Superior: Am. Jour. Sci., 2d ser., vol. 4, pp. 118-119, 1847.

Eames, Henry H.

Geological reconnaissance of the northern, middle, and other counties of Minnesota, 58 pp., St. Paul, 1866.

Report of the State geologist on the metalliferous region bordering on Lake Superior, 21 pp.; 2 d ed., 23 pp., St. Paul, 1866.

Egleston, Thomas.

Copper mining on Lake Superior: Am. Inst. Min. Eng. Trans., vol. 6, pp. 275-312, 1879.

[The conglomerates of the Lake Superior copper region]: Am. Inst. Min. Eng. Trans., vol. 6, pp. 606-611, 1879. Eights, JAMES.

Outlines of the geological structure of Lake Superior mineral region: New York and Lake Superior Mining Co. First Ann. Rept., appendix, 21 pp., Albany, 1846.

Elftman, Arthur Hugo.

The geology of the Keweenawan area in northeastern Minnesota: Am. Geologist, vol. 21, pp. 90-109, map, 175-188; vol. 22 , pp. 131-149, map, 1898.

Élie de Beaumont, Leonce.

[On the age of the Lake Superior sandstone]: Soc. géo]. France Bulf., 2d ser., vol. 7, p. 209, 1850.

EMmons, EBenezer.

(Copper mines of Lake Superior), American geology, vol. 1, pt. 1, pp. 171-173, 1855.

FINLAY, J. R.

Appraisal of mining properties of Michigan by the State Board of Tax Commissioners, 1911.
Foshag, William $\mathrm{F}$.

(and Larsen, E. S.) Eakleite from Isle Royale, Mich.: Am. Mineralogist, 7th ser., vol. 2, pp. 23-24, 1922.

Foster, John Wells.

[Report of field work in the Lake Superior land district]: 30th Cong., 2d sess., S. Ex. Doc. 2, pp. 159-163, 1849.

(and Whitney, J. D.) Synopsis of the explorations . . . in the Lake Superior land district in the northern peninsula of Michigan; 31st Cong., 1st sess., S. Ex. Doc. 1, pt. 3, and H. Ex. Doc. 5, pt. 3, pp. 605-626, maps, 1849.

[Field notes of work in Lake Superior region]: Idem, pp. 766-801.

(and Hill, S. W.) Statistics of the mines of Keweenaw Point: Idem, pp. 759-765.

(and Whitney, J. D.) Mineral reports [Lake Superior land district]: 31st Cong., 2d sess., H. Ex. Doc. 9 (Gen. Land Office Rept., 1850), pp. 147-152, 1850.

(and Whitney, J. D.) Report on the geology and topography of a portion of the Lake Superior land district in the State of Michigan, pt. 1, Copper lands: 31st Cong., 1st sess., H. Ex. Doc. 69, 224 pp., maps, 1850.

(and Whitney, J. D.) On the age of the sandstone of Lake Superior, with a description of the phenomena of the association of igneous rocks: Am. Assoc. Adv. Sci. Proc., vol. 5 , pp. $22-38,1851$.

(and Whitney, J. D.) Sur les terrains siluriens du district métallifère du lac Supérieur: Soc. Géol. France Bull., 2d ser., vol. 8, pp. 89-100, 1851.

Catalog of rocks, minerals, etc., collected by J. W. Foster: Smithsonian Rept., 1854, pp. 384-387.

(and Whitney, J. D.) On the origin and stratigraphical relations of the trappean rocks of Lake Superior (abstract): Ann. Sci. Discovery for 1861, p. 285, 1861.

GAY \& Sturgis (publishers).

Copper, a weekly review of the Lake Superior mines (A. L. Carnahan, editor), vols. 1, 2, and 3, Apr. 4, 1908, to Nov. 19, 1910.

Gordon, W. C.

The Black River section near Bessemer [Mich.]: Michigan Acad. Sci. Rept. 7, pp. 188-195, 1905.

(assisted by Lane, A. C.) A geological section from Bessemer down Black River: Michigan Geol. Survey Rept. for 1906, pp. 397-507, map, 1907.

Grant, U. S.

Note on the Keweenawan rocks of Grand Portage Island, north coast of Lake Superior: Am. Geologist, vol. 13, pp. 437-439, 1894; abstract, Minnesota Univ. Quart. Bull., vol. 2, p. 92, 1894.

Preliminary report on the copper-bearing rocks of Douglas County, Wis.: Wisconsin Geol. Survey Bull. 6 (Econ. ser. 33), 525 pp. maps, Madison, Wis., 1900.

Junction of Lake Superior sandstone and Keweenawan traps in Wisconsin (abstract): Geol. Soc. America Bull., vol. 13, pp. 6-9, 1901.

Gray, A. B.

Mineral lands of Lake Superior region: 28th Cong., spec. sess., S. Ex. Doc. 175, pp. 14-22, 1845.

Report on mineral lands on Lake Superior: 29th Cong., 1st sess., H. Doc. 211, 23 pp., map, 1846.

Grout, Frank Fitch.

Keweenawan copper deposits: Econ. Geology, vol. 5, pp. $471-476,1910$.

(and Soper, E. K.) Geology of Minnesota: U. S. Geol. Survey Bull. 678 , pp. 70-105, 2 pls. (incl. map), 3 figs., 1919.

Contribution to the petrography of the Keweenawan: Jour. Geology, vol. 18, pp. 633-657, map, 1910.

The pegmatites of the Duluth gabbro: Econ. Geology, vol. 13, pp. 185-197, 1918. 
Grout, Frank Fitch-Continued.

The lopolith, an igneous form exemplified by the Duluth gabbro: Am. Jour. Sci., 4th ser., vol. 46, pp. 516-522, 1918.

Internal structures of igneous rocks; their significance and origin; with special reference to the Duluth gabbro: Jour. Geology, vol. 26, pp. 439-458, 1918; abstract, with discussions by W. J. Miller and M. E. Wilson: Geol. Soc. America Bull., vol. 29, pp. 100-101, 1918.

Guck, Homer.

Geology of the Michigan copper district: Eng. and Min. Jour., vol. 108, pp. 948-949, 1919.

Hall, Christopher Webber.

Field report: Minnesota Geol. Survey Seventh Ann. Rept., pp. 26-29, 1878.

Report of Professor C. W. Hall, Minnesota Geol. Survey Eighth Ann. Rept., pp. 126-138, 1879.

A brief history of copper mining in Minnesota: Minnesota Acad. Nat. Sci. Bull., vol. 3, pp. 105-111, 1889; abstract, Minnesota Univ. Quart. Bull., vol. 1, p. 91, 1893.

Keweenawan area of eastern Minnesota: Geol. Soc. America Bull., vol. 12, pp. 313-342, map, 1901.

HaLl, James.

On the Silurian system of the Lake Superior region: Am. Jour. Sci., 2d ser., vol. 17, pp. 181-194, 1854.

Hayes, Augustus Allen.

On the occurrence of massive datolite in the mines of Lake Superior: Boston Soc. Nat. Hist. Proc., vol. 8, pp. 62-64, 1861.

HeNWOOD, William JoRY.

On the native copper of Lake Superior: Royal Geol. Soc. Cornwall Trans., vol. 8, pp. 385-489, 1871.

Hill, Samuel W. (See Foster, John Wells.)

Hodge, James Thacher.

On the mineral region of Lake Superior: Am. Assoc. Adv. Sci. Proc., vol. 2, pp. 301-308, 1850.

Hopper, Walter E.

Michigan copper industry in 1915: Michigan Geol. Survey Pub. 21, (Geol. ser. 17), pp. 11-56, 1916.

Hore, Reginald Edwin.

In the Michigan copper country: Canadian Min. Jour., vol. 30 , pp. 421-422, 1909.

The copper-mining industry of Michigan: Min. World, vol. 36, pp. 601-603, 656-658, 707-710, 763-767, 1912.

The copper industry of Michigan: Michigan Geol. Survey Pub. 8 (Geol. ser. 6), pp. 15-115, 1912.

The Michigan copper industry in 1913: Michigan Geol Survey Pub. 16 (Geol. ser. 13), pp. 11-37, 1914.

Michigan copper deposits: Michigan Geol. Survey Pub. 19, pp. 19-161, 1915.

Hotchisis, William Otis.

Mining and mineral resources of Wisconsin: Am. Min. Cong. 9th Ann. Sess. Rept. Proc., pp. 220-225, 1907.

Report of the Director of the Survey: Wisconsin Geol. and Nat. Hist. Survey Twelfth Bienn. Rept., 37 pp., 2 figs., 1920.

The Lake Superior geosyncline: Geol. Soc. America Bull., vol. 34 , pp. 669-678, 1923.

(See also Thwaites, F. T.)

Houghton, Douglass.

Report of the State geologist: Michigan H. Doc. 14, S. Doc. 16,37 pp., 1838.

Second annual report of the State geologist of the State of Michigan, 39, 123 pp., Detroit, 1839.

Third annual report of the State geologist of the State of Michigan: Michigan H. Doc. 8, 124 pp., map, 1840.

Fifth annual report of the State geologist: Michigan $\mathrm{H}$. Doc. 2, sess. 1842, pp. 436-441, 1842.
Houghton, Douglass-.-Continued.

Metalliferous veins of the northern peninsula of Michigan: Am. Jour. Sci., vol. 41, pp. 183-186, 1841; Assoc. Am. Geologists Rept., 1843, pp. 35-38.

Sixth annual report of the State geologist: Michigan Legisl. Doc. 8, sess. 1843, pp. 398-402, 1843.

Seventh annual report of the State geologist: Michigan Legisl. 1844, Joint Doc. 11, 3 pp., 1844.

Copper on Lake Superior: Am. Jour. Sci., vol. 47, pp. 107, 132,1844 .

Fourth annual report of the State geologist: Michigan H. Doc. 27, 184 pp., 1841. In part, with title General geology of the Upper Peninsula: 29th Cong., 2d sess., H. Rept. 591, pp. 6-38, map, 1846.

Report on the copper of Lake Superior, in Schoolcraft, H. R., Narrative of an expedition through the upper Mississippi to Itasea Lake, pp. 287-292, New York, 1834; also in Schooleraft, H., R., Summary narrative, pp. 526-531, Philadelphia, 1855.

Lithology [of the Upper Peninsula]: Michigan Geol. Sur. vey, vol. 2, pp. 239-246, 1873.

Houghton, JACOB, jr.

(and Bristol, T. W.) Reports of Wm. A. Burt and Bela Hubbard on the geography, topography, and geology ... of the south shore of Lake Superior, 109 pp., map, Detroit, 1846.

The ancient copper mines of Lake Superior: Wisconsin Hist. Soc. Coll., vol. 8, pp. 140-151, 1879.

Hovey, EDMUnd Otis.

An analcite copper boulder from the Keweenaw Range, Michigan: Science, vol. 22, p. 93, 1893.

HubBard, Bela.

General observations upon the geology and topography of the district south of Lake Superior: 29th Cong., 1st sess., S. Ex. Doc. 357, pp. 20-29, 1846.

Geological report [of field work in Lake Superior land district]: 31st Cong., 1st sess., S. Ex. Doc. 1, pt. 3, and H. Ex. Doc. 5, pt. 3, pp. 833-842, 882-932, 1849.

HubBard, Lucius Lee.

Macroscopic minerals of Michigan: Michigan Geol. Survey Rept. for 1891-92, pp. 174-176, 1893.

Two new geological cross sections of Keweenaw Point: Lake Superior Min. Inst. Proc., vol. 2, pp. 79-96, 1894.

The relation of the vein at the Central mine, Keweenaw Point, to the Kearsarge conglomerate: Lake Superior Min. Inst. Proc., vol. 3, pp. 74-83, 1895.

Keweenaw Point with particular reference to the felsites and their associated rocks: Michigan Geol. Survey, vol. 6, pt. 2, 155 pp., maps, 1898.

Sixth annual report of the State geologist, 9 pp., Lansing, 1899.

Work of the Geological Survey in the Upper Peninsula: Michigan Miner, vol. 3, No. 3, p. 9, 1901.

Geological notes on the Lake Superior copper formation: Lake Superior Min. Inst. Proc., vol. 17, pp. 9-11, 1912.

In the Lake Superior area what influence, if any, did the thickness and contour of footwall beds have upon the subsequent deposition and distribution of copper in overlying beds? [with discussion]: Lake Superior Min. Inst. Proc., vol. 17, pp. 227-237, 1912.

(See also Koenig, G. A.)

Hulbert, E. J. (See Booth, John C.)

Hunt, T. Sterry.

On some points in American geology: Am. Jour. Sci., 2d ser., vol. 31, pp. 392-414, 1861.

The geognostical history of the metals: Am. Inst. Min. Eng. Trans., vol. 1, pp. 313-334, 1873.

The origin of metalliferous deposits: Idem, pp. 413-426. 
Hont, T. Sterry-Continued.

The geology of the north shore of Lake Superior (supplementary note): Am. Inst. Min. Eng. Trans., vol. 2, pp. 58-59, 1873.

Azoic rocks, part 1: Second Pennsylvania Geol. Survey Rept. E, 253 pp., 1878.

The history of some pre-Cambrian rocks in America and Europe: Am. Jour. Sci., 3d ser., vol. 19, pp. 268-283, 1880.

Irving, Roland Duer.

On the age of the copper-bearing rocks of Lake Superior and on the westward continuation of the Lake Superior synclinal: Am. Jour. Sci., 3d ser., vol. 8, pp. 46-56, map, 1874.

On some points in the geology of northern Wisconsin: Wisconsin Acad. Sci. Trans., vol. 2, pp. 107-119, 1874.

Note on the age of the crystalline rocks of Wisconsin: Am. Jour. Sci., 3d ser., vol. 13, pp. 307-309, 1877.

Note on the stratigraphy of the Huronian series of northern Wisconsin and on the equivalency of the Huronian of the Marquette and Penokee districts: Am. Jour. Sci., 3d ser., vol. 17, pp. 393-398, 1879.

Geological structure of northern Wisconsin, with maps: Wisconsin Geol. Survey, vol. 3, pt. 1, pp. 1-25, 1880.

Geology of the eastern Lake Superior district, with atlas: Wisconsin Geol. Survey, vol. 3, pt. 3, pp. 51-238, 1880.

The copper-bearing rocks of Lake Superior: U. S. Geol. Survey Mon. 5, xvi, 464 pp., maps, 1883; Third Ann. Rept., pp. 89-188, map, 1883.

The copper-bearing rocks of Lake Superior: Science, vol. 1, pp. 140-141, 359-360, 422, 1883.

The copper-bearing rocks of Lake Superior: Am. Jour. Sci., 3d ser., vol. 29, pp. 258-259, 1885.

(and Chamberlin, T. C.) Observations on the junction between the Eastern sandstone and the Keweenaw series on Keweenaw Point, Lake Superior: U. S. Geol. Survey Bull. 23, 124 pp., 1885; review, Am. Geologist, vol. 1, pp. 44-57, 1888.

On the classification of the early Cambrian and pre-Cambrian formations: U. S. Geol. Survey Seventh Ann. Rept., pp. 365-454, 1888.

Jackson, Charles Thomas.

[On minerals from Keweenaw Point, Lake Superior]: Boston Soc. Nat. Hist. Proc., vol. 1, p. 203, 1845.

[On copper ores of the Lake Superior region]: Boston Soc. Nat. Hist. Proc., vol. 2, pp. 57-58, 1845.

On the copper and silver of Keweenaw Point, Lake Superior [with discussion by C. U. Shepard]: Am. Jour. Sci., vol. 49, pp. 81-93, 1845; Assoc. Am. Geologists Proc., vol. 6, pp. $53-61,1845$.

Sur le gisement de cuivre et d'argent natifs des bords du lac Supérieur: Compt. Rend., vol. 20, pp. 593-595, 1845; Soc. géol. France Bull., 2d ser., vol. 2, pp. 317-319, 1845; abstract, Neues Jahrb., 1845, pp. 479-480.

[On the copper and silver ores of the Lake Superior region]: Boston Soc. Nat. Hist. Proc., vol. 2, pp. 110-114, 1846.

Chemical analyses of the [copper] ores [of the Lake Superior region]: 29th Cong., 1st sess., H. Rept. 591, pp. 38-44, 1846.

Ores and minerals from Lake Superior: Boston Soc. Nat. Hist. Proc., vol. 2, pp. 256, 259, 260, 1847.

Mineral lands of Lake Superior: 30th Cong., 2d sess., S. Ex. Doc. 2, No. 2, pp. 153-163, 1847.

[Report on the survey of the mineral lands in Michigan]: Idem, pp. 175-230.

Report on the progress of the geological survey of the mineral lands of the United States in Michigan: Idem, pp. 185-191.
Jackson, Charles Thomas-Continued.

[Notes on the Lake Superior region]: Boston Soc. Nat. Hist. Proc., vol. 3, pp. 76-77, 228, 1848.

Report on the geological and mineralogical survey of the mineral lands of the United States in the State of Michigan: 31st Cong., 1st sess., S. Ex. Doc. 1, pt. 3, and H. Ex. Doc. 5, pt. 3, pp. 371-502, maps, 1849.

Copper of the Lake Superior region: Am. Jour. Sci., 2d ser., vol. 7 , pp. 286-287, 1849.

On the geological structure of Keweenaw Point: Am. Assoc. Adv. Sei. Proc., vol. 2, pp. 288-301, 1850; Am. Jour. Sci., 2d ser., vol. 10, pp. 65-77, 1849; Annales des mines, 4th ser., vol. 17 , pp. 103-115, 1850.

Remarks on the geology, mineralogy, and mines of Lake Superior: Am. Assoc. Adv. Sci. Proc., vol. 2, pp. 283-287, 1850; Soc. géol. France Bull., 2d ser., vol. 7, pp. 667-673, 1850 .

Analyses of pitchstone porphyry from Isle Royale and of a crystal of phosphate of lime from Hurdstown, N. J.: Boston Soc. Nat. Hist. Proc., vol. 4, pp. 39-41, 1851; Am. Jour. Sci., 2d ser., vol. 11, pp. 401-403, 1851.

On the age of the sandstones of the United States: Boston Soc. Nat. Hist. Proc., vol. 3, pp. 335-339, 1850.

Rain-drop and air-bubble impressions: Boston Soc. Nat. Hist. Proc., vol. 4, pp. 131-132, 1853.

Igneous origin of calcite veins: Idem, pp. 308-309.

Geology, mineralogy, and topography of the lands around Lake Superior: 32 d Cong., 1st sess., S. Ex. Doc. 112, pp. 232-244, 1853.

Ueber den Metall-führenden Distrikt am Oberen See im Staate Michigan: Archiv Mineralogie, vol. 25, pp. $656-667,1853$.

Observations sur quelques mines des Etats-Unis et sur le grès rouge du lac Supérieur: Compt. Rend., vol. 39, pp. $803-807,1854$.

Catalog of rocks, minerals, and ores collected during the years 1847 and 1848 on the geological survey of the United States mineral lands in Michigan: Smithsonian Inst. Ann. Rept., vol. 9, pp. 338-367, 1855.

[Trap dikes]: Boston Soc. Nat. Hist. Proc., vol. 6, pp. 23-24, 1856.

[On the Ashbed and the origin of the copper]: Boston Soc. Nat. Hist. Proc., vol. 5, pp. 280-281, 1856; vol. 7, p. 31, 1859.

Age of the Lake Superior sandstone: Boston Soc. Nat. Hist. Proc., vol. 7, pp. 396-398, 1860.

On domeykite from the vicinity of Portage Lake, Lake Superior: Boston Soc. Nat. Hist. Proc., vol. 8, p. 258, 1862.

Sur les mines de cuivre du lac Supérieur et sur un nouveau gisement d'étain dans l'Êtat du Maine: Compt. Rend., vol. 69, pp. 1082-1083, 1869.

JACKson, J. F.

Copper mining in Upper Michigan, a description of the region, mines, and some of the methods and machinery used: Mines and Minerals, vol. 23, pp. 535-540, 1903.

Joy, Charles A.

Examination of a few American minerals: New York Lyc. Nat. Hist. Annals, vol. 8, pp. 120-125, 1865.

Julien, Alexis Anastay.

Lithology: Michigan Geol. Survey, Upper Peninsula, vol. 2 , pp. 1-197, 1873

Microscopical examination of eleven rocks from Ashland County, Wis.: Wisconsin Geol. Survey, vol. 3, pp. 224-238, 1880.

Notes on a feldspar from the Calumet copper mine, Keweenaw Point, Mich. [abstract]: Science, new ser., vol. 9, p. 719,1899 ; New York Acad. Sci. Annals, vol. 12 , pp. $650-654,1900$.

(See also Brooks, Thomas Benton.) 
Keller, H. F.

(and Lane, A. C.) Chloritoid von Champion, Mich., U. S. A.: Zeitschr. Kryst. Min., vol. 19, pp. 383-385, 1891.

(See also Lane, A. C.)

KLoos, J. H. (See Streng, A.)

Kenny, H. C. (See Benedict, C. H.)

Koch, Friedrich Karl Ludwig.

Die Mineralgegenden der Vereinigten Staaten NordAmerikas am Lake Superior, 72 pp., Göttingen, 1851.

Kupfer- und Eisenerze am Lake Superior: Deutsch. geol. Gesell. Zeitschr., vol. 3, pp. 355-358, 1851.

Die Mineral-Regionen der obern Halbinsel Michigan's (N. A.) am Lake Superior und die Isle Royale, 248 pp., map, Göttingen, 1852; Göttingischer Ver. bergmännischer Freunde (J. F. L. Hausmann) Studien, vol. 6, pp. 1-248, map, 1854; abstract, Min. Mag., vol. 1, pp. 261-268, 1853.

Koenig, George Augustus.

(and Hubbard, L. L.) On powellite from a new locality [Houghton County, Mich.]: Am. Jour. Sci., 3d ser., vol. 46, pp. 356-358, 1893; Zeitschr. Kryst. Min., vol. 22, pp. 463-466, 1894.

Ueber Mohawkit, Stibiodomeykit, Domeykit, Algodonit und einige künstliche Kupferarsenide: Zeitschr. Kryst. Min., vol. 34, pp. 67-77, 1901; Am. Jour. Sei., 4th ser., vol. 10 , pp. $439-448,1900$ (translation?).

On the new species melanochalcite and keweenawite, with notes on some other known species: Am. Jour. Sci., 4th ser., vol. 14, pp. 404-416, 1902.

On artificial production of crystallized domeykite, algodonite, argentodomeykite, and stibiodomeykite: Am. Philos. Soc. Proc., vol. 42, pp. 219-237, 1903.

Kraus, Edward Henry.

Occurrence and distribution of celestite-bearing rocks: Am. Jour. Sci., 4th ser., vol. 19, pp. 286-293, 1905; abstract, Am. Geologist, vol. 35, p. 130, 1905; Geol. Soc. America Bull., vol. 16, p. 574, 1906; Sci. Am. Suppl., vol. 59, p. 24326, 1905.

Lane, Alfred Church.

(and Keller, H. F., and Sharpless, F. F.) Notes on Michigan minerals: Am. Jour. Sci., 3d ser., vol. 42, pp. 499-508, 1891.

(and Keller, H. F.) Chloritoid von Champion, Mich., U. S. A.: Zeitschr. Kryst. Min., vol. 19, pp. 383-385, 1891.

Microscopic characters of rocks and minerals of Michigan: Michigan Geol. Survey Rept. for 1891-92, pp. 176-183, 1893.

The geology of Lower Michigan with reference to deep borings [edited from notes of C. E. Wright]: Michigan Geol. Survey, vol. 5, pt. 2, 100 pp., map, 1895.

Geological report on Isle Royale, Mich.: Michigan Geol. Survey, vol. 6, pt. 1, 281 pp., map, 1898.

Isle Royale; what has been accomplished in unearthing its mineral wealth: Michigan Miner, vol. 1, No. 11, pp. 18-21; No. 12, pp. 14-18, 1899.

The geothermal gradient in Michigan: Am. Jour. Sci., 4th ser., vol. 9, pp. 434-438, 1900.

The Geological Survey; annual report of the State geologist for the year ending Dec. 31, 1899: Michigan Miner, vol. 2 , No. 3, pp. 9-13, 1900.

Suggestions from the State geologist: Michigan Miner, vol. 3 , No. 10, p. 9, 1901.

Suggested changes in nomenclature of Michigan formations: Michigan Miner, vol. 3, No. 10, p. 9, 1901.

The economic geology of Michigan in its relations to the business world: Michigan Miner, vol. 4, No. 1, pp. 9-15, 1901.
Lane, Alfred Church-Continued.

Annual report of the State geologist [for 1900]: Michigan Miner, vol. 3, No. 2, pp. 13-21, 1901.

Third annual report of the State geologist ... for the year 1901: Michigan Geol. Survey Rept. for 1901, 304 pp., maps, 1902.

Recent work of the Geological Survey: Michigan Acad. Sci. Rept., vol. 3, pp. 38-39, 1902.

Geothermal gradient: Michigan Geol. Survey Rept., for 1901, pp. 244-251, 1902.

Economic geology [of Michigan]: Michigan Geol. Survey Rept. for 1901, pp. 121-137, 1902.

Variation of geothermal gradient in Michigan [abstract]: Science, new ser., vol. 15, p. 88, 1902; Geol. Soc. America Bull., vol. 13, pp. 528-529, 1903.

Annual report Geological Survey of Michigan [for 1902]: Michigan Miner, vol. 5, No. 2, pp. 16-26 (reprinted, 26 pp., map), 1903

The economic geology of Michigan [abstract]: Science, new ser., vol. 17, p. 218, 1903; Eng. and Min. Jour., vol. 75, p. 152, 1903; Sci. Am. Suppl., vol. 55, p. 22666, 1903.

Fifth annual report of the State geologist, for the year 1903: Michigan Geol. Survey Rept. for 1903, 342 pp., maps, 1905; Sixth . . . for 1904: Idem for 1904; pp. 113-168, 1905; Seventh ... for 1905: Idem for 1905, pp. 535-571, 1906; Eighth . . . for 1906: Idem for 1906, pp. 573-594, 1907; Ninth . . for 1907: Idem for 1907, pp. 3-31, 1908; Tenth . . for 1908: Idem for 1908, pp. 1-19, map, 1909.

Magnetic phenomena around deep borings: Michigan Acad. Sci. Rept., vol. 4, pp. 166-167, 1904.

Historical review of the geology of Michigan: Michigan Acad. Sci. Rept., vol. 5, pp. 184-195, 1904.

The theory of copper deposition: Michigan Miner, vol. 6, No. 2, pp. 9-11, No. 3, pp. 9-11, 1904; Am. Geologist, vol. 34, pp. 297-309, 1904; Michigan Geol. Survey Rept. for 1903, pp. 239-249, 1905.

Waters of the Upper Peninsula of Michigan: Michigan Geol. Survey Rept. for 1903; pp. 111-167, 1905.

The Tamarack mine cross section and the Keweenawan lodes: Michigan Geol. Survey Rept. for 1903, pp. 251$270,1905$.

Comment on the "Report of the special committee on the Lake Superior region": Jour. Geology, vol. 13, pp. 457$461,1905$.

Underground waters of Michigan: U. S. Geol. Survey Water-Supply Paper 114, pp. 242-247, map, 1905.

Black River work: Michigan Geol. Survey Rept. for 1904, pp. 158-162, 1905.

The geology of Keweenaw Point, a brief description: Lake Superior Min. Inst. Proc., vol. 12, pp. 81-104, 1907; abstract, Mines and Minerals, vol. 27, pp. 204-206, 1906.

The formation of Lake Superior copper: Science, new ser., vol. 25 , p. 589, 1907.

Different manifestations of the ophitic texture [abstract]: Science, new ser., vol. 25, pp. 774-775, 1907.

(and Seaman, A. E.) Notes on the geological section of Michigan; Part I, The pre-Ordovician: Jour. Geology, vol. 15 , pp. 680-695, 1907.

Ophitic texture (abstract): Geol. Soc. America Bull., vol. 18, pp. 648-649, 1908.

Mine waters: Lake Superior Min. Inst. Proc., vol. 13, pp. 63-152, 1908.

Summary of the surface geology of Michigan: Michigan Geol. Survey Rept. for 1907, pp. 89-152, map, 1908.

Salt water in the Lake mines: Lake Superior Min. Inst. Proc., vol. 12, pp. 154-163, 1907; Michigan Miner, vol. 11, No. 4, pp. 24-26, 1909. 
Lane, Alfred Church-Continued.

Notes on the geological section of Michigan; Part II, From the St. Peters up: Michigan Geol. Survey Rept. for 1908, pp. 43-105, 1909.

Geology of the Porcupine Mountains: Michigan Min World, vol. 30, pp. 1115-1117, 1909.

Mine waters and their field assay: Geol. Soc. America Bull., vol. 19 , pp. 501-512, 1909.

The decomposition of a boulder in the Calumet \& Hecla conglomerate, and its bearing on the distribution of copper in the Lake Superior copper lodes as indicating the trend and characters of the waters forming the chute: Econ. Geology, vol. 4, pp. 158-173, 1909.

Michigan iron mines and their mine waters: Min. World, vol. 31 , pp. 413-416, 1909.

(and Seaman, A. E.) Notes on the geological section of Michigan for geologists, teachers, and drillers, Part I, The Ordovician: Michigan Geol. Survey Rept. for 1908, pp. 21-42, 1909.

The Keweenaw series of Michigan: Michigan Geol. Survey Pub. 6 (Geol. ser. 4), 2 vols., 983 pp., maps, 1911.

Native copper deposits: Canadian Min. Inst. Quart. Bull., vol. 13, pp. 81-87, 1911; Canadian Min. Inst. Jour., vol. 14, pp. 316-322, 1912; reprinted in Types of ore deposits (ed. by H. F. Bain), pp. 133-139, 1911.

Unexplored parts of the copper range of Keweenaw Point [with discussion]: Lake Superior Min. Inst. Proc., vol. 17, pp. 127-143, 1912.

Diamond drilling at Point Mamainse, Province of Ontario; with introduction by Alfred W. G. Wilson: Canada Mines Branch Bull. 6, 59 pp., map, 1912.

The age of the Keweenawan series [abstract]: Michigan Acad. Sci. Rept. 14, pp. 107-108, 1912.

New light on the Keweenaw fault [abstract]: Geol. Soc. America Bull., vol. 24, p. 718, 1913.

Mine-water composition an index to the course of orebearing currents: Econ. Geology, vol. 9, pp. 239-263, 1914; Tufts Coll. Studies, vol. 4, No. 1, pp. 239-263, 1914.

Keweenaw fault: Geol. Soc. Ameriea Bull., vol. 27, pp. 93-100, 1916.

The origin of the mirabilite from the Isle Royale mine [Houghton, Mich.]: Am. Mineralogist, vol. 2, pp. 63-64, 1917.

(See also Gordon, W. C.; Wright, F. E.)

Lang, S. S.

Porphyry intrusions of the Michigan copper district: Eng. and Min. Jour., vol. 107, p. 452, 1919.

Copper deposits of Lake Superior: Min. and Sci. Press, vol. 121, pp. 407-408, 1920.

Lapham, InCREASE A.

The Penokee Iron Range: Wisconsin Agr. Soc. Trans., vol. 5, pp. 391-400, with map, 1860.

Larsen, E. S. (See Foshag, Wm. F.)

Lawson, Andrew Cowper.

The correlation of the pre-Cambrian rocks of the region of the Great Lakes: California Univ. Dept. Geology Bull., vol. 10 , pp. 1-19, 1916.

Leith, Charles Kenneth.

A summary of Lake Superior geology, with special reference to recent studies of the iron-bearing series: Am. Inst. Min. Eng. Bimonthly Bull., vol. 3, pp. 453-507, map, 1905; Am. Inst. Min. Eng. Trans., vol. 36, pp. 101-153, map, 1907; reprinted in part in Emmons, S. F., Ore deposits, pp. 633-656, map, 1913.

(See also Van Hise, C. R.)

Leverett, Frank.

Glacial lakes and their correlative ice borders in the Superior basin [abstract]: Michigan Acad. Sci. Ann. Rept., vol. 19, pp. 101-102, 1917.
Lindgren, WALDEMAR.

Genesis of copper with zeolites in basic rocks: Min. and Eng. World, vol. 35, No. 27, p. 1311, 1911.

Some modes of deposition of copper ores in basic rocks: Econ. Geology, vol. 6, No. 7, pp. 687-700, 1911.

LOCKe, JоHN.

Geology of Porters Island and Copper Harbor: Am. Philos. Soc. Trans., vol. 9, pp. 311-312, maps, 1846.

Observations made ... to determine the magnetical dip and the intensity of magnetical force in several parts of the United States [includes notes on geology of stations]: Am. Philos. Soc. Trans., new ser., vol. 9, pp. 283-328, 1846.

[Geological observations in the Upper Peninsula of Michigan]: Gen. Land Office Rept. for 1847 (30th Cong., 1st sess., S. Ex. Doc. 2), pp. 183-199, 1847.

Catalog of rocks, minerals, ores, and fossils collected by Dr. John Locke [Lake Superior region]: Smithsonian Inst. Ann. Rept., vol. 9, for 1854, pp. 367-383, 1855.

Logan, William E.

Remarks on the mining region of Lake Superior, and a report on mining locations claimed on the Canadian shores of the lake, $31 \mathrm{pp}$., with maps, Montreal, 1847.

On the geology and economic minerals of Lake Superior: Canada Geol. Survey Rept. Progress for 1846-47, pp. 8-34, 1847.

Report on the north shore of Lake Huron, 51 pp., Canada Geol. Survey, 1849.

On the age of the copper-bearing rocks of Lakes Superior and Huron: Am. Jour. Sci., 2d ser., vol. 14, pp. 224-229, 1852 .

Considerations relating to the Quebec group and the upper copper-bearing rocks of Lake Superior: Canadian Naturalist, vol. 6, pp. 199-207, 1861.

Geology of Canada, 983 pp., with atlas, Montreal, 1863.

Kupfererzeführende Gesteine am Obern See: Jahrb. Mineralogie, 1864, p. 741.

Notes on the report of Mr. Robert Bell on the Nipigon region: Canada Geol. Survey Rept. Progress for 18661869, pp. 471-475, 1870.

Longyear, Clyde S.

Results of drilling in the Nonesuch formation between the White Pine mine and Lake Superior: Michigan Geol. Survey Pub. 24 (Geol. ser. 20), pp. 19-20, 1916.

McCracken, Stephen B.

The State of Michigan, embracing sketches of its history, position, resources, and industries [Mineral resources, pp. 48-73], 136 pp., Lansing, Mich., 1876.

McDermott, Walter.

The Silver Islet vein, Lake Superior: Eng. and Min. Jour., vol. 23, pp. 54-55, 70-71, 1877; Inst. Min. Met. Trans., vol. 18, pp. 220-231, 1909; Canadian Min. Jour., vol. 30, pp. 135-138, 1909.

Macfarlane, Thomas.

[Report on the geology of Lake Superior]: Canada Geol. Survey Rept. Progress for 1863-1866, pp. 115-148, 1866.

On the rocks and cupriferous beds of Portage Lake, Mich.: Canada Geol. Survey Rept. Progress for 1863-1866, pp. 149-164, 1866; Canadian Naturalist, new ser., vol. 3, pp. $1-18,1866$.

On the geological formations of Lake Superior: Canadian Naturalist, new ser., vol. 3, pp. 177-201, 241-256, $1867-68$.

On the geology and silver ore of Wood's Location, Thunder Cape, Lake Superior: Canadian Naturalist, 2d ser., vol. 4, pp. 37-48, 459-463, 1869.

MCINTYRe, James.

Report on Isle Royale: 31st Cong., 1st sess., S. Ex. Doc. 1, pt. 3, and H. Ex. Doc. 5, pt. 3, pp. 506-509, 1849. 
Marcou, John Belknap.

(and Marcou, Jules.) Geologic maps of Michigan: U. S. Geol. Survey Bull. 7, pp. 77, 78, 79, 80, 81, 82, 83, 85, $87,88,1884$.

Marcou, Jules.

Réponse à la lettre de MM. Foster et Whitney sur le lac Supérieur: Soc. géol. France Bull., 2d ser., vol. 8, pp. 101-105, 1851 .

A geological map of the United States and the British provinces of North America, with an explanatory text, geological sections, etc., 92 pp., Boston, 1853.

Dyas et Trias, ou le nouveau grès rouge en Europe, dans l'Amérique du Nord et dans l'Inde, 63 pp., Zurich, 1859.

(See also Marcou, John Belknap.)

Marvine, Archibald Robertson.

General structure and lithology of the Eagle River section; descriptive eross section of the Eagle River district: Michigan Geol. Survey, vol. 1, pt. 2, pp. 95-140, 1873.

Correlation of the rocks of Houghton and Keweenaw Counties: Idem, pp. 47-61, 95-140.

Mattice, Asa Edson.

How Michigan was made: Michigan Miner, vol. 2, No. 1, pp. $15-17$; No. 2 , pp. 9-14; No. 3 , pp. $13-17$; No. 4 , pp. 20-22; No. 5 , p. $9,1899-1900$.

Meads, Alfred.

The copper district on Lake Superior: Eng. and Min. Jour., vol. 70, p. $694,1900$.

MeUche, A. H.

The development of the copper mines of Lake Superior and their geological relations: Michigan Geol. Survey Pub. 6 (Geol. ser. 4), vol. 2, pp. 887-931, 1911.

Some practical suggestions for diamond-drill explorations: Lake Superior Min. Inst. Proc., vol. 16, pp. 77-81, 1911.

Monroe, H. S.

The losses in copper dressing at Lake Superior: Am. Inst. Min. Eng. Trans., September, 1879.

Mosler, Chr.

Der Kupferbergbau am Obern See in Nord-Amerika [copper, Lake Superior district]: Zeitschr. Berg-, Hütten- u. Salinen-wesen preuss. St., vol. 25, pp. 203-221, map, 1877 ; vol. 27 , pp. $77-97,1879$; vol. 28 , pp. $210-236,1880$.

Müller, Albrecht.

Ueber die Kupferminen am Obern See im Staate Michigan, Nord-Amerika: Naturf. Gesell. Basel Verh., vol. 1, pp. 411-438, 1857; abstract, Neues Jahrb., 1857 , pp. 79 $81,589-590$.

Murray, Alexander.

[North shore of Lake Superior]: Canada Geol. Survey Rept. Progress for 1846-47, pp. 47-57, 1847.

Nebel, Merle L.

The basal phases of the Duluth gabbro near Gabamichigami Lake, Minnesota, and its contact effects: Econ. Geology, vol. 14, pp. 367-402, 4 pls., 3 figs., 1919.

Nicholson, Henry Alleyne.

On the mining districts on the north shore of Lake Superior: North England Inst. Min. Eng. Trans., vol. 24, pp. 237-249, maps, 1875.

Nishio, KeiJiro.

Native copper and silver in the Nonesuch formation, Michigan: Econ. Geology, vol. 14, pp. 324-334, 1 pl., 1 fig., 1919.

Noggerath, Johann Jacob.

Gediegen Kupfer und Silber von Lake Superior: Neues Jahrb., 1848, p. 555.

Norwood, Joseph Gran ville.

Geological report of a survey of portions of Wisconsin and Minnesota, in Owen, D. D., Report of a geological survey of Wisconsin, Iowa, and Minnesota, pp. 209-418, Philadelphia, 1852.
ODENDALL, LEONHARD.

Die Kupfererzlagerstätten in Nordamerika (Inaug. Diss., Univ. Bonn., 63 pp., Köln, 1909.

Owen, David D.

On the age, character, and true geological position of the Lake Superior red sandstone formation, in Report of a geological survey of Wisconsin, Iowa, and Minnesota, pp. 187-193, Philadelphia, 1852.

Palache, Charles.

The crystallization of the calcite from the copper mines of Lake Superior: Michigan Geol. Survey, vol. 6, pt. 2, pp. 161-184, 1898.

Powellite crystals from Michigan: Am. Jour. Sci., 4th ser., vol. 7, pp. 367-369, 1899; Zeitschr. Kryst. Min., vol. 31, pp. 529-531, 1899.

(and Vassar, H. E.) Some minerals of Keweenaw copper deposits; pumpellyite, a new mineral; sericite; saponite: Am. Mineralogist, vol. 10, pp. 412-418, 1925.

Patton, Horace Bushnell.

Microscopic study of some Michigan rocks: Michigan Geol. Survey Rept. for 1891-92, pp. 184-186, 1893.

Peck, Albert B.

Mirabilite from the Isle Royale copper mine, Houghton, Mich.: Am. Mineralogist, vol. 2, pp. 62-63, 1917.

Penfield, Samuel Lewis.

Crystals of analeite from the Phoenix mine, Lake Superior copper region: Am. Jour. Sci., 3d ser., vol. 30, pp. 112-113, 1885.

Pettit, William.

Remarks respecting the copper distriet of Lake Superior: Franklin Inst. Jour., 3d ser., vol, 13, pp. 338-345, map, 1847.

Phelps, Frank B.

The copper region of Michigan: Eng. Mag., vol. 4, pp. 47-63, 1892.

Piggot, Aaron Snowden.

History of the copper region of Lake Superior: Min. Mag., vol. 10, pp. 124-142, 1858. From his The chemistry and metallurgy of copper, pp. 216-254, Philadelphia, 1858.

Posselt, C.

Die Kupfer-Distrikte des Obersee's Lake Superior: Neues Jahrb., 1856, pp. 1-10.

Pumpelly, Raphael.

The paragenesis and derivation of copper and its associates on Lake Superior: Am. Jour. Sci., 3d ser., vol. 2, pp. 188-198, 243-258, 347-355, 1871.

Copper district [Upper Peninsula]: Michigan Geol. Survey, vol. 1 , pt. 2,143 pp., 1873.

Metasomatic development of the copper-bearing rocks of Lake Superior: Am. Acad. Arts Sci. Proc., vol. 13, pp. 253-309, 1878.

Lithology of the Keweenawan system: Geology of Wisconsin, vol. 3, pp. 27-49, Wisconsin Geol. Survey, 1880.

(See also Brooks, Thomas Benton.)

Rath, Gerhard vom.

Ein ausgezeichneter Kalkspathkrystall vom Oberen See in Nordamerika: Annalen der Physik, vol. 152, pp. 17-21, 1874.

Einige krystallographische Beobachtungen am Kupfer vom Obern See: Zeitschr. Kryst. Min., vol. 2, pp. 169$173,1878$.

Read, Matthew Canfield.

Copper mining in Michigan: Min. Mag., vol. 12, pp. 220$224,1915$.

Rice, Claude T.

Copper mining at Lake Superior: Eng. and Min. Jour., vol. 94, pp. 119-124, 171-175, 217-220, 267-270, 307-310, 365-368, 405-407, 1912. 
RichaRdS, JosEpH W.

"Mohawkite" (ledouxite): Am. Jour. Sci., 4th ser., vol. 11, pp. $457-458,1901$.

Rickard, Thomas Arthur.

The copper mines of Lake Superior, 164 pp., New York, 1905; Eng. and Min. Jour., vol. 78, pp. 585-587, 625-627, 665-667, 705-706, 745-747, 785-787, 825-827, 905-907, 945-950, 985-987, 1904.

Rivot, L. E.

Voyage au lac Supérieur: Annales des mines, 5th ser., vol. 7 , pp. 173-328, 1855; translation, Min. Mag., vol. 6, pp. 28-37, 99-106, 207-213, 414-418, 1856; vol. 7, pp. 249 $255,359-367,1856$; vol. 9 , pp. $60-65,1857$.

Sur le gisement du cuivre natif au lac Supérieur, ÉtatsUnis d'Amérique: Compt. Rend., vol. 40, pp. 1306-1390, 1855.

Ueber die Kupfererz-Lagerstätten am Obern See in den Nord-amerikanischen Freistaaten: Berg- u. hüttenm. Zeitung, vol. 15, pp. 261-263, 269-271, 277-279, 293-295, $314-315$, 317-318, 325-328, 333-334, 341-343, 349-351, 357-359, 365-367, 381-382, 1856.

Notice sur le lac Supérieur: Annales des mines, 5th ser., vol. 10, pp. 365-474, 1856.

Robinson, W. I. (See Case, Ermine Cowles.)

Rogers, Henry Darwin.

[On the geology and mineralogy of the southern shore of Lake Superior]: Boston Soc. Nat. Hist. Proc., vol. 2, pp. 124-125, 1846.

Rogers, William B.

[On the origin of the actual outlines of Lake Superior]; Am. Assoc. Adv. Sci. Proc. 1st meeting, pp. 79-80, 1848.

Age of the sandstone: Boston Soc. Nat. Hist. Proc., vol. 7, pp. 394, 395, 1860.

Rominger, CarL LUdwig.

Observations on the Ontonagon silver-mining district and the slate quarries of Huron Bay: Michigan Geol. Survey, vol. 3, pt. 1, pp. 151-166, 1876.

Paleozoic rocks [Upper Peninsula]: Michigan Geol. Survey, vol. 1 , pt. 3, 105 pp., 1873.

Report of the State geologist for 1881-82: Michigan Geol. Survey Rept. for $1891-92$, pp. $25-28,1893$; . . for 1882-83: Idem, pp. 29-31.

Geological report on the Upper Peninsula of Michigan iron and copper regions: Michigan Geol. Survey, vol. 5, pt. 1, 179 pp., 1895.

Ruggles, Daniel.

Considerations respecting the copper mines of Lake Superior: Am. Jour. Sci., vol. 49, pp. 64-72, 1845.

Ruthven, A. G.

An ecological survey in the Porcupine Mountains and Isle Royale, Mich.: Michigan Geol. Survey Ann. Rept. for 1905 , pp. 17-47, 1906 .

(See also Allen, R. C.)

Sanders, George N.

[Mineral region of Lake Superior]: 28th Cong., 2d sess., S. Ex. Doc. 117 , pp. $3-9,1845 ; 28$ th Cong., spec. sess., S. Ex. Doc. 175, pp. 8-14, 1845.

Savage, Thomas Edmund.

(and Crooks, H. F.) Early Silurian rocks of the northern peninsula of Michigan: Am. Jour. Sci., 4th ser., vol. 45, pp. 59-64, 1918.

SAVICKI, WILLIAM V.

Geological survey of Michigan; report of field work for 1900: Michigan Miner, vol. 3, No. 3, pp. 9-11, 1901.

Schaller, Waldemar Theodore.

The supposed vanadic acid from Lake Superior in copper oxide: Am. Jour. Sci., 4th ser., vol. 39, pp. 404-406, 1915.
Schoolcraft, Henry Rowe.

Account of the native copper on the southern shore of Lake Superior: Am. Jour. Sci., vol. 3, pp. 201-216, 1821; translation in Struve, H. von, Beiträge zur Mineralogie und Geologie des nordlichen Amerikas, pp. 23-49, Hamburg, 1822.

On the number, value, and position of the copper mines on the southern shore of Lake Superior: 17th Cong., 2d sess., S. Doc. 5, 33 pp., 1822.

Bericht über das gediegene Kupfer das sich an der Südküste des Ober-Sees in Nord-Amerika in grossen Massen findet: Annalen der Physik (Gilbert), vol. 70, pp. 337-348, 1822.

Notice of a recently discovered copper mine on Lake Superior, with several other localities of minerals: Am. Jour. Sci., vol. 7, pp. 43-49, 1823.

Remarks on native silver from Michigan: New York Lyc. Nat. Hist. Annals, vol. 1, pp. 247-248, 1825.

Observations on the geology and mineralogy of the region embracing the sources of the Mississippi River and the Great Lakes basin, during the expedition of 1820: Summary narrative of an exploratory expedition to the sources of the Mississippi River in 1820, resumed and completed by the discovery of its origin in Itasca Lake in 1832 , pp. $303-362$, Philadelphia, 1854.

Seaman, A. E.

A new locality for Silurian limestone in northern Michigan: Am. Jour. Sci., 3d ser., vol. 48, p. 173, 1894.

Geology of Mineral Range: First annual review of coppermining industry of Lake Superior, pp. 49-60, 1899.

(See also Lane, A. C.)

Selwyn, Alfred R. C.

Notes of a geological reconnaissance from Lake Superior to Fort Garry: Canada Geol. Survey Rept. Progress for 1872-73, pp. 8-18, 1873.

Sharpless, F. F. (See Lane, A. C.)

Shepard, Charles U.

On the copper and silver of Keweenaw Point, Lake Superior: Assoc. Am. Geologists Proc. 6th meeting, pp. 60-61, New Haven, 1845.

Shepard, Forrest.

Remarks on a boulder mass of native copper from the southern shore of Lake Superior: Am. Jour. Sci., 2d ser., vol. 4, pp. 115-116, 1847.

Sмith, R. A.

Mineral resources of Michigan: Michigan Geol. Survey Pub. 32 (Geol. ser. 26), 145 pp., 1922.

(See also Barrett, L. P., and Allen, R. C.)

Smyth, Henry Lloyd.

On the origin of the copper deposits of Keweenaw Point [abstract]: Science, new ser., vol. 3, pp. 251-252, 1896.

Soper, E. K. (See Grout, F. F.)

Spencer, Joseph William Winthrop.

On the Nipigon or copper-bearing rocks of Lake Superior: Canadian Naturalist, new ser., vol. 8, pp. 55-81, 1876.

Sperr, F. W.

Failures of the rule of following the hanging in the development of Lake Superior copper mines [with discussion]: Lake Superior Min. Inst. Proc., vol. 17, pp. 238-246, 1912.

SpUrR, J. E.

The copper ores of Lake Superior: Eng. and Min. Jour., vol. 110 , pp. $355-357,1$ fig., 1920.

Stevens, Horace Jared.

General information of the geology and mines of the Lake Superior copper district: Am. Inst. Min. Eng. Bimonthly Bull., vol. 1, pp. 208-222, map, 1905.

Mines of the Lake Superior copper district: Lake Superior Min. Inst. Proc., vol. 12, pp. 8-24, 1907. 
Stevens, Horace Jared-Continued.

Copper Handbook, 1900-1911.

First annual review of Lake Superior copper-mining industry, 1899.

Stevens, William H.

The prospects of the Lake Superior mining region: Min. Mag., vol. 2, pp. 149-153, 1854.

Stockton, JoHn.

[Mineral lands of Lake Superior region]: 28th Cong., spec. sess., S. Ex. Doc. 175 , pp. 2-4, 1845.

Streng, A.

(and Kloos, J. H.) Utber die krystallinischen Gesteine von Minnesota in Nord-Amerika: Neues Jahrb., 1877, pp. 31-56, 113-138, 225-242.

Strong, Moses. (See Chamberlin, T. C.)

SweET, E. T.

Notes on the geology of northern Wisconsin: Wisconsin Acad. Sci. Trans., vol. 3, pp. 40-55, 1876.

Geology of the western Lake Superior district: Wisconsin Geol. Survey, vol. 3, pp. 303-362, with an atlas map, 1880 .

SwINEFord, A. P.

History and review of the copper, iron, silver, slate, and other material interests of the south shore of Lake Superior, 280 pp., Marquette, Mich., 1876.

TAYLOR, F. B.

A reconnaissance of the abandoned shore lines of the south coast of Lake Superior: Am. Geologist, vol. 13, pp. 365-383, map, 1894.

Changes of level in the region of the Great Lakes in recent geological time: Am. Jour. Sci., 3d ser., vol. 49, pp. 69-71, 1895.

Teschemacher, James Englebert.

On the vanadium minerals from Lake Superior: Am. Jour. Sci., 2d ser., vol. 11, pp. 233-234, 1851.

Thомson, Elims.

A reexamination of keweenawite: Toronto Univ. Studies, Geol. ser. 20, pp. 35-38, 1925.

Thwaites, Fredrik Turville.

(and Hotchkiss, W. O.) Map of Wisconsin showing geology and roads, 1911, Wisconsin Geol. Survey, 1912.

Sandstone of the Wisconsin coast of Lake Superior: Wisconsin Geol. Survey Bull. 25 (Sci. ser. 8), 117 pp., map, 1912.

U. S. Geological Survey.

World Atlas of commercial geology, pt. 1, Distribution of mineral production, 72 pp., 72 pls. (maps), 1921.

Van Hise, Charles Richard.

An attempt to harmonize some apparently conflicting views of Lake Superior stratigraphy: Am. Jour. Sci., 3d ser., vol. 41 , pp. 117-137, 1891.

The Huronian volcanies south of Lake Superior [abstract]: Geol. Soc. America Bull., vol. 4, pp. 435-436, 1893.

Sketch of the pre-Cambrian geology south of Lake Superior, with references to illustrative localities: Internat. Geol. Cong., 5th sess., Washington, 1891, Compt. Rend., pp. 489-512, maps, 1893 .

Excursion to Lake Superior; Pre-Cambrian geology of the Lake Superior district: Idem, pp. 110-150.

A central Wisconsin base-level: Science, new ser., vol. 4, pp. 57-59, 1896.

A northern Michigan base-level: Idem, pp. 217-220.

(and Leith, C. K.) The geology of the Lake Superior region: U. S. Geol. Survey Mon. 52, 641 pp., maps, 1911; abstract, Washington Acad. Sci. Jour., vol. 1, pp. 157-160, 1911.

Geological work in the Lake Superior region: Lake Superior Min. Inst. Proc., vol. 7, pp. 62-69, 1902.
Wadsworth, Marshman Edward.

Notes on the geology of the iron and copper districts Lake Superior: Harvard Coll. Mus. Comp. Zoolog Bull., vol. 7 (Geol. ser. 1), pp. 1-157, 1880; in part, with title On the jasper and iron ore of the Marquette region: Am. Jour. Sci., 3d ser., vol. 22, pp. 403-408, 1880.

On the age of the copper-bearing rocks of Lake Superios [abstract]: Am. Assoc. Adv. Sci. Proc., vol. 29, pp. 429-430, 1881; Eng. and Min. Jour., vol. 32, p. 270 1881 .

On the filling of amygdaloidal cavities and veins in the Keweenaw Point district of Lake Superior; a reply to Prof. James D. Dana: Boston Soc. Nat. Hist. Proc., vol. 21, pp. 91-103, 1881 .

Keweenaw Point geology: Science, vol. 1, pp. 248-249, 1883.

United States geologists, sandstones, and the Keweenaw series: Idem, p. 307.

On the relation of the Keweenawan series to the eastern sandstone in the vicinity of Torch Lake, Mich.: Boston Soc. Nat. Hist. Proc., vol. 23, pp. 172-180, 1885; ab. stract, Science, vol. 3 , p. $553,1884$.

On a supposed fossil from the copper-bearing rocks of Lake Superior: Boston Soc. Nat. Hist. Proc., vol. 23, pp 208-212, 1886.

The South Trap Range of the Keweenawan series: Am. Jour. Sci., 3d ser., vol. 42, pp. 417-419, 1891.

Report of the State geologist for 1888-89: Michigan Geol. Survey Rept. for $1891-92$, pp. $39-44,1893$; . . f for 1899-90: Idem, pp. $45-49$; . . . for 1890-91: Idem, pp. 51-57; ... for 1891-92: Idem, pp. 59-73.

A sketch of the geology of the Marquette and Keweenawan districts, in Ralph, Julian, Along the south shore of Lake Superior, pp. 63-82, copyrighted by C. B. Hibbard, of the Duluth, South Shore \& Atlantic Ry., 1890; 2d ed., pp. 75-99, 1891.

The relations of the Eastern sandstone of Keweenaw Point to the Lower Silurian limestones: Science, vol. 18, p. 25, 1891; Am. Jour. Sci., 3d ser., vol. 42, pp. 170-171, 1891.

Subdivisions of the Azoic or Archean in northern Michigan: Science, vol. 20, p. 355, 1892; Am. Jour. Sci., 3d ser., vol. 45 , pp. $72-73,1892$.

A sketch of the geology of the iron, gold, and copper districts of Michigan [abstract]: Geol. Mag., dec. 3, vol. 9, pp. 571-572, 1892.

A sketch of the geology of the iron, gold, and copper districts of Michigan: Michigan Geol. Survey Rept. for 1891-92; pp. 75-174, 1893.

The copper deposits of Michigan: Geol. Mag., dec. 4, vol. 3 , pp. 20-23, 1896.

The origin and mode of occurrence of the Lake Superior copper deposits: Am. Inst. Min. Eng. Trans., vol. 27 pp. 669-696, 1898.

Weed, Walter Harvey.

The copper mines of the United States in 1905: U. S. Geol. Survey Bull. 285, pp. 93-124, 1906.

The Copper Handbook, vol. 11, 1912-13.

The Mines Handbook and Copper Handbook, vols. 12-15, 1916-1922.

Whitney, Josiah Dwight.

Report of work in the Upper Peninsula of Michigan: Gen. Land Office Rept. for 1847 (30th Cong., 1st sess., S. Ex. Doc. 2), pp. 221-230, 1847.

Description and analysis of three minerals from Lake Superior: Boston Jour. Nat. Hist., vol. 5, pp. 486-489, 1847. 
Whitney, Josiah Dwight-Continued.

[On jacksonite, a new mineral from the Lake Superior region]: Boston Soc. Nat. Hist. Proc., vol. 3, pp. 5-6, 1848.

[On the composition of chloritoid or chlorite spar and masonite; and on oxide of copper from Copper Harbor, Lake Superior]: Boston Soc. Nat. Hist. Proc., vol. 3, pp. 100-103, 1849.

[Report of field work in the Lake Superior land district]: 30th Cong., 2d sess., S. Ex. Doc. 2, pp. 154-159, 1849.

Notes on the topography, soil, geology, etc., of the district between Portage Lake and the Ontonagon: 31st Cong., 1st sess., S. Ex. Doc. 1, pt. 3, and H. Ex. Doc. 5, pt. 3, pp. 649-701, 1849 .

Field notes for 1847 [in the Lake Superior region]: Idem, pp. 713-758.

[On the mineral lands of the Lake Superior region]: Boston Soc. Nat. Hist. Proc., vol. 3, pp. 210-212, 1850.

Catalog of the rocks, minerals, etc., collected on the district between Portage and Montreal River during the years 1847 and 1848: Smithsonian Inst. Ann. Rept., vol. 9, for 1854, pp. 387-392, 1855 .

Remarks on some points connected with the geology of the north shore of Lake Superior: Am. Assoc. Adv. Sci. Proc. for 1855 , pp. 202-209, 1856.

Notes on the geological position of the Lake Superior sandstone: Min. Mag., 2d ser., vol. 1, pp. 435-446, 1860.

(See also Foster, John Wells.)

Wells, Roger C.

Chemistry of deposition of native copper from ascending solutions: U. S. Geol. Survey Bull. 778, 1925.

Whittlesey, Charles.

Copper regions of Lake Superior, 64 pp., 1846.

Description of part of Wisconsin south of Lake Superior, with maps, in Owen, D. D., Report of a geological survey of Wisconsin, Iowa, and Minnesota, pp. 425-470, 1852.

Drift etchings, Lake Superior: Annals Sci., vol. 2, pp. 57-59, Cleveland, 1854.

On the origin of the Azoic rocks of Michigan and Wisconsin: Am. Assoc. Adv. Sci. Proc., vol. 13, pp. 301-308, 1860.

Ancient mining on the shores of Lake Superior: Smithsonian Inst. Contr. Knowledge, vol. 13, art. 4 (155), 29 pp., 1863.

The Penokie mineral range, Wis.: Boston Soc. Nat. Hist. Proc., vol. 9, pp. 235-244, 1863.

Physical geology of Lake Superior: Am. Assoc. Adv. Sei. Proc., vol. 24, pp. 60-72, 1876.

On the origin of mineral veins: Am. Assoc. Adv. Sci. Proc., vol. 25 , pp. 213-216, 1877.

On the Iron River silver district: Eng. and Min. Jour., vol. 23 , pp. 254-255, 278-279, 1877.

Preglacial channel of Eagle River, Mich. [abstract]: Am. Assoc. Adv. Sci. Proc., vol. 31, p. 352, 1883.

The preglacial channel of Eagle River, Keweenaw Point, Lake Superior: Am. Jour. Sei., 3d ser., vol. 29, pp. 392$397,1885$.

Williams, Charles P.

(and Blandy, J. F.) ... the Copper Range of Lake Superior: Am. Jour. Sci., 2d ser., vol. 34, pp. 112-120, 1862.

Winchell, Alexander.

Notice of a small collection of fossils from the Potsdam sandstone of Wisconsin and the Lake Superior sandstone of Michigan: Am. Jour. Sci., 2d ser., vol. 37, pp. 226-232, 1864.

The soils and subsoils of Michigan, 30 pp., Lansing, 1865.

Map of the State of Michigan colored to show the geological formations, 15 by 18 inches, 1864(?); notice, Neues Jahrb., 1868, pp. 99-101,
Winchell, Alexander-Continued.

Notes on some post-Tertiary phenomena in Michigan [abstraet]: Am. Naturalist, vol. 4, pp. 504-505, 1870.

Report on the progress of the State Geological Survey of Michigan, 64 pp., Lansing, 1871.

Michigan; being condensed popular sketches of the topography, climate, and geology of the State [extracted from Walling's Atlas of Michigan], 121 pp., maps, Claremont, N. H., 1873.

The diagonal system in the physical features of Michigan: Am. Jour. Sci., 3d ser., vol. 6, pp. 36-40, 1873.

Syllabus of a course of lectures on geology to be delivered in the Syracuse University during the winter term of 1874-75, 32 pp., Syracuse, 1875.

Winchell, Alexander Newton.

Use of "ophitic" and related terms in petrography: Geol. Soc. America Bull., vol, 20, pp. 661-667, 1908.

(and others). Handbook of mining in the Lake Superior region, prepared for Lake Superior meeting of Am. Inst. Min. and Met. Eng., August, 1920, 260 pp., illus. (incl. maps), Minneapolis, 1920.

Winchell, Horace Vaughan.

Historical sketch of the discovery of mineral deposits in the Lake Superior region: Lake Superior Min. Inst. Proc., vol. 2, pp. 33-78, 1894; Minnesota Geol. Survey Ann. Rept., vol. 23, pp. 116-155, 1895.

Winchell, Newton Horace.

Sketch of the work of the season of 1878: Minnesota Geol. Survey Seventh Ann. Rept., pp. 9-25, 1879.

The cupriferous series at Duluth: Minnesota Geol. Survey Eighth Ann. Rept., pp. 22-26, 1880.

Preliminary list of rocks: Minnesota Geol. Survey Ninth Ann. Rept., pp. 10-114, 1881.

Typical thin sections of the rocks of the cupriferous series in Minnesota: Am. Assoc. Adv. Sci. Proc., vol. 30, pp. 160-166, 1882; Minnesota Geol. Survey Tenth Ann. Rept., pp. 137-143, 1882; abstract, Science, vol. 2, p. $441,1881$.

Irving and Chamberlin on the Lake Superior sandstone: Am. Geologist, vol. 1, pp. 44-57, 1888.

Steps of progressive research in the geology of the Lake Superior region prior to the late Wisconsin survey: Am. Geologist, vol. 16, pp. 12-20, 1895 .

The Keweenawan according to the Wisconsin geologists: Idem, pp. 75-86.

A rational view of the Keweenawan: Idem, pp. 150-162.

The latest eruptives of the Lake Superior region: Idem, pp. 269-274.

Comparative taxonomy of the rocks of the Lake Superior region: Idem, pp. 331-337.

(and Grant, U. S.) Voleanic ash from the north shore of Lake Superior: Am. Geologist, vol. 18, pp. 211-213, 1896.

Thomsonite and lintonite from the north shore of Lake Superior: Am. Geologist, vol. 22, pp. 347-349, 1898.

Common zeolites of the Minnesota shore of Lake Superior: Am. Geologist, vol. 23, pp. 176-177, 1899.

Adularia and other secondary minerals of copper-bearing rocks: Idem, pp. 317-318.

General index of the annual reports of the Minnesota Survey: Minnesota Geol. Survey Twenty-fourth Ann. Rept., pp. 179-284, 1899.

The Keweenawan at Lake of the Woods in Minnesota [abstract]: Science, new ser., vol. 23, p. 289, 1906; Am. Assoc. Adv. Sci. Proc., vol. 55, p. 378, 1906.

Woods, Thomas S.

The porphyry intrusions of the Michigan copper district: Eng. and Min. Jour., vol. 107, pp. 299-302, 3 figs., 1919. 
Wright, Charles E.

First annual report of the commissioner of mineral statistics of the State of Michigan, for 1877-78 and previous years, 229 pp., Marquette, 1879.

Report of the State geologist from May 1, 1885, to January 1, 1888: Michigan Geol. Survey Rept. for 1891-92, pp. $33-37,1893$.

Wright, Fred Eugene.

Report of progress in the Porcupines: Michigan Geol. Survey Rept. for 1903, pp. 33-44, 1905.

Notes on the rocks and minerals of Michigan, to accompany the loan collection issued by the Michigan College of Mines, prepared by the department of geology, 105 pp., map, Houghton, 1905.

The intrusive rocks of Mount Bohemia, Mich.: Michigan Geol. Survey Rept. for 1908, pp. 355-402, map, 1909; abstract, Science, new ser., vol. 27, p. 768, 1907.

(and Lane, A. C.) Preliminary geological map of the Porcupine Mountains and vicinity: Michigan Geol. Survey Rept. for 1908, pl. 1, 1909.

Wright, James NeY.

The development of the copper industry of northern Michigan: Michigan Polit. Sci. Assoc. Pubs., vol. 3, No. 5, Ann Arbor, 1899.

\section{GEOGRAPHY}

Location.-The copper district of Michigan is in the extreme northern part of the northern peninsula, in Keweenaw, Houghton, and Ontonagon Counties. Its mines all lie within a narrow belt from 2 to 4 miles wide and more than 100 miles long.

Topography.-The most prominent topographic feature of the copper country is a broad flat-topped ridge or narrow plateau extending in a northeasterly direction through the district and falling off to a lowland both to the north and to the south. The northern portion projects into Lake Superior as Keweenaw Point. This plateau rises to a general level of 500 to 600 feet above Lake Superior, with ridges such as the Greenstone and Bohemia Ranges, in Keweenaw County, rising still higher. In the south end of the district the Porcupine Mountains form a prominent feature north of the main ridge.
The main ridge or plateau is cut through by several low transverse gaps or valleys. The deepest are the Portage Lake and Ontonagon River valleys, but there are many others of similar type.

The drainage is mainly outward from the central ridge, and most of the streams are small. The largest is Ontonagon River, which rises south of the main ridge and flows northward through the Ontonagon Gap. As most of the streams have small basins; they are subject to marked variations in flow. In dry summers and continuously cold winters the flow in many of the streams is very small, but while the snow is rapidly melting in the spring there is a large flow.

Climate.-The following statements of the climatic conditions are taken from the summary for 1924 prepared by Howard B. Cowdrick, meteorologist of the Houghton station of the Weather Bureau, United States Department of Agriculture. The Houghton station is in the Portage Lake valley, 82 feet above lake level, and the average conditions on the Copper Range Plateau both north and south of it are somewhat more severe. The waters of Lake Superior on three sides of the region greatly temper the climate. Killing frost in the autumn is later than at many stations much farther south, and although the spring opens late, there are almost never periods of high temperature followed by injurious freezing weather. For the last 23 years the average date of the last killing frost in spring has fallen in May and that of the first in autumn has fallen in October, and the average interval between them has been 149 days. The summer climate, with its long sunny days and cool nights, is almost perfect. The winters are cold but not unpleasant. A great amount of snow falls, but it is usually dry, and because of expertness developed through many years of experience in handling it, the railroads and electric lines are not seriously inconvenienced. Sleet is almost unknown.

Weather conditions at Houghton, Mich., 1901-1924

\begin{tabular}{|c|c|c|c|c|c|c|c|c|c|c|c|c|c|c|c|c|}
\hline \multicolumn{8}{|c|}{ Temperature $\left({ }^{\circ} \mathrm{F}.\right)$} & \multicolumn{2}{|c|}{$\begin{array}{l}\text { Relative humid- } \\
\text { ity (per cent) }\end{array}$} & \multicolumn{3}{|c|}{ Cloudiness (tenths of sky) } & \multicolumn{4}{|c|}{ Precipitation (inches) } \\
\hline & \multicolumn{3}{|c|}{ Means } & \multicolumn{4}{|c|}{ Extremes } & \multirow[b]{3}{*}{$\begin{array}{l}\text { a } \\
\text { \& } \\
\stackrel{-}{\infty}\end{array}$} & \multirow[b]{3}{*}{$\begin{array}{l}\text { : } \\
7 \\
\check{7}\end{array}$} & \multirow[b]{3}{*}{$\begin{array}{c}\text { a } \\
\text { d } \\
n \\
\end{array}$} & \multirow[b]{3}{*}{$\begin{array}{l}\text { हีं } \\
\text { خ }\end{array}$} & \multirow{3}{*}{ 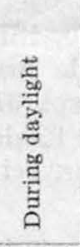 } & \multirow[b]{3}{*}{ : } & \multicolumn{2}{|c|}{ Greatest in 24 hours } & \multirow{3}{*}{ 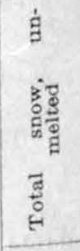 } \\
\hline & \multirow[b]{2}{*}{ 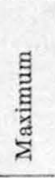 } & \multirow{2}{*}{ 慁 } & \multirow{2}{*}{ 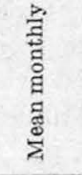 } & \multicolumn{2}{|c|}{ Highest } & \multicolumn{2}{|c|}{ Lowest } & & & & & & & & & \\
\hline & & & & 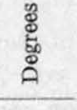 & $\stackrel{\Xi}{\text { A็ }}$ & 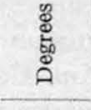 & $\stackrel{\Xi}{\Xi}$ & & & & & & & 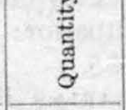 & ⿷匚ّ & \\
\hline $\begin{array}{l}\text { January } \\
\text { February. } \\
\text { March } \\
\text { April } \\
\text { May } \\
\text { June. } \\
\text { July } \\
\text { August. } \\
\text { September } \\
\text { October } \\
\text { November } \\
\text { December.... } \\
\end{array}$ & $\begin{array}{l}22 \\
22 \\
33 \\
46 \\
59 \\
70 \\
74 \\
72 \\
65 \\
54 \\
39 \\
27 \\
\end{array}$ & $\begin{array}{r}7 \\
5 \\
16 \\
29 \\
40 \\
49 \\
56 \\
54 \\
48 \\
39 \\
28 \\
15 \\
\end{array}$ & $\begin{array}{l}15 \\
14 \\
24 \\
38 \\
49 \\
60 \\
65 \\
63 \\
57 \\
46 \\
34 \\
21 \\
\end{array}$ & $\begin{array}{r}50 \\
54 \\
78 \\
88 \\
94 \\
101 \\
103 \\
96 \\
94 \\
87 \\
67 \\
58 \\
\end{array}$ & $\begin{array}{l}1906 \\
1906 \\
1910 \\
1901 \\
1921 \\
1901 \\
1917 \\
1916 \\
1913 \\
1908 \\
1903 \\
1923 \\
\end{array}$ & $\begin{array}{r}-31 \\
-19 \\
-22 \\
-10 \\
22 \\
34 \\
41 \\
37 \\
31 \\
18 \\
3 \\
-16 \\
\end{array}$ & $\begin{array}{l}1915 \\
1905 \\
1917 \\
1923 \\
1909 \\
1913 \\
1905 \\
1915 \\
1912 \\
1905 \\
1914 \\
1916 \\
\end{array}$ & $\begin{array}{l}78 \\
78 \\
80 \\
78 \\
77 \\
81 \\
80 \\
83 \\
89 \\
86 \\
84 \\
83 \\
\end{array}$ & $\begin{array}{l}76 \\
76 \\
71 \\
65 \\
61 \\
65 \\
69 \\
66 \\
71 \\
69 \\
78 \\
80 \\
\end{array}$ & $\begin{array}{l}8.6 \\
7.8 \\
6.7 \\
5.9 \\
5.6 \\
5.0 \\
4.5 \\
5.1 \\
5.6 \\
6.4 \\
8.2 \\
8.6 \\
\end{array}$ & $\begin{array}{l}\text { 7. } 9 \\
\text { 7. } \\
6.4 \\
5.9 \\
4.8 \\
4.8 \\
5.0 \\
4.7 \\
5.7 \\
\text { 3. } 9 \\
7.9 \\
9.0 \\
\end{array}$ & $\begin{array}{l}8.1 \\
7.2 \\
6.0 \\
5.5 \\
5.1 \\
5.0 \\
5.6 \\
5.1 \\
5.8 \\
5.2 \\
8.1 \\
8.5 \\
\end{array}$ & $\begin{array}{l}\text { 2. } 47 \\
\text { 1. } 65 \\
\text { 1. } 99 \\
\text { 2. } 14 \\
\text { 2. } 85 \\
\text { 2. } 69 \\
\text { 2. } 23 \\
\text { 2. } 38 \\
\text { 3. } 23 \\
\text { 2. } 68 \\
\text { 2. } 98 \\
\text { 2. } 78 \\
\end{array}$ & $\begin{array}{l}0.95 \\
1.56 \\
1.54 \\
1.91 \\
\text { 2. } 65 \\
\text { 2. } 14 \\
2.30 \\
1.74 \\
3.70 \\
2.31 \\
2.93 \\
1.88 \\
\end{array}$ & $\begin{array}{l}1901 \\
1922 \\
1917 \\
1914 \\
1918 \\
1905 \\
1921 \\
1906 \\
1905 \\
1903 \\
1919 \\
1917 \\
\end{array}$ & $\begin{array}{r}27.3 \\
17.3 \\
14.3 \\
6.7 \\
.7 \\
0 \\
0 \\
0 \\
.2 \\
2.7 \\
16.8 \\
28.0 \\
\end{array}$ \\
\hline Year & 48 & 32 & 40 & 103 & $\begin{array}{l}\text { July, } \\
1917\end{array}$ & -31 & $\begin{array}{l}\text { Jan., } \\
1915\end{array}$ & 81 & 71 & 6.5 & 6.3 & 6.3 & 30.26 & 3. 70 & 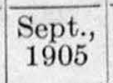 & 110.1 \\
\hline
\end{tabular}


Weather conditions at Houghton, Mich., 1901-1924-Continued

\begin{tabular}{|c|c|c|c|c|c|c|c|c|c|c|c|c|c|c|c|c|c|c|}
\hline \multicolumn{14}{|c|}{ Number of days for conditions specifled } & \multicolumn{5}{|c|}{ Wind } \\
\hline & \multirow{3}{*}{ 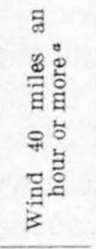 } & \multirow[b]{3}{*}{ 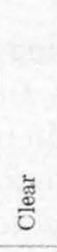 } & \multirow{3}{*}{ 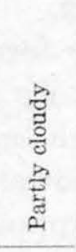 } & \multirow[b]{3}{*}{$\begin{array}{l}\vec{\Xi} \\
\stackrel{\Xi}{0}\end{array}$} & \multirow{3}{*}{ 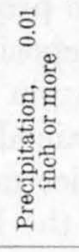 } & \multirow{3}{*}{ 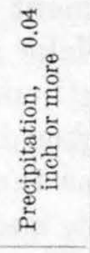 } & \multirow{3}{*}{ 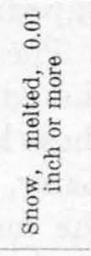 } & \multirow{3}{*}{ 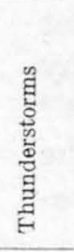 } & \multirow{3}{*}{ 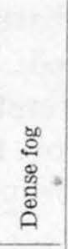 } & \multicolumn{4}{|c|}{ Temperature } & \multirow{3}{*}{ 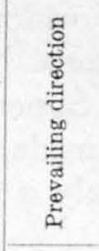 } & \multicolumn{3}{|c|}{$\begin{array}{l}\text { Maximum velocity for } \\
5 \text { minutes }\end{array}$} & \multirow{3}{*}{ 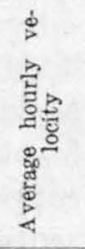 } \\
\hline & & & & & & & & & & \multicolumn{2}{|c|}{ Maximum } & \multicolumn{2}{|c|}{ Minimum } & & \multirow{2}{*}{ 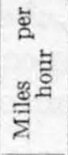 } & \multirow{2}{*}{ 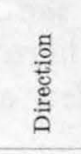 } & \multirow[b]{2}{*}{ ¿્ّ } & \\
\hline & & & & & & & & & & 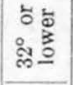 & $\begin{array}{l}5 \\
5 \\
\vdots \\
\&\end{array}$ & 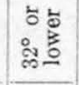 & 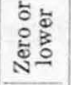 & & & & & \\
\hline January _. & 17 & 3 & 6 & 22 & 18 & 14 & 18 & 0 & 1 & 25 & 0 & 31 & 9 & NW. & 58 & W. & 1923 & 8. 3 \\
\hline February $\ldots$ & 16 & 5 & 7 & 16 & 18 & 14 & 18 & 0 & 0 & 23 & 0 & 28 & 10 & NW. & 63 & W. & 1923 & 8. 1 \\
\hline March ........ & 19 & 8 & 10 & 13 & 13 & 10 & 11 & 1 & 1 & 16 & 0 & 29 & 4 & E. & 54 & W. & 1918 & 9. 0 \\
\hline April . - & 10 & 11 & 8 & 11 & 12 & 9 & 6 & 1 & 1 & 3 & 0 & 19 & 4 & E. & 50 & NW. & 1922 & 9. 1 \\
\hline May - & 12 & 10 & 11 & 9 & 12 & 9 & 1 & 3 & 2 & 0 & 5 & 4 & 0 & E. & 60 & W. & 1916 & 8. 8 \\
\hline June - & 10 & 11 & 11 & 8 & 11 & 8 & 0 & 4 & 2 & 0 & 23 & 0 & 0 & E. & 52 & SW. & 1918 & 8. 3 \\
\hline July .... & 7 & 13 & 11 & 7 & 10 & 8 & 0 & 5 & 2 & 0 & 25 & 0 & 0 & W. & 52 & NW. & 1920 & 7. 6 \\
\hline August_....... & 3 & 10 & 12 & 9 & 11 & 8 & 0 & 4 & 3 & 0 & 7 & 0 & 0 & W. & 43 & W. & 1923 & 7. 6 \\
\hline September.... & 9 & 9 & 9 & 12 & 13 & 9 & 0 & 3 & 3 & 0 & 7 & 0 & 0 & W. & 63 & NW. & 1919 & 8. 4 \\
\hline October ....... & 13 & 7 & 7 & 17 & 14 & 9 & 3 & 1 & 2 & 0 & 0 & 6 & 0 & W. & 52 & W. & 1921 & 8. 6 \\
\hline November.... & 14 & $\begin{array}{l}3 \\
?\end{array}$ & 6 & 21 & 16 & 11 & 11 & 0 & 1. & 7 & 0 & 21 & 0 & NW. & 52 & W. & 1924 & 9. 5 \\
\hline December....- & 17 & 2 & 5 & 24 & 19 & 14 & 18 & 0 & 0 & 21 & 0 & 30 & 3 & NW. & 58 & W. & 1922 & 9. 0 \\
\hline Year... & 146 & 94 & 102 & 169 & 158 & 218 & 81 & 22 & 18 & 94 & 67 & 167 & 25 & E. & 63 & W. & 1923 & 8. 8 \\
\hline
\end{tabular}

- Total for period.

Industries.-The chief industry of Keweenaw Point is copper mining and smelting; of far less importance are lumbering and agriculture. In addition to these there is some fishing and a little manufacturing.

Copper mining has been the most important industry for many years, and until the end of the World War, when copper mining nearly everywhere was curtailed, it had made a pretty steady growth.

Lumbering is of course decreasing in importance as the original timber is removed, but there is still much original hardwood timber standing, and lumbering will continue for some time. As the timber has been cut some of the land has been cleared for farming, and agriculture has been steadily expanding. Much of the soil is good, and although the seasons are short, especially on the higher lands of the Copper Range, the region is suited to certain types of agriculture, especially the growing of potatoes and root crops generally. Dairy products are also more than sufficient to supply local demands.

Transportation.-The district borders on Lake Superior, and Portage and Torch Lakes and the Portage Lake Canal bring lake transportation into its heart. Most of the heavy freight, such as fuel and much of the copper, therefore has the advantage of lake freight rates. Lake transportation usually opens by May 1 and closes in December.

The district is also connected with outside points by the Chicago, Milwaukee \& St. Paul Railway and the Duluth, South Shore \& Atlantic Railroad. It is also served by the Mineral Range Railroad and the Copper Range Railroad. The Keweenaw Central Railroad has served the northern part of the district in the past and would undoubtedly resume operation if conditions should justify. Several of the mines are connected with the mills and smelters by privately owned railroads.

An improved highway extends from Copper Harbor, near the end of Keweenaw Point, to Rockland, on Ontonagon River. This road, together with numerous branches, brings practically all parts of the district within a few miles of good highways, which are open to automobile traffic for about eight months of the year.

The north end of the Porcupine Mountain section also has improved highways, and the Chicago, Milwaukee \& St. Paul Railway has a branch to the White Pine mine.

Power.-Practically all power for the district is generated from coal brought in by Lake steamers. Much of the power is used directly as steam power or as compressed air produced by steam power, but there is a steadily increasing use of electric power generated at central plants.

The only water-power plant in the district is that of the Victoria Copper Co. on the West Branch of Ontonagon River. A fall of 71 feet was utilized to produce compressed air directly, which operated all the machinery of the mine and mill. A dam to store water in Lake Gogebic helps to equalize the flow of the river, and the power available could be considerably increased by raising the dam. There is a fall on the East Branch of Ontonagon River that has not yet been utilized for developing power, and some power could also be generated on other small streams in the district. The irregular seasonal flow of the streams, however, would make storage dams necessary to develop power continuously. 


\section{PHYSIOGRAPHY}

An account of the development of the physiographic features of the copper district requires consideration of a much wider area than the district itself. Such descriptions have been prepared by Martin ${ }^{7}$ for the Lake Superior region, by Leverett ${ }^{8}$ for the northern peninsula, and by Lane ${ }^{9}$ for the copper district, and only a brief outline will be presented here.

The ridge or plateau known as the Copper Range represents an old mature erosion surface with monadnocks rising above its general level and also valleys below that level. With the elevation of this old surface the softer rocks on each side of the present range were eroded to form the present lowlands, while the crystalline rocks were but little affected. (See pl. 53.) This was the condition of the region before the glacial epoch.

The glaciation had little to do in forming the major physiographic features, but it affected the minor features profoundly. When the ice swept over the region it scoured off the soil and the weathered outcrops of the rocks. It smoothed the outlines and probably widened and deepened the valleys somewhat, but it did not change the major rock features. In local protected areas the effect of preglacial weathering is preserved - for example, it can be well seen in a shaft on the Petherick vein, near Copper Falls, Keweenaw County.

The deposits laid down by the ice and the accompanying streams are prominent features of the detail of the physiography and are economically important both from the viewpoint of the farmer, because they form the soil, and from that of the miner, because they constitute a rock cover which affects the ease of both exploration and development. There are four principal types of glacial deposits on the Copper Range the general till sheet or ground moraine; moraines formed around the margins of the ice tongues; deposits formed in glacial lakes; and deposits laid down by streams flowing from the ice.

The most extensive of these deposits is the ground moraine, which was left in greater or less amount everywhere as the ice melted. It covers practically all the range except a few steep ridges from which it has been removed or on which it could not accumulate.

Over much of the area it forms a rather shallow mantle, which is not continuous but fills minor depressions and covers the outerops of the weaker rocks such as the amygdaloids.

The marginal moraines cover a much smaller area. The most prominent one, which outlines the ice lobe that moved down Keweenaw Bay, touches the Copper Range at Wheal Kate Mountain, near South Range,

\footnotetext{
Martin, Lawrence, U. S. Geol. Survey Mon. 52, p. 85, 1911

8 Leverett, Frank, Michigan Geol. Survey Pub. 7, Geol. ser. 5, 1911.

- Lane, A. C., Michigan Geol. Survey Pub. 6, Geol. ser. 4, p. 48, 1911.
}

and follows it southwestward to a point beyond Winona, where it turns southward around Keweenaw Bay. This moraine buries the rocks deeply and is a serious impediment to prospecting.

The lake deposits were formed in the lakes along the south margin of the ice. In their early stages these lakes drained into the basin of Mississippi River. Later, as the ice melted, lower outlets were opened to the east, and the lakes dropped to successively lower levels. The most extensive of these lakes in the Copper Range was Lake Duluth, which covered most of the area. At Calumet its highest shore line surrounds Centennial Heights, about 700 feet above the level of Lake Superior, and in the south end of the district only the higher summits projected as islands. Thi highest stage was followed by successively lower stage whose positions are marked by old beach lines. Since these were formed the land has been tilted so that there is a slight rise in altitude of each beach line from south to north, the amount of which has not been determined for the Copper Range.

In these lakes were formed extensive deposits of clay mixed with boulders, especially in the southern part of the range. These deposits have not buried the rocks as deeply as the marginal moraine, but in places they constitute a decided handicap to prospecting.

Since the glacial epoch erosion has modified the deposits somewhat, especially near streams, but in the main there has been little change. (See pl. 54.)

\section{BEDROCK GEOLOGY}

\section{BROADER RELATIONS}

Location and extent.- The native copper deposits of Lake Superior are inclosed in rocks of Keweenawan age. The area in which these rocks are exposed lies in the southern part of the pre-Cambrian shield of North America and forms a part of the Lake Superior basin. Along the south shore of the lake it extends from Keweenaw Point southwestward through northern Wisconsin into Minnesota. (See pl. 2.) The Keweenawan rocks border the north shore of the lake in Minnesota to the Canadian boundry, crop out on Isle Royal, and in Canada appear in the Black Bay and Thunder Bay districts and extend northward around Lake Nipigon. To the east of this almost continuous area they occur in scattered outcrops along the shore and on islands of Lake Superior.

Character of the rocks. - The Keweenawan series comprises coarse clastic sediments and intrusive and extrusive igneous rocks. Both the base and the upper part of the series were formed during periods of sedimentation. The igneous activity became dominant after a maximum of 1,500 feet of sediments had been deposited, when basaltic flows were poured out, one after another, with occasional short intervening periods of sedimentation. More rarely acidic eruptions occurred. The flows were probably fissure 


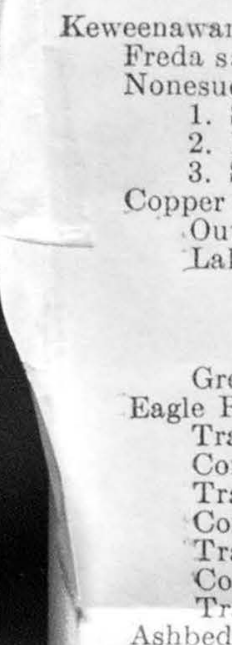

(1.t)

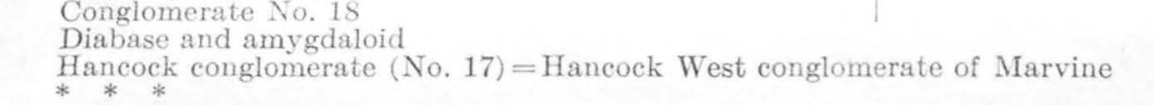

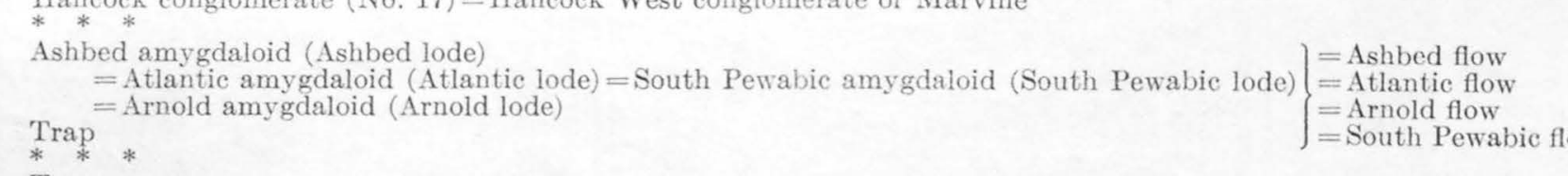

Trap :

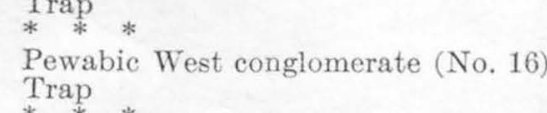

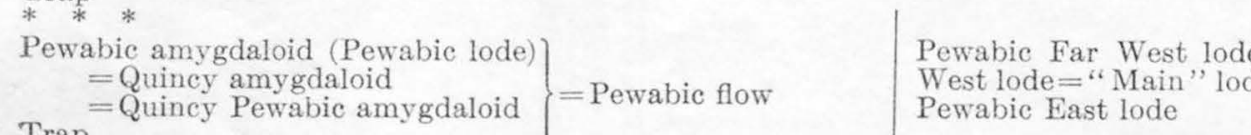

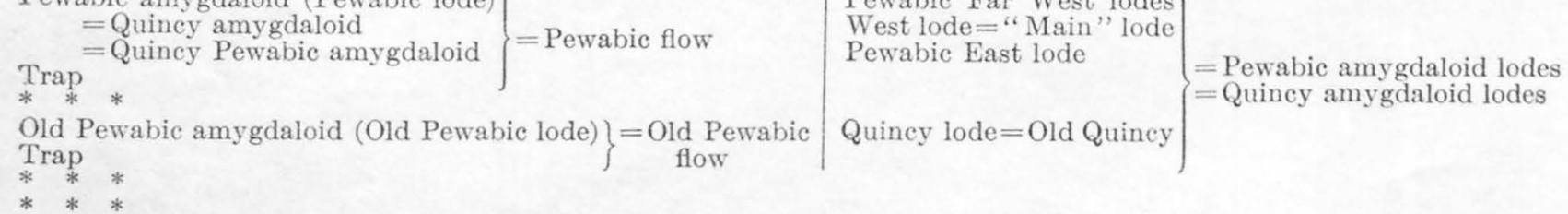

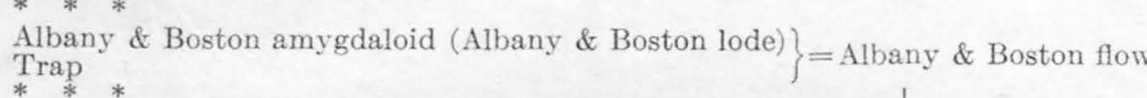

"Mesnard" epidote="St. Mary,"

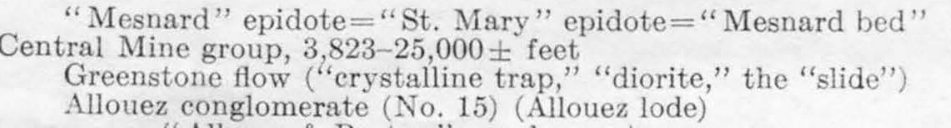

Medora

Thedora amygdaloid (Medora lode) $\}$ Medora flow
Trap
Manitou amy gdaloid (Manitou lode) $\}=$ Manitou flow
Traip

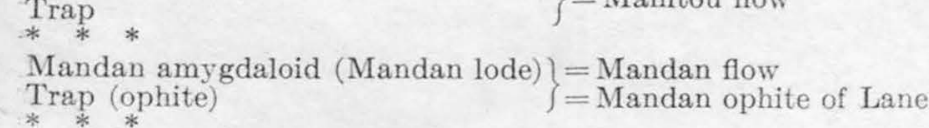

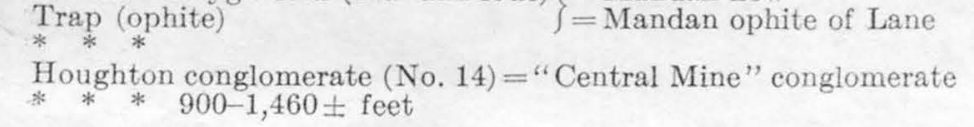

Calumet \& Heclac conglomerate (No. 13)
Can
$* * *$ Calumet" conglomerate

Talumet amygdaloid (Calumet lode) $\}=$ Calumet flow

$\begin{aligned} & * * * \\ & \text { Osceola anygdaloid (Osceola lode) } \\ & \text { Ophite }\end{aligned}=$ Osceola flow

$\begin{aligned} & \text { North } \\ & \text { Tramygdalaiod (North lode) }\}\end{aligned}=$ North flow

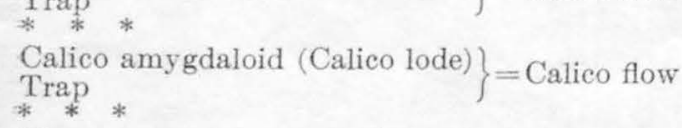

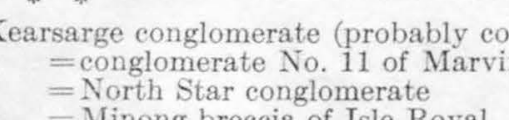

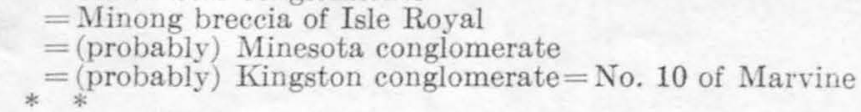

Minong porphyrite Occur on Isle Ro

Huginnin porphyrite of Isle Roya

$\underset{\substack{\text { Kearasarge West amygdaloid (Kearsarge West lode) } \\ \text { Tearsarge West tlo }}}{\text { Tha }}$

Kearsar

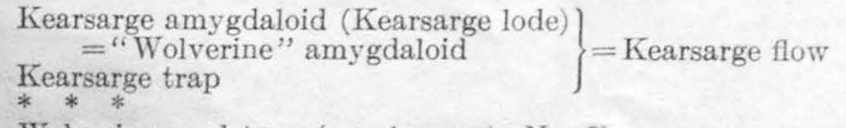

Wolverine sandstone (conglomerate No. 9

Old Colony amygdaloid (OId Colony lode) $\}=$ Old Colony flo
Trap

trap *

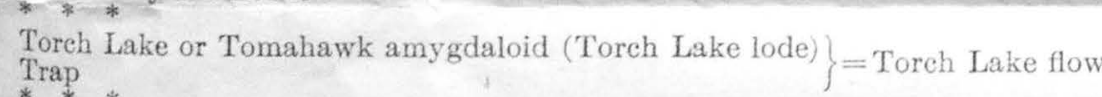

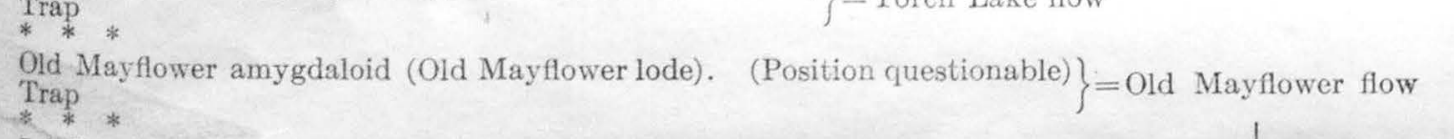

tite

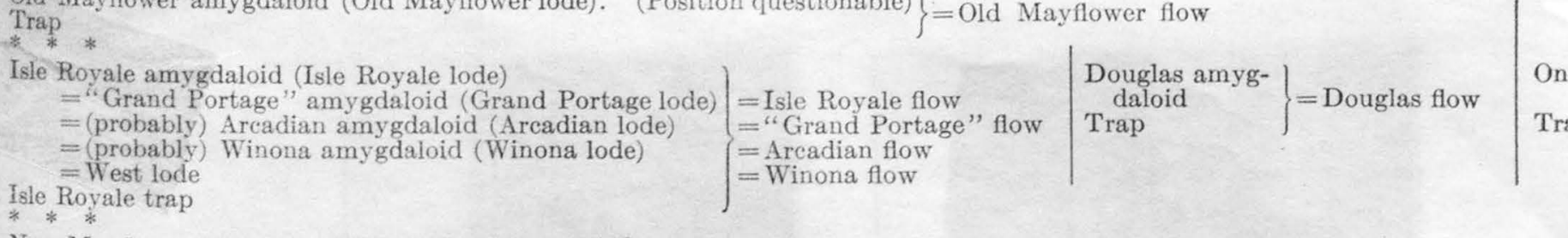

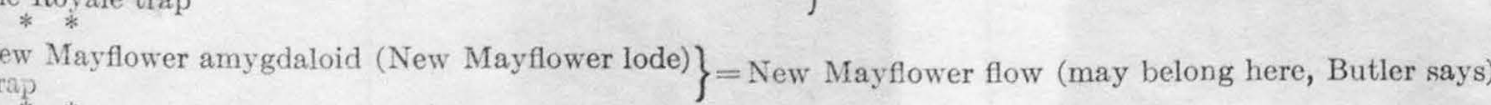

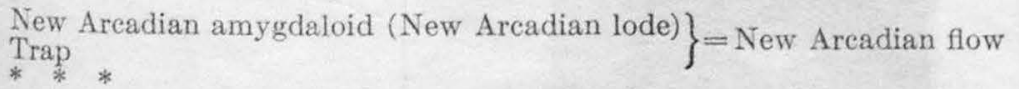

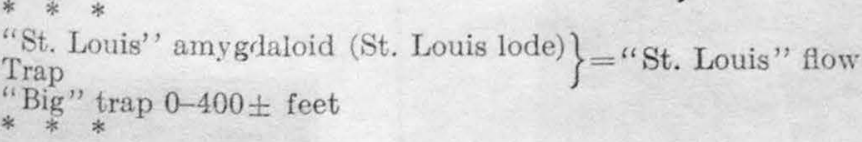

Bohemian Range group, $9,500 \pm$ feet:
Bothemia conglomerate $($ N.

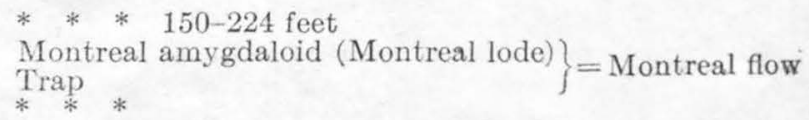
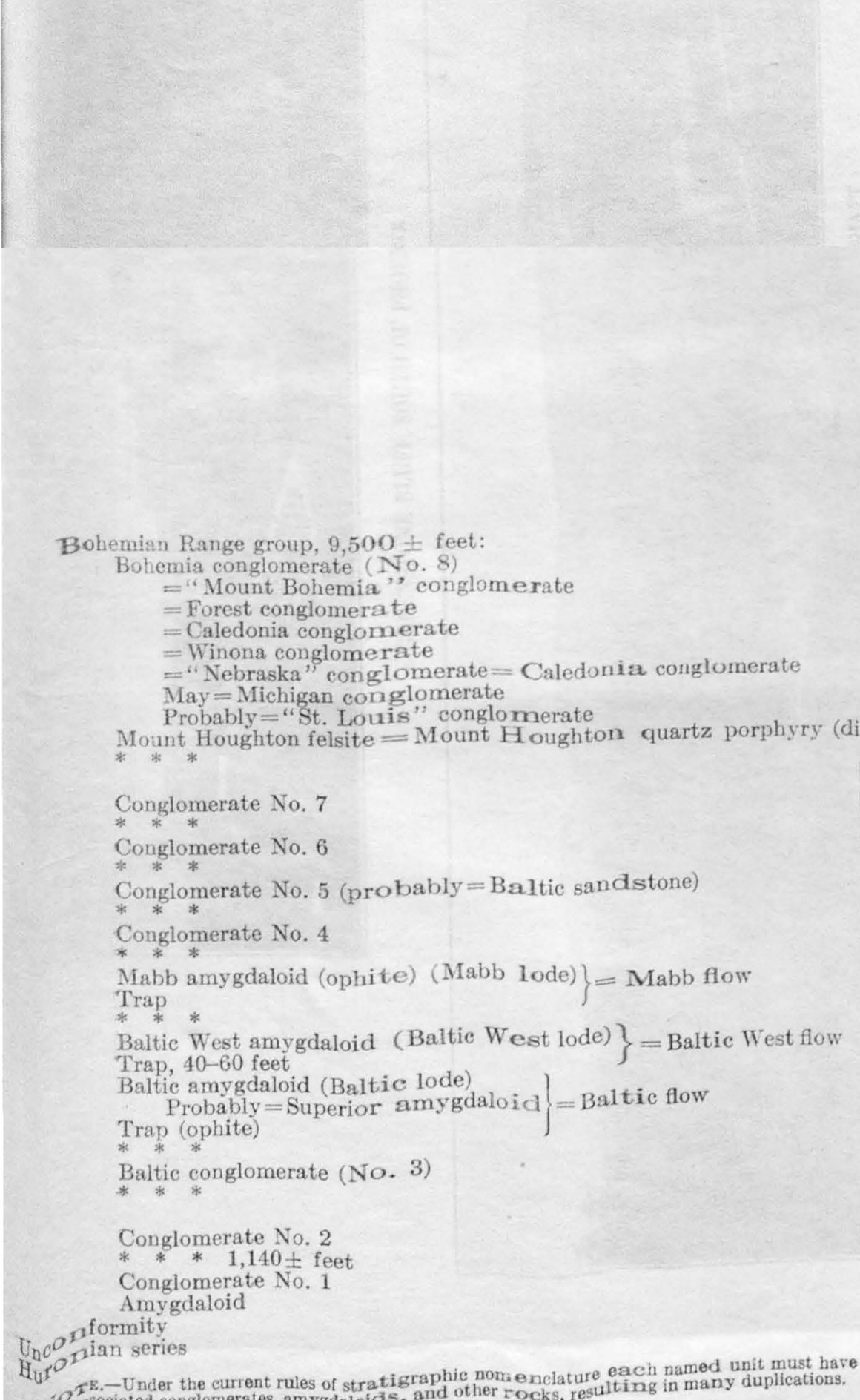

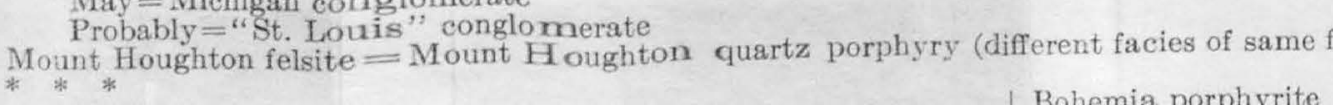

Conglomerate No. 7

Conglomerate No. 6

Witomerate N. 5 (probably $=$ Baltic sandstone

Jabb amygdaloid (ophite) (Mabb lode) $\}=$ Mabb flow

* F *
Baltic West amygdaloid (Baltic West lode) $\}=$ Baltic West flo

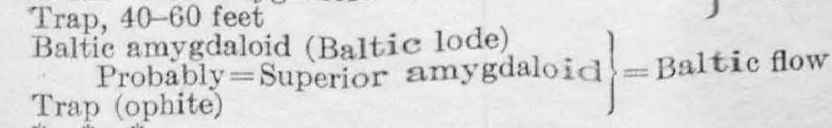

Trapt (ophite)
Baltic conglomerate (No. 3)
s.t.

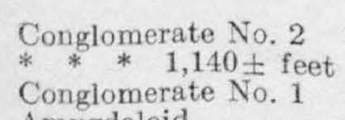

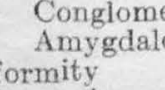

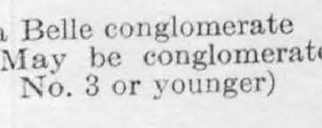
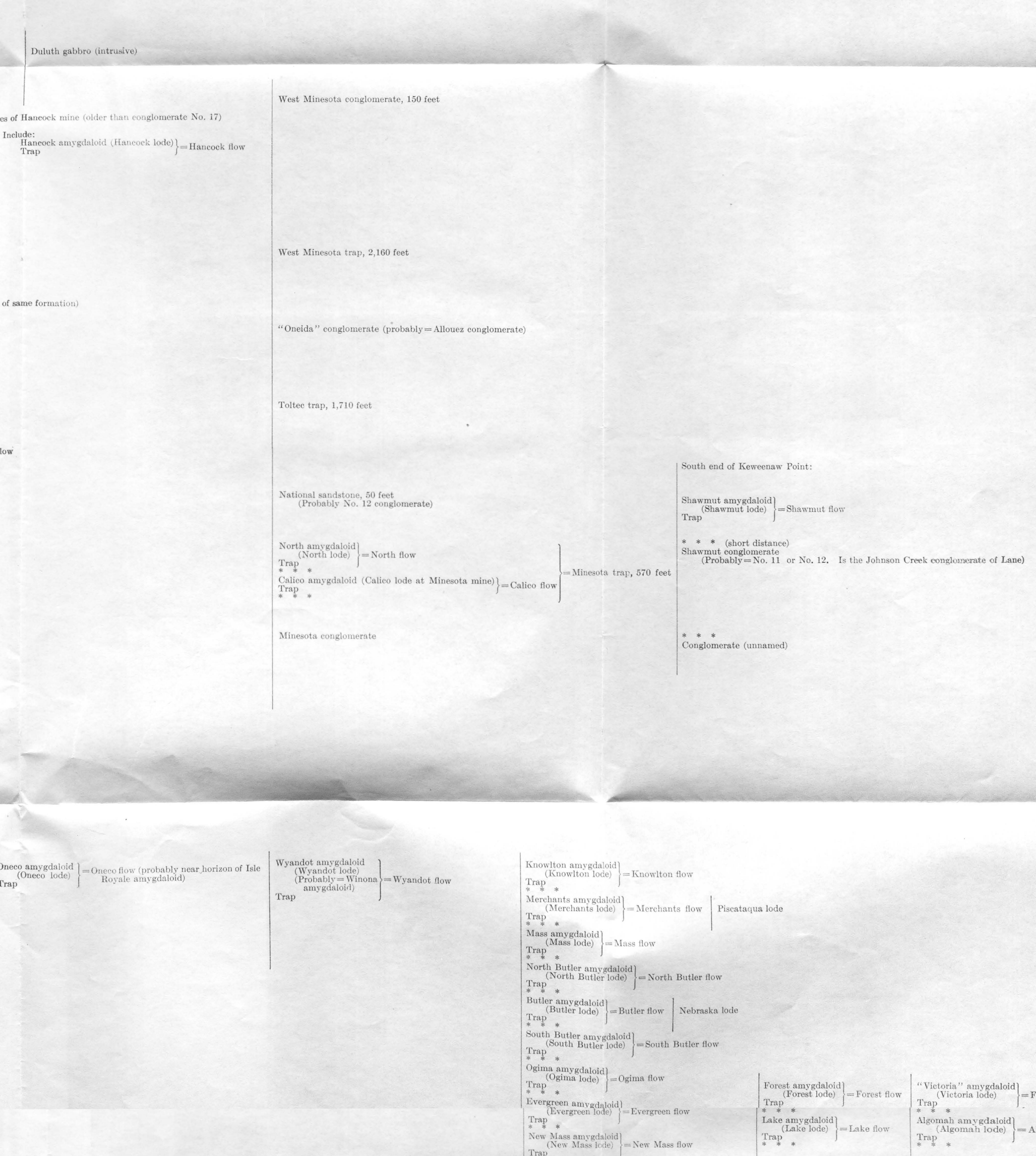

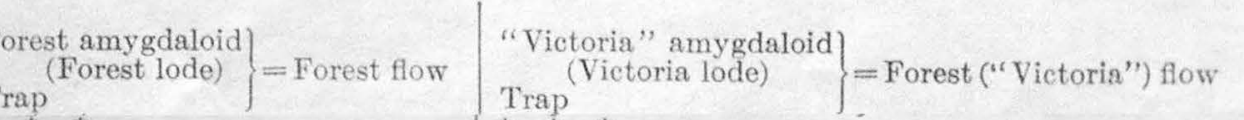

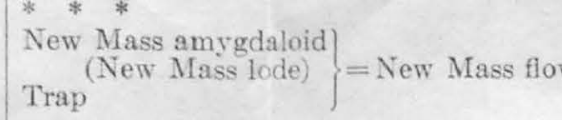

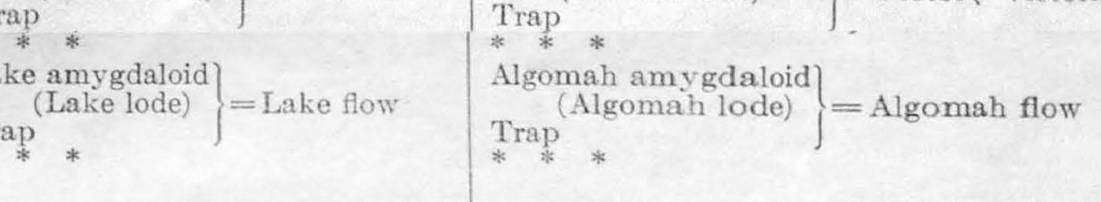

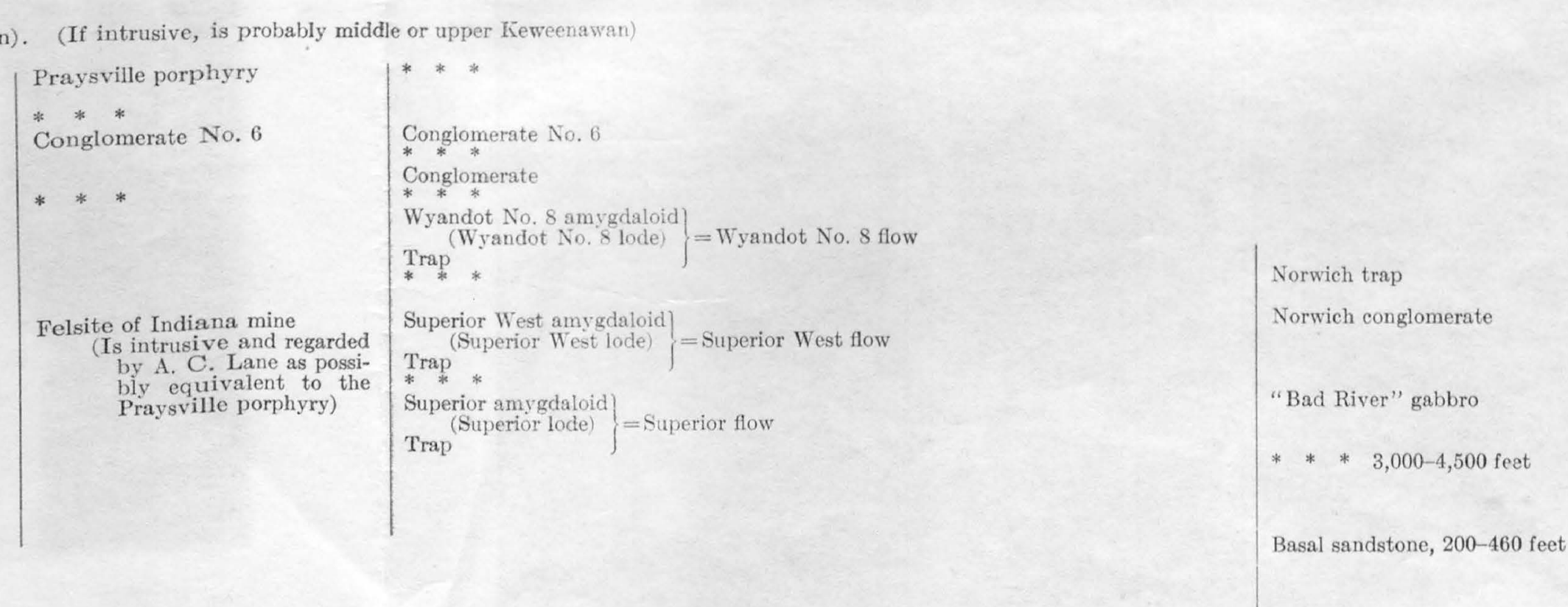

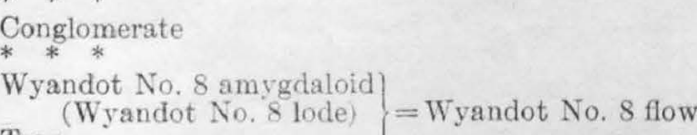



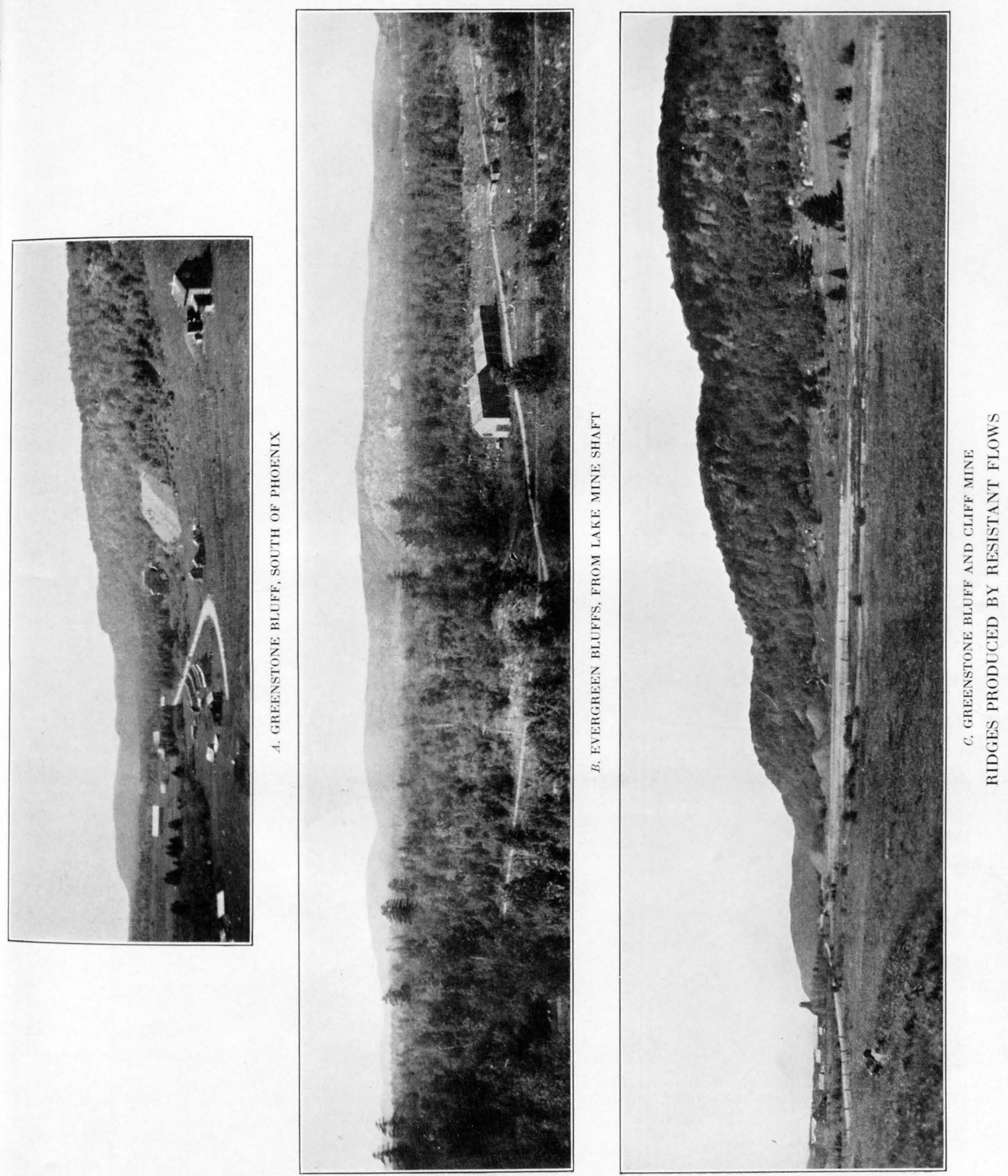


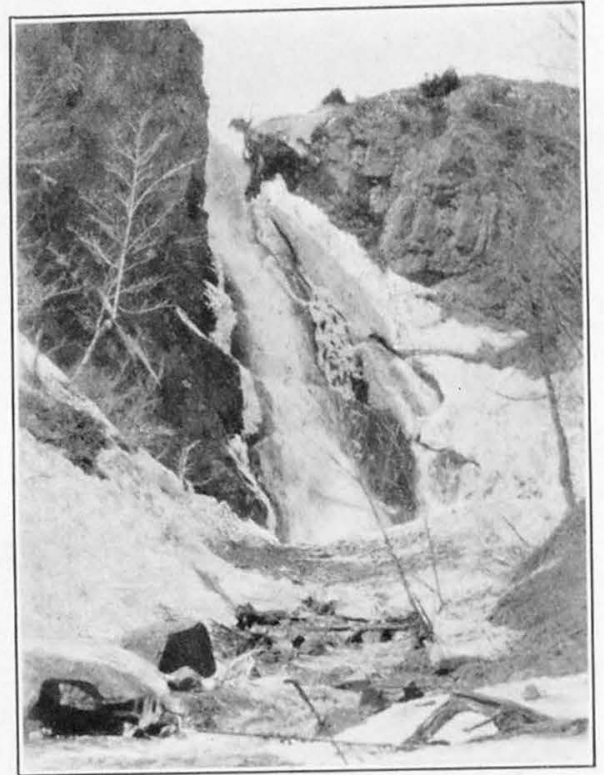

A. DOUglass houghton FALLS

One of the falls of the Keweenaw fault fall line. Photograph_by C. V. Rawlings

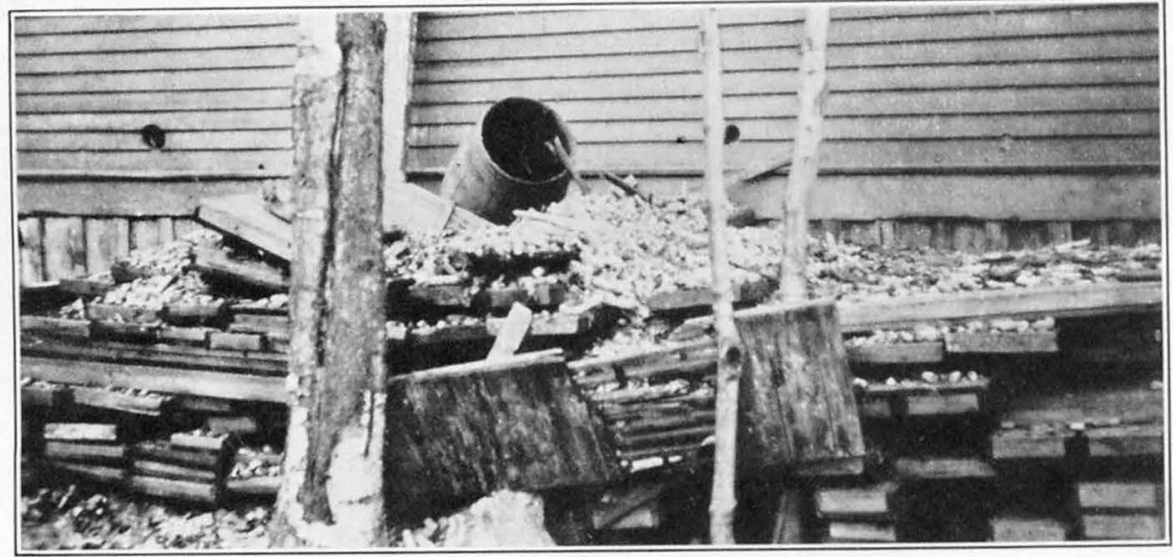

B. DRILL CORES IMPROPERLY STORED

Costly and valuable information going to waste

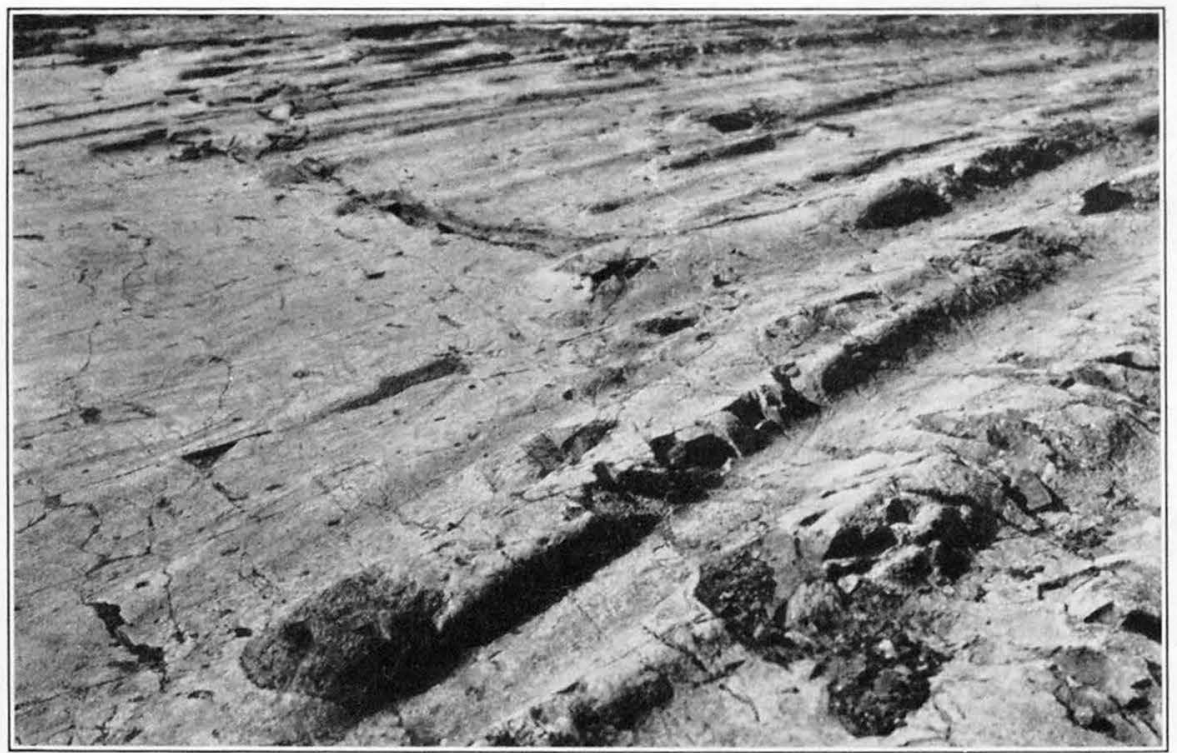

C. GLACIATED SURFACE, SHOWING RESISTANCE OF AMYGDULAR INCLUSIONS

Inclusion zone in Calumet and Hecla conglomerate 
eruptions; how many there were is not known, but they are to be numbered in the hundreds. Igneous activity gradually ceased, the intervening periods of sedimentation becoming more frequent and longer. The upper part of the series is made up largely of a thick conglomerate overlain by a thick sandstone.

Intrusion probably though not certainly occurred during the Keweenawan epoch. On the north shore the great Duluth gabbro laccolith of Minnesota was intruded essentially along the unconformity at the base of the Keweenawan. Similar intrusive rocks occur south of the lake in Wisconsin, and it is thought that these are outcrops of the same great body extending beneath the lake, from one side of the Lake Superior synclinal basin to the other. Smaller intrusive bodies occur tow ard the base of the Keweenawan at intervals along Keweenaw Point. Both their petrographic character and their position in the series suggest that they are contemporaneous with and derived from the same magma as the Duluth gabbro. Other examples of intrusive rocks that are probably of Keweenawan age are the dikes in the Gogebic iron country and the Logan sills in Minnesota and Ontario.

\section{STRATIGRAPHY}

\section{MAPS AND SECTIONS}

The detailed geologic maps and sections (pls. 2-32) are based largely on data from diamond drilling and underground openings. Outcrops have of course been used as far as possible. As the region is largely covered with drift and the depth to bedrock is unknown except at the location of drill holes or other openings, it was decided to show the rock beds on the surface map as projected on their dip through the drift to the surface. Where there is no drift cover the outcrop as shown coincides with the actual bedrock outcrop. Where there is a drift covering a given contact in westward-dipping beds is shown farther east than its position on the bedrock surface by a distance that varies with the thickness of the drift and the dip of the beds. The dip is indicated on the map and shown on the sections, and the thickness of drift at the drill holes is shown on the sections, and it is also indicated on the map by a gap between the location of the hole and the position of the bedrock.

Near the Keweenaw fault, where the beds are in general considerably broken and in many places have low dips, the surface outcrop has not been shown. The structure so far as it is known is indicated in the sections.

On both maps and sections the character of the traps is shown by letters, as $\mathrm{O}$ for ophites, $\mathrm{M}$ for melaphyres. The character of amygdaloids, as fragmental, scoriaceous, or cellular, is shown by symbols.

\section{AGE AND RELATIONS}

The rocks of Keweenaw Point are of Keweenawan and Cambrian age. On the Gogebic Iron Range, near by, the Keweenawan rests unconformably upon the upper Huronian, and Keweenawan dikes cut the earlier rocks. Overlying the upper Keweenawan, without apparent unconformity or abrupt change of character, is a sandstone which has been considered to be Upper Cambrian. This relation does not exist on Keweenaw Point, where the upper Keweenawan sandstone (called the Freda) is separated from the Upper Cambrian'sandstone (the Jacobsville, "Eastern," or Lake Superior sandstone) by a great overthrust fault. In the valley of St. Croix River, in western Wisconsin, fossiliferous Upper Cambrian sandstone lies unconformably on middle Keweenawan beds. The Jacobsville sandstone may be likewise unconformable on the Keweenawan in the South Trap Range of Michigan, but there the relations are obscured by faulting, and the problem is complicated further by the doubt that exists regarding the equivalence of the Jacobsville ("Eastern") sandstone to the Upper Cambrian of the St. Croix Valley. This relation may mean simply that the Lake Superior basin was forming during Keweenawan time and in places the latest member was laid down unconformably on the earlier members, which had been already tilted, though there was no break in the general series.

In northern Wisconsin the Freda sandstone is overlain conformably by other sandstones of Keweenawan age, into which, indeed, it seems to grade imperceptibly. It would appear from this relation that the formations were laid down in one period of continuous deposition without interruption by diastrophic movements. Although the accepted usage of the United States Geological Survey is to group the Keweenawan with the pre-Cambrian, the fact that the apparently major unconformity lies below the Keweenawan series rather than above it has led some geologists to the view that the major division between the Cambrian and pre-Cambrian should be placed at the base of the Keweenawan. Thus, Lane groups the rocks of the Keweenawan as Cambrian. ${ }^{10}$ The present work has contributed nothing of significance toward determining the relations, and it seems to be still an open question with good arguments on both sides. ${ }^{10 \mathrm{a}}$

\section{GENERAL CHARACTER AND DISTRIBUTION}

The Keweenawan series is divided in a general way into upper, middle, and lower Keweenawan, which are further subdivided into groups and formations. ${ }^{11}$ The several workers in the district have classed the subdivisions somewhat differently, as indicated in the following table:

10 For a discussion of the age and relations of the Keweenawan see Van Hise, C. R., and Leith, C. K., The geology of the Lake Superior region: U. S. Geol. Survey Mon. 52 , pp. $384,389,415,416,616,620,625,1911$; Lane, A. C., The Keweenawan series of Michigan: Michigan Geol. Survey Pub. 6 (Geol. ser. 4), pp. 41, 629, 630 , 941-942, 1909

10a Since this report was prepared C. R. Stauffer (Age of the red clastic series of Minnesota: Geol Soc. America Bull., vol. 38, pp. 469-478, 1927) has reported the finding of Middle Cambrian fossils near the top of the red sediments below the St. Croixan series in Minnesota. These rocks have in the past been correlated, somewhat uncertainly, with the Keweenawan.

11 Lane, A. C., op. cit., p. 20. 
Classification of subdivisions of Keweenawan series

\begin{tabular}{|c|c|c|c|c|}
\hline \multirow{2}{*}{ Name } & \multirow{2}{*}{ Thickness (feet) } & \multicolumn{3}{|c|}{ Classification } \\
\hline & & Irving & Van Hise and Leith & Lane and Gordon \\
\hline $\begin{array}{l}\text { Freda sandstone } \\
\text { Nonesuch shale } \\
\text { Outer conglomerate }\end{array}$ & $\begin{array}{rr}900- & (?) \\
350- & 600 \\
1,000- & 3,500\end{array}$ & Upper Keweenawan.... & Upper Keweenawan_... & Upper Keweenawan. \\
\hline $\begin{array}{l}\text { Lake Shore trap } \\
\text { Great conglomerate } \\
\text { Eagle River group } \\
\text { Ashbed group } \\
\text { Central Mine group } \\
\text { Bohemian Range group }\end{array}$ & $\begin{array}{r}400-1,800 \\
340-2,200 \\
1,417-2,300 \\
1,456-2,400 \\
3,823-25,000 \\
(?)-9,500\end{array}$ & Lower Keweenawan..... & $\begin{array}{l}\text { Middle Keweenawan..... } \\
\text { Lower Keweenawan...... }\end{array}$ & Lower Keweenawan. \\
\hline
\end{tabular}

The rocks consist of acidic and basic intrusive and extrusive rocks, shale, sandstone, conglomerate, ash, and tuff. The same rock types, both igneous and sedimentary, are characteristic of the Keweenawan of the entire Lake Superior region. The Keweenaw Point belt extends southwestward into northern Wisconsin and dips northwestward under Lake Superior. Rocks of the same types emerge on the north side of the Lake Superior syncline in Minnesota, Isle Royal, and Ontario. Lane believes that some of the specific horizons identified in the Michigan copper district can be recognized on Isle Royal. ${ }^{12}$

\section{SEDIMENTS}

\section{DISTRIBUTION}

The sediments are decidedly subordinate in the lower groups on Keweenaw Point. They become increasingly abundant in the upper groups, however, constituting practically the entire thickness of the series above the Eagle River group.

\section{GENERAL CHARACTER}

The sediments are predominantly red in color, feldspathic, and poorly sorted; they show horseshoe-shaped ripple marks, cross-bedding, and mud cracks, and so far as known they havenofossils. Their characteristics indicate that they were deposited largely or entirely under terrestrial conditions. ${ }^{13}$

\section{CONGLOMERATE}

Under conglomerate, as here considered, are included rocks of two types-those that are composed predominantly of felsitic material and those that are composed of fragments of amygdaloid in a basic sand and have heretofore been called either amygdaloid conglomerate or scoriaceous amygdaloid. A bed of the second type immediately underlies or forms the lower part of the felsitic Calumet \& Hecla conglomerate but is distinct from it in character and is far more

12 Lane, A. C., Geological report on Isle Royale, Mich.: Michigan Geol. Survey, vol. 6, pt. 1,1898 .

13 Van Hise, C. R., and Leith, C. K., op. cit., p. 417. Lane, A. C., The Keweenawan series of Michigan: Michigan Geol. Survey Pub. 8, Geol. ser. 4, p. 32, 1909. extensive. The two types are distinct in composition and in source of material, and it seems desirable for certain purposes to regard them as separate units, though from purely stratigraphic considerations they might well be grouped together, as they commonly have been.

\section{FELSITE CONGLOMERATE}

Extent and thickness of beds.-Conglomerate of the felsitic type is the principal sedimentary rock in the copper district. Beds of it range in thickness from a few inches to 3,500 feet. Some have been traced for many miles along the strike; the Allouez conglomerate, for instance, is recognized for over 50 miles along the strike and has been identified by Lane across the lake on Isle Royal, though nowhere is it known to be more than 50 feet in thickness. The recognition and enumeration by Marvine ${ }^{14}$ of 22 conglomerates numbered from the base of the series upward to the Great conglomerate constitutes the chief basis of correlation used in all the later geologic work in the district.

Vertical distribution.-The conglomerates form a relatively small proportion of the lower part of the series and a large proportion of the upper part. In the lower part many of the flows have no felsitic sediment between them, indicating that sedimentation at a given place, at least, was intermittent.

Character of material. - The felsitic conglomerates are siliceous in general composition, the most abundant rocks in them being felsite and quartz porphyry. In the north end of the district every bed contains many varieties of such rocks, from the densest felsite to very coarse quartz and feldspar porphyries and from highly siliceous rocks to rocks that are strongly feldspathic and rich in iron. In the south end of the district felsitic pebbles predominate and those of quartz porphyry are practically absent so far as observed. Amygdaloid pebbles are present in most of the felsite conglomerates, and locally such basic material may become plentiful, but fragments of trap are decidedly unusual. In the south end of the dis-

\footnotetext{
14 Marvine, A. R., Michigan Geol. Survey, vol. 1, pt. 2, 1873
} 
trict pebbles of iron formation have been observed, and in the Calumet \& Hecla conglomerate there are a few pebbles of hard white quartzite, which is not known elsewhere in the Keweenawan series. Except for the amygdaloid pebbles, which are of local derivation, all the constituents are physically and chemically resistant. Most of the pebbles are fairly well rounded; some, however, are subangular and might be regarded as having been transported no great distance were it not that similar angularity is to be found among hard materials on beaches subject to strong wave action and can not be taken to indicate feeble abrasion.

Character of beds.-The beds, as is true of conglomerates in general, are lenticular, thinning or thickening rather rapidly along the strike. Where thin they are usually of rather fine texture, consisting of sandstone or grit; the coarser material, the largest boulders in which are rarely over a foot in diameter, is usually present in rather thick beds, though the thick beds are not at all places composed of coarse material. The Wolverine sandstone included in the conglomerate of Marvine, for example, in places attains a considerable thickness, though usually retaining the texture of a sandstone or shale. Lenses of sandstone are present in much of the conglomerate. Cross-bedding, mud cracks, and ripple marks are common features. (See pl. 55.)

Character of underlying bed.-Commonly the felsitic conglomerate is underlain by a soft red or brownish basic sandstone, locally ripple-marked, and contains pebbles of amygdaloid that become increasingly abundant toward the base and were evidently derived from the underlying amygdaloid. This is what Lane has designated amygdaloidal conglomerate. Where the felsite conglomerate is underlain by the more basic fragmental material, amygdaloid pebbles are likely to be present in the felsitic layer and more noticeably toward its base but rarely in abundance. Much less commonly a felsite pebble may be found in the basic layer. On the whole there has been little commingling of the two kinds of material, and as a rule the boundary between the felsite and the basic layers is pretty distinct. Rarely does either the felsitic rock or the underlying basic conglomerate rest directly on trap without the intervention of a band of amygdaloid, though there is in many places evidence that some of the amygdaloid has been eroded.

Source of material.- The principal material of the felsite conglomerate is similar to that composing several masses of felsite and acidic porphyry, in part at least intrusive, that are exposed in the district. Lane has called attention to the similarity between certain pebbles in the Calumet \& Hecla conglomerate and an intrusive rock near the Keweenaw fault east of Calumet. There are conglomerates of like character, however, that are older than any of the exposed masses of similar igneous rocks, and the exposed masses seem much too small to have furnished the large amount of material that the conglomerates contain. The variety of acidic igneous types is greater in the conglomerate beds than would be expected if they were derived wholly or mainly from the breakdown of any single igneous body. Furthermore, as already mentioned, pebbles of iron formation and of foreign quartzite are present sparingly in the conglomerate beds, and on Michipicoten Island similar conglomerates carry pebbles of granite and gneiss. Lane ${ }^{15}$ and others have suggested that certain extensive flows of felsite, poured out on top of the basalt flows, immediately succumbed to erosion, thus forming a nearly contemporaneous conglomerate. Some of the pebbles of felsitic texture show flow structure which may be a result of surface flow; but it is not necessarily so, for similar structure is present in felsite that is known to be intrusive, and these pebbles showing flow structure are mingled with an abundance of others of such coarse porphyritic and holocrystalline texture as to make their derivation from effusive rocks unlikely.

Aldrich, ${ }^{16}$ of the Wisconsin Geological Survey, believes that much of the material in the conglomerates of Wisconsin is derived from rhyolite flows. He describes conglomerates resting on rhyolite flows and made up in part of pebbles that are similar to the flows and are thought to have come from them. Nowhere in the Michigan copper region, however, is a conglomerate known to rest upon or be in contact with a felsitic mass that can be regarded as effusive.

It seems probable that the conglomerate pebbles were not of immediate local derivation but came from long-lived uplands composed mainly of felsite and quartz porphyry, and that the débris from these uplands, together with a small proportion of other material from different sources, was spread intermittently on the adjacent piedmont plains occupied mainly by the basic flows.

Where such uplands were located is not known, for no remnants of formations that seem adequate to have furnished the material for the conglomerates have been found. They may have been outside the present limits of the Keweenawan and in the area now covered by the Jacobsville ("Eastern" or Cambrian) sandstone, or they may have been inside these limits and in the area now occupied by the Freda sandstone (upper Keweenawan). It seems probable that they came from the same direction as the flows and were spread over and carried down the gently sloping surfaces of the flows. Aldrich ${ }^{17}$ and Hotchkiss ${ }^{18}$ believe that the source of the similar acidic and basic rocks in Wisconsin was in the interior of the Lake Superior

18 Lane, A. C., The Keweenawan series of Michigan: Michigan Geol. Survey Pub. 6 (Geol. ser. 4), p. 753, 1908.

${ }^{16}$ Aldrich, H. R., Magnetic surveying on the copper-bearing rocks of Wisconsin: Econ. Geology, vol. 18, p. 569, 1923.

${ }^{17}$ Idem, p. 571.

18 Hotchkiss, W. O., Lake Superior geosyncline: Geol. Soc. America Bull., vol. 34 pp. $669-678,1923$. 
basin, and there are reasons for supposing a similar source for the rocks in Michigan, as is pointed out in the discussion of igneous rocks on page 26 .

Manner of deposition.-The upper surfaces of many of the lava flows are not eroded and are immediately overlain by other flows without the intervention of any sediment. Sedimentation therefore must have been intermittent. Two contrasting ways in which the intermittent deposition of the felsite conglomerates might have been accomplished have been imaginedthat the conglomerates are marine deposits and were accumulated in a body of water that alternately advanced and retreated from the area during the period of lava accumulation; or that they are dominantly terrestrial deposits and were accumulated intermittently on a plain that was being flooded by lava.

The second hypothesis appears the more probable. There has been an increasing tendency among geologists, including workers in the Michigan region, to regard sediments of this general type as having accumulated on land or in very shallow water. Within the stratigraphic limits that embrace the conglomerates no sediments of undoubted marine origin are known, nor any that are more probably marine than the conglomerates themselves. The presence of ripple marks and mud cracks is strongly indicative of deposition in streams, puddles, or shallow sheets of water. Perhaps these Michigan conglomerates find their closest analogy in point of origin with the extensive Gila conglomerate of Arizona and western New Mexico and similar deposits of whose terrestrial origin there can be little doubt.

Emphasis should be placed on the fact that the red color of the conglomerates is not due mainly to weathering and oxidation, the causes most commonly assigned in explaining red sediments. The conglomerates are red because the pebbles in them are red. Comparison shows that the felsite and porphyry are but little redder than the red felsite and quartz porphyry masses, such as Mount Houghton, the Bare Hills, and the body east of Calumet. The pebbles in these conglomerates are aimost as free from weathering as the freshest similar massive rock in glaciated outcrops. The color in both is due to minute plates of primary hematite. The cementing material of the conglomerates contains much iron oxide in grains not inclosed in rock. In the Great conglomerate the oxide is magnetite partly altered to hematite and limonite. In the Calumet \& Hecla conglomerate little unaltered magnetite remains. It is probable that some of the limonite resulted from surface oxidation.

\section{AMYGDALOIDAL CONGLOMERATE}

Relation to felsite conglomerate.-The Calumet \& Hecla felsite conglomerate is immediately underlain by a fragmental layer consisting chiefly of basaltic material-in part basic sand, in part pebbles or boulders of amygdaloid-resting upon the amygda. loidal upper part of a basaltic flow. To material of this type Lane has applied the name "amygdaloidal conglomerate." Similar material underlies most of the felsite conglomerates and is present on numerous flows without accompanying felsitic material. Ap. parently Lane and others have regarded such basic fragmental stuff as a part of a single conglomerate formation, of which the overlying felsite portion is perhaps the more conspicuous and certainly the more important economically. For purposes of stratigraphic correlation this view leads to no difficulty, but as the acidic and basic portions are derived from different sources and as they also differ in distribution and persistence, it seems advisable, especially for the copper-bearing conglomerates, to make a separation between the amygdaloidal conglomerate and the felsite conglomerate.

For example, the copper of the Calumet \& Hecla conglomerate lode is confined almost exclusively to the upper, felsite portion, the underlying basic portion being nowhere an ore; the felsite portion is of slight lateral extent, thinning out to sandstone and then pinching almost entirely, but the basic sedimentary portion continues on regardless of whether or not the felsite conglomerate is present. To designate the amygdaloidal conglomerate the Calumet \& Hecla conglomerate without qualification at places where the felsite portion is absent might lead to \& misunderstanding as to the possibility of finding ore at such places. In the sections and maps this and similar beds have been classed under the term "scoriaceous amygdaloids," a term well established in the records of the district, though it is recognized that "amygdaloidal conglomerate" conveys a better idea of their probable mode of formation.

Origin.-These scoriaceous amygdaloids or amygdaloidal conglomerates have often been considered true "ash beds" or the accumulation of explosive volcanic material-bombs and volcanic ash. That some explosive material was produced in connection with the basic flows is entirely possible, but the evidence that it was of noteworthy amount is not clear, and the sedimentary origin seems adequate to account for the deposits as they are. The felsite sediments are characteristically underlain by amygdaloidal conglomerate. It is not uncommon to find some felsitic sediment resting on the amygdaloidal conglomerate where no well-defined and persistent felsite conglomerate is present. There are, however, many beds of amygdaloidal conglomerate with which no felsite is associated. Very commonly the amygdaloid of the underlying flow has been partly eroded, and in places it has been entirely removed so that the dark conglomerate rests directly on trap. It is clear, therefore, that the amygdaloidal conglomerates have been 
formed repeatedly at horizons where both erosion and sedimentation have taken place, and that they are products of erosion rather than of explosive eruption. The amygdaloidal conglomerates with which no felsite sediment is associated are similar to those that are accompanied by felsitic rock and doubtless are of similar origin.

It seems most likely that the amygdaloidal conglomerates represent the early stages of a period of erosion and sedimentation, when the sedimentary material was mainly derived near at hand from the readily eroded amygdaloids. Where the sedimentation persisted a long time, so that the basic lavas were extensively mantled with gravel and sand, felsitic débris from more distant sources mingled with that from the basic lava and became the dominant material of the sediment. Where the period was short only the basic material accumulated.

\section{SANDSTONE AND SHALE}

At the top of the Keweenawan series occur the Nonesuch shale and the Freda sandstone. The Nonesuch formation consists of black and red shales interstratified with layers of sandstone. The Freda sandstone is the uppermost formation of the Keweenawan series in Michigan. Its material indicates that it was derived mainly from basic igneous rocks, and Lane regards its source as having been predominantly in pre-Keweenawan rocks. ${ }^{19}$

\section{ASH AND TUFF}

Material that may be ash, though not abundant, is widely distributed. Many of the flows with brecciated tops contain small quantities of finely granulated material mingled with the coarse that may be ash, though it may be merely small fragments of the same origin as the larger. The Ashbed and similar beds are considered on page 33, under types of amygdaloids, but their probable mode of origin is outlined above, under amygdaloidal conglomerate. One siliceous layer, called the "Mesnard" epidote, is said to contain quantities of acidic ash ${ }^{20}$ and is ascribed to a period of rhyolite eruption.

\section{IGNEOUS ROCKS}

The major part of the igneous rocks exposed on Keweenaw Point are basic lava flows, which make up most of the central portion of the Keweenawan series and whose outcrop forms the higher portion or backbone of Keweenaw Point. Intrusive rocks of the gabbro and "red rock" types, similar to the Duluth gabbro and "red rock," and felsite and quartz porphyry intrusives, are present at several localities near the base of the series, and intrusives are also present

\footnotetext{
${ }^{19}$ Van Hise, C. R., and Leith, O. K., op cit., p. 414. Lane, A. C., Jour. Geology vol. 15 , p. 690,1907 .

${ }^{20}$ Lane, A. C., The Keweenaw series of Michigan: Michigan Geol. Survey Pub. 6 (Geol, ser. 4), pp. 409, 565, 1909.
}

high in the series in the Porcupine Mountains. It is possible that some of the felsite bodies are surface flows.

\section{EXTRUSIVE ROCKS}

DISTRIBUTION

The basic lava flows in the central portion of the Keweenawan series extend as a belt 1 to 3 miles wide from the end of Keweenaw Point into Wisconsin. (See pl. 2.) A southern belt of flows, the South Trap Range, diverges from the main range near the Michigan-Wisconsin boundary and extends eastward toward Keweenaw Bay. In addition to these main belts there are a few small flows, the Lake Shore trap, in the prevailingly sedimentary rocks of the upper part of the Keweenawan series.

\section{EXTENT OF BEDS}

Several of the flows have been traced for 40 or 50 miles along the outcrop. The Greenstone flow, for example, which forms Greenstone Cliff, in Keweenaw County, is known from the end of Keweenaw Point to a locality south of Portage Lake; the "Big" trap, immediately above the "St. Louis" conglomerate, extends from a point considerably south of Calumet well toward the end of Keweenaw Point; the Kearsarge flow has been traced for 40 miles. Doubtless there are numerous flows not so easily recognized and followed that persist for miles.

At several horizons there are series of relatively thin flows which can be traced, collectively, for long distances, though it is rarely possible to correlate the individual flows between distant outcrops. The Pewabic flows, in the northern part of the district, and the Evergreen and succeeding flows, in the southern part, are of this character.

Lane believes that he can recognize some of the individual flows of Keweenaw Point in the outcrops on Isle Royal, which lies 50 miles distant, near the north side of the Lake Superior basin.

\section{THICKNESS}

There is a notable variation in the thickness of the portion of the Keweenawan series composed predominantly of lava flows at different points along the range. The total thickness of the series is nowhere known, as it everywhere abuts against the Keweenaw fault.

In Keweenaw County the thickness between the Great conglomerate and the Keweenaw fault is about 15,000 feet. At Calumet about 11,000 feet is exposed between the Great conglomerate and the fault, but the fault apparently cuts the series at a much higher horizon here than in Keweenaw County. Near South Range about 11,000 feet is exposed, but here the fault cuts the series much lower than at Calumet. At Victoria probably not more than 8,000 feet is exposed $58540-29-3$ 
between the Great conglomerate and the Keweenaw fault.

The beds that have been most definitely correlated through the district are the Great conglomerate

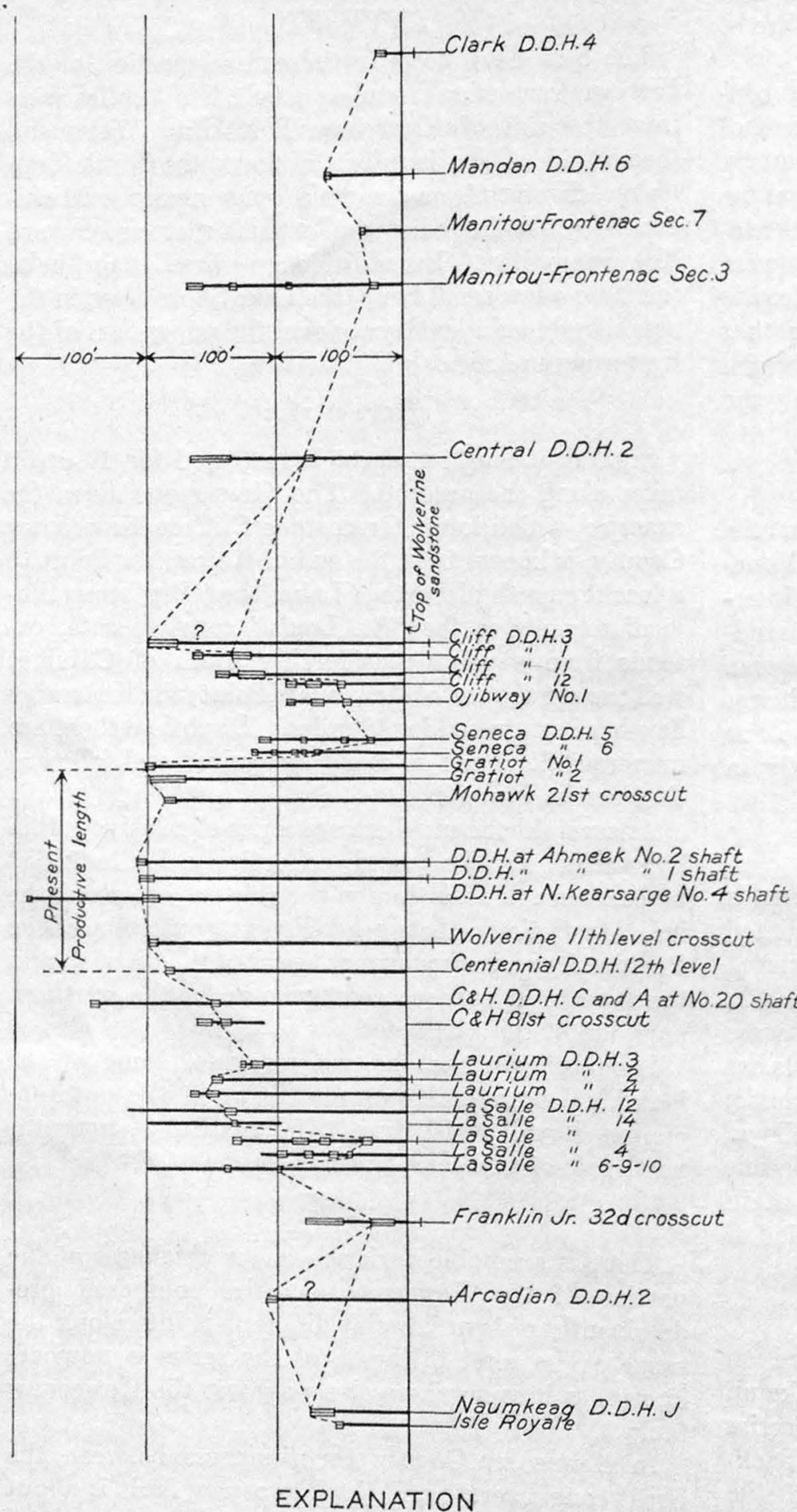

"St. Louis" conglomerate near Calumet and with the Bohemia conglomerate in Keweenaw County. These correlations are probable but not certain. Likewise No. 8 conglomerate in Ontonagon County is not positively known to be the extension of $\mathrm{N}_{0.8}$ at Portage Lake but is thought to be.

If these correlations are correct it is appar. ent from an examination of the plate showing correlation of sections that the greatest thick. ness between conglomerates No. 8 and $\mathrm{N}_{0}$. 15 is at Calumet, where it is about 8,000 feet; at Franklin it is about 6,000 feet; at South Range it is little over 5,000 feet; and at Winona and farther south it is little more than 4,000 feet.

The greater thickening in the vicinity of Calumet seems to be due, in large part at least, to the presence of the "Big" trap above No. 8 conglomerate and to 1,000 to 1,500 feet of thin flows that seem to be largely absent at Portage Lake and farther south. A somewhat similar thinning seems to occur northward into Keweenaw County. There is a tendency to thinning southward higher in the series, as can be seen by inspection of the plate, but it is much less marked.

Between the Allouez conglomerate ( $N 0.15)$ and the Great conglomerate (No. 22) the greatest recorded thickness is about 4,000 feet at Eagle River. At Calumet the interval is about 3,000 feet. South of Calumet it is about 2,700 feet at Franklin Junior and about 2,400 feet at South Range.

The greatest cause for variation in this part of the section is the difference in thickness of the Greenstone flow.

The individual flows vary greatly in thickness from place to place. In general the more extensive flows are thick; the Greenstone flow has a maximum thickness of 1,300 feet in Keweenaw County; the "Big" trap exceeds 400 feet, and the Kearsarge flow (fig. 1) exceeds 200 feet. These great flows commonly thin rather gradually from their thicker portions, as is well shown by the Greenstone flow, which thins southward from Keweenaw County, where it forms the great Greenstone Cliff, to only moderate thickness at Calumet, and which can not be positively identified south of Portage Lake except by its relations to other beds. An inspection of Plate 2 will show the rather gradual thinning of other flows, though some thin rather abruptly, as the Mandan flow north of Delaware, in Keweenaw County, and the thick flow above No. 8 conglomerate near South Range.

Although certain flows can be traced for long distances, and in certain places and horizons all the indi-
(No. 22), the Allouez conglomerate (No. 15), and the No. 8 conglomerate. The correlation of No. 8 is not as certain as that of the other two. The No. 8 conglomerate at Portage Lake is correlated with the 
ridual flows throughout a considerable thickness can be closely correlated, at other places and horizons there is little certainty in the correlation of individual beds, even in sections but a short distance apart, though there may be and frequently is a good correlation of the general series of flows.

In certain portions of the series the flows over long distances are prevailingly much thinner or thicker than the general average. One persistent belt of thin flows lies above the "St. Louis" and No. 8 conglomerates; with the exception of the heavy trap that is immediately above the conglomerate in places the flows in this belt, for several hundred feet statigraphically, are thin, many being only 5 or 10 feet thick. To a less pronounced degree this is true of the belt above the "Mesnard" epidote. The flows for several hundred feet below the Allouez conglomerate or between the Allouez and Kearsarge conglomerates, on the other hand, average unusually thick, many of them reaching 100 to 200 feet or even more.

In addition to the broader variation in thickness of the flows over long distances discussed above and shown on the geologic maps and sections, there are local variations due largely to irregularities in the top of a flow or of the surface on which it rests. The surfaces of some of the flows are irregular and hummocky, showing differences in altitude of as much as 20 feet or even more. It is evident that the thickness of a flow measured from the tops of the hummocks would differ materially from the thickness measured from the bottoms of the depressions, especially if the flow should rest on one with equally irregular top and a depression in the upper flow lay over a hummock in the lower. In the flows with fragmental tops, in which most of the copper deposits occur, marked variations in thickness are the rule and make a close determination of the thickness of a flow from place to place impossible. In general it may be said that the flows having cellular or smooth tops are the most uniform in thickness and those having fragmental or rough tops the least uniform.

Sedimentary deposits commonly approach a plane. The base of a flow that rests on a conglomerate, sandstone, "scoriaceous" amygdaloid, or cellular amygdaloid will therefore be a nearly plane surface; a flow that rests on a fragmental amygdaloid will have an uneven base, and its thickness will vary accordingly.

\section{COMPOSITION OF FLOWS}

The great bulk of the flows of the Keweenawan series are basaltic, rather simple mineralogically, and monotonously similar in appearance. The district contains, however, numerous types of lava grading from typical olivine basalt through andesite to rhyolite.

The more basic flows are typical olivine basalts composed essentially of feldspar, pyroxene, olivine, and magnetite, the last two now largely altered to other minerals. . In the flows of more andesitic com- position olivine decreases and disappears and the proportion of feldspar to pyroxene increases. Biotite has been noted in the feldspathic flows but is not common or abundant. Toward the Michigan State line, north of Lake Gogebic, are feldspathic flows, with a very low proportion of dark mineral but without visible quartz phenocrysts, which approach rhyolite, and farther south, in Wisconsin, Aldrich ${ }^{21}$ noted rhyolite porphyry flows, which also occur in the series north of Lake Superior.

The Keweenawan flows are of the "plateau" type. (See p. 25.) In the following tabulation of analyses two of the typical Keweenawan flows are compared in composition with plateau basalts from other localities as given by Washington ${ }^{2 z}$ and with Daly's average basalt.

Average composition of plateau basalts

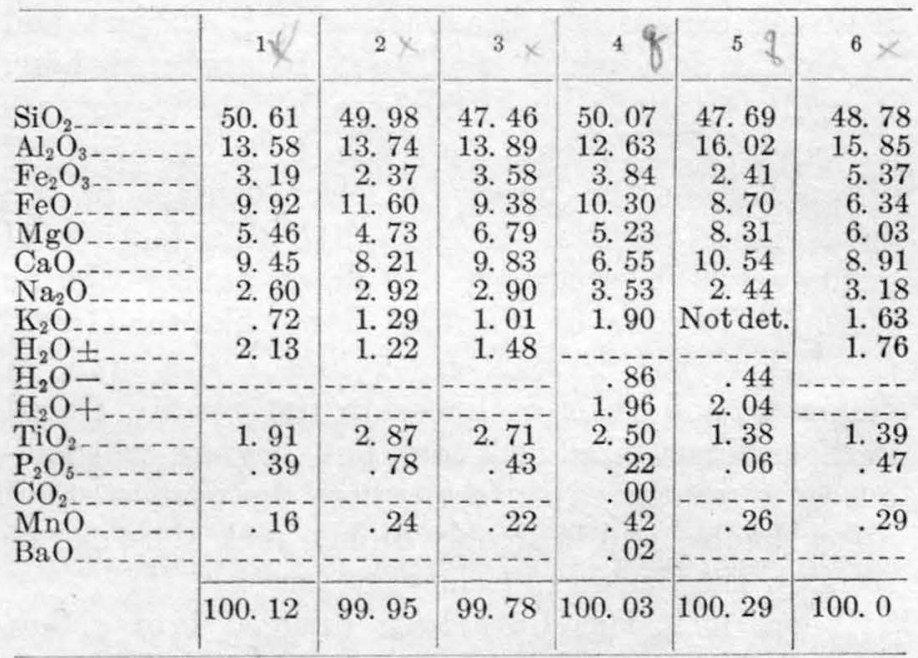

1. Deccan basalts; 11 analyses.

2. Oregonian basalts; 6 analyses.

3. Thulean basalts; 33 analyses.

4. Bed No. 65, Eagle River, Keweenaw Point, Mich.; Lane, A. C., The Keweenaw series of Michigan: Michigan Geol. Survey Pub. 6 (Geol. ser. 4), p. 110.

5. Greenstone flow, Keweenaw Point, Mich.; idem, p. 112.

The Greenstone flow (No. 5) is an olivine basalt; the Eagle River rock (No. 4) is more feldspathic but clearly of basaltic type.

\section{TEXTURAL TYPES}

The one outstanding characteristic of the flows that is most useful in their classification is their texture, which serves as one of the major bases of correlation from section to section. Textural classification may be made in hand specimen, drill core, or outcrop and gives to some extent an indication of the variation in chemical composition. Lane has distinguished four general types-ophite, melaphyre, porphyrite, and glomeroporphyrite. The many variations of these types, which, indeed, grade into one another, are designated by modifying adjectives, such as feldspathic. Lane also recognizes dolerites, which are a coarse or pegmatitic facies of any of the others.

21 Aldrich, H. R., Econ. Geology, vol. 18, p. 570, 1923.

${ }_{22}$ Washington, H. S., Deccan traps and other plateau basalts: Geol. Soc. America Bull., vol. 33, pp. 774, 779, 789, 1922. 
There may be differences of opinion as to the appropriateness of the names used in this classification, but to anyone who has examined drill cores from this series of rocks there can be no doubt as to the usefulness of the distinctions. The textural features that have been emphasized come out very strongly on the ground surface of drill cores, as can be seen by reference to Plate 56. Lane's classification has therefore been used in the maps and sections accompanying this report.

Ophite.-Ophitic texture is the roughly circular mottling of the rock produced by crystals of pyroxene that surround and inclose the feldspar crystals (pls. 56, 57). The ophitic lavas are the "luster-mottled melaphyres" of the earlier publications on the district. The size of the pyroxene crystals varies with their distance from the contact of cooling and somewhat with the composition of the lava. Lane ${ }^{23}$ has given an exhaustive discussion of this subject and its application, which need not be repeated here. Roughly he finds that the size of the pyroxenes increases 1 millimeter for each 8 to 10 feet of distance from the upper or lower contact of the flow. It is needless to say that this fact is of great value in studying the flows having ophitic texture. In some of the thick flows, like the Greenstone flow, the crystals are 2 inches and more in diameter, and their outlines are not readily traced in the ordinary sized drill core, but they are conspicuous on a weathered surface, where the centers stand up as knobs, and in freshly broken rock they can be seen by the flashing of cleavage faces.

Where inclusions have been dragged into a flow the mottling around them is finer than elsewhere at a corresponding distance from the surfaces of the flow. This may account for some of the ophites of varying or banded mottling.

Porphyrites.-The porphyrites are rocks that contain well-defined crystals, usually of feldspar, of an older generation than the same mineral in the groundmass.

Glomeroporphyrites.-In the glomeroporphyrites the feldspars show a considerable variation in size, though not so definite a difference in size and time of formation as is shown between the feldspar phenocrysts and the groundmass feldspars in the porphyrites. The larger feldspars are collected into bunches or clots.

Melaphyre.-Melaphyre is a term applied to rocks that show none of the distinctive textures indicated above. Many beds that show a distinctive texture near the center lose it near the margins, and many thin flows do not show a distinctive texture in any part. There are also some flows 100 feet or more

\footnotetext{
${ }^{23}$ Lane, A. C., Michigan Geol. Survey Pub. 6 (Geol. ser. 4), vol. 1, p. 145, 1911.
}

in thickness that show no distinctive texture and are classed as melaphyre.

Dolerite.-The term dolerite is used to designate portions, in the lavas of certain types, in which the minerals, especially the feldspars, are unusually coarse and the rock has a pegmatitic texture. Rock of this type occurs in the thicker beds and is regarded $a s$ portions that crystallized late. It is allied to the pegmatite facies of some intrusive rocks. The term dolerite has been used by some petrographers in a different sense.

\section{RELATION OF TEXTURE TO COMPOSITION}

The ophitic texture is best developed in the more basic lavas, where it is conspicuous even in the thin flows and very near to the margin of the thick flows. In the more feldspathic lavas the ophitic texture may be conspicuous near the center of thick flows but absent from the thinner flows and near the margin of the thicker flows.

The porphyritic and glomeroporphyritic textures are characteristic of the more feldspathic beds or those approaching andesite, though phenocrysts are present in some ophitic flows, as the Kearsarge flow, in which they are especially abundant just below the amygdaloidal top.

The melaphyre texture, as already indicated, is found in the less basic beds. The feldspathic beds in the south end of the district show no definite texture and are of the melaphyre type.

\section{DISTRIBUTION OF THE DIFFERENT ROCKS}

Most parts of the section are characterized by the predominance of one or another of these textural types, which were produced by recurrences of different phases of the eruption of lava.

Below No. 6 conglomerate (see pl. 15) the flows are prevailingly ophites, commonly of the banded type. For a few hundred feet below and several hundred feet above No. 8 conglomerate, glomeroporphyrites and melaphyres predominate, especially from Portage Lake north to Keweenaw County. The series of thin beds above No. 8 conglomerate are typically glomero. porphyrites. Between the Kearsarge conglomerate and the "Mesnard" epidote the flows are typically ophites, and above the "Mesnard" glomeroporphyrites and melaphyres prevail. The flows above the Great conglomerate and below the Outer conglomerate - the Lake Shore trap-are melaphyres. Commonly there is a transition zone of varying width between the flows of different types, in which the rock is intermediate and more variable in composition.

In the south end of the district the "Chippewa" felsite, a siliceous rock of rhyolitic composition, forms a continuous belt in the upper part of the lava series and also crops out in the central area of the Porcupine Mountains. This rock is similar in com- 
position and character to some of the felsite intrusives, and its presence in the center of the Porcupine dome therefore naturally suggested, to Irving and those who have studied it since, the possibility that it is intrusive and that the dome is of laccolithic origin. That there are intrusive rocks in this area is known, but those who have studied the felsite have regarded it as an effusive which has been domed with the other rocks and have correlated it with the "Chippewa" felsite belt to the south.

\section{CHARACTER OF ERUPTIVE ROCKS}

The Keweenawan flows clearly belong to the type of volcanic accumulation known as plateau or fissure flows, which are recognized in many parts of the world. Washington ${ }^{24}$ has recently summarized the characteristics of this type of flow in a paper from which the following passage is quoted:

In various parts of the earth and at different geological horizons are large areas covered by very extensive, generally horizontal series of sheets of basaltic lavas, the series of overlying flows often attaining thicknesses of thousands of meters. In some cases they are accompanied by flows of rhyolite. These basalts have poured out in an evidently very fluid condition, as they occupy preexisting valleys and cover the lower topographic features much like floods of water, the separate flows being very long-many of them measured by miles.

It is generally assumed by volcanologists that these extensive, horizontal, very fluid flows have issued quietly from fissures-an idea first suggested by Sir Archibald Geikie. ${ }^{25}$ Volcanic cones, formed of lavas, ashes, or both, are present in places, but these are inconspicuous, being low because of the fluidity of the lavas, and they always form a very minor feature of the complex.

Such lavas are called variously "fissure" or "plateau" flows. The term "plateau" is used here because the word "fissure" connotes the mode of origin, which is still somewhat uncertain, ***

It is well known that the lavas of these plateau eruptions are mostly basalt, and this petrographical character is the usually accepted explanation of the great extension and horizontality of the sheets, since basalts generally are known to be notably fusible at a lower temperature and more fluid when fused than are more silicic lavas. But basalts vary much, both chemically and modally, and many of them are evidently, on extrusion, less fluid than are those of the plateaus. This is especially true of the basalts of many volcanoes of the explosive type, the flows of which do not extend very far and are often found concolidated on steep slopes, as was pointed out nearly 100 years ago by Lyell.

After discussing the Deccan, Oregonian, Thulean or northern Atlantic, Siberian, Patagonian, Algonkian (Keweenawan), and Palisades (New Jersey) regions, Washington reaches the following conclusions:

We may now summarize the general characters of the plateau basalts. Structurally, they have characteristically issued from fissures, although this quiet extrusion is sometimes accompanied by minor explosive activity. They form horizontal flows of very great extent, indicating a high degree of fluidity at the time of extrusion. The flows are individually of considerable

"Washington, H. S., Deccan traps and other plateau basalts; Geol, Soc, America Ball,, vol. 33 , pp. 765-804, 1922.

"Nature, November 4,1880 . thickness, and the total thickness of the series of superimposed flows is very great. Ash beds and layers of scoria are not abundant. In several regions the basalts are associated with flows of rhyolite or toscanite, while accompanying andesite and trachyte are rarely met with, and lenadic lavas, such as phonolite or tephrite, seldom or never occur. They have been extruded at very different geological epochs, from the pre-Cambrian to recent times.

Megascopically, they are very dark, black or occasionally brownish black, rarely dark gray. In granularity they may vary from rather coarsely doleritic to densely aphanitic, some few being evidently highly vitreous. Vesicular forms seem to be rare as compared with ordinary basalts of volcanic cones The great majority are aphyric, but there is some tendency to a porphyritic development of the feldspar, especially in the Thulean region, forming a special textural type. Augite seldom forms megaphenocrysts, and these small and sparse, while olivine phenocrysts are very rarely present, except in some of the Algonkian and Palisadan [Triassic] diabases. * * *

Chemically, the plateau basalts differ materially from other basalts in one or two features. In the table are given the averages of analyses of basalts of various regions, with the average basalt as computed by Daly from 161 analyses of basalts so named by the authors. ${ }^{26}$ [See p. 23.]

The averages of the three most typical plateau basalt regions - the Deccan, Oregonian, and Thulean - are closely alike. * * * The chief difference is seen in the much higher amount of iron oxides, with ferrous oxide greatly preponderating over ferric oxide. In the typical plateau basalts the combined iron oxides would amount to about 14 per cent or more, and this is the more marked if only the most abundant group of the more femic basalts are considered. I am inelined to think that the comparatively high ferric oxide shown in Daly's average is due in part to oxidation of ferrous oxide through slight alteration and in part to defective determination of the ferrous oxide - a not unusual analytical error. The percentage of titanium dioxide is appreciably high in the plateau basalts.

It would thus appear that the plateau basalts differ from what might be called the cone basalts essentially in the higher iron and titanium content of the former and possibly in the relatively less oxidized condition of the iron. This must be considered as a broad general distinction. Examples may be found among typical plateau basalts in which the iron oxides are not specially high, just as examples may be found among cone basalts in which the iron oxides are much higher than the average. Mineralogically, as we have seen, this chemical difference is expressed in the presence of highly ferromagnesian hedenbergitic enstatite-augite in the plateau basalts, in contrast to that of highly calcic or diopsidic augite in the cone basalts. It may also find expression in the striking tendency of the augite and magnetite to be among the last minerals to crystallize; so that the glass present in the not wholly crystallized plateau basalts would have a composition corresponding to a mixture of augite and magnetite, examples of which we have seen on the island of Skye, in Colorado, and possibly elsewhere.

The preceding descriptions of the plateau basalts, showing that one of their main chemical characteristics is the high percentage of iron oxides, and especially of ferrous oxide, furnish an explanation of their great fluidity at the time of extrusion. It is a matter of common observation that basalts generally are fusible at a lower temperature and are more fluid when molten than are more feldspathic or more silicic rocks. It is also well known that ferrous silicates are more readily fusible than are magnesium or calcium silicates. The experience of iron and steel workers and smelters bears testimony to the lower fusibility and greater fluidity of slags containing considerable iron. * * *

${ }^{20}$ Daly, R. A., Am. Acad. Proc., vol. 45, p. 224, 1910. 
Inasmuch as the fissure eruptions which furnished the plateau basalts show slight explosive activity, it is to be inferred that the magma contained comparatively little gas, so that the effect of this class of components in lowering the fusing point or increasing the fluidity should be less than in ordinary basalts of the explosive cone type. We seem, therefore, to be justified in ascribing the peculiar physical condition of these basalts during their extrusion chiefly to their high iron content.

It is clear that the Keweenawan flows belong with the plateau type, that they were probably erupted from fissures, and that they were highly fluid, forming sheets of nearly uniform thickness over large areas, a feature in which they approach sedimentary formations. Whether their great fluidity was due primarily to the high iron content, to a high initial temperature, to high gas content, or to a combination of these conditions is not so clearly established.

\section{LOCATION OF VOLCANIC VENTS}

Although it seems likely that the flows issued from fissures, there is no positive evidence to indicate where these fissures were located. It has been suggested that the Keweenawan dikes, which, as Van Hise and Leith ${ }^{27}$ point out, practically surround Lake Superior, fill the fissures through which the lavas issued. The same authors consider it possible that similar vents may underlie Lake Superior. The presence of deepseated intrusive rocks near the Keweenaw fault has led Lane ${ }^{28}$ to believe that the fault is possibly the fissure through which the lavas poured. Hotchkiss ${ }^{29}$ believes that fissures centralized within the Lake Superior basin were of chief importance as lava vents and cites evidence to support this view.

The work on which this report is based has added little positive evidence of the direction of flow of the lavas. The "pipe" amygdules, however, which have been formed at the base of some of the flows, are in places bent away from the basin, or up the present dip, suggesting a flow from the north or from some locality within the basin. The Calumet \& Hecla conglomerate also thickens down the dip, and the cross-bedding in places suggests currents from down the present dip. Both these facts seem to indicate that the lavas came from the north.

As is pointed out in the discussion of structure (p. 50), there is reason to believe that the Lake Superior basin was being formed while the lava series was being built up. The filling of the basin could have been accomplished either by lava flowing into the basin from the rim or by lava issuing from fissures within the basin. If Lane is correct in correlating beds on opposite sides of the basin, it would perhaps be more likely that the lava flowed outward both north and south from vents within the basin than that it originated on one side, filled the basin, and then extended completely across.

${ }^{27}$ Van Hise, C. R., and Leith, C. K., U. S. Geol. Survey Mon. 52, p. 411, 1911.

${ }^{28}$ Lane, A. C., Unexplored parts of Keweenaw Point: Lake Superior Min. Inst. Proc., vol. 17, p. 135, 1912.

${ }^{20}$ Hotchkiss, W. O., The Lake Superior geosyncline: Geol. Soc. America Bull, vol. 34, pp. $669-678,1923$.

\section{AMYGDALOIDS}

Each flow is made up of two major parts, which grade into each other. The larger part in most flows, especially in the thick ones, is a massive rock, varying, principally in texture, from center to bottom and top. This is the trap portion. The top of the flow, usually to a depth of several feet, is porous and cellular. This is the amygdaloid portion. There is usually an amygdaloid portion at the base also, but as a rule it is only a few inches in thickness.

\section{TRAP}

The trap makes up 80 to 90 per cent of the total thickness of the thicker flows but constitutes a smaller proportion of the thinner flows. It is a dark-gray or greenish-gray rock, ordinarily of rather uniform appearance except for grain. It is commonly much cut by joints of varying directions, which cause it in mining to present blocky, angular surfaces that serve to distinguish it, even on dust-covered faces, from the "shorter" or more granular fracture of the amygdaloid. Only in the Greenstone and a few other flows, and there crudely, has the columnar jointing so common in basalts been observed.

As has been noted generally in other regions and emphasized particularly by Lane for this region, the top and bottom portions of the trap are likely to be of finer grain than the middle portion. This variation in size of grain, especially in the ophites, may be 80 constant that it is possible to determine approximately the distance of a specimen from the margin of the flow by determining its average size of grain. As a rule, the thicker the flow the coarser the texture of its middle portion; in the Greenstone flow, for instance, the coarsest material is composed of grains 2 inches or more in diameter. In many of the coarser-grained flows, the presence of large crystals of pyroxene with included feldspar crystals gives the peculiar spotted appearance that characterizes Pumpelly's "luster. mottled melaphyre" and Lane's "ophite." A notable variation within some of the thicker flows is afforded by lenses of coarse pegmatitic material rich in feldspar and frequently in iron oxide which Lane has called "doleritic" bands. These are present in the Greenstone flow and other large "ophites" but are more abundant in the more highly feldspathic flows. The trap of certain flows, notably those in the Ashbed group, contains small laths or plates of lighter-colored feldspar scattered more or less sparingly through the fine-grained groundmass.

In some flows and possibly in all there is a slight tendency toward the concentration of more basic material near the bottom by settling. At the base of the amygdaloid of the Kearsarge flow there is a zone from a few inches to several feet thick containing abundant feldspar phenocrysts that collected by rising from the underlying lava. But such evidences of gravitative segregation are relatively inconspicuous. 
The most noteworthy chemical variation in the flows is an increase in ratio of ferric to ferrous iron from bottom to top. This feature is discussed on page 34 .

In the early days, before the true character of the rocks had been ascertained, the "amygdaloid" and the "trap" were not recognized as parts of a single geologic unit but were regarded as independent bodies, and a more definite distinction was accordingly made between them than would be made now. The commercial importance of the amygdaloid as contrasted with the trap has, however, caused this distinction to survive long after the geologic relation of the two had been recognized, and even now there are many who do not clearly realize that a given layer of amygdaloid is any more closely connected to the underlying trap than to the overlying one. The trap represents that portion of the flow from which the gas had escaped before consolidation and crystallization of the rock took place; the amygdaloid represents the upper bubbly or frothy crust in which the rising gas bubbles were frozen before they could escape because the top of the flow consolidated more quickly than the main portion underneath. The thin amygdaloid layer at the base of a flow was likewise produced by the freezing-in of gas bubbles.

\section{BOTTOM AMYGDALOID LAYER}

Many descriptions of flowing lava refer to the continual falling down of solidified lava blocks and fragments over the advancing front of the flow, which overrides and buries them. This would imply that at the bottom of the flow there should be found an accumulation of fragmental material of the same nature as that which makes up the brecciated tops; indeed, some descriptions mention the fragmental layers at both top and bottom of flows. In the Michigan lavas no such fragmental material is consistently present at the bottoms of the flows. Examination has been made of the bottoms of many flows, including some of both the smooth-top and the brecciated or rough-top types, without revealing fragmental material that has been clearly rolled under. At the bases of some flows that rest on sedimentary rocks, however, a few feet of amygdaloid is found in some places. As this basal amygdaloid is particularly well developed in flows resting on sediments and in its stronger development has not been noted in flows resting directly on other flows, it seems more likely that it has resulted from some characteristic of the underlying bed-water content, for examplethan from material rolled under the advancing flow. $N_{0}$ evidence has been seen to indicate that fragmental material that may have been rolled under the flow was either remelted or was floated up into the flow. The same statement applies to the material of the underlying bed. All the evidence indicates that the bottom froze very quickly, though where a flow covered very open-textured material the lava filled the spaces between the fragments for a short distance below the surface. This is especially noticeable where a flow covered coarse trappy fragmenta] amygdaloid.

Characteristically the basal amygdaloid consists of a lower layer of finely amygdular rock, usually not more than an inch in thickness, and an overlying layer containing larger amygdules, which in some places are elongated upward and are then called "pipe" amygdules. This second layer is commonly only 2 or 3 inches thick but may be a foot or more, and the pipe amygdules range from a fraction of an inch to more than 6 inches in length. The pipe amygdules are not strongly developed in all flows. They are well shown at some places in the flows that overlie the Kearsarge flow, the Calumet \& Hecla conglomerate, and the Pewabic lode and in certain flows in the Mayflower-Old Colony mine. Other flows, as those above the Osceola, Isle Royale, and Baltic lodes, show very little basal amygdaloid.

Usually the pipes extend upward perpendicular to the underlying surface, but at some places in the flow above the Calumet \& Hecla conglomerate and in the Mayflower-Old Colony mine the upper parts of the pipes are bent over in a common direction which is believed to be the direction of flow. The basal amygdaloid above some sedimentary beds may reach a few feet in thickness and be distinctly fragmental.

The evidence seems to indicate that the basal amygdaloid was formed by the rapid cooling of the lava in contact with the underlying rock. The thin layer immediately above the cooler rock solidified very quickly, and the gas liberated from the lava was entrapped as small bubbles. Above this bottom layer there was more time for the gas bubbles to collect and coalesce, and much larger ones were formed. Under certain conditions these bubbles expanded upward into the less viscous lava, forming the pipe-shaped cells which, when later filled with minerals, became pipe amygdules. The fact that the basal amygdaloid is more strongly developed above sedimentary beds than above other flows suggests that the gas that filled the cavities may have been in part derived from the underlying material and also that the sedimentary beds contained more water than the flows. Such water -was converted to steam and absorbed by the overflowing lava and was thus a factor in the formation of the basal amygdaloid.

The thinness or absence of basal amygdaloid in some flows may mean that the lava flowed over a surface not yet cooled and that solidification was slow enough to permit the gas to escape before the lava became sufficiently viscous to retain it as bubbles.

\section{THE LAVA TOPS}

VARIETIES

The copper derived from the amygdaloidal tops of the lava flows has amounted to nearly half the total production from the region and now exceeds that 
from conglomerate lodes and fissures combined. The greatest part of this production from amygdaloids has come from only six flows of the scores that are present. It is essential, therefore, that the character and method of origin of these upper parts of the flows be understood if a clear idea is to be gained of the conditions that determined the deposition in them of commercial ore.

The tops of lava flows have long been divided by geologists into two general types - smooth tops and rough tops - to which the native Hawaiian names, respectively "pahoehoe" and "aa," are commonly applied. The smooth tops are highly vesicular or cellular; the rough tops less so. Both types are plentifully represented by the Keweenawan flows, and the differences between them are such as to affect materially the ease of copper deposition in them. The smooth tops may be further divided into normal vesicular tops and coalescing vesicular tops; the rough tops are separable into fragmental or brecciated tops and scoriaceous tops. (See pls. 58-61.)

In their typical development the different types of tops are perfectly distinct in character, but there are all gradations between the different types in different flows and between most of the types in some single flows. Thus the Kearsarge lode has in some places a typical cellular top, in others a well-developed fragmental top. The same is true of some of the Pewabic flows. The Ashbed flow is typically scoriaceous but locally fragmental.

Many flows, however, have a tendency to be either cellular or fragmental over long stretches. The tops of the thin series of flows above No. 8 conglomerate are rather typically cellular. The Osceola flow and other flows have fragmental tops for many miles. The thickness of the flow does not seem to control the character of the top. Many of the thin flows have cellular tops, but the tops of thick flows may be either cellular or fragmental. More of the fragmental tops occur, however, on thick flows, though there are numerous examples of fragmental tops on relatively thin

The differences between the rough and the smooth tops go far beyond mere difference in texture of surface; the smooth tops approach much more nearly a. plane surface, but the rough tops were hummocky and irregular, with differences in altitude of probably 30 feet. This difference is brought out strikingly in the drifts that follow the tops of the flows. In the Pewabic lode, a smooth-top flow, the drifts are essentially straight for hundreds of feet, but in the Osceola lode, a rough-top flow, they are exceedingly irregular.

\section{SMOOTH TOPS}

The most notable differences in the smooth tops arise from the size and distribution of the gas bubbles or vesicles, now chiefly filled with minerals to form amygdules. In the prevailing class of smooth tops the vesicles are abundant, of moderate size, and arranged more or less definitely in layers parallel to the surface of the flow, so that the rock commonly has a banded appearance. Generally the amygdules are small and abundant near the top and increase in size and decrease in number deeper in the flow. The layers may be closely spaced or may be separated by layers of rock containing relatively few amygdules, several times as thick as the diameter of an average amygdule. Irreg. ular spacing of the layers is the rule, though in places in the Pewabic lode (see pl. 56) there is an approach to regular spacing. The individual vesicles are for the most part not spherical but flattened in the plane of the flow, some being decidedly elongated and a few showing a tendency to be flatter on their upper side.

The distribution of the vesicles in layers and the elongation of the vesicles in the plane of the lode have commonly been ascribed to flow movement in the lavas. It seems likely that the banding in the Michigan flows may be explained as follows: A period in which many rising gas bubbles collected under a solidified surface was followed by a period of relatively rapid consolidation when few bubbles collected, and this in turn by another period when many bubbles collected, and so on till a depth was attained where the gas was not present in sufficient quantity to form vesicles. The amygdules are fewer and the banding less distinct near the base of an amygdaloid. A similar grouping of vesicles is present in slags solidified in pots where there is no flow movement of the liquid.

The individual bubbles in a layer may be separated by rock stuff exceeding their own diameter, or they may be so closely spaced that two or more adjacent ones may coalesce into a unit that is of irregular shape because the lava had become too viscous to permit the enlarged bubble to assume the usual rounded form. In this way some extremely irregular amygdules may result, and those that are large and conspicuous, as in places near the bottom of the vesicular zone, constitute what Pumpelly and Marvine called "pseudo-amyg. dules," on the assumption that they were formed chiefly by replacement of rock rather than by filling of gas cavities. Some amygdules were slightly enlarged by replacement, but there is little to suggest that this process took place generally or on a large scale.

Rarely if at all in this or in any of the other types of tops is the degree of vesiculation such as to justify the term pumice. A structure more like that of Swiss cheese is the common one.

Permeability is the quality of the amygdaloid tops that makes them more receptive to copper deposition than the traps. The cellular or banded vesicular rock of the smooth-top flows is more permeable than nonvesicular rock, such as the underlying trap, for the reason that in a given volume of it only part is solid rock. A rock in which the vesicles make up 50 per 
cent by volume would have twice the permeability of otherwise similar but nonvesicular rock. But this cellular rock has no through-going and continuous openings, such as would be favorable to high permeability; instead, each opening is of small extent and is walled off from other openings by solid rock. The difference in permeability between the cellular tops and the brecciated tops is therefore very great, and for this reason the smooth tops of the normal sort contain little copper as compared to the rough tops. A subdivision of the cellular type of smooth lava top is recognized in which the individual vesicles are much larger, reaching an inch or more in diameter, at least in certain layers. Many of these vesicles in the same layer coalesce into a thin, jagged gash that may attain a lateral extent of as much as 10 or 12 feet in a single cross section and perhaps form a connected opening for scores of feet in the plane of the flow. Rock containing these openings may be called a coalescing top, or "lode." A series of such openings with little rock material between may constitute almost unbroken openings for long stretches along the plane of the flow. Several such open layers may occur in the same flow top. Where the degree of coalescing of the vesicles is less than that just described, the large vesicles, now filled with minerals, may be closely spaced like beads on a string,

The cause of this coalescing of the vesicles is probably to be found in the differing temperature and gas content of the lavas. The best-known examples of the coalescing cellular top are the Pewabic lodes. These flows are thin and have ropy surfaces in places. They are so smooth and even that the Quincy mine workings, which follow them, are essentially straight for hundreds of feet. The tops or vesicular portions of the flows are only a few feet thick but very regular, and the banding caused by the larger and the smaller vesicular openings is strikingly even and persistent. (See pl. 58.) All the relations suggest that these flows were very fluid and relatively full of gas when they were poured out. They spread with tops almost as flat and smooth as that of a lake. Possibly flow had ceased before a crust had formed, but if not, the flow of lava under the crust disturbed it very little. In the highly liquid lava, the rising gas bubbles were able to combine into much larger ones that, on reaching the bottom of the crust at any given stage of its formation, coalesced commonly into the extensive flat layers already described. In other parts of these flows, however, the tops are broken into a typical breccia or "fragmental" amygdaloid.

The economic significance of this modification of the smooth-top flow is that the resulting rock is of much higher permeability and therefore much more susceptible to replacement than the normal type, with its small and more evenly distributed vesicles. The broad, flat openings in this coalescing facies are separated by only short distances from other similar openings, so that solutions could move for a long distance parallel to the flow surface without having to penetrate solid rock for more than a small fraction of that distance. It is a striking and significant fact that of the six amygdaloid lodes that have been large producers of copper, only one is of the smooth-top type, and that one, the Pewabic lode or series of lodes, is of this relatively more permeable coalescing variety. Other flows lower in the series show a similar structure but not in so marked a degree as the Pewabic lodes; no ore has yet been found in them.

FRAGMENTAL OR BRECCIATED TOPS

Character.-The rough-top flows, as already indicated, are much less numerous than those of smooth top, but they are of especial interest because four of the six profitable amygdaloid deposits are predominantly of this type and the other two are in part of this type. Most of the other amygdaloid deposits that have yielded considerable copper are also of this type.

The brecciated tops consist of fragments of lava ranging in size from minute grains to massive blocks several feet in dimension. Ordinarily the individual fragments are under 6 or 8 inches in diameter, and the average size is less than half that. In consequence only rarely does one of the larger blocks or slabs project noticeably above the general level of the flow surface. These flows, therefore, though classed in the rough-top type, have a surface less rough and blocky than that of the modern flows to which the name "aa" is commonly applied, and the general smoothness and regularity of the bottom of the overlying flow show that these breccia tops have not been changed from a rough, blocky condition to their present state by crushing and packing due to the weight of rock above.

In shape the fragments range from slabs or irregularly angular pieces through subangular to rounded. In general the larger pieces are the more angular and the smaller ones more rounded, though many small pieces are angular. Large and small fragments are promiscuously jumbled together, though in some flows the smaller fragments predominate near the top and the larger ones near the bottom of the fragmental layer. The general accumulation of material gives an appearance not unlike a conglomerate, and probably for this reason it has sometimes been called "amygdaloidal conglomerate," though that term as used by Lane apparently does not include these brecciated tops.

There is considerable variation in the texture of different fragments, even of those that are contiguous. A rounded piece entirely surrounded by a fine-grained margin but of coarser center may lie against one that is rather uniformly amygdular and another of 
fine even grain; or a piece may be fine grained on one side and gradually become coarser toward the other side. Smaller pieces may be uniformly fine or coarse, though even those not more than an inch across may show marked differences in texture.

The greater number of these fragments were vesicular and are now amygdular through filling of the vesicles. Some of the fragments show the same banded arrangement of vesicles as in the smooth tops and undoubtedly were broken from a larger structure of that kind; others may exhibit, particularly near their margins, an arrangement of vesicles more or less parallel to the outlines of the fragment. In many fragments the vesicles near the surface are smaller than those farther in. Very commonly an outer shell a fraction of an inch thick is of dense material containing countless minute, even microscopic vesicles; it closely resembles the thin layer at the very top of the smooth flows and is clearly the result of quick chilling. Some fragments showing this chilled margin around part of their periphery may be coarser grained for the remainder of their circumference, as if broken away from a large mass after the chilled surface had formed and after the interior part had solidified. Still other fragments have a finely granular, almost trappy texture, but fine grain may also be present throughout a fragment in consequence of rapid cooling. Most of the smaller fragments consist of the more finely vesicular material, and most of the larger ones of the more coarsely vesicular, but many exceptions are to be seen. The spaces between the larger fragments are filled with finer material of the same general character grading down to fine particles.

In most of the flows studied that possess the brecciated type of top this mixture of fragmental material gives place downward in the flow rather abruptly to the crystalline trap. The contact between the two is likely to bo irregular on a small seale but appears smooth and rather regular when viewed broadly. The trap for a few feet under the fragmental layer may contain included fragments of amygdular rock similar to that in the fragmental zone but generally more rounded, as if partly remelted or resorbed. The layer of trap containing these inclusions is designated the "amygdaloid inclusion zone." It is present in the traps not only under the brecciated tops but also under some scoriaceous tops or so-called amygdaloidal conglomerates, but it has not been seen under the nonbrecciated smooth tops.

In the tops of the Isle Royale and Osceola flows, which are excellent examples of the brecciated type, there may occur in the midst of the breccia layer slabs of trap a few feet in thickness and as much as 20 feet or even more in length. This material, called by the miners "vein trap," is likely to contain partly resorbed amygdular patches like those of the amyg- daloid inclusion zone. The slabs are commonly paral. lel to the plane of the lode, but some may be tipped at an angle to it. The fragmental material under. neath these slabs is of the same character as that above them. In places these slabs show feeble pipe amygdules on their under side in contact with the lower layer of fragmental stuff. Where this develop. ment of vein trap is considerable, the separation of the fragmental material produces a sort of double lode.

A modification of the brecciated top which suggests an approach toward the smooth tops is especially well shown in the Kearsarge lode. In the productive portion of this lode a layer of typical fragmental material ordinarily occupies the upper few feet; the fragments are notably small near the top and coarser below. Without abrupt change the fragments become larger downward, the fragmental character becomes less and less evident, the vesicles increase somewhat in average size, and the banded cellular structure assumes prominence. In short, the chief characteristics of the smooth tops are attained. But this cellular rock underlying fragmental rock is not everywhere continuous over large areas but is composed of blocks or fragments, as if the crust had been broken up while it was still in a semiplastic condition. The blocks may be tilted at an angle with the plane of the lode and show a tendency to chilled margins and coarser interior, suggesting that the final crystallization occurred after the breaking, as indeed is true of the small frag. ments in the brecciated portion of the lode. In places lava has filled the spaces between the blocks as a cement. Where the brecciated portion of the lode is absent or slightly developed, as outside the productive area of the Kearsarge lode and over considerable tracts within the main productive area, the tendency for the cellular portion to be broken into large blocks is much less conspicuous or is absent. The cellular portion is in places composed of several small flows or gushes showing banded amygdaloid and chill margin.

The intermediate zone of the Kearsarge top has been called "cellular middle lode," to distinguish it from the "fragmental lode" above. It is not present in all parts of the lode and not equally conspicuous at all places where present. A very little of the same sort of thing is seen here and there in the midst of the Isle Royale lode, which for the most part is of the brecciated type, and it is present in parts of the Baltic lode, especially in areas where the lode is relatively thin.

Still farther down in the Kearsarge top below the "middle lode" horizon the rock becomes coarser in texture, and the vesicles become less numerous and larger and show little tendency to gather in bands. This lower, chloritic zone of the Kearsarge top is called "foot lode." Material of this character is common on the underside of many of the lodes, such 
as the Baltic, Isle Royale, Evergreen, and succeeding lodes of that series. Still deeper in the Kearsarge the amygdaloid inclusion zone occurs locally, though it is nowhere conspicuous and in most places is absent, and this passes, as usual, into the main trap of the flow.

The Pewabic series of flows likewise illustrates characteristics of both the cellular and the fragmental tops. The tops of these flows are chiefly of the cellular and cellular coalescing type. In many places, however, the uppermost foot or less of the lode consists of breccia, which gives place downward to the rock with coalescing vesicles. In such places the breccia is commonly made up of fragments of coalescing lode more or less well developed and has obviously resulted from the breaking up of a coalescing top that continued to form beneath it.

In other places over large areas the lode is typically fragmental but of more uniform thickness than is characteristic of "fragmental lode." Of such character is part of the East lode in the lower levels in the south end of the Quincy mine. Here the lode changes within a few feet from typically coalescing to typically fragmental. The fragmental portion seems to be elliptical in outline and to pitch rather flatly southward; its lower portion extends below the mine workings and has not been traced.

In the upper levels of the Quincy mine the "Main" lode over large areas is typically fragmental, is much thicker than the coaleseing portion of the lode, and shows the irregularities in thickness characteristic of fragmental lodes. In the lower levels of the mine this lode is of the coalescing type. The zone of change was not seen, as it lies in a worked out and caved portion of the mine.

The tops of the breccias, though not coarsely jagged, undulate more markedly than the nonfragmentai tops. The fragmental material is piled up in hummocks or ridges, separated by basins or valleys. The thicker breccias naturally show greater irregularities of surface than thin fragmental layers like the Kearsarge lode, but alternations of elevations and depressions are generally characteristic of the type. The maximum range from top of hummock to bottom of sag is perhaps 30 feet, and in places the slope from hummock to basin may be steep.

Where this undulating surface of the breccia tops, covered and preserved by succeeding flows and later tilted, is followed by the mine workings, the hummocks bulge up into the overlying flow, whereas in the basins or depressions the overlying trap seems to bulge down into the lode. These irregularities are economically important, not only because they necessitate crooked mine workings but because thick accumulations of breccia are found as a rule to be better mineralized than thin ones near by. It is noteworthy that where the fragmental material has piled up above the general surface of the flow it has also sunk deeper into the underlying trap, and conversely, where depressions occur on the breccia surface, the top of the traps is higher than elsewhere; this produces a podlike thickening and thinning of the breccia layers. Whether or not these variations in thickness of the breccia have any definite relation to the direction of lava flow has not been determined, but a somewhat systematic repetition of variations in certain flows suggests that there may be such a relation.

It is evident that these layers of fragmental material must be much more permeable than the smooth tops, even though these are highly and coarsely vesicular. In part as a consequence of this greater permeability, the brecciated tops, though probably not more than one-tenth as numerous as the smooth tops, include the four great productive lodes-the Kearsarge, Baltic, Osceola, and Isle Royale; moreover the Pewabic only in part represents the smooth tops, there being large areas of fragmental material in this lode.

Origin.-The origin of this fragmental texture in Keweenawan lavas has been variously explained. It has been argued by Hubbard and others that part of the material, at least, is erosion débris. Hubbard and Lane have also explained much of it as a consequence of brecciation due to sliding along the flow contacts at the time of uptilting of the beds, and Hubbard has predicted that the thicker the flow the more brecciation will its top show.

Grant, who studied the flows in Wisconsin, attributed the brecciated tops to flow movement modified in some places by erosion and deposition. The hypothesis that the typical fragmental tops are of sedimentary origin seems to be entirely lacking in support, though many of them have been reworked by erosional and depositional agencies, which have produced the "amygdaloidal conglomerates" or "scoriaceous amygdaloids."

The hypothesis that they are primarily due to slipping between beds seems also without support. The irregular "dovetailing" of the contact with the overlying flow, due to the hummocky nature of rough tops, did not make such contacts favorable to slipping. Moreover, where the breccia was coarse and open, the top part of it was filled with the lava from the overlying flow, showing clearly that the breccia was present before the overlying flow covered it and of course before tilting of the beds.

The inclusion of amygdaloid fragments partly resorbed in the traps under the amygdaloids seems to indicate clearly that the fragmental tops were formed while the interior portions of the flows were still fluid and presumably still moving. The irregular piling up of the fragments on the flow can probably be best explained by flow forces similar to those in a moving floating ice field. Such movement would result in 
much abrasion of the fragments. The fact that where the fragments are piled above the general level they also sink deeper into the flow indicates that they were piled up while the underlying lava was still fluid enough to permit the sinking of the material, as ice sinks deeper where it is piled higher above the water surface.

It seems likely, therefore, that flow movement was a factor in producing the rough tops as we now see them, but it evidently was not the sole factor, because all the flows must have been moving and in general over surfaces of the same type with the same gradient, some solidifying as smooth tops, some as rough. There must, therefore, have been some difference in the lava itself. That the difference was not necessarily very great is indicated by the fact that a top may pass from one type to another within a very short distance. That the composition as we now find it was not the cause is indicated by the close similarity in composition of flows with tops of different types and the presence of tops of different types on parts of the same flow.

The influence of the gaseous constituents of lavas that escape during solidification is a factor not easily studied in these old flows, but it has been given much study in recent and active flows. Washington ${ }^{30}$ has recently summarized the evidence and the views of various writers on this subject, as well as contributing the conclusions from his own study, and as his summary has so direct a bearing on the formation of the tops of different types in this district, it is in large part quoted below.

The cause of the differences between the two forms has been the subject of much discussion and is still an unsolved problem, the chief difficulties centering about the formation of aa or block lava.

According to Dutton "pahoehoe is formed by small offshoots of very hot and highly liquid lava from the main stream driven out laterally or in advance of it in a succession of smail belches. These spread out very thin and are quickly cooled." On the other hand, "the. fields of ' $a$ ' are formed by the flowing of large masses of lava while in a condition approaching that of solidification." * * * Dutton lays stress on the much greater thickness of the "aa" flows and regards this and the consequent differences in cooling as the causes of the diverse characters.

Dana thinks that "in an 'aa' flow the lava must have been subjected to some deeply acting cooling agency," and that "the cooling was not from above downward, as in pahoehoe, but largely from below upward." He concludes that this cooling agency is subterranean water in the region passed over, an explanation which is combated by Hitchcock and which does not seem to be supported by field evidence.

Daly attributes the difference to "gas control," which he thinks is shown by the different vesiculation of the two forms. The vesicles in pahoehoe are relatively more numerous, more regular in form, being mostly spherical, smaller in size, and more evenly distributed than in "aa," in which they are irregularly scattered through the mass, most of them of very much greater

30 Washington, H. S., The formation of aa and pahoehoe: Am. Jour. Sci., 5th ser., vol. 6 , pp. $409-423,1923$. size, relatively fewer, and of irregular shape, many being muen elongated. Their total volume is generally less per unit volume of rock than in pahoehoe, and " the 'aa' vesicle has undoubtedly grown through the coalescence of many bubbles of gas, * * * The difference in field habit is thus explained by the relative abundance of volatile matter and, still more, by the evenness of its distribution."

Day and Shepherd 31 call attention to "the rapid expansion of the gases with the release of pressure (as 'aa' lava reaches the surface), which is a cooling phenomenon, and which, if the expansion takes place suddenly from a high pressure into the air, might be extremely rapid. * * * Such rapid expansion and consequent cooling, when occurring suddenly at the surface, may very well be the sufficient cause of the 'aa' lava formation Great blocks appear to have cooled in this way so rapidly that no opportunity was given for the suddenly projected and rapidly expanding lava to 'heal' and resume liquid flow. The projected masses are cooled almost instantly throughout their mass and remain discrete blocks." Doctor Day's belief is that pahoehoe lava is the high-temperature form, containing relatively little gas, whereas the "aa" issues at a lower temperature, contains much gas, and cools quickly throughout its mass because of the rapid expansion and elimination of the gas.

Jaggar thinks it "probable that the quantity of confined gas, in solution or in bubble form, controls the method of freezing. Possibly the gases are nearer equilibrium in pahoehoe than in 'aa.' The heat equation plays an important rôle, and this involves reaction between the gases as well as their oxidation in air. Gas expansion may be more rapid in 'aa' and so induce internal solidification. Furthermore, there are enormous differences in the state of oxidation of the iron at the moment of internal solidification, and as yet we know nothing of the progress of crystallization in the field."

At Vesuvius, according to Mercalli, ${ }^{32}$ the most rapid flows and those which contain most gas take the "aa" form, whereas the slower and more viscous lavas generally are of the pahoehoe type. He thinks that the difference between the two depends on "different conditions of cooling," but that difference in the angle of slope has a marked effect. Similar views are expressed by Von Waltershausen ${ }^{33}$ in describing the lavas of Etna.

There seems to be general agreement in the belief that the "aa" form is produced from a highly gas-charged lava by rapid cooling due to the escape of gas, but the question as a whole must still be considered unsettled. There are, however, two or three differential features of the two forms of lava which do not seem to have as yet been studied in connection with this problem but which may throw some light on it. These are the relative amounts of the iron oxides, the different degrees of crystallinity of the two forms, and the different sizes of the respective flows.

After showing that there is no essential difference in chemical composition but that the smooth tops are distinctly less crystalline than the rough, Washington continues:

Inasmuch as the chemical compositions of the "aa" and the pahoehoe forms of these lavas are identical some other factor or factors, physical or physico-chemical, must be sought to explain these differences in the crystallinity, which appear to be connected with the structural and field differences of the lavas.

Any difference in the initial temperature at the time of extrusion does not seem to be adequate in itself, as this difference would not be very great and would be eliminated soon after extrusion.

31 Geol. Soc. A merica Bull., vol. 24, p. 598, 1913.

${ }^{32}$ Mercalli, G., Vulcani attivi della terra, p. 179, 1907

${ }^{33}$ Von Waltershausen, S., Der Etna, vol. 2, pp. 393 et seq., 1880. 
The only factor that appears to be competent to serve as an adequate cause is the gas content of the magma. * * * That the magma which solidifies as "aa" has a very high gas content is commonly recognized. It is shown by the loud roaring and hissing noises of a moving "aa" flow, the numerous flames on the front and over the surface of "aa" flows, and by the abundance of noxious gases, which often make near approach difficult. The lesser gas content of pahoehoe is evident from the much quieter, almost noiseless flow and the absence of flames. Indeed, so quiet and so free from gas are most pahoehoe flows that one can easily (apart from the heat) study them from their brinks. Although pahoehoe flows are fairly fluent on their extruson their viscosity increases very rapidly. An excellent illustration of this is given by Brigham ${ }^{34}$ in his description of a pahoehoe flow issuing from a dome. "It was white-hot cream when it came out from under the crust, but in the distance of perhaps a foot had changed to a cherryred molasses, while a few feet more transformed the stream into full-red tar."

The formation of the two forms of lava takes place about as follows, according to my conception of it. Pahoehoe lava comes out highly heated, probably in large part by internal gas reactions, but not highly charged with gas, much of this having been lost by simmering in the throat near the surface or elsewhere in the course of flow. Because of the high temperature the greater part of the comparatively small amount of gas that remains after effusion is soon lost, whereby the fluidity of the lava rapidly diminishes and with it the possibility of internal molecular motion, so that an early stop is put to crystallization, although the semimolten, highly viscous glass is still capable of slow continuous motion. As the temperature falls and the viscosity increases, the comparatively small amount of gas still present in the magma is gradually expelled from solution and there being few solid points to serve as nuclei and the material being very viscous, the gas is liberated quite uniformly throughout the mass and forms small, spheroidal, rather uniformly distributed bubbles. Slabs of pahoehoe generally show an increase in size and number of vesicles toward the bottom, an effect probably caused by the quicker cooling and solidification of the upper part, which radiates its heat into the air.

"Aa" issues at a lower temperature than pahoehoe, certainly more highly charged with volatile matter, so that the gas present renders the "aa" magma, in spite of its lower temperature, initially much more fluid than is the pahoehoe. Under these conditions of great fluidity and lower temperature the crystallization of labradorite and augite begins early and proceeds with rapidity. The fluidity of the liquid portion and the consequent rapidity of crystallization are maintained and, indeed, enhanced by several circumstances. In the first place, the separation of the crystals, in which the gases are not appreciably soluble, increases the gas concentration (and the pressure) within the remaining liquid, thus maintaining a high degree of fluidity and consequent possibility of internal molecular movement, so that crystallization is facilitated. This increase in gas concentration rapidly reaches or exceeds the point of saturation, the liberation or desolution (if I may be permitted to coin a word) of the gas being greatly facilitated by the presence of innumerable crystals whose angles and edges serve as nuclei and give abundant opportunity for the escape of gas, in virtue of the action of such solid points as centers of the liberation of gas. The gas will thus tend to coalesce into large bubbles and so pass out of the liquid, which remains constantly saturated with gas throughout the continuous crystallization and hence remains very fluid and favorable to crystallization.

Two other factors also tend to preserve the fluidity of the gradually diminishing liquid portion of the lava. **** The one is connected with what has been called the "second boiling u Brigham, W. T., The voleanoes of Kilnuea and Mauna Loa: Bishop Museum
Mem., vol. 2, No. 4, p. 141, 1909 point" 35-that is, the increased gas pressure resulting from the formation of crystals in a cooling liquid. The formation of crystals in a liquid lava gives out latent heat, ${ }^{36}$ as silicate minerals appear to be normal in this respect, so that the crystallization itself will tend to maintain the temperature of the still molten portion or diminish the slope of the cooling gradient. It follows that, in so far as we now know the thermal behavior of silicates, the crystallization or partial solidification of the lava may have a very appreciable effect in maintaining the fluidity of the remaining liquid portion by retarding the increase in viscosity.

The other possible factor is indicated by study of the thin sections of the crystalline basaltic lavas of Hawaii and of other localities. This shows that feldspar begins to crystallize first, augite and magnetite belonging to the later stages of crystallization. *** Because of this early crystallization of feldspars the portion of the lava that remains liquid becomes increasingly femic and therefore more and more fluid, so that the flow of the lava stream is maintained, in spite of the abundant crystallization, and with its continued liquidity also the facility for crystallization.

The liberation of gas from the mass of "aa" will thus be increasingly rapid, possibly violent toward the end, and the crystallization of the lava which forms "aa" is consequently very rapid after a certain degree of fluidity has been reached, the great fluidity of the steadily diminishing liquid portion of the flow being maintained up to the point of complete solidification, as is demanded by the microtextural features of the "aa" lava. This accounts well for the fantastic, rough surface forms and for the large, elongated, random bubbles, both of which are characteristic of the "aa" form.

The conclusions reached by Washington from the study-of recent and active flows strongly suggest that varying gas content was a controlling factor in forming the different types of tops in the Keweenawan lavas.

$$
\text { "SCORIACEOUS TOPS" }
$$

The misnamed type of rock known locally as "scoriaceous tops" has already been described in the section on amygdaloidal conglomerate (p. 20). Briefly, it consists of amygdaloidal fragments in a matrix of fine basic sand which grades downward into normal amygdaloidal rock and in many places upward into fine basic sediment and at numerous horizons finally into felsitic sandstone or conglomerate. As the name implies, lodes of this type have been regarded as the result of explosive volcanic action, the sediment being considered volcanic ash. The Ashbed is the type example.

The "scoriaceous amygdaloids" are more permeable than the smooth cellular tops but less permeable than the brecciated tops, because the interstices between the fragments are filled with a fine sandy to clayey sediment.

Of the numerous examples of this type the Ashbed lode, on which the Atlantic, Copper Falls, and other mines are located, is the only one from which ore has been produced.

ss Morey, G. W., The development of pressure in magmas as a result of erystalliza tion: Washington Acad. Sci. Jour., vol. 12, p. 219, 1922.

${ }^{36}$ Mercalli (Vulcani attivi della terra, p. 189, 1907) attributes the long-continued preservation of heat by lava flows, often amounting to several years, to this development of latent heat of crystallization. In July, 1914, Doctor Day and I could scorch paper in crevices of the flow of 1910 at Etna. 


\section{ALTERATION}

\section{ALTERATION OF TRAPS}

Except for the alteration effected by the copperdepositing solutions, the basaltic rocks are surprisingly fresh in view of their basic composition and their great age. As the ore-depositing solutions moved in quantity only along the more permeable pathways, the dense traps have escaped most of the chemical and mineralogical changes that accompanied the deposition of copper. Glaciation largely removed whatever weathering products had been formed earlier, and since glaciation only incipient kaolinization and limonitization and slight physical decomposition of the traps have occurred, even where the rocks were not covered by glacial deposits.

The principal alterations, aside from ore deposition and surface weathering, occurred in the olivine and the magnetite; the pyroxene and the feldspar of the traps are usually unaffected. The olivine, which at the time of crystallization was common in many of the traps, is now preserved in relatively few. Its former space is filled with serpentine and hematite that have replaced it. This breakdown appears to have caused no marked change in chemical composition within the limits of the olivine individuals but to have been, rather, a rearrangement of the elements into minerals of greater stability under the conditions existing.

The magnetite was altered more or less completely to hematite. The hematite seems to have worked in from the surface, but it also permeated all through the magnetite individuals, which therefore present a pitted appearance under the microscope. In places where magnetite is completely altered to hematite minute irregular stringers and tendrils of hematite extend out from the magnetite grain among the surrounding minerals, suggesting that in the alteration of the iron mineral an increase in volume forced some of the hematite to lodge outside the original boundary of the magnetite. Some of the magnetite was evidently titaniferous, for its alteration has produced numerous granular particles of a nonmetallic mineral, probably titanite, in the midst of the more abundant hematite.

The alteration of these two minerals, so far as has been ascertained, was almost magmatic - that is, it took place very shortly after the rock had solidified, unless, indeed, these early iron-bearing minerals were already altered by the time the pyroxene and the feldspar had crystallized around them, as is discussed later (p. 53). The dominant tendency in the alteration of both these minerals was the conversion of ferrous to ferric iron. This oxidation of iron suggests association in origin with the hematite in the tops of many of the flows and is again referred to in that connection (p. 35).

\section{ALTERATION OF THE LAVA TOPS}

Alteration of the tops of the lava flows is of two types, produced at different times and by different causes - the development of plentiful hematite and the filling of the vesicular and other openings, together with more or less replacement of the rock by lode minerals.

The formation of hematite caused or accompanied in some of the tops an increase in iron content, notably above that in the deeper parts of the flow. Whether this increase is an alteration or an original magmatic effect is not altogether clear; the question is discussed on page 36 .

The cavities or vesicles of the lava tops, in the main, long remained empty, though probably some chlorite and perhaps feldspar was deposited in them during the cooling of the lava. There seems no reason to believe that the vesicles of one flow were filled before the next flow appeared, nor that during the general period of lava extrusion there were successive periods of vesicle filling. The vesicles appear to have been filled after all the flows had been spread, the overlying thick sedimentary formation deposited, and the rocks tilted to their present attitude. Practically all the fractures, large and small, that were produced by deformation of the rocks carry the same minerals as those which form the amygdules. The minerals of the amygdules and of the fractures are, in fact, identical with the gangue minerals accompanying the copper. They are therefore further discussed under the heading "Ore deposits" (p. 107).

\section{RED COLOR OF AMYGDALOID TOPS}

STATEMENT OF THE PROBLEM

The oxidation and concentration of the iron in the tops of the flows appear to have received little investigation; these processes, therefore, will be discussed in considerable detail, and several possible methods by which they might have been effected will be considered. The conclusion reached may be stated at the outset; it is that both the oxidation and the concentration of iron were accomplished by gases escaping from the solidifying and crystallizing lava. The inclosed gases were either neutral or reducing toward iron at the temperature at which the lava emerged but became strongly oxidizing as the temperature decreased, with the result that much of the ferrous iron was converted to the ferric state, the conversion being more and more complete as the upper part of the flow was approached.

A striking feature of the tops of many of the Michigan flows is their red color, which ranges in intensity from bright brick-red through darker and duller shades to faint browns but always contrasts with the dark gray or greenish gray of the deeper portions of the flow. This red hue may disappear before the bottom of the amygdular zone is reached or it may extend for a short distance into the trap. It is useful in the recognition of amygdaloid beds on outcrops, in crosscuts, or in drill cores. It is present in many of the cellular smooth-topped amygdaloids and is strongly 
developed in the brecciated tops. In the "scoriaceous tops" or amygdaloid conglomerates the red color may be rather faint or altogether wanting, although the fine mud is usually brown. This red color, which is due to the presence of ferric oxide, is present in all the amygdaloid lodes (and in the felsite conglomerates as well) from which noteworthy quantities of copper have been produced, and some explanation of it is involved with almost every theory of the origin of the copper deposits that has been advanced. It therefore merits careful investigation.

The enrichment of the lava tops in ferric oxide has been ascribed by some observers to weathering, a process which was supposed to be facilitated by the brecciation that certain tops have undergone. Other investigators, laying stress on the fact that all the red tops are mineralized in one way or another, have inferred that ferric oxide was a by-product of various kinds of mineralization. The present discussion may well begin by putting these hypotheses to the test.

The problem is presented in simplified form by the red tops which have been described as occurring in many parts of the world on lavas that have been erupted in comparatively recent times and appear to be virtually unaltered. Such lavas were studied by T. M. Broderick in the Snake River and Columbia River regions for the purpose of obtaining light on the history of the Michigan flows.

RED TOPS OF UNALTERED WESTERN FLOWS

The red color is well shown in the tops of many basaltic flows of the Snake River and Columbia River lava plains. In both regions the cellular, nonfragmental tops prevail. The Snake River flows, with their vesicles still unfilled, have not been attacked by later mineralizing solutions, such as have caused the marked alteration of the Keweenawan flows, and they have escaped almost wholly the limonitic alteration and the disintegration which the surfaces of the older Columbia River flows have suffered in consequence of weathering. The Snake River flows are therefore well suited to show simply and directly the chemical and mineralogical changes of which the reddening is the visible effect.

A series of specimens taken at different intervals from the top of a flow 40 feet thick at Twin Falls, Idaho (fig. 2), show the following contents of ferrous and ferric iron:

Iron content of lava top at Twin Falls, Idaho

[H. C. Kenny, analyst]

\begin{tabular}{|c|r|r|r|}
\hline \multirow{2}{*}{$\begin{array}{c}\text { Distance } \\
\text { from top } \\
\text { of flow } \\
\text { (feet) }\end{array}$} & \multicolumn{3}{|c|}{ Iron (per cent) } \\
\cline { 2 - 4 } & Ferric & Ferrous & Total \\
\hline & & & \\
0 & 7.7 & 3.7 & 11.4 \\
3 & 4.9 & 6.8 & 11.7 \\
6 & 3.0 & 9.0 & 12.0 \\
12 & 1.6 & 9.9 & 11.5 \\
25 & 1.3 & 10.1 & 11.4 \\
\hline
\end{tabular}

These results show a virtually constant iron content from the surface down, but a marked and progressive change in the state of oxidation of the iron. At the surface 70 per cent of the iron is ferric; this percentage gradually diminishes, so that in the lowest sample, from about the middle of the flow, less than 12 per cent of the iron is ferric.

Examination of polished and thin sections of the minerals in these flows shows that the chief ironbearing minerals in the deep parts of the flow are magnetite, olivine, and pyroxene. In the upper, red portion, hematite accounts for most of the iron. Some of the hematite was formed by alteration from magnetite or, together with serpentine, from olivine; but some shows no sign of ever having been anything else, and this occurs in platy or bladed crystals, generally of minute size, found characteristically in the glassy matrix surrounding the plagioclase crystals. The plagioclase is practically unaltered.

Nothing in the chemical results or in the minerals present in these Idaho flows suggests that iron has

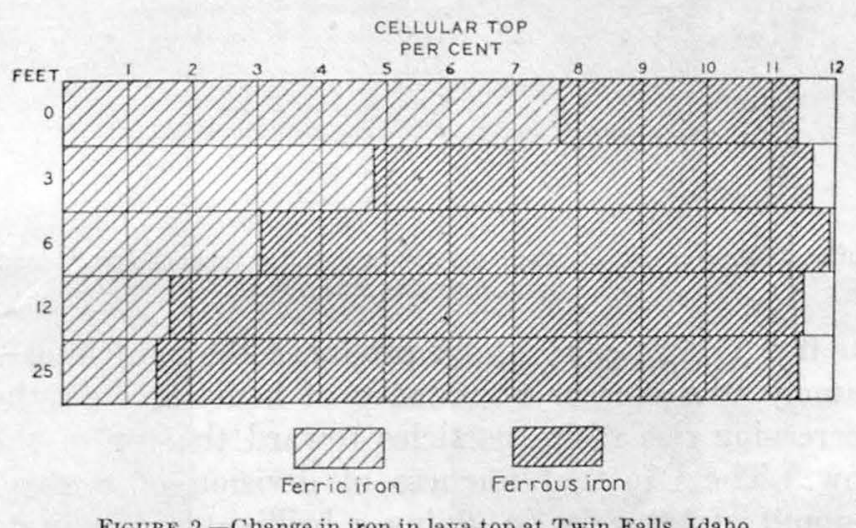

Figure 2.-Change in iron in lava top at Twin Falls, Idaho

been added to the tops. No vesicle fillings or veins of later minerals are to be seen. A partial rearrangement of the iron and an increase in the degree of its oxidation near the tops of the flows seem to be all that has happened. These changes can not be ascribed to any later alteration but appear to have been accomplished by the time the lava had solidified or very shortly afterward.

\section{OXIDATION IN SMOOTH-TOP FLOWS OF KEWEENAWAN SERIES}

Many of the Keweenawan flows show the same kind of transition from unoxidized trap to oxidized top as the more recent western lavas. The following analyses of samples from a smooth-top flow, the second flow below the Wolverine sandstone at the Wolverine mine (fig. 3 ), indicate that the changes involved are closely similar to those represented in the analyses of the Idaho flow. The samples are grouped into composites each of which represents a horizontal distance of 50 feet in a crosscut which traverses the flow at right angles to the strike from top to bottom. The dip of the flow is approximately $40^{\circ}$. 
Iron content of typical smooth-top Keweenawan flow

H C. Kenny, analyst]

\begin{tabular}{|r|r|r|r|r|}
\hline \multicolumn{2}{|c|}{ Distance from top of flow (feet) } & \multicolumn{3}{|c|}{ Iron (per cent) } \\
\cline { 1 - 2 } Along crosscut & $\begin{array}{r}\text { Normal to top } \\
\text { (approximate) }\end{array}$ & Ferric & Ferrous & Total \\
\hline $0-50$ & $0-30$ & 4.5 & 3.7 & 8.2 \\
$50-100$ & $30-60$ & 4.4 & 3.4 & 7.8 \\
$100-150$ & $60-90$ & 3.7 & 4.7 & 8.4 \\
$150-200$ & $90-120$ & 2.7 & 5.1 & 7.8 \\
\hline & & & & \\
\hline
\end{tabular}

Here, as in the Snake River lavas, the total iron is essentially constant, but the ferric iron increases steadily toward the top and the ferrous iron decreases almost as steadily. Both the Idaho and the Michigan analyses show that the red tops are the extreme expression of a change which has taken place throughout

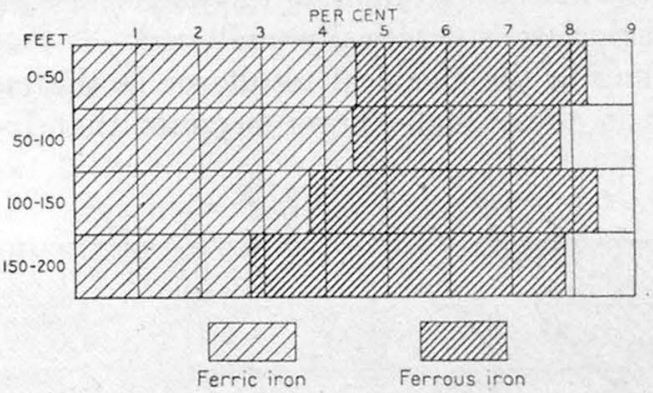

FIGURE 3.-Iron content of smooth-top flow (second flow below W olverine sandstone, Wolverine mine)

the flow. Two causes have produced the reddeningnamely, the greater abundance of hematite and the decreasing size of its particles toward the top of the flow. The effect of fineness of division of a small amount of hematite in giving a brilliant red color to agates and jaspers is well known, and a similar effect is clearly revealed by microscopic study of these Michigan lavas.

\section{OXIDATION AND CONCENTRATION IN BRECCIATED-TOP FLOWS}

Although the red flow tops of the cellular, smoothtop type contain so far as determined about the same proportion of total iron as the body of the flow some of the fragmental tops contain a considerably higher percentage of total iron than the rest of the flow, but, just as in the nonfragmental tops, most of the iron is in the ferric state and occurs as hematite. (See pls. 62,63 .) The Kearsarge lode is a conspicuous example of concentration of iron in the top and is the one that has been most studied. The following table shows the iron content at varying distances from the top of the Kearsarge flow in a single section. Distances are horizontal; the dip of the beds is $30^{\circ}$ to $40^{\circ}$.

Iron content of Kearsarge flow, Wolverine mine

$$
\text { H. C. Kenny, analyst }
$$

\begin{tabular}{|c|c|c|c|c|}
\hline \multicolumn{2}{|c|}{ Distance from top (feet) } & \multicolumn{3}{|c|}{ Iron (per cent } \\
\hline Along crosseut & $\begin{array}{l}\text { Normal to top } \\
\text { (approximate) }\end{array}$ & Ferric & Ferrous & Total \\
\hline $0-50$ & $0-30$ & 6.7 & 2.4 & 9. 1 \\
\hline $50-100$ & $30-60$ & 4. 4 & 3. 3 & 7. 7 \\
\hline $100-150$ & $60-90$ & 4. 2 & 3. 6 & 7. 8 \\
\hline $150-200$ & $90-120$ & 3. 9 & 3. 7 & 7. 6 \\
\hline $200-250$ & $120-150$ & 3. 1 & 4. 9 & 8. 0 \\
\hline $250-300$ & $150-180$ & 3. 0 & 5. 6 & 8. 6 \\
\hline
\end{tabular}

This series of specimens, which represents a section of the entire flow from top to bottom, shows a concentration of iron in both top and bottom as compared

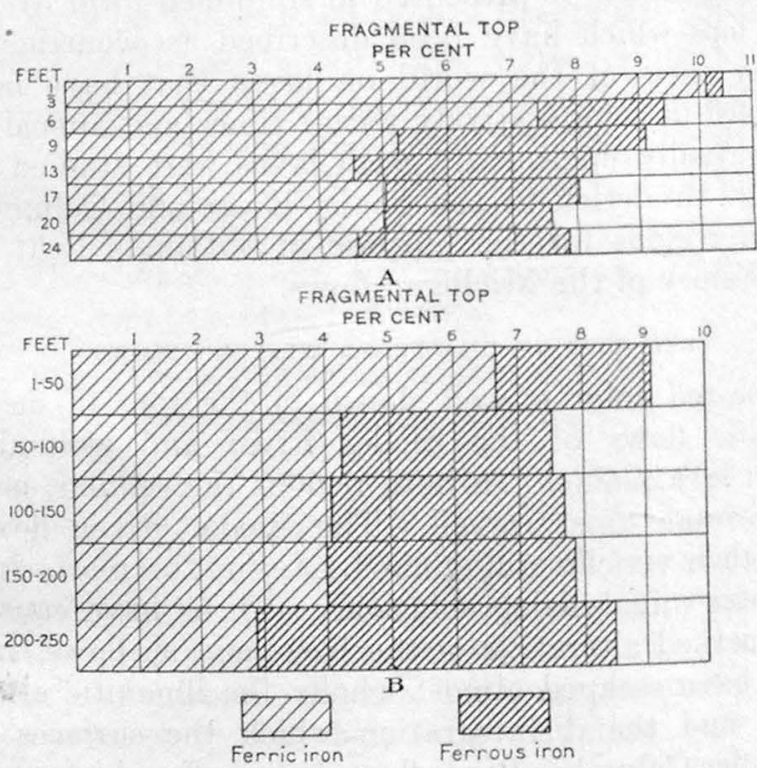

Figure 4,-Iron content of Kearsarge flow. A, Calumet \& Hecla mine 81si level; $\mathrm{B}$, Wolverine mine

with the middle portion, the greater concentration being at the top. (See fig. 4, B.) The ferric iron content increases steadily and the ferrous iron decreases steadily from the bottom upward. The upper part of the Kearsarge flow has been sampled at shorter intervals to show still more closely where the notable changes in proportion of ferrous to ferric iron and the most marked increase of ferric iron are to be found (fig, $4, \mathrm{~A}$ ), and the results are as follows: 

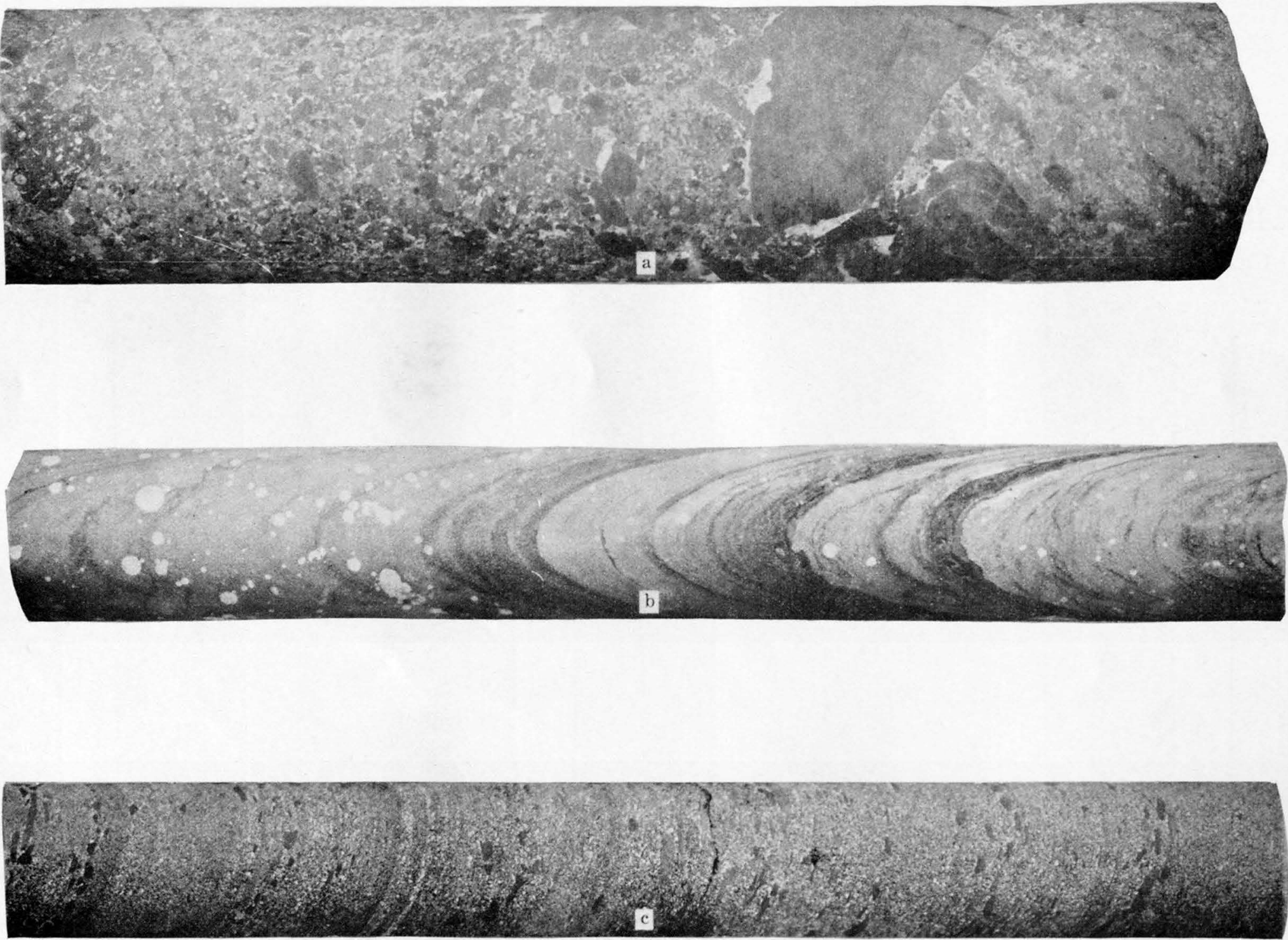

TEXTURE OF SEDIMENTARY ROCKS AS SHOWN IN DIAMOND-DRILL CORES

a, Felsite conglomerate (Keweenawan); b, Jacobsville ("Eastern ") sandstone, showing bleached areas; c, Jacobsville (" Eastern ") sandstone, showing "mud flakes" 

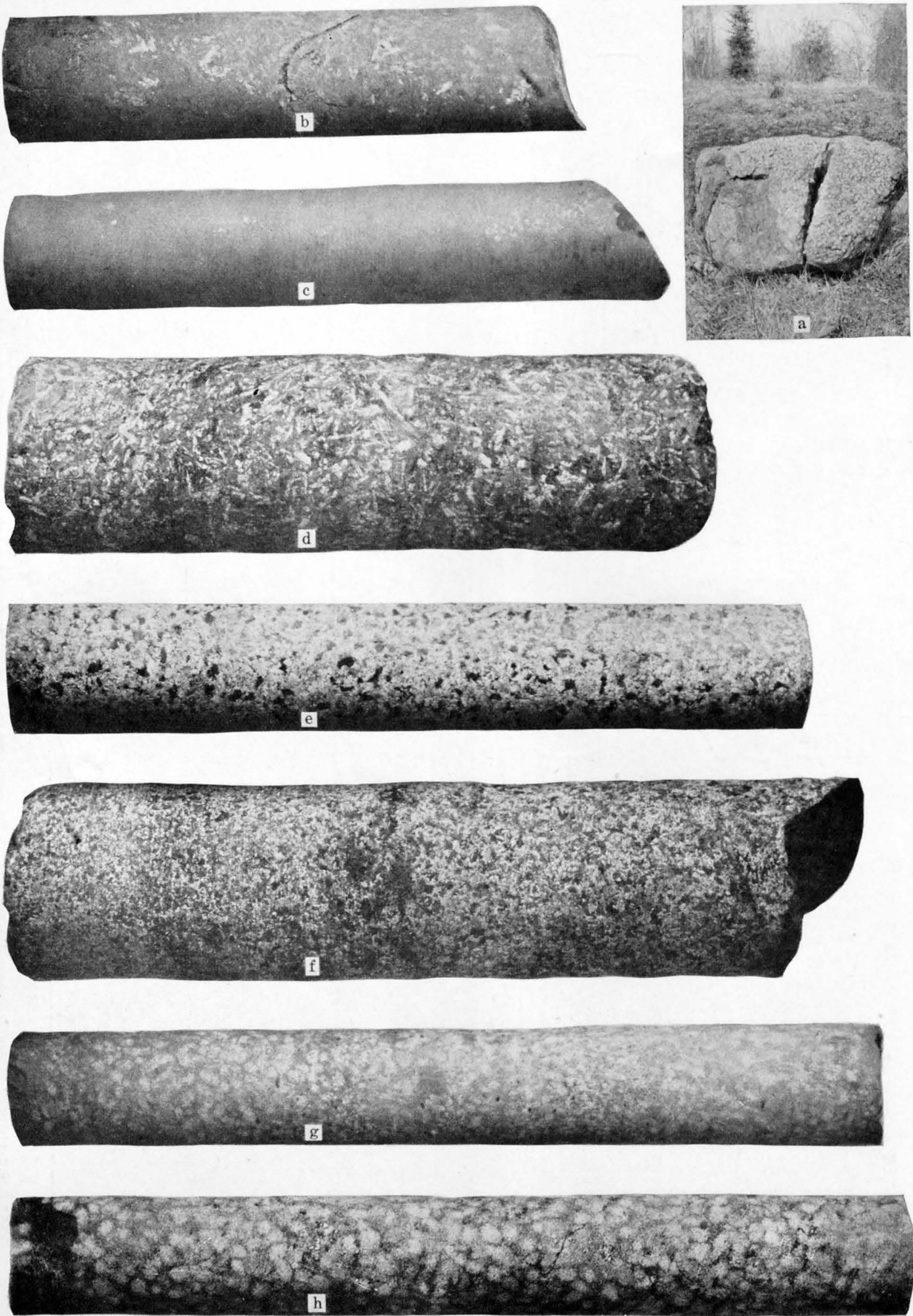

TEXTURE OF LAVAS AS SHOWN IN DIAMOND-DRILL CORES

a, Ophitic texture as seen on weathered surface; b, porphyrite; c, melaphyre; d, "dolerite," pegmatitic facies of traps; e, finer glomeroporphyrite; f, coarse glomeropor" phyrite; $g$, banded ophite; $h$, typical ophite 

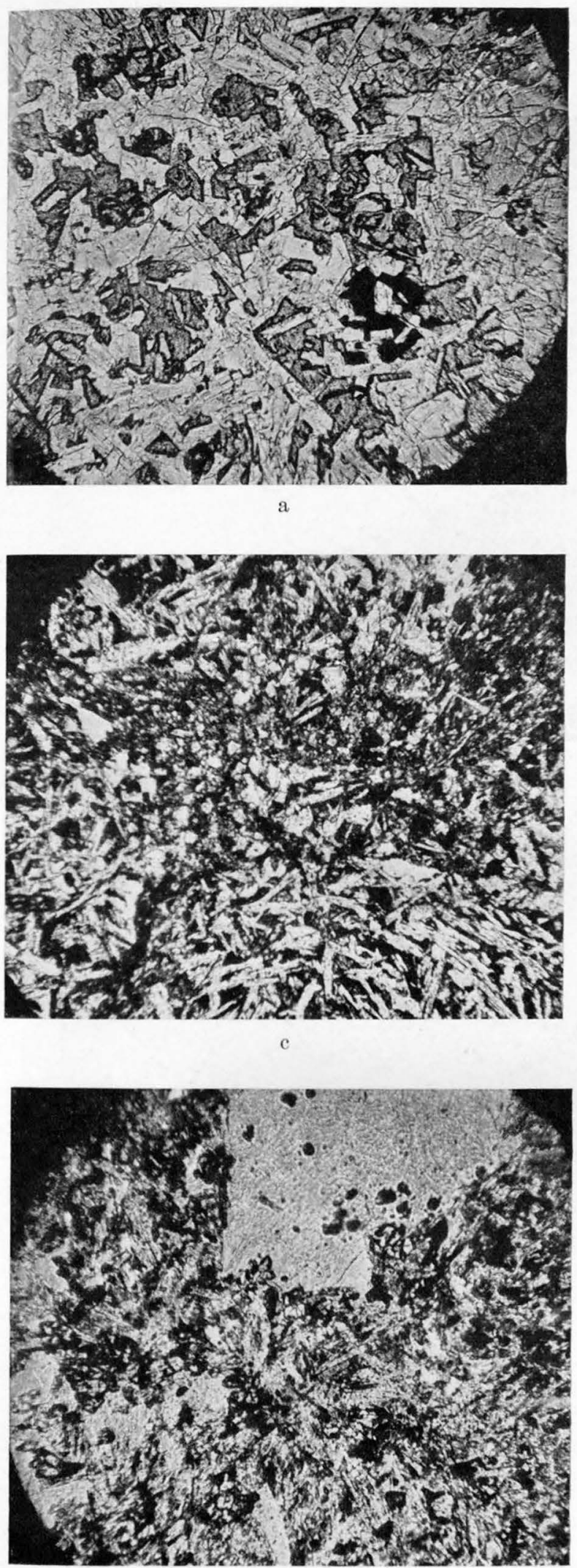
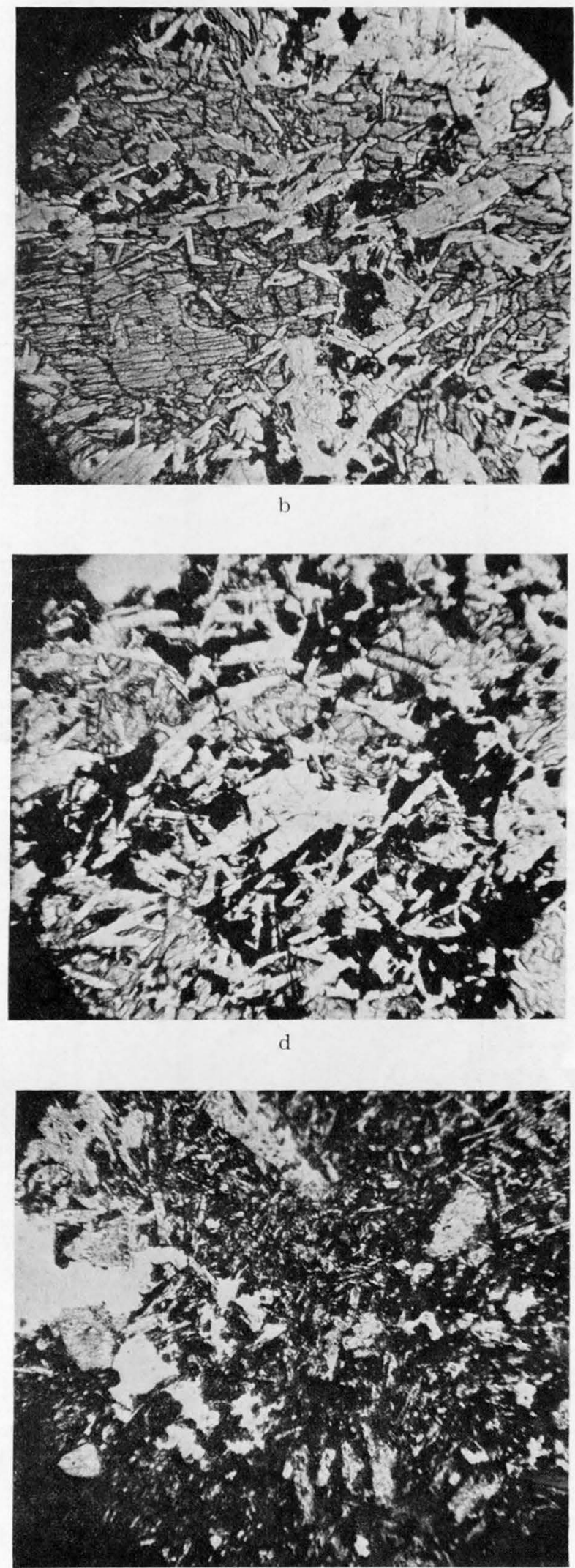

TEXTURE OF LAVAS AS SHOWN IN MICROSCOPIC SECTIONS

a, Typical ophite from the Greenstone; b, diabasic structure in flow below the Calumet Hecla conglomerate; c, trap just above the Calumet Hecla conglomerate; d, fairly fresh ophite from Osceola flow; e, foot trap from Kearsarge flow; f, typical "foot lode" from Kearsarge flow. 


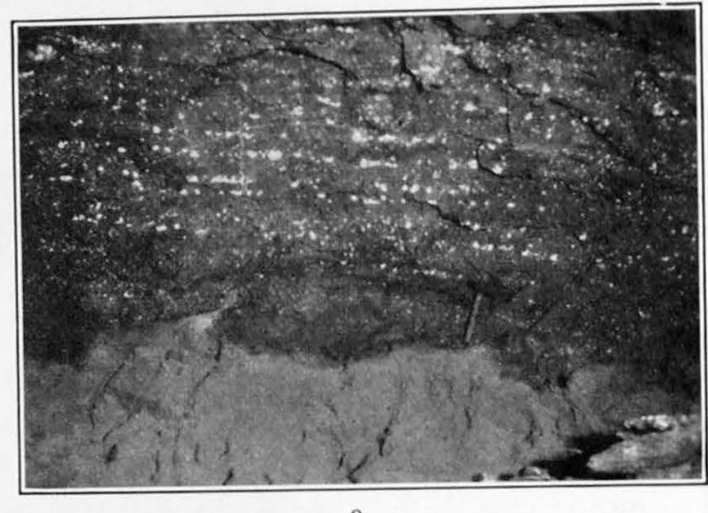

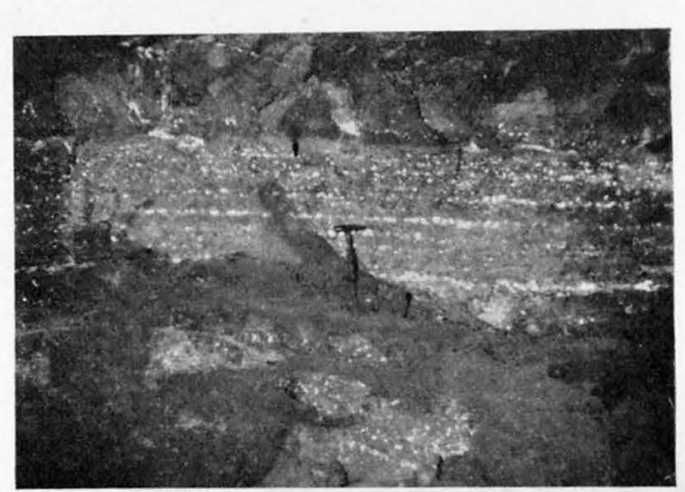

b

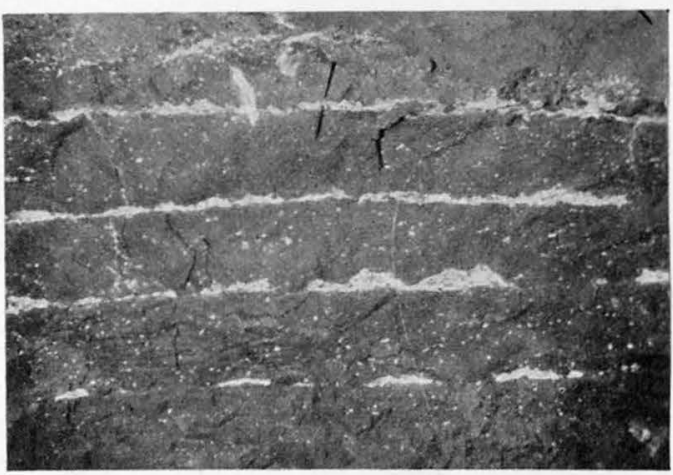

d

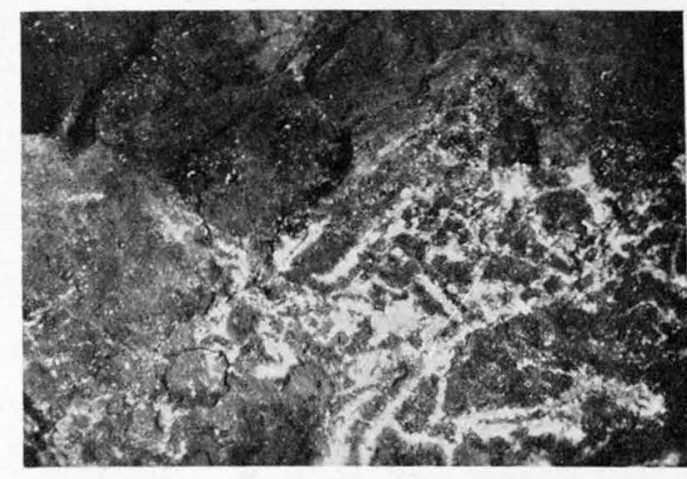

f

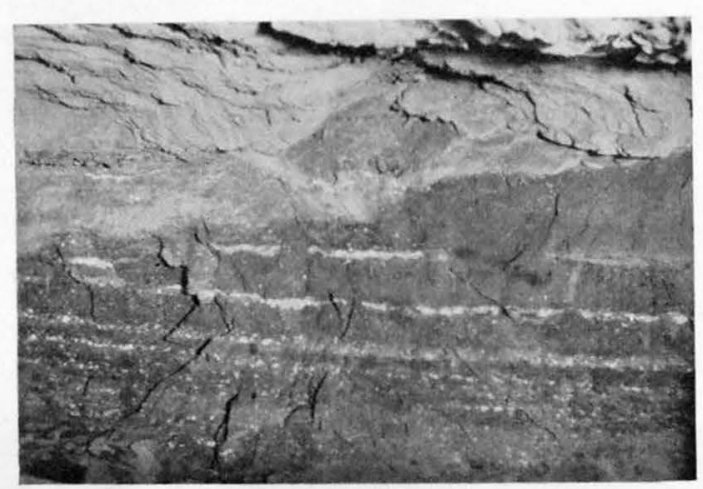

c

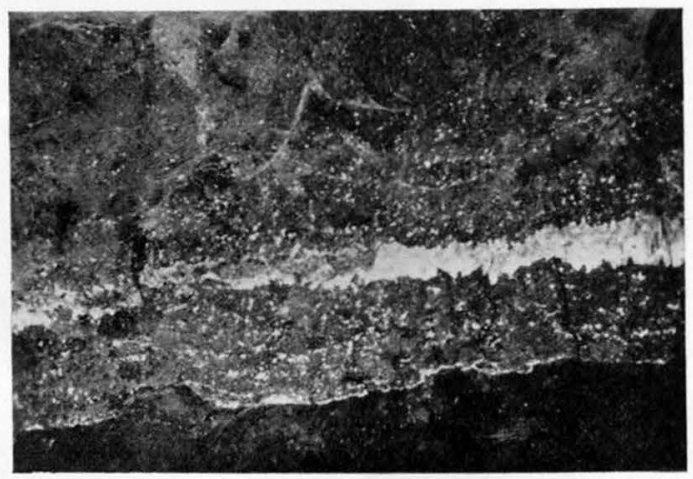

e

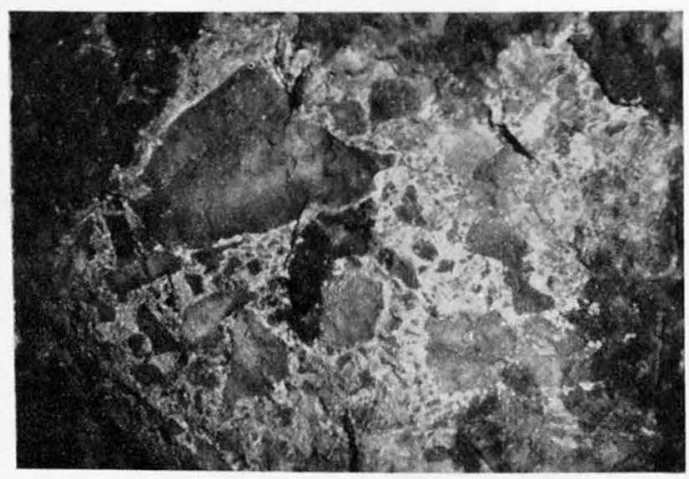

$\mathrm{g}$

TEXTURE OF FLOW TOPS AS SEEN IN LODES

a, Cellular lode, tending toward coalescing; b, cellular lode, somewhat coalescing; c, coalescing lode; d, banded coalescing lode; $\mathrm{e}$, strong band in coalescing lode; $\mathrm{f}, \mathrm{g}$, fragmental lode. All from Quincy mine 


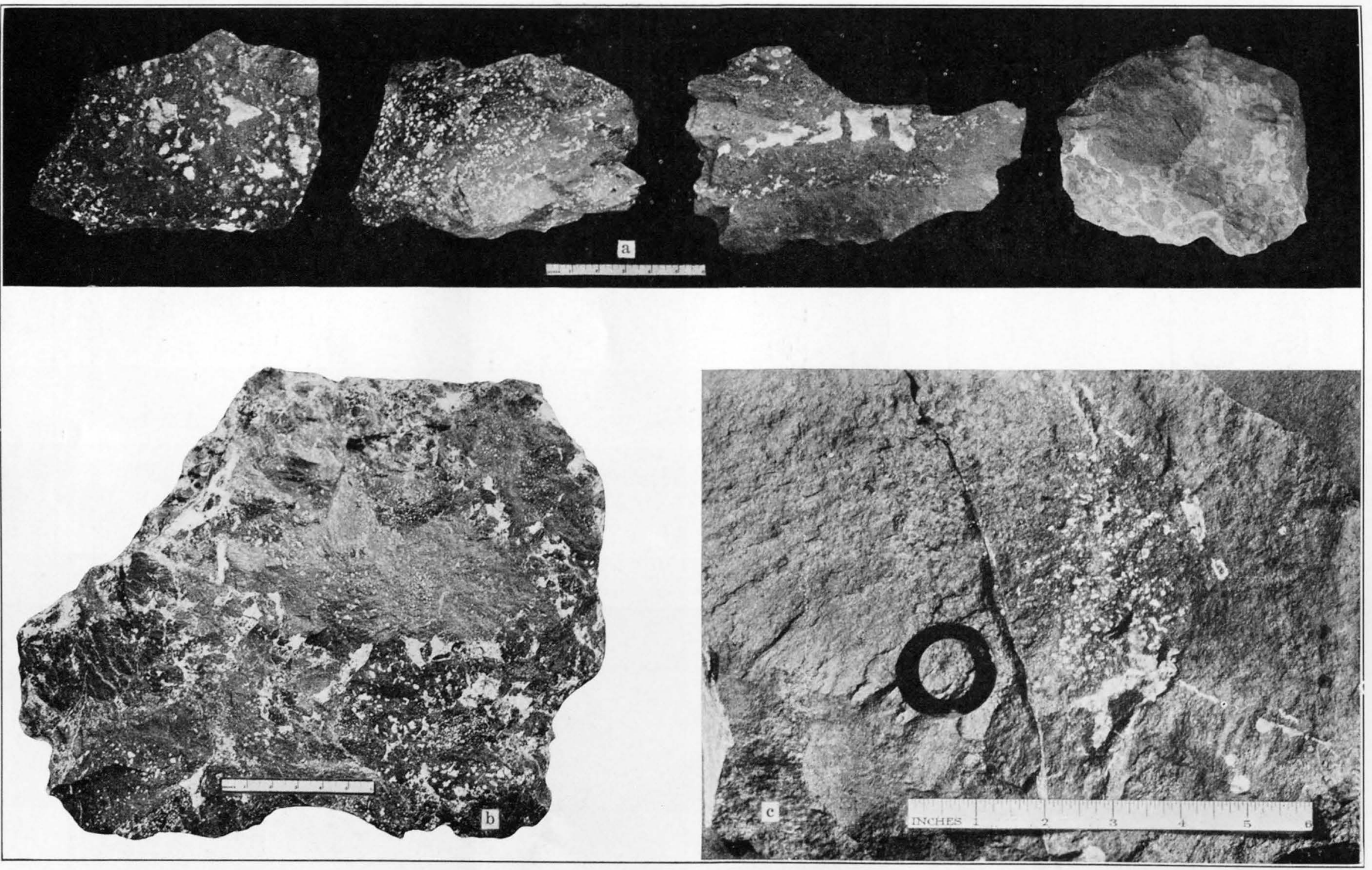

TEXTURE OF FLOW TOPS AS SEEN IN SPECIMENS

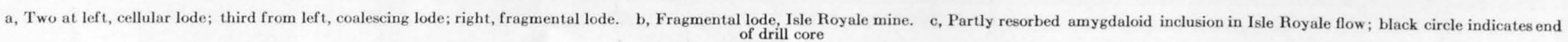



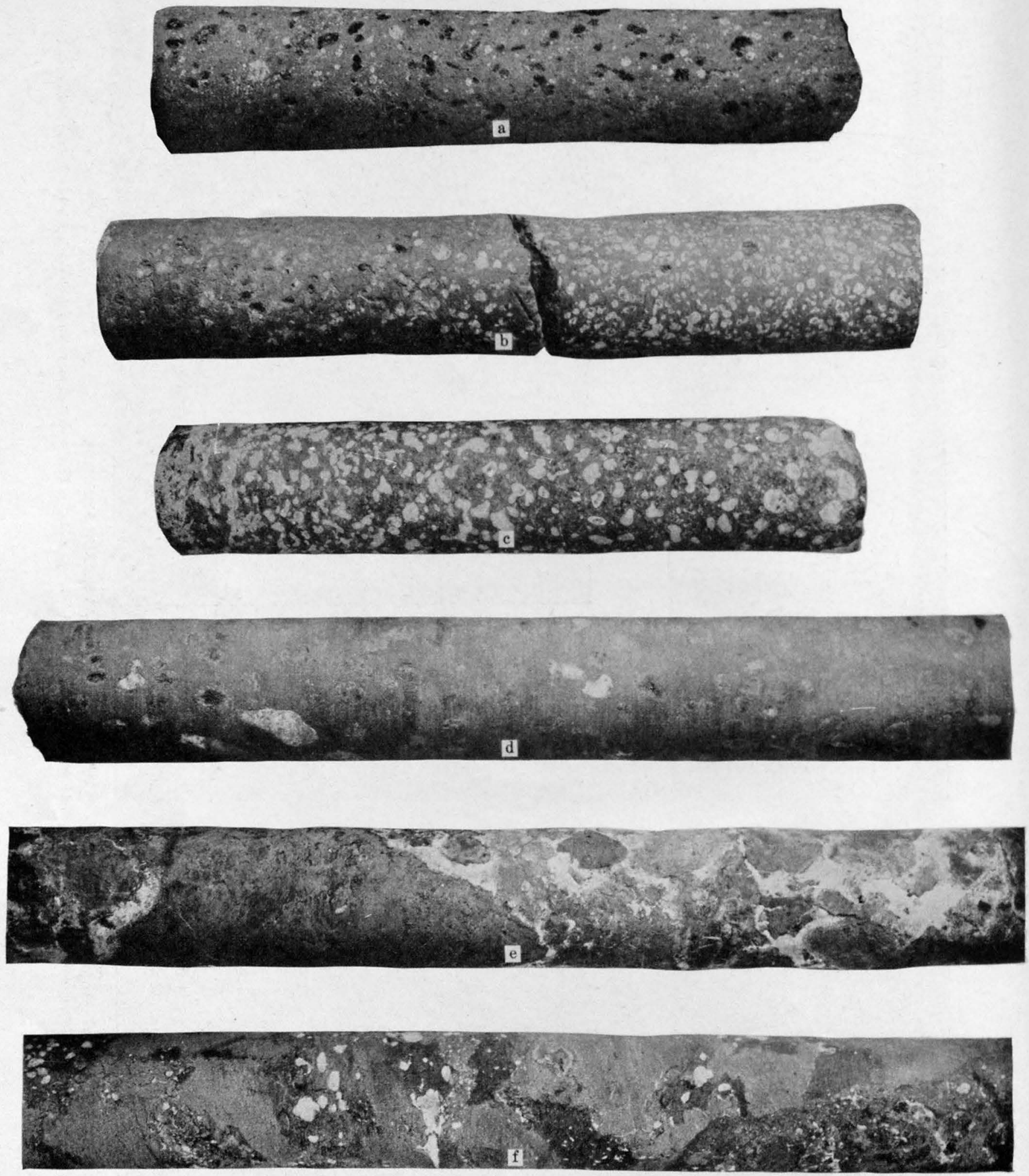

TEXTURE OF FLOW TOPS AS SEEN IN DIAMOND-DRILL CORES a, b, Cellular amygdaloid, upper part; c, amygdaloid of glomeroporphyrite flow; d, cellular amygdaloid deep in amygdaloid; e, fragmental amygdaloid;
f, scoriaceous amygdaloid or amygdaloidal conglomerate 

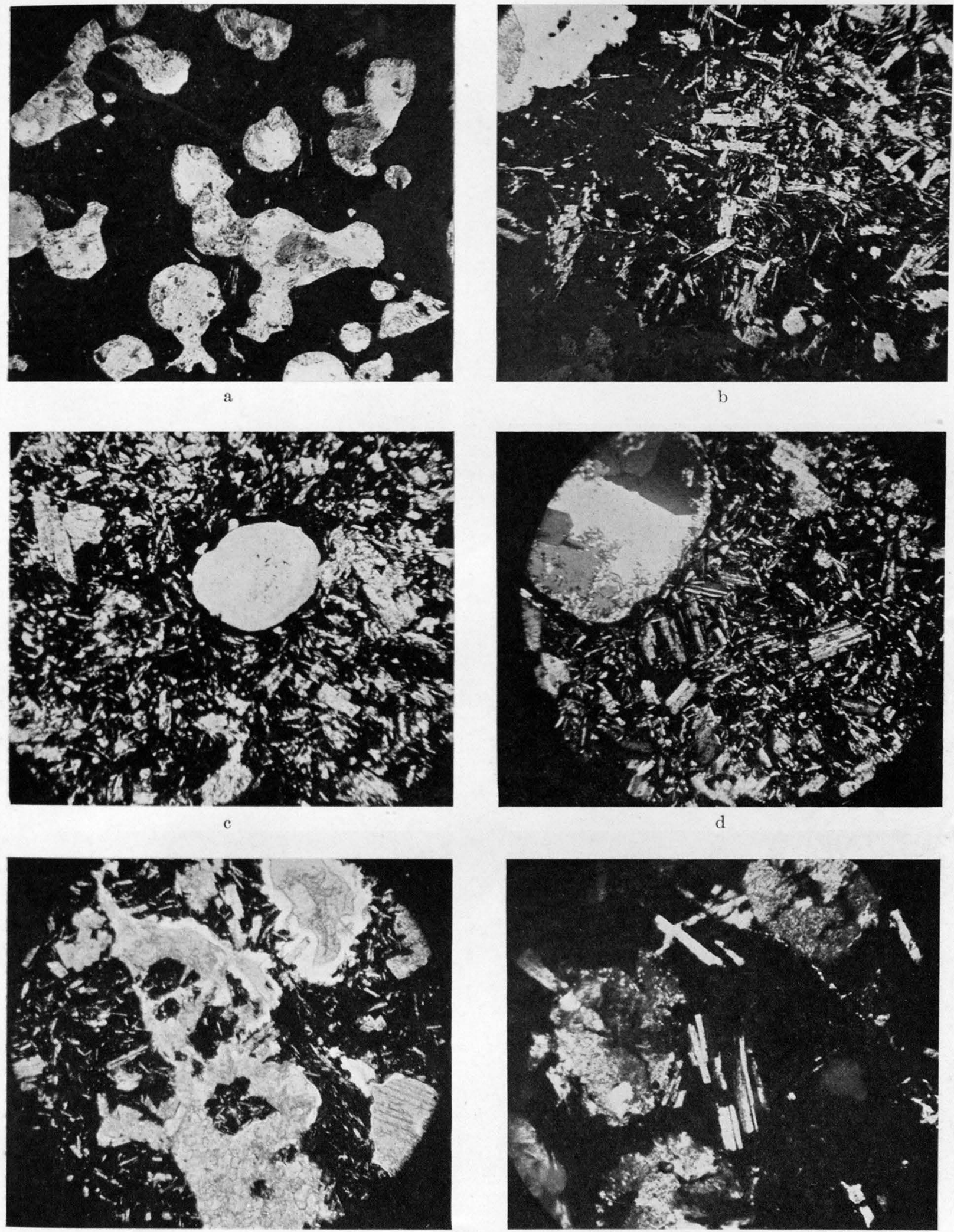

TEXTURE OF FLOW TOPS AS SEEN IN THIN SECTIONS

a, Vesicular top of Kearsarge lode, rich in hematite, $\times 32 ; b$, typical chilled Kearsarge amygdaloid, $\times 32$; $c$, thin trappy lode from Isle Royale mine, $\times 32$; , top of Ouincy lode showing fresh feldspar, with amygdule of quartz and epidote, $\times 21$; e, calcite-cemented breccia, Isle Royale amygdaloid, $\times 32 ; \mathrm{f}$, fresh feldspar in hematite-rich top, Kearsarge lode, $\times 298$. All enlargements approximate 

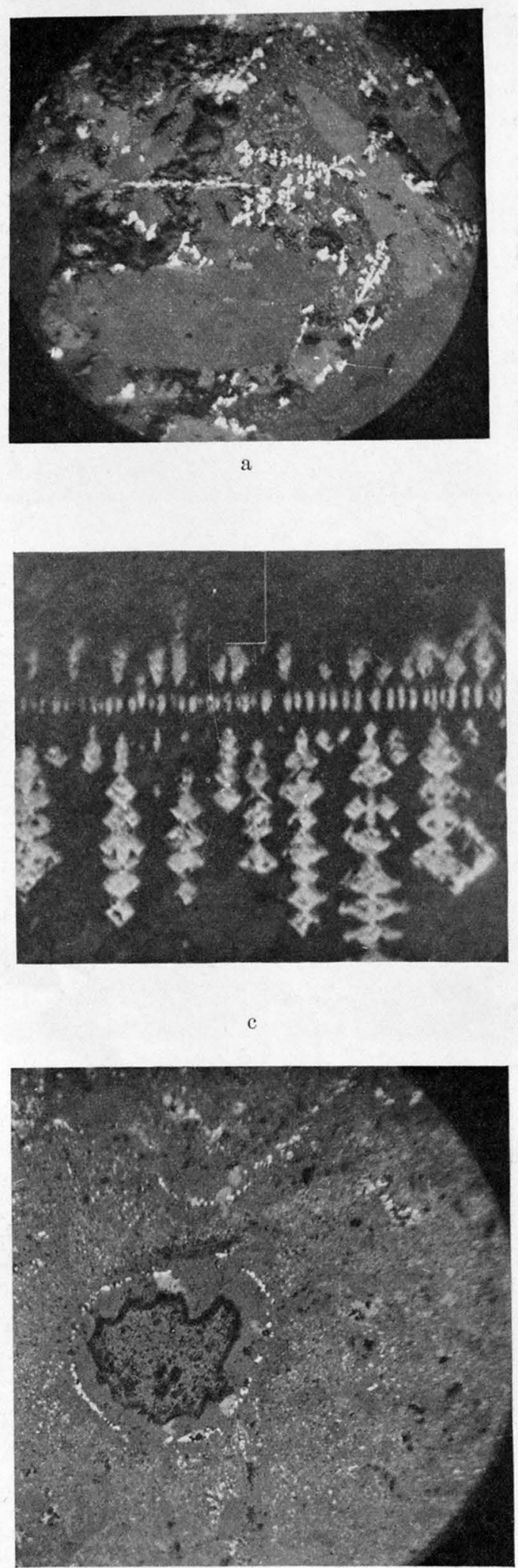

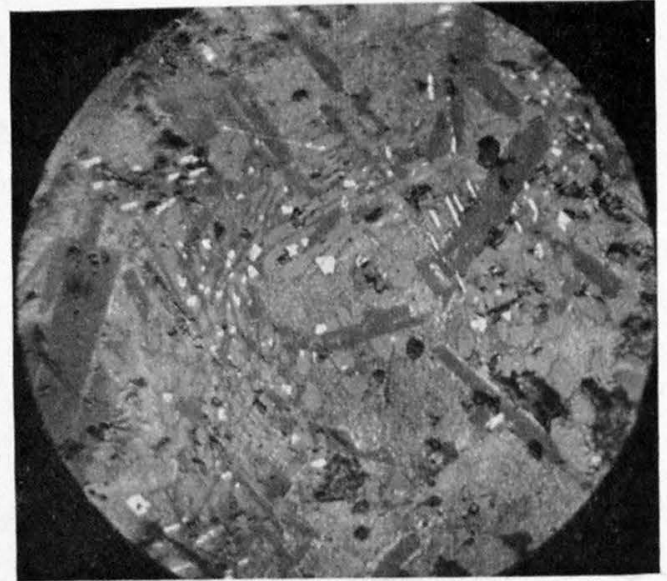

b

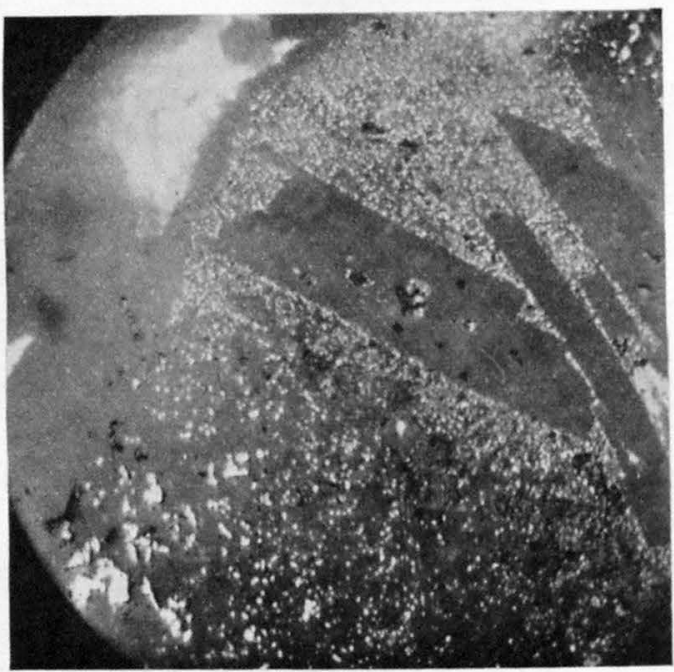

d

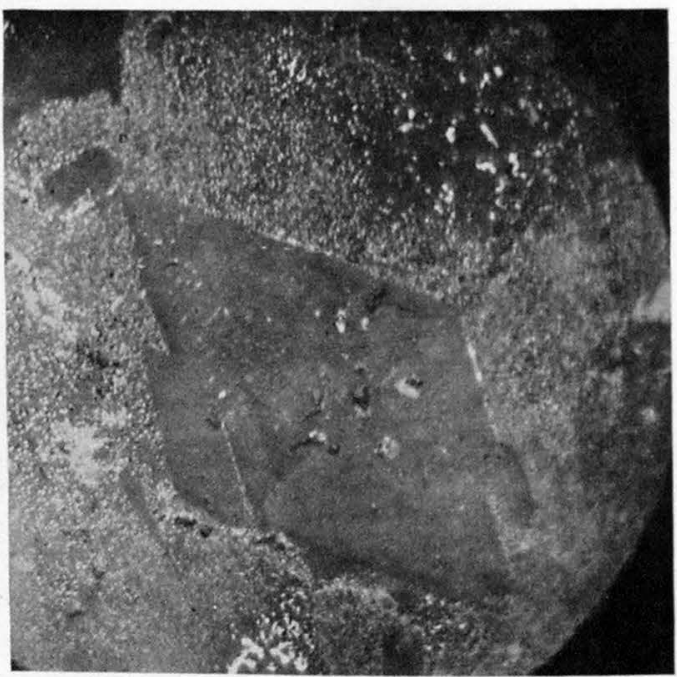

IRON OXIDES IN FLOW TOPS AS SEEN IN POLISHED SECTIONS

a, Dendrites of magnetite altered completely to hematite, Hawaii, $\times 215 ; \mathbf{c}$, same, $\times 640 ; \mathrm{b}$, magnetite altered to hematite, with intersertal areas full of finely divided hematite, $\times 215$; d, disseminated hematite surrounding feldspar, Kearsarge amygdaloid, $\times 338$; e, disseminated hematite, Kearsarge amygdaloid, $\times 338$; $f$, disseminated hematite, Kearsarge lode, $\times 103$. All enlarge- 

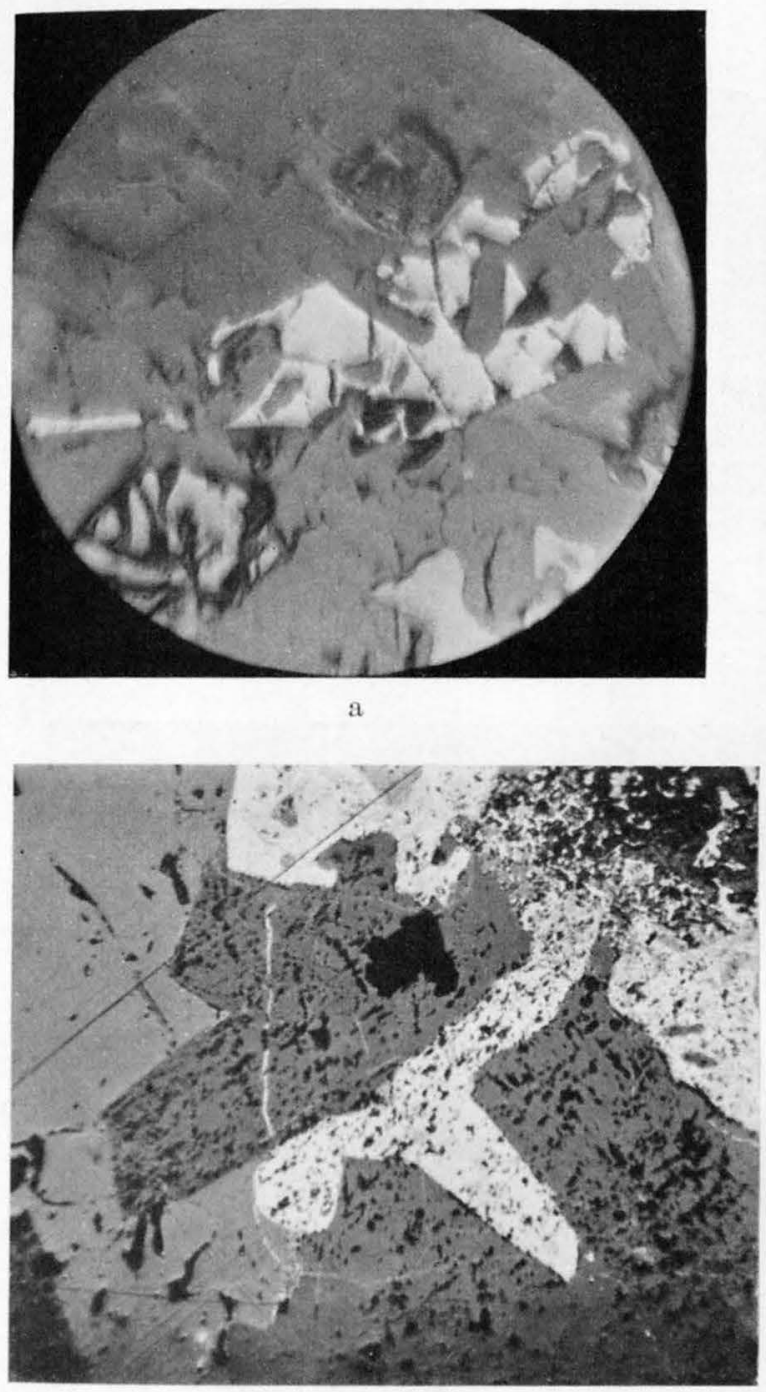

C

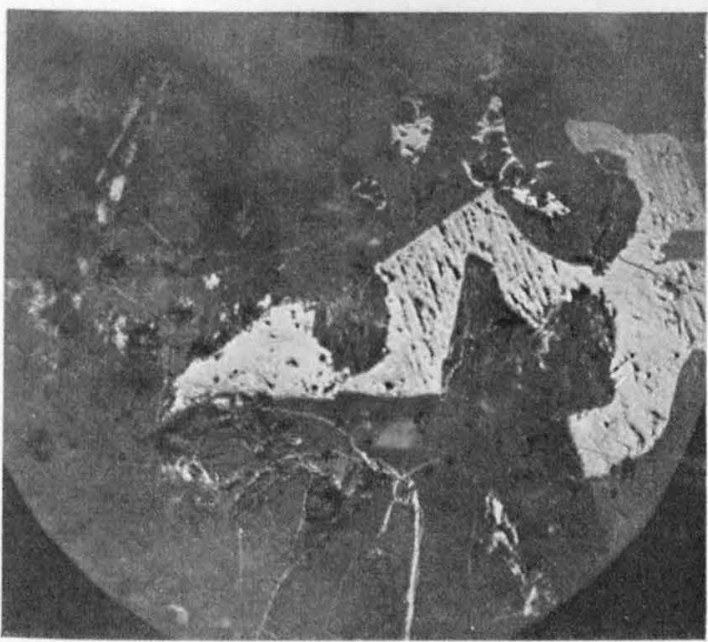

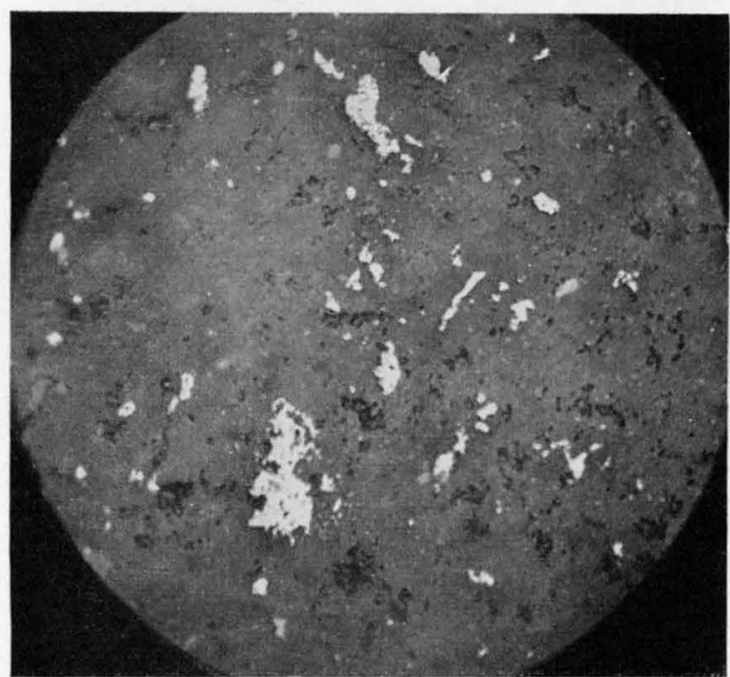

b

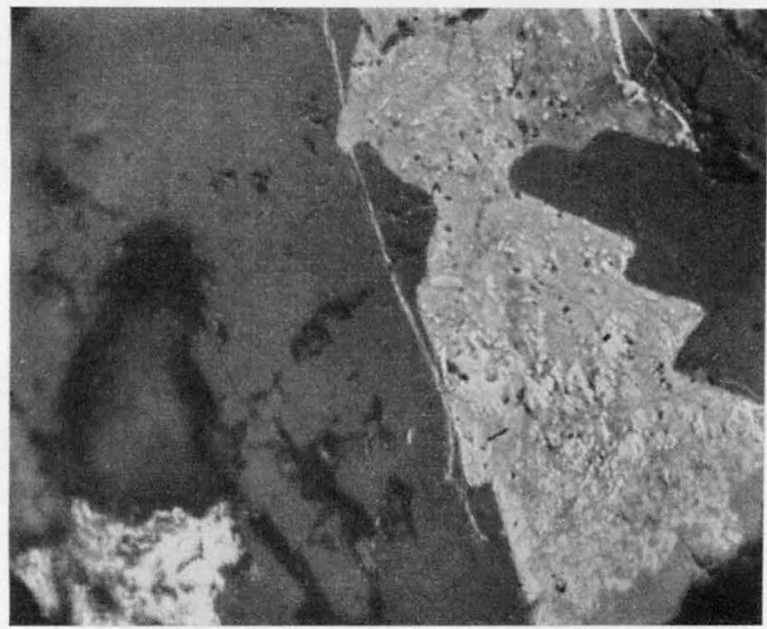

d

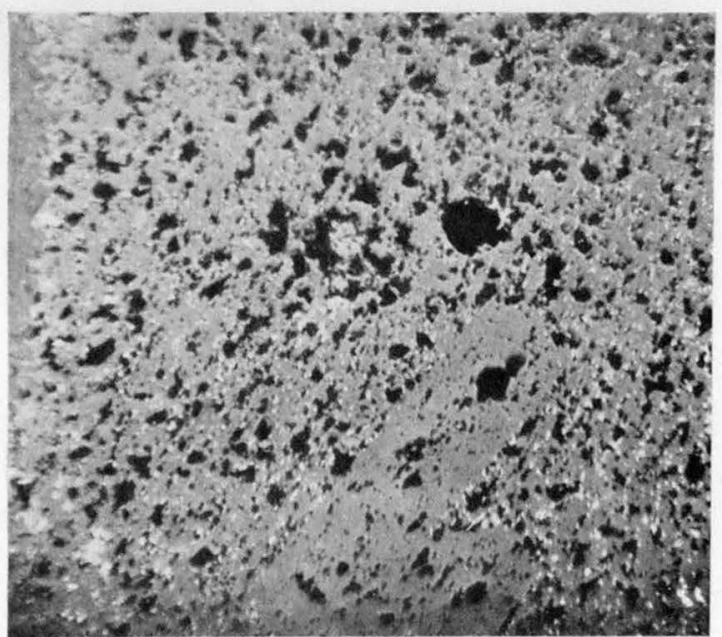

f

IRON OXIDES IN ROCKS AS SEEN IN POLISHED SECTIONS

a, Unaltered magnetitefrom the Greenstone, olivineparly altered $\times 82$, b, $f$ hematite in felsite pebbles from the Calumet Hecla conglomerate, $\times 115$; c, magnetite largely altered to hematite, trap above Isle Rovale lode (note strings of excess hematite), $\times 115 ; d$, magnetite altering to hematite, middle of second flow below Calumet Hecla conglomerate, $\times 158$; e, titaniferous magnetite altering to hematite, $\times 228$. All enlargements approximate 


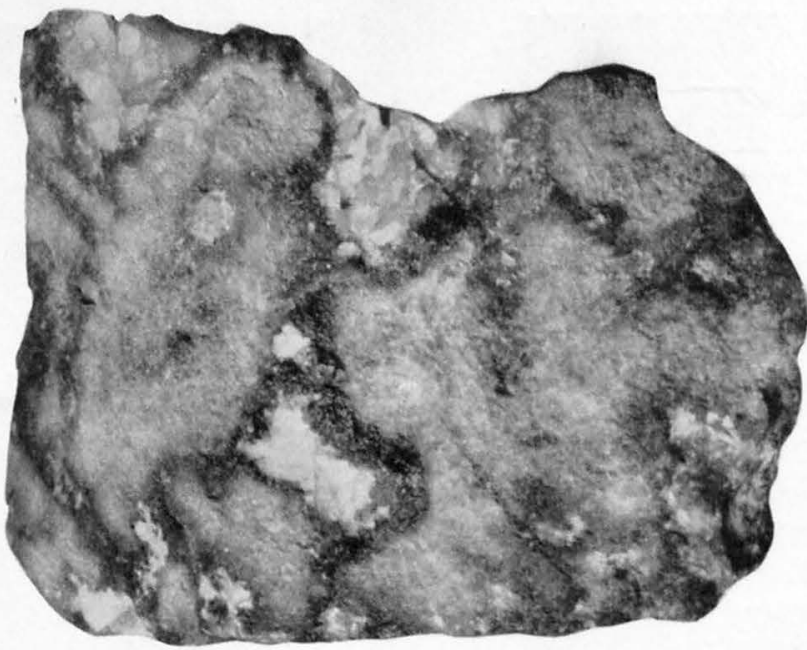

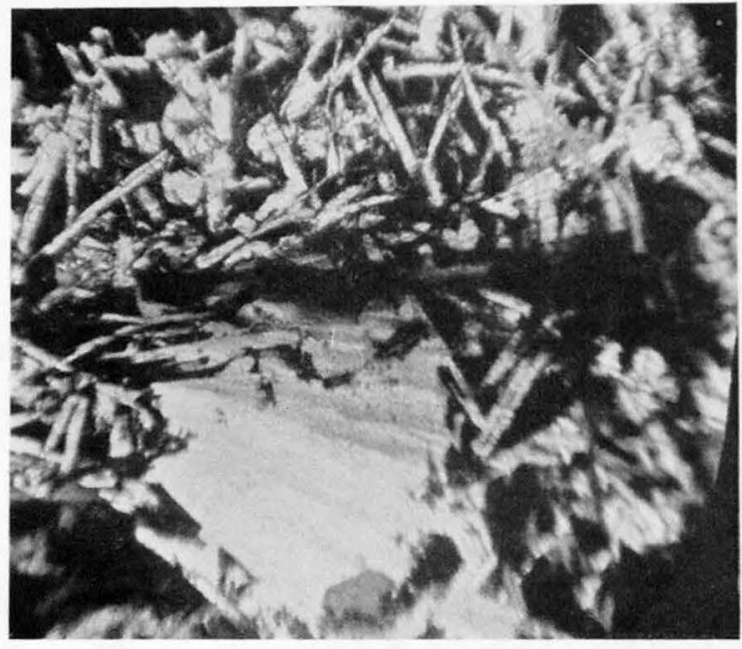

b

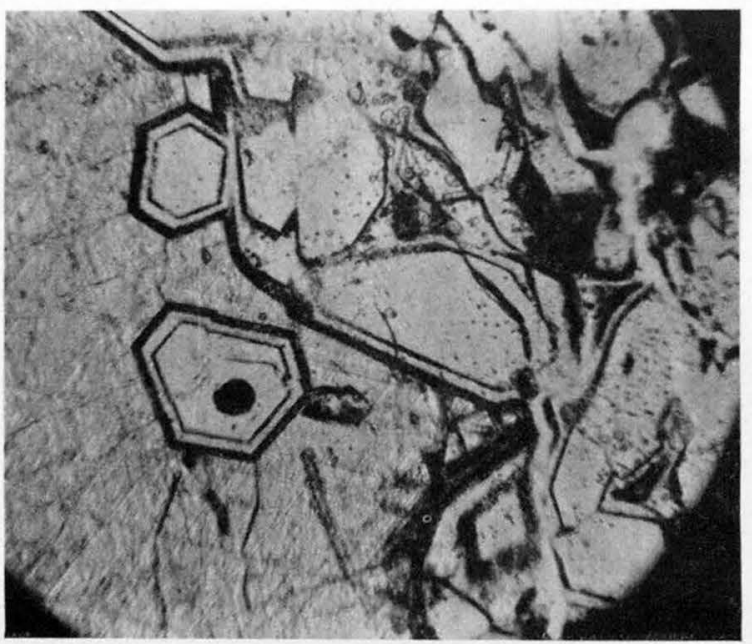

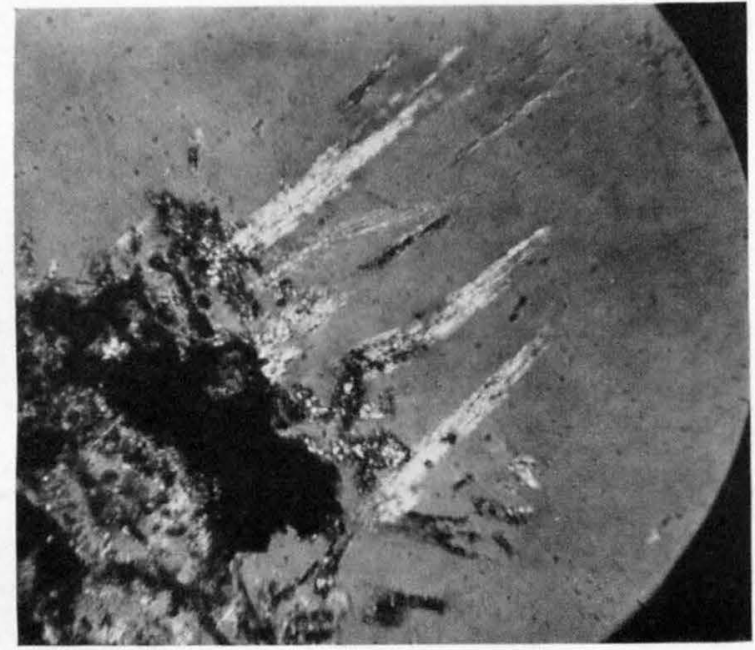

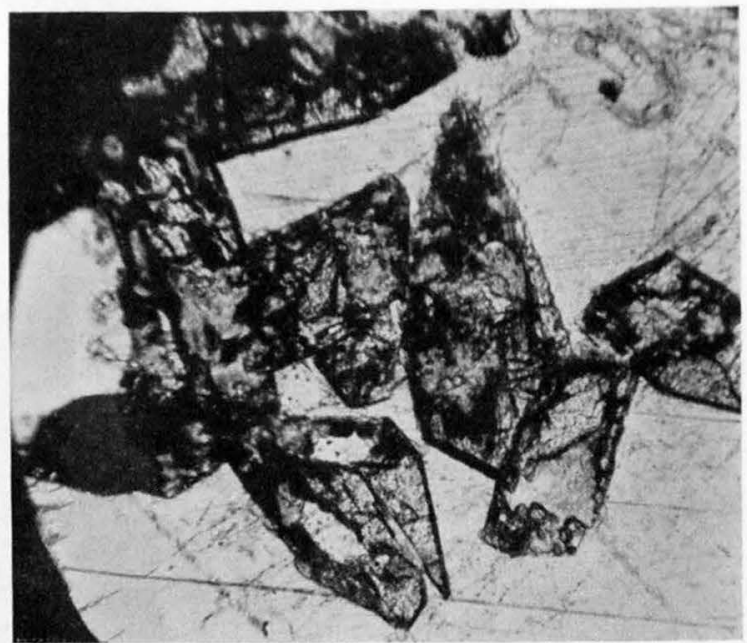

ALTERATION AND REPLACEMENT OF MINERALS

a, Red feldspar (dark areas) replacing amygdaloid, light areas quartz and carbonate, Mass mine; $b$, prehnitization of feldspar, $\times 60 ; c$, pumpellyite in quartz altered to sericite, $\times 200 ; \mathrm{d}$, quartz and calcite along Ahmeek mass fissure (note zonal growth of quartz), $\times 30$; , epidote 
Iron content of top of Kearsarge flow, Red Jacket crosscut, Calumet \& Hecla mine

Analyzed at mill laboratory, Calumet \& Hecla Consolidated Copper Co.]

\begin{tabular}{|c|c|c|c|}
\hline \multirow{2}{*}{$\begin{array}{l}\text { Horizontal dis- } \\
\text { tance from top } \\
\text { of lode (feet) }\end{array}$} & \multicolumn{3}{|c|}{ Iron (per cent) } \\
\hline & Ferric & Ferrous & Total \\
\hline $1 / 3$ & 10. 1 & 0.3 & 10. 4 \\
\hline 6 & 7. 4 & 2. 0 & 9. 4 \\
\hline 9 & 5. 2 & 3. 9 & 9. 1 \\
\hline 13 & 4. 5 & 3.7 & 8. 2 \\
\hline 17 & 5. 0 & 3. 0 & 8. 0 \\
\hline 20 & 5. 0 & 2. 6 & 7. 6 \\
\hline 24 & 4. 6 & 3. 3 & 7. 9 \\
\hline
\end{tabular}

The results of the two groups of analyses are represented graphically in Figure 4. The noteworthy features are (1) the higher percentages of total iron both at the top and toward the bottom of the flow, that at the top being the highest; (2) the steady increase in ferric iron from bottom to top, with a sudden increase in rate in the upper 20 feet-that is, in the brecciated amygdular top; (3) the increase of total iron at the top associated with an increase in ferric iron, but the increase in total iron in the bottom third of the flow associated with a slight decrease in ferric iron.

Five pairs of complete rock analyses are available for a contrast between the oxidized tops and the deeper unoxidized parts of the corresponding flows of Keweenawan lavas. These analyses are further discussed under "Weathering" (p. 40), especially 5a and $5 \mathrm{~b}$, which are the only ones that have been studied by the writers.

Analyses of upper and lower parts of Keweenawan flows

\begin{tabular}{|c|c|c|c|c|c|c|c|c|c|c|}
\hline & 1a & $1 \mathrm{~b}$ & $2 a$ & $2 \mathrm{~b}$ & $3 a$ & $3 \mathrm{~b}$ & $4 \mathrm{a}$ & $4 \mathrm{~b}$ & $5 a$ & $5 b$ \\
\hline $\begin{array}{l}\mathrm{S} \mathrm{O}_{2} \\
\mathrm{~A}_{2} \mathrm{O}_{2} \\
\mathrm{~F}_{2} \mathrm{O}_{2} \\
\mathrm{~T} \mathrm{O}_{\mathrm{O}} \mathrm{Fe}\end{array}$ & $\begin{array}{r}\text { 45. } 83 \\
\text { 18. } 92 \\
6.02 \\
6.24 \\
9.06 \\
8.49 \\
9.28 \\
2.10 \\
.32 \\
2.50 \\
2.70 \\
.10 \\
01 \text { ? }\end{array}$ & $\begin{array}{r}49.40 \\
16.12 \\
11.51 \\
2.13 \\
9.71 \\
3.52 \\
10.90 \\
3.02 \\
.58 \\
.10 \\
2.30\end{array}$ & $\begin{array}{r}\text { 46. } 78 \\
\text { 17. } 04 \\
\text { 7. } 95 \\
6.31 \\
\text { 10. } 46 \\
\text { 6. } 31 \\
\text { 6. } 94 \\
\text { 3. } 44 \\
\text { 1. } 10 \\
.66 \\
\text { 3. } 62 \\
.08\end{array}$ & $\begin{array}{r}\text { 46. } 66 \\
\text { 16. } 97 \\
9.52 \\
4.16 \\
9.90 \\
5.02 \\
9.37 \\
\text { 4. } 08 \\
.44 \\
.91 \\
2.79 \\
.02\end{array}$ & $\begin{array}{r}\text { 47. } 74 \\
\text { 16. } 75 \\
2.55 \\
6.31 \\
6.69 \\
8.32 \\
\text { 11. } 40 \\
\text { 1. } 93 \\
.14 \\
\text { 2. } 73 \\
1.02 \\
\end{array}$ & $\begin{array}{r}42.71 \\
\text { 14. } 93 \\
\text { 7. } 45 \\
\text { 3. } 45 \\
7.92 \\
2.70 \\
22.76 \\
.54 \\
.04 \\
\text { 3. } 56 \\
\text { 1. } 29 \\
\end{array}$ & $\begin{array}{r}45.70 \\
20.44 \\
9.50 \\
8.95 \\
13.60 \\
2.24 \\
7.46 \\
.80 \\
.28 \\
.35 \\
2.78 \\
1.10\end{array}$ & $\begin{array}{r}46.22 \\
10.22 \\
12.88 \\
7.45 \\
14.81 \\
.84 \\
\text { 15. } 56 \\
.18 \\
1.04 \\
.58 \\
3.91 \\
.95\end{array}$ & $\begin{array}{r}47.0 \\
20.8 \\
6.6 \\
4.2 \\
7.88 \\
4.3 \\
11.8 \\
? 2.7 \\
? 3.0\end{array}$ & $\begin{array}{r}43.6 \\
18.0 \\
14.5 \\
.4 \\
\text { 10. } 46 \\
3.4 \\
12.0 \\
? 3.9 \\
? 4.1 \\
.04\end{array}$ \\
\hline
\end{tabular}

1a. Specimen 47500 , country rock 70 feet from the lode, seventh level, Winona mine, Michigan.

1b. Specimen 47499, center of lode, same locality as 15. Analyses la and lb by R. D. Hall, Univ. Wisconsin.

2a. Specimen 47506,12 feet from footwall of 63 d level of Quiney mine, Michigan.

2b. Specimen 47505 , footwall near lode, same locality as $2 \mathrm{~b}$. Analyses $2 \mathrm{a}$ and $2 \mathrm{~b}$ by R. D. Hall, Univ. Wisconsin.

3a. Melaphyre, lower zone of bed 64, Eagle River section, Michigan.

3b. Prehnitized upper zone of bed 64, same locality as 3a. Pumpelly, Raphael, Metasomatic development of the copper-bearing rocks of Lake Superior: Am. Acad. Arts and Sci. Proc., vol. 13, p. 293, 1878.

4a. Fresh basaltic rock from center of flow, 15 feet from lode, Dingle Creek mine, Douglas County, Wis.

4b. Superjacent amygdaloidal lode, same flow as $4 \mathrm{a}$. Analyses $4 \mathrm{a}$ and $4 \mathrm{~b}$ by W. G. Wilcox, Univ. Wisconsin.

5a. Kearsarge amygdaloid lode, 81st level, Calumet \& Hecla mine.

5b. Same, specimen from top 4 inches of lode. Analyses $5 \mathrm{a}$ and $5 \mathrm{~b}$ made at mill laboratory, Calumet \& Hecla Consolidated Copper Co.

Analyses la to 4 b are quoted from Van Hise, C. R., and Leith, C. K., U. S. Geol. Survey Mon. 52, p. 583, 1911.

From these pairs of analyses, each of which shows an increase of ferric iron and a decrease of ferrous iron toward the top and all but one of which show an increase in total iron upward, certain inferences may be drawn in regard to other changes that accompany these increases in iron and oxygen. Frequent reference will be made to these analyses in the ensuing discussion. It must be borne in mind that the analyses represent the composition of the rocks after they have been affected by many kinds of alteration in the period that has elapsed from the time of lava outflow to the present day, and that in the top or amygdaloidal portion of the flows the combined effect of alteration has been, as a rule and perhaps without exception, much greater than in the trap. Only the specimens represented by $5 \mathrm{a}$ and $5 \mathrm{~b}$ have been studied by the writers, and the discussions are based primarily on these, but the application to the other analyses is pointed out. Samples $5 \mathrm{a}$ and $5 \mathrm{~b}$ were selected from rock that showed the least effect of the mineralizing solutions. Explanation of some of the features of the other analyses could be ventured only if the nature of the material were known.

\section{MINERALOGIC FEATURES}

The mineralogic expressions of these variations in oxygen and iron content are mentioned, so far as the traps are concerned, in the section dealing with alteration (p. 34), as the changes evidently affect rock minerals previously crystallized. But beyond the partial or complete conversion of olivine and magnetite to hematite, the trap seems to be in the same state 
as when first erystallized, and there is nothing in the rock itself to suggest that it crystallized under abnormal conditions. The significant mineralogic features attending iron oxidation and concentration in the lava tops are also outlined above (p. 35), but some further details may pertinently be given before discussion of the cause of the behavior of oxygen and iron.

The texture of the upper, vesicular part of a flow is always finer than that of the trap in the same flow. The finest-grained, densest portions are at the very top of the smooth flows and around the margins of fragments of the brecciated tops. In these densest parts vesicles are plentiful but exceedingly small; deeper in the smooth flows or toward the center in the fragments the vesicles increase in size, but the texture of the rock itself, though coarsening somewhat, remains comparatively fine so long as vesicles are plentiful.

All this fine-grained material is seen in thin section to comprise constituents of two kinds - minute crystals or microlites and a compact matrix which, despite especial efforts to obtain sections of unusual thinness, remains nontransparent. Among the transparent crystals feldspar predominates; it is present in delicate microlites of fairly perfect lath-shaped outline except for attenuated elongation of the sides of the crystal beyond the middle to give the characteristic pitchfork terminations. (See pl.61.) This shape of the feldspars implies an increasing viscosity of the surrounding medium, ${ }^{37}$ which was to be expected in these quickly chilling lava tops. Commonly the feldspar is strikingly elear and fresh, with plagioclase twinning easily seen. (See pl. 61.) It ranges from oligoclaseandesine to andesine; the feldspar of the trap portion is labradorite, in part highly calcic. Here and there are pseudomorphs whose outlines distinctly or vaguely suggest olivine but whose transparent part is now serpentine. Hematite is the only other recognizable mineral present (except for the vesicle fillings, which are of later introduction and are considered farther on). In these lavas, as in the lavas of Idaho, the hematite is partly in small ragged lumps or irregular spongy patches derived from magnetite or olivine, but it mainly occurs as minute short crystalline plates distributed through the opaque matrix. For the most part this distribution of the hematite plates is even and systematic, suggestive of the intersertal pattern, but around the feldspar crystals and the vesicles the hematite particles appear crowded and piled up, as if either pushed aside by or attracted to the expanding gas bubble or the growing feldspar microlite, neither of which contains hematite.

The groundmass or matrix of these various crystals is opaque, probably because the hematite plates are so abundant as everywhere to overlap, even in a thin

\footnotetext{
87 Day, A. L., Allen, E. T., and Iddings, J. P., The isomorphism and therma properties of the feldspars: Carnegie Inst, Washington Pub. 31, p. 91, 1905,
}

section. Presumably it is an undifferentiated material that contains the equivalent of the pyroxene pres. ent in the traps (but not crystallized in these dense tops); as well as of additional feldspar, olivine, and magnetite. It is this groundmass which gives the red color to the lava tops, and the red color is plainly due to the hematite; the accordance between abundance and fineness of grain of the hematite, as seen under the microscope, and the intensity of the red color is notably close.

This dense rock of the upper part of the flows may thus be described as a devitrified glassy base containing microlites of feldspar and other minerals; such a description is allowable if devitrification is considered possible, as Geikie, Harker, and others believe, not only long after a rock is formed but also before a rock has lost its original heat and perhaps even before all of it has solidified.

\section{CAUSE OF IRON OXIDATION AND CONCENTRATION}

Several possible causes of the increase of ferric iron and of total iron toward the tops of the flows merit consideration- $-(a)$ present-day weathering; $(b)$ action of solutions independent in origin from the lavas; $(c)$ normal weathering of the flow while exposed at the surface prior to covering by the next flow; $(d)$ alteration by water or gases given off from later flows; (e) rapid atmospheric oxidation while the top of the flow was hot; $(f)$ pneumatolytic alteration by gases given off by the lava of the flow itself before, during, and after solidification; $(g)$ direct magmatie segregation.

\section{MODERN WEATHERING}

Modern weathering may be eliminated by the following considerations and dismissed without further argument: The oxidation is clearly earlier than the copper, which as shown in the discussion of ore deposition (p. 53) is not of recent formation; and the oxidation of a given flow is the same at a vertical depth of 5,000 feet, where the rocks are tight and dry, as it is in the zone of actively circulating ground waters.

$$
\text { INDEPENDENT SOLUTIONS }
$$

Under the action of independent solutions may be considered two unrelated influences - the action of circulating oxygenated ground waters after a flow has been covered by others and thus protected from direct atmospheric oxidation, and the action of oxidizing mineralizing solutions such as those believed by Pumpelly to have both deposited the copper and oxidized the ferrous iron minerals.

The activity of oxygenated waters is so closely related to ordinary weathering that it must be, in large measure, credited or discredited on the evidence regarding that process, which is discussed below and rejected.

Pumpelly's ideas of the nature and source of the solutions that carried the copper and of the reactions 
by which the metal was deposited are discussed fully under "Ore deposits" (p. 120) and are regarded as not in accord with the facts now available. That argument need not be anticipated here, but the following general considerations may be mentioned as controverting the close relation assumed by Pumpelly to exist between oxidation of iron and deposition of copper.

1. The oxidation is no more marked in one part of the series than in another. A flow in the upper part of the series, thousands of feet stratigraphically above the flows carrying copper in commercial quantities, is as well oxidized as one of similar texture carrying minable copper.

2. In a given lava top-for example, that which contains the Osceola lode - the degree of oxidation is the same where it is minable as it is miles distant, where it is barren.

3. The western lavas, which show no evidence of the action of mineralizing solutions, such as vesicle filling, display the same features of oxidation as the flows in the Michigan copper district.

SURFACE WEATHERING IMMEDIATELY AFTER EXTRUSION

Normal weathering at the surface involves wellunderstood processes, both mechanical and chemical. The mechanical processes are disintegration and transportation, which together constitute erosion. The chemical processes are oxidation, hydration, and carbonation, followed by removal of the soluble compounds produced. These processes result in the formation of characteristic end products, among which are kaolin, limonite, and calcite, the development of pore space, the softening of the rock, and a textural breakdown. In general, the chemical changes are farthest advanced at the surface, decreasing and disappearing in depth. They extend outward from joints and cracks into the adjacent rock. Under the conditions that probably prevailed during the epoch of lava outflow in Michigan, the general order of weathering attack on a basic flow is glass and olivine first, followed by pyroxene, feldspar, and finally magnetite. Magnetite is very resistant, commonly remaining sufficiently unaltered to retain its strong magnetic property in a residual soil or a black sand.

The principal chemical changes characteristically shown by weathered basic rocks as compared with their fresh equivalents are these: The ratio of silica to alumina is diminished, as shown in 16 out of 17 pairs of analyses cited by Leith and Mead, ${ }^{38}$ and the ratio of total iron to alumina either decreases or remains nearly constant. In 13 out of 15 pairs of analyses compared total iron is either lost or essentially constant relative to alumina; in the other two iron has increased.

Such, then, are the outstanding chemical and physical changes which should be exhibited to a greater

\footnotetext{
"s Leith, C, K., and Mead, W. J., Metamorphic geology, p. 24, 1915.
}

or less degree by the tops of basic flows if their color and their increased iron and oxygen content were occasioned by normal weathering. It can readily be shown that the Keweenawan flows do not exhibit these changes.

Most of the flows of the smooth cellular type show no evidence of disintegration. Ropy tops are preserved intact, as well as all the minute original textural details of the rock, even to the very surface. There has been no crumbling, softening, or development of pore space; there has been no slumping and therefore no considerable lateritic concentration; there is no visible relation between amount of oxidation and proximity to joints, and therefore no considerable movement of iron or oxygen by solutions can have occurred after the rocks were formed.

In the Columbia River flows, where the rock has clearly weathered to form a residual soil, the trap underneath the soil has crumbled and rotted to a great depth along the joint planes, but the greater part of any thick flow at the top of which the soil may lie is left intact. Limonitic alteration stains the rock along all joints and fractures, both on a large scale and microscopically. Yet in these Michigan flows that have the red tops the increase in ferric oxide, though at its maximum in the upper 10 to 20 feet, starts practically at the base of the flow and is nowhere seen to be related to joints and fractures. It is difficult, therefore, to ascribe the state of oxidation of the iron to weathering.

Still more difficult is it to explain the actual increase in total iron as a consequence of weathering. If simply the oxidation of the iron normally contained in the rock were involved, it would perhaps suffice to say that the glassy portions are highest in ferric iron because they are most susceptible to alteration. But they are actually higher not only in ferric but in total iron. No evidence of iron enrichment after solidification has been recognized, except such as is related to the copper mineralization, which occurred much later, and except for rare and minor coatings of specularite. No concentration of ferric iron has been found to have taken place by the filling of openings. The hematite is uniformly distributed throughout the devitrified groundmass, in which the most minute textures have been preserved.

The downward decrease of the ferric oxide is not obviously incompatible with weathering, but the distribution of total iron is not to be explained by weathering. It increases toward the top and to a slight extent toward the bottom of the flow. Detailed study of the distribution of the ferric iron reveals other features difficult of explanation by weathering. For example, on the Osceola and Isle Royale lodes there are not uncommonly stretches of dense trappy material in the midst of the fragmental material that divide it into an upper and a lower portion. It would 
be natural to expect that weathering would be somewhat less intense below this relatively impermeable trap than above it, but no difference can be detected; both upper and lower layers are iron-rich and highly oxidized. Large areas of the Kearsarge lode are covered by one or more nonfragmental flows of local extent which are possessed of characteristics so like the Kearsarge that they are regarded as probably of the amygdaloid below the gushes had opportunity to be removed. Nor can it have been derived from the overlying gushes, for they have not been leached.

The chemieal changes involved in weathering are not those which distinguished the red tops from the deeper portions of the flow. The chemical criteris must, indeed, be used with caution, because the analyses show the composition of the tops of the

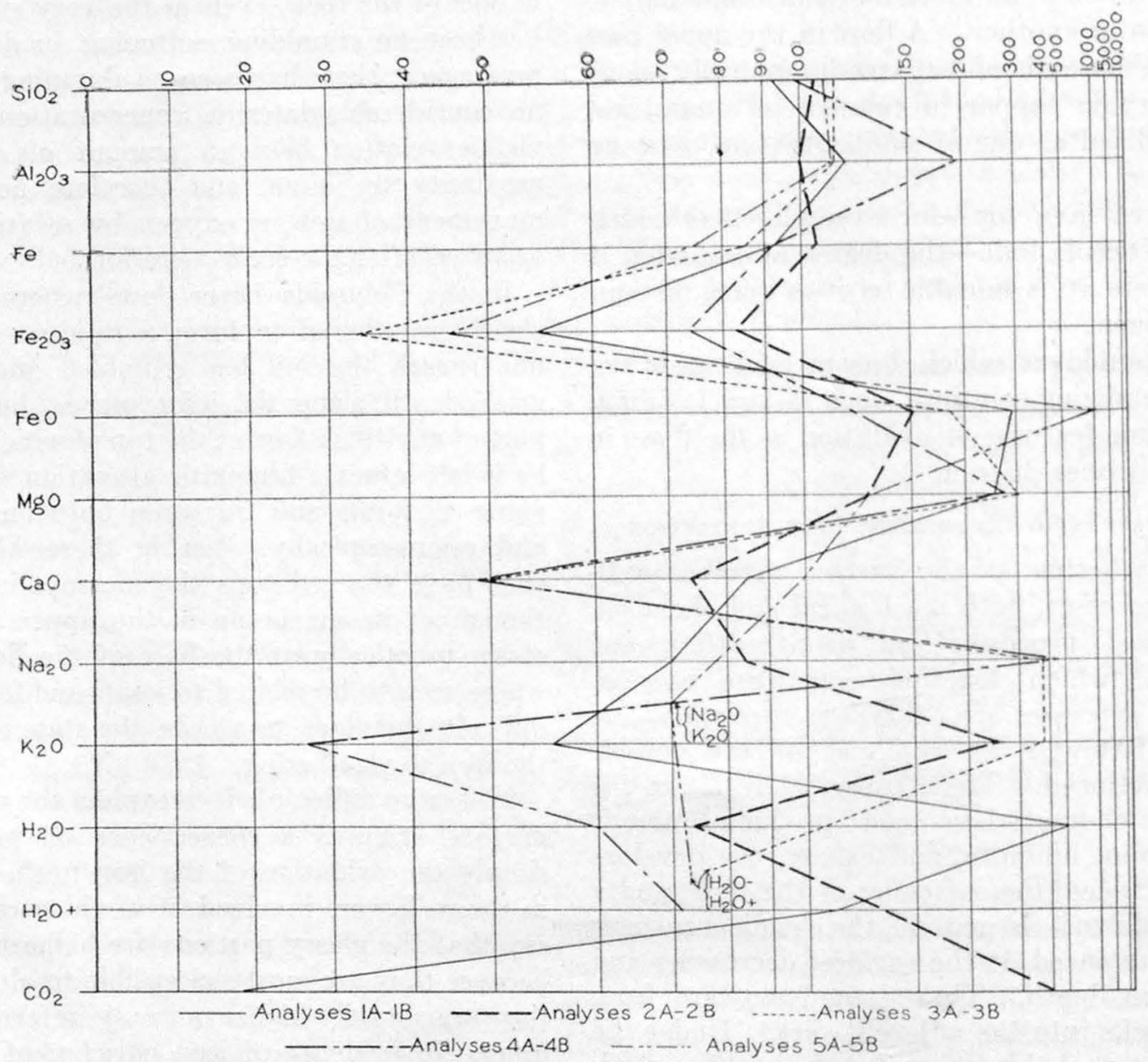

FIGURE 5.-Gains and losses in constituents in oxidized tops as compared with trap portions of flows. (See analyses, p. 37.) Points on the diagram are obtained by dividing the percentage of each constituent in the trap by the percentage of the same constituent in the amygdaloidal top of that trap, and multiplying the quotient by 100 . The points then indicate for each constituent the number of grams of amygdaloid required to furnish the amount of that constituent present in $100 \mathrm{grams}$ of the equivalent trap. Thus the diagram shows that there is as much $\mathrm{Fe}_{2} \mathrm{O}_{3}$ in 35 to 85 grams of amygdaloid (according to which pair of analyses is chosen) as there is in 100 grams of the corresponding trap. Assuming any constituent as constant, all points for other constituents to the right indicate a loss, and to the left a gain. Thus assuming $\mathrm{SiO}_{2}$ or $\mathrm{Al}_{2} \mathrm{O}_{3}$ to have remained constant in the change from trap material to amygdaloid, $\mathrm{Fe}_{2} \mathrm{O}_{3}$ and $\mathrm{CaO}$ have been added and $\mathrm{FeO}$ and $\mathrm{MgO}$ have been lost. (Leith and Mead, Metamorphic geology, p. 288, New York, 1915)

small surface gushes from the Kearsarge flow itself. The Kearsarge lode is as well oxidized below these gushes as elsewhere. A similar condition is present on the Baltic flow. If weathering has been effective in producing ferric oxide, it either must have worked with surprising rapidity before the gushes covered the main flows, or else it has shown a surprising preference for action on the main flows. Especially difficult is it to explain the increase in total iron content in the Kearsarge amygdaloid where covered by these gushes. The extra iron can not have come from lateritic concentration of the Kearsarge flow, for that is precluded by the evidence already adduced, and moreover none
Michigan flows after they have undergone several periods of alteration and mineralization and the changes due to each period are not readily separated. Two of the changes found to be characteristic in the weathering of basic igneous rocks have been pointed out.

In the five pairs of analyses (see p. 37 and fig. 5) available for the comparison of oxidized tops and deeper traps silica is constant or has gained relative to alumina. In four out of the five total iron has gained relative to alumina; in the fifth pair the iron-alumina ratio is about constant, in spite of the fact that the specimen that represents the top of the flow in this 
pair was taken from the lower part of a nonfragmental amygdaloid, which is always lower in iron than the upper part.

The later mineralizing processes have apparently exerted little effect on the silica-alumina ratios. The traps themselves contain about 46 per cent $\mathrm{SiO}_{2}$ and 17 per cent $\mathrm{Al}_{2} \mathrm{O}_{3}$. The chief minerals added to the tops of the flows that would affect the $\mathrm{SiO}_{2}-\mathrm{Al}_{2} \mathrm{O}_{3}$ ratio are epidote, pumpellyite, chlorite, and quartz. The first three of these have less silica and more alumina than the trap ratio; the quartz, of course, would increase the silica, but it is probably not present in a proportion sufficient to exceed the silica deficiency of the other three. The introduction of epidote, pumpellyite, and chlorite would cause a loss of iron in the tops of flows relative to alumina and hence would accentuate any effects of weathering. The fact, then, that the red tops, as compared with their corresponding traps, show a gain of both silica and total iron relative to alumina, in spite of opposing tendencies introduced by the later mineralization, argues against weathering.

By the evidence of structure, texture, and distribution of ferric oxide, therefore, the weathering hypothesis appears to be eliminated. The mineralogic evidence points to the same conclusion. Weathering of basalts, as in the Columbia River lava field, has yielded kaolinic and limonitic soil but has left much of the magnetite unoxidized. In the red tops of the Michigan and Idaho flows there is neither kaolin nor limonite; the feldspars, notwithstanding their minute size and intimate contact with hematite, are strikingly fresh, but the magnetite is altered almost completely. In Michigan the magnetite has in many places been changed to hematite throughout the thickness of the flow. In the basalts of Idaho and in those of Washington that have not been affected by recent weathering the alteration of the magnetite is more closely confined to the upper parts of the flows, where the content of ferric iron is highest.

\section{HYDROTHERMAL ALTERATION}

Alteration of rocks by hot solutions emanating from an igneous mass is a common phenomenon; a lava flow, therefore, might conceivably be altered by solutions derived from a later flow with which it is in intimate contact. No proof has been found, however, that such action has occurred to an appreciable degree in the Michigan lavas, and this agency could not possibly explain the differences which the top and the bottom of a given flow exhibit. Downward passage of solutions from a liquid flow to the cooled flow beneath it would, moreover, be greatly impeded by the thin chilled skin, which, as already shown, was usually rolled under the advancing flow or quickly formed at the bottom.

A modification of this idea is that the altering solution did not come entirely from the overlying flow but was afforded by moisture and air present in the permeable top of the underlying flow and entrapped there by the outpouring of the next flow. The resulting steam and hot air might cause some oxidation, but it seems unlikely that the permeable top would originally hold enough oxygen as air to equal the amount present in excess ferric iron; and as for iron concentration, it is evident that nothing could be
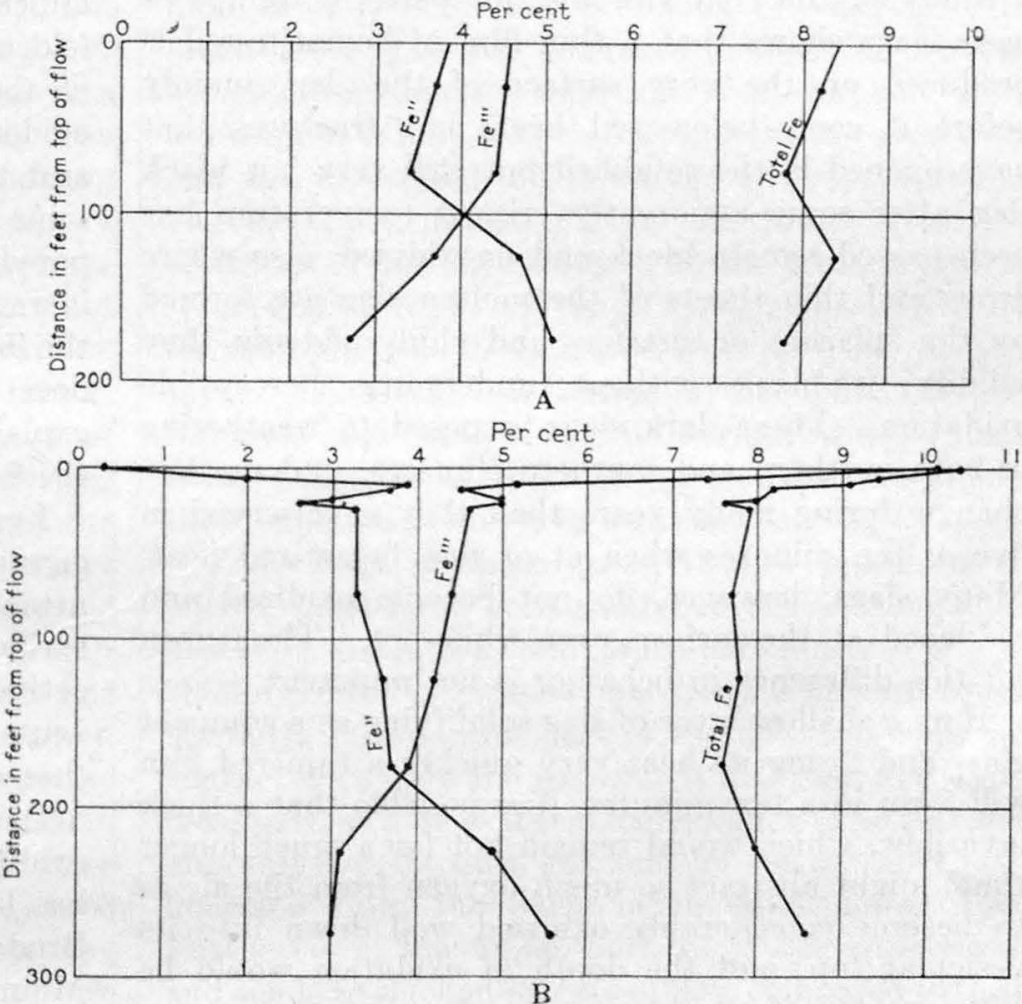

Figure 6.-Change in character and content of iron in different parts of lava flows. A, Smoothtop flow; B, breccia-top flow

accomplished by such a process, unless it left a correspondingly iron-leached mass or unless the ironrobbed material was removed by solution - neither of which has happened.

Under either form of the hypothesis, it would seem that a basalt flow which was able to force oxygen downward for scores of feet into the amygdaloid, and even into the trap, of the underlying flow, ought to produce some perceptible effect on the top of an underlying felsite conglomerate, even though the felsite was already almost completely oxidized and though felsite is a more stable rock than basalt. Yet the tops of felsite conglomerates that are directly overlain by basalt nowhere show any special oxidation or any other change that can be ascribed to the action of the lava. Nor are the amygdaloidal conglomerates more 
thoroughly oxidized where they are in direct contact with the next overlying flow than where they are separated from it by a bed of felsitic conglomerate. This hypothesis, therefore, seems to receive no support from field observation.

ATMOSPHERIC OXIDATION OF HOT TOPS

There is much to commend the idea that the lava tops have undergone very rapid surface oxidation while they were exposed to the atmosphere in a highly heated condition..$^{39}$ This process might account for the production of hematite instead of limonite, and for the freshness of the feldspar microlites and the survival of the delicate texture of the rock.

Study of the cold and the hot parts of dumps of basic slags shows that a thin film of hematite-red is produced on the very surface of the slag, mainly before it cools below red heat; but fractures that have opened in the solidified but still very hot black slag after some apparently critical temperature has been passed remain black and unoxidized; also where drops and thin sheets of the molten slag are formed by the splashes or spatters and chill suddenly they solidify jet-black without undergoing perceptible oxidation. These dark slags, exposed to weathering in both northern and southern climates, undergo less change during many years than they experienced in five or ten minutes when at or just below red heat. Many slags, however, do not become oxidized and reddened at the surface, even while hot. The reason for this difference in behavior is not apparent.

If on a shallow layer of slag solidifying as a compact glass and losing its heat very quickly a thin red film will form in a few minutes, it is possible that a thick lava flow, which would remain hot for a much longer time, might abstract so much oxygen from the air as to become considerably oxidized well down into its vesicular top; and the depth of oxidation would be still greater if the top were brecciated. Jaggar, indeed, believes that air is earried down by convection from the surface to the deeper portions of the flow, where it combines rapidly with the ferrous iron of the lava.

But such action, while it may and probably does account for some of the oxidation of the tops and perhaps might cause a little oxygen to penetrate deeply into the lava that solidified as trap, could not aid in the concentration of iron toward the flow surfaces. This hot oxidation might have helped to raise the oxygen content of the flow tops, but some other process must have produced the main features of iron and oxygen distribution.

\section{MAGMATIC PROCESSES}

The remaining possible causes of those listed on page 38 relate to the behavior of molten magma and

\footnotetext{
30 Russell, I. O., A reconnaissance in southeastern Washington: U. S. Geol. Survey Water-Supply Paper 4, p. 43, 1897. Jaggar, T. A., Seismol. Soc. America Bull, vol. 10, p. 155, 1920.
}

are so closely allied that a choice between them is neither easy nor positive.

Magmatic segregation.-The quickly chilled tops and bottoms of flows are supposed to have solidified before differentiation had made pronounced changes and therefore to represent closely the composition of the original magma. Within the flow, where solidification by crystallizing proceeded more slowly, sinking of heavy crystals has, in numerous examples, produced a concentration of the ferromagnesian constituents toward the base, leaving the upper portion less basic, and floating of lighter crystals has increased this effect. ${ }^{40}$

That gravitative differentiation has operated is indicated by occurrences like the zone filled with feldspar crystals just under the amygdaloid portion of the Kearsarge flow, in which the crystals have evidently moved upward from deeper in the flow; and the increase in total and in ferrous iron which some of the flows show in their lower third, as compared with the middle, is consistent with slight increase in magnetite, olivine, and pyroxene toward the base. Rising and sinking of crystals, however, does not account for deep oxidation and does not explain the concentration of either iron or oxygen in the flow tops.

Fumarolic alteration.- - It is well established that a crystallizing magma gives off gases which may attack not only older adjacent rocks but also the earlier solidified portions of the magma itself. In active voleanic regions the lava bordering fumarolic vents is conspicuously altered by the heated gases that emanate from the underlying, still fluid magma.

It is known, in particular, that ferrous iron may be oxidized by fumarolic action. ${ }^{41}$ One example that has been described by Diller ${ }^{42}$ and observed by Mr. Broderick occurs in the flow of the Cinder Cone, near Mount Lassen, Calif. As shown by Diller, the Cinder Cone itself was formed about 200 years ago, but the near-by flow of black quartz basalt was poured out somewhat later. The flow came out into a small lake and is of the aa type, exceedingly rough and difficult to walk upon. It contains many great blocks of black lava that are reddened on some portion of their surface, which may be the top, the bottom, or any side; and it is strewn with many little heaps of loosely cemented brilliant-red vesicular fragments. Along part of the rim of the deep crater at the top of the Cinder Cone the exposed surfaces of lava fragments are colored bright orange and red. The distribution of all these colorations of the rock shows clearly that they are related to fumarolic action.

10. Daly, R. A., Igneous rocks and their origin, p. 450,1914. Bowen, N. L., The late stages of the evolution of igneous rocks: Jour. Geology, vol. 23, No. 8, suppl, 1915.

"Gautier, Armand, Compt. Rend, vol. 132, pp. 61, 189, 932, 1901; vol. 136, p. 16, 1903.

${ }^{42}$ Diller, J. S., A late voleanic eruption in northern California: U. S. Geol. Survey Bull. $79,1891$. 
Thin and polished sections of this reddened basalt greatly resemble some that were cut from the finegrained iron-rich parts of breccias in the Keweenawan series. In the recent as in the ancient lava fresh microlites of feldspar and crystals of olivine partly or wholly altered to hematite are embedded in a glassy matrix crowded with minute particles of hematite, the abundance of which accounts for the red color and for the high proportion of ferric iron found by chemical analysis. The black vesicular basalt of Cinder Cone contains 4.30 per cent of iron in the ferrous state and 1.51 per cent of iron in the ferric state, a total of 5.81 per cent. The reddened equivalent, altered by hot gases, contains virtually the same amount of total iron, 5.85 per cent, but only 0.79 per cent of this is in the ferrous state, 5.07 per cent being in the ferric state. This, then, is a case of simple oxidation by fumarolic action of iron already present in the rock. What the oxidizing agent was is not known; it may have been steam or some more vigorously oxidizing gas, or it may have been atmospheric oxygen affecting the rock where hot gases kept it heated for a longer time than elsewhere.

Thus, at Cinder Cone fumarolic action is a factor, direct or indirect, in locally oxidizing the iron of basalt without altering its amount, and the resulting rock is much like that in many of the red tops of the Michigan basalts. It may next be inquired whether or not fumarolic action, or any action of voleanic gases, can account not only for the oxidation of iron but for that increase in quantity of iron which has occurred in flow tops like the Kearsarge amygdaloid. This increase is not merely a relative one, such as would be accomplished by a partial removal of some other constituents, for, as already emphasized, there is no evidence that such removal has occurred. There has been an actual addition of iron, and this iron has been introduced into the solid glassy part of the rock without filling the vesicular cavities.

The deposition of ferric compounds, including hematite and ferric chloride, around fumaroles has often been observed. ${ }^{43}$ Whether or not such additions of ferric iron could be incorporated into the rock matter itself is a question on which there is no evidence available. Even if it is granted, however, that typical fumaroles could produce a thorough permeation of the rock by ferric oxide around local vents, it is not easy to understand how they could affect to a marked and fairly uniform degree the tops of scores of superposed flows. In the brecciated tops that were continuously broken as the flow was in progress gases might rise at all points through the top from the underlying lava. In the smooth tops it would be expected that the gases would escape through more localized vents, but no such vents have been recognized. Any such action

\footnotetext{
4 Clarke, F. W., The data of geocbemistry, 5th ed.: U. S. Geol. Survey Bull. 770, pp. 261 et seq., 1924. Allen, E. T., Chemical aspects of volcanism: Franklin Inst, Jp. 261 et seq., 1924. Alle
Jour., vol. 193, p. $34,1922$.
}

is closely akin to the action from the gases of the flows before solidification that is discussed in the following section.

- Fumarolic action in the strict sense then, although it may accomplish both the oxidation and the deposition of iron around local vents, could not affect the widespread, continuous, and deeply penetrating oxidation seen in the Michigan flows.

Action of gases from the flows.- There remains to be considered the action of gases given off from the flow itself before solidification and acting on the melt and on the gathering crust as they ascended. That gas rising from the lower parts of the Michigan flows was abundant in the upper parts while they were still fluid is shown by the profusion of vesicles. How much more gas was liberated before the viscosity became sufficient to imprison it as bubbles is not known, but it may well be that in both the smooth-top and the brecciated-top flows the gas represented by vesicles is the smaller part of the total. Nearly all observers of flowing lava refer to the great volumes of steam and other gases given off from its top. Silvestri, ${ }^{44}$ for example, who investigated voleanic gases at Etna, says: "The fresh, still flowing lava acts like one great fumarole and emits from its surface white fumes." Other examples of the high gas content are cited in the discussion of the lava flows on page 32 .

The effects of these gases, if they produced any effects, must have been similar in distribution to the observed oxidation and iron enrichment. As the chief direction of escape of the gases is upward toward the surface, the lower part of the flow will come into contact with only the gas that it held, but the uppermost part, so long as it remains liquid, will be traversed not only by its own gas but by nearly all that is liberated from the parts of the melt lower down. Furthermore, the upper part, as it becomes viscous and tends to slacken its rate of flow compared with the more fluid material deeper down, will receive the gas not only from the portions originally below it but also from those new portions that flow underneath it. If, then, a given portion of lava is changed chemically in proportion to the quantity of gas that passes through it, the chemical effect of the gas should be least near the bottom of the flow and greatest near the top. The distribution of hematite is thus in striking harmony with the hypothesis that it was formed through the agency of gas liberated from the flow as it gradually cooled.

The hypothesis receives further support from the distribution of the hematite as seen under the microscope. The particles of hematite form a pattern that seems characteristically igneous. They are not deposited in the vesicles nor included in the feldspar microlites but are crowded around both, as if pushed aside by or attracted to the growing crystals and expanding

4 Cited by Clarke, F. W., U. S. Geol. Survey Bull. 770, p. 266, 1924. 
bubbles. All this suggests that the hematite was formed before the solidification of the rock and is not a product of later alteration by fumaroles or otherwise.

The chemical composition of the gases whose action on the Keweenawan flows is so strongly suggested can only be conjectured. Information regarding the gases even of modern lavas is not abundant, but there is evidence that they may contain both a volatile compound of iron and an oxidizing agent.

The emanations from some of the lavas of Etna contained ferric chloride, though those from others did not. Iron oxide was deposited by fumaroles in the Valley of Ten Thousand Smokes, Alaska, ${ }^{45}$ and many other instances could be cited. Emanations from intrusive magmas, again, have in many places deposited not only magnetite but hematite in large quantity. The iron is supposed by some to have been expelled in

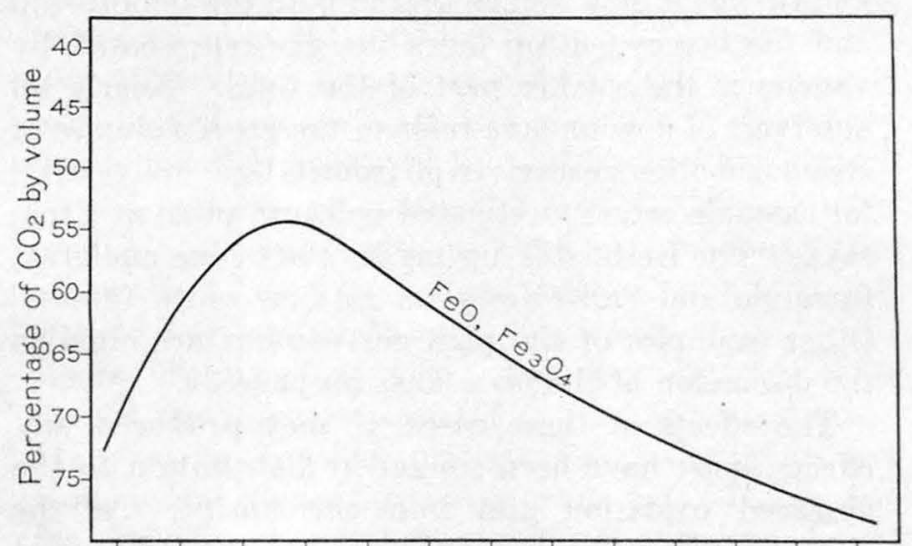

$330^{\circ} 350^{\circ} 400^{\circ} 450^{\circ} 500^{\circ} 550^{\circ} 600^{\circ} 650^{\circ} 700^{\circ} 750^{\circ} 800^{\circ} 850^{\circ} 900^{\circ} 950^{\circ} 990^{\circ}$ Degrees Centigrade

Figure 7 . - Stability relation for the equation $\mathrm{Fe}_{3} \mathrm{O}_{4}+\mathrm{CO} \rightleftarrows 3 \mathrm{FeO}+\mathrm{CO}_{2}$. (After Findlay)

the form of ferric chloride. It is therefore reasonable to suppose that the gases of the lavas contained some volatile compound of ferric iron, together with agents capable of oxidizing the iron already in the flow.

If the iron was conveyed upward as volatilized ferric chloride, its fixation as hematite may have been aided, if not mainly accomplished, by atmospheric oxygen, which would doubtless be very active at certain temperatures. Jaggar ${ }^{46}$ believes that its action may penetrate deeply under certain conditions.

Few data are available regarding the gases given off from these old flows. It is of interest, nevertheless, to consider some possible or probable reactions, though it must be recognized that the actual reactions were much more complex. The following is possibly the simplest condition.

Steam or water vapor is the most abundant gas given off by cooling lavas, and next in amount is carbon dioxide. Day and Shepherd found the gases from Kilauea to consist largely of water and the dried gases to contain from about 24 to 74 per cent of $\mathrm{CO}_{2}$, most of them 60 per cent or more, and 3.5

is Zies, E. G., The fumarolic incrustations in the Valley of Ten Thousand Smokes: Nat. Geog. Soc. Contr. Technical Papers, vol. 1, No. 3, 1924.

io Jaggar, T. A., jr., Seismol. Soc. America Bull,, vol. 10, p. 155, 1920. to 5.6 per cent of $\mathrm{CO}$. The temperature of basaltic lavas on issuing is probably above $1,000^{\circ} \mathrm{C}$. We may consider, then, the probable reaction of these two most abundant gases during the cooling of the flows. For the equation

$$
3 \mathrm{FeO}+\mathrm{H}_{2} \mathrm{O} \rightleftarrows \mathrm{H}_{2}+\mathrm{Fe}_{3} \mathrm{O}_{4}
$$

Eastman and Evans ${ }^{47}$ have shown that from $675^{\circ}$ to $1,000^{\circ} \mathrm{C}$. the hydrogen in the mixture ranges from 46 to 9.9 per cent by volume - that is, at the higher temperature there was little tendency to the oxidation of ferrous iron, but at the lower temperature such oxidation was pronounced.

Day and Shepherd ${ }^{48}$ have shown that at $1,100^{\circ} \mathrm{C}$. water is essentially neutral to powdered basaltic rock. There are no published data on the reaction of water and ferrous iron below $675^{\circ} \mathrm{C}$., but Shepherd ${ }^{49}$ states oxygen, and iron, which has been discussed by that at and below $600^{\circ}$ C. steam has a strongly oxidizing effect upon ferrous iron.

Much is known of the chemical system carbon, Findlay. ${ }^{50}$ The stability relations of most interest in the present discussion are those of $\mathrm{CO}_{2}, \mathrm{CO}$, $\mathrm{FeO}$, and $\mathrm{Fe}_{2} \mathrm{O}_{3}$. Figure 7 gives the stability relation for the equation $\mathrm{Fe}_{3} \mathrm{O}_{4}+\mathrm{CO}_{4} \rightleftarrows 3 \mathrm{FeO}+\mathrm{CO}_{2}$. The temperature most favorable for the movement of the reaction to the left is $490^{\circ}$; at $1,000^{\circ}$ the tendency is strongly to movement to the right.

It would appear, then, that when the lavas issued and until they had reached a temperature below $1,000^{\circ}$ the tendency for $\mathrm{H}_{2} \mathrm{O}$ or $\mathrm{CO}_{2}$ to oxidize $\mathrm{FeO}$ would not be marked. As the temperature decreased, however, this tendency would increase to a maximum at $490^{\circ}$ for $\mathrm{CO}_{2}$ and a maximum at some undetermined temperature, probably below $600^{\circ}$, for $\mathrm{H}_{2} \mathrm{O}$, or a point at which the tops would have been solidified or very viscous. The tops of the flows would reach the oxidizing temperature for $\mathrm{FeO}$ soonest and would doubtless be held at a favorable temperature as long as large volumes of gas were passing through them, so that in respect to temperature and quantity of gas passing through them the tops are most favorably situated for a relatively long period and consequently high degree of oxidation. Any rainfall on the surface of the flows while they were still hot would act as an oxidizing agent, so that this may have been an additional factor in the high oxidation of the top, as well as contact with the oxygen of the air.

As set forth in the section on formation of lava tops the smooth tops occur on flows that issued with a low gas content and the rough fragmental tops on flows that issued with a high gas content. It is a

47 Eastman, E. D., and Evans, R. M., Equilibria involving the oxides of iron: Am. Chem. Soc. Jour., vol. 46, p. $888,1924$.

48 Day, A. L., and Shepherd, E. S., Water and volcanic activity: Geol. Soc America Bull., vol. 24, p. $603,1913$.

40 Shepherd, E. S., oral communication.
so Findlay, Alexander, The phase rule and its applications ,5th ed., p. 248, 1923 
reasonable assumption that the high oxidation of the breccia tops is due to their relatively high gas content and that the relatively slight oxidation of the smooth-top flows is due to low gas content.

This long discussion, then, leads to the general conclusion that, although the oxidation of the iron in the flows may have been due to several agencies, it was effected in dominant part by the action of the gases given off by the lava itself; and it is regarded as probable that the gases most active in the process were $\mathrm{H}_{2} \mathrm{O}$ and $\mathrm{CO}_{2}$.

\section{COPPER CONTENT OF THE BASALTS}

The literature holds many references to the presence of copper in fresh basic rocks, both intrusive and extrusive. The analyses of basalts, diabases, and gabbros compiled by Washington ${ }^{51}$ show that copper was determined in few, but in the eleven analyses in which copper was determined it was reported in quantities ranging from a trace to 0.94 per cent of $\mathrm{CuO}$. The average of these is 0.27 per cent of $\mathrm{CuO}$, or 0.22 per cent of $\mathrm{Cu}$. As shown beyond, this amount is five or six times that of the copper found in fresh traps from the Keweenawan series.

Lane ${ }^{52}$ and Grout ${ }^{53}$ have asserted that the fresh Keweenawan basalts contain small quantities of copper as an original or pyrogenetic constituent. If the basalts contained unusual amounts for rock of this type, that fact might have, as these authors emphasize, a significant bearing on the origin of the commercial concentration of copper. Lane ${ }^{54}$ concluded that the whole basaltic series in its present condition contains about 0.02 per cent of copper. Grout found from 0.012 to 0.029 per cent of copper in several samples of basalt that he regarded as fresh, taken from the Keweenawan of Minnesota. He also found that the freshest specimens contained the most copper and the most altered specimens (character of alteration not given) the least copper, and he inferred that copper was removed by the alteration. From microscopic work and from finding that in a partly altered rock containing 0.02 per cent of copper only one-tenth of this amount was soluble in nitric acid, Grout concluded that most of the copper is present, in the fresh rock, not as metallic copper or as sulphide but in the form of an insoluble silicate, probably associated with the abundant basic silicates of the rocks.

Morozewicz, ${ }^{55}$ on the other hand, estimated that the basalt dikes of the Commander Islands carry copper in the fresh rock to the extent of 0.04 per cent. From tests made on several mineral constituents he concluded that the magnetite contains the copper; no

\footnotetext{
"Washington, H. S., U. S. Geol. Survey Prof. Paper 99, pp. 1049-1106, 1917.

"Lane, A. C., Michigan Geol. Survey Pub. 6, vol. 1, pp. 175 et seq., 1911

$"$ Grout, F. F., Econ. Geology, vol, 5, pp, 473-476, 1910.

"Op. cit., vol. 2, p. 778.

s Morozewicz, J., Das Vorkommen von gediegenem Kupfer auf den KomandorInseln: Com. géol. Mém., new ser, livr. 72, pp. 45-88, 1912.
}

copper was found in the pyroxene, and no sulphur was found in the rock.

In the course of the present examination, an independent estimate of the copper present in the Michigan basalts was made. About 20 pieces of drill core, each representing the freshest-appearing trap obtainable, were taken from drill holes on the Cliff, LaSalle, Seneca, Ahmeek, and Osceola properties. All of them were combined into a composite sample, which was analyzed for copper soluble in nitric acid, for total copper by fusion, and for sulphur. The purpose of determining copper after fusion and sulphur was to ascertain the total copper present and gain an idea of its state of combination. If more copper were obtained by fusion than by solution in nitric acid, the fact would lend support to the commonly held views that copper was present in the silicates as copper silicate, or in magnetite as an oxide.

Similarly, a composite sample was made, from the same drill cores, of trap that looked altered or was fissured and chloritized but that contained no copper visible to the naked eye, and a third sample consisting of amygdaloids, which likewise held no visible copper. The reason for making these two composites was that Lane had included materials of these kinds in the samples from which he estimated the average copper content of the traps, and it was thought that his inclusion of amygdaloids and of altered and fissured trap probably gave him a higher average copper content than would have been obtained from the freshest traps alone. The composite samples were assayed by W. J. Hillenbrand, of the Calumet \& Hecla Co., with the following results, which are subject to an error of about 0.02 per cent.

Copper and sulphur in composite samples of trap and amygdaloid

Fresh trap.

Altered and fissured trap..........
Amygdaloid.

\begin{tabular}{|r|r|r}
$\begin{array}{r}\text { Copper } \\
\text { soluble in } \\
\text { nitric acid }\end{array}$ & $\begin{array}{c}\text { Copper by } \\
\text { fusion }\end{array}$ & Sulphur \\
\hline & & \\
\hline 0.040 & 0.048 & 0.012 \\
.036 & .034 & .021 \\
.032 & .032 & .014 \\
\hline
\end{tabular}

Thus, the freshest obtainable traps of the district contain a few hundredths of 1 per cent of copper. The quantity is greater than that found by Lane and by Grout in the Keweenawan of Minnesota, but it is much less than that shown in analyses of similar rocks from some other localities. It was expected that the altered trap and the amygdaloids would run higher in copper, but the results show that they have about the same amount as the freshest trap.

The copper obtained by fusion is the same, within the limits of error, as the copper soluble in nitric acid, so that little, probably none of the copper is contained in insoluble silicates. Olivine is soluble in nitric acid, and if olivine were present in the rocks any copper 
that it contained would be soluble in acid. However, the olivine is practically all altered, and whether or not its alteration product, serpentine, would yield any copper it might contain to a nitric acid solution is not known. Sulphur is present in small amounts, more than enough to combine with all the copper as chalcocite but not so much as would be present if the copper occurred in chalcopyrite alone. The analyses suggest, therefore, that the copper is probably not present as silicate but that it may be present in part as sulphide and in part in some other state of combination or as native copper, or wholly as chalcocite, or as chalcocite and chalcopyrite together.

Polished sections of the duplicates of the trap samples included in the composite sample show under the microscope that copper is present in tiny rounded specks of native metal and chalcopyrite. Native copper is more abundant than the sulphide. In some sections both are present, but most contain only the one or the other. Specimens of the Greenstone flow (none of which was included in the composite sample) show native copper, chalcopyrite, and probably chal-

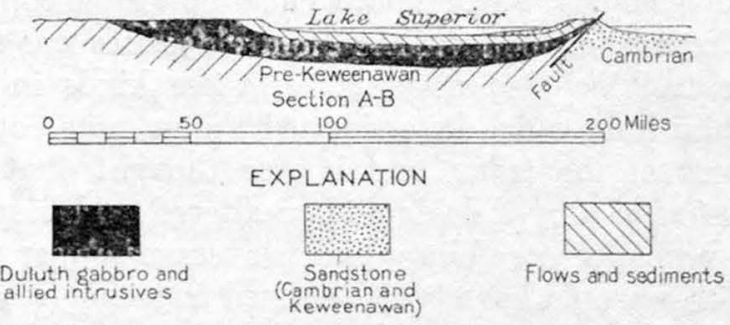

Figure 8.-Geologic section from Vermilion Lake, Minn., to Calumet, Mich., showing probable extent of Duluth laccolith beneath Lake Superior basin. (See pls. 1 and 3 for areal geology.)

cocite. Although microscopic estimation of amounts so minute can not be quantitative, the definite copper minerals seen appear to be present in the proper order of abundance to account for all the copper indicated by the analyses, and it is probable that all or very nearly all of the copper is present as native metal or sulphides.

Is the copper in the basalts primary, or has it been introduced after the rocks were formed? If the Keweenawan lavas came from the same general magmatic source as that from which the copper of the ore deposits was subsequently drawn, it would seem reasonable to suppose that they would cuntain a little primary copper; on the other hand, all the rocks have suffered more or less alteration, and some copper may have been introduced into even the least altered.

The facts from which conclusions are to be drawn are these: (a) The freshest traps that can be obtained contain only minute quantities of copper. The available analyses of rocks of the same family from other localities show on the average six times as much copper as the Michigan basalts; $(b)$ these freshest traps, however, have been somewhat altered; $(c)$ the freshest traps, the fissured and altered traps, and the amygdaloids, when all are carefully selected to show no copper to the eye, contain substantially equal quantities of copper, within the limits of analytical error; (d) analyses show the presence of sulphur and suggest but do not positively prove that the copper is not present as silicate or oxide; (e) microscopic exam. ination of polished sections taken from the same small pieces as were analyzed chemically reveals the presence of minute particles of native copper and copper sul. phide throughout even the freshest trap.

From these facts the following more or less tentative deductions may be made: (a) The presumption is strong that these definite copper minerals contain all the copper which the analyses show; $(b)$ the presumption is also strong that part at least of these copper minerals are primary constituents of the trap; $(c)$ it is possible or even probable that some of the copper was introduced by mineralizing solutions.

In the coarse pegmatitic or doleritic lenses that are common in some of the thick flows both native copper and copper sulphide occur in intimate association with the rock minerals as well as with calcite and locally with prehnite. It seems most likely that all these minerals are primary to the pegmatite, which evidently resulted from a differentiation of the lava during cooling.

\section{INTRUSIVE ROCKS}

\section{GENERAI FEATURES}

Throughout the district intrusive rocks occur in the lower part of the series, near the Keweenaw fault. (See fig. 8.) To the south, at Porcupine Mountain, and north of Lake Gogebic they are present in the middle and upper part of the series also. These intrusive rocks comprise gabbro and "gabbro aplite" similar to the gabbro and red rock of the Duluth laccolith or lopolith; quartz porphyry and felsite, which are regarded as probably the fine-grained equivalents of the Duluth red rock; and dark chloritized basic dikes, which are present north of Lake Gogebic. These rocks have been intruded in masses of various form; a stock occurs at Mount Bohemia and probably some of the bodies near the Wisconsin boundary also are stocks; the Mount Houghton intrusive body and some bodies north of Lake Gogebic appear to be sills or laccoliths; and dikes occur at many places toward the Wisconsin boundary and very rarely in the northern portion of the district.

The similarity of the rocks to the Duluth gabbro and red rock series and their occurrence near the base of the Keweenawan and along the great Keweenaw fault has led to the belief that they are a part of the Duluth laccolith, which crops out in a similar relation on the north side of the basin and probably extends beneath the basin, as is more fully discussed under "Structure" (p. 50). . $^{56}$

56 Van Hise, C. R., and Leith, C. K., op. eit., pp. 377-378. Grout, F. F., The lopolith, an igneous form exemplified by the Duluth gabbro: Am. Jour. Sci., th ser., vol. 46, pp. 516-522, 1918. 
Rocks of the gabbro and red rock type occur at Mount Bohemia and near the Michigan-Wisconsin boundary, where relatively large bodies are surrounded by zones showing pronounced rock alteration. Diamond drilling at the Indiana mine also encountered gabbro.

The gabbro of Mount Bohemia is a dark gray-red granitoid rock of variable though typically medium grain. Its essential minerals are plagioclase, pyroxene, and magnetite in roughly equal amounts. Accessory minerals are hornblende, apatite, quartz, titanite, and sulphides. The pyroxene is partly altered to hornblende and chlorite, and the feldspar to sericite and chlorite. Leucoxene occurs as an alteration product of titaniferous magnetite. This rock has been described by Wright ${ }^{57}$ and called oligoclase gabbro.

The associated red rock or gabbro aplite is a coarsertextured rock composed essentially of oligoclase-albite and quartz with subordinate orthoclase, magnetite, apatite, titanite and zireon. It occurs as dikes and as a stock in the gabbro and adjacent rocks.

The following analyses, taken from Lane's report, ${ }^{58}$ show the chemical composition of these and allied intrusive rocks:

Analyses of intrusive rocks from Keweenaw Point

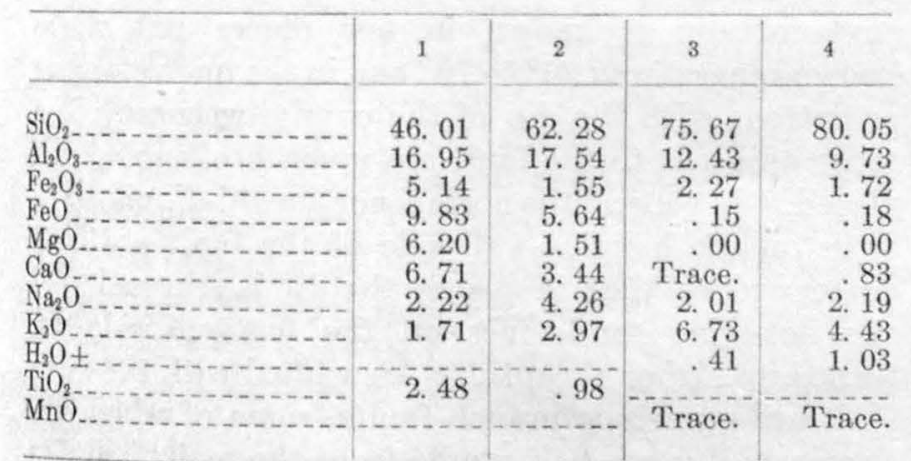

1. Oligoclase gabbro, Mount Bohemí. L. Kirschbraum, analyst.

2. Gabbro aplite, Mount Bohemia. L. Kirschbraum, analyst.

3. Mount Houghton quartz porphyry. Michigan Geol. Survey, vol. 5, pt. 2

4. Mount Houghton quartz porphyr.

\section{QUARTZ PORPHYRY AND FELSITE}

Bodies of quartz porphyry and felsite are present at several places near the Keweenaw fault. The larger known bodies near the fault from north to south are at Fish Cove, Bare Hills, and Mount Houghton, south of Cliff, south of Ahmeek, east of Calumet, and at the Indiana mine. North of Lake Gogebic are some large masses of quartz porphyry that are probably intrusive. At several of the localities there is no clear evidence of the relation of these masses to the flows and sediments, but where the relation is obvious they are intrusive into these rocks. The fine felsite may show distinct flow structure in bodies that are known to be intrusive, as is common for rocks as

\footnotetext{
"Wright, F. E., The intrusive rocks of Mount Bohemia, Mich.: Michigan Geol. Survey Rept, for 1908, pp. 363-370, 1909.

1911.
Lane, A. C., Michigan Geol, Survey Pub. 6 (Geol. ser. 4), vol, 1, pp. 106-109,
}

siliceous and fine textured as these. The "Chippewa" felsite and the felsite of Porcupine Mountain are similar to those just described but have been regarded by geologists who have given most study to them as flows. There is also a similar rock at the Bear Lake prospect, west of Calumet, which has the appearance of a rhyolite flow but may be intrusive. This is in the Freda sandstone and is stratigraphically the highest known occurrence of felsite.

The rocks vary considerably in texture in different bodies and also in a single body. In the coarser varieties phenocrysts of quartz and feldspar 2 or 3 millimeters in diameter are present rather abundantly. These are inclosed in a felsitic groundmass of quartz and feldspar. The finer varieties are typical felsites, in which phenocrysts are either small and scarce or altogether absent. Dark minerals are characteristically absent from these rocks, but practically all have a reddish color due to the presence of countless dustlike particles of hematite, which appears to be an original constituent. All these rocks, as well as the pebbles of similar felsites and quartz porphyries in the conglomerates, are rich in ferric iron. The chemical composition of the Mount Houghton mass is shown in the analyses given above. The other bodies are apparently of similar composition.

\section{BASIC DIKES}

Very few basic dikes have been noted in the part of the district that has been most studied. A few examples of probable dikes were seen in the drill cores from the north end of the district. In the Onondaga drill section, north of Lake Gogebic, numerous small fine-grained green, highly chloritized dikes cut both the quartz porphyry and the lava flows. The intruded rocks for a few inches from the dike contact are considerably chloritized.

\section{AGE OF INTRUSIVE ROCKS}

There is no basis for determining the age of the intrusive rocks more definitely than as Keweenawan or post-Keweenawan. The felsite fragments in the conglomerates closely resemble those found in place and are generally believed to have been derived from similar masses, as they are unlike any earlier rocks known in the region. If this belief is correct, felsitic intrusion, extrusion, or both must have begun early in Keweenawan time to have formed the source of the early conglomerates, and the igneous activity probably continued into late Keweenawan time, at least in the Porcupine Mountain area, where the latest known Keweenawan rocks are involved in the domical structure that is attributed to intrusion. Similar evidence of late igneous activity is afforded by the presence of a fine-grained acidic rock well up in the Freda sandstone (upper Keweenawan) near Bear Lake. Whether the intrusive rocks near the base of the series, as represented along Keweenaw Point, are early or late is not known. 


\section{STRUCTURE}

The broader structural features of the Lake Superior region have been summarized by Van Hise and Leith, ${ }^{59}$ and only such features need be set forth here as bear directly on the rocks of the copper district.

\section{FOLDS}

The dominating structural feature of the region is the Lake Superior syncline. This structural basin is roughly outlined by the present area of Lake Superior with a southwestern extension into Minnesota. West of Keweenaw Point the general strike of the axis of the basin is about N. $30^{\circ}$ E., extending into Minnesota. East of Keweenaw Point the strike is east of south. In this direction the syncline extends to the east end of Lake Superior. Keweenaw Point is on the south limb of this syncline. The north limb is exposed on the north shore of Lake Superior and on Isle Royal. Beds that are thought to be at essentially the same horizons crop out on Keweenaw Point and on Isle Royal, about 50 miles apart across the general strike of the basin.

The syncline is asymmetrical, the beds on the south limb dipping notably more steeply than those on the north. There is a steady flattening in the dip of the beds from the base of the Keweenawan series toward the top. On Keweenaw Point the dip ranges from $80^{\circ}$ in the lower beds to $10^{\circ}$ at some points where the upper Keweenawan sandstones dip under the lake.

The south limb of the Lake Superior syncline is irregular in detail, being made up of a series of transverse anticlines and synclines that pitch down the dip of the main trough. (See pl. 3.) Keweenaw Point is near the crest of a northward-pitching anticline that causes the strike of the beds to change between the south and north ends from north of east, through euist, to south of east. 'To the southwest the Keweenaw anticline merges into the Ontonagon syncline. West of the Ontonagon syncline is another anticline with its crest about at Bessemer and Ironwood. These are very broad, open folds, the distance between the adjacent crests of the Bessemer and Keweenaw anticlines being approximately 110 miles. On these large cross folds are numerous subordinate anticlines and synclines of similar character and trend as the Allouez anticline, the Isle Royale (mine) syncline, the Baltic anticline, the Winona anticline, the Firesteel River syncline, and the Mass anticline. These also are broad, open folds but are only 5 to 10 miles across, as contrasted with 100 miles for the major cross folds. Some of the folds, such as the Allouez anticline and the Isle Royale syncline, show a rather uniform bending of the beds, with some faulting near the crest. In others, such as the Baltic and Mass anticlines, the beds are bent sharply at the crests and at the margins of the folds, but the limbs of the folds are fairly straight.

${ }^{80}$ Van Hise, C. R., and Leith, C. K., U. S. Geol. Survey Mon. 52, p. 620, 1911.
The domical uplift at Porcupine Mountain, also a minor fold on the south limb of the Lake Superior syncline, is 12 to 15 miles long and 4 to 6 miles wide. It has the same general trend as the Lake Superio syncline. Numerous faults are associated with this dome.

\section{FAULTS}

The Keweenaw fault, the major fault of the region, strikes in a general northeasterly direction, parallel with the Lake Superior syncline in this area. It varies in strike, however, and in general bends with the transverse northward-pitching anticlines and synclines on the south limb of the Lake Superior Basin. The fault is known from Bete Gris Bay, near the end of Keweenaw Point, where it is covered by the waters of Lake Superior, to Lake Gogebic, a distance of about 100 miles. It doubtless extends farther east under Lake Superior and may be represented to the west by faults that have been found in Wisconsin. ${ }^{60}$. The fault is reverse or overthrust and has forced the Keweenawan rocks up and over the Jacobsville ("Eastern" or Cambrian) sandstone and thus duplicated the Keweenawan and the overlying sandstone. The rocks of the main Copper Range and the South Trap Range are believed to have been once continuous and are now separated by the Keweenaw fault. The fault dips northwest. The angle of dip is known in few places but where known ranges from $20^{\circ}$ to $70^{\circ}$ and in the main steepens or flattens with the dip of the overlying lavas. The rocks adjacent to the fault are much broken and displaced. In general the normal northward-dipping lavs flows on the hanging-wall side of the fault are bent downward so that in places the dip is reversed, and the flat-lying sandstones on the footwall side are turned up rather abruptly. Associated with the main fault are numerous branch faults, some of which are known to diverge half a mile from the main fault, as that at the Mayflower-Old Colony mine. The flows in the block between the main fault and the branch are nearly flat-lying or have a southerly dip.

The rocks of the lava flows for several hundred feet from the fault are in most places greatly broken and brecciated. This condition has rendered diamond drilling near the fault difficult and expensive and is the main reason why so little definite information regarding the attitude of the fault is available. The sandstone is less brecciated. In the following paragraphs are recorded the definite facts concerning the fault that are available:

At Bete Gris the fault can be seen under the shallow waters of the bay, but little is known of its attitude

Southeast of Cliff a diamond-drill section shows two faults over half a mile apart, with a block of nearly horizontal flows between them.

At the Mayflower-Old Colony mine diamond drilling has shown a branch diverging from the main fault to

${ }^{60}$ Aldrich, H. R., op. cit., p. 569. 
a maximum distance of about half a mile. Between the main fault and the branch the beds are nearly horizontal or have a slight southerly dip opposite to the normal dip. The branch fault was evidently formed after there had been some movement on the main fault, as it reaches the "Eastern" sandstone in depth. The dip of the branch fault is somewhat steeper than the normal dip of the trap beds at this locality. The dip of the main fault is not known but is evidently less.

At Wall Ravine the fault is poorly exposed but seems to dip about $20^{\circ}$. The "Eastern" sandstone beneath and adjacent to the fault is sharply upturned, and a vertical "wall" formed by a resistant layer of the upturned "Eastern" sandstone has given the name to the ravine.

The St. Louis diamond-drill sections show the fault to dip almost parallel with the normal dip of the trap beds, about $38^{\circ}$, and there seems to be little disturbance of the rocks near the fault.

Where exposed at Douglass Houghton Falls the fault dips $30^{\circ}-32^{\circ}$, a flatter angle than the normal dip of the beds. The beds near the fault, however, dip only $15^{\circ}-20^{\circ}$.

In the Torch Lake diamond-drill section the relations are complicated by intrusion, so that the dip of the fault is uncertain. The beds, however, flatten very much as they approach the fault.

Where exposed at Hungarian Falls the fault dips $30^{\circ}-32^{\circ}$. The beds above the fault are relatively flat and are evidently dragged down by the fault.

At Oneco two diamond-drill holes cut the fault at depth, and its outerop has been located fairly closely near by. The average dip of the fault is $17^{\circ}$ between the outcrop and the nearer hole and $22^{\circ}$ between the outcrop and the more distant hole. The beds flatten in dip toward the fault and are possibly overturned near it.

According to H. W. Fesing the trap beds exposed by the explorations near the fault along the supposed Baltic horizon in the lands of the Arcadian Consolidated Copper Co. are completely overturned and dip to the east.

Where exposed in a ravine south of Isle Royal the fault dips $56^{\circ}$, nearly parallel to the beds above it. There are other faults, probably related to the Keweenaw fault, within the trap series near by.

At the Atlantic prospect the fault was located at points 1,200 feet apart vertically and 300 feet horizontally; the dip, as indicated by these points, is $50^{\circ}$, which is somewhat flatter than the dip of the trap beds immediately above.

In the vicinity of the Indiana mine the beds near the fault are much broken and contain intrusive rocks.

At the Lake and South Lake mines there is a broad, gentle syncline and a narrow, steep anticline between the fault and the point where the rocks have the normal westerly dip. The folding that produced these features was a part of the fault movement.
The fault has been exposed at the Victoria mine, where a section of the adit shows that it dips about $70^{\circ}$, a little more steeply than the beds.

In addition to the Keweenaw fault and those closely associated with it already mentioned, there are many fissures near the Keweenaw fault that dip nearly parallel with or somewhat steeper than the beds. These are particularly conspicuous in the mines opened near the Keweenaw fault. On these strike fissures the movement may be scarcely noticeable or may be a few feet but is rarely large.

There are also a few reverse faults which cut the beds transversely at a somewhat higher angle, such as the Hancock and Isle Royale faults, with apparent horizontal displacements of about 600 and 175 feet, respectively, but in which the actual displacement along the direction of movement was doubtless several times as much. The Branch fissure of the Michigan (Minesota mine) may be of this class but has a relatively small displacement.

Another group that may be put in this class are faults or slips that parallel the beds. These are difficult to recognize, and it is usually impossible to determine the amount of movement on them, but there can be no doubt that faulting has occurred between the beds, especially on the conglomerate beds, which rather characteristically have on the hanging-wall side a heavy gouge that has resulted from movement. Evidently the plane surface of the conglomerates as contrasted with the rough surface of most of the flows made the top of the conglomerates a zone of easy slipping, and much of the movement during the tilting of the beds appears to have occurred on the conglomerates. L. L. Hubbard ${ }^{61}$ has particularly emphasized faulting of this type.

There are large reverse faults around the Porcupine Mountain dome. Wright and Lane ${ }^{62}$ show a fault extending along the entire south margin of the dome, and there is a strong reverse fault in the workings of the White Pine mine.

Near the crests of the anticlines there are numerous transverse fissures that apparently have resulted from the bending of the rocks when the anticlines were formed. These are particularly noticeable on the Keweenaw anticline, from the North American mine to Copper Harbor, where the fissures cut the Greenstone ridge. In the straight stretch between the Allouez anticline and the beginning of the sharp curving of the Keweenaw anticline at the North American mine the Greenstone flow is massive and almost free from fissures, but it is strongly fissured around the anticline. Many of the fissures are mineralized-the Cliff, Phoenix, Copper Falls, Central, Delaware, and many others. Most of the low gaps through the Greenstone flow have also evidently been determined by fissures. Along many of the tension

61 Michigan Geol. Survey, vol. 6, p. 91, 1898.

62 Wright, F. E., and Lane, A. C., Michigan Geol. Survey Rept. for 1908, pl. 1, 1909. 
breaks there has been some movement, and along some it may reach tens and possibly hundreds of feet, though there are no great faults. Fissures and faults of the same character are present on some of the smaller folds, as the Allouez, Baltic, and Mass anticlines.

Where there is much displacement on the faults associated with the anticlines, it is commonly in a wide zone of shattering, in some extending over a hundred or even several hundred feet, as in the Allouez shatter zone, on the Allouez anticline, and the zone between the Baltic and Trimountain mines, on the Baltic anticline. Commonly where there has been much movement one or more planes in the zone show strong gouges.

The fissures and faults on the smaller anticlines are mineralized - for example, the Mass fissure and Arsenide fissure, on the Allouez anticline, and similar though less highly mineralized cross fissures on the Baltic and other anticlines.

\section{AGE AND CAUSE OF FOLDING AND FAULTING}

There is a very close relation between folding, faulting, and igneous activity in the region, and all three processes are probably different expressions resulting from a common cause.

Two general ideas have been advanced regarding the relations of folding to igneous activity. One assumes that the synclinal structure of the Lake Superior basin is the result of some phase of igneous activity. Thus Lane ${ }^{63}$ has thought that the material of the lavas came from beneath the Lake Superior basin and that the space thus vacated was filled by the settling or slumping of the crust above. Grout ${ }^{64}$ considers the subsidence of the roof of the Duluth gabbro laccolith or lopolith a factor in the formation of the Lake Superior syncline. Hotchkiss ${ }^{65}$ likewise considers the origin of the syncline to be associated with the igneous activity. He pictures a great body of igneous material rising slowly through the earth's crust beneath the present Lake Superior basin. For a long period before Keweenawan time this rising igneous mass elevated the surface above it and tilted the rock away from the present basin. The rising surface was eroded, and the material thus derived was deposited around the margin. In Keweenawan time the magma broke through to the surface as basaltic and felsitic flows. This release of pressure and transfer of material to the surface caused the crust to settle. The process of transfer and settling continued through the Keweenawan epoch, resulting in a tilting of the beds toward the axis of the basin, the earlier beds being most affected and the later ones progressively less, as outlined below.

\footnotetext{
${ }^{6}$ Lane, A. C., Michigan Geol. Survey Pub. 6 (Geol. ser. 4), vol. 1, p. 22, 1911

6 Grout, F. F., The lopolith-an igneous form exemplified by the Duluth gabbro: Am. Jour. Sci., 4th ser., vol. 46, pp. 516-522, 1918.

os Hotchkiss, W. O., The Lake Superior geosyncline: Geol. Soc. America Bull., vol. 34 , pp. $667-678,1923$.
}

According to the second conception, orogenic move. ment, one phase of which was the folding of the Lake Superior syncline, is regarded as the cause rather than the effect of the igneous activity. Van Hise and Leith, ${ }^{66}$ though not denying the possible dependence of the folding upon the extrusion of the Keweenawan basalts, believe it reasonable to assume that the dominant trend of the folds of the pre-Cambrian shield was probably established before Keweenawan time and that a thrust from the south against a continental area to the north was effective in the folding of the Lake Superior syncline.

Whichever cause was effective or predominant, the folding took place during Keweenawan time. However, it took place slowly. If Lane's correlation of flows and sediments from one side of the lake to the other is correct, erosion and deposition must have kept pace with the formation of the syneline, so that there was no considerable physiographic basin at any period, and if the material moved from the center of the basin outward, the center must have been a physiographic elevation. In both explanations the folding is presumed to have been in progress during Keweenawan time and to have been essentially completed at its end, so that late Keweenawan beds were little affected.

The domical character of the Porcupine Mountain uplift and the known presence of intrusive rocks within it strongly suggest that this fold has resulted from the intrusion of igneous material, possibly in laccolithic form. There are also outcrops of intrusive bodies near the crests of the Keweenaw anticline and the Bessemer-Ironwood anticline, and an intrusive body underlies the Allouez anticline. Some small intrusive bodies, however, such as that east of Calumet and that at the Indiana mine, are not associated with notable anticlines. On the whole there seems to be some suggestion that the transverse folds are associated with intrusive bodies, but it is not clear whether the intrusion was the cause or the effect of the folding. The transverse folds involve rocks of late Keweenawan age and were evidently formed during or after Keweenaw an time.

The cause and time of formation of the Keweenaw fault are not susceptible of rigid proof with the evidence now available, as is indicated by the differences of opinion concerning it. Van Hise and Leith regard the faulting as post-Cambrian, possibly post-Cretaceous. Lane believes that it started in Keweenawan time and continued "ages later."

It is of course clear that there has been movement since the deposition of the Jacobsville ("Eastern") sandstone. The reverse or overthrust character of the fault and the attitude of the adjacent rocks indicate that this, like many such faults, started as a fold, which broke when the elastic limit of the rocks was

\footnotetext{
6 Van Hise, C. R., and Leith, C. K., op. cit., pp. 411, 622, 623.
} 
exceeded. The fault closely parallels the Lake Superior syncline, and the block to the north, toward the center of the syncline, was thrust upward and outward relative to the block to the south. If it is assumed that the entire Keweenawan series was laid down before the formation of the Lake Superior basin mation during Keweenawan time and the fold that preceded the fault was also being formed then, the Jacobsville sandstone was laid down unconformably on the upturned edges of the earlier Keweenawan beds and a movement on the fault of only a few thousand feet would account for the known displace-
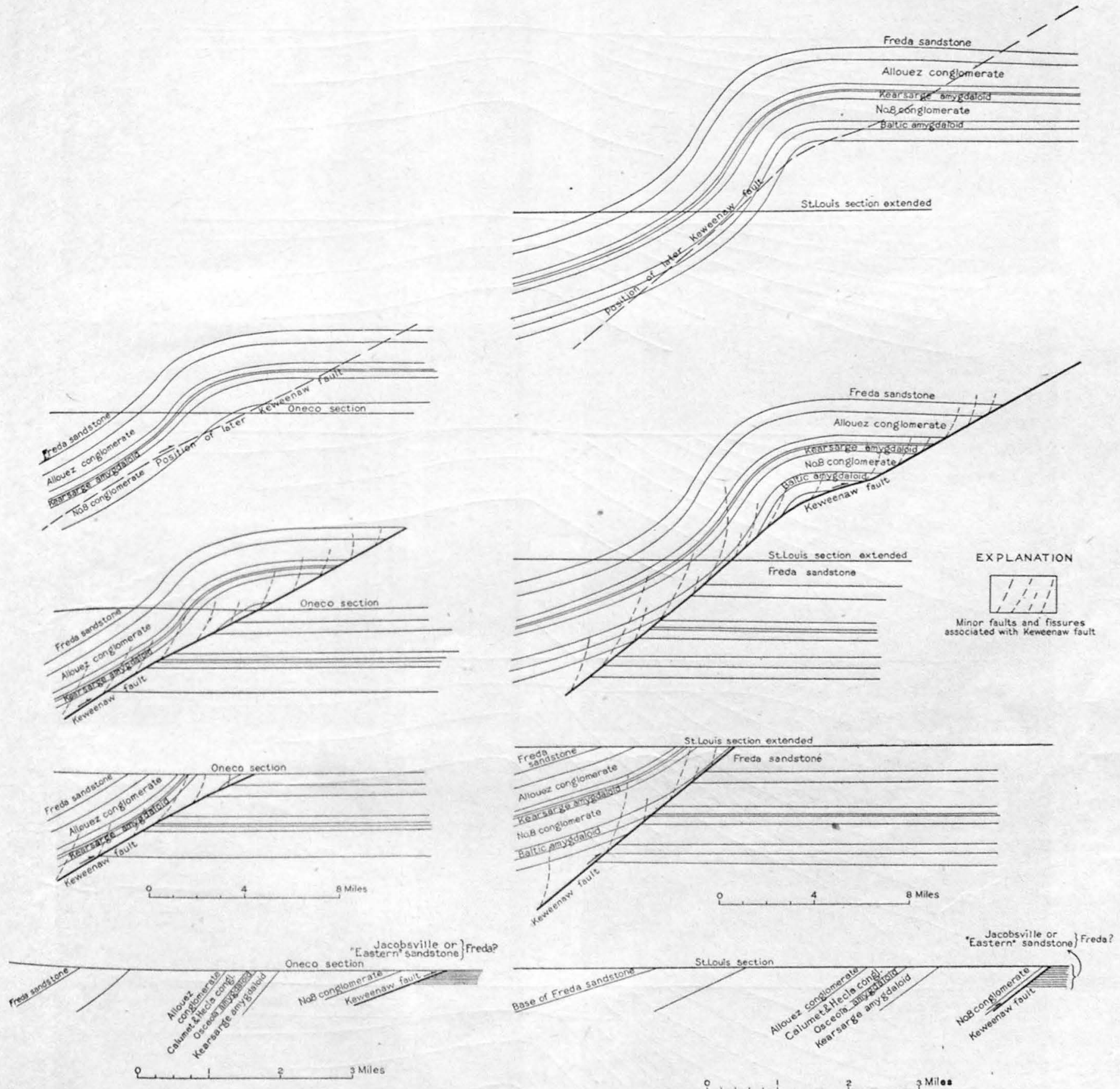

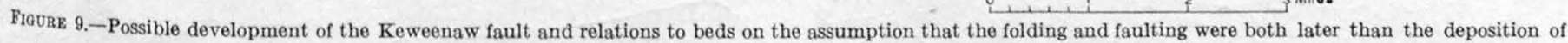
the Jacobsville sandstone

Was begun, the displacement on the fault necessary to bring the Cambrian Jacobsville sandstone into contact with middle Keweenawan beds would be about 3 miles, and the relations as they exist might have been produced by combined folding and faulting, as shown in the accompanying diagram. (See fig. 9.) If, as seems likely, the Lake Superior basin was in process of for- ment of the Jacobsville sandstone and produce the attitude of the beds adjacent to the fault as they are known and as is shown in Figure 10.

Under this second assumption the movement on the fold and subsequent fault began in Keweenawan time and continued after the Jacobsville ("Eastern") sandstone was laid down, possibly for a long time after. 

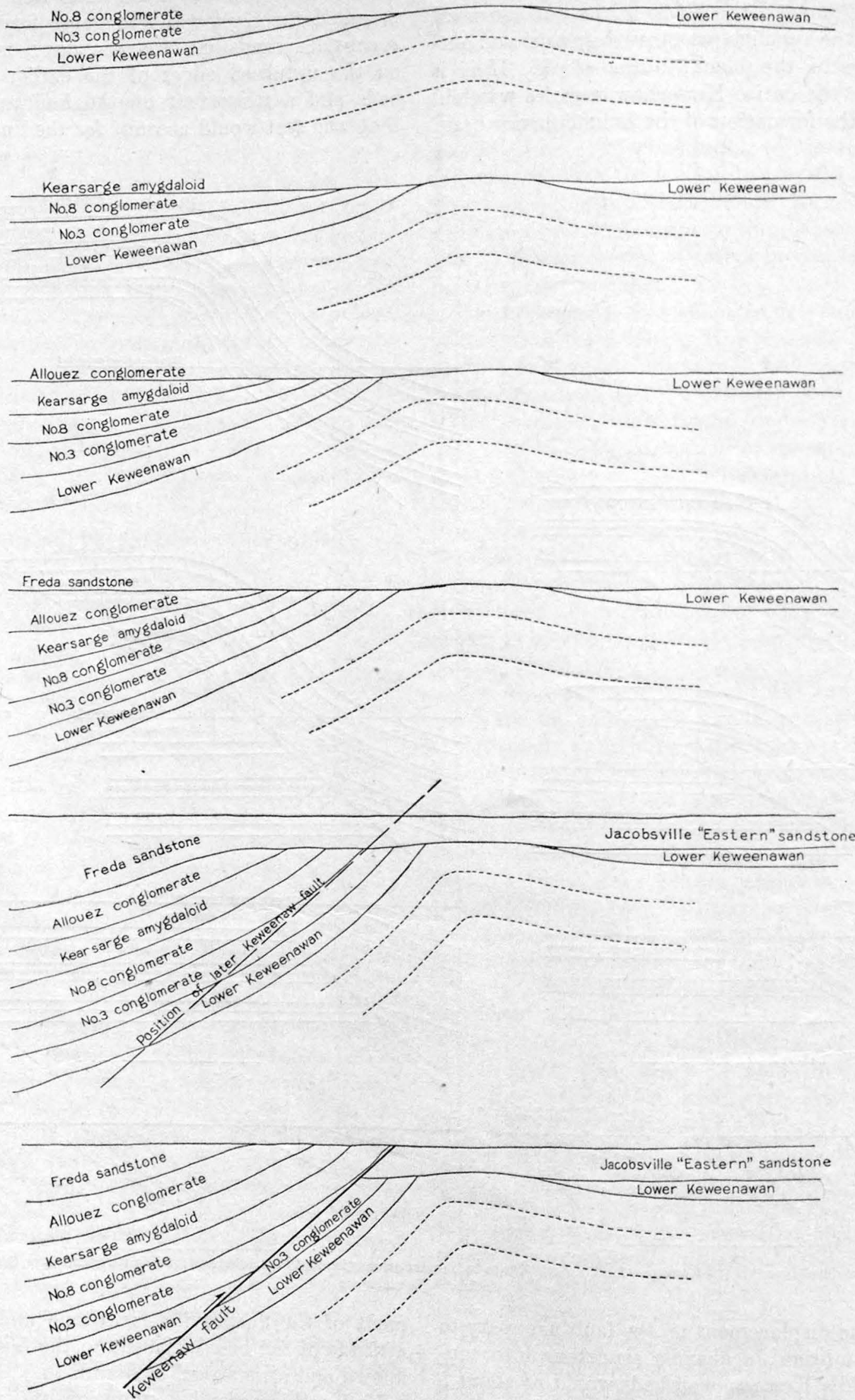

운

10 Miles

Frgure 10.-Possible development of the Keweenaw fault on the assumption that the folding was earlier than the deposition of the Jacobsville sandstone 

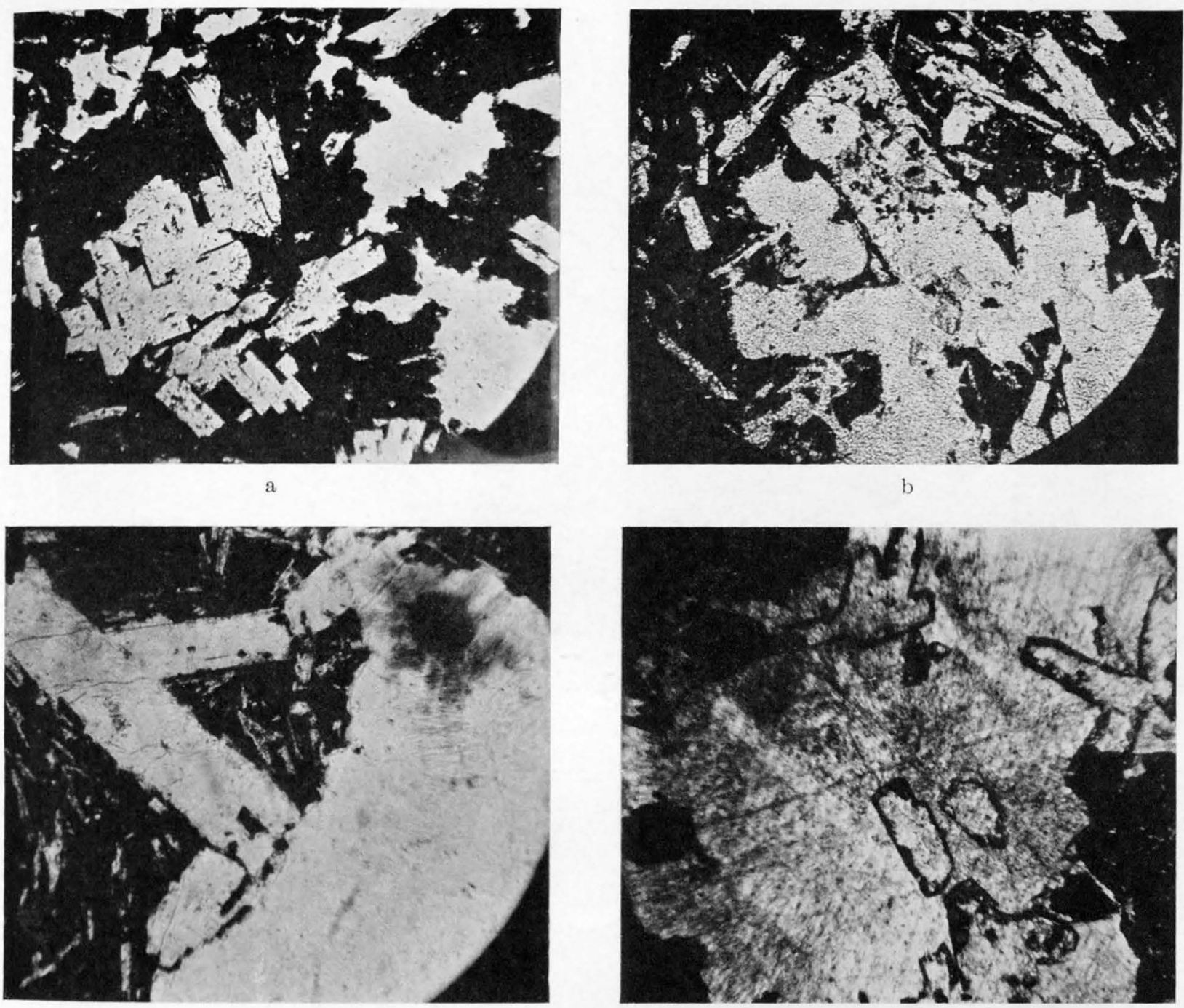

c
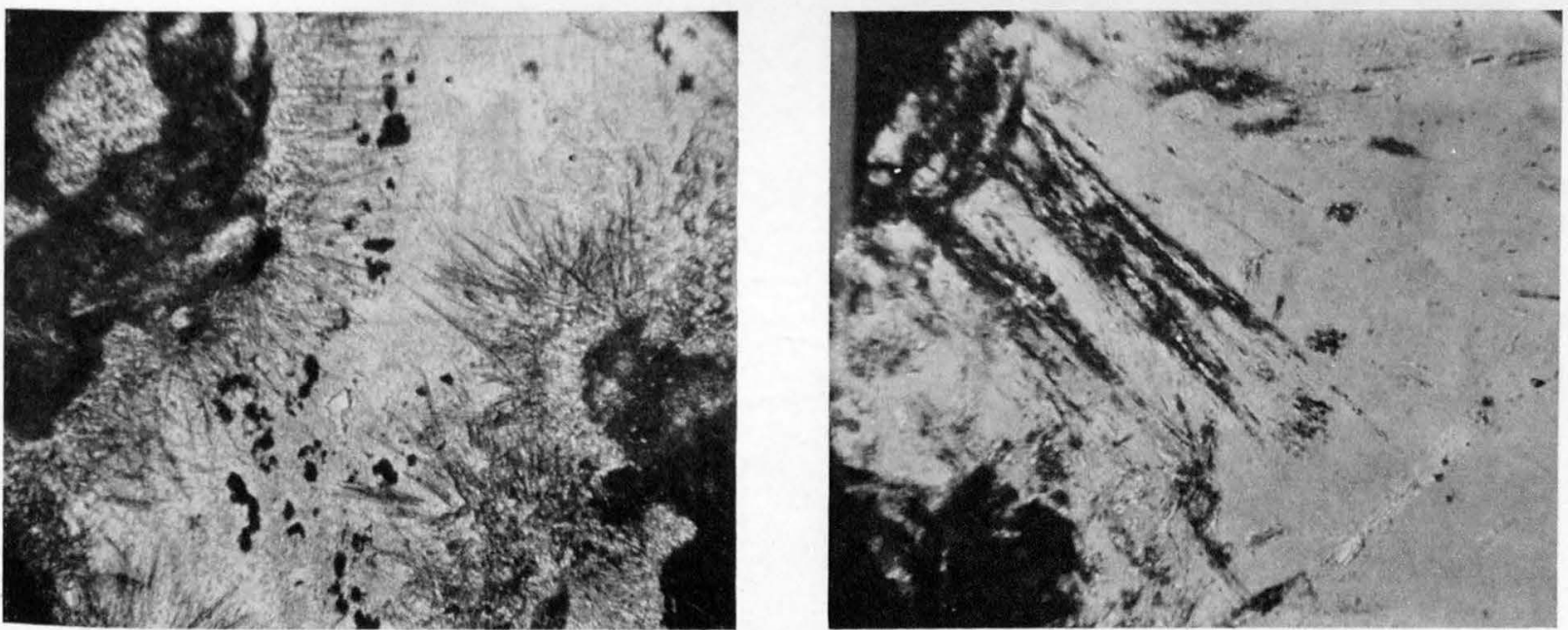

ALTERATION AND REPLACEMENT OF MINERALS

a, Complete silicification of feldspar, Quincy mine, $\times 32$; b, feldspar completely altered to sericite, Isle Royale lode near veinlet of domeykite, $\times 166$; c, feldspar completely altered to saponite, Osceola lode, $X 77 ; \mathrm{d}$, shells of epidote in calcite, $\times 32 ;$ e, pumpellyite in sericite, $\times 205 ; \mathrm{f}$, pumpellyite in quart $z, \times 32$. All enlargements approximate 

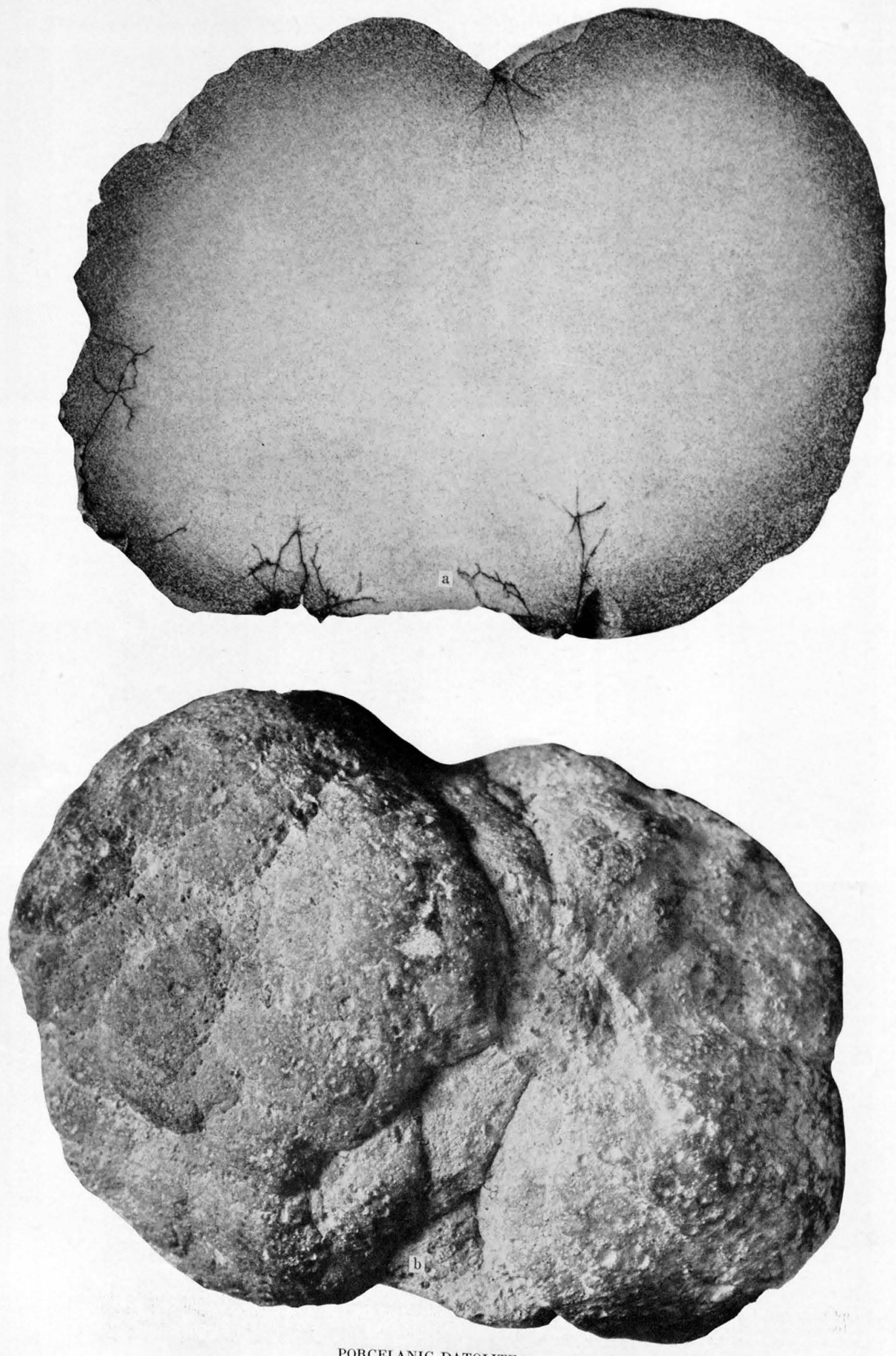

PORCELANIC DATOLITE

a, Porcelanic datolite inclosing copper (dark spots); b, mammillary surface of porcelanic datolite 


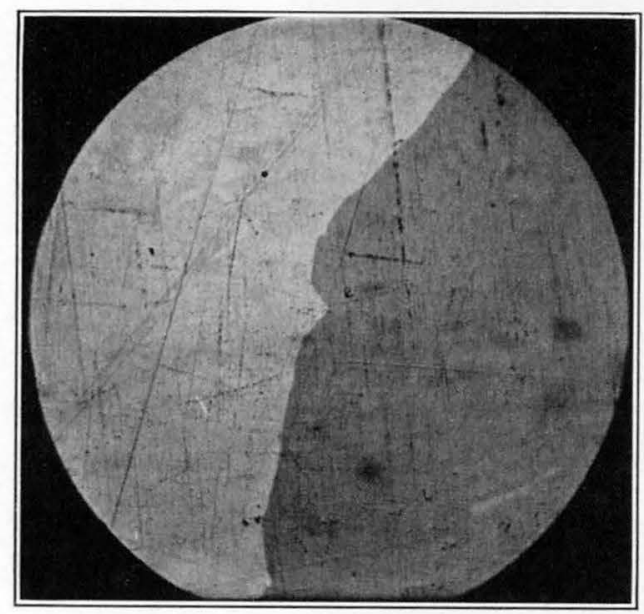

A. INTERGROWTH OF COPPER AND SILVER Enlarged about 69 diameters

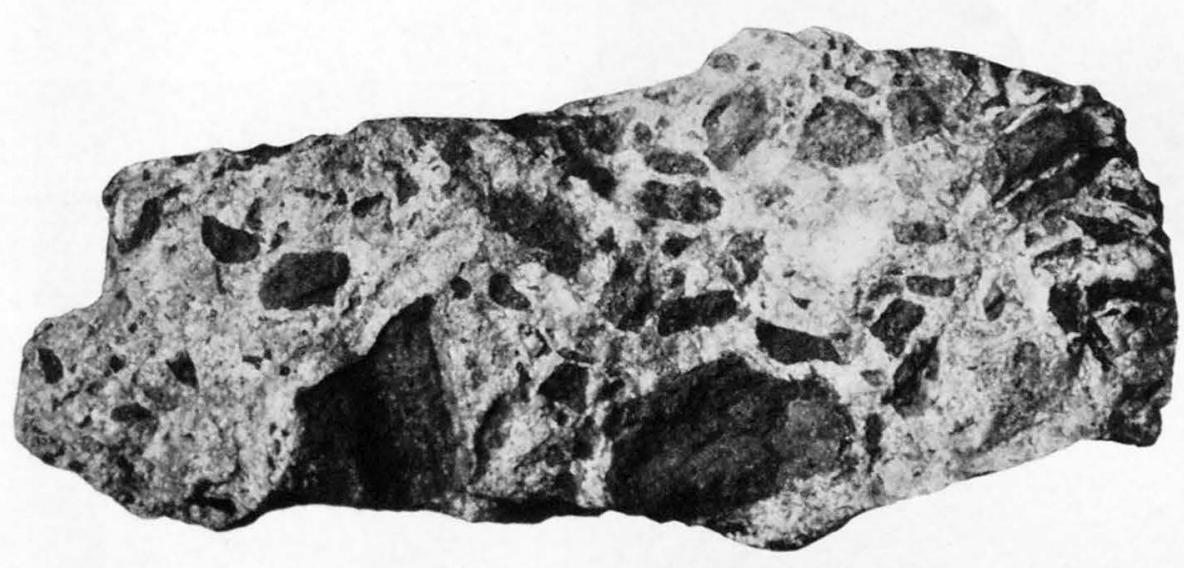

B. FISSURE BRECCIA PARTLY REPLACED BY DATOLITE

Owl Creek fissure, Copper Falls mine

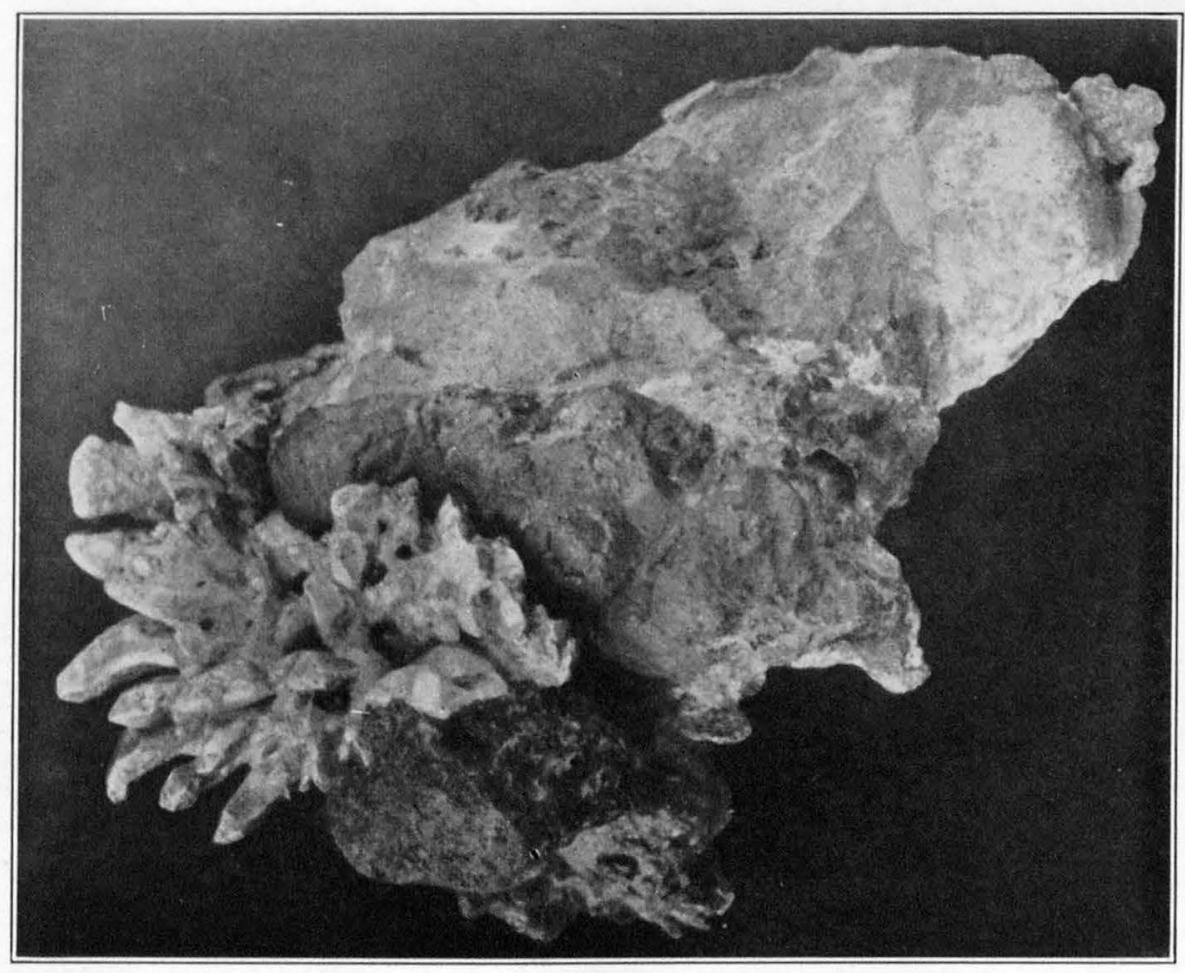

C. NATIVE SILVER (LIGHT CRYSTALS) ON NATIVE COPPER

North Kearsarge mine. Photograph by F. T. Reeder from specimen in his collection 

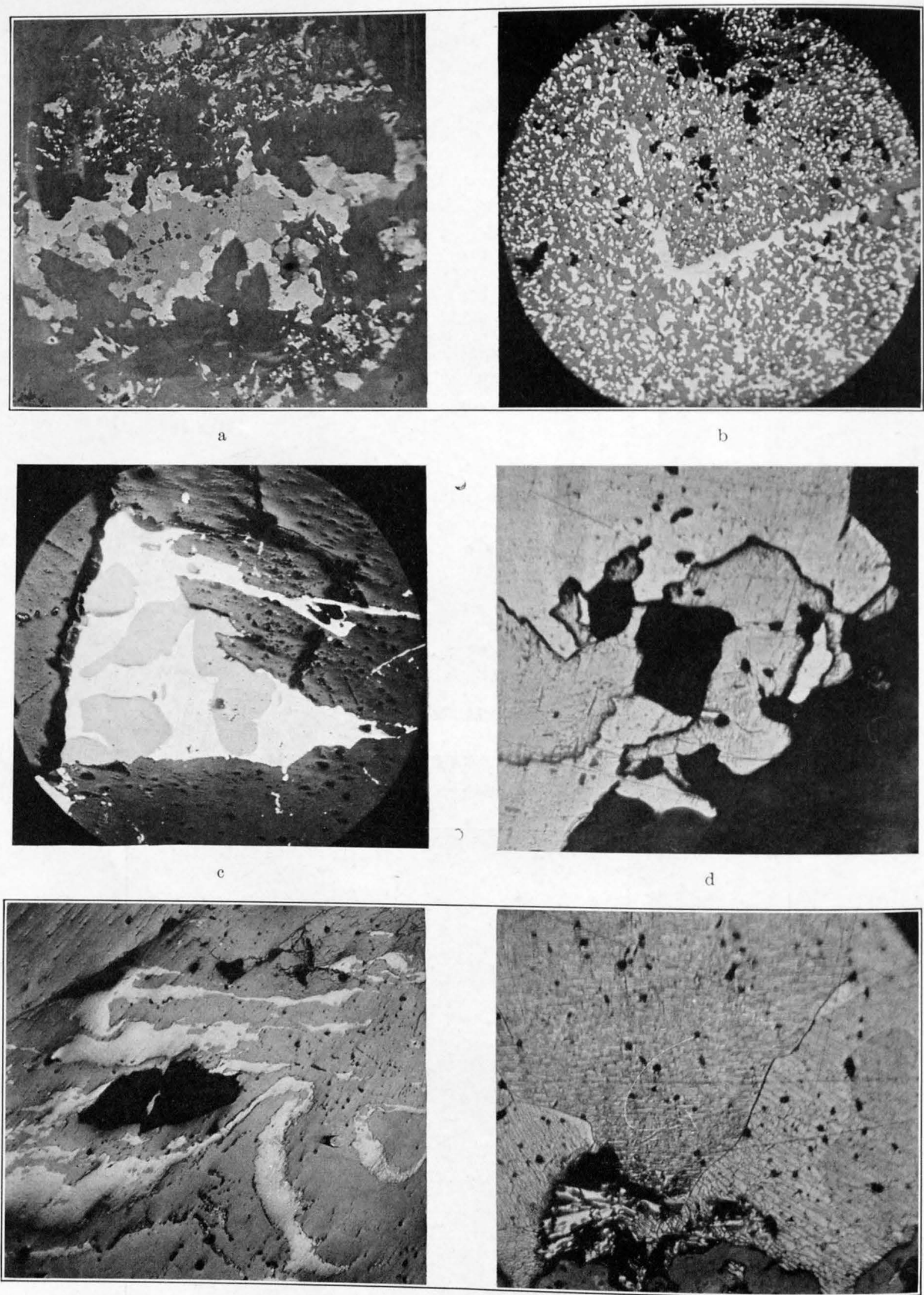

f

RELATION OF SULPHIDES AND OTHER MHNERAIS

a, Bornite and chalcopyrite from Wolverine sandstone, $\times 85 ; \mathrm{b}$, chalcocite intergrown with calcite, $\times 85$; c, chalcocite (dark) and arsenical copper $\times 43$; $\mathrm{f}$, etched chalcocite surrounding specularite, Baltic mine, $\times 119$. All mine, etched, $\times 85$; e, copper arsenide in chalcocite, Baltic mine, 
The thrust movement from the interior of the basin suggests that the cause of the Keweenaw fault was probably closely allied to the formation of the Lake Superior syncline and the intrusion of the laccolith. It seems possible that successive upward thrusts alternating with outpouring of lava and settling during the igneous activity produced the folding and finally the faulting along the margin of the area. The faults and fissures on the anticlines and synclines are pretty clearly tension cracks produced during the folding of the rocks.

\section{MINERALOG Y}

The following discussion of the mineralogy is based largely on the notes of Charles Palache and Alfred Wandke. Doctor Palache made a study of the general mineralogy of the district, and Doctor Wandke did much of the microscopic work on rocks and minerals. In addition Dr. T. M. Broderick made a special study of the arsenides. The work of these men was carried on for the Calumet \& Hecla Consolidated Copper Co. and has been supplemented by observations made throughout the investigation.

The minerals of the district readily fall into three main groups, based upon their periods of formationthose of the rock-forming period, those of the oreforming period, and those of the period of weathering. (See fig. 11.)

\section{ROCK-FORMING PERIOD}

The cooling of the basaltic lava flows resulted in the crystallization of olivine, plagioclase, pyroxene, and magnetite or ilmenite, together with the formation of more or less glass. Gas bubbles in the viscous lavas left open cavities or vesicles. Interstices in the ophites may also have been gas filled and later left open or filled with glass.

As the rock cooled and crystallized, it was permeated with gaseous emanations, which may have been the chief agents in producing the first alterations of the minerals or glass already formed. These changes were principally the breaking down of glass, with setting free of dissolved minerals - hematite, pyroxene, and feldspar (in spherulitic form); the serpentinization of olivine, with or without setting free of iron oxide, mainly hematite; probably the formation of chlorite from glass of interstitial spaces or migration to fill such areas if open; and the oxidation of ferrous iron in the glass, magnetite, and silicates to hematite. It was in this period that the red tops of the lavas were formed.

During the corresponding period in the formation of felsites, quartz, feldspar, and hematite were the principal minerals to be formed. Some of the felsites were later broken up and deposited to form the conglomerates with little mineral change.

$$
58540-29-5
$$

\section{ORE-FORMING PERIOD}

The main ore-forming period occurred after the rocks had been tilted to essentially their present position and broken by many fractures. They were then permeated by hot, chemically active solutions, which tended to rearrange the constituents of the rocks into new mineral combinations and also to introduce some additional constituents.

Within this period there was a broad general sequence of mineral formation, but this sequence was subject to many variations and is likely to be obseured by its own complexity. The early part of the period was characterized by the formation of the anhydrous or less hydrous minerals, such as feldspar, chlorite, and epidote; the later part by the formation of the more hydrous minerals, such as laumontite, analcite, and saponite. (See fig. 11.) Copper was formed mainly in the intermediate part of the period.

Many of the minerals were formed along a path leading away from a source of solutions, as outward from a fissure or channelway, and minerals of one type would be forming at the advancing front of the replacement wave while minerals of another type were replacing these earlier minerals nearer the source at the same time and perhaps only a few inches away. Thus the front of the replacement wave in amygdaloid is marked by the destruction of hematite and the formation of epidote and pumpellyite, but these same minerals nearer the source of the solutions were being replaced by copper. In the iron-rich boulders in the Calumet \& Hecla conglomerate the rock was chloritized at the front of the replacement wave and replaced by copper a little nearer the source, both processes evidently having been in progress at the same time and, in places, but a fraction of an inch apart.

The complexity of this period is illustrated by the relations of minerals in the Allouez shatter zone, where movement was in progress during mineralization and there was repeated opening of fissures and healing with other minerals. (See pls. 64, 65.) The general sequence of events in this zone is believed to have been as follows:

1. Fissuring occurred, and quartz and epidote were formed.

2. During the silicification of the fissure walls a little of the hematite, which antedated the fissuring, was removed.

3. As epidote developed, hematite decreased in amount, owing in part to the recombination of hematite into epidote.

4. As silicification proceeded, a little of the pulverulent ferric oxide may have recrystallized into the specular black variety.

5. A little pumpellyite was formed. 


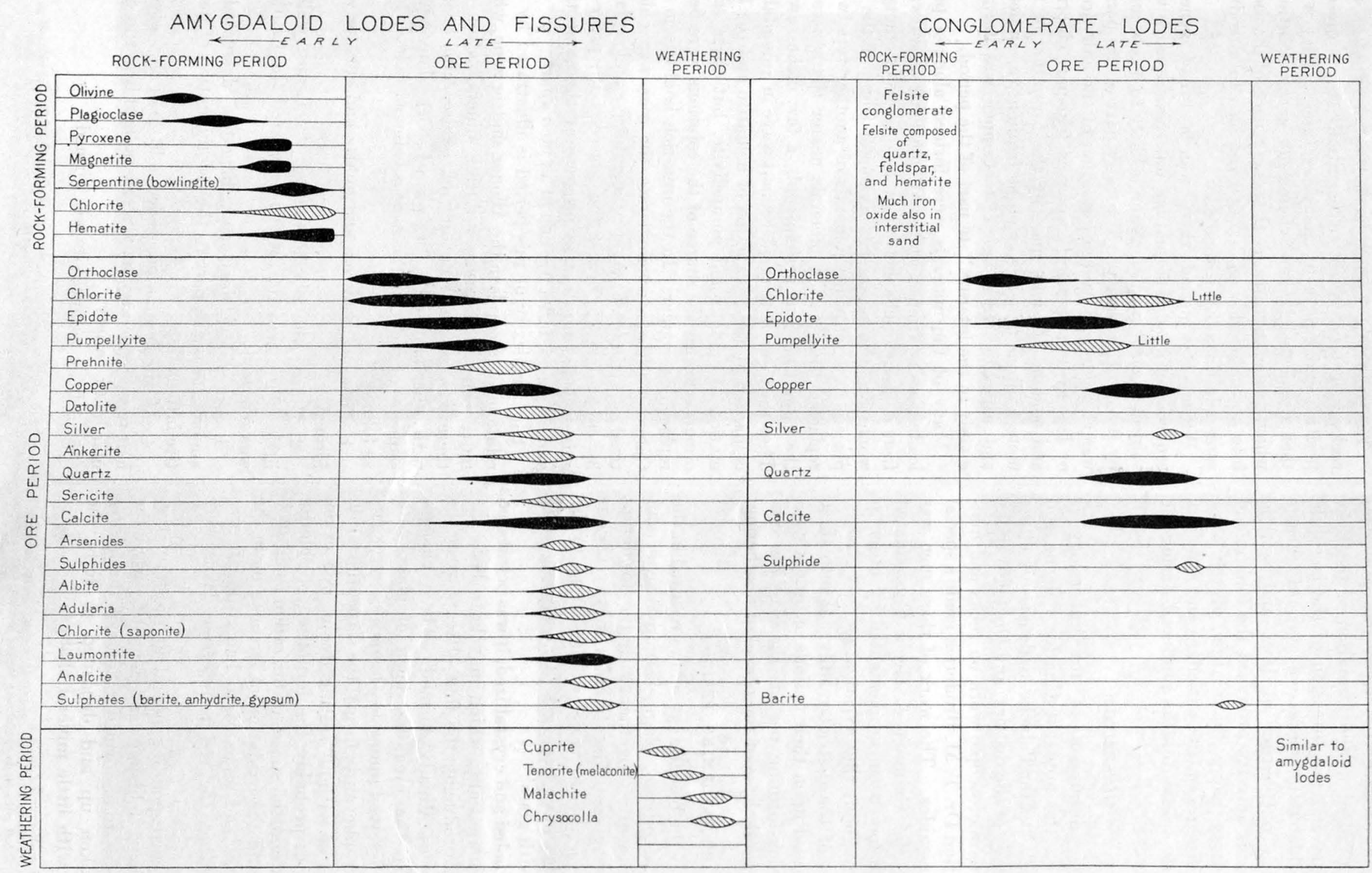

EXPLANATION 
6. The early quartz-epidote mixture was shattered, and quartz, epidote, calcite, and prehnite were deposited in the fractures.

7. Prehnite partly replaced epidote, quartz, and calcite, and copper was deposited.

8. The minerals already formed were again shattered, and more calcite and quartz were deposited, together with copper.

9. Shattering was renewed, and quartz and calcite, with some laumontite, entered.

The minerals of this period both filled open cavities and replaced minerals of the rock-forming period and the earlier part of the ore-forming period. The replacement generally occurred volume for volume, but in places the altering solutions removed more than they deposited and formed cavities near the main channels, which may have become places of deposit for later minerals. The veins were formed mainly by replacement, though there was doubtless some filling of open spaces.

\section{PERIOD OF WEATHERING}

The glaciation of the region has removed most of the products of preglacial weathering. It is only in areas protected from glacial action or areas of shattering where weathering was probably unusually deep or in association with minerals that were readily susceptible to oxidation that any notable amount of weathered material is present. In weathering native copper has generally, as is usual in other regions, been altered first to oxide and later to carbonate or silicate.

\section{MINERALS OF THE KEWEENAWAN COPPER-BEARING ROCKS}

In the following alphabetic list are included the principal known minerals of the district, and following that is a short description of the occurrence of each. In the description the minerals are grouped according to Dana's system.

$\begin{array}{lll}\text { Adularia. } & \text { Datolite. } & \text { Powellite. } \\ \text { Algodonite. } & \text { Domeykite. } & \text { Prehnite. } \\ \text { Analcite. } & \text { Epidote. } & \text { Pumpellyite. } \\ \text { Anhydrite. } & \text { Faujasite. } & \text { Pyrite. } \\ \text { Ankerite. } & \text { Feldspar. } & \text { Pyrolusite. } \\ \text { Apatite. } & \text { Fluorite. } & \text { Pyroxene. } \\ \text { Apophyllite. } & \text { Galena. } & \text { Quartz. } \\ \text { Arsenides. } & \text { Gypsum. } & \text { Rutile. } \\ \text { Atacamite. } & \text { Hematite. } & \text { Saponite. } \\ \text { Barite. } & \text { Heulandite. } & \text { Sericite. } \\ \text { Biotite. } & \text { Hornblende. } & \text { Serpentine. } \\ \text { Bornite. } & \text { Hydrocarbon. } & \text { Silver. } \\ \text { Bowlingite. } & \text { Ilmenite. } & \text { Specularite. } \\ \text { Brucite. } & \text { Kaolin. } & \text { Sphalerite. } \\ \text { Calcite. } & \text { Laumontite. } & \text { Stilbite. } \\ \text { Chalcedony. } & \text { Limonite. } & \text { Tenorite. } \\ \text { Chalcocite. } & \text { Magnetite. } & \text { Thomsonite. } \\ \text { Chalcopyrite. } & \text { Malachite. } & \text { Titanite. } \\ \text { Chlorastrolite. } & \text { Manganite. } & \text { Tourmaline. } \\ \text { Chlorite. } & \text { Natrolite. } & \text { Whitneyite. } \\ \text { Chrysocolla. } & \text { Olivine. } & \text { Zircon. } \\ \text { Copper. } & \text { Plagioclase. } & \text { Zoisite. } \\ \text { Cuprite. } & & \end{array}$

\section{NATIVE METALS}

Silver (Ag) occurs in varying amounts in all the lodes and fissures. Among the fissures the Cliff has probably been most productive of silver and among the lodes the Pewabic. Silver occurs in the sulphide and arsenide fissures as well as in the native copper fissures. Some of it was formed at the same time as the associated copper, though in its most conspicuous occurrences in vugs it was apparently formed slightly later than most of the copper. (See pl. 67.)

Native copper $(\mathrm{Cu})$ occurs in amygdaloids, conglomerates, and fissures throughout the district. It forms masses ranging from those of microscopic size to some weighing 600 tons. Commonly it is without definite crystal outline, but in vugs it occurs in crystals and crystal aggregates, usually with rather imperfect crystal form. This crystallized copper has apparently been deposited in open spaces, without replacing other minerals. Some crystallized copper has formed in fault gouge. In the main the metal has been formed by replacement of the earlier minerals of the ore period, such as chlorite, epidote, and zoisite, as well as of the rock-forming minerals. It is very commonly intergrown with prehnite and datolite and less commonly with quartz and calcite. Most of the copper is earlier than the zeolites laumontite and analcite and earlier than saponite, adularia, barite, anhydrite, and gypsum, though a little copper has been deposited as late as any of these minerals. Where copper is associated with chalcocite in fissures either mineral may be the earlier, or the two may be contemporaneous. In the lodes the sulphide-bearing fissures are at least in part later than the copper of the lodes. The lode rock adjacent to copper is characteristically bleached by the removal and alteration of hematite, as is discussed in the section on ore deposits (p. 133).

\section{SULPHIDES}

Galena $(\mathrm{PbS})$ is rare, but minute crystals of it have been noted at the Mendota diamond-drill hole No. 40 with chalcopyrite and at South Cliff with pyrite and sphalerite.

Chalcocite $\left(\mathrm{Cu}_{2} \mathrm{~S}\right)$, though formed before copper in some places, is one of the later minerals of the oreforming period. It is of widespread occurrence in fissures cutting rocks of all kinds. It is especially conspicuous in fissures in the Baltic lode, where it occurs with ankerite, and it is also present locally in the lode itself. It is rather common in fissures in the Isle Royale lode, where it occurs with ankerite and a little specularite and where it is later than the specularite. The rock adjacent to the veins in this lode is strongly bleached. Finely divided chalcocite darkens the small calcite veins that occur in the Allouez conglomerate wherever it has been opened, and the mineral occurs similarly in several other conglomerates. In the Calumet \& Hecla conglomerate it is most abundant 
at the Centennial shafts, north of the main ore shoot. It is present in veins and vugs at Mount Bohemia. Calcite-chalcocite veins are plentiful in the White Pine and Carp Lake mines, and chalcocite is disseminated in part of the sandstone. In short, chalcocite is widespread but nowhere abundant, though the Baltic lodes contain veins of nearly solid chalcocite several inches wide. (See pls. 68, 69.)

Sphalerite $(\mathrm{ZnS})$ is rare but is reported from a fissure at South Cliff with pyrite and galena.

Bornite $\left(\mathrm{Cu}_{5} \mathrm{FeS}_{4}\right)$ in small amount accompanies the chalcocite in some of the sulphide fissures. The fissures in the Baltic lode contain bornite most abundantly, but it is present also in fissures in the Isle Royale lode. It is a common mineral in the veins and vugs in the gabbro and gabbro aplite of Mount Bohemia.

Chalcopyrite $\left(\mathrm{CuFeS}_{2}\right)$ is of rather rare occurrence. It is present in the veins of Mount Bohemia and was seen in drill cores near a felsite intrusive at Mendota. It occurs sparingly in veins with chalcocite in the Isle Royale and Baltic lodes and was observed in veins in quartz porphyry in the Onondaga drill cores. It is visible in some of the pegmatitic lenses in the thicker flows and is present as microscopic crystals in some of the freshest normal trap. It occurs also in the Wolverine sandstone in the Ahmeek mine.

Pyrite $\left(\mathrm{FeS}_{2}\right)$ is reported in a small fissure with sphalerite and galena at South Cliff. Pyrite is notable for its practical absence.

\section{ARSENIDES}

Arsenic, in the form of copper arsenides (pl. 71), occurs in Michigan associated with the copper in deposits of all types-amygdaloid and conglomerate lodes and fissures-but is most abundant in certain of the fissure deposits, and in the lodes it is especially localized near the arsenide fissures. The lode copper of the Baltic and Isle Royale lodes, however, is arsenical throughout and distinctly lighter in color than the arsenic-free copper. On etched surfaces the "arsenical" copper approaches in appearance some of the arsenic compounds.

Compounds of copper and arsenic.-As they occur in Michigan, the arsenides form mixtures so intimate and complex that the early investigators ${ }^{67}$ mistook different combinations of minerals for new species. Examination in polished section shows at least seven recognizable varieties, not including three that contain nickel and cobalt. It has not been possible to separate these varieties and determine their chemical composition by analyses, and the composition assigned to them is that given in the textbooks. It is

${ }^{67}$ Koenig, G. A., On artificial production of crystallized domeykite, algodonite argentodomeykite, and stibiodomeykite: Am. Philos. Soc. Proc., vol. 42, pp. 219$237,1903$. entirely possible that some of them, especially those high in copper and low in arsenic, may be solid solutions or alloys and not definite minerals. Domeykite $\left(\mathrm{Cu}_{3} \mathrm{As}\right)$ is highest in arsenic, and it was the earliest to form, being preceded only by magnetite and the nickel. cobalt arsenides. Domeykite is veined and replaced by algodonite, whose formula has been given as $\mathrm{Cu}_{8} d s$. Etching polished surfaces of a'godonite shows that it is not a simple substano out an intergrowth of two minerals, which are here designated $\alpha$ and $\beta$ algodonite. Algodonite is in turn succeeded and in part replaced by substances still higher in copper; several of these are now recognized, though all were formerly called whitneyite and assigned the formula $\mathrm{Cu}_{9} \mathrm{As}$. These are here designated $\alpha, \beta, \gamma$, and $\delta$ whitneyite. They may well be solid solutions or alloys rather than def. nite compounds. Etching tests show that these sub. stances are veined by native copper. Thus there is a definite order of deposition in the series. This order is invariably domeykite, algodonite, whitneyite, and native copper. Each mineral partly replaced its im. mediate predecessor; domeykite, so far as observed, has not been replaced by whitneyite or native copper, nor algodonite by native copper. Each arsenide was followed by the one next higher in copper content, until finally native copper was precipitated. The order of deposition of the individual members of the general algodonite and whitneyite group can not be so definitely stated. Even this, however, seems to be consistent with the general rule of elimination of arsenic. For example, where whitneyite was replaced or followed by copper, the whitneyite is of the $\gamma$ or $\delta$ variety, but the whitneyite that replaced algodonite is in most places the lighter, more arsenical $\alpha$ or $\beta$ whitneyite. In some specimens two members of the whitneyite group seem to grade into each other, instead of having sharply defined contacts. Every specimen of algodonite so far examined is an intimate intergrowth of the two constituents $\alpha$ and $\beta$ algodonite. Where $\alpha$ predominates over $\beta$ the color of the mixture is tin white, but with a predominance of $\beta$ the specimen has a distinct pinkish tone, as if $\beta$ had a highet copper content. The algodonite that has replaced domeykite generally has a predominance of the a variety, but where algodonite is replaced by whitneyite the $\beta$ variety is predominant.

Although the physical and chemical properties as described serve in general to determine roughly the arsenides present in a given specimen, examination in polished section makes it possible to differentiate varieties that are not distinguishable in the hand specimen and to determine their paragenesis. Below is a list of the copper arsenides arranged in the order of their known or inferred copper content, together with their diagnostic properties in polished section. 
Diagnostic properties of copper arsenides

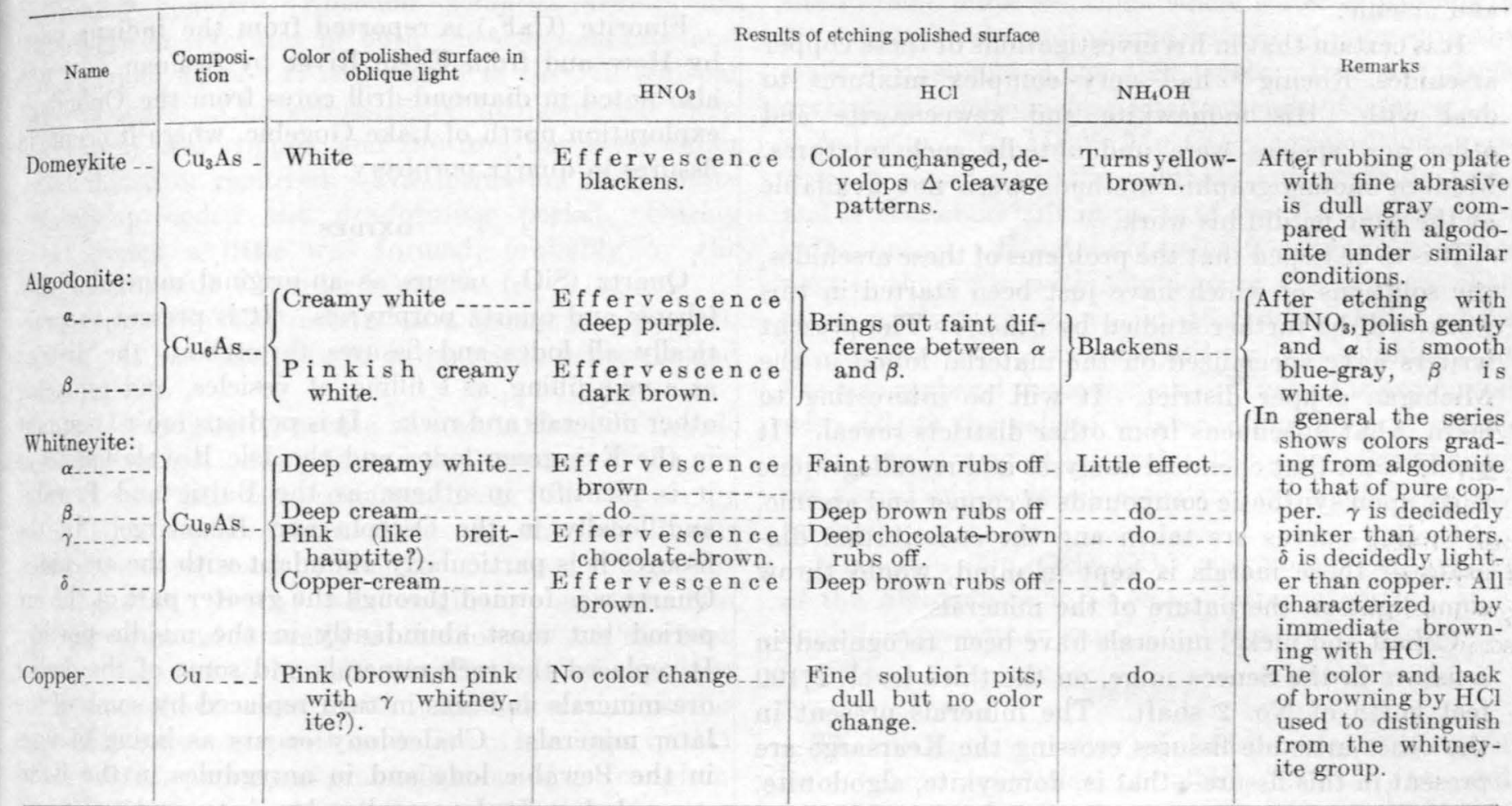

The several groups of arsenides are not difficult to recognize in hand specimens. The colors range from the white of domeykite and algodonite through the pale copper-reds of the whitneyite group to the copperred of pure copper. One per cent of arsenic in arsenical copper causes a perceptible lightening of the color. The malleability of the minerals also varies. Domeykite is decidedly brittle, algodonite is much less so, and the whitneyite group is decidedly malleable but less so than pure copper. (See pl. 70.)

Heating in glass tubes drives off the arsenic easily from domeykite and algodonite, but with extreme difficulty from whitneyite, the lower arsenic compound.

The alterations of the arsenides are characteristic. Domeykite rapidly tarnishes to a chalcopyriteyellow. Some has weathered to cuprite. The brightgreen coloration that has developed along the arsenide fissures underground since they were opened by mining is probably due to the formation of an arsenate and seems to be chiefly connected with algodonite. Whitneyite tarnishes brown rather quickly.

Origin.-It is pointed out in the section on ore deposits (p. 132) that in general, although there are some notable exceptions, the higher the lode is in the series the lower its arsenic content. This is also true of the occurrence of sulphides of copper, and what is said of the distribution of arsenic may be said of the distribution of sulphur. The explanation of this relation, which seems to be consistent with the chemical theory favored by the writers, is that the solutions which traversed the lower beds had not been in intimate contact with the oxidizing environment of the lodes for as long a time as those which deposited copper in the higher beds, and for that reason their arsenic and sulphur failed to become completely oxidized into a more soluble state. There are three possible reasons why those solutions should have had less opportunity for oxidation: (1) The rocks toward the base of the series are more fissured than those higher up, hence solutions could find in the fissures a more permeable pathway than the oxidized amygdaloids. The arsenides and sulphides occur by far the most abundantly in fissures. (2) The occurrence of several intrusive bodies toward the base of the series may mean that a magmatic source for the copper lies much nearer the present surface in this part of the series than elsewhere. Thus the failure of complete oxidation of the solutions may be due to the fact that in that general area they were too close to the magmatic source. (3) Similarly, if the shattered zone associated with the Keweenaw fault is regarded as the main trunk channel for solutions emanating from a deep magmatic source, such solutions had not been in contact with an oxidizing environment sufficiently long when they traversed the rocks adjacent to that trunk channel.

The presence of sulphides in the Nonesuch lode near the Porcupine Mountains does not help in deciding which of these possible causes had the greatest effect, for major faulting, fissuring, and intrusive rocks are all present near by.

Another possibility which merits consideration is that the deposition of arsenides and sulphides in the fissures occurred subsequent to the main period of mineralization and was due to a change in the character 
of the solutions, the later ones being higher in sulphur and arsenic.

It is certain that in his investigations of these copper arsenides Koenig ${ }^{68}$ had very complex mixtures to deal with. His mohawkite and keweenawite and other new species were undoubtedly such mixtures. Modern metallographic methods were not available at the time he did his work.

It is to be hoped that the problems of these arsenides, the solutions of which have just been started in this work, will be further studied by others. The present writers have specialized on the material found in the Michigan copper district. It will be interesting to learn what specimens from other districts reveal. It would seem that chemical analyses and metallographic work upon synthetic compounds of copper and arsenic, if cooling curves are taken and the constitution diagram of those metals is kept in mind, would throw some light on the nature of the minerals.

Cobalt and nickel minerals have been recognized in a fissure in the Seneca mine, on the third level, 2,100 feet north of No. 2 shaft. The minerals present in the other arsenide fissures crossing the Kearsarge are present in this fissure - that is, domeykite, algodonite, and whitneyite. The microscope reveals in addition at least three other arsenides, one a white mineral, another a pinkish white, and the third a brownish pink, like niccolite. Chemical tests by Mr. Hillenbrand at the Calumet \& Hecla smelter show abundant nickel. Borax bead tests show cobalt. The late George Heath, of the Calumet \& Hecla smelter, stated that in the arsenides of the Ahmeek fissures there is but a trace of nickel. Therefore the nickel and cobalt are probably accounted for by the new minerals. The sequence in age seems to be, first, the white mineral, next the pinkish white, then the domeykite, followed by the other copper arsenides in their usual order. The brownish-pink mineral is present in very minor amounts in the sections seen, and its relations were not determined. The magnetite was formed early in the nickel-cobalt stage.

The tests on the white and pinkish-white minerals so far have not corresponded to those of any described mineral. The pinkish-white mineral shows the following properties in polished section: Hardness, that of magnetite; effect of $\mathrm{HNO}_{3}$, effervesces, fumes slightly brown, no coating or etching; of $\mathrm{HCl}$, negative; of $\mathrm{HgCl}_{2}$, brown, rubs clean; of $\mathrm{KCN}$, negative; of $\mathrm{FeCl}_{3}$, negative. The white mineral is hard and is negative to $\mathrm{HNO}_{3}, \mathrm{HCl}$, and $\mathrm{FeCl}_{3}$.

If further investigation of these nickel-cobalt arsenides should establish them as new species, it would be desirable to retain the names mohawkite and keweenawite which Koenig gave to certain intimate mixtures of arsenides from these fissures.

${ }^{88}$ Koenig, G. A., op. cit.
HALOIDS

Fluorite $\left(\mathrm{CaF}_{2}\right)$ is reported from the Indiana mine by Hore and from Eagle River by Seaman. It was also noted in diamond-drill cores from the Onondaga exploration north of Lake Gogebic, where it occurs in fissures in quartz porphyry.

\section{OXIDES}

Quartz $\left(\mathrm{SiO}_{2}\right)$ oceurs as an original mineral in the felsites and quartz porphyries. It is present in practically all lodes and fissures throughout the district as a vein filling, as a filling of vesicles, and replacing other minerals and rock. It is perhaps most abundant in the Evergreen lodes and the Isle Royale lode, but it is plentiful in others, as the Baltic and Pewabic and locally in the Osceola and Kearsarge. In the fissures it is particularly abundant with the arsenides. Quartz was formed through the greater part of the ore period but most abundantly in the middle portion It replaced the rock minerals and some of the earlier ore minerals and was in turn replaced by some of the later minerals. Chalcedony occurs as lining of rugs in the Pewabic lode and in amygdules in the Kearsarge lode. It has replaced zoisite and calcite in many places.

Cuprite $\left(\mathrm{Cu}_{2} \mathrm{O}\right)$ occurs in well-formed crystals at the Indiana mine as an oxidation product of copper; it occurs similarly at the Algomah mine, where it is largely altered to tenorite. The copper in many of the mine openings is colored with a film of cuprite. In places this film has clearly formed after the mines were opened. In other places, especially in the higher levels, it probably formed before the mines were opened.

Tenorite (melaconite, $\mathrm{CuO}$ ), the black oxide of copper, is especially abundant at the Algomah mine and at Copper Harbor and doubtless ocours elsewhere, It is a product of oxidation of other minerals,

Atacamite $\left(\mathrm{Cu}_{2} \mathrm{Cl}\left(\mathrm{OH}_{3}\right)\right)$ occurs in well-formed radiating crystals as an oxidation product at the Algomah mine.

Hematite $\left(\mathrm{Fe}_{2} \mathrm{O}_{3}\right)$ is apparently a primary mineral in the felsite and in the felsite pebbles of the conglomerates. The abundant hematite in the red tops of the lava flows is believed to have been formed from magnetite and the iron silicates or from the glassy portion of the tops of flows, or possibly in part crystallized directly during the solidification and cooling of the flows. Deeper in the flows the hematite has formed from magnetite and olivine, likewise probably during solidification. This process is fully discussed in the section on oxidation of lava tops (p. 38). Hematite occurs in small amount in some of the veins that contain sulphide and arsenide. In these it is usually associated with ankerite. In the conglomerate 
specular hematite is present in some of the iron-rich porphyry boulders. Specular hematite also occurs sparingly in fractures in both the conglomerate and amygdaloid lodes. It is included in the red feldspar of the lodes. Characteristically hematite has been destroyed near copper, and the iron has been either recombined or removed. The formation of hematite mainly preceded the ore-forming period. During that period a little was formed, probably by the recrystallization of earlier hematite.

Ilmenite $\left(\mathrm{FeTiO}_{3}\right)$ occurs as a primary mineral in traps. It has been altered in places to hematite and titanite.

Brucite $\left(\mathrm{MgO}_{2} \mathrm{H}_{2}\right)$ occurs in vugs in the Isle Royale and Kearsarge lodes. It is a late mineral of the ore period. In the one specimen from the Kearsarge lode it has replaced laumontite. In the Isle Royale mine it was replaced by sericite

Magnetite $\left(\mathrm{Fe}_{3} \mathrm{O}_{4}\right)$ was originally an abundant primary mineral in nearly all the flows, but it has been entirely altered to hematite in the tops of the flows and throughout some flows. This alteration is discussed in connection with oxidation of lava tops (p. 34). Magnetite is present as grains in some of the conglomerates, as the Great conglomerate and the Houghton conglomerate, but in most of them it has been altered to hematite or limonite. It is rarely present in the fissure veins. The magnetite of the flows is titaniferous, and hematite, titanite, and rutile were formed from it on alteration.

Rutile $\left(\mathrm{TiO}_{2}\right)$ occurs in basalt as an alteration product of titaniferous iron ore, and it occurs also in the felsites, where it was possibly derived from biotite.

Manganite $\left(\mathrm{Mn}_{2} \mathrm{O}_{3} \cdot \mathrm{H}_{2} \mathrm{O}\right)$ occurs as small crystals in vugs in the Calumet \& Hecla conglomerate. At the Manganese mine, near Copper Harbor, it occurs with other manganese minerals as a "vein," essentially coinciding with an amygdaloid a short distance below the Great conglomerate. The "vein" was opened for a few hundred feet along the strike, and some ore was shipped from the mine.

Pyrolusite $\left(\mathrm{MnO}_{2}\right)$ occurs at the Manganese mine, near Copper Harbor.

Limonite $\left(2 \mathrm{Fe}_{2} \mathrm{O}_{3} \cdot 3 \mathrm{H}_{2} \mathrm{O}\right)$ occurs sparingly on weathered surfaces of trap. It is present in the conglomerates, probably as alteration product of magnetite. It is rarely seen in the amygdaloid lodes.

\section{CARBONATES}

Calcite $\left(\mathrm{CaCO}_{3}\right)$ is perhaps the most widespread mineral of the ore-forming period. It occurs as crystals in open cavities and replaces other minerals and is everywhere present in veins, amygdaloids, and conglomerates. It was formed from about the middle to the end of the ore-forming period, and therefore it has replaced many minerals and has itself been replaced by several. It occurs in the pegmatitic lenses in some of the thick traps. It is also being formed in the present mine workings where water is dripping in the upper levels and around masses of copper in the walls of openings in the deep levels. In many places crystals of calcite inclose small crystals of copper.

Ankerite $\left((\mathrm{Ca}, \mathrm{Mg}, \mathrm{Fe}, \mathrm{Mn}) \mathrm{CO}_{3}\right.$, composition variable) is common in the sulphide and arsenide veins and is also abundant in parts of the Baltic lode as a lode mineral. In sulphide veins it commonly occurs next to the walls, with sulphides in the center. The same relation is shown in the Baltic lode, where the carbonate lines cavities and incloses sulphide. It has also replaced the lode rock. Where it is associated with calcite the calcite is later. The mineral apparently was formed at intermediate to late stages in the ore period and is closely associated with sulphides and arsenides.

Malachite $\left(\mathrm{Cu}_{2}(\mathrm{OH})_{2} \cdot \mathrm{CO}_{3}\right)$ was noted particularly at the Algomah mine as an oxidation product. It is doubtless present in small amount at other places.

\section{SILICATES}

The plagioclase series of feldspars, consisting of isomorphous mixtures of albite $\left(\mathrm{NaAlSi}_{3} \mathrm{O}_{8}\right)$ and anorthite $\left(\mathrm{CaAl}_{2} \mathrm{Si}_{2} \mathrm{O}_{8}\right)$, is represented by plagioclase of intermediate composition, which forms an abundant original constituent of all the flows. Albite is present in the felsites. The feldspars of the flows underwent little alteration during the oxidation of the flow tops, the microlites of plagioclase being still remarkably fresh. Plagioclase was, however, one of the earliest minerals to be attacked by the ore solutions, though locally it remains remarkably fresh in otherwise altered rock. The feldspar was commonly replaced by chlorite, epidote, zoisite, sericite, or calcite, but prehnite or any of the later minerals have replaced plagioclase.

Albite in relatively small amount is present in many places as one of the later minerals of the ore-forming period.

Orthoclase ( $\left.\mathrm{KAISi}_{3} \mathrm{O}_{8}\right)$ occurs in three distinct ways-as an original mineral of the felsite, as an early mineral of the ore period (red feldspar), and as adularia, a late mineral of the ore period. The original orthoclase of the felsites occurs both as phenocrysts and in the groundmass. Red feldspar, probably of variable composition, is abundant in several of the lodes and is also present in many fissures. It is especially abundant in the Butler lode and adjacent lodes, in the Superior lode, and in parts of the Kearsarge and Osceola amygdaloids. It is present but not abundant in the conglomerates. It occurs in fissures and amygdules, and it replaces the rock, especially in the Evergreen and succeeding lodes but to some extent in most of the other lodes. It was one of the earliest minerals of the ore period and was replaced by chlorite, epidote, and later minerals. 
Copper occurs with red feldspar, but the association is not notably close. The feldspar, like many minerals of the ore period, is far more widespread than copper.

Adularia occurs to a minor extent in lodes and fissures as well-formed white to pinkish crystals, usually in open spaces. It was apparently a relatively late mineral of the ore period

Pyroxene $\left(\mathrm{Ca}(\mathrm{Mg}, \mathrm{Fe}) \mathrm{Si}_{2} \mathrm{O}_{6}\right)$ is an abundant primary mineral of all the basic flows. Its usual alteration is to hematite and serpentine. In places it is stained with limonite. It was rather resistant to alteration by the ore solutions, but where the alteration was intense it was replaced, like the other rock minerals.

Hornblende was noted in the Greenstone flow assoeiated with biotite.

Olivine $\left.(\mathrm{Mg}, \mathrm{Fe})_{2} \mathrm{SiO}_{4}\right)$ was an early mineral to crystallize in most of the lava flows. It is now mostly altered, characteristically to serpentine or bowlingite and hematite. These minerals were in places further altered to others. Fresh olivine was observed only in the coarse phases of the Greenstone flow.

Zircon $\left(\mathrm{ZrSiO}_{4}\right)$ occurs as a primary mineral of the felsites.

Pumpellyite $\left(6 \mathrm{CaO} .3 \mathrm{Al}_{2} \mathrm{O}_{3} .7 \mathrm{SiO}_{2} .4 \mathrm{H}_{2} \mathrm{O}\right)$, provisionally called zoisite, occurs in bluish-green lath-shaped crystals or needles, in most places in radiating groups. It is this mineral that gives the characteristic bluishgreen color to much of the lode material in the mines in the south end of the district. It is near zoisite in composition but differs from zoisite crystallographically. Doctor Palache ${ }^{69}$ has described this mineral in detail.

Analysis of pumpellyite

[Helen E. Vassar, analyst]

\begin{tabular}{|c|c|c|c|}
\hline \multirow[b]{2}{*}{$\begin{array}{l}\mathrm{SiO}_{2} \\
\mathrm{Al}_{2} \mathrm{O}_{3} \\
\mathrm{Fe}_{2} \mathrm{O}_{3} \\
\mathrm{FeO} \\
\mathrm{MgO}\end{array}$} & \multirow{2}{*}{ 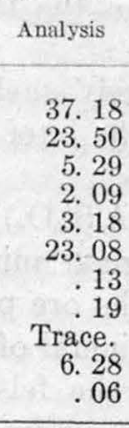 } & \multicolumn{2}{|c|}{ Molecular ratio } \\
\hline & & 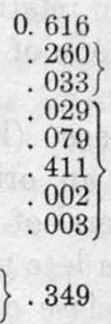 & $\begin{array}{l}0.616=7 \\
.293=3 \\
.524=6\end{array}$ \\
\hline & 100.97 & & \\
\hline
\end{tabular}

The mineral is abundant in all the amygdaloid lodes and in all the fissures. It is present but not usually abundant in the conglomerates.

It is especially conspicuous in the Isle Royale lode and in the Evergreen and succeeding lodes, but hardly more so than in parts of the Baltic and Pewabic lodes. It occurs in open cavities and replaces the rock. In

60 Palache, Charles, and Vassar, H. E., Some minerals of the Keweenaw copper deposits; pumpellyite, a new mineral; sericite; saponite: Am. Mineralogist, vol. 10, pp. $412-418,1925$. many places pumpellyite with quartz has parly replaced large volumes of rock. It commonly fol: lowed epidote in formation but preceded copper. It replaced the earlier minerals of the ore period, such as chlorite and epidote, and in turn was replaced by the later minerals, including copper. It is not usually abundant in highly oxidized rock, such as the top of the Kearsarge amygdaloid. It is closely associated with copper in many places, but apparently, like mant of the gangue minerals, is far more widespread in occurrence than copper. The lodes of the Pewabie series in particular in numerous places are rather highly pumpellyitized where they are not known to contain abundant copper.

Epidote (composition variable, approximately $\mathrm{HC} 8$ $\left.(\mathrm{Al}, \mathrm{Fe})_{3} \mathrm{Si}_{3} \mathrm{O}_{13}\right)$, a yellow-green mineral, is every. where abundant in both veins and lodes, being per. haps especially abundant in the Evergreen and suc. ceeding lodes of that series and in the Isle Roygle lode. It is also abundant locally in the Calumet \& Hecla conglomerate. Epidote characteristically has replaced the rock minerals, though it has also been formed in openings. It commonly first replaced plagioclase but eventually replaced much of the rock in mass. In the Calumet \& Hecla conglomerate it replaced sandstone lenses. In the Kearsarge lode it is relatively abundant in the upper, highly oxidized portion as eontrasted with the lower, less oxidized portion. The iron entering the epidote was apparently derived from the hematite of the rocks. Epidote is one of the early minerals of the ore-forming period, in the main preceding copper, but it also appears to have been formed to a slight extent later than copper, as it cuts anhydrite and sericite - in the Isle Royale mine, for instance. Epidote is in many places closely associated with copper, but, like chlorite and calcite, it is far more widespread than the commerciall? valuable copper minerals.

Tourmaline occurs in felsite fragments in the conglomerates. It is unrelated to the copper mineralization.

Laumontite $\left(\mathrm{CaAl}_{2} \mathrm{Si}_{4} \mathrm{O}_{12} \cdot 4 \mathrm{H}_{2} \mathrm{O}\right)$ is usually pink or salmon-colored, but in places, especially in some vugs, it is white. It occurs in practically all the fissures and amygdaloids. It is abundant in many fissures and locally in the amygdaloids but is practically absent from the conglomerates. It is one of the later minerals of the ore period and has replaced the earlier minerals but was in turn replaced by some of the later minerals. It was mainly later than copper, but a little copper was formed after the laumontite. It is not closely associated with copper and is far more widespread than copper in occurrence. Where latmontite is abundant the lodes are usually relatively poor in copper.

Natrolite $\left(\mathrm{Na}_{2} \mathrm{Al}_{2} \mathrm{Si}_{3} \mathrm{O}_{10} \cdot 2 \mathrm{H}_{2} \mathrm{O}\right)$ occurs with analcite and adularia at Copper Falls. 
Analcite $\left(\mathrm{NaAlSi}_{2} \mathrm{O}_{6} \cdot \mathrm{H}_{2} \mathrm{O}\right)$ occurs commonly as a vein mineral, more rarely in vugs in the lodes. It occurs in vugs as white, well-formed crystals, in many of which the centers are partly dissolved. In veins it rarely shows crystal form and is pinkish in color. It is one of the late minerals of the ore-forming period but in places was followed by saponite and calcite. It is a common mineral but nowhere abundant. Most occurrences were noted in the Kearsarge lode. Stilbite $\left(\mathrm{CaAl}_{2} \mathrm{Si}_{6} \mathrm{O}_{16} \cdot 6 \mathrm{H}_{2} \mathrm{O}\right)$ occurs in the Osceola amygdaloid and at Copper Falls.

Heulandite $\left(\mathrm{CaAl}_{2} \mathrm{Si}_{6} \mathrm{O}_{16} .5 \mathrm{H}_{2} \mathrm{O}\right)$ is one of the rarest zeolites of the district.

Thomsonite $\left(\mathrm{CaAl}_{2} \mathrm{Si}_{2} \mathrm{O}_{8} \cdot 21 / 2 \mathrm{H}_{2} \mathrm{O}\right)$ occurs mainly as a filling of amygdules but also in veins. It is usually not closely associated with copper.

Apophyllite was observed in the St. Clair, Robbins, Cliff, and North American fissures. It is one of the latest minerals.

Chlorastrolite occurs as amygdule filling in flows on Isle Royal. It is worn from the matrix by wave action, and the stones are gathered on the beaches.

Faujasite $\left(\mathrm{H}_{2}\left(\mathrm{CaNa}_{2}\right) \mathrm{Al}_{2}\left(\mathrm{SiO}_{3}\right)_{5} \cdot 9 \mathrm{H}_{2} \mathrm{O}\right)$ from Copper Falls is in the Whitney collection.

Datolite $\left(\mathrm{H}_{2} \mathrm{Ca}_{2} \mathrm{~B}_{2} \mathrm{Si}_{2} \mathrm{O}_{10}\right)$ occurs in both fissures and lodes. It is probably present in most of the amygdaloid lodes, but it is relatively abundant in the Evergreen and succeeding lodes, especially at the Mass Mine, in parts of the Kearsarge and Osceola lodes, in parts of the Pewabic lodes, and in the Ashbed lodes in Keweenaw County. It has not been noted in the conglomerate lodes. It occurs in fissures at many places and is abundant at the Copper Falls (Owl Creek) and Petherick fissures, where locally at least it formed the main gangue mineral. Datolite forms both welldeveloped crystals and dense porcelanic masses. The crystalline datolite occurs in both fissures and lodes. It may be pink from included copper, and where the crystals are small they occur as a loose, crumbly granular aggregate. The porcelanic variety occurs characteristically as irregular spheroidal masses with a botryoidal surface. (See pl. 66.) These masses of datolite commonly contain many small specks of copper, which are usually concentrated near the surface of the mass, though less commonly the concentration is toward the center. This variety has been found most abundantly in the higher levels of the Pewabic lodes but is present in other lodes. Datolite apparently was one of the intermediate to later minerals of the ore period.

Prehnite $\left(\mathrm{Al}_{2}\left(\mathrm{SiO}_{4}\right)_{3} \mathrm{Ca}_{2} \mathrm{H}_{2}\right)$ commonly occurs in radiating crystal aggregates but in the veins especially may appear massive. Much of it has a light applegreen tint, but it varies greatly in color, some of it being nearly black. It is abundant in veins through$58540-29-6$ out the district. It is present in most of the amygdaloids, where it has filled vesicles or replaced earlier minerals or rock. Locally it is abundant in the amygdaloids, as in the Osceola lode, where it largely replaced basic sediment. It is rare in the conglomerates. Prehnite was formed mainly as an intermediate mineral of the ore period, but some was later. In the veins it is very commonly associated with copper, which in many places is disseminated through it in minute grains. The highly prehnitized amygdaloid, however, is not usually high in copper. Prehnite has been replaced by the later minerals.

Sericite (muscovite, $\mathrm{Al}_{3} \mathrm{KH}_{2} \mathrm{Si}_{3} \mathrm{O}_{12}$ ) has mainly replaced rock and earlier ore minerals but also filled open spaces. It is most abundant as a replacement mineral in the walls of the arsenide and sulphide fissures and in some of the lodes, as the Isle Royale and locally in the Baltic. In the Isle Royale lode it is rather abundant as a soft talcose mineral replacing fragmental amygdaloid. Sericite seems to have been formed from a moderately early stage in the oreforming period to a rather late stage.

Analysis of sericite from Isle Royale amygdaloid

[Helen E. Vassar, analyst]

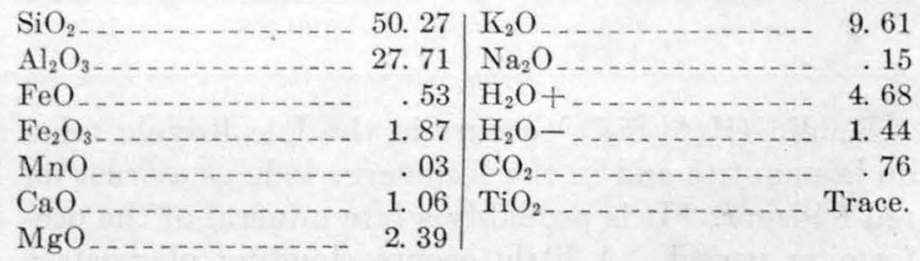

Biotite $\left(\mathrm{Al}_{2} \mathrm{Mg}_{2} \mathrm{KHSi}_{3} \mathrm{O}_{12}\right.$, with variable proportions of ferric and ferrous iron) is a rare primary constituent of some of the basic lava flows, such as the Ashbed group and the Greenstone flow.

Chlorite (delessite, $\mathrm{H}_{10}(\mathrm{Mg}, \mathrm{Fe})_{4} \mathrm{Al}_{4} \mathrm{Si}_{4} \mathrm{O}_{22}$, variable) occurs abundantly as a vesicle filling and as a vein mineral, and it has also replaced rock minerals. It is particularly abundant in some of the veins and has replaced the adjacent wall rocks. In the amygdaloids it is especially conspicuous in the less oxidized parts, such as the lower portion. In the Calumet \& Hecla conglomerate it has replaced some of the iron-rich pebbles, where it is associated with copper. At White Pine it surrounds hydrocarbon and has been replaced by copper. Some chlorite was probably formed during the cooling and solidification of the lavas. It was an abundant early mineral of the ore-forming period but apparently continued to form till late in that period. It replaced many minerals and was replaced by several, being very commonly replaced by copper.

Serpentine $\left(\mathrm{Mg}_{3} \mathrm{H}_{4} \mathrm{Si}_{2} \mathrm{O}_{9}\right)$ is a common alteration product of olivine in the traps, and it also occurs in cavities in the amygdaloid lodes. The serpentine of 
the former type was earlier than the ore period; that of the latter type was formed late in the ore period.

Bowlingite is the common alteration product of olivine in many of the flows. It is resistant to alteration but has been replaced in places by prehnite and calcite.

Saponite $\left(\mathrm{Al}_{2} \mathrm{O}_{3} \cdot \mathrm{MgO} \cdot 10 \mathrm{SiO}_{2} .15\right.$ or $\left.16 \mathrm{H}_{2} \mathrm{O}\right)$ occurs in several of the lodes, where it has filled vesicles, replaced other minerals, and formed as a crust on other minerals. It was noted most abundantly in the Kearsarge lode. It is apparently a late mineral of the ore period.

Analyses of saponite from the Kearsarge lode

[Helen E. Vassar, analyst]

\begin{tabular}{l|r|r}
\hline & $\begin{array}{r}\text { South Kearsarge } \\
\text { mine }\end{array}$ & Ahmeek mine \\
\cline { 1 - 2 } & & \\
$\mathrm{SiO}_{2}$ & 42.78 & 42.99 \\
$\mathrm{Al}_{2} \mathrm{O}_{3}$ & 6.44 & 6.26 \\
$\mathrm{Fe}_{2} \mathrm{O}_{3}$ & 1.27 & 2.57 \\
$\mathrm{FeO}_{\mathrm{MgO}}$ & 24.78 & 22.96 \\
$\mathrm{MaO}$ & 2.35 & 2.03 \\
$\mathrm{MnO}$ & .12 & .11 \\
$\mathrm{Na}_{2} \mathrm{O}$ & .75 & 1.04 \\
$\mathrm{~K}_{2} \mathrm{O}$ & Trace. & Trace. \\
$\mathrm{H}_{2} \mathrm{O}+$ & 7.90 & 6.85 \\
$\mathrm{H}_{2} \mathrm{O}-$ & 13.96 & 13.65 \\
\hline & 100.35 & 100.29 \\
& & \\
\hline
\end{tabular}

Kaolin $\left(\mathrm{H}_{4} \mathrm{Al}_{2} \mathrm{Si}_{2} \mathrm{O}_{9}\right)$ occurs in the Isle Royale mine on laumontite and in the Kearsarge lode as a crust on red feldspar. It is probably a late mineral of the oreforming period. A little occurs clouding plagioclase that is believed to have been formed when the lavas were exposed at the time of extrusion.

Chrysocolla $\left(\mathrm{CuSiO}_{3} \cdot 2 \mathrm{H}_{2} \mathrm{O}\right)$ occurs as an oxidation product at the Algomah mine and the Allouez conglomerate mine and at Copper Harbor.

Titanite $\left(\mathrm{CaTiSiO}_{5}\right)$ is rather abundant in all the flows as an alteration product of olivine, pyroxene, or titaniferous magnetite. In highly altered lode rock it is common as a residual mineral.

\section{PHOSPHATES}

Apatite $\left(\mathrm{Ca}_{5}\left(\mathrm{PO}_{4}\right)_{3} \mathrm{~F}\right.$ or $\left.\mathrm{Ca}_{5}\left(\mathrm{PO}_{4}\right)_{3} \mathrm{Cl}\right)$ occurs rather sparingly as needles or prisms in the felsite pebbles of the conglomerates and in the lava flows. It is an early original mineral of the rocks.

\section{SULPHATES}

Barite $\left(\mathrm{BaSO}_{4}\right)$ occurs most commonly in veins, in many places with sulphide. It also occurs in several of the amygdaloids and in the iron-rich pebbles of the Calumet \& Hecla conglomerate. At the White Pine mine it is a vein mineral and a cement in the sand. stone. It was among the late minerals, though fol. lowed in places by saponite, adularia, and datolite. It is widespread but nowhere abundant.

Anhydrite $\left(\mathrm{CaSO}_{4}\right)$ occurs in vugs and has replaced rock in the Isle Royale mine. It was also collected from the dump of the Mass mine. It seems to be of the late ore-forming stage but is veined in the Isle Royale mine by laumontite and epidote.

Gypsum $\left(\mathrm{CaSO}_{4} \cdot 2 \mathrm{H}_{2} \mathrm{O}\right)$ occurs sparingly at numerous places, both in fissures and in the lodes. It is nowhere abundant. It appears to be a late mineral. In the Isle Royale mine it seems to have been formed from anhydrite. In the Victoria mine it has formed in puddles of salt water that stand in a crosscut.

\section{MOLYBDATES AND TUNGSTATES}

Powellite $\left(\mathrm{Ca}(\mathrm{Mo}, \mathrm{W}) \mathrm{O}_{4}\right)$ has been reported from the Isle Royale mine, and a few well-formed crystals have been found in the Calumet \& Hecla conglom. erate. The mineral is said to contain both molyb. denum and tungsten.

\section{HYDROCARBON}

A dark hydrocarbon is rather plentiful in the Nonesuch lode at the White Pine mine, where it occurs in fissures and as a cement in the sandstone. In places it is surrounded by and was evidently earlier than copper. The hydrocarbon in the fissures contains abundant copper. 


\section{PART 2. ORE DEPOSITS}

\section{HISTORY}

That the existence of native copper in the Lake Superior district was known to early Indians and that copper was mined by them is shown by numerous ancient pits containing masses of native copper in various stages of removal, together with the crude stone tools used in mining, and by the implements made from copper that are found in the region. (See pl. 1.)

The earliest visits to the district by white men were made about the middle of the seventeenth century. In 1672 two Jesuit priests published a map of Lake Superior, and from time to time the Jesuit missionaries and others brought accounts of copper found along its shores. The names of these early explorers-La Salle, Allouez, Mesnard, Marquette, and Du Luthhave been preserved in the geographic nomenclature of the region.

In 1771 Alexander Henry, an Englishman, began the first mining operations on the banks of Ontonagon River near the present Victoria mine, where a great boulder of copper had been found. This boulder attracted much attention and was eventually sent to Washington, where it is still on exhibition at the National Museum. This work was soon abandoned, however, for the country rock was the unproductive Jacobsville ("Eastern") sandstone, the boulder as it later appeared being a glacial erratic derived from lodes that crop out farther north.

The Lake Superior copper industry had its real beginning in 1830, the year in which Dr. Douglass Houghton, Michigan's first State geologist, made his initial visit to the region. His report, published in 1841 , aroused a general interest in the district. In 1844 the Federal Government began a land survey at the instance and under the direction of Doctor Houghton, which was combined with the geologic and topographic surveys he was then making for the State of Michigan. These surveys, though interrupted by the death of Doctor Houghton late in 1845 , were pushed to rapid completion and served both to increase interest in the district and to facilitate its early exploration and development. Mining permits were issued by the Federal Government, the first in 1844 , but they were abolished in 1846 , and all mining lands were placed on sale.

The Pittsburgh \& Boston Mining Co., organized in 1844, began operations at Copper Harbor, where a few tons of black oxide of copper was mined. In the following year it opened the first successful mine, the Cliff mine, on a cross fissure vein in the north end of the district; the first dividend was paid in 1849 . The Minesota mine was opened on a strike fissure toward the southwest end of the district in 1849 and paid its first dividend in 1854, followed by the neighboring National mine with a dividend in 1861 . The Central mine, operating on the Central fissure, northeast of the Cliff mine, made its first shipment in 1856 and began to pay dividends in 1864. These fissure mines were noted for the enormous pieces of "mass" copper encountered in them. Several of these masses were estimated to weigh about 500 tons each.

The Pewabic and Quincy mines were the first successful mines on an amygdaloid lode. They were opened on the Pewabic amygdaloid, in the Portage Lake region, in the central part of the district, in 1856; both mines began paying dividends in 1862 .

The Isle Royale lode, ${ }^{1}$ also in the Portage Lake region, had been opened as early as 1852 by the Isle Royale Mining Co., incorporated originally to mine on Isle Royal, in Lake Superior. Although worked intermittently by a number of companies, this lode yielded no dividends until 1913.

The Atlantic lode was discovered in 1864 and explored by the South Pewabic Mining Co. Intensive development was begun by the Atlantic Mining Co. in 1872 .

The famous Calumet \& Hecla conglomerate was opened in 1864, and the company paid its initial dividend in 1869. Ten years later the Kearsarge and Osceola lodes were opened.

The Baltic lode was discovered in 1882 but remained unexplored until 15 years later. This was the last important lode to be opened.

Most of the fissure deposits have long since ceased to be productive. Of the lode deposits, all that have been largely productive are still producing or may be expected to produce under favorable conditions, though some of the mines on the lodes have been worked out or consolidated with others.

1 The terms "lode" and "fissure deposit" are here applied in accordance with local usage. Strictly speaking, the "fissure deposits" are lodes, and the so-called "lodes" are not so, being rather in the nature of bed-replacement deposits. The latter, however, will consistently be called lodes in the present report; for the word is convenient and readily understood, and its use in this sense is perhaps not positively incorrect. As much can hardly be said of other applications of the term that are current in the district, where the word is used to designate (1) lava tops or conglomerates, or parts of them, which, though susceptible of mineralization, are not actually mineralized; (2) rock substance that has been mineralized; and (3) rock substance that is susceptible of mineralization. In general the use of the word in any of these senses will be avoided in this report, as being not only illogical but likely to cause confusion where the word is used in two or more senses in the same sentence. 


\section{PRODUCTION}

The first production of copper in the Lake Superior district marked the real beginning of copper mining as a great industry in the United States. In its first six years of activity-from 1844 to 1850 - the district

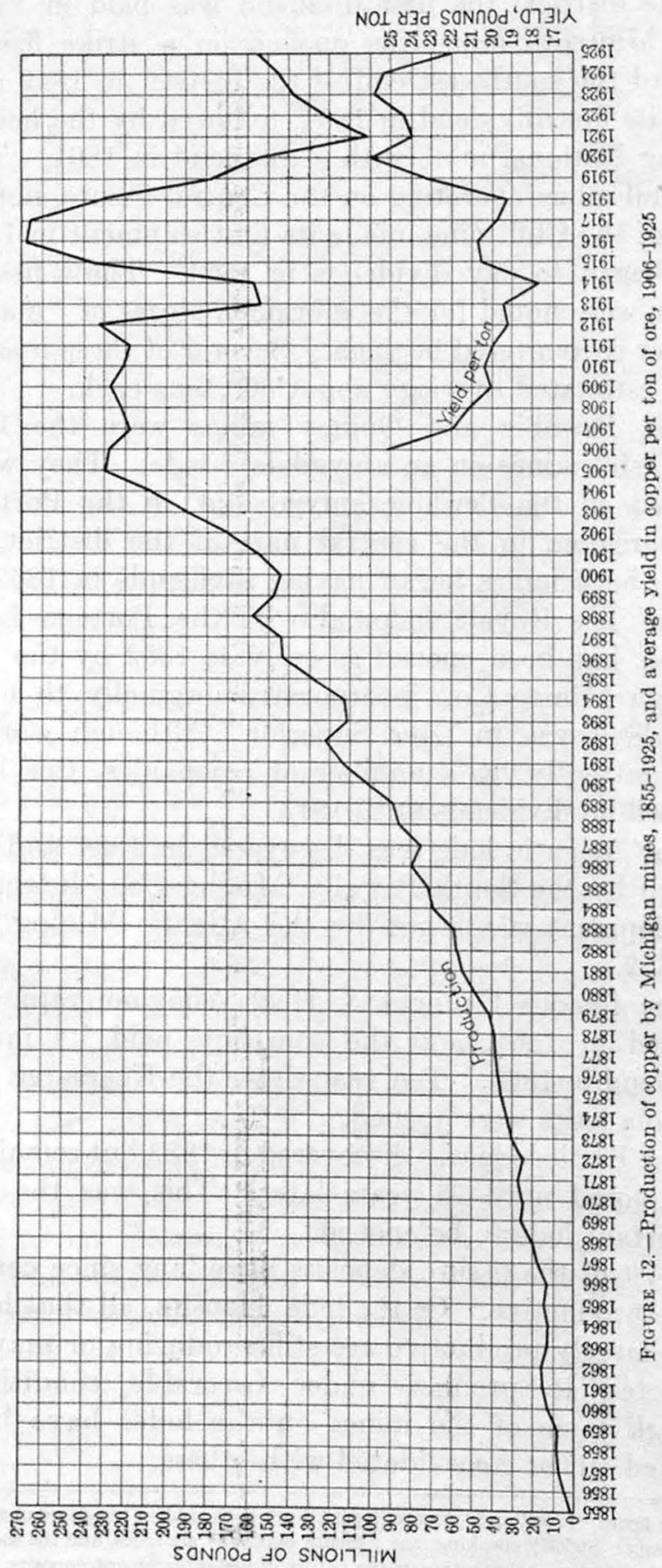

produced more than 4,000,000 pounds, while all the rest of the country produced less than one-fourth as much. Yearly production steadily increased to a maximum of $269,700,000$ pounds in 1916 .

The total production from 1845 to the end of 1925 has been 7,500,000,000 pounds. Among the copper districts of the United States the Lake Superior district ranks second in total production. As a State, Michigan ranks third, having produced 21 per cent of all the copper produced in the United States to the end of 1925, while Arizona had produced 31 per cent and Montana 25 per cent. ${ }^{2}$

During the 18 years 1906-1923, for which definite figures are available, an average of $9,240,000$ short tons of ore was mined annually, which yielded an average of $200,000,000$ pounds of copper, or 21.56 pounds to the ton. The yield was 25.2 pounds to the ton for 1906, but dropped to 17.7 pounds for 1914. For 1918, 1919,1920 , and 1921 the respective yields were 19.2, $22.1,23.7$, and 24 pounds to the ton.

The following tables show the production of the district by years, by mines, and by lodes from the beginning of operations to the end of 1925. (See also figs. 12-14.)

\begin{tabular}{|c|c|c|c|}
\hline \multicolumn{4}{|c|}{$\begin{array}{l}\text { [Compiled from U. S. Geol. Survey Mineral Resources; figures for } 1924 \text { and } 1 \% \% \\
\text { furnished by Bureau of Mines. Smelter production] }\end{array}$} \\
\hline & Pounds & & Pounds \\
\hline $1845 \ldots$ & 26,880 & $1887 \ldots \ldots$ & $75,471,890$ \\
\hline $1846 \ldots \ldots$ & 58,240 & $1888 \ldots \ldots$ & $86,472,034$ \\
\hline $1847 \ldots \ldots$ & 477,120 & $1889 \ldots$ & $88,175,675$ \\
\hline $1848 \ldots \ldots$ & $1,032,640$ & $1890 \ldots$ & $101,410,277$ \\
\hline $1849 \ldots \ldots$ & $1,505,280$ & 1891 & $114,222,709$ \\
\hline $1850 \ldots \ldots$ & $1,281,280$ & $1892 \ldots$ & $123,198,460$ \\
\hline $1851 \ldots \ldots$ & $1,744,960$ & $1893 \ldots$ & $112,605,078$ \\
\hline $1852 \ldots \ldots$ & $1,744,080$ & $1894 \ldots$ & $114,308,870$ \\
\hline $1853 \ldots \ldots$ & $2,905,280$ & $1895 \ldots \ldots$ & $129,330,749$ \\
\hline $1854 \ldots \ldots$ & $4,074,560$ & 1896 & $143,524,069$ \\
\hline $1855 \ldots \ldots$ & $5,808,320$ & $1897 \ldots$ & $145,282,059$ \\
\hline $1856 \ldots \ldots$ & $8,211,840$ & $1898 \ldots$ & $158,491,703$ \\
\hline $1857 \ldots \ldots$ & $9,531,200$ & $1899 \ldots$ & $147,400,338$ \\
\hline $1858 \ldots \ldots$ & $9,157,120$ & 1900 & $145,461,498$ \\
\hline $1859 \ldots \ldots$ & $8,926,400$ & $1901 \ldots$ & $156,289,481$ \\
\hline $1860 \ldots$ & $12,069,120$ & $1902 \ldots$ & $170,609,228$ \\
\hline $1861 \ldots \ldots$ & $15,037,120$ & 1903 & $192,400,577$ \\
\hline $1862 \ldots$ & $13,585,600$ & 1904 & $208,309,130$ \\
\hline $1863 \ldots \ldots$ & $12,985,280$ & $1905 \ldots$ & $230,287,992$ \\
\hline $1864 \ldots \ldots$ & $12,490,240$ & 1906 & $229,695,730$ \\
\hline $1865 \ldots \ldots$ & $14,358,400$ & 1907 & $219,131,503$ \\
\hline $1866 \ldots$ & $13,749,120$ & 1908 & $222,289,584$ \\
\hline $1867 \ldots \ldots$ & $17,525,760$ & $1909 \ldots$ & $227,005,923$ \\
\hline $1868 \ldots \ldots$ & $20,935,040$ & $1910 \ldots \ldots$ & $221,462,984$ \\
\hline $1869 \ldots$ & $26,624,640$ & $1911 \ldots$ & $218,185,236$ \\
\hline $1870 \ldots$ & $24,622,080$ & $1912 \ldots$ & $231,112,228$ \\
\hline $1871 \ldots \ldots$ & $26,750,080$ & $1913 \ldots \ldots$ & $155,715,286$ \\
\hline $1872 \ldots \ldots$ & $24,552,640$ & 1914 & $158,009,748$ \\
\hline $1873 \ldots \ldots$ & $30,089,920$ & $1915 \ldots$ & $238,956,411$ \\
\hline $1874 \ldots \ldots$ & $34,332,480$ & $1916 \ldots \ldots$ & $269,794,531$ \\
\hline $1875 \ldots \ldots$ & $36,039,360$ & $1917 \ldots \ldots$ & $268,508,098$ \\
\hline $1876 \ldots \ldots$ & $38,270,400$ & 1918 & $231,096,150$ \\
\hline $1877 \ldots \ldots$ & $39,025,280$ & $1919 \ldots$ & $177,594,135$ \\
\hline $1878 \ldots$ & $39,690,560$ & $1920 \ldots$ & $153,483,952$ \\
\hline $1879 \ldots \ldots$ & $42,848,960$ & $1921 \ldots$ & $100,918,001$ \\
\hline $1880 \ldots \ldots$ & $49,736,960$ & $1922 \ldots \ldots$ & $122,545,126$ \\
\hline $1881 \ldots \ldots$ & $54,573,120$ & $1923 \ldots \ldots$ & $137,691,306$ \\
\hline $1882 \ldots \ldots$ & $56,982,765$ & $1924 \ldots \ldots$ & $145,333,227$ \\
\hline $1883 \ldots \ldots$ & $59,702,404$ & 1925 & $138,029,764$ \\
\hline $1884 \ldots \ldots$ & $69,353,202$ & & \\
\hline $1885 \ldots \ldots$ & $72,148,172$ & & 504,2 \\
\hline & $79,890,798$ & & \\
\hline
\end{tabular}

2 Figures furnished by Bureau of Mines. 


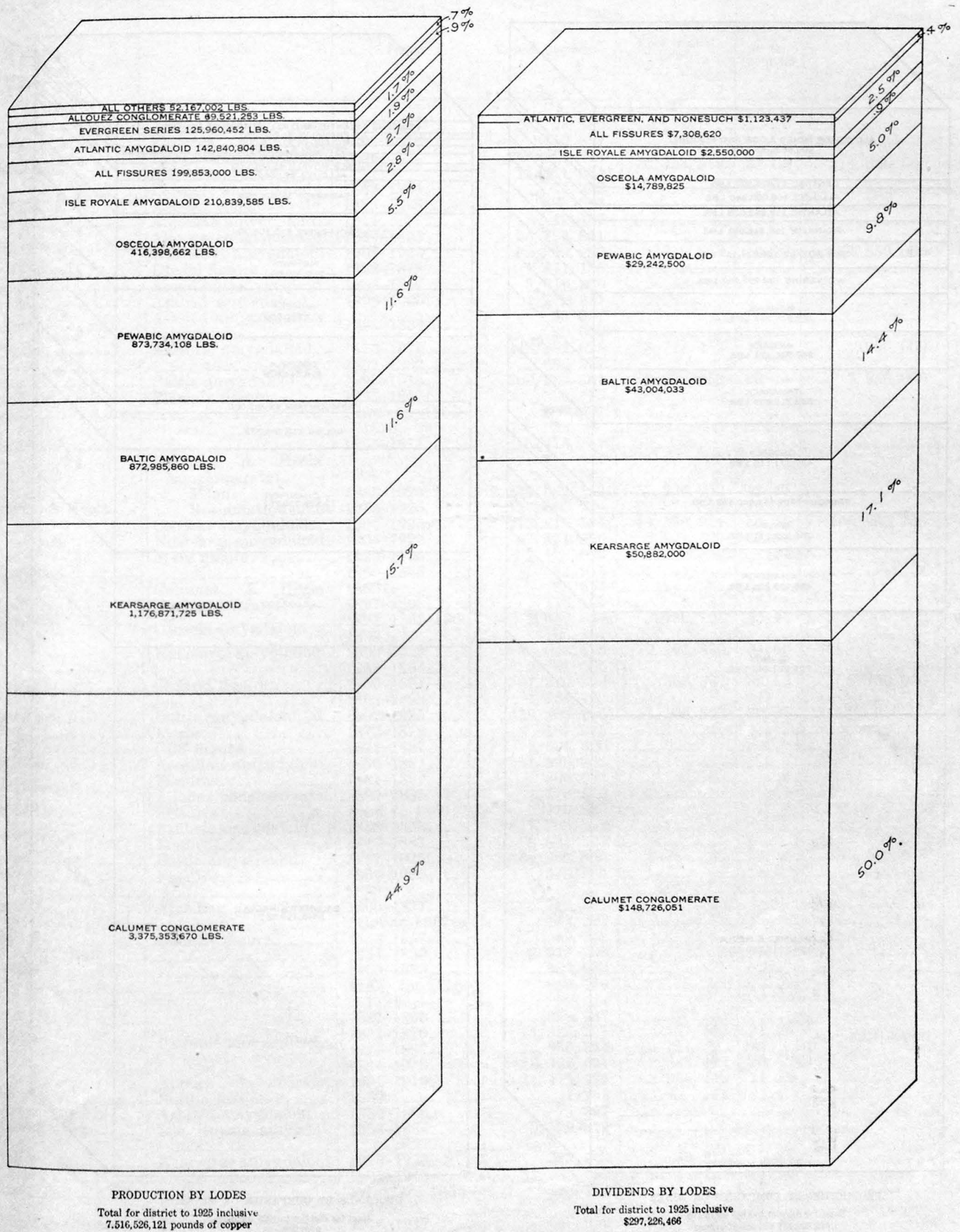

Total for district to 1925 inclusiv
$7.516,526,121$ pounds of copper $\$ 297,226,466$

FroURE 13.-Production and dividends of Michigan copper mines to end of 1925 , by lodes 


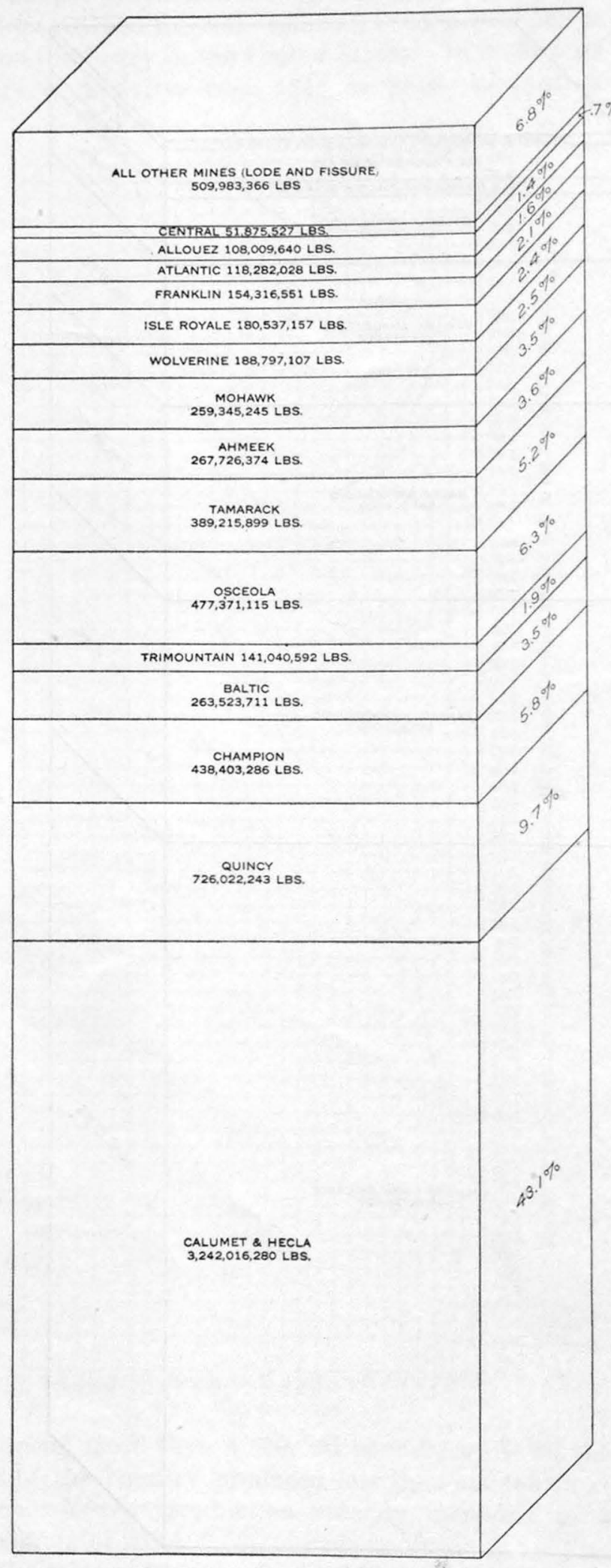

PRODUCTION BY COMPANIES OR MINES Total for district to 1925 inclusive $7,516,526,121$ pounds of copper

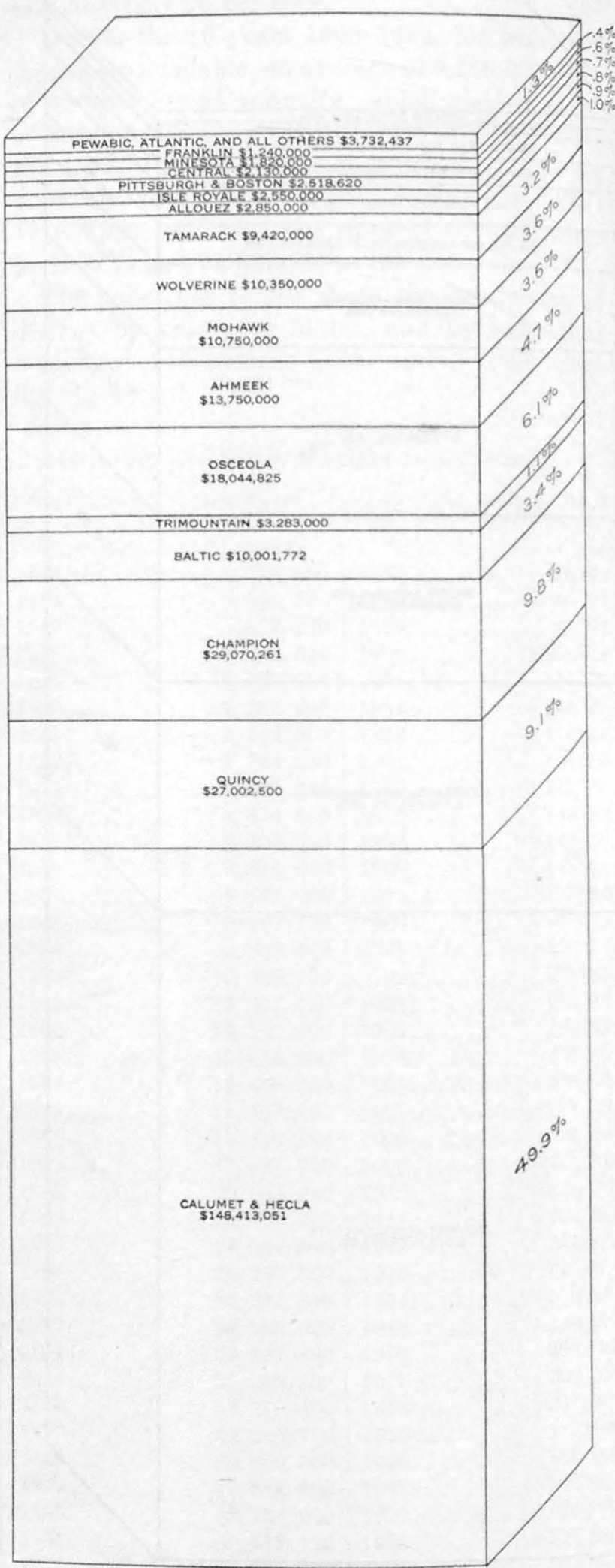

DIVIDENDS BY COMPANIES OR MINES

Total for district to 1925 inelusive

Figure 14.-Production and dividends of Michigan copper mines to end of $1925,226,466$
, by companies or mines 
Statistics of copper production in Michigan copper district, 1845-1925, by companies

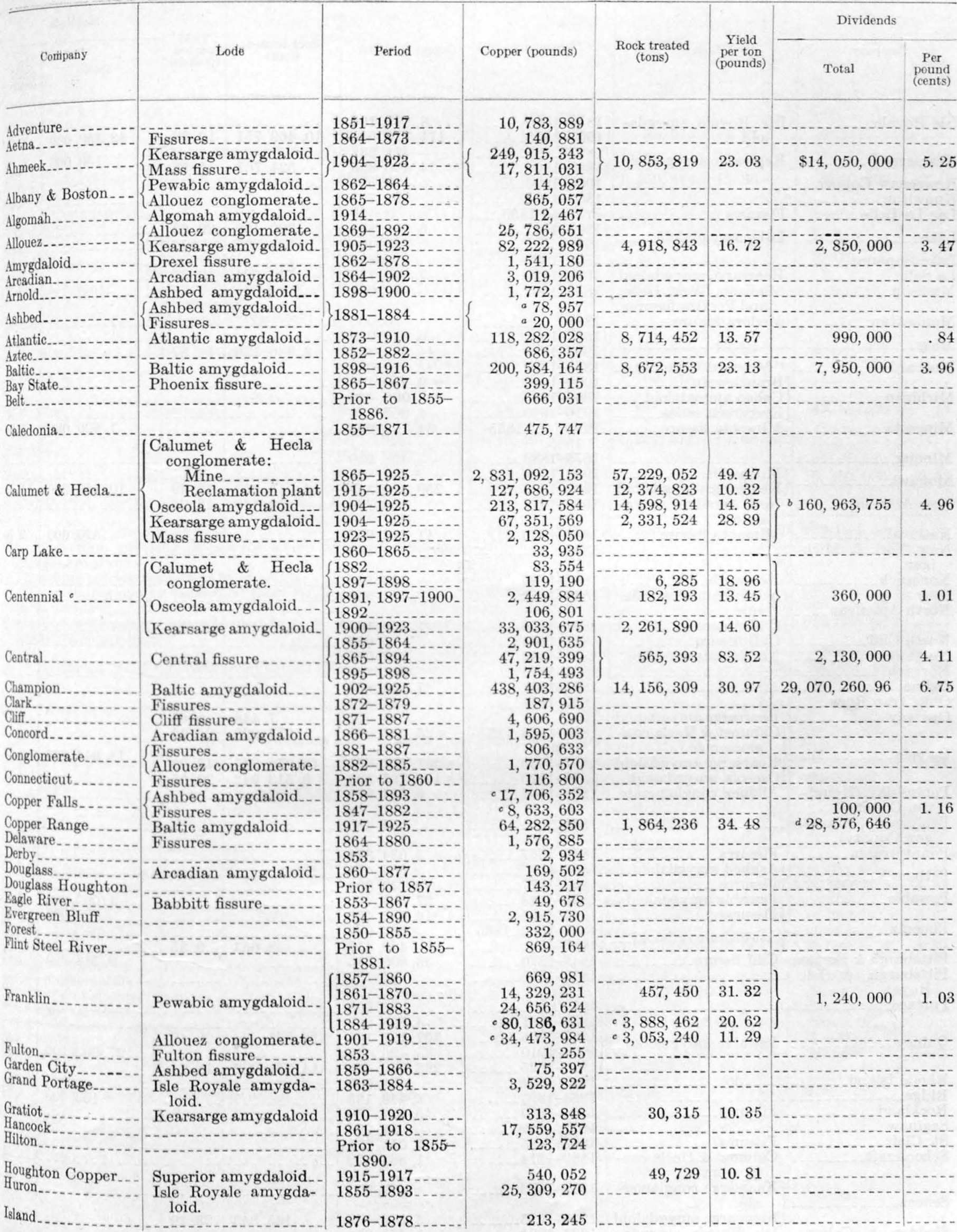


Statistics of copper production in Michigan copper district, 1845-1925, by companies-Continued

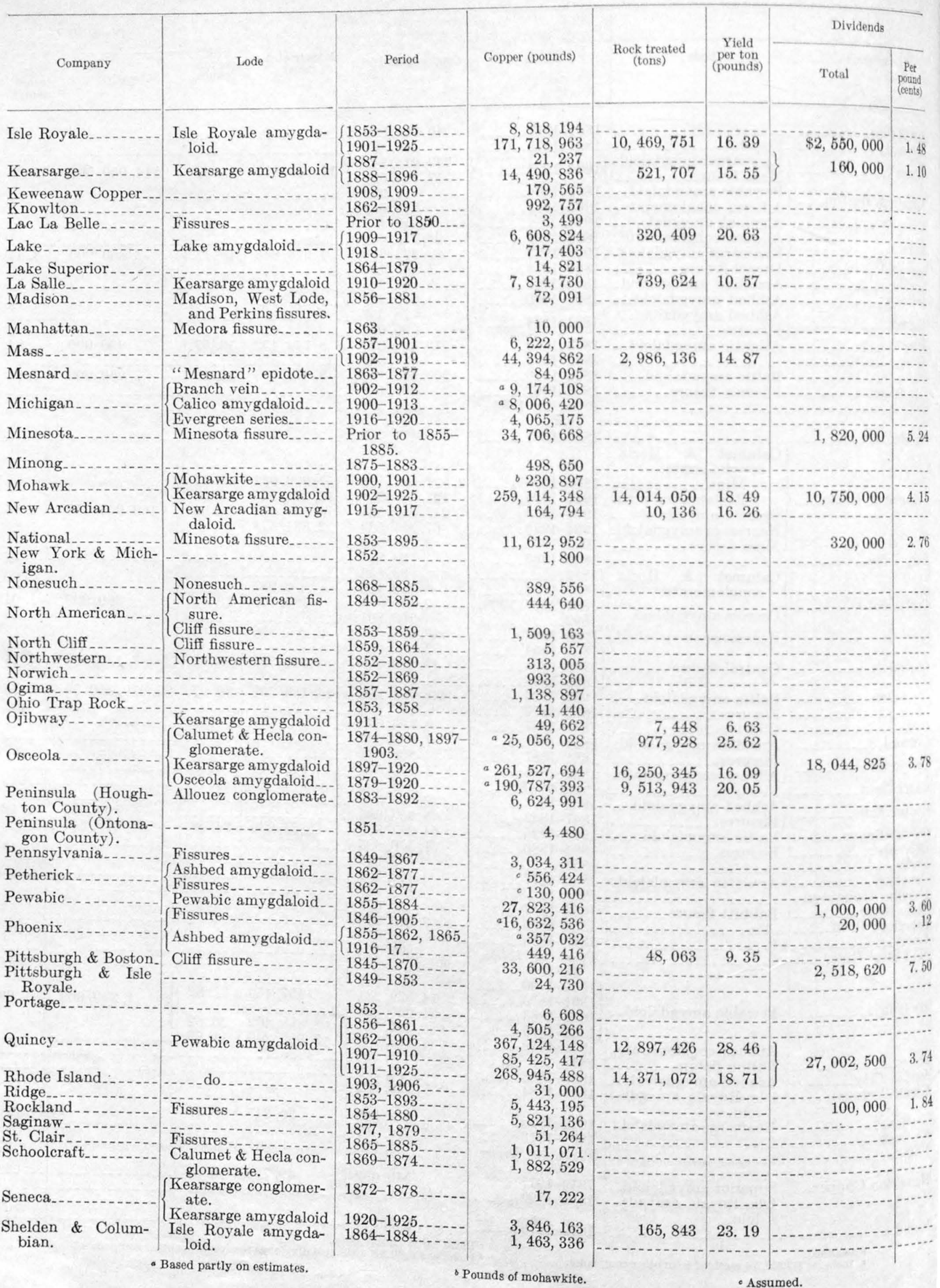


Statistics of copper production in Michigan copper district, 1845-1925, by companies-Continued

\begin{tabular}{|c|c|c|c|c|c|c|c|}
\hline \multirow[b]{2}{*}{ Company } & \multirow[b]{2}{*}{ Lode } & \multirow[b]{2}{*}{ Period } & \multirow[b]{2}{*}{ Copper (pounds) } & \multirow[b]{2}{*}{$\begin{array}{l}\text { Rock treated } \\
\text { (tons) }\end{array}$} & \multirow[b]{2}{*}{$\begin{array}{c}\text { Yield } \\
\text { per ton } \\
\text { (pounds) }\end{array}$} & \multicolumn{2}{|l|}{ Dividends, } \\
\hline & & & & & & Total & $\begin{array}{c}\text { Per } \\
\text { pound } \\
\text { (cents) }\end{array}$ \\
\hline $\begin{array}{l}\text { Siskowit........ } \\
\text { Bouth Lake..... }\end{array}$ & & $\begin{array}{l}1849-1853 \\
1915-1918\end{array}$ & 190,736 & & & & \\
\hline South Pewabic....... & Atlantic amygdaloid. & $\begin{array}{l}1915-1918 \\
1866-1870\end{array}$ & $\begin{array}{l}1,042,211 \\
3,562,967\end{array}$ & 80,075 & 13.02 & & \\
\hline $\begin{array}{l}\text { Star. } \\
\text { Superior (Houghton }\end{array}$ & $\begin{array}{l}\text { Fissures } \\
\text { Superior amygdaloid. }\end{array}$ & $\begin{array}{l}1855-1881 \\
1908-1920\end{array}$ & $\begin{array}{r}17,938 \\
30,018,271\end{array}$ & & - & 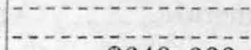 & \\
\hline $\begin{array}{l}\text { County). } \\
\text { Superior (Ontonagon }\end{array}$ & & $1858-1879 \ldots$ & $\begin{array}{r}30,018,271 \\
525,880\end{array}$ & $1,550,474$ & 19. 36 & $\$ 649,000$ & 2. 16 \\
\hline County). & $\left\{\begin{array}{l}\text { Calumet \& Hecla con- } \\
\text { glomerate. }\end{array}\right.$ & $\left\{\begin{array}{l}1882-1883 \\
1885-1917\end{array}\right.$ & 7, 798 & & & & \\
\hline Tamarack Junior.... - & $\left\{\begin{array}{l}\text { glomerate. } \\
\text { Osceola amygdaloid... }\end{array}\right.$ & $(1885-1917 \ldots \ldots$ & $\begin{array}{r}37,237,000 \\
\quad 9,2001\end{array}$ & $13,591,141$ & 28. 64 & $9,420,000$ & 2. 48 \\
\hline Tamarack Junior....- & $\begin{array}{l}\text { Calumet \& Hecla con- } \\
\text { glomerate. }\end{array}$ & $1892-1896 \ldots \ldots$ & $9,462,191$ & & & & \\
\hline Tecumseh & Kearsarge amygdaloid & $\begin{array}{l}1906 \\
1853-1866\end{array}$ & $\begin{array}{r}59,874 \\
379,153\end{array}$ & & & & \\
\hline Trimountain & Baltic amygdaloid.... & $\begin{array}{l}1902-1923 \ldots \\
1863-1878,1904\end{array}$ & $\begin{array}{r}139,697,289 \\
124,721\end{array}$ & $6,703,079$ & 20. 84 & $3,250,000$ & 2. 33 \\
\hline $\begin{array}{l}\text { Vietoria...... } \\
\text { Vulcan }\end{array}$ & & $\left\{\begin{array}{r}1906-1921 \ldots \ldots \\
1864\end{array}\right.$ & $\begin{array}{r}19,567,792 \\
613\end{array}$ & $1,700,518$ & 11. 51 & & \\
\hline $\begin{array}{l}\text { White Pine... } \\
\text { Windsor. }\end{array}$ & Nonesuch & $\begin{array}{l}1915-1920 \\
\text { Prior to } 1856\end{array}$ & $\begin{array}{r}18,233,169 \\
68,000\end{array}$ & 887,654 & 20.54 & $33,437.50$ & 18 \\
\hline Winona & & $\{1902-1919$ & $\begin{array}{r}68,000 \\
16,497,396\end{array}$ & $1,207,471$ & 13.66 & & \\
\hline & Kearsarge amygdaloid & $\begin{array}{l}{ }^{b} 1918,1920 \ldots \\
\{1882-1886\end{array}$ & $\begin{array}{l}1,186,838 \\
1,979,378\end{array}$ & & & & \\
\hline & nearsarge anyguato & 1891-1925 & $186,817,729$ & $8,468,263$ & 22. 06 & $10,350,000$ & 5. 48 \\
\hline & & & & & 13. 66 & & \\
\hline \multirow{2}{*}{\multicolumn{3}{|c|}{$\begin{array}{l}\text { Total production, omitting figures for which no corresponding } \\
\text { tonnages are given: } \\
\text { Including copper reclaimed from sands } \\
\text { Not including copper reclaimed from sands } \\
\text { Total dividends. }\end{array}$}} & $7,516,504,197$ & $251,320,142$ & & $335,969,044.46$ & \\
\hline & & & $7,031,648,114$ & $251,320,142$ & 27. 98 & & \\
\hline \multicolumn{3}{|c|}{$\begin{array}{l}\text { Not including copper reclaimed from sands } \\
\text { Total dividends.- } \\
\text { Duplication (estimated dividends paid from dividends received }\end{array}$} & $6,903,961,190$ & $251,320,142$ & 27.47 & & \\
\hline \multirow{2}{*}{\multicolumn{3}{|c|}{$\begin{array}{l}\text { Duplication (estimated dividends paid from dividends received } \\
\text { from other companies }{ }^{c} \text { ). }\end{array}$}} & & & & $335,969,044.46$ & \\
\hline & & & & & & & \\
\hline \multicolumn{3}{|c|}{ Estimated dividends paid from actual mining operations. } & & & & $297,266,466.46$ & 3.95 \\
\hline
\end{tabular}

- Based partly on estimates. $\quad$ b Tribute copper for 1918.

e Calumet \& Hecla, \$12,550,704; Copper Range (estimated), \$26,491,874.

Production and dividends from principal lodes, 1845-1925

\begin{tabular}{|c|c|c|c|c|}
\hline \multirow[b]{2}{*}{ Lode } & \multicolumn{2}{|c|}{ Refined copper (pounds) } & \multicolumn{2}{|c|}{ Dividends } \\
\hline & Total & Perton & Total & $\begin{array}{l}\text { Per pound of } \\
\text { copper(cents) }\end{array}$ \\
\hline $\begin{array}{l}\text { Calumet \& Hecla conglomerate. } \\
\text { Kearsarge amygdaloid } \\
\text { Pewabic amygdaloid. } \\
\text { Baltic amygdaloid. } \\
\text { Osceola amygdaloid } \\
\text { Isle Royale amygdaloid. } \\
\text { Atlantic amygdaloid } \\
\text { Allouez conglomerate } \\
\text { Evergreen and succeeding lodes } \\
\text { Superior amygdaloid } \\
\text { Forest ("Victoria") amygdaloid } \\
\text { Nonesuch lode. } \\
\text { Lake amygdaloid. }\end{array}$ & $\begin{array}{r}375,300,000 \\
1,176,900,000 \\
873,700,000 \\
873,000,000 \\
416,400,000 \\
210,800,000 \\
142,800,000 \\
69,500,000 \\
66,500,000 \\
30,500,000 \\
20,000,000 \\
18,200,000 \\
7,300,000\end{array}$ & $\begin{array}{r}51.26 \\
19.14 \\
23.11 \\
26.91 \\
16.75 \\
\text { c } 16.39 \\
13.55 \\
\text { d } 11.29 \\
10 \text { to } 20 \\
19.04 \\
11.55 \\
20.54 \\
20.62\end{array}$ & $\begin{array}{r}\$ 148,726,051 \\
\text { b } 50,882,000 \\
29,242,500 \\
43,004,032 \\
\text { b } 14,789,825 \\
2,550,000 \\
990,000 \\
\text { None. } \\
\text { None. } \\
649,000 \\
\text { None. } \\
33,437 \\
\text { None. }\end{array}$ & $\begin{array}{r}4.41 \\
\text { 4. } 32 \\
\text { 3. } 35 \\
\text { 4. } 93 \\
\text { 3. } 55 \\
\text { 1. } 21 \\
\text {. } 69 \\
1.12 \\
\\
\end{array}$ \\
\hline
\end{tabular}


Production and dividends in Michigan copper district, 1845-1925, by lodes and mines

Calumet \& Hecla conglomerate

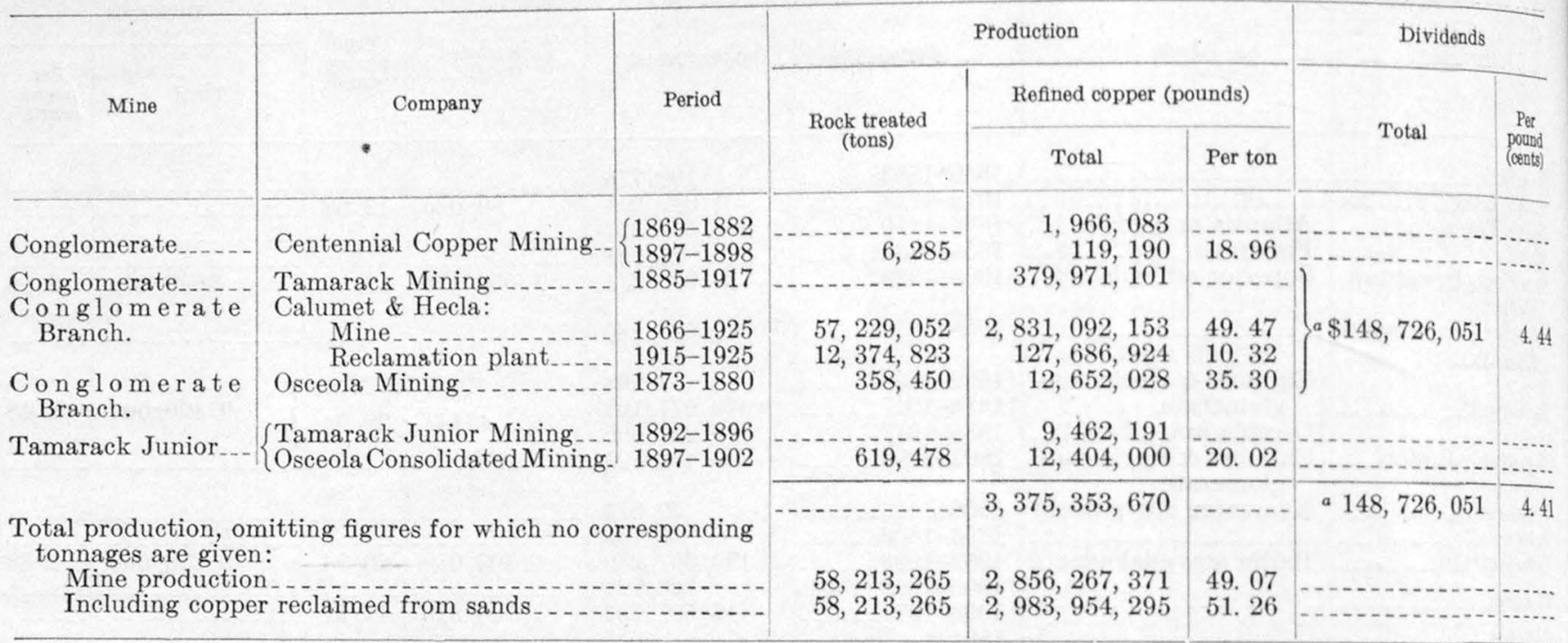

Kearsarge amygdaloid

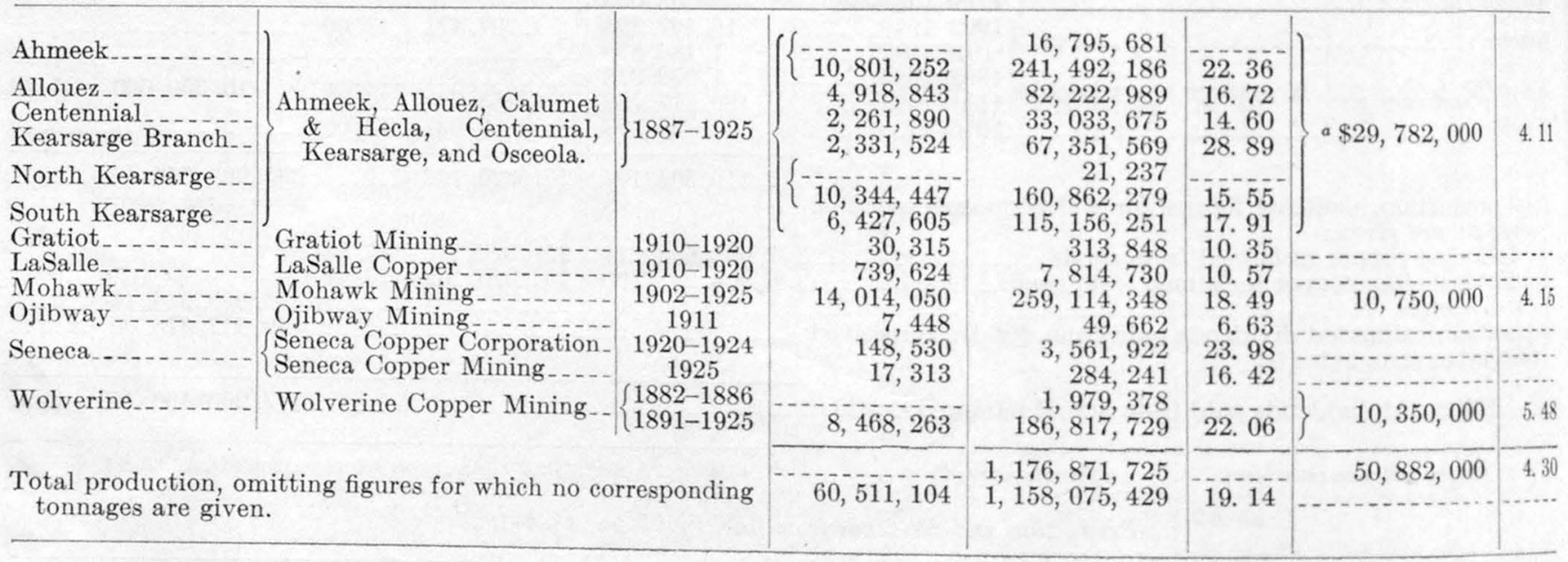

Pewabic amygdaloid

\begin{tabular}{|c|c|c|c|c|c|c|c|}
\hline Albany \& Boston..- & Albany \& Boston Mining ... & $1862-1864$ & & 14,982 & & & \\
\hline Franklin _.. & Franklin Mining ........... & $\left\{\begin{array}{l}1857-1860 \\
1861-1870\end{array}\right.$ & 457,450 & $\begin{array}{r}669,981 \\
14,329,231\end{array}$ & $-\overline{31} \cdot \overline{32}$ & & \\
\hline Franklin & & (1871-1883 & 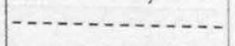 & $24,656,624$ & - n. - n & $\$ 1,240,000$ & 1. 03 \\
\hline Franklin Junior .... & & $1883-1919$ & a $3,888,462$ & a $80,186,631$ & a 20.62 & & \\
\hline Pewabic $\ldots \ldots$ & Pewabic Mining...... & $\begin{array}{r}1855-1884 \\
1856-1861 \\
1862-1906\end{array}$ & pho & $27,823,416$ & 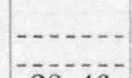 & $1,000,000$ & 3.60 \\
\hline Ruincy & $\begin{array}{l}\text { Quincy Mining } \\
\text { Rhode Island Copper }\end{array}$ & $\left\{\begin{array}{l}1862-1906 \\
1907-1910 \\
1911-1925 \\
1903,1906\end{array}\right.$ & $\begin{array}{r}12,897,426 \\
14,371,072 \\
\end{array}$ & $\begin{array}{r}367,124,148 \\
85,425,417 \\
268,945,488 \\
31,000\end{array}$ & $\begin{array}{c}28.46 \\
-\overline{18.71} \\
-\overline{-}-\overline{-}\end{array}$ & $27,002,500$ & 3.74 \\
\hline \multicolumn{3}{|c|}{$\begin{array}{l}\text { Total production omitting figures for which no corresponding } \\
\text { tonnages are given. }\end{array}$} & $31,614,410$ & $\begin{array}{l}873,712,184 \\
730,585,498\end{array}$ & $\overline{2} 3 . \overline{11}$ & $29,242,500$ & 3.55 \\
\hline
\end{tabular}

Baltic amygdaloid

\begin{tabular}{|c|c|c|c|c|c|c|c|}
\hline \multirow{2}{*}{$\begin{array}{l}\text { Baltic } \\
\text { Trimountain } \\
\text { Champion }\end{array}$} & \multirow{4}{*}{$\begin{array}{l}\left\{\begin{array}{l}\text { Baltic Mining } \\
\text { Copper Range }\end{array}\right. \\
\text { \{opper Range } \\
\text { Trimountain Mining } \\
\text { Champion Copper } \\
\text { Superior Copper } \\
\text { Houghton Copper }\end{array}$} & \multirow{4}{*}{$\begin{array}{l}1898-1916 \\
1917-1925 \\
1924-1925 \\
1902-1923 \\
1902-1925 \\
1908-1920 \\
1915-1917\end{array}$} & $\begin{array}{l}8,672,553 \\
1,820612\end{array}$ & $200,584,164$ & 23. 13 & $\$ 7,950,000$ & 3.96 \\
\hline & & & & & 34.51 & a $2,084,772$ & 3. 23 \\
\hline $\begin{array}{l}\text { Champion } \\
\text { Superior } \\
\text { Houghton }\end{array}$ & & & $\begin{array}{r}6,703,079 \\
14,156,309 \\
1,550,474 \\
49,729\end{array}$ & $\begin{array}{r}1,343,303 \\
139,697,289 \\
438,403,286 \\
30,018,271 \\
540,052\end{array}$ & $\begin{array}{l}\text { 30. } 79 \\
\text { 20. } 84 \\
30.97 \\
19.36 \\
10.86\end{array}$ & $\begin{array}{r}3,250,000 \\
29,070,261 \\
649,000\end{array}$ & $\begin{array}{r}2.33 \\
6.75 \\
2.16 \\
\end{array}$ \\
\hline & & & $32,996,380$ & $873,525,912$ & 26. 50 & $43,004,033$ & 4. 93 \\
\hline
\end{tabular}


Production and dividends in Michigan copper district, 1845-1925, by lodes and mines-Continued

Osceola amygdaloid

\begin{tabular}{|c|c|c|c|c|c|c|c|}
\hline \multirow{3}{*}{ Mine } & \multirow{3}{*}{ Company } & \multirow{3}{*}{ Period } & \multicolumn{3}{|c|}{ Production } & \multicolumn{2}{|l|}{ Dividends } \\
\hline & & & \multirow{2}{*}{$\begin{array}{l}\text { Rock treated } \\
\text { (tons) }\end{array}$} & \multicolumn{2}{|c|}{ Refined copper (pounds) } & \multirow{2}{*}{ Total } & \multirow{2}{*}{$\begin{array}{c}\text { Per } \\
\text { pound } \\
\text { (cents) }\end{array}$} \\
\hline & & & & Total & Per ton & & \\
\hline $\begin{array}{l}\text { Osceola Branch.... } \\
\text { Osceola Branch.... } \\
\text { Osceola } \\
\text { Osceola Branch. }\end{array}$ & $\begin{array}{l}\text { Calumet \& Hecla } \\
\text { Centennial Copper Mining } \\
\text { Osceola Consolidated } \\
\text { Tamarack Mining }\end{array}$ & $\left\{\begin{array}{c}1904-1925 \\
1891 \\
1892 \\
1897-1900 \\
1897-1923\end{array}\right.$ & $\begin{array}{r}14,598,914 \\
28,531 \\
9,513,943 \\
9,562\end{array}$ & $\begin{array}{r}213,817,584 \\
531,983 \\
106,801 \\
1,917,901 \\
190,787,393 \\
a 9,237,000\end{array}$ & $\begin{array}{l}14.65 \\
18.64 \\
12.48 \\
20.05\end{array}$ & a $\$ 14,789,825$ & $-\cdots$ \\
\hline $\begin{array}{l}\text { Total production on } \\
\text { tonnages are giver }\end{array}$ & itting figures for which no co & rresponding & $24,295,050$ & $\begin{array}{l}416,398,662 \\
407,054,861\end{array}$ & 16.75 & a $14,789,825$ & 3. 55 \\
\hline
\end{tabular}

Isle Royale amygdaloid

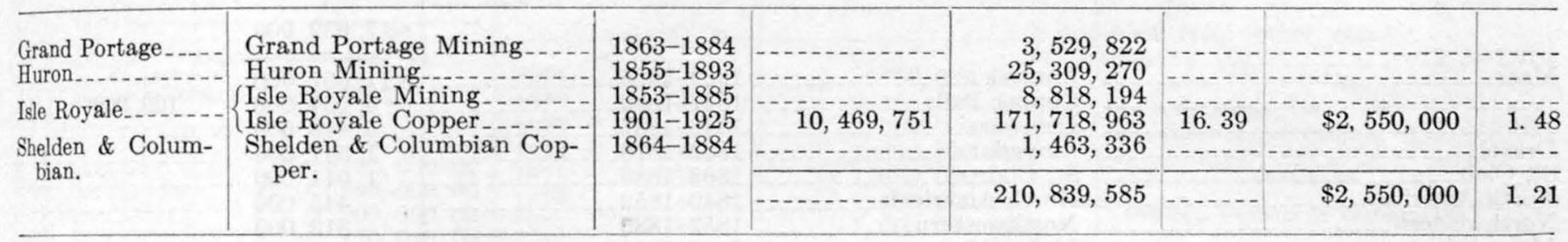

Ashbed (=Atlantic) amygdaloid

Arnold

Ashbed

Atlantic

Copper Falls

Garden City

Petherick

Phoenix.

(1...........

South Pewabic

Total production omitting figures for which no corresponding tonnages are given.
Arnold Mining-

Atlantic Mining

Copper Falls Mining

Garden City Mining

Petherick Mining

Phoenix Consolidated Cop-

per.

South Pewabic Mining .....

\begin{tabular}{|c|c|c|}
\hline $1898-1900$ & & $1,772,231$ \\
\hline 1881-1884 & & в 78,957 \\
\hline $1873-1910$ & $8,714,452$ & $118,282,028$ \\
\hline $1858-1893$ & - n & a $17,706,352$ \\
\hline $1859-1866$ & $\ldots \ldots$ & 75,397 \\
\hline $1862-1877$ & $\ldots .$. & в 556,424 \\
\hline $\begin{array}{c}1855-1862 \\
1865\end{array}$ & & a 357,032 \\
\hline $1916-1917$ & 48,063 & 449,416 \\
\hline $366-1870$ & $\cdots-\cdots$ & $3,562,967$ \\
\hline & 8,762 & $\begin{array}{l}142,840 \\
118,731\end{array}$ \\
\hline
\end{tabular}

1898-1900

1873-1910

$1858-1893$

1862-1877

185-1862,

1916-1917

$8,762,515$

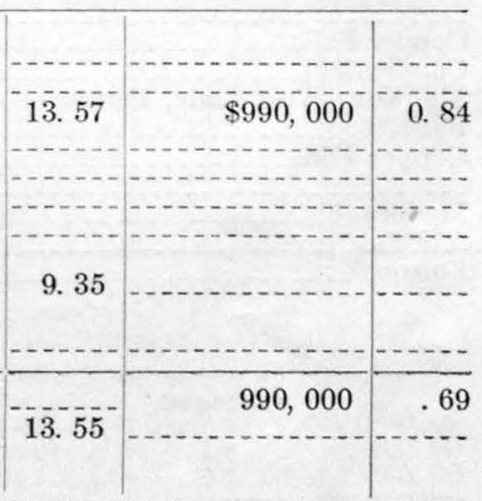

Allouez conglomerate

Albany \& Boston.

Allowez . -

Delaware

Franklin Junior

Peninsula
Albany \& Boston Mining ...

Allouez Mining

Conglomerate Mining .... $1882-1885$

Franklin Mining _ 1901-1919

Peninsula Mining-

\begin{tabular}{|r|r|r|r|r|}
$1865-1882$ & & 861,057 & & \\
$1869-1892$ & $\ldots$ &
\end{tabular}

Nonesuch lode

Nonesuch.

White Pine
Nonesuch
White Pine Copper
$1868-1885$

$1915-1920$

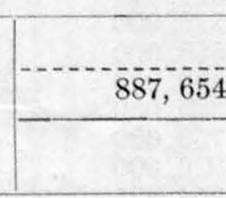

\begin{tabular}{r|r|r|r|}
389,556 & -5.54 & $33,437.50$ & 0.18 \\
\hline $18,233,169$ & 20.54 & $33,437.50$ & 0.18
\end{tabular}


Production and dividends from fissures in Michigan copper districts, 1845-1925

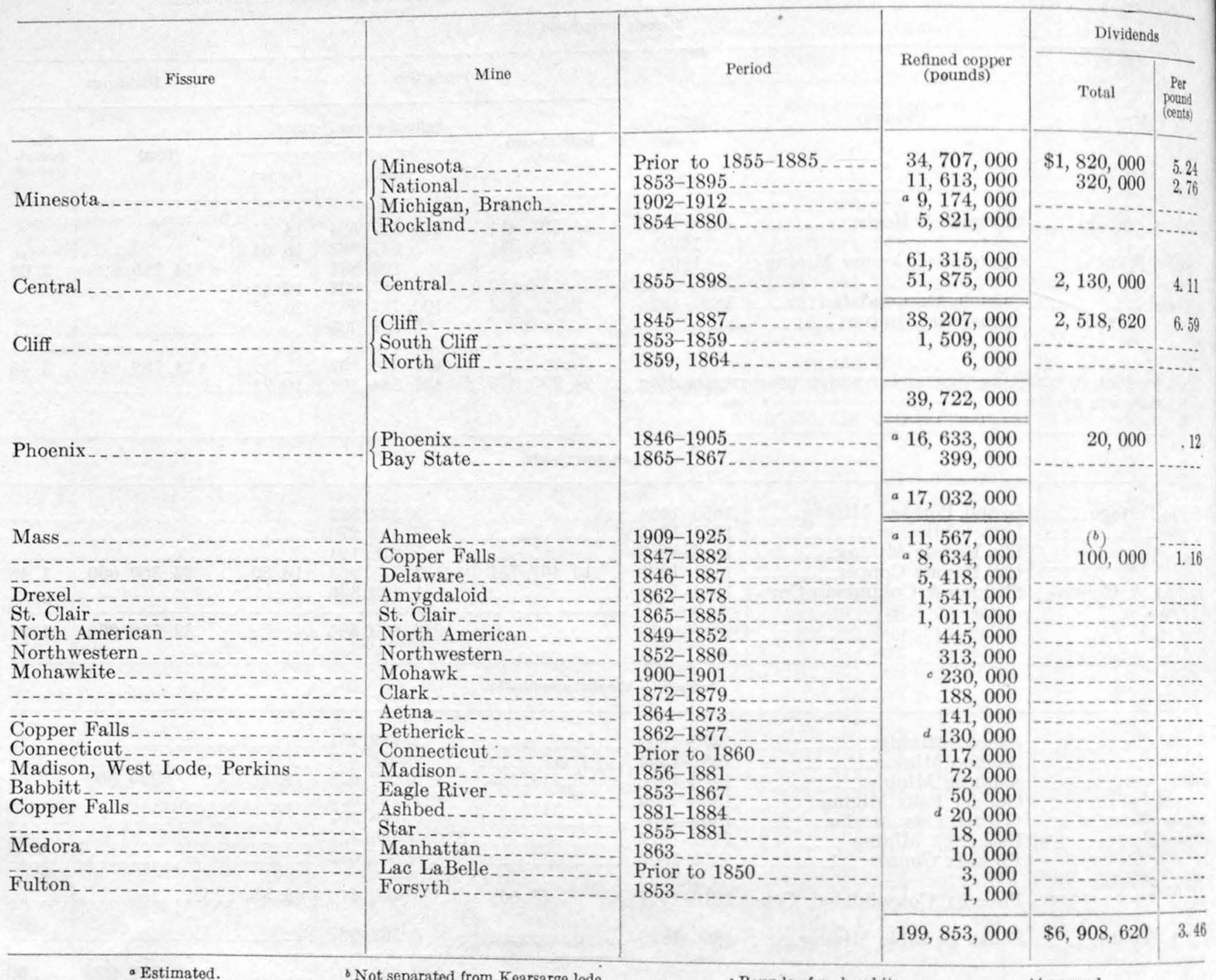

Dividends paid in Michigan copper district, 1845-1925

\begin{tabular}{|c|c|c|}
\hline Company & Period & Dividends \\
\hline Ahmeek & $1911-1923$ & $\$ 14,050,000$ \\
\hline Allouez & $1915-1919$ & $2,850,000$ \\
\hline Atlantic & $1878-1905$ & 990,000 \\
\hline Baltic $\ldots \ldots \ldots \ldots$ & $1905-1913$ & $7,950,000$ \\
\hline Calumet \& Hecla & $1869-1925$ & a $160,963,755$ \\
\hline Centennial $\ldots$ & $1916-1918$ & 360,000 \\
\hline Central _... & $1864-1905$ & $2,130,000$ \\
\hline Champion & $1903-1925$ & $29,070,260.96$ \\
\hline $\begin{array}{l}\text { Copper Falls } \\
\text { Copper Range }\end{array}$ & $1864-1871$ & 100,000 \\
\hline $\begin{array}{l}\text { Copper Range } \\
\text { Franklin }\end{array}$ & $1905-1925$ & b $28,576,646$ \\
\hline $\begin{array}{l}\text { Franklin } \\
\text { Isle Royale. }\end{array}$ & $1863-1894$ & $1,240,000$ \\
\hline $\begin{array}{l}\text { Sile Royale. } \\
\text { Kearsarge }\end{array}$ & $1913-1925$ & $2,550,000$ \\
\hline $\begin{array}{l}\text { Mearsarge } \\
\text { Minesota }\end{array}$ & $1890-1897$ & 160,000 \\
\hline Mohawk & $\begin{array}{l}1854-1876 \\
1906-1925\end{array}$ & $1,820,000$ \\
\hline 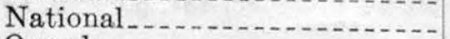 & $\begin{array}{l}1906-1925 \\
1861-1872\end{array}$ & $10,750,000$ \\
\hline Osceola_. & $1878-1923$ & $\begin{array}{r}320,000 \\
18,044,825\end{array}$ \\
\hline
\end{tabular}

\begin{tabular}{|c|c|c|}
\hline Company & Period & Dividends \\
\hline Pewabic & $1862-1895$ & $\$ 1,000,000$ \\
\hline Phoenix & 1877 & 20,000 \\
\hline Pittsburgh \& Bostun... & $1849-1879$ & $2,518,620$ \\
\hline Quincy ........................ & $1862-1920$ & $27,002,500$ \\
\hline Ridge & $1873-1881$ & 100,000 \\
\hline Superior & $1916-1922$ & 649,000 \\
\hline Tamarack...... & $1888-1907$ & $9,420,000$ \\
\hline Trimountain & $1903-1919$ & $3,250,000$ \\
\hline White Pine.... & $1917-1918$ & $33,437.50$ \\
\hline Wolverine & $1898-1920$ & $10,350,000$ \\
\hline \multirow{3}{*}{\multicolumn{2}{|c|}{$\begin{array}{l}\text { Duplication (estimated dividends paid from } \\
\text { dividends received from other companies }{ }^{c} \text { ) } \\
\text { Estimated dividends paid from ac- } \\
\text { tual mining operations }\end{array}$}} & $335,969,044.46$ \\
\hline & & $39,042,578.00$ \\
\hline & & $297,226,466.46$ \\
\hline
\end{tabular}


Dividends paid in Michigan copper district, 1845-1925, by companies and years

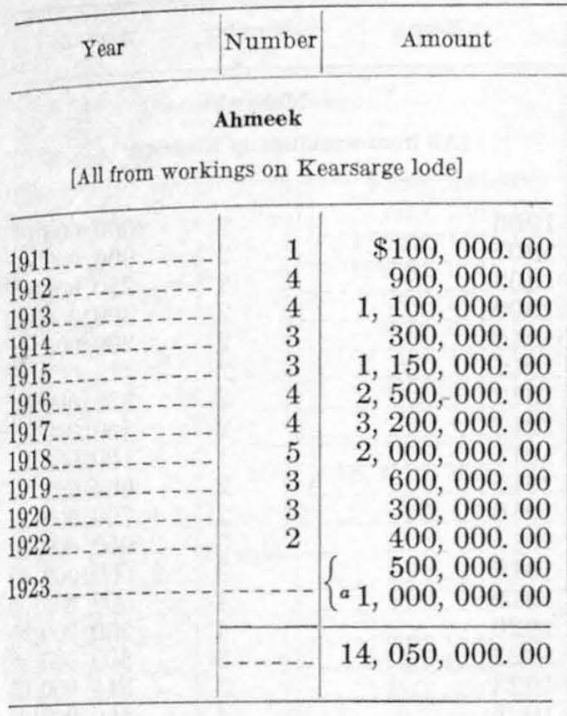

\section{Allouez}

[All from workings on Kearsarge lode]

\begin{tabular}{r|r|r}
\hline $1915 \ldots$ & $\cdot$ & $\$ 100,000.00$ \\
$1916 \ldots$ & 4 & $700,000.00$ \\
$1918 \ldots 19$ & 4 & $1,200,000.00$ \\
& 5 & $750,000.00$ \\
1 & $100,000.00$ \\
\hline & 15 & $2,850,000.00$ \\
\hline \multicolumn{3}{|c}{ Atlantic }
\end{tabular}

[All from workings on Atlantic (Ashbed) amygdaloid]

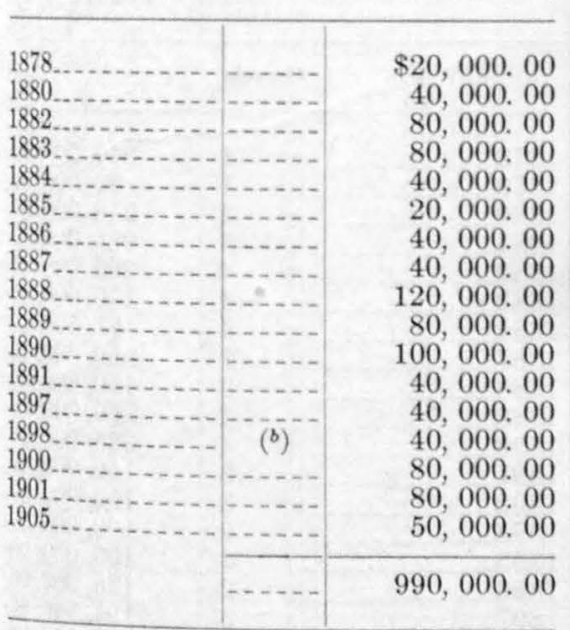

\section{Baltic}

[All from workings on Baltic lode]

\begin{tabular}{r|r|r}
\hline $1905 \ldots$ & $\$ 1,250,000.00$ \\
1906 & $1,400,000.00$ \\
1908 & $1,000,000.00$ \\
1909 & $900,000.00$ \\
1910 & $1,000,000.00$ \\
1911 & $1,000,000.00$ \\
1912 & $500,000.00$ \\
& $200,000.00$ \\
\hline . Liquidating. & & \\
\hline
\end{tabular}

\begin{tabular}{|c|c|c|}
\hline Year & Number & A mount \\
\hline \multicolumn{3}{|c|}{$\begin{array}{l}\text { Calumet \& Hecla } \\
\text { CALUMET MINING }\end{array}$} \\
\hline \multirow[t]{2}{*}{$\begin{array}{l}1870 \\
1871 \ldots\end{array}$} & $\begin{array}{l}2 \\
1\end{array}$ & $\begin{array}{r}\$ 200,000.00 \\
100,000.00\end{array}$ \\
\hline & 3 & $300,000.00$ \\
\hline
\end{tabular}

\begin{tabular}{r|r|r}
\hline $1869 \ldots$ & 1 & $\$ 100,000,00$ \\
$1870 \ldots 00.00$ \\
\end{tabular}

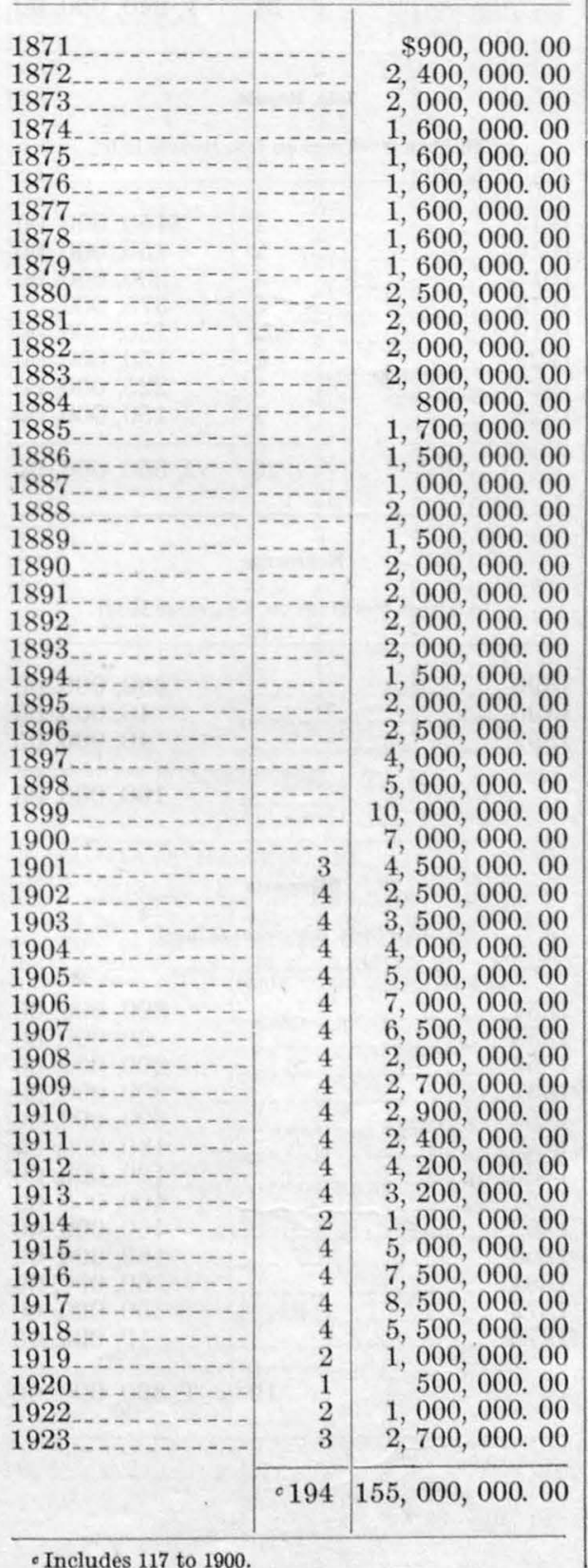

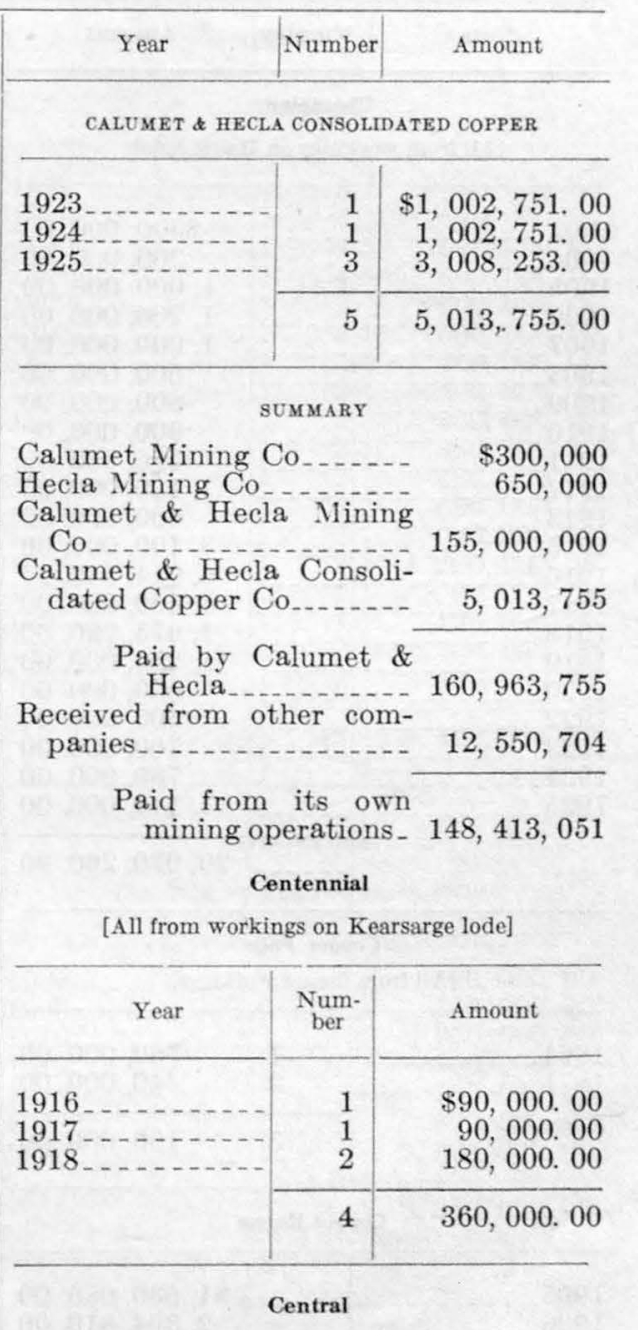

[All from fissure workings]

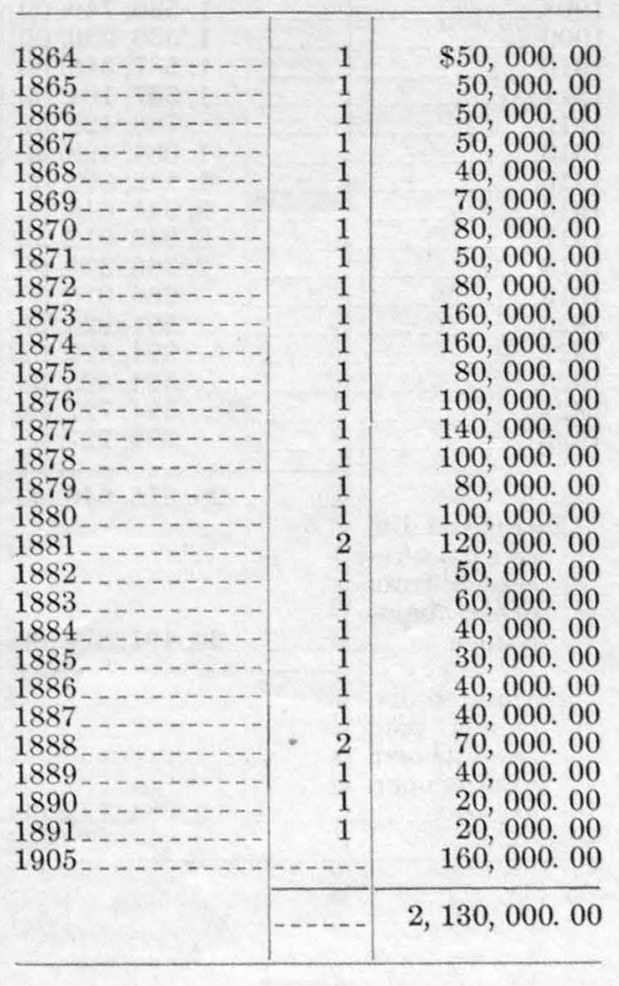


Dividends paid in Michigan copper district, 1845-1925, by companies and years - Continued

\begin{tabular}{c|c|c|}
\hline Year & Number $\mid$ Amount \\
\hline & Champion
\end{tabular}

[All from workings on Baltic lode]

\begin{tabular}{r|r}
\hline 1903 & $\begin{array}{r}\$ 300,000.00 \\
200,000.00\end{array}$ \\
1904 & $1,000,000.00$ \\
1905 & $1,200,000.00$ \\
1906 & $1,000,000.00$ \\
1908 & $500,000.00$ \\
1909 & $800,000.00$ \\
1910 & $900,000.00$ \\
1911 & $500,000.00$ \\
1912 & $1,100,000.00$ \\
1915 & $900,000.00$ \\
1916 & $3,100,000.00$ \\
1917 & $6,014,540.96$ \\
1918 & $480,000.00$ \\
1919 & $1,975,720.00$ \\
1920 & $1,280,000.00$ \\
1922 & $600,000.00$ \\
1923 & $600,000.00$ \\
1925 & $700,000.00$ \\
& $780,000.00$ \\
& $1,140,000.00$ \\
\hline & $29,070,260.96$
\end{tabular}

Copper Falls

[All from fissure workings]

\begin{tabular}{r|r|r}
\hline $1864 \ldots 00,000.00$ \\
$1871 \ldots 000.00$ \\
\hline
\end{tabular}

\begin{tabular}{|c|c|}
\hline \multicolumn{2}{|c|}{ Copper Range } \\
\hline $\begin{array}{l}1905 \\
1906 \\
1907 \\
1908 \\
1909 \\
1911 \\
1912 \\
1913 \\
1915 \\
1916 \\
1918 \\
1919 \\
1920 \\
1923 \\
1924 \\
1925\end{array}$ & $\begin{array}{r}\$ 1,536,086.00 \\
2,304,810.00 \\
2,304,810.00 \\
1,536,740.00 \\
1,536,930.00 \\
1,537,340.00 \\
1,357,104.00 \\
788,428.50 \\
1,084,498.00 \\
1,182,003.00 \\
3,941,648.00 \\
3,943,912.50 \\
2,366,394.00 \\
986,015.50 \\
591,625.50 \\
394,422.00 \\
394,425.00 \\
394,727.00 \\
394,727.00\end{array}$ \\
\hline $\begin{array}{l}\text { Estimated div- } \\
\text { id end s re- } \\
\text { ceived from } \\
\text { other com- } \\
\text { panies }\end{array}$ & $28,576,646.00$ \\
\hline $\begin{array}{l}\text { Estimated div- } \\
\text { idends paid } \\
\text { from its own } \\
\text { mining oper- } \\
\text { ations }\end{array}$ & $2,084,772.00$ \\
\hline
\end{tabular}

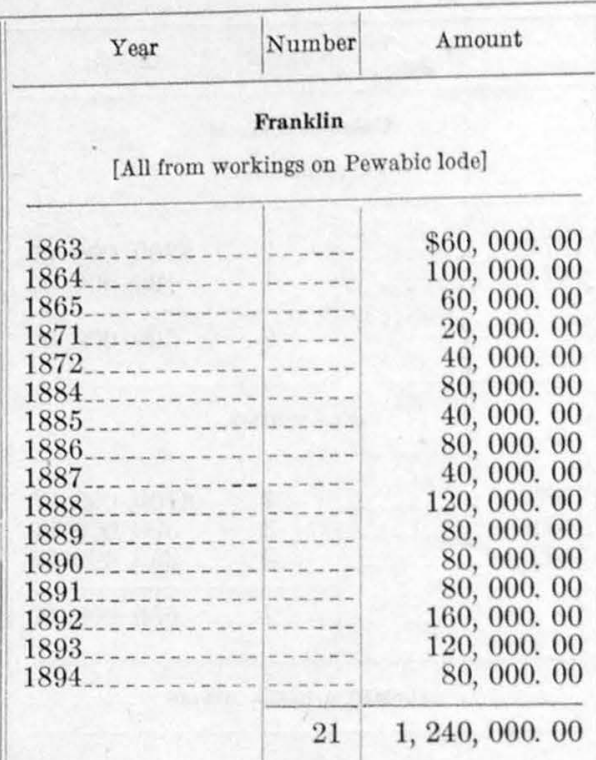

Isle Royale

[All from workings on Isle Royale lode]

\begin{tabular}{l|r|r}
\hline 1913 & 1 & $\$ 150,000.00$ \\
1916 & 2 & $450,000.00$ \\
1917 & 4 & $900,000.00$ \\
1918 & 5 & $375,000.00$ \\
1919 & 2 & $150,000.00$ \\
1922 & 2 & $150,000.00$ \\
1925 & 3 & $225,000.00$ \\
& 1 & $150,000.00$ \\
\hline & 20 & $2,550,000.00$ \\
\hline
\end{tabular}

\section{Kearsarge}

[All from workings on Kearsarge lode]

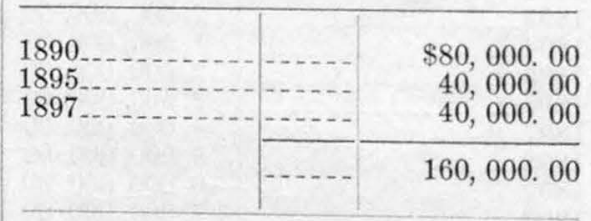

\section{Minesota}

[All from fissure workings]

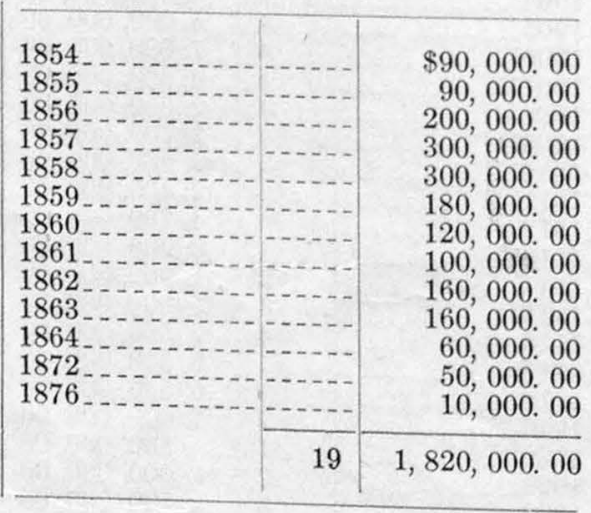

Year

$\mid$ Number Amount
Mohawk

[All from workings on Kearsarge lode]

\begin{tabular}{l|r|r}
\hline 1906 & 2 & $\$ 500,000.00$ \\
1907 & 2 & $900,000.00$ \\
1908 & 1 & $250,000.00$ \\
1909 & 2 & $300,000.00$ \\
1910 & 2 & $200,000.00$ \\
1911 & 2 & $175,000.00$ \\
1912 & 2 & $350,000.00$ \\
1913 & 2 & $500,000.00$ \\
1914 & 1 & $100,000.00$ \\
1915 & 2 & $600,000.00$ \\
1916 & 2 & $1,700,000.00$ \\
1917 & 3 & $2,050,000.00$ \\
1918 & 3 & $1,000,000.00$ \\
1919 & 4 & $500,000.00$ \\
1920 & 3 & $550,000.00$ \\
1922 & $300,000.00$ \\
1923 & 3 & $315,000.00$ \\
1925 & 4 & $460,000.00$ \\
& & \\
& 44 & $10,750,000.00$ \\
\end{tabular}

National

[All from fissure workings]

\begin{tabular}{l|l|r}
\hline $1861 \ldots$ & 2 & $\$ 80,000.00$ \\
1862 & 2 & $80,000.00$ \\
$1864 \ldots 000.00$ \\
1865 & 2 & $80,000.00$ \\
1871 & 1 & $40,000.00$ \\
1872 & 1 & $20,000.00$ \\
& 1 & $20,000.00$ \\
\hline & 9 & $320,000.00$ \\
\hline
\end{tabular}

Osceola

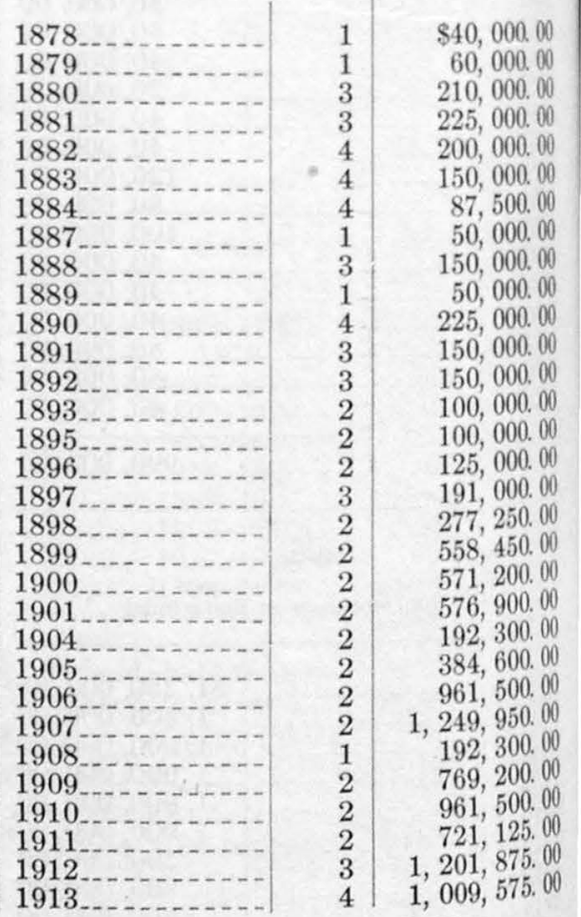


Dividends paid in Michigan copper district, 1845-1925, by companies and years-Continued

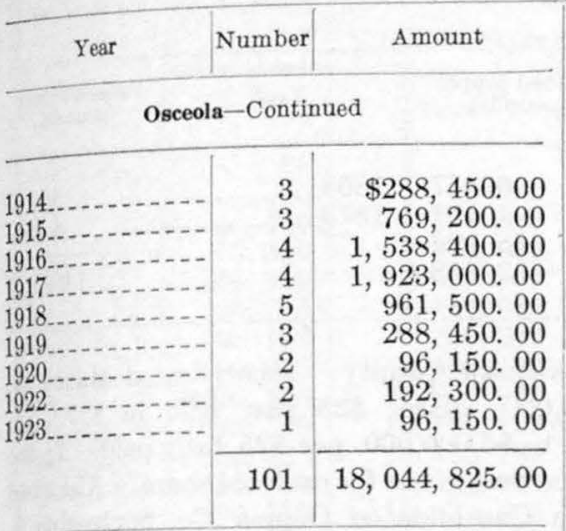

Pewabic

\begin{tabular}{|r|r|r}
\hline $1862 \ldots$ & 1 & $\$ 60,000.00$ \\
$1863 \ldots 4 \ldots$ & 2 & $120,000.00$ \\
$1871 \ldots$ & 2 & $200,000.00$ \\
$1872 \ldots$ & 1 & $20,000.00$ \\
$1873 \ldots$ & 2 & $40,000.00$ \\
1895 & 1 & $20,000.00$ \\
& $400,000.00$ \\
& & $140,000.00$ \\
\hline
\end{tabular}

Phoenix

\begin{tabular}{l|l|l}
\hline $1877 \ldots \ldots$ & 1 & $\$ 20,000.00$
\end{tabular}

Pittsburgh \& Boston

[All from workings on Cliff fissure]

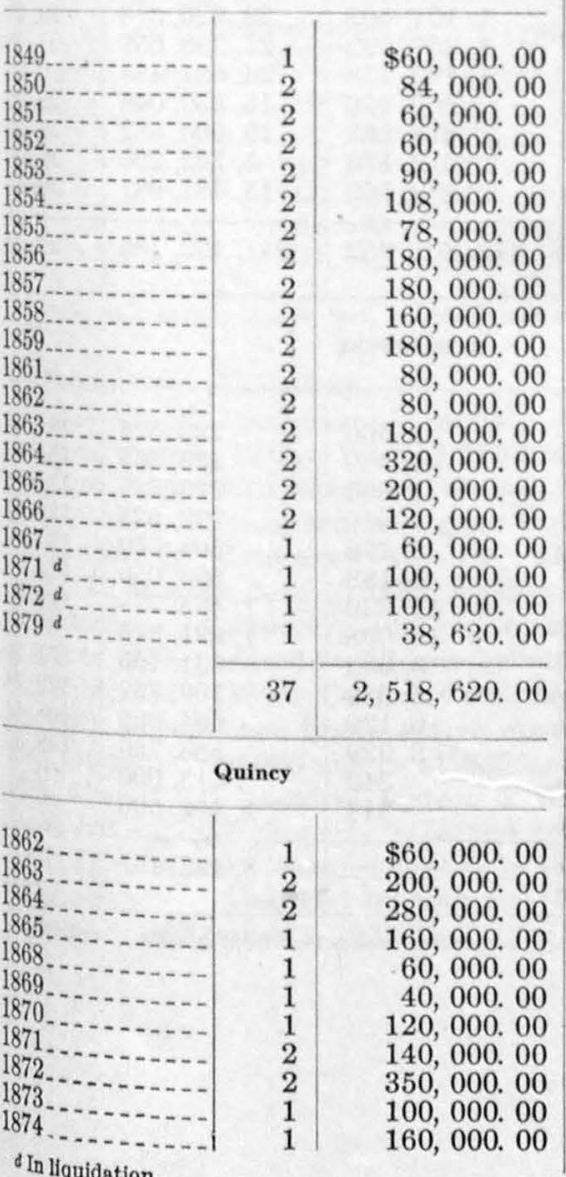

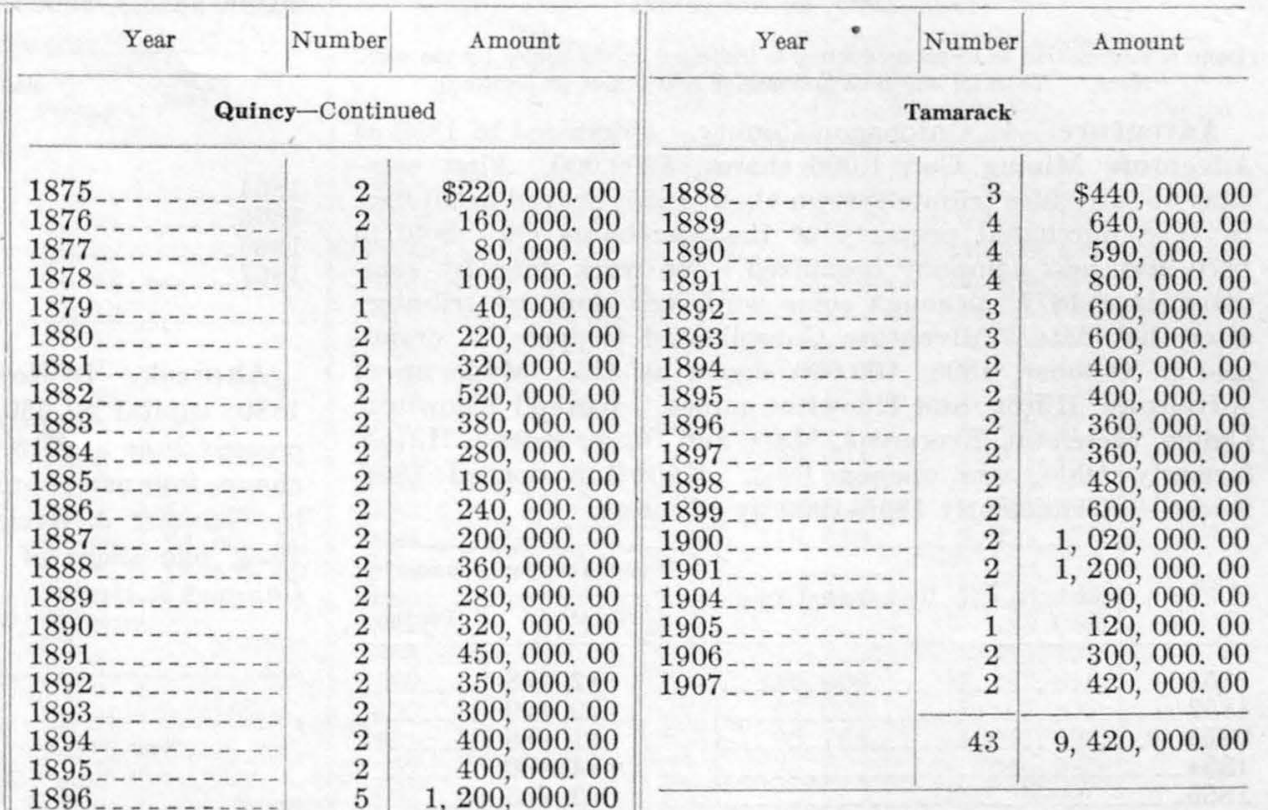

$1,200,000.00$ $650,000.00$ $950,000.00$ $900,000.00$ $900,000.00$ 700, 000. 00 $550,000.00$ 500, 000. 00 $600,000.00$ $1,250,000.00$

$1,485,000.00$ $495,000.00$ 440, 000. 00 $550,000.00$ $440,000.00$ $550,000.00$ $412,500.00$ $55,000.00$ $880,000.00$

$1,760,000.00$

1, $980,000.00$

$935,000.00$ $440,000.00$ $110,000.00$

1919

1920

$13027,002,500.00$ Note.-Copper Handbook, 1922, says: "Year 1918
marked Quiney's seventieth anniversary. During this marked Quincy's seventieth anniversary. During this and still had $\$ 2,803,124$ cash surplus; this is equivalent to a profit of $41 / 3$ cents on each of $613,596,622$ pounds to a pront of $41 / 3$ cents on each of entire 70 years of 16.13 cents, equal to $\$ 98,973,406$."

Ridge

\begin{tabular}{|c|c|c|}
\hline \multirow[t]{2}{*}{$\begin{array}{l}1873 \ldots \ldots \\
1874 \ldots \\
1875\end{array}$} & $\begin{array}{r}1 \\
1 \\
1 \\
1\end{array}$ & $\begin{array}{l}50,000.00 \\
20,000.00 \\
20,000.00 \\
10,000.00\end{array}$ \\
\hline & 4 & $100,000.00$ \\
\hline \multicolumn{3}{|c|}{ Superior } \\
\hline \multirow[t]{2}{*}{$\begin{array}{l}1916 \\
1917 \\
1922 \\
1925\end{array}$} & 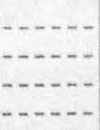 & $\begin{array}{r}100,000.00 \\
100,000.00 \\
+200,000.00 \\
+249,000.00\end{array}$ \\
\hline & $\ldots$ & $649,000.00$ \\
\hline
\end{tabular}

Trimountain

[All from workings on Baltic lode]

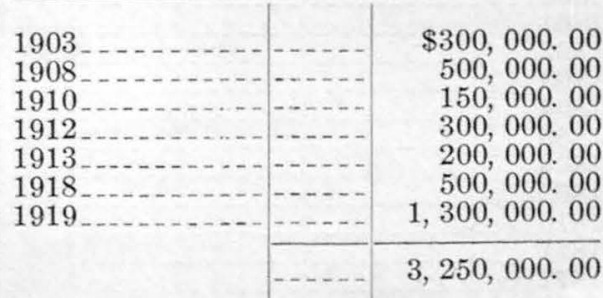

White Pine

\begin{tabular}{r|r}
\hline 1917 & $\$ 29,062.50$ \\
$4,375.00$ \\
\hline
\end{tabular}

\begin{tabular}{|c|c|c|}
\hline $1898 \ldots$ & 1 & $\$ 60,000.00$ \\
\hline $1899 \ldots \ldots$ & 2 & $210,000.00$ \\
\hline $1900 \ldots$ & 2 & $240,000.00$ \\
\hline ........... & 2 & $240,000.00$ \\
\hline 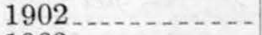 & 2 & $240,000.00$ \\
\hline (n) & 2 & $330,000.00$ \\
\hline . & 2 & $450,000.00$ \\
\hline 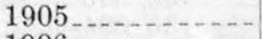 & 2 & $660,000.00$ \\
\hline$\ldots \ldots$ & 2 & $1,020,000.00$ \\
\hline . & 2 & $1,050,000.00$ \\
\hline n. & 2 & $600,000.00$ \\
\hline$\ldots \ldots$ & 2 & $600,000.00$ \\
\hline - & 2 & $600,000.00$ \\
\hline non & 2 & $540,000.00$ \\
\hline $1912 \ldots$ & 2 & $600,000.00$ \\
\hline $1913 \ldots$ & 1 & $300,000.00$ \\
\hline $1914 \ldots \ldots$ & 1 & $120,000.00$ \\
\hline $1915 \ldots \ldots$ & 2 & $540,000.00$ \\
\hline $1916 \ldots$ & 2 & $720,000.00$ \\
\hline $1917 \ldots$ & 3 & $810,000.00$ \\
\hline $1918 \ldots$ & 2 & $240,000.00$ \\
\hline $1919 \ldots$ & 4 & $150,000.00$ \\
\hline \multirow[t]{2}{*}{$1920 \ldots$} & 1 & $30,000.00$ \\
\hline & 45 & $10,350,00$ \\
\hline
\end{tabular}


Detailed statistics of production in Michigan copper district, 1845-1925, by companies

[Definite information as to no production is indieated in the tables by the word "None." Years for which no information is available are omitted]

Adventure.- In Ontonagon County. Organized in 1850 as Adventure Mining Co.; 1,000 shares, $\$ 200,000$. First company to introduce tribute system about 1855 ; proved profitable. In 1858 purchased property of the Merchants Co. Sold in 1870 and new company organized. No work done by company since 1877 , although some work was done by tributers after that date. Adventure Consolidated Copper Co. organized in October, $1898 ; 100,000$ shares at $\$ 25$. Made up of Adventure, Hilton, and Knowlton mines. Worked Knowlton, Ogima, Merchant, Evergreen, Mass, and Butler lodes. Hilton, formerly Ohio, was opened 1863. Knowlton opened 1860, worked intermittently $1865-1900$ by tributers.

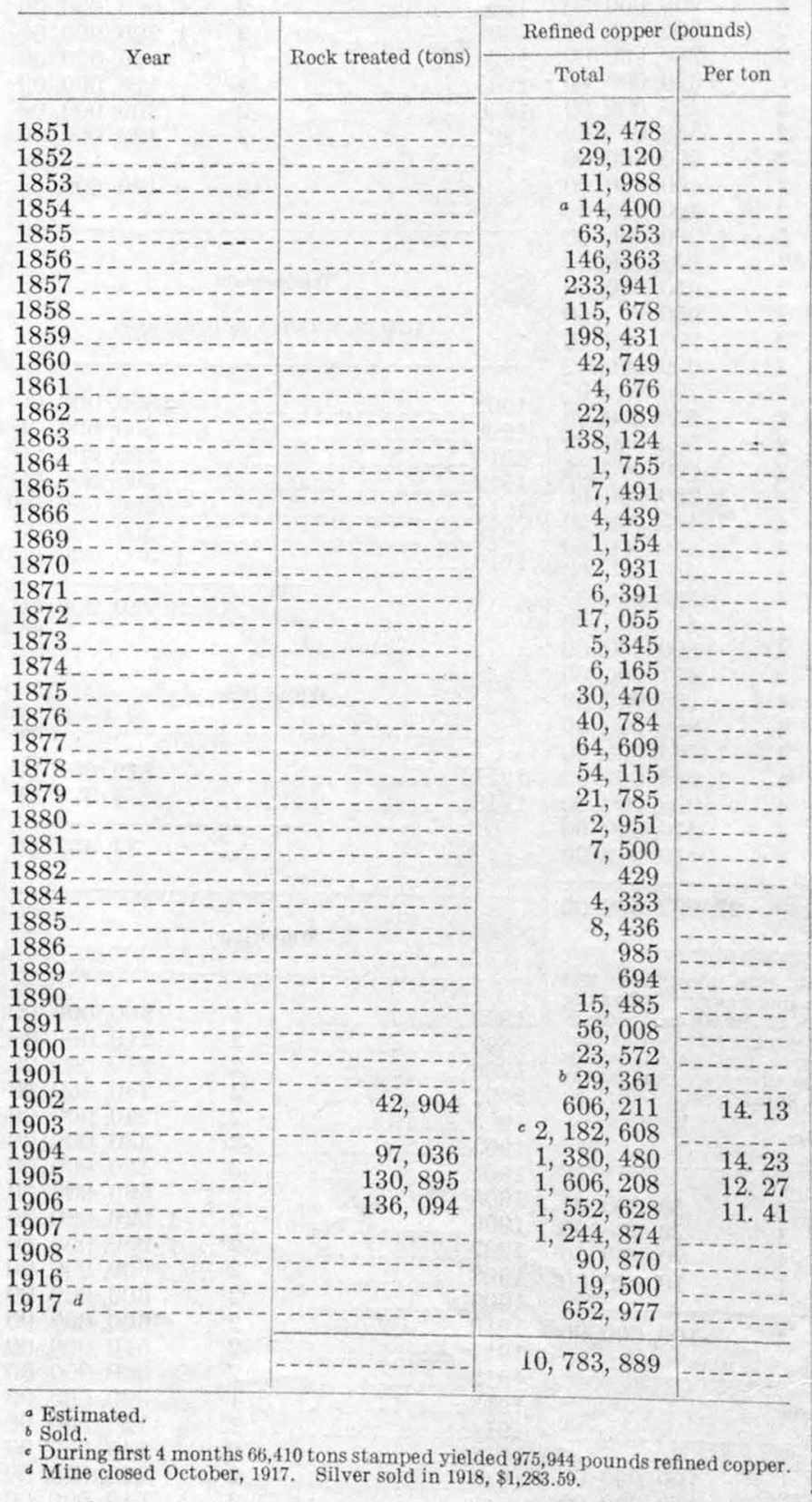

Aetna.- In Keweenaw County. Organized January, 1864; 20,000 shares, $\$ 500,000$.

\begin{tabular}{r|r||r|r}
\hline Year & $\begin{array}{c}\text { Refined copper } \\
\text { (pounds) }\end{array}$ & Year & $\begin{array}{r}\text { Refined copper } \\
\text { (pounds) }\end{array}$ \\
\hline & 6,857 & $1868 \ldots$ & 3,389 \\
$1864 \ldots 5$ & 4,131 & $1873 \ldots$ & 4,650 \\
\hline 1866 & 58,996 & & 140,881 \\
\hline 1867 & 62,858 & & \\
\hline
\end{tabular}

Ahmeek. - In Keweenaw County. Incorporated March 22, 1880 ; capital $\$ 1,250,000$, shares $\$ 25$ par, paid in $\$ 17$. In. creased June 8,1915 , to $\$ 5,000,000$, par $\$ 25$, fully psid. In the change four new shares were given for each old share. Absorbed by Calumet \& Hecla Consolidated Copper Co. September 1, 1923, one share of Ahmeek being given for 2.68 shares of Calumet \& Hecla. REARSARGE AMYGDALOID

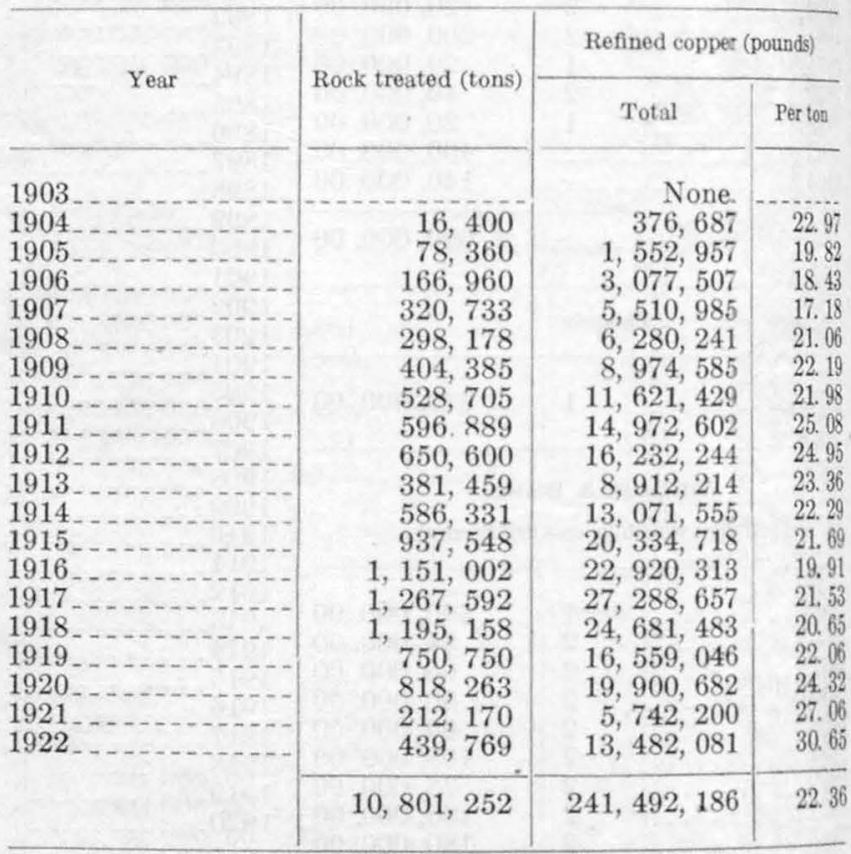

MASS FISSURE

\begin{tabular}{r|r|r|r}
\hline 1909 & 1,660 & 223,525 & 134.65 \\
1910 & 1,660 & 223,525 & 134.65 \\
1911 & 1,660 & 223,525 & 134.65 \\
1912 & 1,660 & 223,525 & 134.65 \\
1913 & 2,290 & 308,660 & 134.79 \\
1914 & 4,188 & 563,050 & 134.44 \\
1916 & 11,326 & $1,465,774$ & 129.42 \\
1917 & 13,008 & $1,221,845$ & 93.93 \\
$1918 \ldots 19$ & 3,683 & 631,155 & 171.37 \\
1919 & 1,383 & 169,752 & 122.74 \\
$1920 \ldots$ & 6,120 & 664,065 & 108.51 \\
1922 & 3,929 & 588,756 & 149.85 \\
& 342 & 513,000 & $(a)$ \\
\hline
\end{tabular}

a No rock from fissure stamped; entire production from masses. Percentage d copper, 1921, 75; 1922, 76.75. 


\begin{tabular}{|c|c|c|c|c|}
\hline \multirow{2}{*}{ Year } & \multirow{2}{*}{$\begin{array}{l}\text { Rock stamped } \\
\text { (tons) }\end{array}$} & \multicolumn{2}{|c|}{ Refined copper (pounds) } & \multirow{2}{*}{ Silver sold } \\
\hline & & Total & Per ton & \\
\hline $\begin{array}{l}1903 \ldots \\
1904 \ldots \\
1905 \ldots \\
1906 \ldots \\
1907 \ldots \\
1908 \ldots \\
1909 \ldots \\
1910 \ldots \\
1911 \ldots \\
1912 \ldots \\
1913 \ldots \\
1914 \ldots \\
1915 \ldots \\
1916 \ldots \\
1917 \ldots \\
1918 \ldots \\
1919 \ldots \\
1920 \ldots \\
1921 \ldots \\
1922 \ldots \\
1923 \text { a } \ldots\end{array}$ & $\begin{array}{r}16,400 \\
78,360 \\
166,960 \\
320,733 \\
298,178 \\
406,045 \\
530,365 \\
598,549 \\
652,260 \\
383,749 \\
590,519 \\
948,874 \\
1,164,010 \\
1,271,275 \\
1,196,541 \\
756,870 \\
822,192 \\
212,170 \\
439,769\end{array}$ & $\begin{array}{r}\text { None. } \\
376,687 \\
1,552,957 \\
3,077,507 \\
5,510,985 \\
6,280,241 \\
9,198,110 \\
11,844,954 \\
15,196,127 \\
16,455,769 \\
9,220,874 \\
13,634,605 \\
21,800,492 \\
24,142,158 \\
27,919,812 \\
24,851,235 \\
17,223,111 \\
20,489,438 \\
6,255,200 \\
14,885,081 \\
17,811,031 \\
\end{array}$ & $\begin{array}{l}\text { 22. } 97 \\
\text { 19. } 82 \\
\text { 18. } 43 \\
\text { 17. } 18 \\
21.1 \\
22.7 \\
22.33 \\
25.4 \\
25.2 \\
24.0 \\
23.1 \\
23.0 \\
20.7 \\
22.0 \\
20.8 \\
22.8 \\
24.9 \\
29.48 \\
33.85 \\
-\cdots\end{array}$ & \begin{tabular}{l} 
\\
$14,026.54$ \\
$16,503.60$ \\
$16,171.37$ \\
\\
\hdashline
\end{tabular} \\
\hline & & $267,726,374$ & & $\cdots$ \\
\hline
\end{tabular}

- To Ang. 31 .

Albany $\&$ Boston.-In Houghton County. Organized June, $1860 ; 20,000$ shares, $\$ 500,000$. In spring of 1862 most of the work suspended in this location. Resumed late in 1862 and continued actively in 1863. Worked Pewabic amygdaloid. About 1864 worked "Albany \& Boston". (Allouez) conglomerate. Sold to Peninsula Copper Mining Co. in 1882, and to Franklin Mining Co. in 1895; mine now known as Franklin Jr.

\begin{tabular}{|c|c|c|c|}
\hline Year & $\begin{array}{l}\text { Refined copper } \\
\text { (pounds) }\end{array}$ & Year & $\begin{array}{l}\text { Refned copper } \\
\text { (pounds) }\end{array}$ \\
\hline 1862. & 7,982 & 1873 & 66,200 \\
\hline 1864. & 7,000 & 1876 . & 6,018 \\
\hline 1865 & ${ }^{a} 318,160$ & 1877 & 11,998 \\
\hline $\begin{array}{l}1866 . \\
1867 .\end{array}$ & 163,906 & $1878 \ldots$ & 1,746 \\
\hline $1868 \ldots$ & 234,536 & & 880,039 \\
\hline
\end{tabular}

- During year ending March, 1866, produced and sold 271,200 pounds of ingot copper.

Albion.-See Manhattan.

Algomah.- In Ontonagon County. Algomah Mining Co. organized June 4, 1910. Worked $1852-1854$ by a company of the same name with negative results. No rock milled. In $1914,12,467$ pounds of refined copper from hand-picked ore.

Allouez. - In Keweenaw County. Organized September, 1859. Little work done to 1869 , when work began on Allouez conglomerate. Temporary suspension, and in 1871 work resumed to 1877. Leased to Allouez Tribute Co. for three years, November, 1877-1880. Company resumed control November 10,1880 , and at once began active operations. Reorganized with capital of 800,000 shares at $\$ 25$ and worked to June 1, 1885 , when it was leased to Watson \& Walls for term of three years, but in 1887 property attached by creditors and work stopped. Company resumed control in 1889 , and a reorganization was made. Absorbed by Calumet \& Hecla Consolidated Copper Co. September 1, 1923.

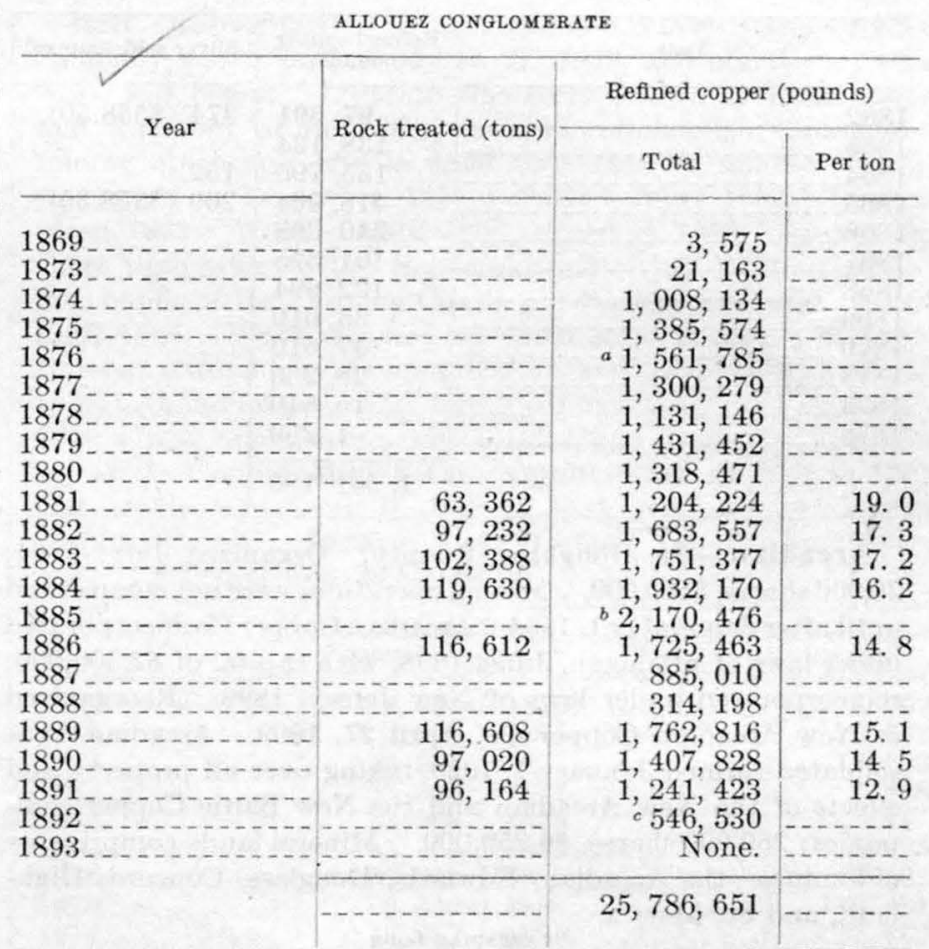

a During year ending July $1,1876,51,135$ tons stamped yielded $1,433,833$ pounds refined copper.

tons stamped by company produced $1,050,546$ pounds ingot, or 16.8 pounds

per ton; tributers produced $1,119,930$ pounds ingot.

KEARSARGE AMYGDALOID

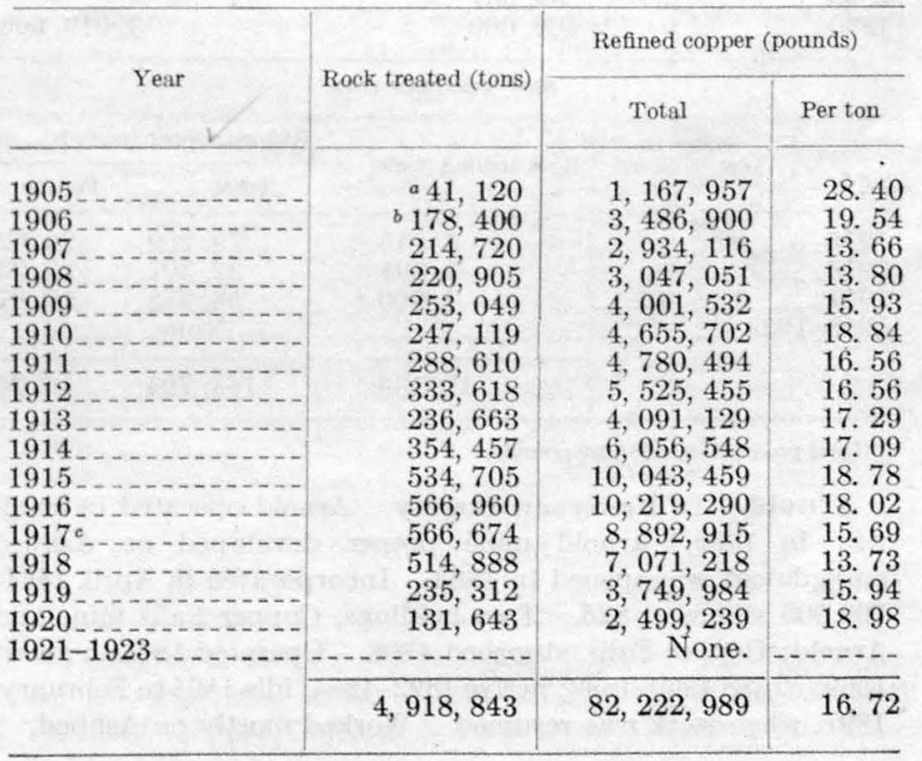

- Includes 4,895 tons from stock pile.

Includes 108 tons from stock pile.

- Silver sold, $\$ 22,589.24$.

Total production, $108,009,640$ pounds.

American.-See North American.

Amygdaloid. - In Keweenaw County. Organized July, $1860 ; 20,000$ shares, $\$ 500,000$. Company operations suspended in 1866 and mine worked on tribute. 


\begin{tabular}{|c|c|c|}
\hline Year & $\begin{array}{l}\text { Refined copper } \\
\text { (pounds) }\end{array}$ & Silver sold (ounces) \\
\hline $\begin{array}{l}1862 \\
1863 \\
1864 \\
1866 \\
1867 \\
1868 \\
1869 \\
1870 \\
1873 \\
1874 \\
1878\end{array}$ & $\begin{array}{r}97,591 \\
138,124 \\
135,795 \\
418,964 \\
340,668 \\
161,375 \\
122,694 \\
33,010 \\
47,610 \\
28,250 \\
15,840 \\
1,259 \\
1,541,180\end{array}$ & $\begin{array}{l}374(\$ 558.50) \text {. } \\
152 \text {. } \\
209(\$ 358.35) .\end{array}$ \\
\hline
\end{tabular}

Arcadian.- In Houghton County. Organized July, 1864; 20,000 shares, $\$ 500,000$. Mining operations were not commenced until after September 1, 1864. Areadian Copper Co. incorporatéd under laws of Michigan, June, 1898, with capital of $\$ 2,500,000$; reincorporated under laws of New Jersey, 1899. Reorganized as New Areadian Copper Co. April 27, 1909. Arcadian Consolidated formed January 1, 1920, taking over all property and effects of the New Areadian and the New Baltic Copper companies; 250,000 shares, $\$ 6,250,000$. Mineral lands comprise six old mines-the Arcadian, Edwards, Douglass, Concord, Highland, and St. Mary's.

ARCADIAN LODE

\begin{tabular}{|c|c|c|c|c|c|}
\hline Year & \multirow{2}{*}{$\begin{array}{r}\begin{array}{c}\text { Refined copper } \\
\text { (pounds) }\end{array} \\
4,593 \\
5,816 \\
24,760 \\
34,037 \\
500,000\end{array}$} & \multicolumn{2}{|c|}{ Year } & \multicolumn{2}{|c|}{$\begin{array}{l}\text { Refined copper } \\
\text { (pounds) }\end{array}$} \\
\hline $\begin{array}{l}1864 \\
1865 \\
1879 \\
1890\end{array}$ & & \multicolumn{2}{|c|}{$\begin{array}{l}1900 \ldots \\
1901 \\
1902\end{array}$} & \multicolumn{2}{|c|}{$\begin{array}{r}1,350,000 \\
500,000 \\
600,000\end{array}$} \\
\hline \multicolumn{6}{|c|}{ NEW ARCADIAN LODE } \\
\hline \multirow{2}{*}{ Year } & \multirow{2}{*}{\multicolumn{2}{|c|}{ Rock treated (tons) }} & \multicolumn{3}{|c|}{ Refined copper (pounds) } \\
\hline & & & Total & & Per ton \\
\hline \multirow[t]{2}{*}{$\begin{array}{l}1915 \\
1916 \\
1917 \\
1918-1925\end{array}$} & \multicolumn{2}{|c|}{$\begin{array}{l}3,845 \\
1,391 \\
4,900\end{array}$} & \multicolumn{2}{|c|}{$\begin{array}{c}79,209 \\
32,307 \\
53,278 \\
\text { None. }\end{array}$} & $\begin{array}{l}\text { 20. } 62 \\
23.23 \\
10.87 \\
\end{array}$ \\
\hline & \multicolumn{2}{|c|}{10,136} & \multicolumn{2}{|c|}{164,794} & 16. 26 \\
\hline
\end{tabular}

Total production, $3,184,000$ pounds.

Arnold.-In Keweenaw County. Arnold operated in small way in 1860. Arnold mine proper, developed on Ashbed amygdaloid, was opened in 1863 . Incorporated in April, 1864; 100,000 shares at $\$ 25$. Two holdings, Copper Falls mine and Arnold; Copper Falls, absorbed 1898. Operated 1863 to about 1869; closed 1869-1892; active 1892-1894; idle 1894 to February, 1897, when work was resumed. Worked mostly on Ashbed.

\begin{tabular}{c|c|c|}
\hline \multicolumn{1}{|c|}{ Year } & $\begin{array}{c}\text { Refined copper } \\
\text { (pounds) }\end{array}$ \\
\cline { 1 - 2 } & & 152,320 \\
\hline 1899 & 763,911 \\
\hline 1900 & 856,000 \\
\hline & & $1,772,231$ \\
\hline
\end{tabular}

Ashbed. - In Keweenaw County. Petherick Mining Co. organized April, 1861, by Copper Falls Mining Co. Worked 1861-1865 and suspended operations; resumed in 1872; became idle again in 1877. In 1873 Indiana mill purchased. In 1877 property closed out at sheriff's sale. In 1880 Ashbed Mining Co. organized; 40,000 shares at $\$ 25$. Work resumed in 1881 and discontinued in 1882, producing a few tons of copper. Between 1898 and 1900 exploratory work carried on; idle in 1900. In June, 1905, resumed activity.

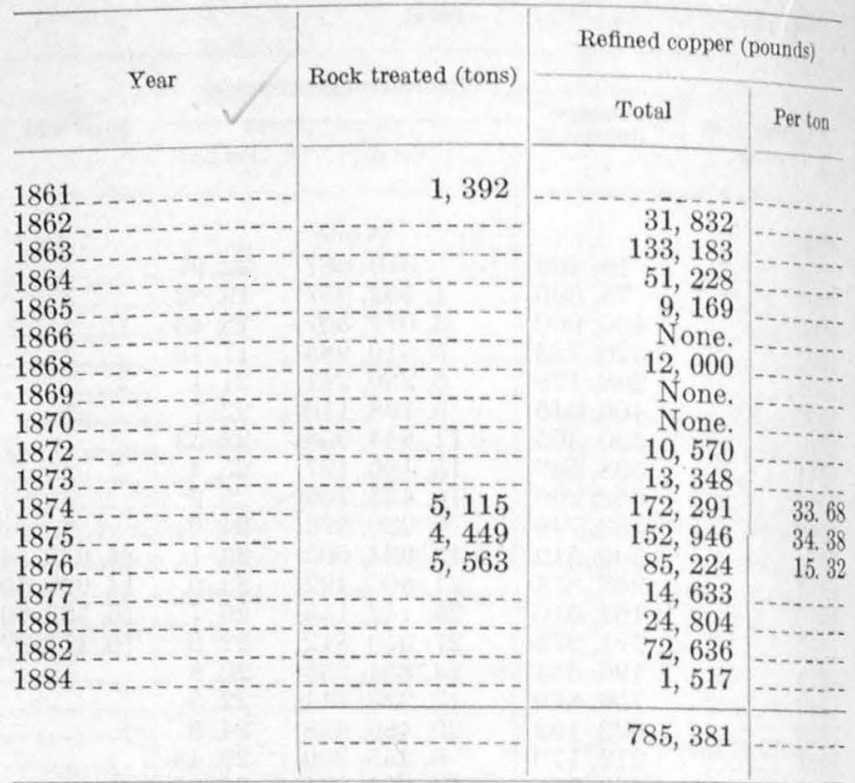

Atlantic.-In Houghton County. Atlantic Mining Co. organized December 31,1872 , by consolidation of South Pewabic and Adams mining companies; 40,000 shares at \$25. (South Pewabic organized 1865; capital exhausted and sold to Atlantic. Started work 1865 ; began production 1866.) Mine closed by caving in May, 1906.

\begin{tabular}{|c|c|c|c|}
\hline \multirow{2}{*}{ Year } & \multirow{2}{*}{ Rock treated (tons) } & \multicolumn{2}{|c|}{ Refined copper (pounds) } \\
\hline & & Total & Per ton \\
\hline $\begin{array}{l}1866 \\
1867 \\
1868 \\
1870 \\
1873 \\
1874 \\
1875 \\
1876 \\
1877 \\
1878 \\
1879 \\
1880 \\
1882 \\
1883 \\
1884 \\
18856 \\
1887 \\
1888 \\
1889 \\
1890 \\
1891 \\
1892 \\
1893 \\
1894 \\
1895 \\
1896 \\
1897 \\
1898 \\
1899 \\
1900 \\
1901 \\
1902 \\
1903 \\
1904 \\
1906 \\
1908 \\
1909 \\
1910\end{array}$ & $\begin{array}{r}51,048 \\
69,728 \\
80,000 \\
96,696 \\
105,780 \\
111,709 \\
122,668 \\
169,825 \\
176,555 \\
189,800 \\
195,669 \\
209,510 \\
241,010 \\
247,035 \\
255,750 \\
298,055 \\
278,680 \\
278,300 \\
297,030 \\
300,900 \\
315,670 \\
315,626 \\
331,058 \\
371,128 \\
394,296 \\
370,767 \\
380,781 \\
410,674 \\
409,124 \\
446,098 \\
431,397 \\
390,526 \\
295,220 \\
75,000 \\
420 \\
768 \\
151\end{array}$ & $\begin{array}{r}13,475 \\
1,760 \\
1,528,258 \\
1,646,857 \\
372,617 \\
863,366 \\
1,372,406 \\
1,567,036 \\
1,835,041 \\
2,054,304 \\
2,006,075 \\
2,339,073 \\
2,423,225 \\
2,528,009 \\
2,631,708 \\
2,682,197 \\
3,163,585 \\
3,582,256 \\
3,503,670 \\
3,641,865 \\
3,974,972 \\
3,698,837 \\
3,619,972 \\
3,653,671 \\
3,703,875 \\
4,221,933 \\
4,437,609 \\
4,832,497 \\
4,894,228 \\
5,109,663 \\
4,377,399 \\
4,675,882 \\
4,930,149 \\
4,666,889 \\
4,949,366 \\
5,505,598 \\
5,321,859 \\
4,049,731 \\
1,439,082 \\
a 10,000 \\
a 11,000 \\
a 44,000\end{array}$ & $\begin{array}{l}16.91 \\
19.68 \\
19.58 \\
18.99 \\
19.42 \\
18.0 \\
19.1 \\
14.3 \\
14.36 \\
13.866 \\
13.71 \\
15.1 \\
14.86 \\
14.18 \\
14.24 \\
13.34 \\
13.27 \\
13.00 \\
12.3 \\
12.31 \\
13.37 \\
14.06 \\
14.6 \\
13.19 \\
12.96 \\
11.8 \\
12.28 \\
12.0 \\
11.4 \\
11.09 \\
12.76 \\
13.63 \\
13.63 \\
19.19\end{array}$ \\
\hline & & $121,844,995$ & \\
\hline
\end{tabular}


aztec.-In Ontonagon County. First known as Aztec Jining Co. Reorganized in August, 1863; 20,000 shares, $\$ 500,000$. In 1871 mine bought by P. T. Rogers, by whom it was sold to Doctor Hussey and a new company organized in July, 1880; 40,000 shares, $\$ 1,000,000$. All work discontinued in July, 1882. Reincorporated in 1909 as South Lake Mining Co.

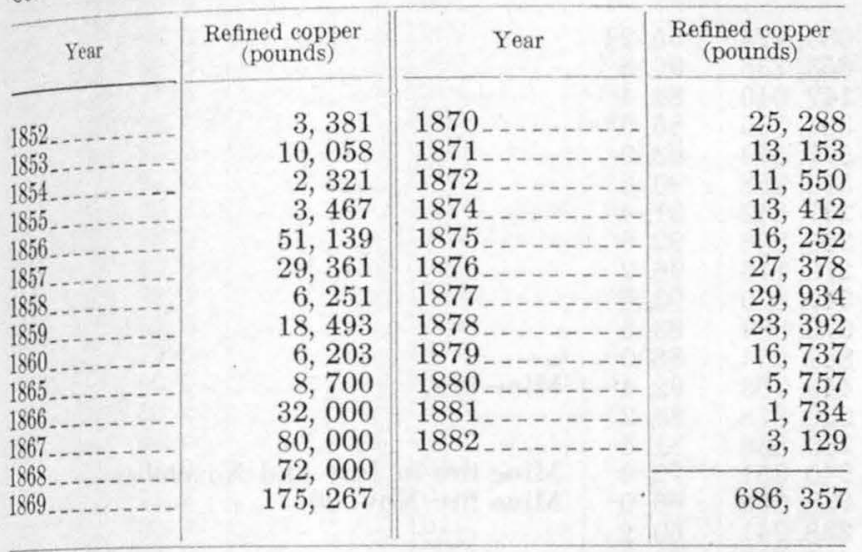

Baltic.-In Houghton County. Exploratory work was first done on the Baltic property in 1882, when the lode was exposed by test pits. Property was purchased from St. Mary's Canal Mineral Land Co. in November, 1897, and Baltic Mining Co. organized December, $1897 ; 100,000$ shares, $\$ 2,500,000$. Absorbed by Copper Range Co. in 1917.

\begin{tabular}{|c|c|c|c|}
\hline \multirow{2}{*}{$\sqrt{ }$ Year } & \multirow{2}{*}{ Rock treated (tons) } & \multicolumn{2}{|c|}{ Refined copper (pounds) } \\
\hline & & Total & Perton \\
\hline $\begin{array}{l}1898 \\
1999 \\
1900 \\
1901 \\
1902 \\
1903 \\
1904 \\
1906 \\
1907 \\
1908 \\
1909 \\
1910 \\
1911 \\
1912 \\
1914 \\
1915 \\
1916 \\
1917 \\
1918 \\
1919 \\
1920 \\
1921 \\
1922 \\
1922 \\
1924 \\
1925\end{array}$ & $\begin{array}{r}2,400 \\
35,411 \\
88,598 \\
114,703 \\
275,175 \\
490,237 \\
535,624 \\
604,709 \\
649,932 \\
761,288 \\
764,117 \\
814,260 \\
781,419 \\
696,795 \\
652,433 \\
333,289 \\
324,433 \\
378,443 \\
369,287 \\
325,342 \\
293,601 \\
235,832 \\
175,357 \\
195,816 \\
165,804 \\
137,801 \\
150,101 \\
140,958\end{array}$ & $\begin{array}{r}42,766 \\
603,570 \\
1,735,060 \\
2,641,432 \\
6,285,819 \\
10,580,997 \\
12,177,729 \\
14,384,684 \\
14,397,557 \\
16,704,868 \\
17,724,854 \\
17,817,836 \\
17,549,762 \\
15,370,449 \\
13,373,961 \\
7,736,124 \\
7,001,945 \\
12,028,947 \\
12,425,804 \\
11,214,861 \\
10,406,097 \\
7,864,653 \\
6,613,918 \\
7,608,847 \\
5,329,568 \\
4,877,248 \\
4,769,286 \\
4,255,069\end{array}$ & $\begin{array}{l}\text { 17. } 8 \\
17.0 \\
\text { 19. } 58 \\
23.0 \\
22.84 \\
21.58 \\
22.74 \\
23.78 \\
22.15 \\
21.94 \\
23.19 \\
21.88 \\
22.46 \\
22.06 \\
20.50 \\
23.21 \\
21.58 \\
31.79 \\
33.65 \\
34.47 \\
35.44 \\
33.35 \\
37.71 \\
38.86 \\
32.14 \\
35.39 \\
31.77 \\
30.18\end{array}$ \\
\hline & $10,493,165$ & $263,523,711$ & 25. 11 \\
\hline
\end{tabular}

Bay State.-In Keweenaw County. Organized May, 1853(?). Purchased by Phoenix in 1868.

\begin{tabular}{l|r|r|}
\multicolumn{1}{c|}{ Year } & $\begin{array}{c}\text { Refined copper } \\
\text { (pounds) }\end{array}$ \\
\cline { 1 - 2 } $1865 \ldots 6$ & 75,000 \\
1867 & 210,000 \\
& 114,115 \\
\hline
\end{tabular}

Belt (Bohemian).- In Ontonagon County. The original company was organized March 27, 1848, and about that time work was begun. Location was early known as Piscatauqua and was sold to Bohemian in 1853. Bohemian commenced mining operations late in 1850 (probably on another tract); suspended in December, 1851; resumed June, 1852. Reorganized 1862. Worked until 1866, closed to 1870 ; resumed for short time after 1870. Bohemian and Great Western passed into hands of Belt Mining Co. by purchase in 1882 and worked until 1885. Work resumed on small scale in spring of 1886 . Company wound up its organization, and property was turned over to bondholders, who foreclosed mortgage and sold. In 1900 a new organization was formed and property acquired by Arctic Copper Mining Co. Option taken on Belt in 1901 and shafts unwatered in June of that year, but work was soon suspended. Became Lake Copper Co. in November, $1905 ; 100,000$ shares, $\$ 2,500,000$.

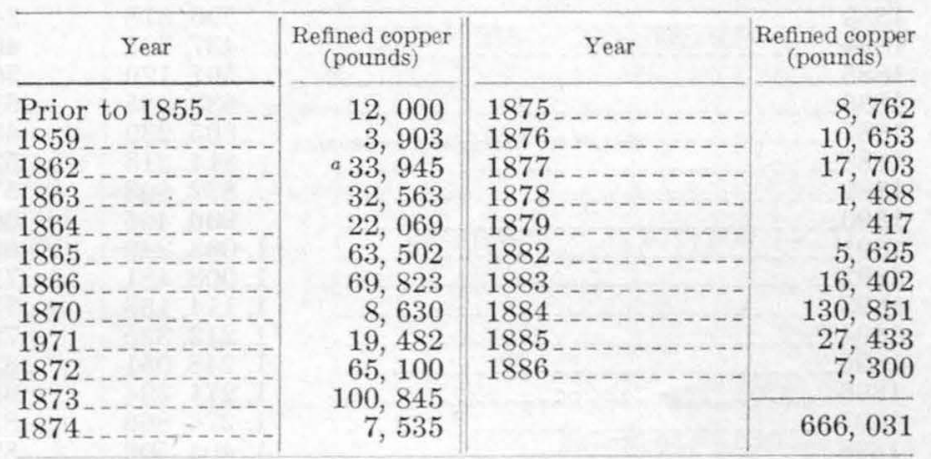

\section{Estimated}

Bohemian.--See Belt.

Caledonia (Nebraska).--In Ontonagon County. Organized March, 1863; 20,000 shares, $\$ 500,000$. Property formerly known as Nebraska. Absorbed by Flint Steel Copper Co. in 1871.

\begin{tabular}{|c|c|c|}
\hline Year & $\begin{array}{l}\text { Refined copper } \\
\text { (pounds) }\end{array}$ & Silver sold \\
\hline 1855 & $\begin{array}{r}54,000 \\
5,500 \\
17,000 \\
40,400 \\
7,730 \\
23,484 \\
104,652 \\
26,243 \\
105,853 \\
87,508 \\
3,377\end{array}$ & $\begin{array}{r}\$ 59.30 \\
57.91 \\
\end{array}$ \\
\hline & 475,747 & \\
\hline
\end{tabular}

Calumet \& Hecla.- In Houghton County. Calumet Mining Co. organized 1865. Hecla Mining Co. organized 1866. Portland Copper Co. and Scott Copper Co. were purchased and on May 1, 1871, were consolidated with the Calumet Mining Co. and the Hecla Mining Co., forming the Calumet \& Hecla Mining Co. Allouez, Ahmeek, Centennial, Calumet \& Hecla, and Osceola were consolidated September 1, 1923, forming the Calumet \& Hecla Consolidated Copper Co. The lands of the company include the following tracts:

$\begin{array}{lll}\text { Ahmeek. } & \text { Frontenac. } & \text { Northwestern. } \\ \text { Allouez. } & \text { Hecla. } & \text { Opechee. } \\ \text { Amygdaloid. } & \text { Iroquois. } & \text { Osceola. } \\ \text { Calumet. } & \text { Lac La Belle. } & \text { Pawnee. } \\ \text { Centennial. } & \text { Laurium. } & \text { Portland. } \\ \text { Central. } & \text { Madison. } & \text { Scott. } \\ \text { Conglomerate. } & \text { Manice Lands. } & \text { St. Louis. } \\ \text { Dana. } & \text { Manitou. } & \text { South Kearsarge. } \\ \text { Delaware. } & \text { Mendota. } & \text { Tamarack. } \\ \text { Eagle Harbor. } & \text { Montreal. } & \text { Tamarack Jr. }\end{array}$

Eagle River. North Kearsarge.

Florida. Northwest.
Northwestern

the

Portland.

Seott.

Tamarack.

Tamarack Jr. 


\section{Production from all lodes}

[Does not include copper reclaimed from sands]

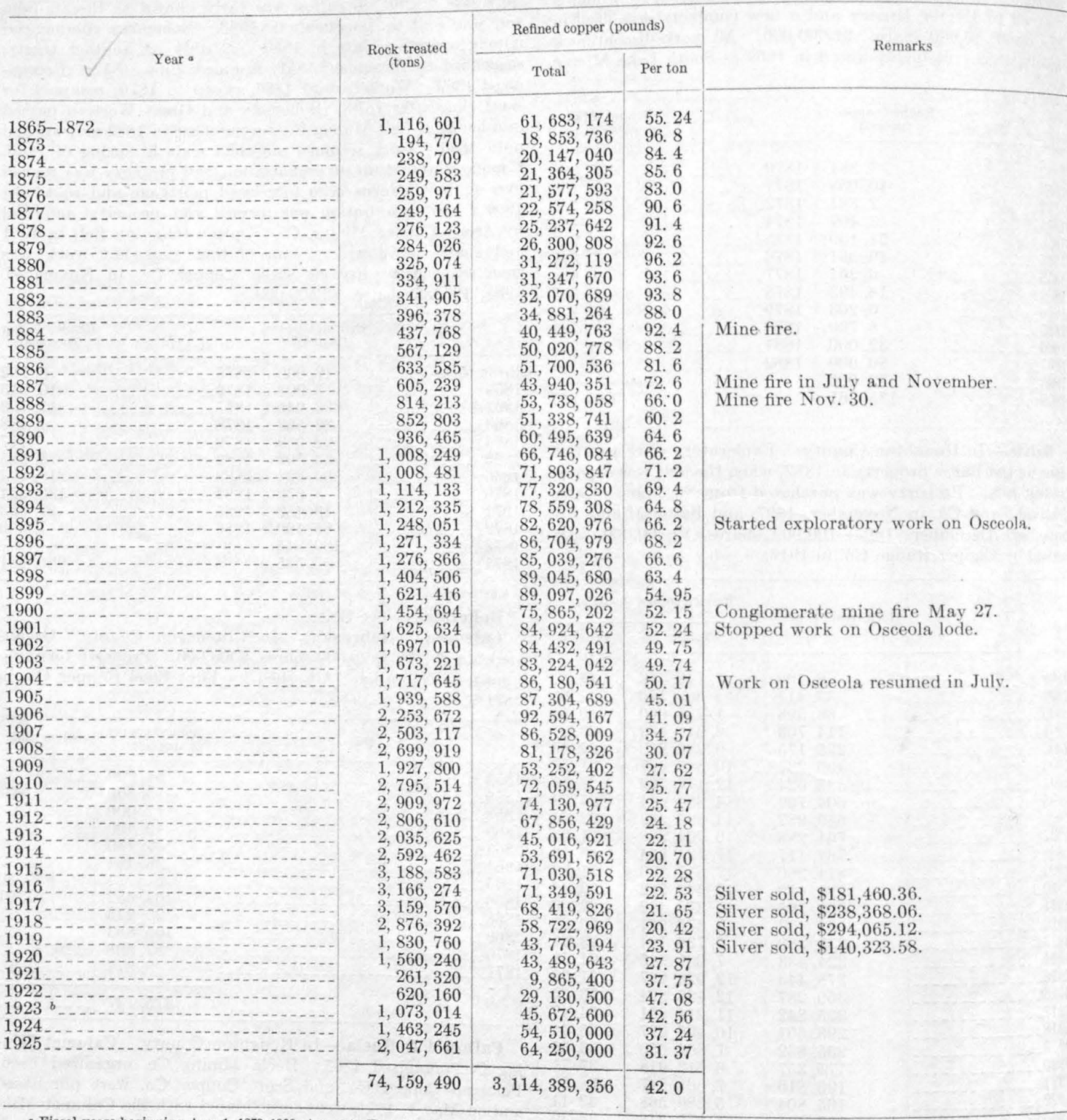

a Fiscal years beginning Apr. 1, 1873-1908; Apr. 1 to Dec. 31, 1909; calendar years 1910-1925.
Includes production of consolidated mines beginning Sept. 1 . 
Refined copper per ton of rock treated (pounds)

\begin{tabular}{|c|c|c|c|c|c|}
\hline Year & $\begin{array}{c}\text { Calumet } \\
\& \text { Hecls } \\
\text { conglom- } \\
\text { erate }\end{array}$ & $\begin{array}{c}\text { Osceola } \\
\text { amygdaloid }\end{array}$ & Year & $\begin{array}{c}\text { Calumet } \\
\& \text { Hecla } \\
\text { conglom- } \\
\text { erate }\end{array}$ & $\begin{array}{c}\text { Osceola } \\
\text { amygdaloid }\end{array}$ \\
\hline & 55. 24 & $-\infty-\infty,-1$ & 1898 & 63.4 & \\
\hline & 96.8 & $\ldots \ldots$ & 1899 & 54. 95 & \\
\hline & 84. 4 & $\ldots \ldots$ & 1900. & 52. 15 & $\ldots \ldots$ \\
\hline & 85.6 & $\ldots \ldots \ldots$ & 1901 . & 52.24 & $\ldots-\cdots$ \\
\hline & 83.0 & $-5-1.0-1$ & 1902. & 49.75 & $\ldots \ldots$ \\
\hline & 90.6 & $\therefore \ldots \ldots$ & $1903 \ldots \ldots$ & 49. 74 & 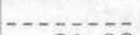 \\
\hline & 91.4 & $\ldots \ldots$ & $1904 \ldots \ldots$ & 51.53 & 21. 38 \\
\hline & 92.6 & $=$ & 1905 & 48. 41 & 19. 51 \\
\hline & 96.2 & - - - & 1906. & 46.19 & 17. 64 \\
\hline & 93.6 & 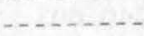 & 1907. & 39. 76 & 18. 52 \\
\hline & 93.8 & $\ldots \ldots \ldots$ & 1908 & 35.04 & 17. 07 \\
\hline & 88. 0 & $\ldots$ & 1909. & 32. 38 & 16. 31 \\
\hline & 92. 4 & $\ldots$ & 1910 & 30. 12 & 15. 82 \\
\hline & 88.2 & $\ldots \ldots$ & $1911_{\text {. }}$ & 30.38 & 15. 89 \\
\hline & 81.6 & $\ldots$ & 1912 & 29. 73 & 15. 08 \\
\hline & 72.6 & $\ldots \ldots$ & 1913. & 27.85 & 14. 31 \\
\hline & 66.0 & $\ldots$ & 1914. & 26. 38 & 13. 62 \\
\hline & 60.2 & $\ldots \ldots$ & $1915_{-}$ & 29.74 & 13. 32 \\
\hline & 64. 6 & $\ldots$. & 1916 & 29. 97 & 13. 60 \\
\hline & 66. 2 & & 1917. & 28. 78 & 12.79 \\
\hline & 71. 2 & & 1918 & 28.00 & 11. 58 \\
\hline & 69. 4 & & 1919 & 29. 61 & 15. 12 \\
\hline & 64.8 & $\ldots$ & 1920 & 35. 10 & 15. 74 \\
\hline & 66.2 & $\cdots \cdots \cdots$ & $1921 \ldots \ldots$ & 37. 75 & $\ldots+\cdots$ \\
\hline & 68.2 & & $1922 \ldots \ldots$ & 47. 08 & $\ldots$ \\
\hline & & & & & \\
\hline
\end{tabular}

Reclamation from old tailings (Calumet \& Hecla conglomerate

CALUMET \& HECLA RECLAMATION PLANT

\begin{tabular}{|c|c|c|c|}
\hline \multirow{2}{*}{ Year } & \multirow{2}{*}{ Rock treated (tons) } & \multicolumn{2}{|c|}{ Refined copper (pounds) } \\
\hline & & Total & Per ton \\
\hline $\begin{array}{l}1915 \\
1916 \\
1917 \\
1918 \\
1919 \\
1920 \\
1921 \\
1922 \\
1923 \\
1924 \\
1925\end{array}$ & $\begin{array}{r}181,732 \\
545,727 \\
730,543 \\
715,007 \\
915,659 \\
1,378,500 \\
367,000 \\
1,378,250 \\
1,743,100 \\
1,687,700 \\
2,125,000\end{array}$ & $\begin{array}{r}1,582,802 \\
5,412,649 \\
9,075,457 \\
9,245,388 \\
9,082,952 \\
14,138,240 \\
5,301,736 \\
11,362,500 \\
16,901,200 \\
18,627,000 \\
20,278,000\end{array}$ & $\begin{array}{r}\text { 8. } 71 \\
\text { 9. } 92 \\
\text { 12. } 42 \\
\text { 12. } 93 \\
9.92 \\
\text { 10. } 26 \\
\text { 14. } 45 \\
\text { 8. } 24 \\
9.70 \\
11.04 \\
9.54\end{array}$ \\
\hline & $11,768,218$ & $121,007,924$ & 10. 32 \\
\hline
\end{tabular}

TAMARACK RECLAMATION PLANT

\begin{tabular}{l|l|l|l}
\hline $1925^{a}$ & 606,605 & $6,679,000$ & 11.01 \\
\hline
\end{tabular}

a $7 \frac{1}{2}$ months.
Calumet \& Hecla conglomerate.

Kearsarge amygdaloid

Mass fissure.

Osceola amygdaloid

\begin{tabular}{|c|c|c|c|}
\hline \multirow{2}{*}{ Period } & \multirow{2}{*}{ Rock treated (tons) } & \multicolumn{2}{|c|}{ Refined copper (pounds) } \\
\hline & & Total & Per ton \\
\hline \multirow{3}{*}{$\begin{array}{l}1865-1925 \\
1904-1925 \\
1923-1925 \\
1904-1925\end{array}$} & $\begin{array}{r}57,229,052 \\
2,331,524\end{array}$ & $\begin{array}{r}a 2,958,779,077 \\
67,351,569\end{array}$ & $\begin{array}{l}51.70 \\
28.89\end{array}$ \\
\hline & $14,598,914$ & $213,817,584$ & 14. 65 \\
\hline & $74,159,490$ & $3,242,076,280$ & 43,72 \\
\hline
\end{tabular}

- Indudes $127,686,924$ pounds reclaimed from tailings.

Carp Lake.-In Ontonagon County. Organized in 1858. Nining begun in 1859 and suspended in 1862. Resumed September 25,1897 , and worked a few months. Work resumed for s short period in summer of 1898 . In 1901 the property was owned by the Porcupine Copper Co.; 500,000 shares at $\$ 5$.

\begin{tabular}{|r|r}
\hline Year & $\begin{array}{r}\text { Refined copper } \\
\text { (pounds) }\end{array}$ \\
\hline 1860 & 6,428 \\
1862 & 2,800 \\
963 & 10,546 \\
1864 & 13,185 \\
& 33,935 \\
\hline
\end{tabular}

Centennial.-In Houghton County. Schooleraft organized in 1863. Work commenced in small way in 1866. Worked without profit 1868-1875 and abandoned. Leased about 1873 . Company went into bankruptcy and Centennial organized about $1878 ; 40,000$ shares at $\$ 25$. In 1880 work was begun by new company on Osceola amygdaloid. Work suspended in tall of 1883 because of lack of funds. Resumed December, 1888. Very little work done to 1897 . Reorganized as Centennial Copper Mining Co. in 1896. Absorbed by Calumet \& Hecla Consolidated Copper Co. September 1, 1923.

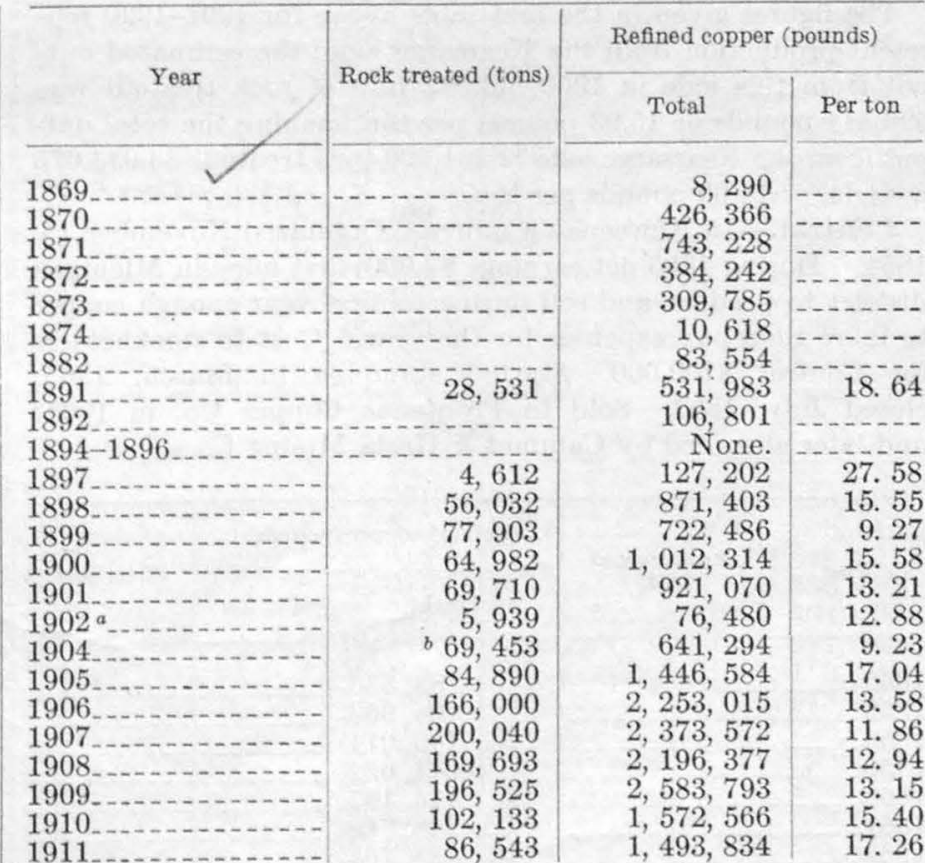

a No production after January.

s July 4 to Dec. 31 . Includes 9,043 tons from stock pile. 


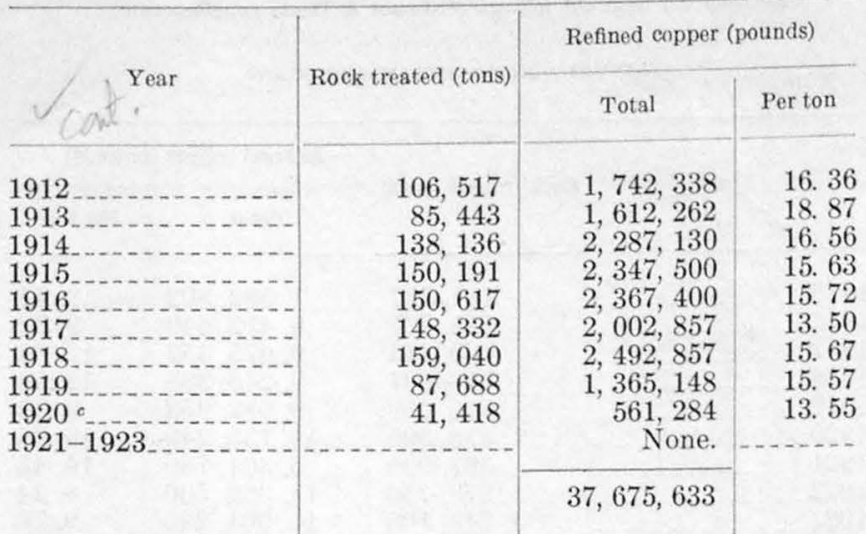

- January to July.

The figures given above for $1869-1874$ and 1882 represent production from the Calumet \& Hecla conglomerate; the estimated quantity derived from the conglomerate in $1897(1,285$ tons) was 35,440 pounds ( 27.58 pounds per ton) and in 1898 ( 5,000 tons) 83,750 pounds ( 16.75 pounds per ton), making a total from the conglomerate of $2,085,273$ pounds. The production from the Osceola lode was as follows:

\begin{tabular}{|c|c|c|c|}
\hline \multirow{2}{*}{ Year } & \multirow{2}{*}{ Rock treated (tons) } & \multicolumn{2}{|c|}{ Refined copper (pounds) } \\
\hline & & Total & Per ton \\
\hline \multirow[t]{2}{*}{$\begin{array}{l}1891 \\
1892 \\
1894-1896 \\
1897 \\
1898 \\
1899 \\
1900\end{array}$} & $\begin{array}{r}28,531 \\
{ }^{a} 3,327 \\
51,032 \\
77,903 \\
a 21,400\end{array}$ & $\begin{array}{r}531,983 \\
106,801 \\
\text { None. } \\
\text { a } 91,762 \\
\text { a } 787,653 \\
722,486 \\
\text { a } 316,000\end{array}$ & 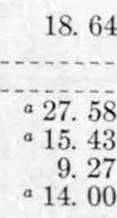 \\
\hline & & $2,556,685$ & \\
\hline
\end{tabular}

- Estimated.

The figures given in the first table above for 1901-1920 represent production from the Kearsarge lode; the estimated output from this lode in 1900 (43,582 tons of rock treated) was 696,314 pounds or 15.93 pounds per ton, making the total output from the Kearsarge lode (2,261,890 tons treated) $33,033,675$ pounds, or 14.60 pounds per ton.

Central. - In Keweenaw County. Organized November 15 1854. During 1855 net earnings $\$ 7,000$; first mine in Michigan district to produce and sell during its first year enough copper to more than pay expenses for the year. Cost to stockholders for Central $\$ 100,000$. Started stamping in March, 1865; closed July, 1898. Sold to Frontenac Copper Co. in 1905? and later absorbed by Calumet \& Hecla Mining Co.

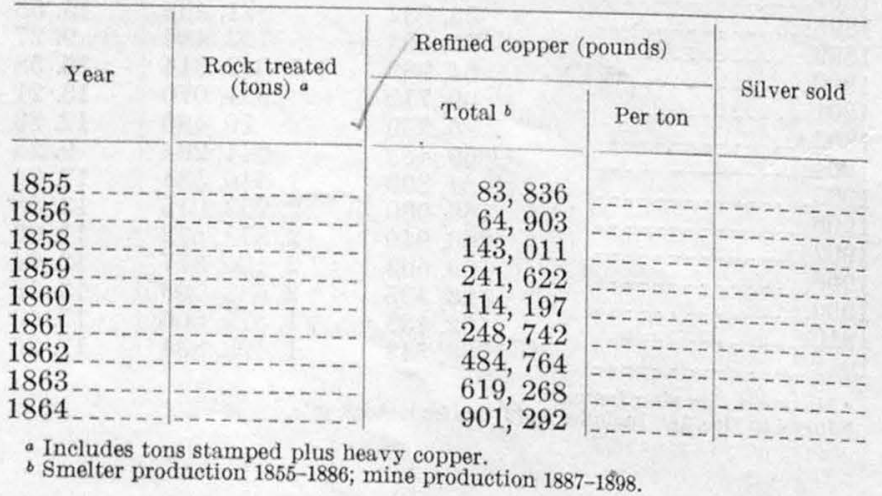

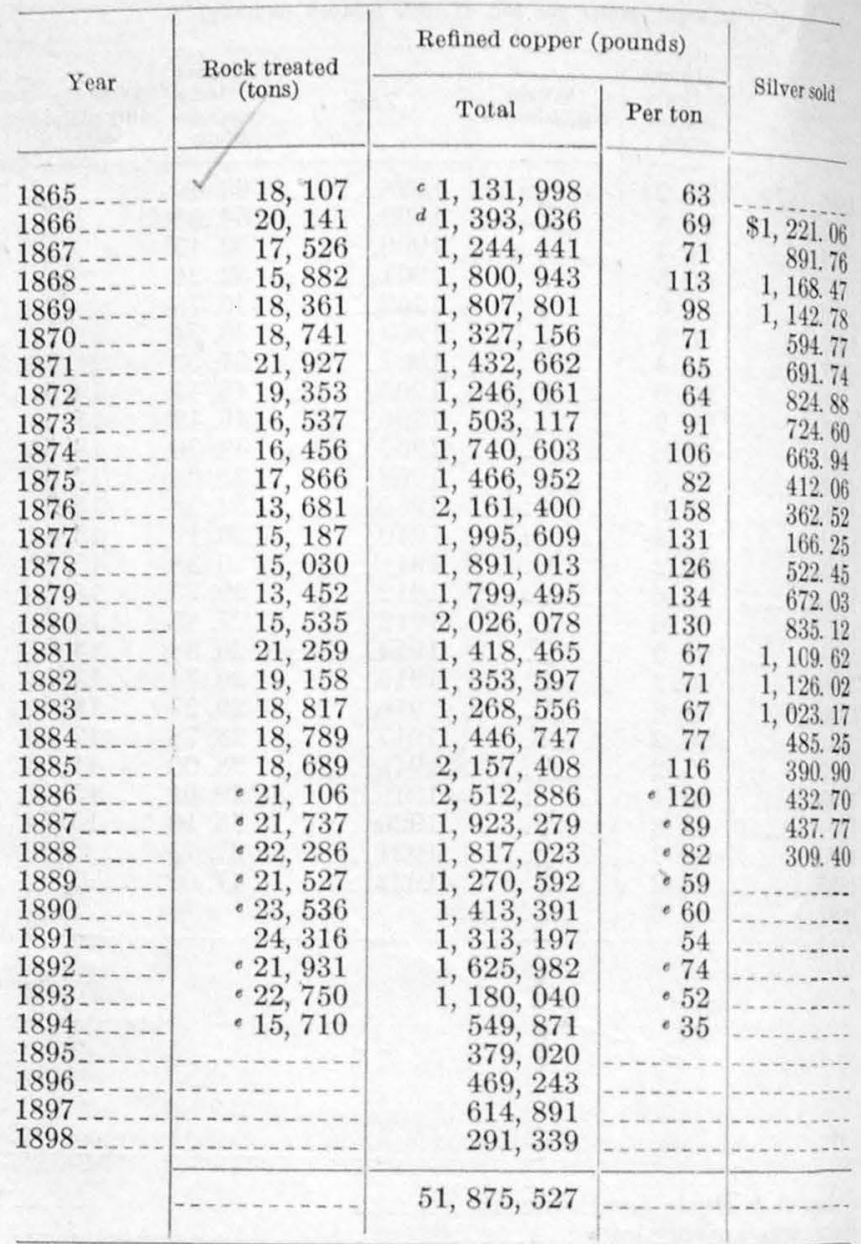

- Includes 32,756 pounds of ingot lost in lake.

$\checkmark$ Includes 60,000 pounds of ingot (estimated) lost in lake. - Estimate.

Champion.-In Houghton County. Organized December, 1899. One-half of capital stock owned by Copper Range Co. and other half by St. Mary's Mineral Land Co. Under Copper Range Co. management.

\begin{tabular}{|c|c|c|c|}
\hline \multirow{2}{*}{ Year } & \multirow{2}{*}{ Rock treated (tons) } & \multicolumn{2}{|c|}{ Refined copper (pounds) } \\
\hline & & Total & Per ton \\
\hline $\begin{array}{l}1902 \\
1903 \\
1904 \\
1905 \\
1906 \\
1908 \\
1909 \\
1910 \\
1911 \\
1912 \\
1913 \\
1914 \\
1915 \\
1916 \\
1918 \\
1919 \\
1920 \\
1921 \\
1922 \\
1923 \\
1924\end{array}$ & $\begin{array}{l}121,478 \\
389,082 \\
442,061 \\
604,483 \\
671,785 \\
708,685 \\
794,703 \\
753,908 \\
722,051 \\
734,392 \\
765,306 \\
421,849 \\
614,854 \\
923,743 \\
936,656 \\
776,036 \\
594,235 \\
503,030 \\
321,664 \\
531,780 \\
503,593 \\
449,130 \\
457,160 \\
414,645 \\
\end{array}$ & $\begin{array}{r}4,165,784 \\
10,564,147 \\
12,212,954 \\
15,707,426 \\
16,954,986 \\
16,489,436 \\
17,786,763 \\
18,005,071 \\
19,224,174 \\
15,639,426 \\
17,225,508 \\
12,080,594 \\
15,807,206 \\
33,407,599 \\
33,601,136 \\
27,550,343 \\
21,748,514 \\
19,886,917 \\
13,610,324 \\
20,719,307 \\
19,583,806 \\
18,412,630 \\
20,061,630 \\
17,957,605 \\
\end{array}$ & $\begin{array}{l}34.29 \\
27.15 \\
27.63 \\
25.98 \\
25.24 \\
23.26 \\
22.38 \\
23.88 \\
26.62 \\
21.30 \\
22.51 \\
28.64 \\
25.71 \\
36.17 \\
35.87 \\
35.50 \\
36.60 \\
39.05 \\
42.42 \\
39.02 \\
38.89 \\
41.03 \\
43.88 \\
43.31 \\
\end{array}$ \\
\hline & $14,156,309$ & $438,403,286$ & 30.97 \\
\hline
\end{tabular}


Clark--In Keweenaw County. Mine was opened in 1858 the French Copper Mining Co. and passed through various In 1900, after 15 years of idleness, work was resumed. Tas under option to Calumet \& Hecla Mining Co. in 1905 and to. S. Smelting, Refining \& Mining Co. in 1910. An unsucwasful attempt was also made to mine a manganese deposit on this property.

\begin{tabular}{|c|c|c|c|}
\hline Year & $\begin{array}{l}\text { Refined copper } \\
\text { (pounds) }\end{array}$ & Year & $\begin{array}{l}\text { Refined copper } \\
\text { (pounds) }\end{array}$ \\
\hline \multirow{2}{*}{$\begin{array}{l}1872 \ldots \ldots \\
1874 \ldots \ldots \\
1875 \ldots \ldots \\
1876 \ldots \ldots \\
1877 \ldots \ldots\end{array}$} & \multirow{2}{*}{$\begin{array}{r}17,749 \\
7,244 \\
67,475 \\
38,774 \\
34,813\end{array}$} & \multirow[t]{2}{*}{$\begin{array}{l}1878 \ldots \ldots \\
1879\end{array}$} & $\begin{array}{r}21,520 \\
340\end{array}$ \\
\hline & & & 187,915 \\
\hline
\end{tabular}

Cliff.-In Keweenaw County. Pittsburgh \& Boston Copper Harbor Mining Co. organized in 1844. Pittsburgh \& Boston Vining Co. organized March 18, 1848, and worked the Cliff fissure to its closing in June, 1870. Paid its first dividend in 1849. First dividend-paying property in district. Paid regular semiannual dividends 1850 to 1857 . The property was sold to Ciff Copper Co. in 1871, and operations were resumed in Ipril, 1872. Affairs of Pittsburgh \& Boston Mining Co. wound un and corporation dissolved in 1879. Property later sold to Tamarack Mining Co. Cliff Mining Co. organized in 1910.

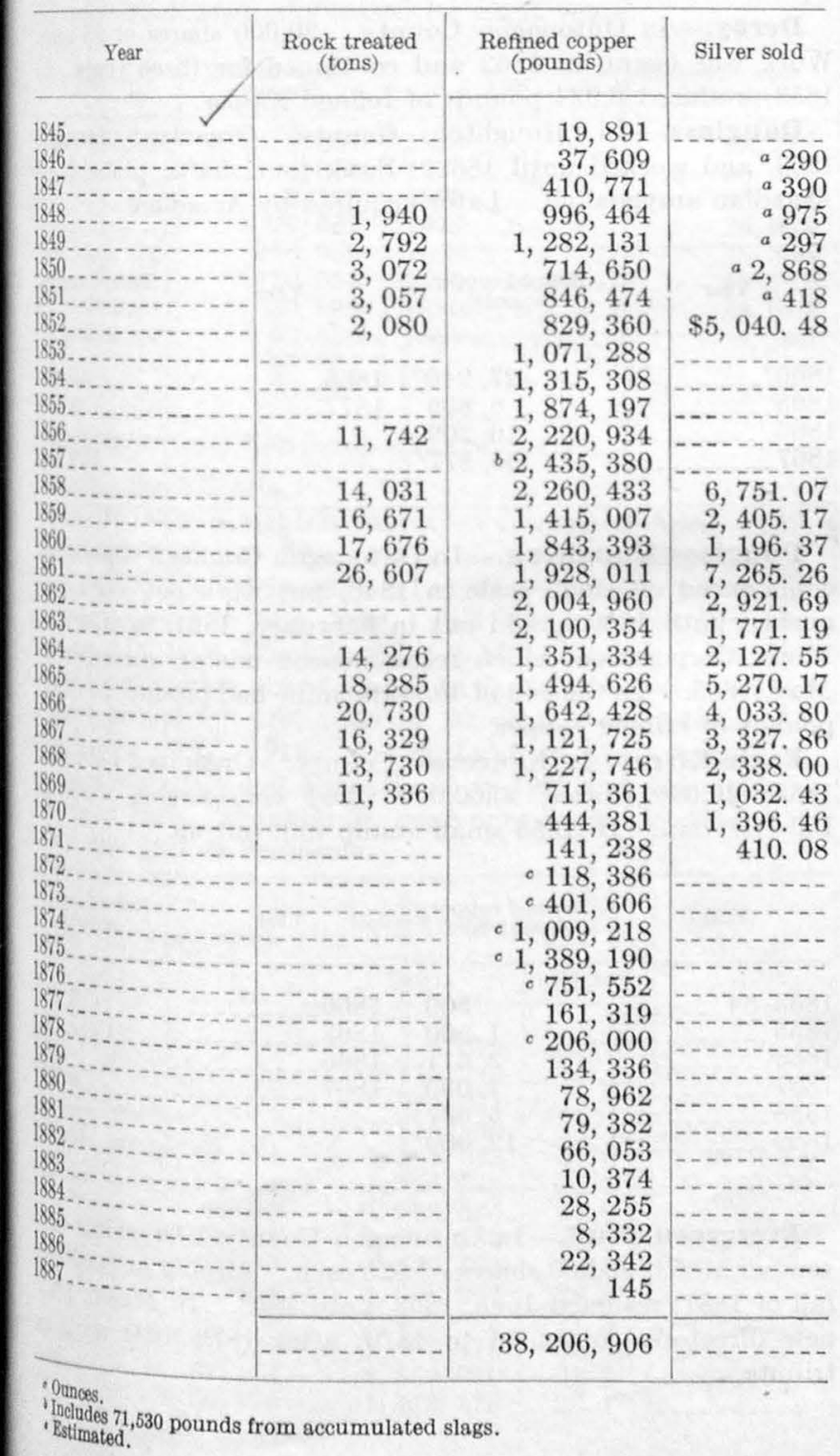

Concord.-In Houghton County. Organized May, 1864. In 1868 Concord and Pewabic consolidated. Concord set off as separate organization in 1879. Absorbed by Arcadian in 1898.

\begin{tabular}{|c|c|c|c|}
\hline Year & $\begin{array}{l}\text { Refined copper } \\
\text { (pounds) }\end{array}$ & Year & $\begin{array}{l}\text { Refined copper } \\
\text { (pounds) }\end{array}$ \\
\hline \multirow{6}{*}{$\begin{array}{l}1866 \\
1867 \\
1868 \\
1870 \\
1871 \\
1872\end{array}$} & \multirow{6}{*}{$\begin{array}{r}9,980 \\
52,020 \\
171,185 \\
9,815 \\
123,626 \\
143,792 \\
122,168\end{array}$} & \multirow{6}{*}{$\begin{array}{l}1874 \\
1875 \\
1876 \\
1880 \\
1881\end{array}$} & 22,518 \\
\hline & & & \\
\hline & & & 900,146 \\
\hline & & & 10,464 \\
\hline & & & 28,849 \\
\hline & & & $1,595,003$ \\
\hline
\end{tabular}

Conglomerate.- See Delaware; Pennsylvania.

Connecticut.- In Keweenaw County. Operated on a fissure west of Delaware. Absorbed by Amygdaloid Co. Produced prior to 1860116,800 pounds of refined copper, including 29,000 pounds in the year ending September 1,1856 , and 37,000 pounds in the year ending September 1, 1857

Copper Falls.-In Keweenaw County. Copper Falls Co. organized October 16, 1845 . In 1848 reorganized as Copper Falls Mining Co. In 1855 a reorganization with eapital stock increased to $\$ 500,000$ divided into 20,000 shares. In 1861 the company set off and organized the Petherick. In 1876 a reorganization with capital stock increased to $\$ 1,000,000$ divided into 20,000 shares. Stamp mill burned in 1878. Worked Ashbed and five fissures. All operations suspended in 1893. ALI LODES

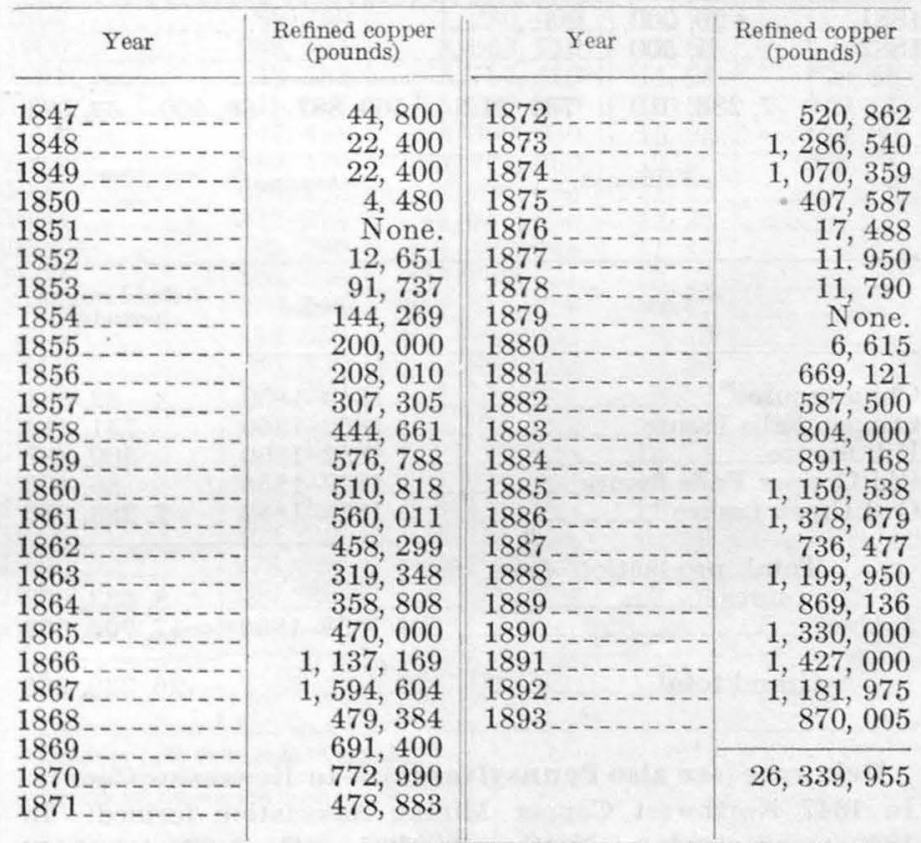

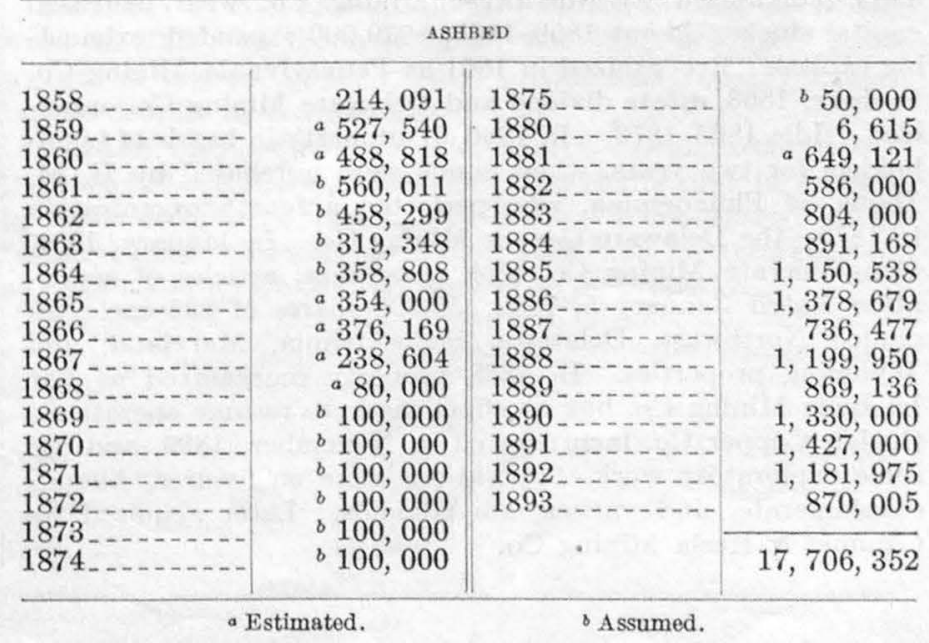




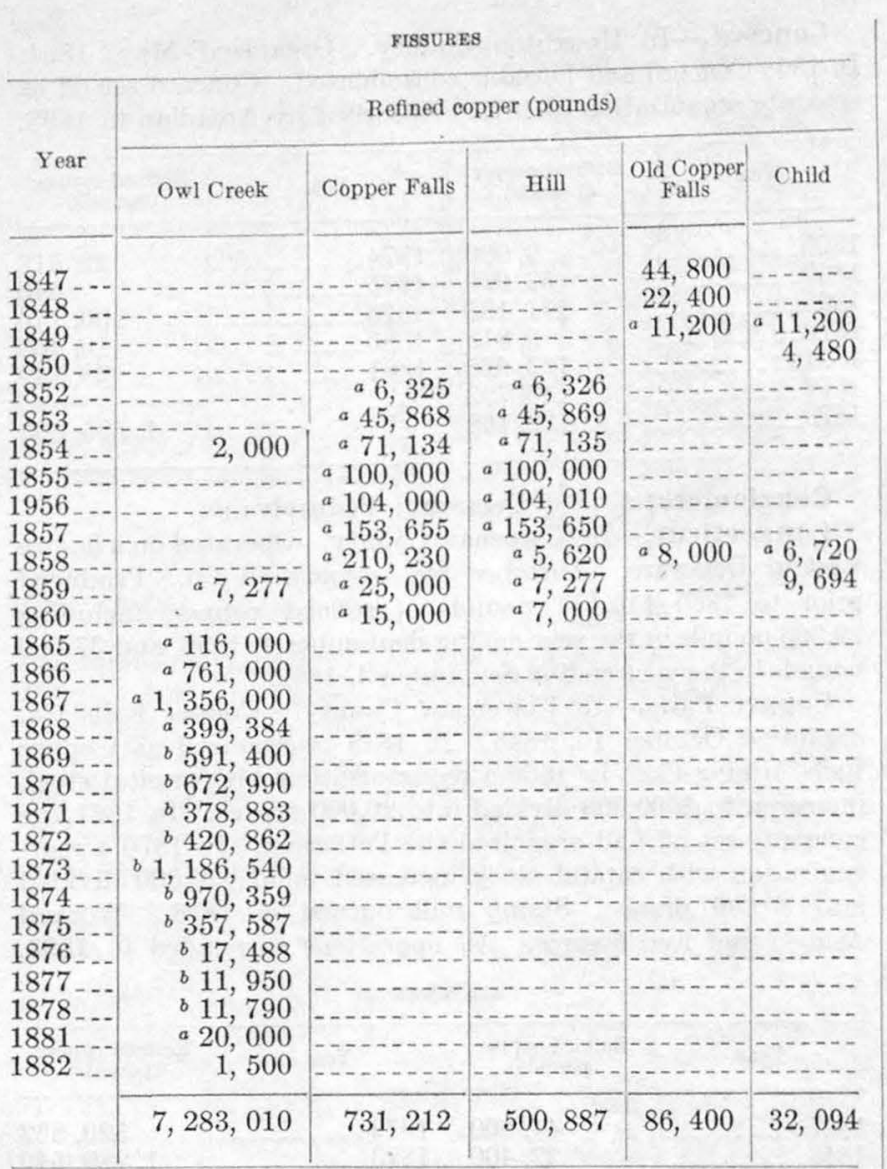

a Estimated.

${ }^{3}$ Assumed.

SUMMARY

\begin{tabular}{|c|c|c|}
\hline Lode & Period & $\begin{array}{l}\text { Refined eopper } \\
\text { (pounds) }\end{array}$ \\
\hline $\begin{array}{l}\text { Child fissure } \\
\text { Copper Falls fissure } \\
\text { Hill fissure } \\
\text { Old Copper Falls fissure } \\
\text { Owl Creek fissure. }\end{array}$ & $\begin{array}{l}1849-1859 \\
1852-1860 \\
1852-1860 \\
1847-1858 \\
1854-1882\end{array}$ & $\begin{array}{r}32,094 \\
731,212 \\
500,887 \\
86,400 \\
7,283,010\end{array}$ \\
\hline $\begin{array}{l}\text { Total production from fis- } \\
\text { sures }\end{array}$ & $1858-1893$ & $\begin{array}{r}8,633,603 \\
17,706,352\end{array}$ \\
\hline Grand total. & & $26,339,955$ \\
\hline
\end{tabular}

Delaware (see also Pennsylvania).-In Keweenaw County. In 1847 Northwest Copper Mining Association formed. In 1849 reorganized as Northwest Mining Co. with increased capital stock. About 1850-1860, $\$ 939,000$ expended, exhausting capital. Reorganized in 1861 as Pennsylvania Mining Co. In June, 1863, estate divided and Delaware Mining Co. organized. Idle 1865-1872. In 1866-67 property in hands of bondholders for two years, when bonds were purchased by E. M. Davis, of Philadelphia, who perfected a fourth organization in 1876-the Delaware Copper Mining Co. In January, 1881, Conglomerate Mining Co. took possession; articles of association dated January 5, 1880; 50,000 shares of $\$ 25$ each; included Northwest, Delaware, Pennsylvania, Maryland, and Wyoming properties. In 1888 property reorganized as Lac La Belle Mining Co. but no effort made to resume operations. Oneida Copper Co. incorporated in November, 1899, and did some exploratory work. Operations were on fissures, Allouez conglomerate, and various amygdaloids. Later acquired by Calumet \& Hecla Mining Co.

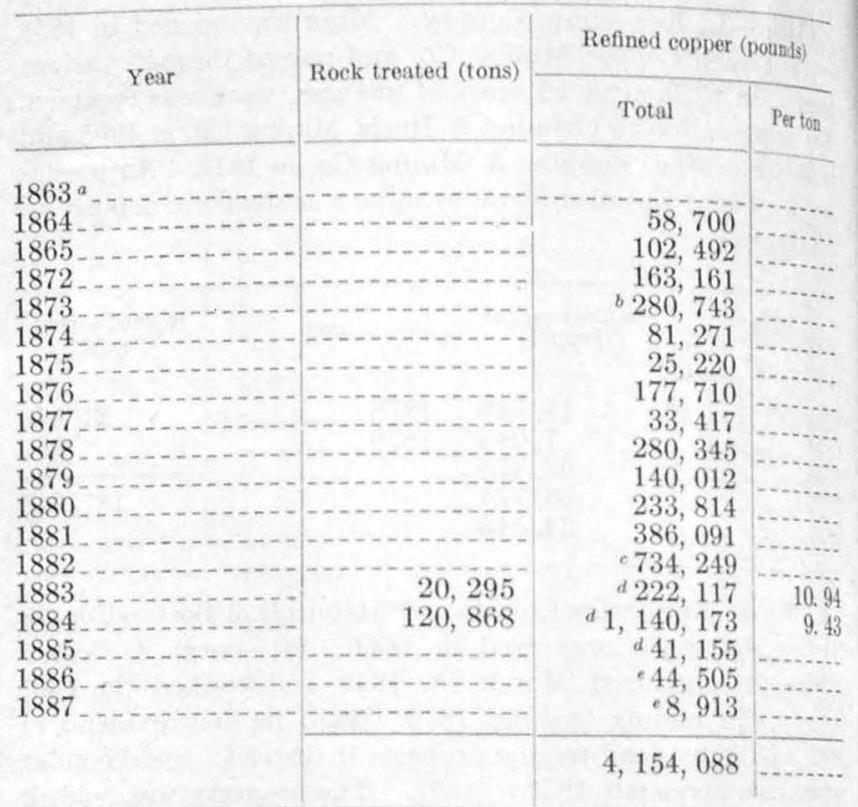

a For production prior to organization of Delaware see Pennsylvania.

'Mineral statistics, 1882 , gives 340,743 pounds

c One-half from Allouez conglomerate; one-half from fissure; 41,104 tons stamped yielded 671,681 pounds refined copper.

From Allouez conglomerate.

From Northwest vein; no work on conglomerate, 1886-1891

Derby.-In Ontonagon County. 20,000 shares of $\$ 5$ each. Work was begun in 1852 and continued for three years. In 1853 produced 2,934 pounds of refined copper.

Douglass.- In Houghton County. Organized January, 1863, and worked until 1868. Sunk four shafts, probably on Arcadian amygdaloid. Later acquired by Arcadian.

\begin{tabular}{|c|c|c|c|}
\hline Year & $\begin{array}{l}\text { Refined copper } \\
\text { (pounds) }\end{array}$ & Year & $\begin{array}{l}\text { Refined copper } \\
\text { (pounds) }\end{array}$ \\
\hline \multirow{2}{*}{$\begin{array}{l}1860 ? \\
1865 \\
1866 \\
1867\end{array}$} & \multirow{2}{*}{$\begin{array}{r}27,240 ? \\
6,809 \\
16,209 \\
65,877\end{array}$} & \multirow[t]{2}{*}{$1868 \ldots$} & $\begin{array}{r}50,109 \\
3,258\end{array}$ \\
\hline & & & 169,502 \\
\hline
\end{tabular}

Douglass Houghton.-In Ontonagon County. Operations commenced on small scale in 1846 , but work not vigorously pushed until 1850. Sold out in February, 1864, to Henwood Mines Corporation, which recommenced mining operations in May, 1865. To the end of 1856 the mine had produced 143,217 pounds of refined copper.

Eagle River.- In Keweenaw County. Organized February, $1853 ; 20,000$ shares, $\$ 500,000$. Did considerable work on Babbitt vein. In 1855 small stamp mill put up.

\begin{tabular}{|c|c|c|c|}
\hline Year & $\begin{array}{l}\text { Refined copper } \\
\text { (pounds) }\end{array}$ & Year & $\begin{array}{l}\text { Refined copper } \\
\text { (pounds) }\end{array}$ \\
\hline $\begin{array}{l}1853-54 \ldots \\
1855 \\
1856 \\
1857 \\
1858\end{array}$ & $\begin{array}{r}500 \\
1,500 \\
2,611 \\
2,000 \\
6,637\end{array}$ & $\begin{array}{l}1860 \\
1862 \\
1866 \\
1867\end{array}$ & $\begin{array}{r}9,651 \\
5,652 \\
738 \\
8,389\end{array}$ \\
\hline $1859 \ldots$ & 12,000 & & 49,678 \\
\hline
\end{tabular}

Evergreen Blufr. - In Ontonagon County. Organized September, $1853 ; 20,000$ shares of $\$ 25$ each. Mining suspended in fall of 1857; resumed June, 1858 , until 1863. In March, 1863 . new directors, continued to 1870 ; after 1878 little work on tribute. 
Grand Portage.-In Houghton County. Portage Mining Co. organized 1852. Reorganized in May, 1860, as Grand Portage Mining Co. and some work done. Sold in 1879 and organized anew in 1880 ; capital $\$ 500,000$. Operations suspended in 1884. In 1897 sold to Isle Royale Consolidated Mining Co.

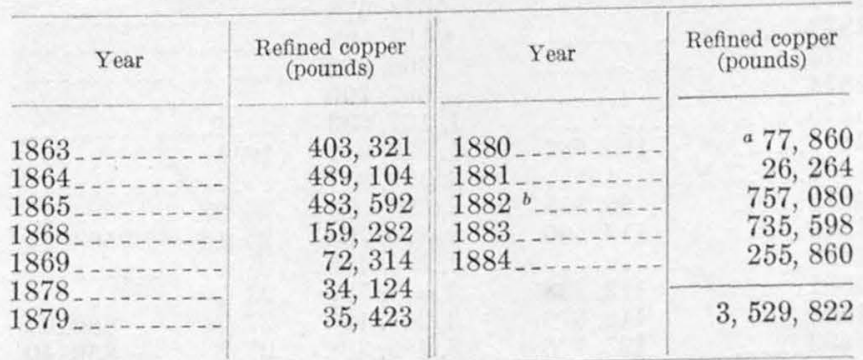

- Mineral Statistics, 1880 , gives product for the year (all tribute work) as 80,326 pounds refined copper.

o Rock treated, 18,959 tons; yield, 39.93 pounds per ton.

Gratiot.-In Keweenaw County. Organized February, 1906. Lately operated by Seneca. In 192322,051 tons hoisted to stock pile.

\begin{tabular}{|c|c|c|c|}
\hline \multirow{2}{*}{ Year } & \multirow{2}{*}{$\begin{array}{l}\text { Rock treated } \\
\text { (tons) }\end{array}$} & \multicolumn{2}{|c|}{ Refined copper (pounds) } \\
\hline & & Total & Per ton \\
\hline \multirow[t]{2}{*}{1910} & $\begin{array}{r}28,522 \\
1,347 \\
\text { b } 446\end{array}$ & $\begin{array}{r}265,869 \\
14,275 \\
33,704\end{array}$ & $\begin{array}{r}9.32 \\
\text { 10. } 60 \\
75.56\end{array}$ \\
\hline & 30,315 & 313,848 & 10. 35 \\
\hline
\end{tabular}

a 13,158 tons hoisted, 35 per cent of which was placed on stock pile.

Great Western.-See Belt.

Hancock (Sumner). - In Houghton County. Organized in April, 1859, as Haneock Mining Co. Company continued work until capital was exhausted and then leased the mine on tribute until 1872, when it was sold; in 1873 name changed to Sumner Mining Co., but little work was done; in winter of 1879 or 1880 it was sold and Hancock Copper Mining Co. organized; 40,000 shares of $\$ 25$ each. Work started July, 1880 , and discontinued in summer of 1885 . Hancock Consolidated Mining Co. organized June, 1906. Idle in 1922-1925. (Sumner organized November, 1867.)

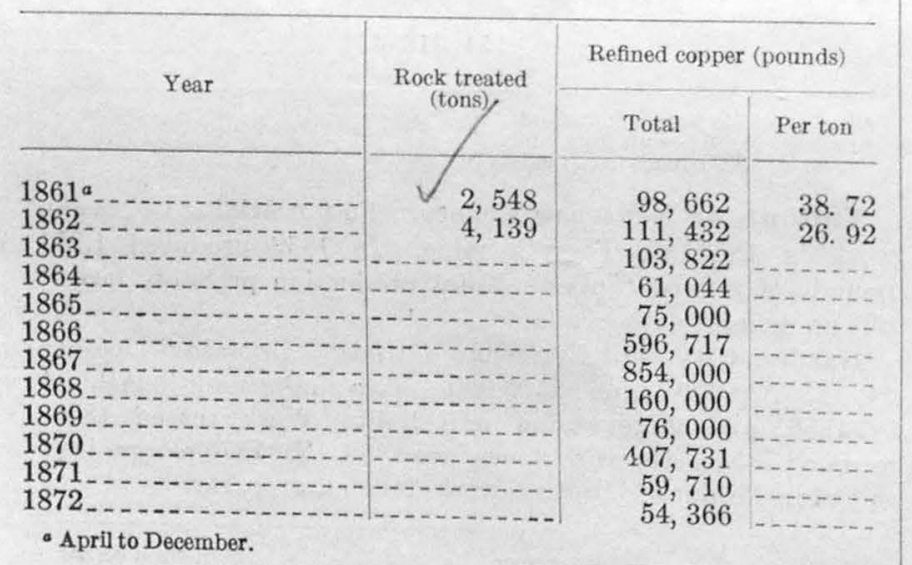

\begin{tabular}{|c|c|c|c|}
\hline & боек & Refined copper & (Dounds) \\
\hline & & Total & Pertion \\
\hline $\begin{array}{l}1873 \\
1874 \\
1875 \\
1879 \\
18801 \\
1882 \\
1883 \\
1884 \\
1885 \\
1886 \\
1911 \\
1913 \\
1915 \\
1916 \\
1917\end{array}$ & $\begin{array}{r} \\
41,499 \\
12,612 \\
203,112 \\
302,725 \\
227,049\end{array}$ & $\begin{array}{r}89,132 \\
61,365 \\
28,229 \\
7,294 \\
3,032 \\
571,897 \\
540,575 \\
484,906 \\
562,636 \\
203,037 \\
150,000 \\
754,749 \\
212,089 \\
488,678 \\
871,124 \\
2,824,934 \\
4,005,882 \\
3,041,514\end{array}$ & 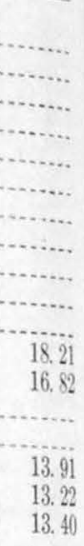 \\
\hline & & $17,559,557$ & \\
\hline
\end{tabular}

Mill test.

- Operations suspended from July 13, 1913, to Jan. 2, 1914.

Hilton (Ohio), - In Ontonagon County. First mining operations on this property in 1850 . Location abandoned from 1853 until May, 1863, when Hilton Mining Co. was organized Sunk a few trial shafts. A few tributers worked since 1865.

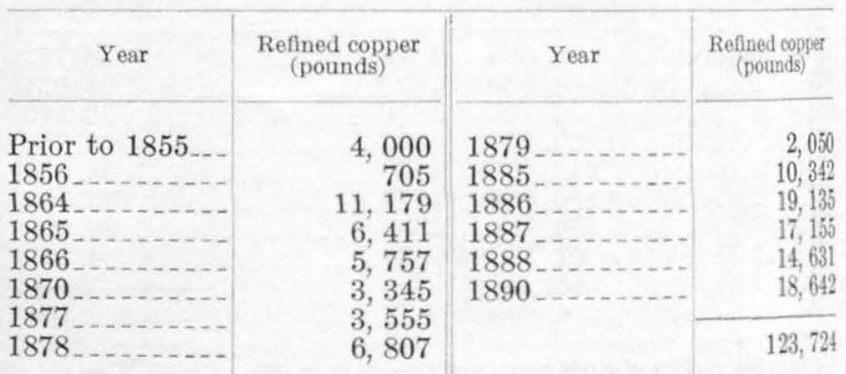

Houghton.-See Huron.

Houghton Copper.- In Houghton County. Incorporated January, 1910.

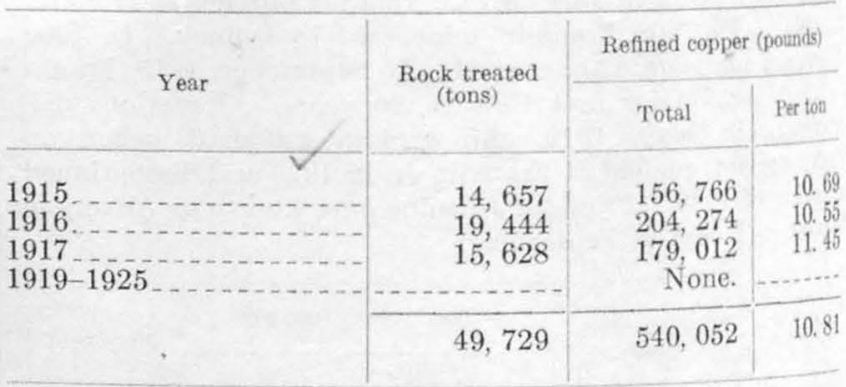

Huron.- In Houghton County. Organized December, 1853 Huron mine opened in 1855 on Isle Royale lode. Called Agswam from 1868 to 1871 , when name was changed to Houghton. In 1880 reorganized as Huron Copper Mining Co. In 1897 included in Isle Royale Consolidated Mining Co. 


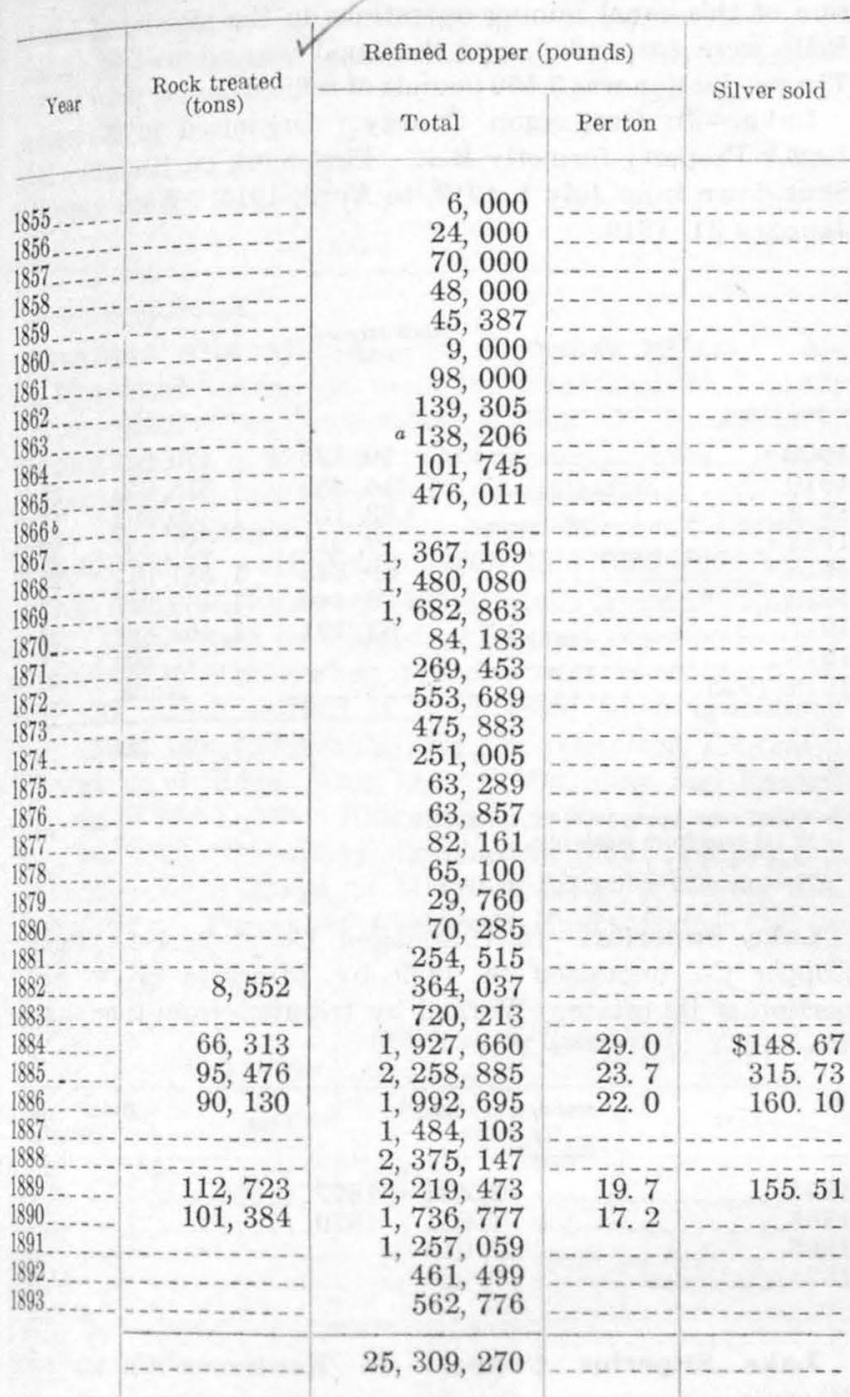

- From Feb. 1 to Oct. $31,85,345$ pounds of refined copper produced.

Thnual report dated 1880 says, "The year 1866 is omitted because an accurate distement of amount mined can not be obtained from any record in possession of froed company."

Indiana.-In Ontonagon County. Indiana Copper Co. organized in 1862 and worked steadily for three years, then stopped; recommenced in July, 1863. Stamp mill sold to Petherick Co. Indiana Mining Co. organized in 1909. No rock milled.

Island.-On Isle Royal. Organized 1874 as Island Mining Co.; 40,000 shares of $\$ 25$ each. Operated three years. Stamp mill built in 1875 and burned in 1876 . Leased on tribute.

\begin{tabular}{c|c} 
Year & $\begin{array}{r}\text { Refined copper } \\
\text { (pounds) }\end{array}$ \\
\hline 1876 & 48,340 \\
1877 & 88,867 \\
& \\
1878,038 \\
\hline
\end{tabular}

\section{'By Island Tribute Co.}

Isle Royale.- In Houghton County. Old Isle Royale mine opened in May, 1852. The work on this property was the first mining done in the Portage Lake district. Company stopped work in 1857, and the mine was leased on tribute to Mabbs Brothers. In 1862 purchased what was known as the Webster Mining Co. property. Company worked again 1863-1870, leasing the mine once more to Mabbs Brothers, who worked it for some years. Isle Royale Copper Co. incorporated 1899 and in April of that year took over Isle Royale Consolidated Mining Co., organized in 1897, and Miners' Copper Co., organized in 1898. Present Isle Royale includes old Isle Royale, Grand Portage, Huron, which comprised original Isle Royale consolidation in 1897, and also Frue and Dodge, which were taken into Miners' consolidation in 1898.

\begin{tabular}{|c|c|c|c|}
\hline Year & $\begin{array}{l}\text { Refined copper } \\
\text { (pounds) }\end{array}$ & Year & $\begin{array}{l}\text { Refined copper } \\
\text { (pounds) }\end{array}$ \\
\hline $\begin{array}{l}1853 \\
1854 \\
1855 \\
1856 \\
1857 \\
1858 \\
1859 \\
1860 \\
1861 \\
1862 \\
1863 \\
1864 \\
1865 \\
1866 \\
1867 \\
1868 \\
1869\end{array}$ & $\begin{array}{r}18,738 \\
\text { a } 97,262 \\
186,000 \\
\text { b } 323,510 \\
356,810 \\
\text { a } 386,000 \\
416,056 \\
336,198 \\
.896,139 \\
\text { c } 826,770 \\
\circ 588,130 \\
582,386 \\
787,547 \\
532,793 \\
762,852 \\
295,033 \\
150,672\end{array}$ & $\begin{array}{l}1871 \\
1872 \\
1873 \\
1874 \\
1875 \\
1876 \\
1877 \\
1878 \\
1879 \\
1880 \\
1881 \\
1882 \\
1884 \\
1885\end{array}$ & $\begin{array}{r}181,217 \\
250,164 \\
240,100 \\
180,876 \\
96,682 \\
28,199 \\
31,985 \\
31,933 \\
26,880 \\
77,469 \\
47,308 \\
35,447 \\
16,874 \\
30,164 \\
8,818,194\end{array}$ \\
\hline
\end{tabular}

a Estimated.

- Includes 11,125 pounds of refined copper estimated in mineral lost in lake.

d 14,000 tons stamped from Mabbs vein, yielding about 2.5 per cent.

\begin{tabular}{|c|c|c|c|c|}
\hline \multirow{2}{*}{ Year } & \multirow{2}{*}{$\begin{array}{l}\text { Rock treated } \\
\text { (tons) }\end{array}$} & \multicolumn{2}{|c|}{ Refined copper (pounds) } & \multirow{2}{*}{ Silver sold } \\
\hline & & Total & Per ton & \\
\hline $1853-1885$ & & $8,818,194$ & & \\
\hline $1901 \ldots \ldots$ & 185,175 & $2,171,955$ & 11.7 & \\
\hline $1902 \ldots \ldots$ & 263,672 & $3,569,748$ & 13.5 & a $\$ 8,881.61$ \\
\hline $1903 \ldots \ldots$ & 199,493 & $3,134,601$ & 15. 7 & $\ldots \ldots$ \\
\hline $1904 \ldots \ldots$ & 154,830 & $2,442,905$ & 15. 8 & $\ldots$ \\
\hline $1905 \ldots \ldots$ & 195,150 & $2,973,761$ & 15. 2 & $\ldots \ldots$ \\
\hline $1906 \ldots \ldots$ & 192,210 & $2,937,098$ & 15. 3 & $\ldots \ldots . . . .$. \\
\hline $1907 \ldots \ldots$ & 175,450 & $2,667,608$ & 15. 2 & $\ldots+\ldots . . .6$ \\
\hline $1908 \ldots \ldots$ & 218,940 & $3,011,664$ & 13. 8 & \\
\hline $1909 \ldots \ldots$ & 401,280 & $5,719,056$ & 14. 3 & $12,073,18$ \\
\hline $1910 \ldots \ldots$ & 520,860 & $7,567,399$ & 14.5 & $23,215.99$ \\
\hline $1911 \ldots \ldots$ & 457,440 & $7,490,120$ & 16. 37 & $20,336.55$ \\
\hline $1912 \ldots \ldots$ & 531,105 & $8,186,957$ & 15. 41 & $38,126.16$ \\
\hline $1913 \ldots \ldots$ & 314,679 & $4,158,548$ & 13.21 & $14,878.01$ \\
\hline $1914 \ldots \ldots$ & 474,349 & $6,601,235$ & 13. 91 & $17,477.98$ \\
\hline 1915 & 680,270 & $9,342,106$ & 13. 73 & $38,973.56$ \\
\hline 1916 & 925,419 & $12,412,111$ & 13.41 & $53,086.76$ \\
\hline $1917 \ldots$ & 922,160 & $13,480,921$ & 14. 6 & $84,962,44$ \\
\hline $1918 \ldots \ldots$ & 974,508 & $15,442,508$ & 15. 9 & $80,743.43$ \\
\hline $1919 \ldots \ldots$ & 724,667 & $13,007,647$ & 17.95 & $94,144.01$ \\
\hline $1920 \ldots \ldots$ & 591,971 & $10,621,801$ & 17. 94 & $75,075.53$ \\
\hline $1921 \ldots \ldots$ & 116,576 & $2,491,000$ & 21. 37 & . \\
\hline $1922 \ldots \ldots$ & 246,641 & $6,639,970$ & 26. 92 & \\
\hline 1923 & 308,940 & $8,002,244$ & 25. 90 & -....... \\
\hline $1924 \ldots \ldots$ & 315,507 & $8,103,000$ & 25. 68 & 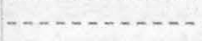 \\
\hline \multirow[t]{2}{*}{$1925 \ldots \ldots$} & 378,459 & $9,543,000$ & 25. 22 & \\
\hline & & $180,537,157$ & & \\
\hline
\end{tabular}

a 18,523 ounces. 
Kearsarge.-In Houghton County. Organized as Kearsarge Mining Co.; 50,000 shares of $\$ 25$ each. Absorbed by Osceola Consolidated Mining Co. in December, 1897.

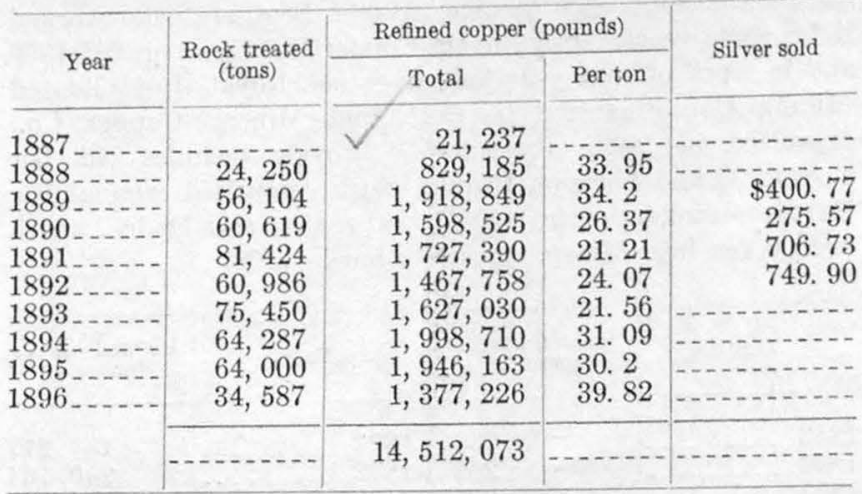

Keweenaw Copper.-In Keweenaw County. Organized March 13, 1905. Work was started in summer of 1905 by diamond drilling on Medora and Mandan properties. Includes Aetna, Empire, Girard, Hanover, Copper Harbor, Washington, Keweenaw, Mandan, Medora, Vulcan, Resolute, Boston, and Phoenix (Penn?). Resolute was sold to Keweenaw Copper Co. late in 1905 or early in 1906. 7,500 tons of stamp rock on stock pile in 1906 .

\begin{tabular}{|c|r|}
\hline Year & $\begin{array}{r}\text { Refined copper } \\
\text { (pounds) }\end{array}$ \\
\hline 1908 & 122,474 \\
\hline 1909 & 57,091 \\
\hline
\end{tabular}

King Philip.-See Winona.

Knowlton.-In Ontonagon County. Organized August 6, 1860. Mine opened in 1862; discontinued on company account 1866-1867, then worked on tribute. Absorbed by Adventure Consolidated Copper Co. O. Ashley says (Copper mines of Lake Superior, 1873): "1,086,000 pounds ingot copper taken out from 1863 to 1869 .'

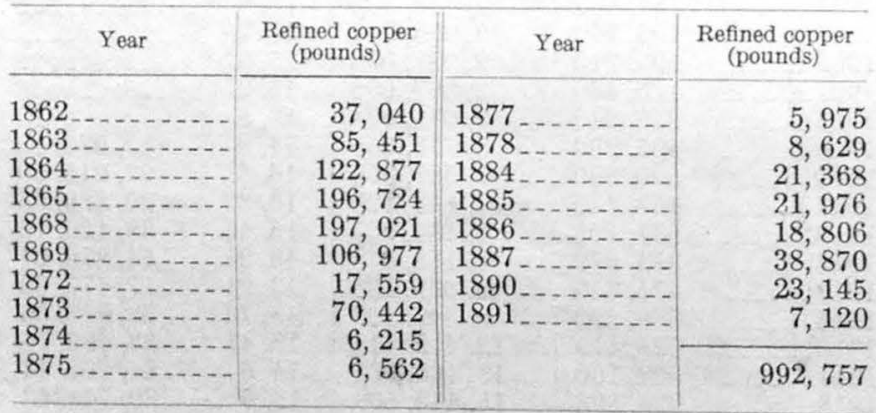

Lac La Belle.- In Keweenaw County. Prior to 1850 the Lac La Belle Co. had driven a tunnel into the hill 400 feet and found a vein 18 inches wide. No further work was done until 1866. The following statement is taken from Eng. and Min. Jour., October 18, 1890, p. 448: "Mendota Mining Co. commenced operations in 1866 on property formerly worked by the Lac La Belle Mining Co,, secs. 29 and 32 , T. 58 , R. 29, Keweenaw County. Three hundred feet of sinking and 700 feet of drifting were done and operations were suspended. Later the lands of the company were sold for taxes. Company owned 4,320 acres surrounding Lac La Belle. In fall of 1866 this company completed a canal from Lac La Belle to Bete Gris at cost of $\$ 100,000$, receiving from the Government in consideration therefor 100,000 acres of land in Schooleraft County, Mich. About the time of the comple- tion of this canal mining operations in the vicinity of $\mathrm{Lac}$ Is Belle were suspended, and the canal was allowed to fll up." The production was 3,499 pounds of refined copper prior to 1850

Lake.- In Ontonagon County. Organized in November 1905. Property formerly Belt. First work on Knowlten lode. Shut down from July 1, 1913, to April, 1915. Work suspended January 31, 1919.

\begin{tabular}{|c|c|c|c|}
\hline \multirow{2}{*}{ Year } & \multirow{2}{*}{$\begin{array}{l}\text { Rock treated } \\
\text { (tons) }\end{array}$} & \multicolumn{2}{|c|}{ Refined copper (punds) } \\
\hline & & Total & Per ton \\
\hline $\begin{array}{l}1909{ }^{a} \\
1910 \\
1912 \\
1913 \\
1915 \\
1916 \\
1917 \\
1918 \\
1919\end{array}$ & $\begin{array}{r}10,125 \\
14,485 \\
63,109 \\
19,211 \\
59,848 \\
70,440 \\
63,191 \\
\end{array}$ & $\begin{array}{r}170,801 \\
318,050 \\
1,300,562 \\
287,200 \\
1,581,071 \\
1,489,247 \\
1,461,893 \\
717,403 \\
\text { None. }\end{array}$ & $\begin{array}{l}21.06 \\
21.96 \\
15.64 \\
15.39 \\
26.42 \\
21.14 \\
23.13\end{array}$ \\
\hline & & $7,326,227$ & \\
\hline
\end{tabular}

a Fiscal year April, 1909, to A pril, 1910

12,141 tons from stock pile.

c May 1 to July 1 .

d Nine months ending A pr. 30, 1916.

Lake Superior.-In Ontonagon County. Lake Superior Copper Co. organized in 1859 by Minesota Co. to work a portion of its estate. Worked by tributers from time to time after 1874

\begin{tabular}{c|r|r|r}
\hline Year & $\begin{array}{c}\text { Refined copper } \\
\text { (pounds) }\end{array}$ & \multicolumn{1}{c|}{ Year } & \multicolumn{1}{c}{$\begin{array}{c}\text { Refined copper } \\
\text { (pourds) }\end{array}$} \\
\hline & 2,432 & $1877 \ldots$ & \\
\hline $1864 \ldots 5$ & 1,951 & $1879 \ldots$ & 2,106 \\
1866 & 2,018 & & 1,086 \\
\hline 1874 & 5,228 & & 14,821 \\
\hline
\end{tabular}

Lake Superior Copper.-In Keweenaw County. See Phoenix.

La Salle.- In Houghton County. Organized December. 1906. Includes Caldwell and other lands. Purchased Tecumseh in May, 1910. Mined on Kearsarge amygdaloid and drove crosscut from Osceola amygdaloid to Allouez conglomerate. All production is from Kearsarge amygdaloid.

\begin{tabular}{|c|c|c|c|c|}
\hline \multirow{2}{*}{ Year } & \multirow{2}{*}{$\begin{array}{l}\text { Rock treated } \\
\text { (tons) }\end{array}$} & \multicolumn{2}{|c|}{ Refined copper (pounds) } & \multirow{2}{*}{ Silver sold } \\
\hline & & Total & Per ton & \\
\hline \multirow{12}{*}{$\begin{array}{l}1910 \\
1911 \\
1912 \\
1913 \\
1914 \\
1915 \\
1916 \\
1917 \\
1918 \\
1919 \\
1920 \\
1921\end{array}$} & 49,274 & 633,778 & 12.86 & \\
\hline & 18,970 & 280,598 & 14. 79 & \\
\hline & 001 & None. & 1076 & \\
\hline & 2, 221 & 43,906 & 19. 76 & $\$ 3.583 .25$ \\
\hline & $\begin{array}{l}45,509 \\
80\end{array}$ & $\begin{array}{l}540,731 \\
782,493\end{array}$ & $\begin{array}{r}11.88 \\
9.67\end{array}$ & $6,034.90$ \\
\hline & 144,829 & $1,380,352$ & 9.53 & $13,843.80$ \\
\hline & 185,014 & $1,919,775$ & 10. 38 & $12,408.87$ \\
\hline & 176,423 & $1,832,665$ & 10. 39 & \\
\hline & 32,995 & 340,719 & 10. 33 & \\
\hline & 3,430 & 59,713 & 17. 41 & \\
\hline & & None. & - n & \\
\hline & 739,624 & $7,814,730$ & 10.57 & \\
\hline
\end{tabular}

Madison (Summit).- In Keweenaw County. Summit organized 1852-53. Mining work continued until 1856. In August, 1859, reorganized as Madison Mining Co., 20,000 shares of $\$ 25$ each. Work resumed in 1863. Some tribute up to 1876 , when company began again. Property sold at sherif's sale in 1878 but redeemed by company in September, 1879 , and reorganized with 40,000 shares of $\$ 25$ each. Work resumed in 1880 and continued until May, 1882. Property bought by Central about 1885 . 


\begin{tabular}{|c|c|c|c|}
\hline Year & $\begin{array}{l}\text { Refined copper } \\
\text { (pounds) }\end{array}$ & Year & $\begin{array}{l}\text { Refined copper } \\
\text { (pounds) }\end{array}$ \\
\hline \multirow{2}{*}{$\begin{array}{l}1856 \ldots \ldots \\
1857 \ldots \ldots . \\
1865 \ldots . . . \\
1866 \ldots \\
\end{array}$} & \multirow{2}{*}{$\begin{array}{r}4,000 \\
16,000 \\
14,881 \\
34,000\end{array}$} & \multirow[t]{2}{*}{$1878 \ldots$} & $\begin{array}{l}1,676 \\
1,534\end{array}$ \\
\hline & & & 72,091 \\
\hline
\end{tabular}

Manhattan (Old Albion).- In Keweenaw County. Albion commenced operations in 1848; suspended 1857-1862; resumed operations as Manhattan Mining Co. in January, $1863 ; 20,000$ shares of $\$ 25$ each. Abandoned in 1865. 5 tons of copper taken out in sinking shaft (about 1863).

Mass.-In Ontonagon County. Mass Mining Co. organired in May, 1856, worked until 1860, idle 1860-1864, when work was begun on Evergreen lode; totally suspended again in 1868. A little work on tribute. Company resumed in 1874 and continued to 1884 , when property was leased to Mass Tribute Co., which worked it until 1888, when operations ceased. Mass Consolidated Mining Co. organized February, 1899; made up of Ridge, Mass, Ogima, Merrimac, and Hazard mines; capital $\$ 2,500,000$. Ridge began 1850 . Ogima opened 1860; closed 1868. Merrimac organized in 1863. Hazard did little work on North Range, or Minesota Belt. A few old test pits and shafts. Purchased Evergreen Bluff Mining Co. in 1911 (?).

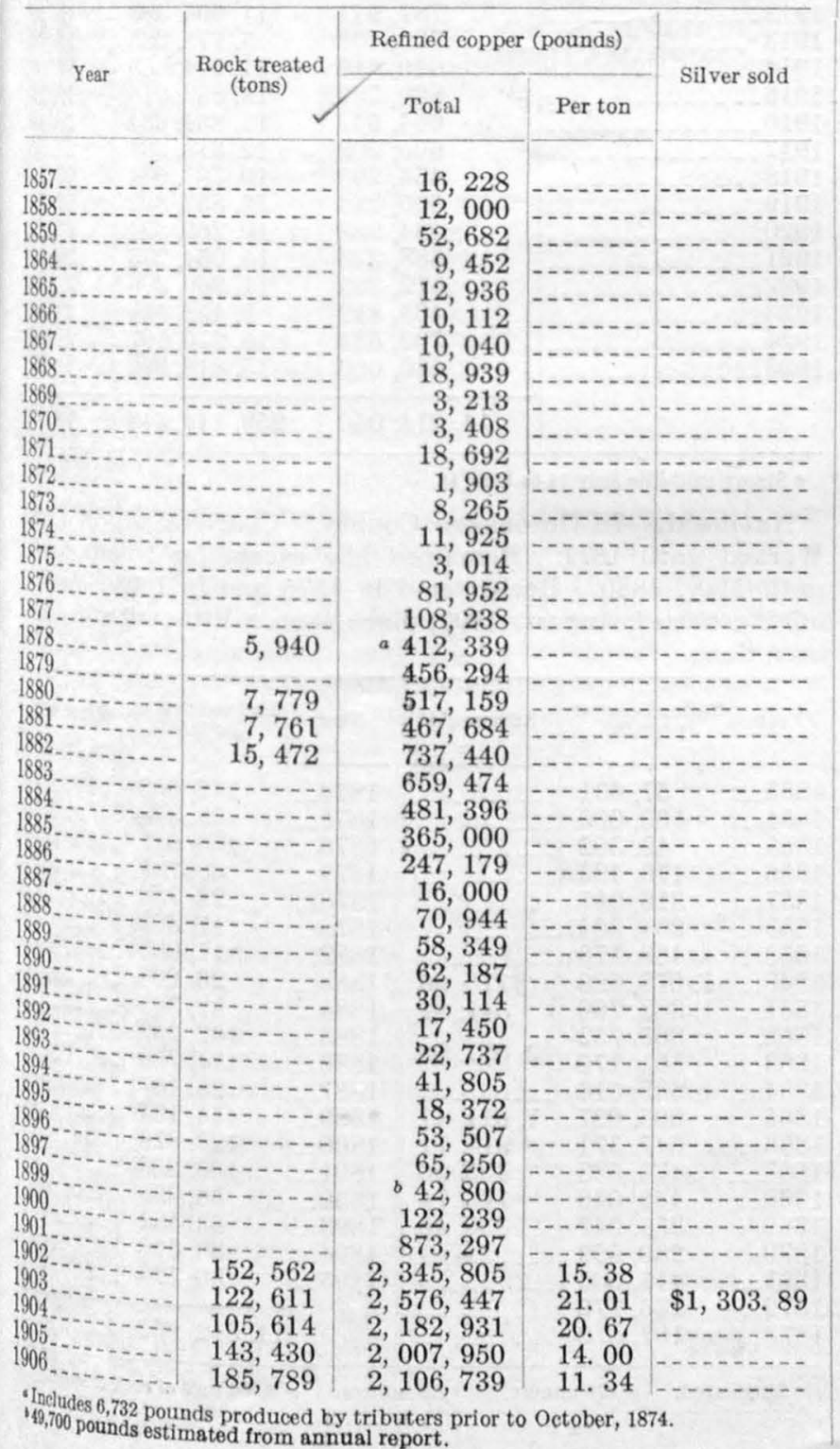

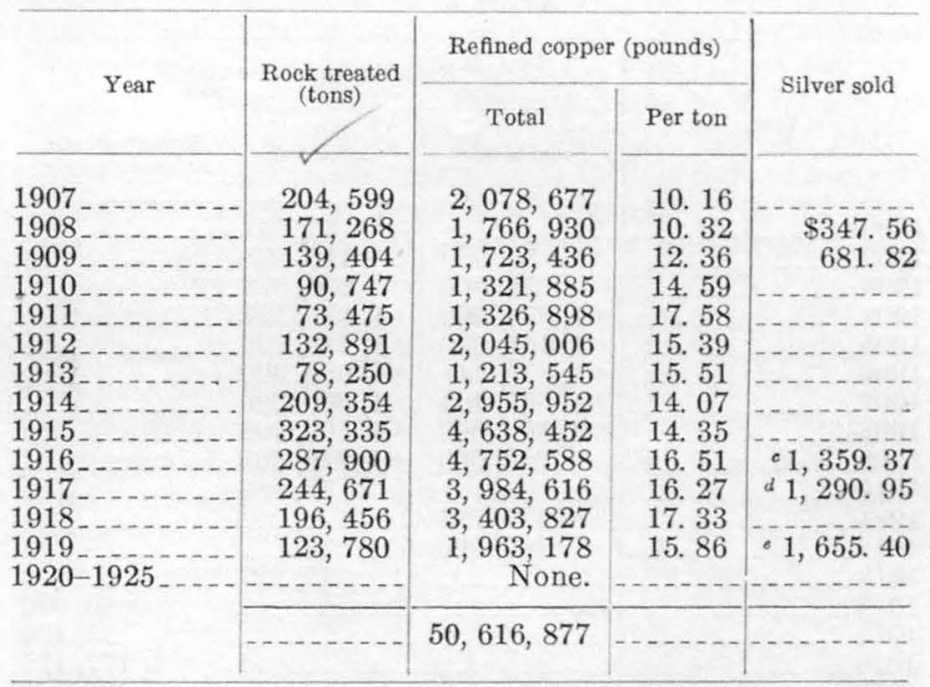

i, 1,813 ounces.

$d 1,572$ ounces. Sale of silver from date of organization to end of $1917, \$ 15,280.37$. $-1,264$ ounces.

Mesnard.-In Houghton County. Organized in May, 1859; 20,000 shares of $\$ 25$ each. Tributers worked after company ceased. In 1876 taken over by Pewabic interests. Sold to Quincy in 1897.

\begin{tabular}{|c|c|c|c|}
\hline Year & $\begin{array}{l}\text { Refined copper } \\
\text { (pounds) }\end{array}$ & Year & $\begin{array}{l}\text { Refined copper } \\
\text { (pounds) }\end{array}$ \\
\hline \multirow{3}{*}{$\begin{array}{l}1863 \\
1864 \\
1865 \\
1868\end{array}$} & \multirow{3}{*}{$\begin{array}{r}43,127 \\
4,000 \\
15,600 \\
5,510\end{array}$} & \multirow{3}{*}{$\begin{array}{l}1873 \\
1877 \\
-\end{array}$} & 9,269 \\
\hline & & & 6,589 \\
\hline & & & 84,095 \\
\hline
\end{tabular}

Michigan.-In Ontonagon County. Organized June, 1898, and began work in September. Reorganized January, 1899. Owns properties formerly known as Minesota, Rockland, and Superior. Rockland set off from Minesota in 1853 and closed in 1870. Little work on tribute. Minesota mine discovered 1847 , opened 1848 , closed 1870 . Little work on tribute after 1870. Michigan discontinued work on company account at end of 1910 and mine let on tribute until May, 1913, when all work stopped and mine was idle until July, 1915. Work was again suspended October 1, 1920. Consolidated with Mohawk Mining Co. in 1923. Silver sold, \$294 (in 1921).

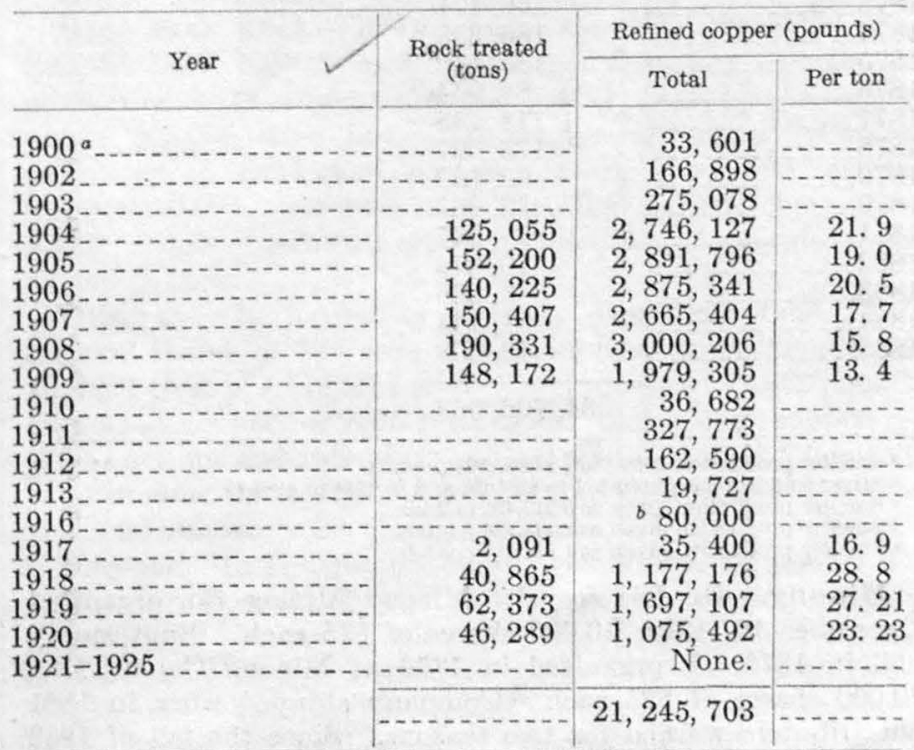

a Mill test of 1,100 tons of rock treated yielded 14,670 pounds of refined copper,

or 13.33 pounds per ton. 


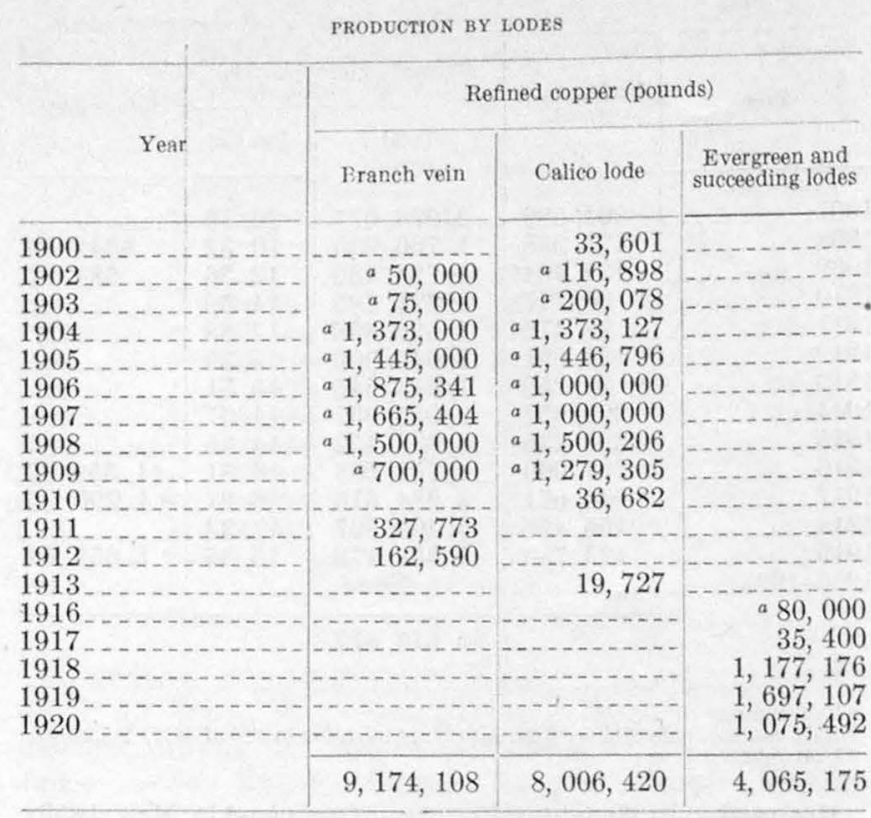

a Estimated.

Minesota.-In Ontonagon County. Incorporated in 1848, 3,000 shares; reorganized in $1855,20,000$ shares of $\$ 50$ each. Mine worked by tributers after 1870 . Later became part of Michigan, which was consolidated with Mohawk in 1923.

\begin{tabular}{|c|c|c|}
\hline Year & $\begin{array}{l}\text { Refined copper } \\
\text { (pounds) } a\end{array}$ & Silver sold ${ }^{b}$ \\
\hline $\begin{array}{l}\text { Prior to } 1855 \\
1855 \\
1856 \\
1857 \\
1858 \\
1859 \\
1861 \\
1862 \\
1863 \\
186456 \\
18667 \\
1868 \\
1869 \\
1870 \\
1871 \\
1872 \\
1874 \\
1875 \\
1876 \\
1877 \\
1878 \\
1879 \\
1881 \\
1882 \\
1883 \\
1884 \\
1885\end{array}$ & $\begin{array}{r}3,020,000 \\
2,080,000 \\
3,490,714 \\
3,952,000 \\
3,802,914 \\
3,344,587 \\
2,680,500 \\
3,016,824 \\
d 2,520,000 \\
\cdot 1,677,500 \\
1,446,000 \\
403,000 \\
391,500 \\
376,500 \\
230,900 \\
227,500 \\
401,500 \\
368,000 \\
252,000 \\
148,171 \\
186,338 \\
133,419 \\
88,954 \\
113,148 \\
175,027 \\
92,762 \\
32,033 \\
24,227 \\
10,672 \\
6,226 \\
1,144 \\
12,608 \\
706,668\end{array}$ & $\begin{array}{l}\$ 986.95 \text { (112 pounds). } \\
\$ 654.44 \text { (78 pounds). } \\
\$ 606.83 \text { (70 pounds). } \\
\$ 644.61 \text { ( } 88 \text { pounds). } \\
\$ 1,039.92 \text { (185 pounds). } \\
\$ 912.71 \text {. } \\
\$ 757.68 \text {. }\end{array}$ \\
\hline
\end{tabular}

a Smelter production $1848-1868,27,307,893$ pounds.

Silver sold in 1852 amounted to $\$ 261.69$, and in 1854 to $\$ 186.46$.

- Smelter production given as 3,212,426 pounds.

- Smelter production given as 2,135,936 pounds.

Minong.-On Isle Royal. Minong Mining Co. organized December 16, $1874 ; 40,000$ shares of $\$ 25$ each. Built stamp mill in 1876. Reorganized in 1879 as Minong Copper Co. 20,000 shares of $\$ 25$ each. Company stopped work in 1881 but tributers worked for two seasons. Since the fall of 1883 no work has been done.

\begin{tabular}{r|r||r|r}
\hline Year & $\begin{array}{r}\text { Refined copper } \\
\text { (pounds) }\end{array}$ & Year & $\begin{array}{r}\text { Refined copper } \\
\text { (pounds) }\end{array}$ \\
\hline 1875 & 48,344 & 1881 & 15,397 \\
$1876 \ldots$ & 114,537 & 1882 & 21,380 \\
1877 & 104,892 & $1883 \ldots$ & 382 \\
\hline 1878 & 90,596 & & 498,650 \\
1879 & 72,515 & & \\
\hline
\end{tabular}

Mohawk.-In Keweenaw County. Mohawk Mining $\mathrm{C}_{0}$. organized November, 1898, and took over part of lands of Fulton Mining Co. Started stamping in December, 1902. Wolverine and Michigan consolidated with Mohawk on August 15,1923 . In 1900 produced 70,000 pounds mohawkite; in $1901,160,897$ pounds.

\begin{tabular}{|c|c|c|c|}
\hline \multirow{2}{*}{ Year } & \multirow{2}{*}{ Rock treated (tons) } & \multicolumn{2}{|c|}{ Refined copper (pounds) } \\
\hline & & Total & Per ton \\
\hline $\begin{array}{l}1902 \\
1903 \\
1904 \\
1905 \\
1906 \\
1908 \\
1909 \\
1910 \\
1911 \\
1912 \\
1913 \\
1914 \\
1915 \\
1916 \\
1918 \\
1919 \\
1920 \\
1921 \\
1922 \\
1923 \\
1924\end{array}$ & $\begin{array}{r}8,613 \\
288,441 \\
459,162 \\
586,305 \\
618,543 \\
640,777 \\
685,823 \\
819,019 \\
802,537 \\
802,548 \\
787,941 \\
366,458 \\
649,649 \\
829,789 \\
664,547 \\
605,202 \\
454,293 \\
560,734 \\
434,988 \\
688,273 \\
512,393 \\
405,412 \\
702,534 \\
640,069\end{array}$ & $\begin{array}{r}226,824 \\
6,284,327 \\
8,149,515 \\
9,387,614 \\
9,352,252 \\
10,107,266 \\
10,295,881 \\
11,248,474 \\
11,412,066 \\
12,091,056 \\
11,995,598 \\
5,778,235 \\
11,094,859 \\
15,882,914 \\
13,834,034 \\
12,313,887 \\
10,781,041 \\
12,857,392 \\
10,269,824 \\
14,054,235 \\
11,209,396 \\
9,452,539 \\
15,215,197 \\
15,819,922\end{array}$ & $\begin{array}{l}26.34 \\
21.79 \\
17.75 \\
16.01 \\
15.12 \\
15.77 \\
15.01 \\
13.73 \\
14.22 \\
15.07 \\
15.22 \\
15.76 \\
17.08 \\
19.15 \\
20.82 \\
20.35 \\
23.73 \\
22.93 \\
23.61 \\
20.42 \\
21.88 \\
23.32 \\
21.66 \\
24.72\end{array}$ \\
\hline & $14,014,050$ & $259,114,348$ & 18. 49 \\
\hline
\end{tabular}

a Stamp mill idle July 14 to Dec. 18

National.-In Ontonagon County. Chartered April, 1848. Worked until 1871. Remained idle except for tribute work until May, 1880. Rechartered in 1878 and in 1908. Active mining ceased August, 1893; since then a little tributing has been done.

\begin{tabular}{|c|c|c|c|c|c|}
\hline Year & $\begin{array}{l}\text { Refined copper } \\
\text { (pounds) }\end{array}$ & Silver sold & Year & $\begin{array}{l}\text { Refined copper } \\
\text { (pounds) }\end{array}$ & Silver sold \\
\hline 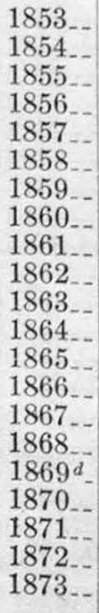 & $\begin{array}{r}57,631 \\
100,000 \\
49,302 \\
176,483 \\
316,957 \\
264,804 \\
488,176 \\
1,078,609 \\
1,383,760 \\
865,752 \\
561,179 \\
688,516 \\
695,027 \\
647,371 \\
475,633 \\
443,048 \\
256,947 \\
260,659 \\
411,086 \\
336,770 \\
167,870\end{array}$ & $\begin{array}{r}\$ 776.96 \\
547.82 \\
2,051.88 \\
1,011.41 \\
\text { ь } 916.71 \\
495.66 \\
178.74 \\
336.40 \\
\end{array}$ & $\begin{array}{l}1874 \\
1875 \\
1876 \\
1877 \\
1878 \\
1879 \\
1882 \\
1883 \\
1884 \\
1885 \\
1886 \\
1887 \\
1889 \\
1890 \\
1891 \\
1892 \\
1893 \\
1894 \\
1895 \\
\end{array}$ & $\begin{array}{r}142,052 \\
98,878 \\
166,647 \\
68,737 \\
22,736 \\
17,506 \\
17,060 \\
26,006 \\
87,368 \\
162,252 \\
184,706 \\
25,187 \\
454,134 \\
123,879 \\
103,888 \\
36,385 \\
63,433 \\
36,390 \\
50,128\end{array}$ & \\
\hline
\end{tabular}

a Estimated. ${ }^{b} 679$ ounces. $\cdot 198$ ounces. $₫ 8,750$ tons of rock treated 
New Arcadian.-See Arcadian.

New York and Michigan. - In Keweenaw County. Opened 1846 ; closed in 1847; reopened 1852-53. Four small masses weighing about 1,800 pounds were shipped in 1852 .

vonesuch.-In Ontonagon County. Organized in June, 1867. Worked at intervals for several years. In 1875 stock ncreased to 40,000 shares. Idle 1875-1877, and stamp mill anned soon afterward. Leased for seven years by Capt. Thomas Hooper. Over $\$ 500,000$ spent.

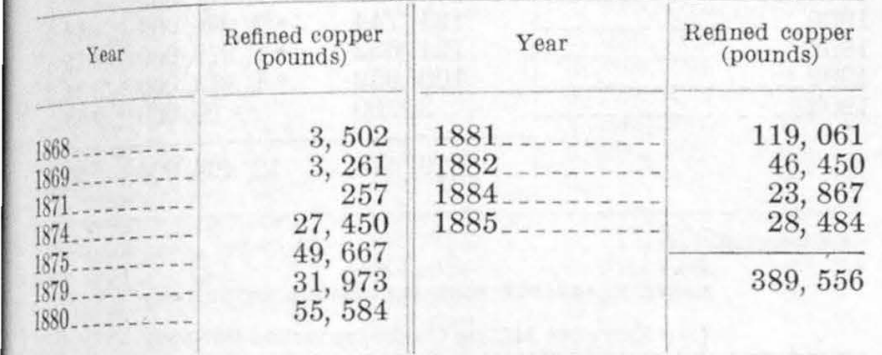

Yorth American.-In Keweenaw County. Organized in 1848; 6,000 shares, $\$ 300,000$. Shares increased to 10,000 with sme capital about 1851. Opened old North American mine in 1846 and worked until 1853. In 1852 opened South Cliff mine. In 1860 sold entire property to Pittsburgh \& Boston Mining Co. It was then let on tribute for three years. In 1864 North Amerian mine set aside by the Pittsburgh \& Boston to be operated by nerly organized American Mining Co. The North American fisure, during the four years it was worked, yielded 445,000 pounds of copper. Remainder of production by North American Mining Co. came from Cliff fissure.

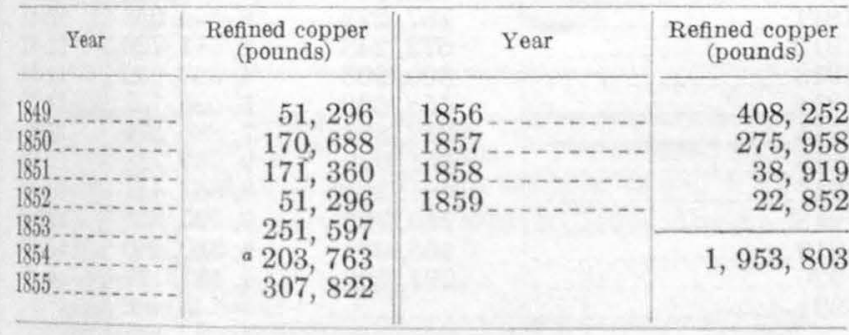

\section{- Fstimated.}

North Cliff.-In Keweenaw County. Organized September 20,1858 , by setting off $1,002.25$ acres from lands of Pittsburgh \& Boston Mining Co. Reorganized March 22, 1859, under special charter which had originally been granted to the "Swamscott Jining Co. of Michigan" and the name changed to North Cliff Mining Co. of Michigan. Operations suspended at end of 1860; resumed in 1863 . In 1859 produced 2,435 pounds of refined copper (from openings); in 1864, 3,222 pounds; total, 5,657 pounds.

North Lake.- In Ontonagon County. Organized August, 1908. No rock milled.

Northwest.-See Pennsylvania.

Northwestern.-In Keweenaw County. Organized April, 1845, as Northwestern Mining Co. Reorganized as NorthNestern Mining Co, of Detroit, March 16, 1848; capital $\$ 300,000$. Stamp mill erected in 1852 . Work suspended in 1857, resumed in spring of 1863, again suspended in January, 1865. Later absorbed by Central. In 1863 silver sold amounting to $\$ 108.54$.

\begin{tabular}{l|r||c|r}
\multicolumn{1}{c|}{ Year } & $\begin{array}{r}\text { Refined copper } \\
\text { (pounds) }\end{array}$ & Year & $\begin{array}{c}\text { Refined copper } \\
\text { (pounds) }\end{array}$ \\
\hline $1852 \ldots$ & 8,622 & 1864 & 6,651 \\
$1853 \ldots$ & 44,166 & 1880 & 961 \\
\hline 1854 & 84,900 & & 313,005 \\
$1856 \ldots$ & & \\
\hline
\end{tabular}

Norwich.-In Ontonagon County, Vein discovered on Norwich and Windsor properties in July, 1846. Operations at Norwich mine began May, 1850 , but not worked with any considerable force until 1852. In February, 1855, American Mining Co. of Vermont organized Norwich Mining Co.; 20,000 shares of $\$ 25$ each. Operations suspended in 1858 because of financial difficulties. Some work done on tribute 1858-1863. In May, 1863, Norwich reorganized and formed a consolidation with Windsor mine, and work recommenced immediately. Consolidation with Hamilton Co. was decided on, April 14, 1864, followed immediately by a division of the property, exchange of stock and the formation of two companies, the Norwich ceding the property known as the Windsor mine and receiving the north part of the Hamilton. Mine was shut down in 1865 . Some work was done in 1899-1900 under the name of Essex Copper Co.

\begin{tabular}{|c|c|c|c|}
\hline Year & $\begin{array}{c}\text { Refined copper } \\
\text { (pounds) }\end{array}$ & Year & $\begin{array}{l}\text { Refined copper } \\
\text { (pounds) }\end{array}$ \\
\hline \multirow{5}{*}{$\begin{array}{l}1852 \ldots \\
1853 \\
1854 \\
1855 \\
1856 \\
1857\end{array}$} & \multirow{5}{*}{$\begin{array}{r}6,339 \\
34,451 \\
\alpha 293,210 \\
216,000 \\
220,000 \\
116,000\end{array}$} & \multirow{5}{*}{$\begin{array}{l}1858 \\
1864 \\
1865 \\
1869\end{array}$} & 39,000 \\
\hline & & & 9,730 \\
\hline & & & 53,330 \\
\hline & & & 5,300 \\
\hline & & & 993,360 \\
\hline
\end{tabular}

a Estimated.

Ogima.-In Ontonagon County. Property worked under tribute 1857-1860. Purchased in fall of 1860 and Ogima Mining Co. organized in December of that year; 20,000 shares of $\$ 25$ each. Stopped work in 1868. Ground above adit level worked at intervals by tributers. In 1888 leased for three years to $\mathrm{A}$. Meads. Later absorbed by Mass.

\begin{tabular}{|c|c|c|c|}
\hline Year & $\begin{array}{l}\text { Refined copper } \\
\text { (pounds) }\end{array}$ & Year & $\begin{array}{l}\text { Refined copper } \\
\text { (pounds) }\end{array}$ \\
\hline $\begin{array}{l}1857 \ldots 1860^{a} \ldots \\
1861 \\
1862 \ldots \\
1863 \ldots \\
1864 \ldots \\
1865 \\
1866 \ldots \ldots \\
1867 \ldots \ldots \\
1868 \\
1869\end{array}$ & $\begin{array}{r}114,650 \\
14,166 \\
40,957 \\
\text { b } 28,700 \\
\text { b } 35,000 \\
167,436 \\
277,310 \\
168,480 \\
199,360 \\
18,045 \\
9,839\end{array}$ & $\begin{array}{l}1878 \ldots \ldots \\
1879 \ldots \ldots \\
1880 \ldots \\
1881 \ldots \ldots \\
1882 \ldots \ldots \\
1883 \ldots \ldots \\
1884 \ldots \ldots\end{array}$ & $\begin{array}{r}2,800 \\
17,937 \\
5,885 \\
16,776 \\
4,207 \\
3,000 \\
1,106 \\
12,291 \\
952\end{array}$ \\
\hline
\end{tabular}

Ohio.-See Hilton.

Ohio Trap Rock.- In Ontonagon County. Special charter granted $1849 ; 6,000$ shares, $\$ 25$ each. Company commenced operations in 1846 and up to September, 1853, had expended about $\$ 90,000$ with but little returns of copper. Capital exhausted in 1855, and company reorganized with capital stock $\$ 300,000$. No work done since 1857 . In 1853 produced 2,755 pounds of refined copper; in $1858,38,685$ pounds; total, 41,440 pounds.

Ojibway.-In Keweenaw County. Organized June, 1907; 100,000 shares of $\$ 25$ each. Worked Kearsarge amygdaloid. In 1911 treated 7,448 tons of rock and produced 49,662 pounds of refined copper, or 6.65 pounds per ton. Mass copper retained at mine amounted to 0.7 pound per ton stamped, bringing total product up to 7.35 pounds per ton, with tailings losses of about 3 pounds.

Osceola.- In Houghton County. Organized September 25, 1873. In 1879 consolidated with Opechee, forming Osceola Consolidated Mining Co. Reincorporated 1903. First worked on Calumet \& Hecla conglomerate. In 1877 Osceola amygdaloid located. Kearsarge and South Kearsarge mines operated on Kearsarge amygdaloid, and Tamarack Jr. on Calumet \& Hecla conglomerate. Reorganized 1897 including three 
mines-Osceola, Tamarack Jr., and Kearsarge. Tamarack Jr. set off from Tamarack about 1890. South Kearsarge mine opened by Osceola Consolidated Mining Co. in 1899. Absorbed by Calumet \& Hecla Consolidated Copper Co. September 1, 1923.

ALL LODES

\begin{tabular}{|c|c|c|c|c|}
\hline \multirow{2}{*}{ Year } & \multirow{2}{*}{$\begin{array}{l}\text { Rock } \\
\text { treated } \\
\text { (tons) }\end{array}$} & \multicolumn{2}{|c|}{ Refined copper (pounds) } & \multirow{2}{*}{ Silver sold } \\
\hline & & Total & Per ton & \\
\hline 1874 & 25,763 & 936,002 & 36.33 & \\
\hline & & $1,330,313$ & & \\
\hline & 43,075 & $1,693,737$ & 39. & \\
\hline & 78,339 & $2,774,777$ & 35. & \\
\hline & 79,439 & ${ }^{a} 2,705,998$ & 34. & $\$ 5,525.61$ \\
\hline 1879 & 95,055 & в $3,197,387$ & 33. & 98. 36 \\
\hline & 107,386 & 3,381 , & 31. 48 & 94. 07 \\
\hline 188 & 160,8 & $4,176,976$ & 26. 0 & 4. 25 \\
\hline & 172,52 & $4,179,7$ & 24. & $3,476.91$ \\
\hline 1883 & 175,320 & $4,256,409$ & 24 . & $3,757.78$ \\
\hline & 181,608 & $4,247,630$ & 23.4 & $2,383.99$ \\
\hline & 72,923 & $1,939,169$ & 26. 6 & \\
\hline & 137,725 & $3,560,786$ & 25.8 & $1,308.93$ \\
\hline & 145,200 & 3,5 & 24. & \\
\hline & 183,036 & $4,134,320$ & 22. & \\
\hline & 175,5 & 4,534, & 25. & 7. 91 \\
\hline 0 . & 183,8 & 5,2 & 28. & $1,238.74$ \\
\hline $1-$ & 234 , & $6,543,358$ & 27. & $1,249.10$ \\
\hline & 247,575 & 7,0 & 28. & 155. 27 \\
\hline & 236,875 & $6,715,8$ & 28. & 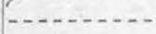 \\
\hline 1894 & 264 & 6,9 & 26. & \\
\hline & 233,2 & 6,2 & 26. & \\
\hline & 248,0 & $6,251,3$ & 25.2 & \\
\hline & 443,0 & $11,201,103$ & 21. & \\
\hline & 505,008 & $12,682,297$ & 25. 1 & - \\
\hline & & 11, & 20 & -. \\
\hline & 683,066 & $12,566,471$ & 18. & \\
\hline 190 & 793,2 & 1 & 17. 3 & 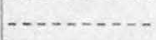 \\
\hline 190 & 836,4 & 16,3 & & \\
\hline 190 & 924,4 & $16,059,6$ & 17. 4 & \\
\hline & $1,095,520$ & 20, & 18 & \\
\hline & $1,007,200$ & $18,938,965$ & 18. & \\
\hline 190 & $1,016,24$ & 18 & 18. 3 & 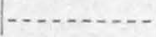 \\
\hline & 811,603 & $14,134,753$ & 17. 4 & \\
\hline & $1,241,4$ & 21 , & 17. 1 & \\
\hline 1908 & $1,494,845$ & 25,2 & 16. & (t) \\
\hline & $1,217,720$ & $19,346,566$ & 15. 9 & 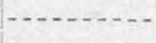 \\
\hline & $1,246,596$ & 18 & 14.8 & 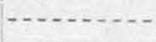 \\
\hline $\begin{array}{l}19 \\
19\end{array}$ & $\begin{array}{r}1,246,557 \\
735,044\end{array}$ & $18,413,3$ & 14. 8 & $-\sigma_{-1}$ \\
\hline 19 & $1,108,44$ & $\begin{array}{l}11,325,010 \\
14,970,737\end{array}$ & $\begin{array}{l}15.4 \\
13.5\end{array}$ & \\
\hline & $1,361,089$ & $19,731,472$ & 14. 5 & \\
\hline & $1,284,681$ & $19,586,501$ & 15. 25 & \\
\hline & $1,237,805$ & $16,084,958$ & 13. 0 & \\
\hline & $1,194,967$ & $15,919,647$ & 13. 3 & \\
\hline $1920 \ldots$ & $\begin{array}{l}739,36 \\
455,98\end{array}$ & $10,824,331$ & 14. 64 & \\
\hline \multirow[t]{2}{*}{$1921-1923$} & 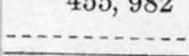 & $\begin{array}{r}765,773 \\
\text { None. }\end{array}$ & 16.37 & \\
\hline & $26,742,216$ & $477,371,115$ & 17. 85 & \\
\hline
\end{tabular}

a Includes 79,878 pounds from sands. - No. 5 Osceola closed in August.

osceola MiNe (CALUMET \& Hecla CONGLOMERATE)

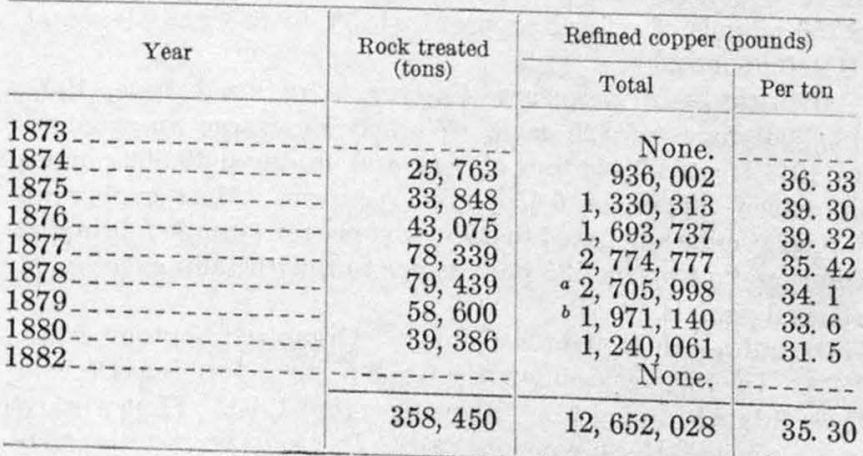

a Includes 79,878 pounds from sands, oIncludes 58,555 pounds from sands.
TAMARACK JUNIOR MINE (CALUMET \& HECLA CONGLOMERATE) [See Tamarack Jr. Mining Co. for production 1892-1896]

\begin{tabular}{|c|c|c|c|}
\hline \multirow{2}{*}{ Year } & \multirow{2}{*}{$\begin{array}{l}\text { Rock treated } \\
\text { (tons) }\end{array}$} & \multicolumn{2}{|c|}{ Refined copper (pounds) } \\
\hline & & Total & Perton \\
\hline $\begin{array}{l}1897 \ldots \\
1898 \\
1899 \\
1900 \\
1901 \\
1902 \\
1903\end{array}$ & $\begin{array}{r}64,857 \\
100,764 \\
105,742 \\
121,744 \\
121,652 \\
100,959 \\
3,760\end{array}$ & $\begin{array}{r}\text { a } 1,655,000 \\
22,620,000 \\
\text { a } 2,511,000 \\
\text { a } 2,276,000 \\
\text { a } 1,879,000 \\
\text { a } 1,413,000 \\
\text { a } 50,000\end{array}$ & 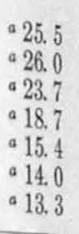 \\
\hline & 619,478 & $12,404,000$ & 20.02 \\
\hline
\end{tabular}

astimated.

NORTH KEARSARGE MINE (KEARSARGE AMYGDALOID)

[See Kearsarge Mining Co. for production 1887-1896]

\begin{tabular}{|c|c|c|c|}
\hline $1897 \ldots \ldots$ & a 68,194 & a $1,305,000$ & a 19.1 \\
\hline $1898 \ldots \ldots \ldots$ & 70,534 & a $2,186,000$ & a 31.0 \\
\hline 1899 & 77,368 & ${ }^{a} 1,544,000$ & 20.0 \\
\hline 1900 & 88,578 & a $1,639,000$ & a 18.5 \\
\hline $1901 \ldots \ldots$ & 104,162 & ${ }^{a} 1,800,000$ & a 17.3 \\
\hline $1902 \ldots$ & 197,601 & a $3,149,000$ & a 15.9 \\
\hline 1903 & 347,600 & ${ }^{a} 6,046,000$ & a 17.4 \\
\hline $1904 \ldots \ldots$ & 456,960 & a $8,446,000$ & a 18.5 \\
\hline $1905 \ldots$ & 381,520 & a $6,993,000$ & a 18.3 \\
\hline 1906 & 345,200 & a $6,023,000$ & a 17,45 \\
\hline 1907 & 256,314 & a $4,306,000$ & a 16.8 \\
\hline $1908 \ldots \ldots \ldots$ & 465,870 & a $8,155,000$ & a 17.5 \\
\hline 1909 & 605,055 & $10,212,628$ & 16.85 \\
\hline $1910 \ldots$ & 701,315 & $10,154,790$ & 14. 48 \\
\hline $1911 \ldots$ & 767,272 & $9,654,053$ & 12. 58 \\
\hline $1912 \ldots$ & 672,248 & $8,611,720$ & 12. 81 \\
\hline n. & 300,903 & $4,369,000$ & 14. 52 \\
\hline 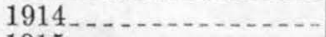 & 458,609 & $5,695,737$ & 12. 42 \\
\hline n. & 612,831 & $7,886,579$ & 12. 87 \\
\hline $1916 \ldots$ & 651,079 & $9,267,738$ & 14. 23 \\
\hline $1917 \ldots \ldots$ & 691,263 & $8,667,441$ & 12. 54 \\
\hline 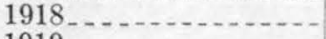 & 745,722 & $9,395,968$ & 12. 60 \\
\hline $1919 \ldots$ & 465,034 & $6,380,660$ & 13.72 \\
\hline $1920 \ldots$ & 291,508 & $4,483,129$ & 15. 38 \\
\hline \multirow[t]{2}{*}{$1921-1923 \ldots \ldots$} & 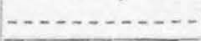 & None. & \\
\hline & $9,822,740$ & $146,371,443$ & 14. 90 \\
\hline
\end{tabular}

- Estimated.

SOUTH KEARSARGE MINE (KEARSARGE AMYGDALOID)

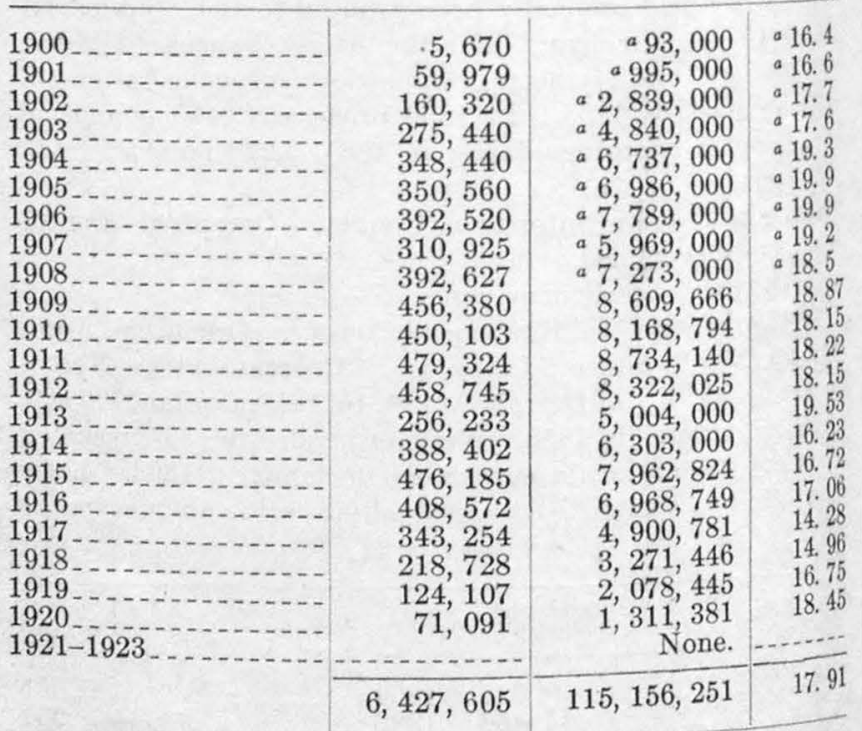

- Estimated 
OSCEOLA MINE (OSCEOLA AMYGDALOID)

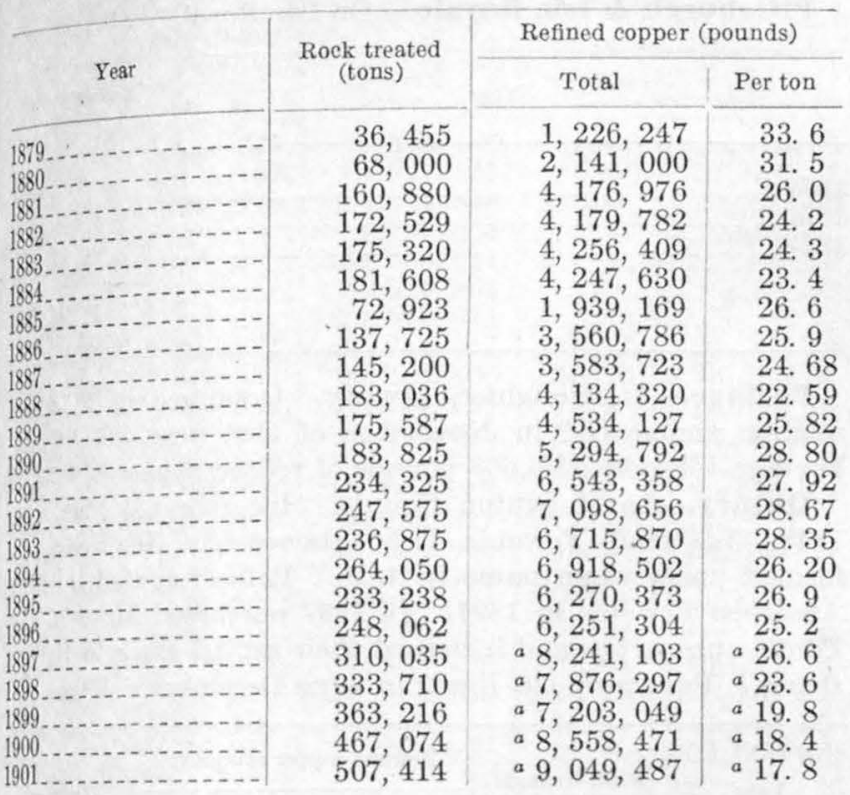

OSCEOLA MINE (OSCEOLA AMYQDALOID)-continued

\begin{tabular}{|c|c|c|c|}
\hline \multirow{2}{*}{ Year } & \multirow{2}{*}{$\begin{array}{l}\text { Rock treated } \\
\text { (tons) }\end{array}$} & \multicolumn{2}{|c|}{ Refined copper (pounds) } \\
\hline & & Total & Per ton \\
\hline $\begin{array}{l}1902 \\
1903 \\
1904 \\
1905 \\
1906 \\
1908 \\
1909 \\
1910 \\
1911 \\
1912 \\
1913 \\
1914 \\
1915 \\
1917 \\
1918 \\
1919 \\
19201 \\
1921923\end{array}$ & $\begin{array}{r}377,520 \\
297,600 \\
290,120 \\
275,120 \\
278,520 \\
244,364 \\
382,903 \\
433,410 \\
66,302 \\
\text { None. } \\
115,564 \\
177,908 \\
261,436 \\
272,073 \\
225,030 \\
203,288 \\
230,517 \\
150,223 \\
93,383 \\
-.--\end{array}$ & $\begin{array}{r}\text { a } 6,015,396 \\
\text { a } 5,123,636 \\
\text { a } 5,289,429 \\
\text { a } 4,959,965 \\
\text { a } 4,776,451 \\
\text { a } 3,859,753 \\
\text { a } 5,822,794 \\
6,474,363 \\
1,022,982 \\
1,479,642 \\
1,952,010 \\
2,972,000 \\
.3,882,069 \\
3,350,014 \\
2,516,736 \\
3,252,233 \\
2,365,226 \\
1,671,263 \\
\text { None. }\end{array}$ & 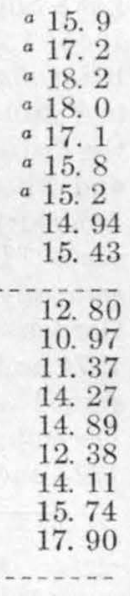 \\
\hline & $9,513,943$ & $190,787,393$ & 20. 05 \\
\hline
\end{tabular}

a Estimated.

SUMMARY

Kearsarge amygdaloid

Osceola amygdaloid.

Peninsula.-In Houghton County. Was Albany \& Boston up to 1882, when it became Peninsula. Mine closed in 1892. Purchased by Franklin Mining Co. in 1894, after which known ss Franklin Jr. mine. Output all derived from Allouez conglomerate.

\begin{tabular}{|c|c|c|c|}
\hline Year & $\begin{array}{l}\text { Refind copper } \\
\text { (pounds) }\end{array}$ & Year & $\begin{array}{l}\text { Refined copper } \\
\text { (pounds) }\end{array}$ \\
\hline \multirow{2}{*}{$\begin{array}{l}1883 \ldots \ldots \ldots \\
1884 \ldots \ldots 5 \\
1886 \ldots \ldots \ldots \ldots \\
1889 \ldots \ldots \ldots \ldots\end{array}$} & \multirow{2}{*}{$\begin{array}{r}849,400 \\
1,225,981 \\
\text { None. } \\
131,556 \\
736,507\end{array}$} & \multirow[t]{2}{*}{$\begin{array}{l}1890 \\
1891 \text { a } \\
1892\end{array}$} & $\begin{array}{r}1,108,660 \\
1,599,670 \\
973,217\end{array}$ \\
\hline & & & $6,624,991$ \\
\hline
\end{tabular}

999,591 tons stamped, yielding 16.06 pounds to the ton.

Peninsula.-In Ontonagon County. Organized July 30 , 1850. A vein was worked to some extent in 1851. Abandoned by 1854, as there was little encouragement to go on. Produced 4,480 pounds of refined copper in 1851.

Pennsylvania (Northwest). - In Keweenaw County. Organized in $1861 ; 20,000$ shares of $\$ 25$ each. See Delaware.

\begin{tabular}{|c|c|c|c|}
\hline Year & $\begin{array}{l}\text { Refined copper } \\
\text { (pounds) }\end{array}$ & Year & $\begin{array}{l}\text { Refined copper } \\
\text { (pounds) }\end{array}$ \\
\hline \multirow{7}{*}{$\begin{array}{l}1849 \ldots \\
1850 \\
1851 \\
1852 \\
1853 \\
1854 \\
1855 \\
1856 \\
1855 \\
1858\end{array}$} & \multirow{7}{*}{$\begin{array}{r}34,322 \\
195,020 \\
293,199 \\
269,174 \\
229,077 \\
a 89,208 \\
198,080 \\
3,348 \\
58,543 \\
166,100\end{array}$} & \multirow{7}{*}{$\begin{array}{l}1859 \\
1860 \\
1861 \\
1864 \\
1865 \\
1867\end{array}$} & 148,144 \\
\hline & & & 242,097 \\
\hline & & & 109,920 \\
\hline & & & $\begin{array}{l}163,96 \\
379,36\end{array}$ \\
\hline & & & 128,090 \\
\hline & & & 326,660 \\
\hline & & & $3,034,311$ \\
\hline
\end{tabular}

\section{'Bstimated.}

Petherick.-See Ashbed

Pewabic.-In Houghton County. Organized April, 1853. Tributers did some work beginning 1855 . In 1868 Concord and Pewabic were consolidated. Mine leased from June, 1870,

\begin{tabular}{|c|c|c|c|}
\hline \multirow{2}{*}{ Period } & \multirow{2}{*}{ Rock treated (tons) } & \multicolumn{2}{|c|}{ Refined copper (pounds) } \\
\hline & & Total & Per ton \\
\hline \multirow{3}{*}{$\begin{array}{l}1874-1880 \\
1897-1903 \\
1897-1920 \\
1879-1920\end{array}$} & 977,928 & $25,056,028$ & 25. 62 \\
\hline & $\begin{array}{r}16,250,345 \\
9,513,943\end{array}$ & $\begin{array}{l}261,527,694 \\
190,787,393\end{array}$ & $\begin{array}{l}\text { 16. } 09 \\
20.05\end{array}$ \\
\hline & $26,742,216$ & $477,371,115$ & 17. 85 \\
\hline
\end{tabular}

to July, 1874. Concord set off as a separate organization in 1879. Purchased by Quincy in 1891.

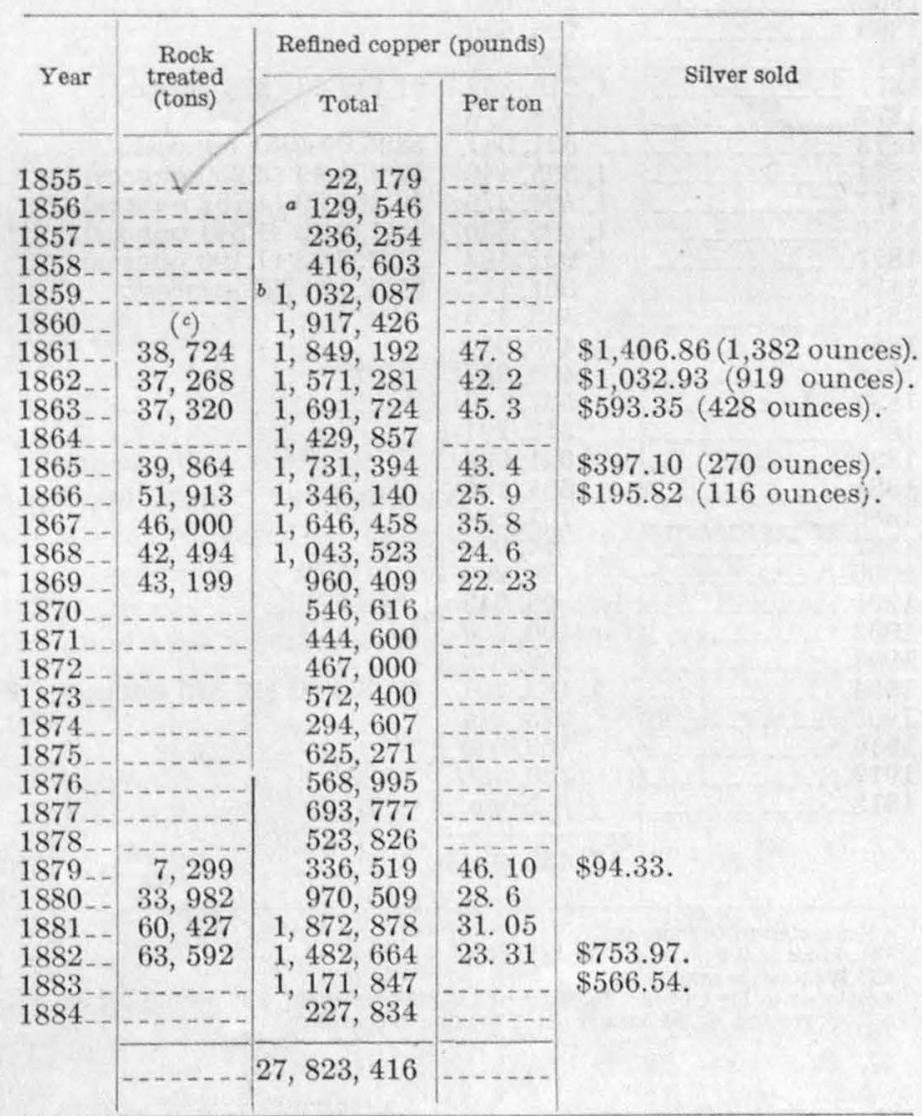

- Includes 21,879 pounds lost by shipwreck.

- Includes 2,138 pounds lost by ship ;reck.
- Stamped 23,912 tons during 7 months and 22 days 
Phoenix.-In Keweenaw County. Phoenix Consolidated Copper Co., organized April, 1899; 100,000 shares of $\$ 25$ each. Comprised old Phoenix, Bay State, St. Clair, Garden City, and 80 acres of the old Atlas purchased in 1900. Successor of Lake Superior Copper Co., which was organized February 22, $1844 ; 1,200$ shares of $\$ 100$. Mining commenced October 22, 1844; abandoned in 1847; recommenced in 1850 and continued to February, 1853. A stamp mill was built in 1845 , the first in the district, but proved a failure. In August, 1849, reorganized and Phoenix Copper Co. took over assets. Started work on Ashbed in 1855 . In 1863 worked Phoenix and Robbins fissures. In 1871 Bay State property acquired. Worked on company account to 1883 and on tribute July, 1883 , to 1886 Garden City worked 1859-1868. St. Clair operated 1865 1874 and 1880-1885. Work discontinued June 15, 1905. Resumed work on Ashbed October, 1913, and continued to December, 1917. Property sold to Keweenaw Copper Co. in 1923 and Phoenix Co. dissolved.

\begin{tabular}{l|l|l}
\hline Year & $\begin{array}{c}\text { Refined } \\
\text { copper } \\
\text { (pounds) }\end{array}$ & Silver sold \\
\hline
\end{tabular}

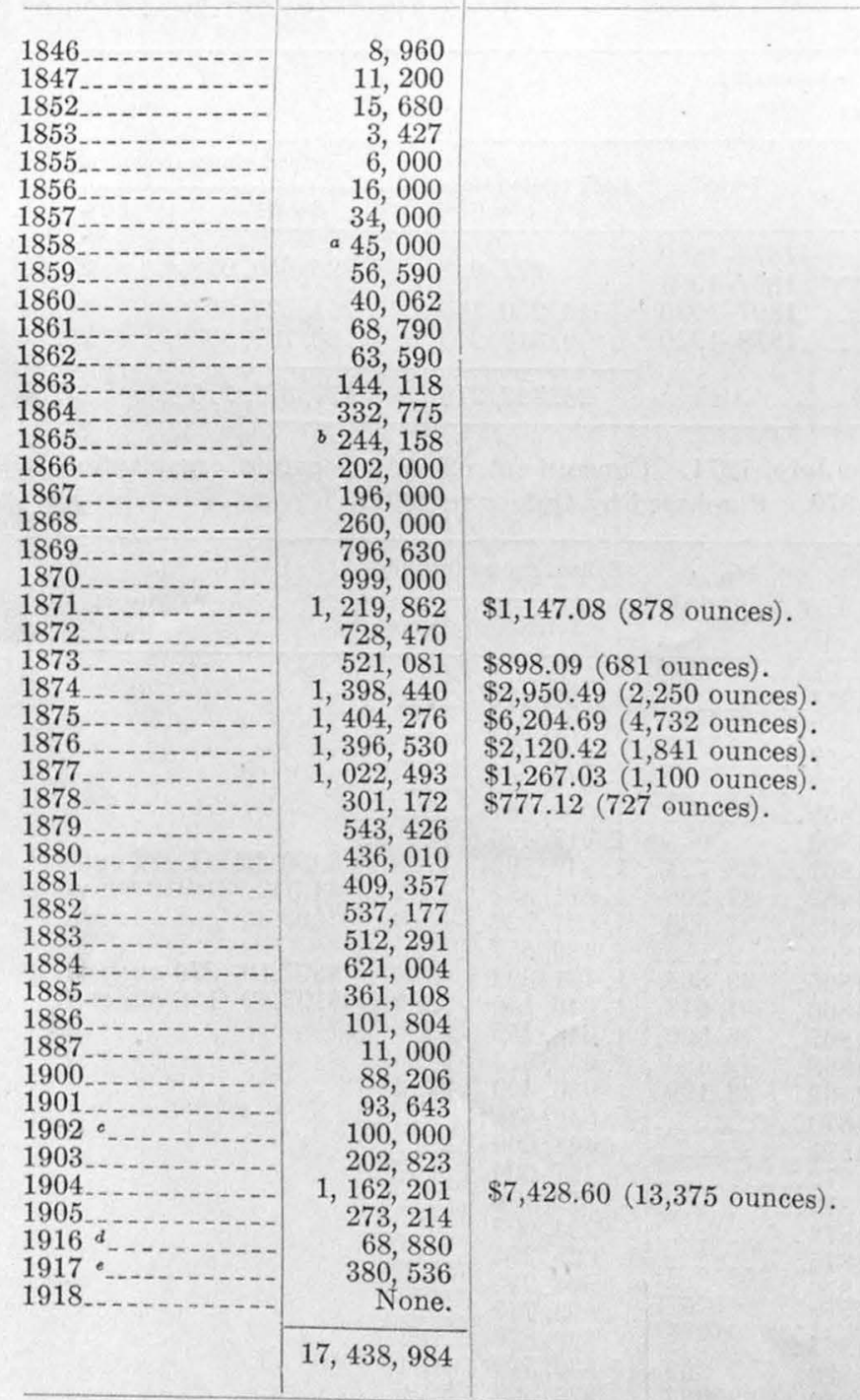

a Estimated to October 29.

Includes 33,000 pounds from Ashbed.

¿ 15,200 tons on stock pile.

- Rock treated, 41,148 tons; rield, 9.25 pounds 6 yield, 9.96 pounds per ton
Pittsburgh \& Boston.-See Cliff.

Pittsburgh \& Isle Royale.-On Isle Royal.

\begin{tabular}{r|r|r|r|r|r|}
\hline Year & $\begin{array}{r}\text { Refined copper } \\
\text { (pounds) }\end{array}$ \\
\hline $1849 \ldots 50$ & 3,360 \\
8,960 \\
12,410
\end{tabular}

Portage.-In Houghton County. Organized in 1852 and mining commenced in November of that year. See Grand Portage. Produced 6,608 pounds of refined copper in 1853 .

Quincy.-In Houghton County. Incorporated March 30 , 1848. In 1856 Pewabic lode discovered. New company formed under same name in 1878. Reincorporated in 1908, Absorbed Pewabic in 1891. In 1897 purchased Mesnard and Pontiac properties and increased their capital stock to 100,000 shares. Purchased old Franklin mine December 1, 1908.

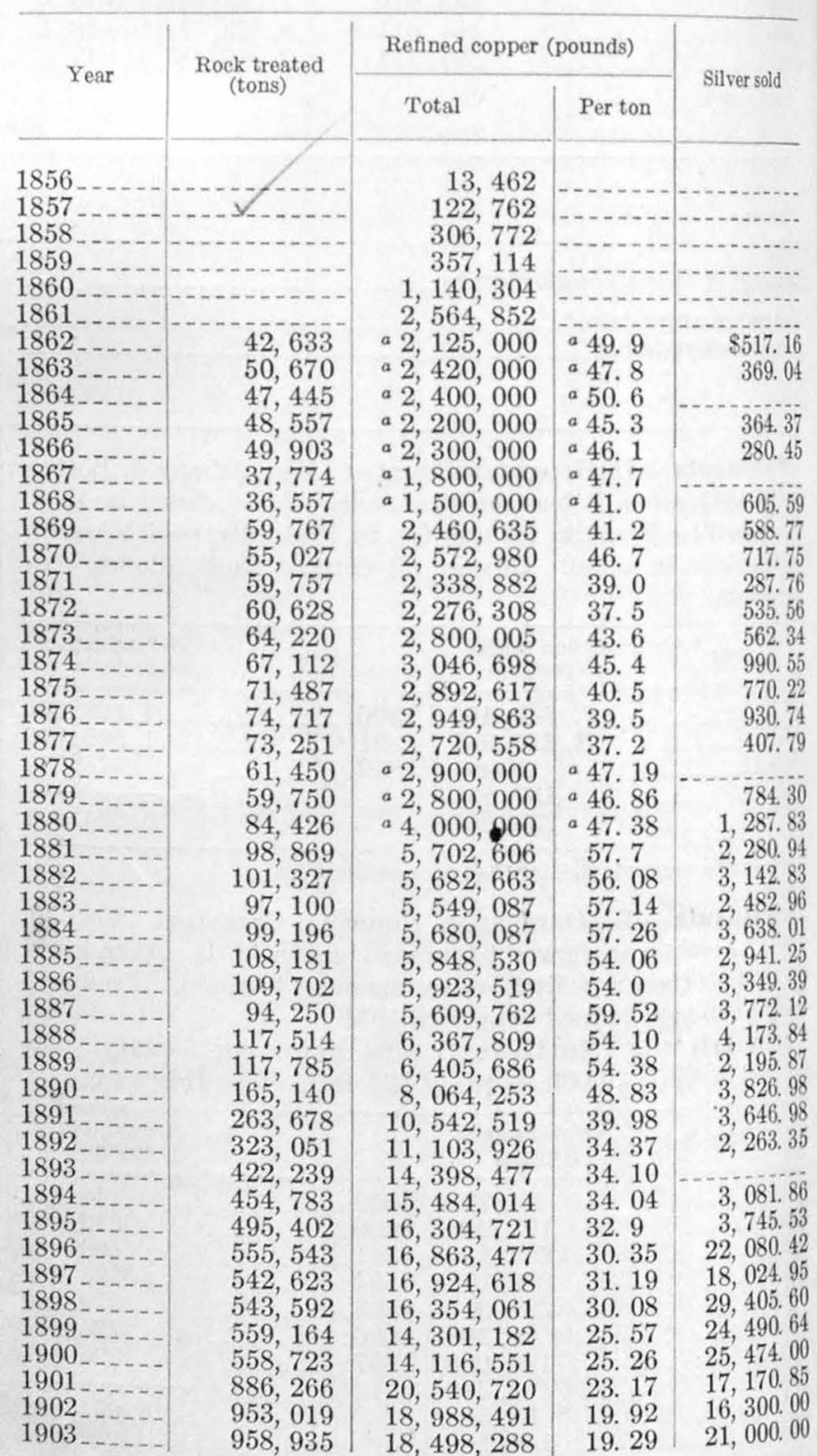




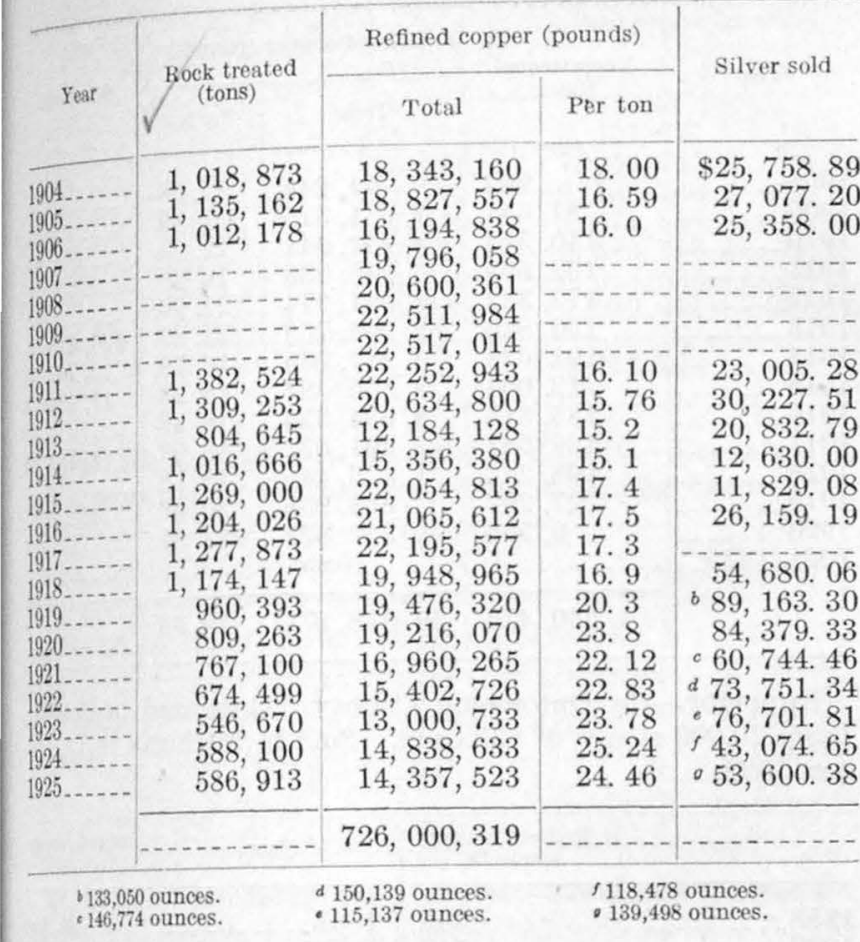

Rhode Island.-In Houghton County. Rhode Island Mining Co. organized about 1860 and worked Allouez conglomerate. Rhode Island Copper Co. organized 1898. First exploratory work done by Rhode Island Mining Co. 1864-65, estending a trench from a point west of highway east to Allouez conglomerate, which exposed all the lodes for that distance. Yo. 1 shaft started on Pewabic lode in 1898.

\begin{tabular}{|c|r}
\hline Year & $\begin{array}{r}\text { Refined copper } \\
\text { (pounds) }\end{array}$ \\
\hline $1903 \ldots 06 \ldots$ & $\begin{array}{r}24,000 \\
b 7,000\end{array}$ \\
\hline
\end{tabular}

- Estimated from 31,611 pounds mass and barrel for the year.

Estimated from 9,892 pounds mass and barrel for the year.

Ridge.-In Ontonagon County. Organized April, 1850. Worked five years; leased 1855-1863. In October, 1863, new company organized. Some work at intervals by tributers. Title lost in 1896 by failure of owners to pay tax. Later beeame part of Mass Consolidated Mining Co. Silver amounting to $\$ 254.55$ sold in 1876 .

\begin{tabular}{|c|c|c|c|c|c|}
\hline Year & $\begin{array}{c}\text { Rock } \\
\text { trateded } \\
\text { (tons) }\end{array}$ & $\begin{array}{l}\text { Refined copper } \\
\text { (pounds) }\end{array}$ & Year & $\begin{array}{c}\text { Rock } \\
\text { treated } \\
\text { (tons) }\end{array}$ & $\begin{array}{l}\text { Refined copper } \\
\text { (pounds) }\end{array}$ \\
\hline $\begin{array}{l}1853 \ldots \\
1854 \ldots \\
1855 \ldots \\
1856 \ldots \\
1857 \ldots \\
1858 \ldots \\
1862 \ldots \\
1863 \ldots \\
1864 \ldots \\
1865 \ldots \\
1866 \ldots \\
1867 \ldots \\
1868 \ldots \\
1870 \ldots \\
1871 \ldots \\
1872 \ldots \\
1873 \ldots \\
1874 \ldots\end{array}$ & & $\begin{array}{r}22,400 \\
\text { a } 37,600 \\
70,631 \\
73,874 \\
58,790 \\
78,690 \\
\text { a } 40,000 \\
\text { a } 60,000 \\
16,917 \\
170,433 \\
142,411 \\
184,037 \\
162,037 \\
253,840 \\
245,400 \\
350,150 \\
257,910 \\
231,140\end{array}$ & $\begin{array}{l}1876 \\
1877 \\
1878 \\
1879 \\
1880 \\
1881 \\
1882 \\
1883 \\
1884 \\
1885 \\
1886 \\
1887 \\
1888 \\
1889 \\
1890 \\
1891 \\
1892 \\
1893\end{array}$ & $\begin{array}{l}2,178 \\
2,017 \\
2,565 \\
3,925 \\
2,300 \\
1,448\end{array}$ & $\begin{array}{r}290,018 \\
296,815 \\
251,837 \\
215,469 \\
223,353 \\
235,606 \\
102,936 \\
60,155 \\
74,030 \\
63,39 \\
158,272 \\
84,902 \\
50,924 \\
28,000 \\
17,645 \\
43,049 \\
23,611 \\
64,363\end{array}$ \\
\hline & & 328,447 & & 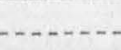 & $5,443,195$ \\
\hline
\end{tabular}

Rockland.-In Ontonagon County. Organized September 27,$1853 ; 20,000$ shares of $\$ 25$ each. Stamp mill erected in 1855-56. In 1870 company shut down. Passed into hands of National interests. Worked by tributers more or less to 1880 .

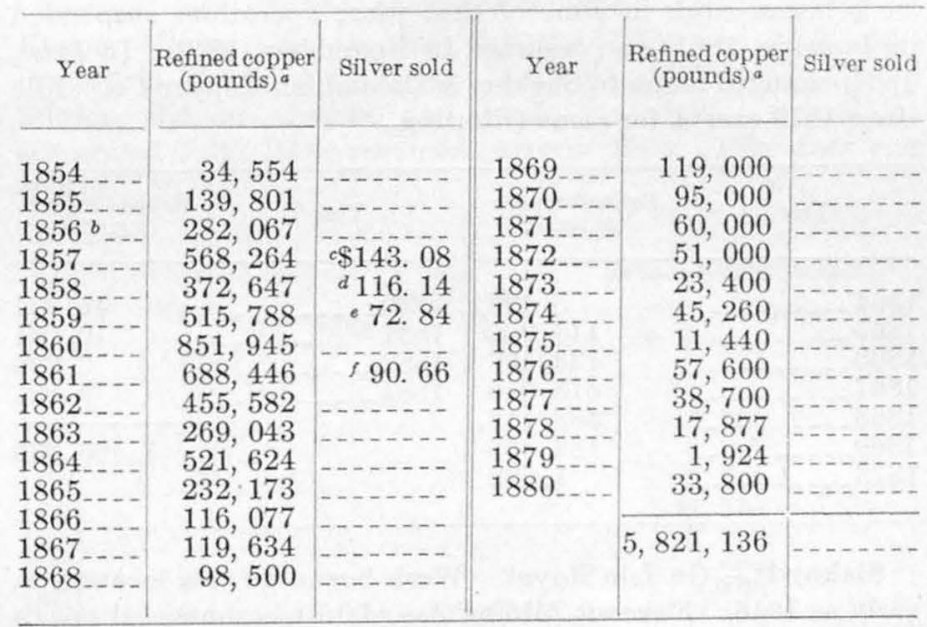

a $1854-1863$ and $1865-1867$ are smelter returns.

1,700 tons of rock treated.

18 pounds.

16 pounds.

7 pounds.

10 pounds.

Saginaw.- On Isle Royal. Worked from 1875 to 1879 . In 1877 produced 1,800 pounds of refined copper; in $1879,49,464$ pounds; total, 51,264 pounds.

Schoolcraft. - See Centennial.

St. Clair.-In Keweenaw County. Organized in 1863 and operated on fissure. Stamp mill erected in 1872 but not used, as work was suspended during panic of 1873 , and property went into hands of creditors until 1879, when company was reorganized. Later became part of Phoenix Consolidated Copper Co.

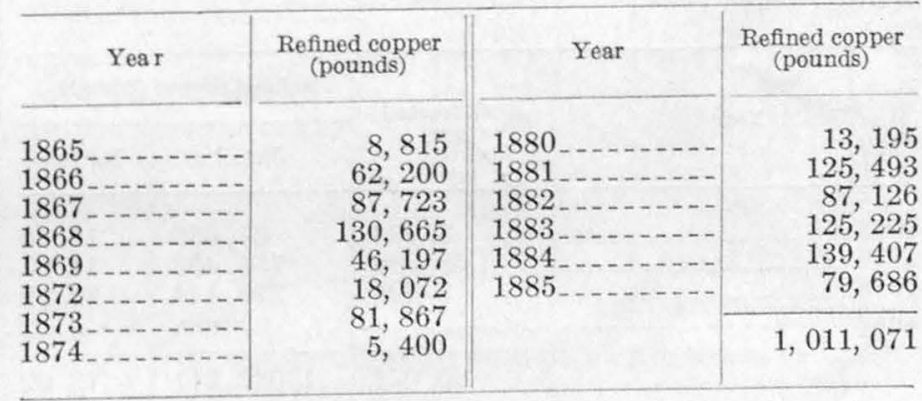

Seneca.-In Keweenaw County. Seneca Mining Co., organized March, 1860; dissolved October 10, 1918, all of its stock being conveyed to the Seneca Copper Corporation, which was incorporated in 1916 in New York. Mine closed in April, 1924. Seneca Copper Mining Co. incorporated February 27, 1925 , and work resumed in November of that year.

\begin{tabular}{|c|c|c|c|}
\hline \multirow{2}{*}{ Year } & \multirow{2}{*}{$\begin{array}{l}\text { Rock treated } \\
\text { (tons) }\end{array}$} & \multicolumn{2}{|c|}{ Refined copper (pounds) } \\
\hline & & Total & Perton \\
\hline $\begin{array}{l}1872 \\
1877 \\
1878 \\
1920 \\
1921 \\
1922 \\
1923 \\
1924\end{array}$ & $\begin{array}{r}21,395 \\
14,397 \\
8,617 \\
21,644 \\
82,477 \\
17,313\end{array}$ & $\begin{array}{r}1,603 \\
7,810 \\
7,809 \\
497,680 \\
466,323 \\
272,182 \\
529,189 \\
1,796,548 \\
284,241\end{array}$ & $\begin{array}{l}23.26 \\
32.39 \\
31.58 \\
24.45 \\
21.78 \\
\text { 16. } 4\end{array}$ \\
\hline & & $3,863,385$ & \\
\hline
\end{tabular}


Shelden \& Columbian.-In Houghton County. Shelden Mining Co., organized in 1853. Albion Mining Co. conducted operations on this property in 1853 . Work suspended in 1857 . In 1860 the property was sold and the Columbian was organized; began work in June of that year; operations suspended in January, 1861, and resumed in November, 1862. In June, 1864, changed name to Shelden \& Columbian Copper Co. Idle since 1870 except for some tributing.

\begin{tabular}{|c|c|c|c|}
\hline Year & $\begin{array}{l}\text { Refined copper } \\
\text { (pounds) }\end{array}$ & Year & $\begin{array}{l}\text { Refined copper } \\
\text { (pounds) }\end{array}$ \\
\hline \multirow{2}{*}{$\begin{array}{l}1864 \\
1865 \\
1866 \\
1867 \\
1868 \\
1878\end{array}$} & \multirow{2}{*}{$\begin{array}{r}5,496 \\
114,200 \\
133,497 \\
618,946 \\
333,118 \\
186,368 \\
1,622\end{array}$} & \multirow[t]{2}{*}{$\begin{array}{l}1880 \\
1881 \\
1882\end{array}$} & $\begin{array}{r}46,931 \\
10,031 \\
3,299 \\
9,828\end{array}$ \\
\hline & & & $1,463,336$ \\
\hline
\end{tabular}

Siskowit.- On Isle Royal. Work began on this location as early as 1845 . Siskowit Mining Association commenced ope ra tions in summer of 1847. Siskowit Mining Co. of Michigan organized May, 1849, and resumed the mining operations which had been suspended by the association. Mine closed in 1855 .

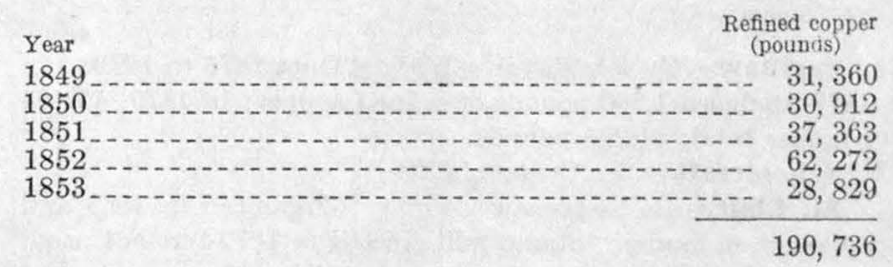

South Lake. - In Ontonagon County. Formerly known as Aztec; reorganized in August, 1909, as South Lake Mining Co. and capital stock increased to $\$ 2,500,000$. Production ceased in July, 1918.

\begin{tabular}{|c|c|c|c|}
\hline \multirow{2}{*}{ Year } & \multirow{2}{*}{$\begin{array}{l}\text { Rock treated } \\
\text { (tons) }\end{array}$} & \multicolumn{2}{|c|}{ Refined copper (pounds) } \\
\hline & & Total & Perton \\
\hline \multirow[t]{2}{*}{$\begin{array}{l}1915 \\
1916-17 \\
1918 \\
1919-1925\end{array}$} & $\begin{array}{r}3,993 \\
68,388 \\
7,694 \\
\end{array}$ & $\begin{array}{r}61,637 \\
754,433 \\
226,141 \\
\text { None. }\end{array}$ & $\begin{array}{l}\text { 15. } 40 \\
\text { 11. } 03 \\
\text { 28. } 09\end{array}$ \\
\hline & 80,075 & $1,042,211$ & 13. 02 \\
\hline
\end{tabular}

Star.-In Keweenaw County. Began work in 1851 and worked until 1857. Resumed in 1864.

\begin{tabular}{|r|r||r|r}
\hline Year & $\begin{array}{c}\text { Refined copper } \\
\text { (pounds) }\end{array}$ & Year & $\begin{array}{r}\text { Refined copper } \\
\text { (pounds) }\end{array}$ \\
\hline 1855 & 1,000 & 1872 & 535 \\
\hline 185788 & 4,778 & 1881 & 758 \\
\hline 1865 & 9,107 & & 17,938 \\
\hline
\end{tabular}

Summit.-See Madison.

Sumner.- See Hancock.

Superior.-In Houghton County. Organized July 23, 1904; 100,000 shares of $\$ 25$ each. Mine closed November, 1920. Property purchased by Calumet \& Hecla and company dissolved in 1925.

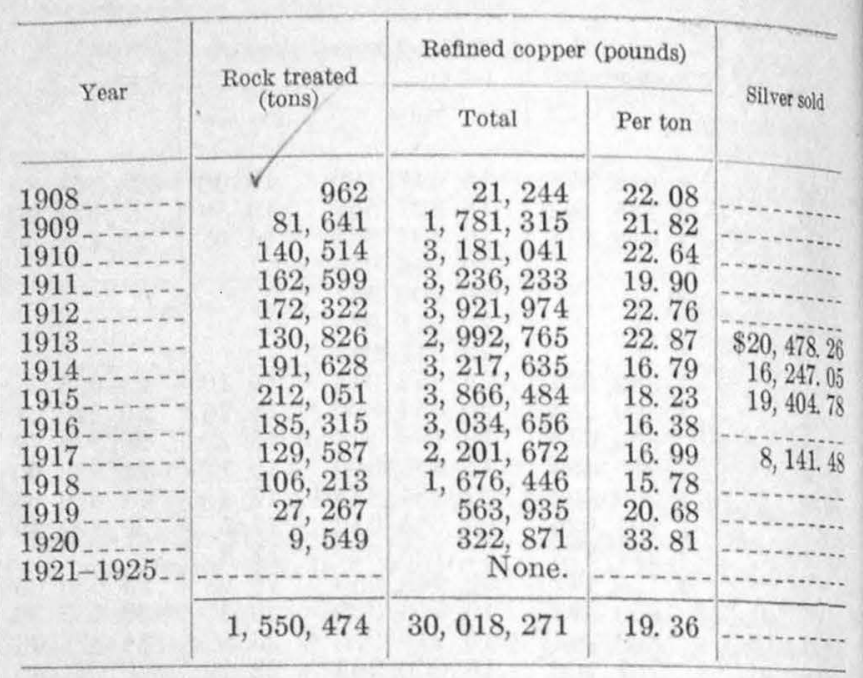

Superior.-In Ontonagon County. Organized in October, $1855 ; 20,000$ shares of $\$ 25$ each. Sold to Michigan in Decem. ber, 1899.

\begin{tabular}{|c|c|c|c|}
\hline Year & $\begin{array}{l}\text { Refined copper } \\
\text { (pounds) }\end{array}$ & Year & $\begin{array}{l}\text { Refined copper } \\
\text { (pounds) }\end{array}$ \\
\hline \multirow[t]{2}{*}{$\begin{array}{l}1858 \\
1859 \\
1860 \\
1861 \\
1862 \\
1863 \\
1864 \\
1865 \\
1866\end{array}$} & $\begin{array}{r}635 \\
1,740 \\
10,000 \\
54,642 \\
70,000 \\
66,500 \\
56,522 \\
89,673\end{array}$ & $\begin{array}{l}1867 \ldots \\
1868 \ldots \\
1869 \ldots \\
1876 \ldots \\
1877 \\
1878 \\
1879\end{array}$ & $\begin{array}{r}36,400 \\
56,000 \\
4,521 \\
3,936 \\
5,870 \\
1,965 \\
1,476\end{array}$ \\
\hline & 66,000 & & 525,880 \\
\hline
\end{tabular}

Tamarack.-In Houghton County. Organized January, 1882. Declared first dividend in 1888. Property sold to Calumet \& Hecla Mining Co. on April 1, 1917, and company dis. solved.

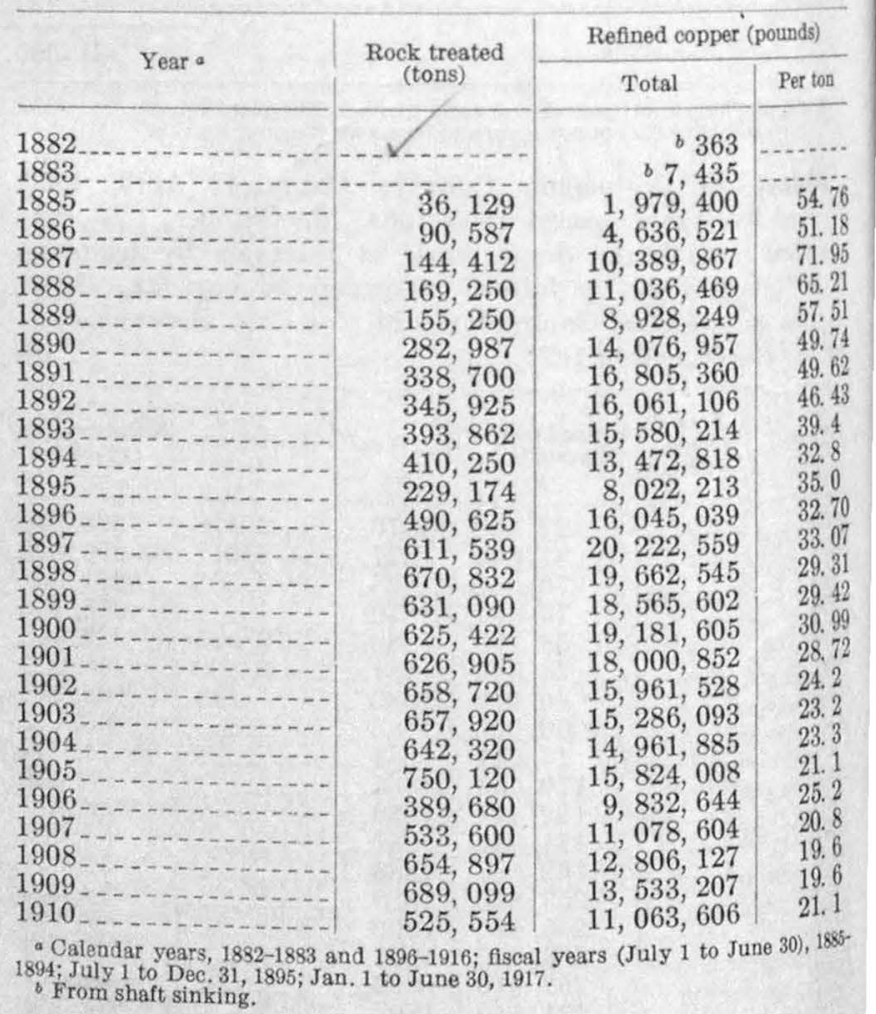


Windsor.- In Ontonagon County. Worked in 1854-55 as a separate and distinct interest of the American Mining Co. of Vermont. Absorbed by Norwich in 1863. Prior to 1856 produced 68,000 pounds of refined copper.

Winona.-In Houghton County. Organized in April, 1864. Few shipments. In 1870 mine was let to tributers. Reorganized as Winona Copper Co. November 3, 1898. In 1911 absorbed King Philip Copper Co. Closed in May, 1920.

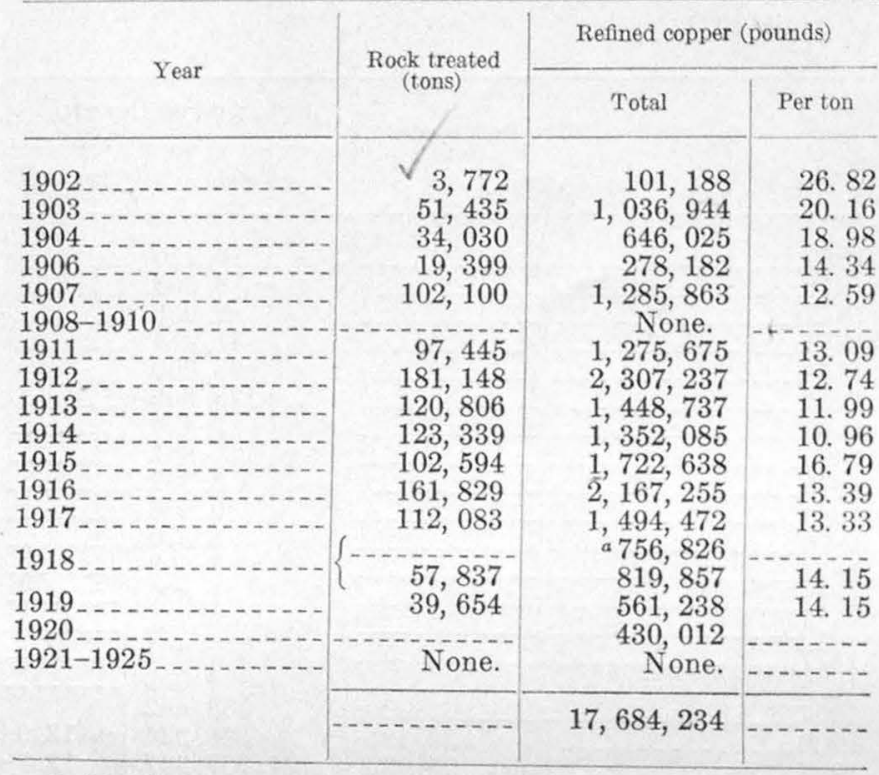

- Produced by lessees.

Wolverine.- In Houghton County. Operated from January, 1882, to November, 1884. Reorganized as Wolverine Copper Mining Co. in August, 1890. Consolidated with Mohawk Mining Co. August 16, 1923. Mine closed April, 1925.

\begin{tabular}{|c|c|c|c|}
\hline \multirow{2}{*}{ Year ${ }^{a}$} & \multirow{2}{*}{$\begin{array}{l}\text { Rock treated } \\
\text { (tons) }\end{array}$} & \multicolumn{2}{|c|}{ Refined copper (pounds) } \\
\hline & & Total & Per ton \\
\hline $\begin{array}{l}1882 \\
1883 \\
1884 \\
18856 \\
1891 \\
1892 \\
1894 \\
1895 \\
1896 \\
1898900 \\
1901 \\
1902 \\
1903 \\
1904 \\
1906 \\
1907 \\
1908 \\
1910 \\
1911 \\
1912 \\
1913 \\
1914 \\
1915\end{array}$ & $\begin{array}{r}31,524 \\
10,491 \\
76,440 \\
90,195 \\
85,155 \\
82,270 \\
130,089 \\
184,799 \\
184,594 \\
190,104 \\
187,482 \\
279,011 \\
314,091 \\
321,813 \\
341,820 \\
344,062 \\
348,860 \\
373,694 \\
390,837 \\
388,476 \\
401,308 \\
388,502 \\
182,127 \\
397,614 \\
388,898\end{array}$ & $\begin{array}{r}25,623 \\
699,622 \\
800,000 \\
370,925 \\
83,208 \\
500,074 \\
218,855 \\
1,611,857 \\
1,744,070 \\
2,011,638 \\
2,237,698 \\
3,470,927 \\
4,700,373 \\
4,756,646 \\
4,907,646 \\
4,984,367 \\
8,260,386 \\
9,300,695 \\
9,729,971 \\
9,681,706 \\
9,372,982 \\
9,356,123 \\
9,995,748 \\
9,757,101 \\
9,617,168 \\
9,408,960 \\
8,350,312 \\
3,435,459 \\
7,250,866 \\
6,641,492\end{array}$ & $\begin{array}{l}0.86 \\
15.86 \\
20.86 \\
\text { 19. } 08 \\
\text { 19. } 62 \\
27.20 \\
26.68 \\
25.43 \\
25.77 \\
25.81 \\
26.59 \\
29.60 \\
29.61 \\
30.23 \\
28.32 \\
27.24 \\
26.82 \\
26.75 \\
24.96 \\
24.75 \\
23.45 \\
21.49 \\
18.86 \\
18.23 \\
17.07\end{array}$ \\
\hline
\end{tabular}

1892 inendar years, 1882-1886 and 1924; 1891 includes Sept. 1, 1891, to A pril, 1892. July ito Dec. 31, 1923; Jantuary to A pril, 1925,

\begin{tabular}{|c|c|c|c|}
\hline \multirow{2}{*}{ Year } & \multirow{2}{*}{$\begin{array}{l}\text { Rock treated } \\
\text { (tons) }\end{array}$} & \multicolumn{2}{|c|}{ Refined copper (pounds) } \\
\hline & & Total & Pet ton \\
\hline $\begin{array}{l}1916 \\
1917 \\
1918 \\
1919 \\
1920 \\
1921 \\
1922 \\
1923 \\
1925\end{array}$ & $\begin{array}{r}352,845 \\
303,498 \\
298,089 \\
257,294 \\
263,053 \\
290,419 \\
244,310 \\
95,408 \\
205,428 \\
43,663\end{array}$ & $\begin{array}{l}5,856,889 \\
4,608,865 \\
4,562,617 \\
3,932,225 \\
3,640,303 \\
3,924,270 \\
3,544,879 \\
1,605,121 \\
3,265,356 \\
574,084\end{array}$ & $\begin{array}{l}16.58 \\
15.19 \\
15.31 \\
15.28 \\
13,89 \\
13.51 \\
14.51 \\
16.82 \\
15,90 \\
13.15\end{array}$ \\
\hline & & $188,797,107$ & \\
\hline
\end{tabular}

Wyandot.-In Houghton County. Organized February 23 $1899 ; 100,000$ shares of $\$ 25$ each. Idle from September, 1914 to April, 1915. Closed late in 1917 or early in 1918.

\begin{tabular}{|c|c|c|c|}
\hline \multirow{2}{*}{ Year } & \multirow{2}{*}{$\begin{array}{l}\text { Rock treated } \\
\text { (tons) }\end{array}$} & \multicolumn{2}{|c|}{ Refined copper (pounds) } \\
\hline & & Total & Per ton \\
\hline \multirow[t]{2}{*}{$\begin{array}{l}1916 \\
1917 \\
1918-1925\end{array}$} & $\begin{array}{l}1,605 \\
1,322 \\
\text { None. }\end{array}$ & $\begin{array}{r}19,973 \\
{ }^{b} 20,000 \\
\text { None. }\end{array}$ & $\begin{array}{l}{ }^{4} 12.54 \\
{ }^{8} 14.9 \\
\end{array}$ \\
\hline & 2,927 & 39,973 & 13.60 \\
\hline
\end{tabular}

\section{OPERATING PRACTICE}

An adequate discussion of the prevailing mining and metallurgical practice in the district at the present time by competent authority would make a very considerable report. Here it is intended only to give the reader a general idea of the methods used.

\section{MINING}

\section{DEVELOPMENT}

The ore bodies are tabular in form, average from 5 to 30 feet or more in thickness, and dip at angles of $30^{\circ}$ to $72^{\circ}$.

All the lodes have been opened from the outcrops by inclined shafts sunk in or close under the lode and spaced, in modern operations, at intervals of 2,500 feet or more along the strike. In early operations the spacing was closer. The deepest of these shafts, which is on the Calumet \& Hecla conglomerate, has a length along the incline of 9,065 feet and attains a vertical depth of 5,459 feet-that is, 4,815 feet below Lake Superior, or 4,213 feet below sea level. The Michigan copper properties are bounded on all sides by vertical planes. This has undoubtedly avoided many of the legal difficulties that have plagued western mining operations, but it has in places been a handicap to the most effective development.

To open the deeper portion of the Calumet \& Hecla conglomerate ore body the old Tamarack $\mathrm{Co}$. sunk five vertical shafts to depths of 3,409 to 5,308 feet and connected them on several levels by crosscuts. In the meantime the Calumet \& Hecla Co. put down a 
deep vertical shaft, the Red Jacket, to serve its deeper levels. The vertical shafts are connected by crosscuts with the drifts on the lode. To reach deep parts of the Kearsarge amygdaloid, where the outcrop was owned by others, the Allouez and Ahmeek companies sunk four shafts at an angle of $10^{\circ}$ from the vertical, curving the shafts into or parallel to the lode where this was reached. The Seneca Co. sunk a vertical shaft to the Kearsarge lode and curved it parallel to the lode. On account of low capacity and expensive maintenance the inclined shafts are less effective for very deep mining, and the Calumet \& Hecla Consolidated Copper Co. is abandoning one after another of its deep inclined shafts on the conglomerate lode and is preparing to work at greater depth by subinclines from a main haulageway on the eightyfirst level, which is tributary to the Red Jacket vertical shaft.

In the early days the distance between levels, measured down the dip, was usually 60 feet (10 fathoms); now the interval is 100 to 150 or even 200 feet.

An effective method of sampling the native copper deposits has not been developed. The choice of ground to be mined is made by the mining captains on the basis of visual inspection, aided by feeling, for the small rough particles of metal may be felt where they are not easily seen. The standards for judgment are empirical, subject to such checks as are afforded by the weekly or monthly mill returns on the ore from all stopes of a given shaft or of the entire mine. In general, any rock in which copper is detected by sight or touch goes as ore, and that in which none is so detected is not intentionally mined.

\section{STOPING}

Open stope.-Where the dip is between $35^{\circ}$ and $45^{\circ}$, as it is in the mines near Calumet, the open stope is commonly used. A raise is put up to the level above, after which stoping proceeds, leaving a floor pillar under the level above and a sufficient number of round pillars in the stope to support the hanging wall. The commonest practice has been to advance these stopes outward from the shaft pillar to the limit of the ground tributary to the shaft, and before abandoning the level to recover as many of the pillars as can be taken out with safety; later still the floor pillars are removed provided they are rich enough to justify this independent operation. The more recent practice, however, carries the drifts to the limit farthest from the shaft and stopes on the retreat. In this way only enough pillars are left to give temporary protection to the breast of the stope, and as the stope retreats, all possible stope pillars and the floor pillars also are mined out. In either case no timber is used except in the construction of loading chutes.
In mining the deeper parts of the Calumet \& Hecla conglomerate lode stope pillars are not used. Instead, timber stulls are used in sufficient number to afford a zone of protection near the breast of the stope, but as this zone moves along with the progress of the stope the timbers are removed, and caving of the hanging wall follows.

Room and pillar.-In the deeper levels of the Quincy mine, where the dip is less than $40^{\circ}$ and the lode narrow, a modification of the open-stope method has been adopted to meet the condition of great rock pressure. The interval between levels is 200 feet; stopes 100 feet long are supported temporarily by short stulls and later are partly or completely filled with waste rock from development operations. Between the stopes pillars 100 feet wide are left extending through from level to level, as round stope pillars have been found inadequate. On the advance, therefore, something over 50 per cent of the lode is mined, the remainder being left for support to be recovered so far as may be possible on the retreat.

Shrinkage stope.-At the Isle Royale mine the dip ranges from $50^{\circ}$ to $56^{\circ}$ and is thus too steep to permit work in an open stope without timber. A timber bulkhead with numerous loading chutes is erected to separate the drift from the stope. Extraction is accomplished by inclined cuts; usually poor ore left unbroken affords sufficient support. The ore is allowed to accumulate to a convenient height, and the surplus is drawn off through the chutes. Upon completion of the stope all ore is drawn off and the stope is abandoned, beginning at the limits farthest from the shaft.

Horizontal cut and fill.-At the Baltic, Champion, and Trimountain mines the dip approximates $70^{\circ}$ and the lode is unusually wide. Two dry walls with openings for loading chutes are constructed of waste rock and covered with timber, forming a haulage way along the center of the lode on the level. As waste from mining operations accumulates behind and above these haulage ways circular dry-walled mill holes are extended upward from the loading chutes and kept even with the top of the fill. Stoping is carried on by horizontal cuts worked from the top of the fill. As each round is blasted down the broken rock is sorted by handling and visual inspection, the ore is thrown into the mill holes, and the reject is left to constitute the filling. Where the lode is rich and the amount of reject therefore inadequate to maintain the fill at a proper height additional filling material is obtained by exploratory stoping along the footwall and by blowing in wet mill tailings shot down from the surface. Floor pillars below the fill of the overlying lavel are supported by large timber cribs and are then stoped by inclined cuts from under the pillar.

The size of shaft pillars varies with the depth. In some of the old inclined shafts no shaft pillars were left 
in the upper levels of the early days. As the shafts were deepened pillars were left, say, 50 feet wide or sometimes less, on each side. At still greater depths the shaft pillars were made 100 feet wide on each side, and now, in certain shafts at the deepest levels, 200 feet is left for each pillar, or a total block of 400 feet for the shaft. Where the shafts are carried in the footwall of the lode shaft pillars are not necessary, and by some it is regarded as better not to leave pillars in the lode over the shaft.

\section{TRANSPORTATION}

The ore is drawn from the stopes through chutes of varying design and construction into cars, which are commonly of several tons capacity. In the flatter stopes drag-line scrapers are used for moving the ore down the footwall. By the use of long platforms erected over the track scrapers are also used to some extent for loading cars where no chutes are provided, as in the deep levels of the Calumet \& Hecla conglomerate, and for mucking in drifts. The so-called mucking machines and other forms of mechanical shovels have gained little foothold in this district.

Power has largely displaced handwork for tramming. At most mines the cars are dumped directly into the skip, but at the Quincy and Seneca mines skip pockets are used. Hoisting is, of course, in balance, except in some of the old inclines. Each shaft is equipped with a rock house containing grizzlies and crusher, so that about 4 inches is the maximum size of material delivered to the railway cars for transportation to the stamp mills.

\section{UNDERGROUND CONDITIONS}

The mines of the district are notably clean and comfortable. Natural ventilation commonly suffices, even in the deepest workings, to maintain the air clear, fresh, and cooler than the adjacent rocks. The rock temperature is low. A compilation of existing data on rock temperature by C. E. Van Orstrand, of the United States Geological Survey, gives the following gradients of increase with depth:

From 60 to 1,080 feet $1^{\circ} \mathrm{F}$. to every 99.1 feet.

From 60 to 1,915 feet $1^{\circ} \mathrm{F}$. to every 105.6 feet.

From 60 to 3,090 feet $1^{\circ} \mathrm{F}$. to every 119.3 feet.

From 60 to 5,367 feet $1^{\circ} \mathrm{F}$. to every 117.4 feet.

The rock temperature on the eighty-first level of the Red Jacket shaft in the Kearsarge lode, at a depth of approximately 4,900 feet, as determined by Mr. Van Orstrand, is $86.2^{\circ} \mathrm{F}$. It seems evident that, so far as temperature is concerned, mining may be extended much deeper without any such serious inconvenience as has been encountered, for example, in the deep St. John del Rey mine, in Brazil.

Except in the upper levels, where water is plentiful, the mines are strikingly dry. So far as possible water is caught and pumped from shallow depths, but some escapes and flows down the shafts and accounts for the greater part of the water encountered at depth. Away from the shafts the workings are dusty, and water has to be piped from the surface for use in the Leyner drills; otherwise the air of the stopes would be filled with dust. Occasional drops accumulate on the roofs of drifts, but rarely is there enough water to drip. Even in newly opened ground only a little water is encountered, and that quickly drains out. The expense of pumping, then, is relatively low. In the Calumet \& Hecla mine," with over 200 miles of drifts and shafts and practically continuous stopes covering between 2 and 3 square miles on the plane of the lode, the total pumping duty amounts to only 1,200 gallons a minute, notwithstanding the fact that removal of so much ore during 60 years of operation has caused much fracturing, crushing, and caving of the hanging wall and thus has made the rocks much more permeable than they were before mining began. The drift cover of the district may contain much water, and if the mine workings break through to the drift a considerable flow of water may result, as occurred in the Champion mine in 1924.

\section{MILLING}

Nearly all the ore mined from the district is sent to the stamp mills. The exceptions are the "masses" encountered in the lodes and commonly in the cross fissures; these are sent direct to the smelter.

In all the mills the ore is first crushed by steam stamps of large capacity. Then follow successive concentrations and crushings, involving ball mills, rod mills, and jigs and tables. Flotation follows gravity concentration in the Calumet \& Hecla and Quincy mills, and ammonia leaching is the final stage in the former. By the best practice a recovery of 95 per cent is obtained. The copper content of the mill concentrates or "mineral" ranges from 50 to 75 per cent and averages about 60 per cent.

A recent development of technical and economic interest is the reworking of the great tonnage of old conglomerate mill tailings accumulated in Torch Lake near the Calumet \& Hecla and Tamarack mills. The mill records of tonnage and copper content of the tailings produced yearly for over half a century gave a basis for computing the copper contained in the entire mass. Both tonnage and metal content were checked by elaborate sampling, and the figures thus obtained were in striking agreement with those derived from the mill records. The winning of copper from

3 Several types of material produced at the mines and mills are known by local terms. "Mass" copper consists of the large bodies of copper found in the fissures and in some of the lodes, ranging in weight from 100 pounds or less to hundreds of tons. Smaller bodies of copper that were separated from the rock were formenly stored and shipped in barrels and were consequently known as "barrel" work, and this term is still used. Rock containing small bodies of copper sent to the mills for separation is known as "mill" rock. The concentrate from the mill rock is known as "mineral." "Ore" as used locally in the district refers to the sulphide an arsenide minerals, but this use of the term is not followed in the present paper. 
these tailings will require many years at the present rate of production. The tailings are elevated by suction dredge and pumped to a plant on shore, where crushing, concentration, flotation, and leaching are employed, with a very satisfactory recovery. The cost per pound of producing copper from these tailings is the lowest in the district.

As the copper is coarser and the rock softer in the amygdaloid than in the conglomerate lodes, the former have always yielded a larger proportion of their copper to initial treatment. Re-treatment of amygdaloid tailings is therefore not yet feasible.

\section{SMELTING}

The copper in the product delivered to the smelters is already almost wholly in the metallic state and forms from 50 to nearly 100 per cent of the product, the proportion depending on whether it is mill concentrate or mass copper of the lower grades. The smelting process is therefore simple in principle, but, as most of the product is furnace-refined, and the standard of quality for Lake copper is high, much care is exercised in the smelting operations. Copper that carries a sufficient amount of silver to make the separation and recovery of this metal profitable is refined electrolytically. Electrolytic refining has been used also in order to purify some of the copper containing small amounts of arsenic, but in recent years nearly all of the arsenical copper is furnace-refined and sold for special uses. Lake copper has long been regarded by some consumers as excelling in certain qualities and has commanded a premium over electrolytic copper.

\section{COPPER DEPOSITS}

\section{PRINCIPAL TYPES}

The copper deposits of Keweenaw Point are commonly divided into two broad groups - lode deposits and fissure deposits. The lode deposits comprise conglomerate lodes, ${ }^{4}$ mineralized beds of felsite conglomerate interstratified with the lavas, and amygdaloid lodes, the mineralized vesicular, brecciated, or "scoriaceous" tops of the lava flows.

The fissure deposits are veins along fractures that parallel or cross the beds. A subtype of the conglomerate lodes is represented in the Porcupine Mountain region by mineralized beds of sandstone and of shale.

All the deposits are thus of tabular form. There are no irregular bodies, large in all dimensions, like those of the well-known low-grade disseminated deposits of copper in other regions.

In the lode deposits and most of the larger fissure deposits the copper is in the metallic state, some of it slightly arsenical. A few of the larger fissure deposits

"The term "lode" as thus used in the region denotes an ore zone parallel to the rock bedding and made up largely of the rock itself $-\mathrm{a}$ restriction of the general stuctural signifleance of the term as applied to an ore deposit of tabular form. carry copper-rich arsenides, and many of the smaller ones carry the copper-rich sulphide chalcocite. Copper arsenides and sulphides are rarely and sparingly present in the lodes independent of fissures.

Although great masses of metallic copper, as much as hundreds of tons in weight, have been encountered in some of the fissures and in certain of the amygdaloid lodes, the deposits as a whole are of low grade; the highest average yield for a year ever attained by the district as a whole was about $41 / 2$ per cent; for the last 10 or 15 years the average recovery for all the mines has been about 20 pounds to the ton, or 1 per cent, and that for certain individual mines as low as 11 to 15 pounds.

\section{DISTRIBUTION IN THE KEWEENAWAN SERIES}

The economically important known deposits with a single exception are confined to the portion of the Keweenawan series that is composed predominantly of lava flows, but they have a wide stratigraphic range within that portion. The principal productive lodes from the base upward are the Baltic amygdaloid, Isle Royale amygdaloid, Kearsarge amygdaloid, Osceola amygdaloid, Calumet \& Hecla conglomerate, Allouez conglomerate, Pewabic amygdaloid, and Ashbed amygdaloid.

The fissure deposits are confined to the same stratigraphic portion of the series, though in the main the valuable fissure deposits and the lode deposits occur in different areas along the strike of the formation.

The exception to the distribution indicated above is the Nonesuch lode, in the formation of that name, well up in the sedimentary portion of the series. The mineralization at this horizon occurred mainly in sandstone, and to a less extent in shale. The abnormally high position of the lode in the Keweenawan rocks is probably due to the presence of intrusive rocks in the near-by Porcupine Mountains.

\section{CONGLOMERATE LODES}

\section{PHYSICAL CHARACTER}

Much of what is said below regarding the conglomerate lodes is based on observation of the Calumet \& Hecla conglomerate, which has been the most closely studied. Most of the other conglomerates, though they have been less thoroughly explored, appear to resemble it in their essential characters.

The conglomerates are composed mainly of siliceous material, chiefly felsite and quartz porphyry. They contain few boulders more than a foot in diameter, and for most of the Calumet \& Hecla conglomerate the largest pebbles are considerably less than a foot in diameter. The matrix consists of fine material of the same general composition as the pebbles. Where the Calumet \& Hecla conglomerate thins to 5 feet or less it is not a true conglomerate but a rock of finer texture 
ranging from coarse grit to sandstone. The horizon of this conglomerate, recognized for many miles along the strike, is marked chiefly by red or brown basic shaly to sandy sediment with some felsitic sand. Near Calumet it opens out rather abruptly into a lens of typical felsite conglomerate, pitching to the north at an angle of about $35^{\circ}$ and broadening and thickening down the dip. Where truncated by the erosion surface the lens has a horizontal extent of about 10,000 feet. On the seventy-fifth level a similar section measures 17,000 feet, and it apparently continues to broaden as it goes deeper; the lowest workings, at the ninetythird level, have not yet been extended to its lateral limits. Within the limits of exploration the thickness of the conglomerate ranges from 5 feet or less near the margins and 10 or 15 feet where the axis reaches the surface to 30 feet and more along the axis of the lens on the lower levels. In other words, the area of a given section of the lode increases from the surface downward to the present depth of development.

Explorations along the horizon of the Calumet \& Hecla conglomerate both north and south of the lens at Calumet have failed to disclose either another thick body of felsite conglomerate or any encouraging evidence of mineralization.

The Allouez conglomerate is very similar in character to the felsitic portion of the Calumet \& Hecla conglomerate, though much more persistent and over considerable areas much thicker. It is lenticular, however, in places pinching out completely or represented only by a thin clay seam. Such clay seams have been called "slides" and interpreted as faults, parallel or nearly parallel to the bedding, which locally have cut out the conglomerate. Similar clay seams are found where the conglomerate is present, and although they undoubtedly represent slipping, there seems to be no reason for believing that they have faulted out the conglomerate. It seems more likely, unless other evidence of important faulting is found, that the so-called "slides" represent areas where the conglomerate was not deposited.

The Kearsarge conglomerate in places closely resembles the Calumet \& Hecla, but at several points where it has been opened, even though much thicker than the Calumet \& Hecla, it is composed mainly of relatively fine material and ranges from a fine conglomerate to grit and sandstone. No. 8 conglomerate is in general similar to the others. Where cut in the Arcadian workings it is somewhat mineralized.

The great conglomerate formations in the upper part of the Keweenawan series are in general similar in character to the lower beds, though in places, at least, they contain a larger proportion of basic material.

\section{IRON CONTENT}

The felsite conglomerates throughout the series are of strong dark-red color. This redness is a property both of the pebbles and of the finer matrix in which they are inclosed. The red color of the felsite and porphyry pebbles, like that of the massive bodies of felsite and porphyry in the district, is due to the presence of small crystals of hematite, which micro. scopic study of thin and polished sections shows to be an original constituent of the rocks. The available data indicate that these siliceous rocks of the Kewee. nawan series are relatively rich in ferric compared with ferrous iron, as is shown by the following determina. tions:

Iron in Mount Houghton felsite and in a felsite pebble from the Allouez conglomerate

\begin{tabular}{|c|c|c|}
\hline & $\mathrm{Fe}_{2} \mathrm{O}_{3}$ & $\mathrm{FeO}$ \\
\hline $\begin{array}{l}\text { Mount Houghton felsite } \\
\text { Do } \\
\text { Do } \\
\text { Felsite pebble from Allouez conglomerate. }\end{array}$ & $\begin{array}{l}\text { 2. } 27 \\
\text { 1. } 72 \\
\text { 1. } 44 \\
\text { 4. } 88\end{array}$ & $\begin{array}{r}0.15 \\
.18\end{array}$ \\
\hline
\end{tabular}

The iron oxide in the finer part of the conglomerate and in the sandy bands is of two kinds-included plates of hematite in the grains of felsite, as just described, and irregular clastic grains of iron oxide that once were titaniferous magnetite. In the sandstone lenses the grains of oxide are in large part concentrated in layers of "black sand," giving the rock a banded appearance; some of these grains, as seen under the microscope, are made up of limonite crossed by bars of ilmenite. In the thin conglomerate beds that mark the lower part of the series these grains consist mainly of hematite with similar ilmenite bars; very few of the grains are attracted by an ordinary magnet. Some of the iron oxide grains in the Great conglomerate, however, are distinctly magnetic and under the microscope are found to consist mainly of magnetite with bars of ilmenite; the magnetite is partly oxidized, but the ilmenite is unattacked. These facts suggest that the clastic grains of iron oxide were derived from the erosion of areas of basalt and that although the amygdaloid and trap were largely destroyed and dissipated (though perhaps represented in part by the red basic mud rock underneath the felsite conglomerates) the compact iron oxide grains, because heavy and chemically stable, were preserved and were accumulated with the felsitic débris.

Hematite, the prevailing oxide in the conglomerates, is not a by-product of copper mineralization; it is present in all the beds whether mineralized or not and mineralization instead of producing it has destroyed it. (See p. 103.) The conglomerates, indeed, though not as rich in hematite as the amygdaloids, eontained before mineralization a notable amount of ferric iron but, except for a few amygdaloid pebbles, very little ferrous iron. 
The average amount of iron in the conglomerates has not been closely determined. A felsite pebble from the Allouez conglomerate was found to contain 4.88 per cent of $\mathrm{Fe}_{2} \mathrm{O}_{3}$ and 0.6 per cent of $\mathrm{FeO}$. The iron content of the conglomerate is probably very close to 5 per cent of $\mathrm{Fe}_{2} \mathrm{O}_{3}$ and 0.6 per cent of $\mathrm{FeO}$. Certain porphyry pebbles and boulders much higher in ferric oxide are of interest because of their especial susceptibility to copper replacement; those that have been peripherally or entirely replaced by copper form, respectively, the copper "skulls" and "boulders" so often described. One of these iron-rich pebbles gave 12.68 per cent of $\mathrm{Fe}_{2} \mathrm{O}_{3}$ and 1.30 per cent of $\mathrm{FeO}$.

\section{MINERALIZATION}

\section{MINERALOGY}

The minerals that have been introduced into the conglomerate since its consolidation are few and of simple character as compared with the corresponding minerals of the amygdaloids. They all belong to the same general period of mineralization as the copper. The more abundant minerals, named in the order of their deposition, are red alkali feldspar, early; epidote and pumpellyite, mainly earlier than copper; calcite and quartz, throughout; copper; chlorite, associated with the alteration accompanying copper, especially in the iron-rich pebbles.

The zeolites and the allied minerals like prehnite are strikingly absent from the conglomerate; laumontite, though present in fissures in the adjacent trap, almost never persists where these fissures continue into the conglomerate. It is evident, therefore, that the zeolites were not a characteristic and necessary product of the mineralizing solutions but that their formation was primarily dependent on the nature of the rock through which the solutions passed.

\section{ROCK ALTERATION}

The copper occurs chiefly in the finer cementing material of the medium to coarse grained conglomerate. Undoubtedly in part it filled pore spaces in the sandy matrix of the pebbles, but mainly it replaced the cement.

The pebbles, especially those of dense felsite, are generally unreplaced, though here and there bleaching may affect their borders or extend through them along planes of permeability. A few pebbles of quartz porphyry were attacked by copper, but even where advanced replacement has occurred the phenocrysts of quartz and of feldspar remain. In some pebbles the feldspar crystals contain minute copper flakes, and the feldspars may have been attacked thus before the groundmass was replaced. Where iron-rich pebbles were partly replaced by copper, the ferric oxide was in part removed and in part reduced and recombined into chlorite, which is a conspicuous alteration product of such pebbles, as described by Pumpelly and Lane. In these pebbles, chloritized and partly converted to copper, crystals of barite may be present.

The most conspicuous alteration associated with the copper was a pronounced bleaching of the conglomerate from a rich brownish red to a light pink or salmon color. This change is recognized by all those working on the lode as an accompaniment of good ore and is so intimately and faithfully associated with copper from the largest masses down to microscopic particles as to leave no doubt that an intimate causal relation exists between the two. It resulted from the removal of a part, commonly a large part, of the hematite of the conglomerate with no very pronounced change in the other minerals. In the mineralized portions of the rock the fine material and the small pebbles are generally bleached entirely, but the larger pebbles may be bleached only at their margins, the centers remaining dark. This bleaching, as exemplified in the Calumet \& Hecla lode, is somewhat more conspicuous in the lower part of the mine than in the upper part but is to be seen practically everywhere.

Alteration of another type, whose effects are most conspicuous in certain lenses of sandstone, converted a large part of the rock into pale yellowish-green epidote. This change resulted from a recombination of the materials originally present, together with a considerable addition of ferric iron. Evidence of alteration of this kind is to be seen especially in the sandy margins of the Calumet \& Hecla conglomerate where it is thinning down.

\section{DISTRIBUTION OF COPPER IN THE LODE}

\section{GENERAL CONTROLS}

The following discussion applies directly to the Calumet \& Hecla conglomerate, but in its general features it relates to the other conglomerate lodes in so far as they are known.

The copper occurs chiefly in the sandy matrix of the medium and coarser conglomerate. It may be present as small isolated grains, but more commonly it forms a spongy mass through the matrix; and in especially rich places the matrix has been largely replaced, so that the ore consists of abundant felsite pebbles in a cement of metallic copper. Deposition of the copper in the matrix, more than in the pebbles, probably was due to physical causes rather than to differences in composition. The contacts between the sand grains of the matrix and the smooth surfaces of the pebbles are much more permeable than the pebbles themselves and notably more so than the masses of closely packed grains in the midst of the sandy matrix or in the larger sandy lenses. Higher permeability means greater facility for the passage of solutions, and all the evidence indicates that the intensity of mineralization varied in proportion to the quantity of solution that passed through a given volume of rock. The rate at which copper was deposited by replace- 
ment of rock was proportionate to the rock surface exposed to replacement, and the ratio of surface to mass is higher in the sandy matrix than in the pebbles. These two controls, then, were favorable to deposition of copper in the sand mixed with abundant pebbles but unfavorable to deposition where sand occurred alone.

Not only in detail but in a larger way the copper is distributed irregularly through the lode. The con-

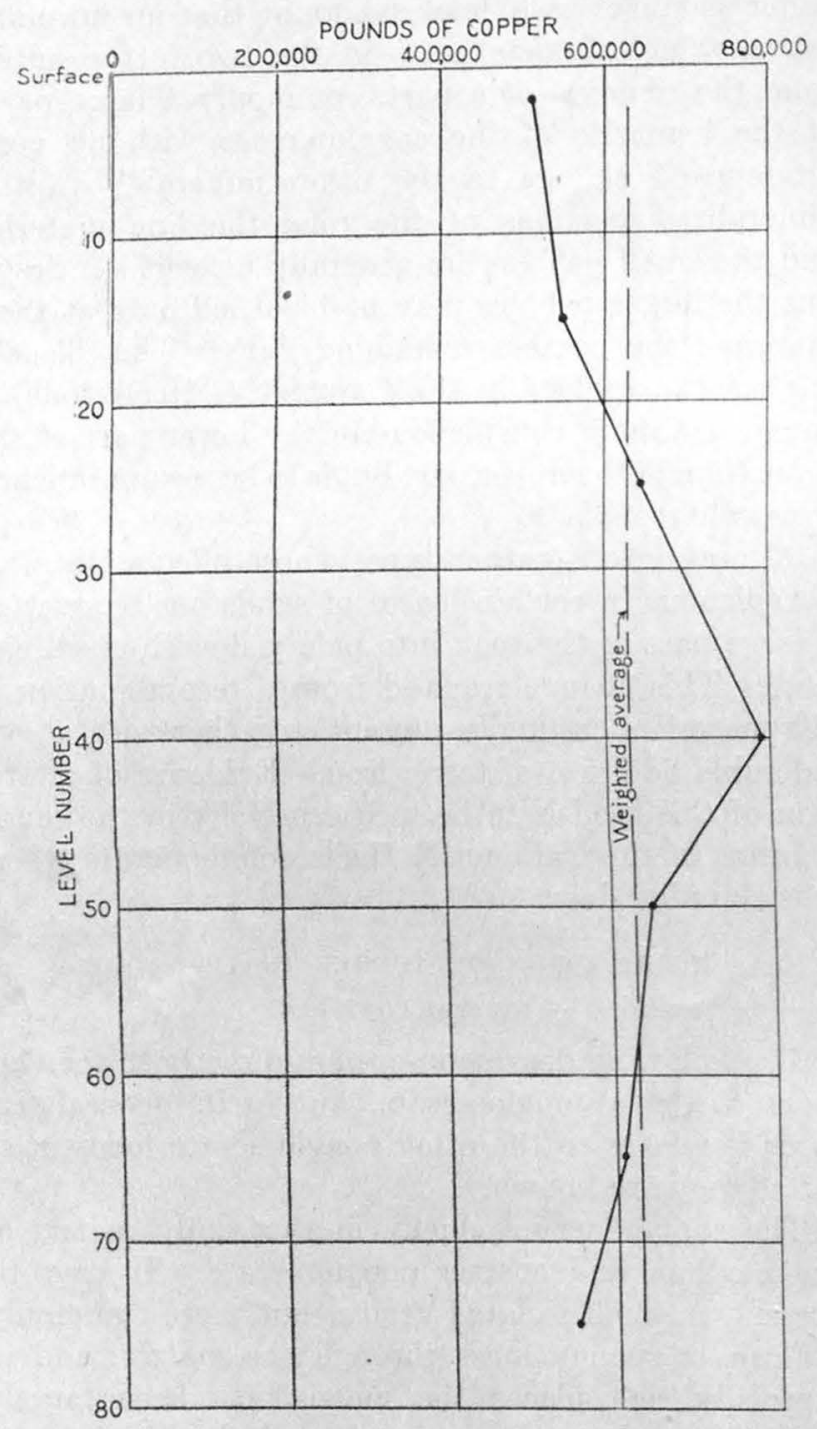

FIGURE 15.-Variation in copper content per foot of depth, Calumet \& Hecla mine

glomerate is distinctly a banded rock, made up of layers or thin lenses that differ in texture. Certain of these bands are well charged with copper; others near by and apparently similar may contain little. This difference in intensity of mineralization from place to place is again not due to variation in composition but is an evident consequence of difference in permeability; the more permeable layers were channelways for the solutions, and in these channelways more copper was precipitated.

In a given cross section of the lode, however, the most permeable layer may not always be the one most largely replaced. This may be the result of local causes. For example, solution that has entered s fairly permeable layer lying near the middle of the lode and bounded on each side by less permeable bands may continue along this channelway for some distance to a place where other layers are more permeable but are dammed off by less permeable bands. Farther along these more permeable beds may be reached by the solution and may eventually become the principal channelways in a given stretch of the lode. The consequence is that the copper is found in overlapping streaks or lenses through the conglomerate bed.

The well-mineralized streak may occupy any position in the lode from footwall to hanging wall, and at places two or more good streaks may be present with lean conglomerate between. These well-mineralized layers may persist for long distances or they may be of relatively short extent.

\section{RICHNESS IN RELATION TO DEPTH}

In the deeper parts of the Calumet \& Hecla mine, where the Calumet \& Hecla conglomerate lens is broad and thick, the mineralized streaks and lenses constitute a smaller proportion of the conglomerate and the poor lenses a larger proportion. Higher up, where the conglomerate body is smaller and thinner, the richer streaks predominate over the poor ones. In consequence, the conglomerate as a whole is distinctly richer in the upper than in the lower part of the mine. The difference in grade, however, is due mainly to the fact that in the lower part a smaller portion of the lode has been mineralized rather than to any material difference in intensity of mineralization or abundance of copper in the part that has been mineralized. That is, if the mineralized lenses of the lower levels could be mined without inclusion of material from the unmineralized parts of the lode, the ore so obtained would compare favorably in copper content with that from higher levels, where the lode as a whole is much richer.

The richest rock in the Calumet \& Hecla conglomerate, averaging about 80 pounds to the ton for yearly yield, was essentially at the present surface (see pl.38), and there has been a fairly steady decrease in richness of the rock mined till at the present depth of operstions the yield is 35 to 40 pounds. The axis of maximum mineralization occupies a position about parallel with and a little above the axis of greatest thickness of the conglomerate lens. (See pl. 38.)

There is no considerable change in total quantity of copper at any given horizontal section from the top to the bottom of the mine that is, horizontal sheets of unit thickness at the twenty-fifth, fiftieth, and serenty-fifth levels would each contain about the same quantity of copper. (See fig. 15.) But as depth is attained and the conglomerate lens increases in size, essentially the same quantity of copper is distributed 
through a greater volume of rock, with resulting lower grade for the lode as a whole at the deeper levels.

In the upper levels, where the lode was relatively thin and the ore rich, the entire width of the lode was stoped, and all the copper that it contained was recovered, even though part of the thickness of the lode was too lean to pay provided it could conveniently have been left unmined. As the lode thickened and decreased in average grade lower down, streaks that were barren or too poor in copper to pay for handling were left unmined wherever they were thick enough or so related to the good ore as to make this possible. Because of the copper thus left the recovery from the lode at depth has been less than the recovery at higher levels, where all the lode was mined.

The actual decline in riclaness from top to bottom, viewed geologically, results apparently from the fact that as the solution rese through the conglomerate mass that contracted upward it encountered a constantly decreasing volume of conglomerate and consequently traveled through and mineralized a larger and larger proportion of it, until, near the present surface, the cross section was so reduced that nearly all the conglomerate was traversed and converted into ore. The inference is that had the Calumet \& Hecla conglomerate maintained to the surface the same cross section as it has at depth, the ore near the surface would be of essentially the same grade as that at the deep levels. The inverted-funnel structure afforded by the conglomerate lens is a special case of the barrier condition, which is considered in more detail on page 115 .

The Allouez is the only other conglomerate that has been explored to any great extent. It has been opened and mined at three localities - at the Franklin Jr., Allouez, and Delaware mines. The mineralization is very similar to that of the Calumet \& Hecla conglomerate, but in all three places the conglomerate is rather thick, and only portions of it are mineralized. It has yielded on the whole a low-grade ore, though it contains lenses of good grade. A notable feature of the Allouez conglomerate is the unusual amount of chalcocite in it wherever it has been opened. This sulphide occurs characteristically intergrown with caicite in veinlets along joints; the calcite is dark because of its chalcocite content, and the metallic luster and streak of the sulphide are obscured by the calcite. Chalcocite occurs similarly though in lesser amount in the Kearsarge conglomerate and, indeed, in all others examined, including the Calumet \& Hecla. In the latter it is apparently most abundant near the margins of the ore shoot, for it is relatively abundant on the dumps of the Centennial shafts and, to a less extent, on those of the Osceola shafts, at the north and south ends of the shoot, respectively.
SANDSTONE AND SHALE LODES

\section{GENERAL RELATIONS}

Sandstone and shale become increasingly abundant in the upper part of the Keweenawan sediments. They are plentiful in the Copper Harbor group and become dominant in the overlying Nonesuch, Freda, and Jacobsville formations.

The only formation that needs special consideration as a copper bearer is the Nonesuch. It consists prevailingly of red sandstone and shale, but in the Porcupine Mountain region it includes a considerable thickness of black, fine-textured shale that covers a considerable area. Immediately beneath this black shale the sandstone, in several localities at least, is gray instead of red. This gray sandstone and the black shale are the principal copper-bearing rocks of the Porcupine Mountain region. The old Carp Lake mine is high up on the north side of the uplift and at a lower horizon-namely, in red sandstone just below the Lake Shore trap.

Most of the exploration at the Nonesuch horizon has been done at the White Pine, Nonesuch, and White Pine Extension mines. These mines are several miles apart, south and southeast of the Porcupine Mountain uplift. The three deposits are near pronounced faults, and the ore bodies at White Pine, at least, are associated with minor cross faults and fissures.

The Porcupine Mountain uplift is probably due to a laccolithic intrusion either of the felsite that forms most of the range, which, however, is commonly regarded as a lava flow, or of coarser porphyry, of which small exposures are known. The fracturing and faulting in the surrounding rocks was, like the doming, a result of this intrusive action. Along the openings so produced the ore solutions probably ascended, and they may be regarded as having come from the same source as the igneous rock.

\section{MINERALIZATION AND ROCK ALTERATION}

In the sandstone, which is arkosic, copper occurs in the more permeable layers, especially those immediately under impermeable covers of shale. It has filled the pore spaces and partly replaced the less resistant grains and is present also along small joints and fractures. The proportion of silver to copper is higher than in most other deposits of the district, and, in exceptional patches a few inches across, silver may quite displace copper and make up a considerable fraction of the rock.

Part of the gray sandstone of the Nonesuch formation has clearly been derived from the red by bleaching, as it repeatedly grades into the red. It is not so clear that the layer immediately under the shale 
was once red and has been bleached. This alteration can not be as definitely ascribed to copper mineralization as the bleaching in the conglomerates and amygdaloids lower in the series. It is believed, however, that the bleaching of the sandstone has been accomplished by sulphur-bearing solutions that deposited the copper. The sandstone that lies immediately below the shale is persistently gray wherever exposed, whether mineralized or not, though sandstones at other horizons are characteristically red except near mineralized rock, where they are bleached gray. The cause for this change of color can not be definitely assigned, but three possible causes have been recognized-namely, the action of bituminous matter from the overlying shales, of hydrocarbon entering the sandstone through the fault fissures, and of the solutions that deposited copper and chalcocite.

In the White Pine mine, where the gray rocks were most thoroughly examined, they contain a considerable amount of black asphaltic hydrocarbon, as well as of copper and of chalcocite. The hydrocarbon or the agencies that deposited it may have exerted a bleaching effect on the rocks. The distribution of both hydrocarbon and copper seems to be controlled by fissuring and by the permeability of the beds, so that in this small area wherever copper is present hydrocarbon is present also, and the influence of each on the iron oxide has not been clearly distinguished. The hydrocarbon appears to be earlier than the copper, for some of it has been partly replaced by chlorite, and some of the chlorite has been in turn replaced by copper. There is also the possibility that the black shale itself, which at the White Pine mine is bituminous, reduced the iron of the sandstone immediately underneath it and thus accounted for the bleaching in that layer. Hydrocarbon in the shale so far as known is confined to the White Pine area, where the fractures extend into the shale. It is possible that the hydrocarbon may have been distilled from the shale by the igneous intrusion, but it may have been introduced into both shale and sandstone from some outside source.

Irving ${ }^{5}$ speaks of having observed cores of magnetite in the copper of the Nonesuch formation, and this statement has been frequently repeated. Nishio ${ }^{6}$ examined specimens from this formation and failed to find magnetite. He did, however, find hydrocarbon with the relations that Irving had attributed to magnetite. Observations of the present writers confirm those of Nishio as to both the absence of magnetite and the presence of hydrocarbon.

Another erroneous impression that may be gained from the literature is that the copper in the Nonesuch formation occurs mainly as chalcocite; this belief prob-

\footnotetext{
S Irving, R. D., Copper-bearing rocks of Lake Superior: U. S. Geol. Survey Mon. 5, p. $132,1884$.

- Nishio, Keijiro, Native copper and silver in the Nonesuch formation, Michigan Econ. Geology, vol. 14, pp. 124-134, 1919.
}

ably resulted from mistaking hydrocarbon for chal. cocite. Samples of all grades of concentrates from the White Pine mill in December, 1918, as reported br Mr. George L. Heath, indicate that about 98 per cent of the copper is native and about 2 per cent occurs as sulphide. This proportion of sulphide, however, is much more than is shown in the conglomerate and amygdaloid lodes.

At the Carp Lake mine the red sandstone immediately below the Lake Shore trap has been mineralized locally from a few inches to a few feet below the base of the trap, and in these places it has been bleached to a gray color. The copper in the bleached sandstone is metallic copper, at least in large part. The bleaching of the red sandstone seems clearly related to the copper. On the dump of the tunnel is fissure material consisting of ankerite or some mixed carbonate containing plentiful chalcocite. In the Carp Lake occurrence no hydrocarbon was noted.

\section{AMYGDALOID LODES}

TYPES OF AMYGDALOID

Three types of amygdaloidal tops of flows have been recognized-banded cellular; brecciated, including some that combine both brecciated and nonbrecciated amygdaloid; and scoriaceous amygdaloid. These types differ from one another in those physical and chemical characters, especially in degree of permeability and hematite content, that determine the extent to which they are likely to be impregnated with copper. The banded cellular amygdaloid is common in the flows of the district, but it is not important as a copper producer except in the coalescing type. Scoriaceous amygdaloids have been still less productive. The brecciated amygdaloid is the dominating type as regards copper production, and it will be described first; the other types will then be contrasted with it.

\section{BRECCIATED AMYGDALOID LODES}

\section{PHYSICAL CHARACTER}

The structural and textural characteristics of the lava tops that were brecciated during solidification are described on page 29. Their chief features that concern ore deposition are variation from place to place in degree of fragmentation - they range from layers of nearly massive material 3 or 4 feet thick to thoroughly brecciated layers $6,10,20$, and even 50 or 60 feet thick; chilled or finer-grained borders for many of the fragments, especially near the top of the flow; and a high degree of vesiculation of most of the fragments. As a rule, the thick parts of these tops are well brecciated and therefore highly permeable; the thin parts are relatively dense and impermeable; the change from one to the other type may be gradual or abrupt. Commonly the thick breccia tops bulge up into the overlying trap and down into the underlying flow; the thin lode breccia, on the contrary, is 
pinched between a sag of the overlying trap and an upward bulge of the underlying trap. The presence of bars or slabs of trappy rock in the midst of the breccia gives in places the effect of a double lode.

The brecciated amygdaloid type is well represented by the Osceola, Isle Royale, and Baltic lodes. The Kearsarge lode, which represents a transition to the banded cellular type (see p. 30), has been subdivided into brecciated amygdaloid, intermediate somewhat broken cellular amygdaloid, and unbroken cellular foot amygdaloid.

\section{IRON CONTENT}

The red color shown by the tops of all the flows is especially conspicuous in those of the brecciated type. It is believed (see p. 34) that the countless tiny plates of hematite to which this red color is due were formed before the copper mineralization, having been produced while each flow was solidifying, whereas the copper was introduced after all the flows and sediments of the series had accumulated and had been tilted. In the amygdaloids, as in the conglomerates, the red color is present throughout the known extent of the lodes, continuing far beyond those relatively small parts of the lodes where copper has been deposited in important amount.

The percentage of ferric iron as hematite in these brecciated amygdaloids exceeds the total percentage of iron in deeper parts of the corresponding flows - in some places by as much as 40 per cent.

\section{MINERALIZATION}

Mineralogy.-The mineral composition of the top rock before it was acted on by the ore solutions was simple. Feldspar, hematite, and glass or its devitrified equivalent were the chief constituents. After the action by the ore solutions, however, the mineralogy was varied and complex. By far the greater number of the long list of mineral species found in this district were produced in these permeable lava tops by heated solutions. Most of these minerals are either present in small amount or are not intimately and significantly associated with the copper. Some characteristically fill vesicles, others occur chiefly in cracks and fissures, still others have replaced the rock material, and most varieties occur in all these ways.

The minerals most intimately associated with the copper are quartz, calcite, epidote, pumpellyite (a greenish fibrous or prismatic mineral which resembles zoisite and which was called zoisite in making the records of drill cores), chlorite, red feldspar, and prehnite. Datolite accompanies the copper in parts of the Pewabic, Osceola, Isle Royale, and Evergreen lodes. Sericite is present plentifully in the Isle Royale lode but is not intimately associated with the copper. It is locally abundant in the Baltic lode with similar relations. Ankerite is abundant in parts of the Baltic lode. The hydrous magnesium-aluminum silicate, saponite, is common in some of the rich ground, especially in the Kearsarge lode.

Analcite is rather widespread but rarely plentiful and as a rule not closely connected with the copper. Apophyllite is found sparingly with copper in the Phoenix mine on the Ashbed lode. Laumontite is the most abundant of the zeolites. It occurs mainly in fissures with little or no copper, and where it is locally abundant in amygdules the lode is generally poor; the mineral is regarded by the miners as a bad sign and apparently justly so. All told, the zeolites play a distinctly subordinate and inconsequential part in the mineralogy of the deposits. Prehnite and datolite, hydrous silicates transitional in character toward the zeolites, are far more intimately connected with the copper.

Sulphides and arsenides of copper are present in veins that cut the lodes at various angles. So also is native copper. The copper of some of the lodes is somewhat arsenical, but in a lode of low arsenic content the proportion of arsenic may rise perceptibly in the lode copper close to an arsenide vein. Native silver is present along with the copper in all the lodes, generally in amount too small to pay for separation, but in some of the lodes or parts of them, especially the Pewabic, it adds in appreciable degree to the value of the product.

Rock alteration.-Alteration of the lava tops, the filling of the vesicles to form amygdules, and the cementation of the breccias were effected at the same time and by the same solutions. The vesicles were still unfilled when mineralization began, for pebbles of amygdaloid included in the felsite conglomerates contain clastic sand grains in their peripheral vesicles, and this sand has been partly replaced by the same minerals that filled the interior vesicles. Each of the minerals in the amygdules is present between fragments and replaces rock material; conversely all the minerals that replaced the rock after the magmatic stage are found also as breccia cement and as amygdule fillings; and all the minerals of the fissures have also replaced rock, cemented breccia, and filled vesicles. Very commonly the material of the amygdule continues beyond the original vesicle boundary, having partly or completely replaced portions of the rock. The cementing of the breccia has also been accomplished largely by replacement of much of the finer material between the larger fragments, though there has been some filling of open spaces.

The most common and abundant minerals of the amygdules are calcite, quartz, epidote, pumpellyite, chlorite, and copper. Epidote and copper favor the upper parts of the lode, or those which were richest in ferric iron; chlorite and pumpellyite are more abundant in the lower parts of the lode, near the horizon where it grades into trap. The same minerals, with the addition of sericite in the Isle Royale lode, are the 
chief constituents of the breccia cement and of the replacement products. Thus it is evident that the three processes of vesicle filling, breccia cementation, and rock replacement were inseparable and interrelated and were associated with the deposition of copper.

In all the amygdaloid lodes, as in the conglomerate lodes, the most conspicuous alteration of the country rock accompanying the deposition of copper was a pronounced bleaching of the red color. Along with this destruction of the red color, which was due to removal of hematite, the rock suffered an even more profound alteration. This occurred around the copper in all the amygdaloid lodes, and in general the same minerals have resulted in all, though there is a marked difference in the proportion of the several alteration minerals in the different lodes and even in different parts of the same lode. Two general types of bleaching are recognized and have been called, from lodes in which each is characteristically shown, the Kearsarge type and the Isle Royale type, or, in descriptive terms, the iron-removal type and the quartz-pumpellyite type. Only here and there was copper deposited in red rock without attendant alteration and bleaching of one or the other of these types, but the deposition of copper occurred at places in the dark part of the lode near the underlying trap without bleaching, though accompanied by rock alteration.

The alteration typical of the red, brecciated upper portion of the Kearsarge and other highly oxidized lodes effected a destruction of hematite and the formation of epidote, calcite, pumpellyite, chlorite, and quartz. The rock around the copper was bleached to a light-gray color of greenish or pinkish cast and commonly somewhat softened; areas rich in copper are thus conspicuous. The copper has been formed largely by replacement of the rock, and apparently having once started to form at a given place, it continued growing till considerable lumps were accumulated. The copper has clearly replaced the altered rock in the bleached zone around it. Roughly, the diameter of a bleached zone is three to four times the diameter of the copper which it surrounds, but both the copper and the bleached zone are very irregular.

In the Isle Royale lode and in many of the lodes in the south end of the district the alteration has resulted in a characteristic grayish-green rock of hard, compact texture composed mainly of pumpellyite, epidote, calcite, and quartz. The pumpellyite is the most abundant mineral and gives the color to the rock. The copper occurs in the midst of the bleached rock into which it grew, as in the Kearsarge type. Bleached rock of this type is conspicuous in the Baltic lode and, with more quartz and less pumpellyite, in the Pewabic lode.

Alteration of a third type occurred in the darkcolored basal portion of the Kearsarge lode and more or less commonly in the other lodes. In the rock thus altered chlorite is abundant and intimately associated with the copper, which occurs mainly in amygdules, producing "shot copper," but also forms films or plates along joints. Red feldspar may be plentiful in places. There has been no conspicuous bleaching, mainly because the rock near the foot of the lode was never very red, and because chlorite, the predominant alteration product, is dark like the trap, and epidote is far less common than in the upper red parts of the lodes, where it seems to have been formed through a recombination of part of the ferric iron. The lower few inches of the overlying trap generally shows altera. tion of this chloritic type, and in places a very little copper is present.

\section{CELLULAR AMYGDALOID LODES}

The only lodes of the cellular type that have been extensively mined are the Pewabic amygdaloid lodes. These lodes belong to the "coalescing" variety of the cellular type; they are composed of layers in which amygdules are relatively scarce, alternating with layers in which the gas bubbles were so abundant that they coalesced so as to form irregular flat carities. These cavities are filled with vein minerals, and the lode has the appearance of a banded vein. In places these cavities extend continuously in a cross section of the lode for as much as 10 to 15 feet, though their average extent is much less. (See pl. 58.) In the plane of the lode some of these openings must have been continuous for tens and perhaps for hundreds of feet. The Pewabic lodes are characterized by this type of top, but they contain large areas of fragmental top and some of the more ordinary type of cellular top. This "coalescing" type of flow is commonly flatsurfaced. The drifts in the Quincy mine that follow the narrow lodes are essentially straight for hundreds of feet and contrast strikingly with drifts following the tops of fragmental lodes.

It is evident that the coalescing top, with its long continuous openings, would be relatively permeable and permit the passage of large quantities of mineralizing solutions.

The coalescing Pewabic lodes are of a brownish color where least mineralized but distinctly less red than most of the fragmental lodes, including the fragmental areas of the Pewabic lodes. They are probably less completely oxidized than these other lodes, though some of the difference in the color may be due to the coarser grains of the hematite.

In the coalescing Pewabic lodes quartz and pumpellyite are the characteristic minerals, though calcite and epidote are not rare. The rock alteration is of the quartz-pumpellyite type, and the lode is consequently hard. Bleaching is not as pronounced as in most of the other lodes. An unusual amount of the copper occurs in masses, some weighing many tons, that characteristically lie parallel with the lode and are 
associated with strongly developed amygdular bands. Most of the copper, however, occurs in small grains scattered throughout the amygdaloid, much of it paring replaced the rock. The fine copper is also commonly associated with strong amygdular bands.

In the fragmental Pewabic lodes bleaching is more pronounced and is in part of the iron-removal type. In the upper levels of the Quincy mine, probably in the fragmental lode, nodular masses of porcelanic datolite were present. No datolite was noted in the deeper levels.

\section{SCORIACEOUS AMYGDALOID LODES}

The Ashbed lode, which has been most productive in the Atlantic mine but has also yielded copper in the Phoenix mine, near Eagle River, and in the Copper Falls mine, farther north, is the principal representative of the amygdaloid lodes of scoriaceous type. 0ther examples of this type are numerous but so far as known contain little copper.

As none of the mines on the Ashbed lode are active there has been but meager opportunity to examine the lode. Apparently it varies much from place to place. In the Atlantic mine its character is apparently rather typically "scoriaceous," as described on page 176. It is composed of amygdular fragments cemented with brown to red sediment and is distinctly soft. The copper was distributed rather uniformly through the rock, and its deposition was accompanied by rather feeble bleaching.

In the Phoenix mine the upper or "gray" lode appears to be similar in character but the lower or "red" lode is possibly less scoriaceous.

At Copper Falls much of the amygdaloid is apparently rather typically fragmental, though containing some sediment. It is well oxidized, and bleached rock of the iron-removal type is conspicuous in association with the copper.

\section{DISTRIBUTION OF COPPER IN AMYGDALOID LODES}

\section{DISTRIBUTION OF SHOOTS IN THE LODES}

None of the important amygdaloid lodes are mineralized over more than a small part of their known extent. The Kearsarge lode has been traced for 40 miles or more but is known to be commercially mineralized for only about 5 miles, though it contains notable amounts of copper for double that distance. The Osceola lode has been developed for but little more than 3 miles along the outcrop, although its length is known to be several times 3 miles. Similar conditions exist in the other lodes. The copper, then, is concentrated in shoots within the lodes.

With the possible exception of the Allouez conglomerate and the Ashbed amygdaloid, neither of which has been shown to be rich at any point, no lode is known to be commercially mineralized in two widely separated parts. This probably does not result from any fundamental cause but is the outcome of generalization from a small number of cases. It is frequently stated in the district that but one mineralized lode is to be found in any one section across the series. This statement, however, is by no means true, as is indicated by the overlapping of the Calumet \& Hecla conglomerate and Osceola ore shoots. Moreover, in the closely spaced series of lodes, like the Pewabic amygdaloid lodes and the Evergreen and succeeding lodes, several ore shoots have been developed in the same cross section. Immediately above the main Baltic lode is an ore shoot in the Baltic West lode, and above the main Superior lode is an ore shoot in the Superior West lode. The distribution of ore bodies in each lode appears to be independent of the adjacent lodes and to be governed by local causes, which are discussed under "Causes of ore shoots" (p. 115).

DISTRIBUTION OF COPPER IN THE SHOOTS

Within the mineralized portion of a lode or what may be regarded as a major ore shoot, the copper shows considerable inequality of distribution, both in the plane of the lode and across the lode.

In drifting along the lode through a major ore shoot patches or zones of lean ground, in part too lean to be worked, are generally encountered. Some of these are areas in which the lode is thin; some occur along fractures or shatter zones. The areas of profitable ground between such lean areas may be regarded as shoots of a second order. An example is afforded by the rich South Kearsarge-Wolverine shoot, which lies within the main shoot that extends from Centennial to Gratiot on the Kearsarge lode. These better shoots differ greatly in size, but all are large as measured by the standards of the usual mining district. Their size, indeed, is generally so great that, although they have been developed to depths and lengths of several thousand feet, neither their shape nor the pattern of their distribution is satisfactorily known. There is strong indication, however, that many of the better shoots are of elongated shape and that some of them pitch rather steeply within the plane of the lode.

Variations across the plane of the lode permit closer investigation. The amygdaloid lodes are generally richest near the hanging wall and decrease in value toward the footwall. This is notably true of the Kearsarge lode. It is also true of the Osceola lode, though in the Osceola and Baltic lodes there are wellmineralized areas near the footwall.

The Pewabic amygdaloid lodes are narrow, and the variation in distribution of copper within them is not so noticeable. No definite information is available for the Ashbed lode. In the Isle Royale lode, in contrast to the others, the richest ground is pretty consistently along the footwall.

Permeability seems to have been a controlling factor in determining the place of deposition of copper in the 
lode. In general the top of an amygdaloid was the more permeable, and the greatest volume of solution passed through that part of the lode. In highly fragmental lodes some of the deeper parts are loose and permeable and therefore were well mineralized.

The reason for the reversal of the usual relation in the Isle Royale lode is not entirely clear. The cause that seems most likely is the presence of joints or shearing planes parallel to the lode near its base. These joints did not develop in the friable most thoroughly brecciated portion of the lode, and the presence of the mineralized zone in and near the joints along the footwall suggests that these fractures, which are continuous for long distances, made this the most permeable portion of the lode.

\section{RICHNESS IN RELATION TO DEPTH}

Several ore bodies in the district have given indication of decreasing copper content with increase in the depth to which they have been mined. The main Superior lode and the Superior West lode were found too poor in depth to justify continued operations, and the Calumet \& Hecla conglomerate is known to have decreased rather steadily downward in grade of rock. The Baltic mine is of low grade in the bottom levels, though the Champion mine, on the same lode, has rich ground in its lower levels; the North Winona shafts went into poorer ground in the lowest levels, though there is indication that the southern shafts encountered the ore shoot pitching downward.

Are such changes in grade due to increase in depth, or are they due to local conditions peculiar to each case? This subject is more fully discussed under "Cause of ore shoots," but it may be said here that where the ore bodies are best known the decrease can be accounted for by conditions peculiar to the particular deposit.

Thus the Calumet \& Hecla conglomerate shoot increases in size down the dip and decreases in grade in about the same ratio. The amygdaloid in the lower levels of the Baltic is relatively thin, cellular, and unfavorable and has the same effect on copper content that similar rock does higher in the shoot, even where surrounded by rich ore. The bottom of the Superior West lode is also relatively thin and cellular. The condition of the bottom of the main Superior shoot is not known. It thus appears that in the amygdaloid deposits the decrease in tenor with depth is due to changes in rock texture that result in similar changes along the strike as well?'as in'depth.

The Quincy mine has been opened for 8,000 feet down the dip. In this mine one lode was found most productive in the upper levels, another in the deeper levels, also one in the north end of the mine, another in the south end. On the whole there is no evidence that there is a notable decrease in the grade of rock to the present depth. In the deep levels, as in the upper levels, favorable lode rock is usually well mineralized and unfavorable rock is poorly mineralized.

In the Kearsarge lode, which has been opened con. tinuously for 4 to 5 miles along the strike, some stretches in the top levels were poor, such as parts of the North Kearsarge and Wolverine ground, but other stretches were rich, such as the South Kearsarge part of the Wolverine, the Ahmeek, and the South Mohawk. These differences are pretty clearly due to differences in character of the amygdaloid. Similar differences occur in the lower workings on the lode and are apparently due to the same cause, and not to change in depth.

No change in the character of minerals or the type of rock alteration has been noted even in the deepest workings, such as those of the Quincy mine.

There is little doubt that for a lode of uniform size and character a depth exists at which the degree of mineralization would change - probably for the worsebecause of factors correlated with increase in depth; if, for example, the lode were fed by fissures, it might be expected that a change would occur where such feeding fissures were passed. The fissure deposits, with the single exception of that on the Ahmeek Mass fissure, have decreased in richness downward to such an extent that they have been abandoned, and in this fact there is certainly a suggestion that depth is influential. There is no clear evidence, however, that the changes of grade observed in the lode mines up to the present time are primarily due to increase in depth.

\section{FISSURE DEPOSITS}

\section{GENERAL FEATURES}

Fissure deposits or veins have been of relatively slight importance in the Michigan copper district as compared with the lode deposits, though a number of mines, notably the Cliff, the Central, and the Minesota, were operated profitably on fissures, and the Ahmeek Mass fissure is being worked by the Calumet \& Hecla $\mathrm{Co}$. in conjunction with its amygdaloid mine. Many other fissures have been developed and have yielded considerable copper. But the combined production from fissure mines has been less than 3 per cent of the total production of the district, and the dividends from these mines have been only about 2.5 per cent of the total dividends.

The fissures in the north end of the district strike across the beds and dip steeply. They are apparently tension cracks that developed during the folding of the beds transverse to the Lake Superior syncline. The fissures in the south end of the district strike nearly parallel with the beds and dip somewhat more steeply. They may possibly be related in origin to the Keweenaw fault.

The principal fissures, in the miner's sense, are not single breaks through the rock but rather zones of 
parallel or interbranching fractures. The width of the fissures or fissure zones ranges from that of a tight crack up to 10 feet or more. At many places there is some brecciation of the rock within the fissure walls, but little gouge is present.

In respect to mineral content, the fissures may be separated into three types - those in which copper is predominantly native, to which all the commercially important fissures belong; those that carry copper arsenides; and those that contain copper sulphides. There is no sharp line between the types, but commonly the copper in a single fissure occurs chiefly. in one of these conditions.

The gangue minerals of the fissures are the same as those associated with the copper in the amygadaloid lodes. In some, like the Mass fissure, the mineralogy is simple, the copper being accompanied chiefly by calcite, quartz, epidote, and chlorite, with only minor quantities of other minerals. In other fissures, like the Copper Falls (Owl Creek), prehnite, datolite, analcite, and some rarer zeolites are plentifully associated with the commoner minerals. Apophyllite is present in some, and laumontite is common in many. Certain fissures carry copper that is distinctly arsenical. Some of the arsenide fissure deposits are essentially quartz-arsenide veins, though most of them contain carbonate, which is in part iron bearing. Many of the sulphide veins contain dolomite and siderite or ankerite, together with a little specularite. The minerals of the fissure veins are similar to those of the lodes, though there is perhaps more extreme variation among the fissures than among the lode deposits.

Rock alteration along the fissures is not extensive where they cut through the dense traps. Chlorite is the most abundant alteration product in these rocks, but pumpellyite, epidote, laumontite, and calcite are common, and sericite is formed plentifully along some of the sulphide and arsenide veins. Alteration of the amygdaloids where they are cut by the fissures is more difficult of recognition because of their complex mineralogy. The most noteworthy change is a darkening of the red amygdaloid lodes for distances in some places as much as 100 feet on each side of the fissures. This darkening is occasioned chiefly by the development of chlorite but in part from removal of hematite, especially that of finest grain.

\section{DISTRIRUTION OF COPPER IN VEINS}

The distribution of copper in the fissure veins is even more irregular than that in the amygdaloid lodes. In some of the fissure veins most of the copper formed large masses weighing a ton or more, finely disseminated copper occurring in but relatively small quantity. In others small masses were commonest; and in a few "stamp copper" (copper disseminated through the vein material in small grains) predominated. Several masses estimated at nearly 500 tons each have been encountered in fissure veins.

It is now impossible to study the underground relations in the more extensively developed old fissure mines, which have been closed for some years, but certain deductions may be drawn from the descriptions and reports concerning them and from examination of the fissures that cross the Kearsarge lode.

In the fissures that cross the Kearsarge lode, both those that contain native copper and those that contain arsenides, the copper was deposited in greater part at and near, mainly above, the crossing of the lode. Few if any masses worth the cost of getting them have been found more than 400 feet from the lode.

Descriptions of the old mines strongly suggest that the fissures in them likewise were more productive where they crossed a series of thick, well-oxidized amygdaloids below the Greenstone flow and at the Ashbed horizon, above the Greenstone flow. A similar relation is suggested in the Minesota fissure, at the south end of the district. This fissure and the associated Branch fissure have been found to be mineralized at and above but not below their intersections with the Minesota conglomerate. Likewise, in the fissures carrying chalcocite, which are rather abundant in the Baltic lode and less so in the Isle Royale lode, the chalcocite seems to be most abundant where the fissures are within the lode or near the points where they cut the lode.

Thus the general rule for copper occurrence in fissures of all types seems to be that it is most abundant at and near the intersections of the fissures with thick, well-oxidized amygdaloids. This concentration of copper at such intersections suggests that hematite is needed for precipitation of copper in fissures as well as in conglomerates and amygdaloids. According to descriptions of old fissure mines, the amygdaloids and conglomerates were commonly mineralized for a short distance from the fissures. In a few places this lode mineralization formed commercial ore. What happened to the Kearsarge lode near the intersecting fissures is not so clear, because of the mineralization of the entire lode for several miles along the strike by solutions that ascended along the lode apparently independently of the fissures. The net result of the mineralization of fissures and lode is that the lode is darkened near the fissures because of chloritization and the removal of hematite and its copper content is somewhat lower than away from the fissures. The reasons for the abundant precipitation of copper at the intersections of some of the fissures with the lodes and the impoverishment of lodes near intersections of other fissures are discussed in the section on genesis (p. 135). 


\section{HAS THERE BEEN ENRICHMENT OF THE DEPOSITS?}

In either prospecting for or developing ore bodies it is important to know the general behavior of the type that is under consideration. It is well established that the richness of some types of deposits is greatest near the surface and decreases downward. Some types have a barren zone at the surface followed by a rich zone, which in turn gives place to ore of lower grade. Many copper deposits are of the latter type, and it has been clearly shown that the barren zone near the surface and the underlying rich zone have resulted from a leaching of metal from the former and its deposition in the latter-a process known as enrichment.

In the following paragraphs the data relative to the behavior of the Lake Superior copper deposits with increase in distance from the outcrop are set forth, and the conclusion is reached that in these deposits enrichment has been unimportant.

\section{NO EVIDENCE THAT THE LODES ARE POOR AT THE SURFACE AND RICHER BELOW}

In either prospecting or developing sulphide deposits, it is of fundamental importance to recognize that an outerop that is nearly barren of copper may give place at depth to a zone of rich ore, which may grade off into material of lower grade.

In the Lake Superior district there seems to be a general though far from definite feeling that the best ore is some hundreds of feet below the outcrop-that is, that there is a gradual increase of copper for some distance below the outcrop to a maximum depth, below which there is a decrease. Lane ${ }^{7}$ has implied his acceptance of this idea by suggesting the explanation that copper is leached in the fresh-water zone and that it attains its maximum richness at about the boundary between the fresh-water and salt-water zones or at the calcium chloride zone, below which it gradually falls off. This influence of water is discussed on page 122 .

If it is true that there is comminy a leached zone near the surface, prospecting of a lode should be carried on at considerable depth, despite the heavy expense entailed by so doing; if it is not true, a given sum of money may be better expended in examining a greater stretch of lode near the outcrop. The location of property boundaries of course must affect any scheme that calls for extended exploration of a lode along the strike, but even so the presence or absence of surface leaching and downward enrichment will materially affect the planning of explorations.

Kearsarge lode.-At the South Kearsarge mine good ore was present practically at the outcrop, and although the ground varied in grade in different parts of the mine, there is no record of a consistent change

\footnotetext{
' Lane, A. C., Lake Superior Min. Inst. Proc., vol. 17, p. 134, 1912
}

from the surface downward. In the Wolverine and North Kearsarge mines and at least a part of the Ahmeek mine the upper levels were relatively poor and the intermediate and lower levels decidedly richer In the south end of the Mohawk mine there was very good ground in the upper levels, notably south of No. 5 shaft, and apparently the rock in the upper levels of this part of the mine was as good as deeper in the mine or as in the North Ahmeek mine, which is opened below it. In the north end of the Mohawk mine surface pits encountered good rock, and so far as known the upper levels of that part of the mine averaged as good as the deeper levels, though this end averages poorer than the south end. It appears, then, that a part of the productive portion of the Kearsarge lode was as rich at or very near the outcrop as at greater depth, but that the remainder of the lode was relatively poor near the surface. A study of all available facts regarding the character of rock in relation to tenor of ore has shown, however, that the areas of low-grade ore near the surface are coincident with areas of relatively thin or cellular, impermeable lode rock. Areas of rock of similar character deeper in the mines are similarly low in copper, a fact which, together with the lack of evidence that these portions ever contained more copper, has led to the belief that the lower copper content is due to the character of the rock, and that depth below the present outcrop of the lode is not causally related to it.

Osceola lode.-The outcrop of the Osceola lode was richest at the north end of the Osceola mine, where, to judge from reports, the rock was as good as any found at depth on the lode. Throughout the Calumet \& Hecla workings on the Osceola lode the top levels average as rich as at any greater depth. South of No. 3 shaft, in the Osceola mine, the top levels were poor. The ground was also poor in No. 6 shaft to the twenty-fifth level and farther south to greater depth. It is thus apparent that for the Osceola lode, as well as for the Kearsarge, the upper portion was good over part of the area and poor over the remainder. There is a bar of thin lode rock along the south boundary of the shoot, and this, rather than any leaching of the lode, is thought to be the cause for the poor ground to the south. This relation is discussed under "Conditions determining position of ore shoots" (p. 115).

Calumet \& Hecla conglomerate.-The Calumet \& Hecla conglomerate lode was rich at the surface between No. 3 Calumet and No. 5 Hecla, and again from a point 400 feet south of No. 10 Hecla to and beyond No. 1 Osceola. In the Osceola mine and in No. 12 shaft of the Hecla the shafts went from good ore into poor ground with depth. Nos. 6, 7, and 8 Hecla went through poor ground into rich ore. No. 2 Hecla to No. 3 Calumet went from rich ore into lower-grade ground with increase in depth. Nos. 5 and 6 Calumet went through poor ground to the thirtieth level before they entered good ore. The outcrop 
of the Calumet \& Hecla conglomerate lode was, in short, rich in some places and poor in others. A study of the character of the lode rock has shown that the differences in copper content are correlated with differences in the original character of the rock; where the ore was poor, the felsite conglomerate was very thin or was represented by a thin bed of sandstone; where conglomerate was present at the outcrop in considerable thickness it was well mineralized. There is no indication that the poor areas were ever mineralized and subsequently leached or that the rich areas have been subsequently enriched. It is therefore logical to conclude that the variation in richness is dependent on the character of the rock rather than on position relative to the outcrop.

Pewabic amygdaloid lodes. - Some of the Pewabic amygdaloid lodes were richest near the surface, and some at greater depth. In general, it may be said that commercial ore was found in the upper levels in the central and southern parts of the Quincy property, whereas to the north, in No. 8 shaft, a long stretch of lode was passed through before commercial ore was encountered, and farther north the profitable ore is still deeper. It appears, then, that the conditions in the Pewabic lodes are similar to those in the other lodes discussed.

Atlantic lode.-The maps of the Atlantic mine indicate that in places stoping was carried close to the outcrop. The grade of the ore in these places is not known, but as the ore in the deeper parts of the lode was of low grade it is reasonable to suppose that the ore near the surface was not much poorer, else it would not have been mined.

Isle Royale lode.-Stoping was carried close to the outcrop in the Isle Royale lode, and although a larger percentage of the lode has probably been mined at the lower than at the higher levels, this fact is apparently more the result of change of mining methods than of difference in character of the lode.

Baltic lode.-At all three mines on the Baltic lode the ground appears to have been good at the outcrop and to have shown no zone of decided enrichment at lower levels.

Evergreen and succeeding lodes.-The mines on the Evergreen and succeeding lodes in the south end of the district have practically all stoped close to the surface with apparently as good ground as at any greater depth.

Nonesuch lode.--In the Nonesuch lode as developed at the White Pine mine there seems to be no evidence to connect grade of the rock with its position relative to the outcrop of the lode.

Veins.-Without following out each important vein in detail, it may be said that in a general way the reins show the same relation as the lodes. Most of the productive veins that have been developed have had good copper near the surface in places, though not necessarily or usually throughout their productive extent. For example, the Cliff fissure was apparently rich in copper at the outcrop east of the Greenstone flow, but No. 4 shaft, which was sunk through the Greenstone flow, did not encounter ore till it had passed through that bed. It is evident that the rich and poor parts of the vein are related to the character of the fissure and of the adjacent rocks rather than to position relative to the present surface. Similar relations might be cited for many of the veins through the district.

\section{NO EVIDENCE OF LEACHING AND REMOVAL OF COPPER NEAR THE SURFACE}

Statistics of production indicate that the lodes at the outcrop have been as rich as at greater depths. The question may be asked, however, if there is physical evidence of leaching of copper near the surface or precipitation at depth. The first point to determine in answering this question is, What constitutes evidence of leaching of copper? At first sight the alterations of the rock associated with the copper might be taken for such evidence. The most striking of these alterations is the bleaching of the rock around the copper. In places there has been considerable bleaching of the pumpellyitization type, with which little deposition of copper was associated, and it might be inferred that this bleaching is of the same origin as that seen in rich copper ore and has persisted after the copper was removed. This barren bleached rock, however, seems as abundant on the deeper as on the higher levels. In rock affected by bleaching of the iron-removal type, copper seems always to be present. In the conglomerate there has been some bleaching associated with epidotization and accompanied by little deposition of copper, but this again seems to be no more abundant near the surface than deep in the mine. The amount of bleached rock associated with copper seems, indeed, to be rather less in the upper than in the deeper parts of the lodes. Nowhere has bleached barren lode rock that suggested that it had once been rich in copper been seen near the surface.

Another evidence of leaching might be the passage from rich ore at depth to lean rock near the surface without change in the character of the lode-forming rock. In the mines studied no example of such a change has been found. On the other hand, in the conglomerate lodes there is a rather steady increase in grade of rock from the deeper levels to the surface. In the amygdaloid lodes change in grade in the mines studied has been much more closely associated with change in character of lode than with increase in distance from the outcrop.

It is to be expected that the ordinary surface waters will dissolve some metallic copper, but the metal has not been so dissolved in sufficient amount to leave evidence that has been recognized. The deep salt waters are also known to contain copper, which will 
be deposited on iron, as has occurred in the waters from deep drill holes in the Baltic mine. (See "Chemistry of ore deposition," p. 121.) In a few places, as at Copper Harbor and the Algomah mine, oxidized copper minerals have been formed, but these are near the surface and afford no evidence of movement of the copper.

\section{NO EVIDENCE OF ENRICHMENT AT THE SALT-WATER HORIZON}

In the mines studied no evidence has been recognized of enrichment at the horizon of the change from fresh to salt water or to calcium chloride water. Lane points out that leaching has probably occurred in some shatter zones and cites particularly the one in section 16, Atlantic. The main evidence of leaching, however, seems to be the lack of copper. If such negative evidence is accepted as valid, the Allouez shatter zone also must be regarded as leached near the surface; yet this zone has been opened well below the top of the salt water without encountering evidence of enrichment. The shatter zones are pretty clearly poor in copper, but, all evidence considered, it seems more likely that copper was not deposited abundantly than that it was deposited and later removed.

\section{SUMMARY AND CONCLUSIONS}

The foregoing details regarding leaching and enrichment may be summarized as follows:

Virtually every lode has been as rich at some place near the surface as in any of its deeper portions.

Where the lode is lean near the surface no evidence is afforded by the way in which the rock has been altered to indicate that this portion of the lode was ever rich in copper.

In every lode examined, where lean ore near the surface gives place to rich ore at depth, it has been found that the change coincides with a change in the original character of the lode rock that seeins adequate to account for the change in copper content.

No evidence of enrichment at the zone of change from fresh to salt water or to calcium chloride water has been found in any of the mines.

\section{PERSISTENCE WITH DEPTH}

All ore deposits must sooner or later show a decrease in metal content with increase in depth; there is however, a great difference in the depth at which such decrease becomes important in different types of deposits, and it is desirable to have some basis for judging what may be expected for a given type, with due allowance for the fact that each deposit has its own peculiarities.

For example, in the well-known type of disseminated copper deposit which owes its better portions to downward enrichment, it is reasonably certain that the enriched zone will be but a few hundred feet thick It is also pretty well established that in the Tertiary type of gold-silver deposits the bulk of the precious metal is likely to be found within 1,000 to 2,000 fees of the surface and that many deposits fail before depth of 1,000 feet is reached. On the other hand, it certain gold-quartz deposits, as those of the Mother Lode of California, the metal content of the veins persists at least to 3,000 feet and probably to considerably greater depth. In planning the develop. ment of mines to work deposits so extensive as those of the Lake Superior copper district, some basis of judgment as to what is to be expected at depth is of prime importance.

In appraising the effect of depth, it is necessary to consider geologic units and not property units. Thus a study of the mineralization of the Calumet \& Hecls conglomerate based on the results attained in depth in the property of the Osceola Mining Co. would lead to conclusions quite different from those reached by considering the ore shoot as a unit.

Developments have been carried to so great a depth in certain deposits that there is a very considerable body of fact on which to base judgment as to what is likely to be found in deposits that have not been so deeply developed, as well as to what may be expected at still greater depth. Development has been carried to a vertical depth of about a mile in the Calumet \& Hecla conglomerate and the Pewabic amygdaloid and to more than half that depth in other amygdaloids. To this depth there has been recognized no significant change in the type of minerals in the lode. In the conglomerate lode there seems to be less bleaching or removal of the iron in the higher levels; locally at least this lack of bleaching is rather pronounced. The same seems to be true for the Osceola lode. That it holds for the other lodes is less certain. Lane ${ }^{8}$ states that sodium minerals, like analcite and natrolite, are corfined to the upper levels. This statement is not sup. ported by the present investigation of the amygdaloid lodes, for analcite has been found on the deeper levels of the Osceola mine. In the Calumet \& Hecla con. glomerate lode zeolites are characteristically absent.

The literature contains numerous statements that silver is more abundant on the upper levels. These statements have not been verified. So far as regards the recovery of silver from the electrolytic treatment of copper, there seems to be no basis for the belief that the ratio of silver to copper decreases with depth. Shoots relatively rich in silver, for the conglomerate lode, are present in the lower levels at the south end of the Calumet \& Hecla conglomerate body. It seems pretty certain that vugs rich in silver, which display the metal conspicuously, were more abundant at the higher levels, but it is not certain that silver was actually more abundant at these levels than lower.

8 Michigan Geol. Survey Pub. 6, p. 871, 1911 
It has also been stated that sulphides are less abundant in depth, but this also has not been verified. In the Isle Royale mine it does not seem to be true, and sulphides appear to be as abundant in the lower levels of the Baltic lode as at higher levels.

Some of the lodes lying near the base of the Keweenawan series were relatively high in arsenic, and it has been suggested that this may be so because the solution that mineralized these lodes had flowed for a relatively short distance in them and therefore had been less completely oxidized than the solution that mineralized the higher lodes. If this is true, it would be expected that there would be, in general, an increase in the arsenic content of a given lode with increase in depth. Such an increase, however, has not been definitely observed to the present depth of mining. Mineralogically, therefore, there is no conspicuous change recognized to the present depth. The available evidence indicates that the native copper of the Lake Superior region was deposited through a wide vertical range. As the content of some of the great lodes has failed to show any systematic decrease with depth after having been followed down for thousands of feet, copper ore may be expected to persist to great depth-even greater than is now known. It is not to be expected, however, that all deposits of the type will attain the same depth, and the suggestion that some have been commercially bottomed is at least warranted by the rather general failure of the fissure deposits with increased depth. It is also possible that some lodes that show strong alteration with little copper may represent the roots of deposits that were richer in their higher parts, which have been eroded.

\section{CONDITIONS DETERMINING POSITION OF ORE SHOOTS}

In general there are two main factors that have influenced the formation of the ore shoots- $(a)$ permeability, which influenced the flow of solutions, and $(b)$ the character of the rocks, which may have had a chemical influence in precipitating minerals. In addition structural relations may have had an important effect. The great ore shoots are related to structural features and peculiarities of the individual lodes. Chief among these are, on the one hand, the occurrence of impermeable or barrier conditions in an otherwise open-textured lode, and, on the other hand, the local opening up of a prevailingly tight, impermeable lode. The former type is exemplified by the Osceola lode; the latter by the Calumet \& Hecla conglomerate and the Kearsarge lode.

\section{PERMEABILITY OF ROCK}

The lode deposits are formed only in the more permeable beds, such as the conglomerates, fragmental amygdaloids, and coalescing amygdaloids, and are consistently lacking in the more abundant but less permeable cellular amygdaloids. The continuous breaks in which the fissure deposits occur also permit the ready flow of solution. Permeable rock, then, is essential to the formation of such ore deposits as these copper lodes. Roughly, the rocks of the district may be grouped in the following order of permeability: Fissured rock, fragmental amygdaloid, felsite conglomerate, coalescing amygdaloid, sandstone, "scoriaceous amygdaloid," ordinary cellular amygdaloid, trappy fragmental amygdaloid more or less lavacemented, trap, shale, fault gouge.

\section{BARRIERS OF RELATIVELY IMPERMEABLE ROCK}

The more permeable rocks are a positive factor in the formation of ore bodies, but the less permeable rocks may be an important negative factor in directing the movement of ore solutions. This is well shown in some of the ore shoots of the district.

The Calumet \& Hecla conglomerate shoot is a relatively small lens of felsite conglomerate which thins in each direction along the strike. The sandy and shaly beds underlying the felsite conglomerate continue along the strike in both directions. The conglomerate body is thinnest and shortest near the outcrop and thickens and lengthens with increased depth, thus giving the effect of an inverted funnel. Solutions rising along the lode are converged by the Jess permeable rocks at the margins of the felsite conglomerate and by the relatively impermeable hanging-wall and footwall rocks into a steadily contracting channel of permeable rock, so that more solution passes through each unit volume of conglomerate in the upper part than in the lower part. (See fig. 16.) The richness of the ore at any depth is about in inverse ratio to the thickness and extent of the lode at that depth, a fact which indicates that copper was deposited in proportion to the amount of solution passing through the rock.

The funneling effect illustrated in the Calumet \& Hecla conglomerate perhaps gives the most favorable conditions for the convergence of solutions and the formation of ore shoots; the Calumet \& Hecla shoot, at any rate, is the richest yet opened. A concentrating effect may, however, result if a barrier of relatively impermeable rock interrupts a permeable lode. Such damming may result either from a change in character of the lode itself, as from fragmental to cellular, or from the offsetting of the lode by a fault.

In all the amygdaloid lodes there are repeated examples of cellular impermeable lava in the fragmental permeable lava, and consistently the cellular lode is poor, apparently because it has not permitted the ready passage of solutions but has diverted them to the more open rock. The south boundary of the Osceola shoot is formed by a southward-pitching inclined bar of cellular amygdaloid in the prevailingly fragmental amygdaloid. (See pl. 39.) The Osceola shoot is richest close under this impermeable bar, and 
it gradually decreases in richness northward and away from the bar. Above the bar the amygdaloid is fragmental and favorable in character but contains little copper. This relation suggests that solutions rising along the lode were diverted by and concentrated under the bar and that the most copper was deposited where the flow was greatest-that is, close under the bar.

The examples cited above illustrate two general conditions favorable to concentration of solutions and the formation of ore bodies - $(a)$, a lode that is generally impermeable but has areas of permeable rock (see fig. 16); (b), a lode that is prevailingly permeable but has bars or areas of impermeable material so placed as to cause a diversion and concentration of solutions rising along the lode.

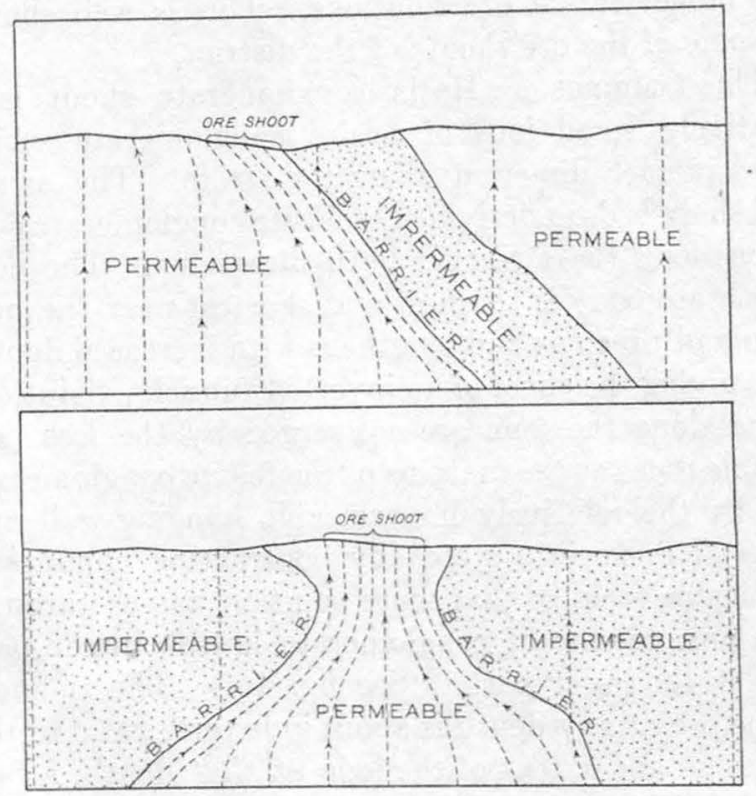

Figure 16.-Influence of varying permeability of rock on flow of solutions and formation of ore shoots

In the first class are the Calumet \& Hecla conglomerate and the Kearsarge lode. The rocks at the Calumet \& Hecla conglomerate horizon have been examined for many miles along the strike, but only at Calumet has a well-developed felsite conglomerate been found. The Kearsarge lode for the 4 to 5 miles in which it is commercially mineralized is in the main a well-developed fragmental lode, but for miles to the north and south, so far as known, it is prevailingly cellular. This class perhaps includes other lodes about which less is known.

In the second class are the Osceola lode and the Allouez conglomerate. The Osceola lode is prevailingly fragmental and permeable for miles and is somewhat mineralized at many places, but it is known to contain a commercial ore shoot only at Osceola, where it is interrupted by an inclined bar of cellular amygdaloid. The Allouez conglomerate is a thick, well-developed conglomerate over long stretches but locally is represented by a clay "seam" or "slide." This conglomerate has been found to be so well mineralized as to encourage extensive development at the Franklin Jr., Allouez, and Delaware mines. The Arcadian lode should probably be assigned to this class and perhaps the Winona, of whose character less is known. The Ashbed is a lode that is permeable over long stretches and mineralized at several places, as at the Atlantic, Phoenix, Arnold, and Copper Falls mines. The details of the character of rock at these places are not well known. Some of the southern lodes may also be in this class, but too little was seen of them to warrant a classification. The rock at the general horizon of the Baltic lode northeast and southwest of the developed area is fragmental lava, but the correlation is somewhat uncertain. The principal developed area of the Baltic lode in the Copper Range mines is bounded in both directions by strong zones of fissuring and shattering.

\section{FAULT BARRIER}

A fault offsetting a lode and so situated that the intersection with the lode makes an angle with the dip of the lode would constitute a barrier similar to an inclined bar within the lode itself. No example of an ore shoot under such a fault barrier has been clearly established; but the Hancock fault forms such an intersection with the lodes it crosses, and practically all the ore from the lodes of the Hancock mine and the Pewabic amygdaloid lodes in the vicinity of the fault has come from the north or lower side of the fault.

The productive portion of the Baltic lode is bounded by faulted zones with heavy gouges, but their attitude, so far as known, does not seem particularly favorable to the converging of solutions.

The fissures in the north end of the district have been most productive for a short distance under the Greenstone flow, which has been regarded by Smyth, Lane, and others as a barrier to rising solutions, but there has been slipping or faulting between the Greenstone flow and the Allouez conglomerate, which has produced fault gouge or "slide," and this gouge is probably the true barrier so far as one exists. There can be no doubt that the fissures are relatively rich under the Greenstone flow or "slide," but the cause may be a combination of barrier and chemical effect, as is shown on page 118. In some of the fissures the copper is said to spread out under the "slide."

At the White Pine mine the Nonesuch shale is thought to have acted as a barrier. Solutions rising along fissures have spread out when they reached the shale, forming an ore shoot in the sandstone under the shale. Lane, who favors the hypothesis of downwardmoving solutions, regards the White Pine fault as a barrier, with the ore shoot above it. 


\section{FOLDS}

The broad pitching anticlines, like the Allouez, Baltic, Winona, and Mass anticlines, might have a converging influence on rising solutions and thus produce ore shoots. If solutions were rising along a lode they would have a tendency to concentrate toward the crests of such anticlines. Several important ore shoots, including the Kearsarge, Baltic, Winona, and Mass, are situated on such anticlines, though their richest portions are not consistently near the crests, and in detail the distribution of rich and poor ground is far more dependent on character of rock than on structural position. The Isle Royale shoot, indeed, has its richest portion near the trough of a syncline, and here too the character of the lode rock seems to have a more effective control than position on the syncline. The effect of the anticlines is therefore somewhat uncertain.

\section{STRIKE FISSURES}

Both Hubbard and Lane have suggested a relationship between mineralization and fissures parallel to the lodes, and they have cited the Baltic lode particularly as an example. Most of the numerous strike fissures in the Baltic lode are slightly steeper than the dip of the lode and cross it at a low angle, so that it seems unlikely that they were produced by simple slipping between beds of trap, as suggested by Hubbard. They may, rather, have been formed by the forces that produced the Keweenaw fault. Regardless of how the fissures were formed, however, the kinds and relation of the minerals in the fissures and in the lode indicate that the mineralization in the lode and that in the fissures had a common origin. A somewhat similar relation between strike veins and lode mineralization exists in the Isle Royale mine.

The Branch fissure, in the Minesota mine, crossed the Calico lode at a low angle. The Calico lode was mined profitably above the intersection but was found poor below. In the Pewabic, Osceola, Calumet \& Hecla conglomerate, and Kearsarge lodes, however, strike fissures are not conspicuous, and there is no eridence to suggest that the mineralization of these odes is dependent on strike fissures. It seems, on the whole, that strike fissures may well be a cause for ore shoots in lodes, but they do not appear to be present in all the lodes nor to be a necessary condition of mineralization.

\section{CROSS FISSURES}

Fissures crossing the strike of the lodes have also been regarded for a long time as a possible cause of ore shoots, and such fissures and their relation to intrusive felsite bodies have been emphasized particularly by T. S. Woods. ${ }^{9}$ Steeply dipping fissures

\footnotetext{
'Woods, T. 8., The porphyry intrusives of the Micaigan copper district: Eng and Min. Jour., vol. 107, pp. 299-302, 1919. $58540-29-9$
}

striking generally across the lodes are numerous on all the anticlines, and practically all the lodes in the district are crossed by such fissures. They are abundant in the Kearsarge lode north of the North Kearsarge mine, in the Isle Royale mine, in the mines on the Baltic lode, and in the Evergreen and succeeding lodes on the Mass anticline; they are present but not abundant in the Quincy mine, the Osceola lode, and the Calumet \& Hecla conglomerate.

Cross fissures are especially abundant in the north end of the district on the Keweenaw anticline. The available descriptions of the fissure deposits in this end of the district indicate that in many places the lodes were mineralized near the fissures and that some were mined for a short distance from the intersections but were soon abandoned because of marked falling off in richness. This relation suggests that the lode rock was mineralized by solutions leaking from the fissures, and so does the fact that in the Kearsarge lode the ore near the arsenic fissures is distinctly arsenical. Here, however, the lode is consistently poorer near the fissures than away from them, and the general relations do not indicate that these fissures served as feeders for the main mineralization. One prominent fissure crosses the Calumet \& Hecla conglomerate, but the mineralization does not seem to have been related to it; in general, the lode is perhaps poorer near the fissure. There is also a prominent fissure crossing the Pewabic lodes, and the lodes were distinctly poorer near it in the upper levels and apparently also, though to a less marked degree, in the lower levels. A prominent fissure is also present in the Atlantic mine, but its relation to mineralization is not known. On the whole there seems to be no close relation between the mineralization and the cross fissure.

It is, then, fairly clear that there was some mineralization of lodes where crossed by well-mineralized fissures; and it is shown on page 110 that the lodes also affected mineralization in the fissure. It does not seem likely, however, that the main mineralization of the larger lode deposits extended outward from cross fissures.

In suggesting a relation to felsite intrusives, Woods has called attention to the felsite bodies, including that of Mount Bohemia, under the Keweenaw anticline; that under the Kearsarge mines, below the Allouez anticline; that east of Calumet; and that at the Indiana mine. He believes that the cross fissures reached the intrusive bodies and that the ore solutions passed outward from these bodies along the fissures.

The presence of felsite under some of the anticlines and the suggestion that intrusive bodies may underlie other anticlines, where not exposed, is discussed under "Structure" (p. 50). On page 124 it is shown to be possible that the ore solutions originated from the same source as the small intrusive bodies and that 
some of the sulphide veins may bear a close relation to certain exposed intrusive bodies such as the one at Mount Bohemia. With due consideration of all these suggestive relations, the evidence does not seem sufficient to prove that the main lodes were mineralized by solutions conducted into them, by way of cross fissures, from the small exposed intrusive bodies, or from unexposed bodies of the same type. The most serious objection seems to be the lack of mineralization in many favorable lodes crossed by the fissures. If the solutions passed along such fissures and from them into the permeable lodes, it would be expected that every lode that was physically and chemically favorable would be mineralized, at least to some extent, where crossed by a mineralized fissure. For instance, two fragmental well-oxidized amygdaloids have been opened in many places between the mineralized portions of the Calumet \& Hecla conglomerate and the Osceola amygdaloid, but nowhere have they been found to contain much copper. This fact is difficult to reconcile with the hypothesis of mineralization by cross fissures, but it may be explained if the solutions found entrance deeper in the lode.

It seems clear that the lodes have influenced the mineralization in cross fissures and that there has been some mineralization of the lodes outward from cross fissures, but it also seems unlikely that the chief mineralization of the great lodes has been effected through the cross fissures. The helpfulness for prospecting in recognizing a relation of ore shoots to cross fissures, to anticlines, or to felsite bodies is apparent, but this fact makes it all the more necessary to beware of exaggerating the closeness of such relations.

\section{INFLUENCE OF THICK FLOWS}

Lane has pointed out that some of the ore shoots may lie below unusually thick flows. This relation has long been recognized for the fissure deposits beneath the Greenstone flow, but, as already suggested, its real cause may be the "slide" at the Allouez conglomerate. An examination of the geologic map does not seem to give strong support to this idea for other known deposits.

The Kearsarge lode is a long distance below the Greenstone flow, which, moreover, is not very thick over the southern part of the productive area of the Kearsarge lode, and the "Big" trap above No. 8 conglomerate is a heavy flow below this lode. There are no particularly thick beds above the Calumet \& Hecla and Osceola lodes at Calumet. The beds above the Pewabic amygdaloid lodes at Quincy are rather thin. The flow above the Isle Royale lode is thick but not exceptionally so; the thickest and most massive flow in the section at the Isle Royale mine is the Mabb ophite, which lies below the Isle Royale lode but above the Baltic lode. Farther south, at the Copper Range mines on the Baltic lode, the thickness of the Mabb ophite has decreased to ordinary size and the thickest bed lies near No. 8 conglomerate, at a considerable distance above the Baltic. Alto- gether, therefore, there seems to be no clear indication of a relation between known ore deposits and thick overlying beds.

\section{CHEMICAL COMPOSITION}

The ferric iron of the rocks is believed to be a con. trolling factor in the precipitation of metallic copper. Ferric iron is abundant in all the amygdaloids and con. glomerates that have a physical character favorable to ore deposition and was therefore present in all the beds through which large volumes of solution passed, and because of this wide distribution it may not have greatly influenced the localization of the ore shoots in the lodes.

Ferric iron may, however, have had a much more active part in forming the ore shoots in the fissure deposits. Developments show that in the arsenide fissures and in the Mass fissure, crossing the Kearsarge lode, most of the copper and arsenide was precipitated near the lode, chiefly above it. Descriptions of the fissure deposits in the north end of the district indicate that a similar relation between copper and a group of well-oxidized fragmental amygdaloids was recognized by those who explored the fissures. In the south end of the district the fissures worked by the Minesota and adjoining mines carried their copper at and abore their intersection with the Minesota conglomerate, \& typical felsite conglomerate. A similar relation is shown in some of the fissures crossing the Baltic lode. Ore shoots in fissures, then, appear to occur most commonly at the intersection of the fissure with a thick, well-oxidized bed.

The foregoing statements regarding the conditions favorable to the formation of ore shoots imply, of course, that mineralizing solutions rose along the lodes and fissures. That even under the most favorable conditions solutions in sufficient volume to form ore bodies traversed all the favorable lodes and all the fissures is not probable.

How the solutions may have gained access to the lodes and fissures is discussed on page 125. It may be stated here that the answer to this question would be very helpful in the search for ore bodies, but at present the problem is obscure, little recognized evidence being available on which to base conclusions. It seems certain, however, that many favorable lodesin fact, most favorable lodes over long stretches-were not traversed by ore-bearing solutions in large volume and therefore do not have ore shoots.

\section{GENESIS OF THE DEPOSITS}

\section{SIMILAR ORIGIN OF ALL TYPES}

The outstanding trait that is common to all the copper deposits of Michigan - to fissure deposits as well as to lode deposits in widely differing rocks-is the fact that the copper is mainly present as native metal. In copper deposits the world over the occulrence of native copper, except as an alteration product of other minerals, is unusual and has eridently 
resulted from conditions that are not widespread. Native copper is abundant, however, in the deposits of all types in this district-a fact which points to common conditions or at least a close similarity in conditions of deposition for all the deposits.

\section{FEATURES COMMON TO ALL TYPES}

A common result in the deposits of different types might come either from a similar solution regardless of the kind of rock in which it acted or from some feature common to all the rocks that produced the result. The idea of the copper being carried in solution as native metal and precipitated as such is regarded as unlikely. (See p. 129.) If the features common to all the types can be separated from the numerous features that are not common to all, the causes of copper precipitation and the nature of the mineralizing solutions are more likely to appear. Such a comparison may be first made between the conglomerate and amygdaloid lodes and extended to the others.

All the rocks that have been mineralized to form lodes were originally relatively permeable. The lode deposits are in the conglomerates, in fragmental and coalescing amygdaloids, and in sandstone, which, however carries ore only near fissures. They are consistently lacking in the relatively impermeable shales, traps, and cellular amygdaloids. The fissures were of course permeable regardless of the type of rock through which they passed.

In original mineral composition the conglomerates are much simpler than the amygdaloids, yet as the copper in the lodes of both types is native, all the conditions essential to the deposition of native copper must have been present in both.

The outstanding feature that seems to have been common to the two types of rock before the copper mineralization was the presence of abundant ferric oxide in the form of hematite. The sandstone lodes also are red and hematite bearing, and the fissures seem to be productive only near the points where they cross red conglomerate or amygdaloid.

The minerals of the ore-depositing period that are common to the conglomerate and the amygdaloid lodes are comparatively few. A red potash-soda feldspar was formed early in lodes of both types. This feldspar is not conspicuous in all the amygdaloids, but in some of those in which it is lacking a potash mica, sericite, is present, though in the Isle Royale lode, where the sericite is particularly abundant, it seems to have been formed, in part at least, late in the mineralizing period. Epidote and pumpellyite are present in both conglomerates and amygdaloids. Chlorite is abundant in the amygdaloid lodes and much less plentiful in the conglomerates. Calcite and quartz are abundant in both. These comprise the minerals that are at all common in the two types of lodes. The whole series of zeolites and allied minerals, which range from rare to abundant in the amygdaloids and the fissure deposits, are practically absent from the conglomerates. There can be little doubt that they have resulted mainly from a recombination of elements in the amygdaloid lodes, which, in contrast with the conglomerates, were chemically unstable in contact with the ore-forming solutions. The boron of datolite, the fluorine of apophyllite, the potash of feldspar and sericite, and perhaps other elements besides the copper doubtless came from the solutions and not from the rock. Most of the minerals introduced into the amygdaloids and the fissures, whether filling vesicles or fractures or replacing the rocks, can not be regarded as essential to the formation of the native copper, but as something is known of their conditions of occurrence elsewhere and, from experimental work, something of their range of stability, these minerals indicate the physical conditions under which the native copper was formed.

The striking alteration that is common to the lodes in conglomerate, in sandstone, and in amygdaloid is the bleaching of the red rock in the immediate vicinity of copper and as a rule nowhere else. This bleaching has resulted in different minerals in different lodes, but the chemical change in all lodes is in the same direction-namely, toward a removal or recombination of the ferric iron. In the fissure deposits a similar tendency is shown by the alteration of part of the hematite and the formation of chlorite in the red lodes near the fissure intersections.

The essential features shown by all the types of deposits are therefore permeability and presence of ferric iron originally and removal or recombination of the iron close to the introduced copper.

\section{SINGLE PERIOD OF MINERALIZATION}

The mineralization has been assigned by various writers to different times according to their conception of the origin of the ores.

Pumpelly, believing that the copper was leached from the sandstones overlying the trap series, supposed that the ore was deposited later than the traps and the overlying sandstone. The general abandonment of the idea of derivation of the copper from the upper sandstones removes that basis for the dating of the ores.

Van Hise and Leith ${ }^{10}$ regarded the main mineralization as confined to middle Keweenawan time and therefore as of essentially the same age as the mineralized rocks. They state, however, that mineralized boulders derived from underlying beds are present in some barren conglomerates and thus indicate an earlier period of mineralization, before the conglomerates were laid down. They do not mention where or by whom this observation was made. In the work

${ }_{10}$ U. S. Geol. Survey Mon. 52, p. 581, 1911. 
on which the present report is based no pebbles or boulders that had been mineralized before being incorporated in a conglomerate were seen. Mineralized amygdaloid boulders in conglomerate were found, but there was good reason to believe that the mineralization occurred long after the conglomerate was deposited. The hypothesis of a preconglomerate period of mineralization needs verification before it is entitled to credit.

Lane believes that the ores were deposited while the basalts were still hot and therefore, presumably, fairly soon after their formation, but his conceptions of imbibition of surface waters and of the dependence of copper deposition on the present position of water zones appear to imply mineralization after tilting had been accomplished. He regards the arsenide and sulphide veins as possibly of later and independent origin.

The conclusion reached in this work is that the major mineralization was effected during a single period of somewhat complex activities that followed the completion of all the essential deformation that the rocks reveal. This deformation, it is thought, began during the outpouring of the Keweenawan lavas and the deposition of the associated sediments and was completed shortly after their accumulation was finished; the mineralization probably followed immediately afterward, perhaps overlapping the last structural adjustments. The evidence upon which this conclusion is based is summarized below.

The Keweenaw fault bends with the cross folds, such as the Keweenaw anticline, the Allouez anticline, and the Isle Royale syncline, and its changes in direction are too great to be reasonably explained in any other way than to assume that the fault itself was folded. It is therefore probably older than at least the last of this folding. The cross fissures from Allouez northward are tension cracks radial to the cross folds and produced at the same time. The countless minor fractures that cut the rocks are also most plausibly ascribed to the stresses that produced the faulting and cross folding, because these minor breaks are more conspicuous and numerous near the places of major deformation and are disposed conformably to them.

Copper mineralization did not occur in the Keweenaw fault itself, so far as known, but it affected the highly fractured zone adjacent to the fault and therefore was undoubtedly later than the fault and this attendant shattering. The mincralization in the cross fissures was of course later than the fissures. The mineralization of the lodes was similar in character to that of the fissures, and the presence of arsenides and sulphides in the lodes adjacent to fissures containing these minerals is a further indication of their close relation.

The same mineral association in all these types and the interrelation of the types indicate mineralization of all types from a single source and during a single period. The sulphide veins contain intergrown metal. lic copper or merge into native copper veins. The same is true of the arsenide veins, with the modifice. tion that the copper is arsenical, as are some of the copper fissures themselves, and the arsenide vein carry some chalcocite. The sulphide and arsenide fissures are thus apparently of the same source and of the same age as the deposits of metallic copper.

The domical uplift of the Porcupine Mountains is not closely connected with the other structures of Keweenaw Point and is probably due to intrusion. Faults of varying magnitude are associated with the uplift. The age relation of the dome to the other structural features of Keweenaw Point is not known though the latest rocks of the region are involved in all of them. The precipitation of native copper and subordinate chalcocite along and near the faults of the Porcupine Mountain region may therefore have occurred in a different period from that of the main mineralization farther northeast, though there is no evidence that it did. Similarly the sulphide fissures that extend out from the intrusive mass of Mount Bohemia may belong to an independent period, but it seems more reasonable and in accord with the known facts to assume that all the mineralization was accomplished in a single period.

Such a period doubtless was of considerable length. Some of the minerals were formed earlier and some later in the period, and the same minerals were de posited at different times in different places. Some veins apparently were slightly earlier than the mineral. ization of the lodes they cut, and some were later There was, however, no cessation of mineralization from the beginning to the end.

As all the rocks of Keweenawan age known on Keweenaw Point were affected by the structural deformation already described, it is evident that the mineralization was later than the Keweenawan rocks of the district. It is believed, however, from evidence given on page 124 , to have been accomplished within the limits of Keweenawan time.

\section{HYPOTHESES OF ORIGIN}

It is clear that the copper is later than the rocks in which it is found and was therefore introduced into them. The important elements of genesis of such epigenetic deposits are the source of the copper, the method of transportation, and the cause of precipits. tion. Two contrasting views of the origin of the Michigan deposits are presented in the literature and may be designated as that of descending origin and that of ascending origin.

\section{DEPOSITION BY DESCENDING SOLUTIONS}

\section{SOURCE OF COPPER}

Pumpelly, who first formulated the hypothesis of descending origin, supposed the copper to have been derived from the sandstones that originally overlay 
the traps. The failure to find copper in the sandstone beds where they are still present has led to the abandonment of the idea that they were a source of the copper.

Lane, whose views are presented in detail in his report on the Keweenawan series, suggests different sources, all directly connected with the basic lava flows. He suggests that the copper was dissolved in the waters of desert lakes or playas that collected on the surface of the lavas. The copper in the waters was either derived from the weathering of the lavas or was contained in volcanic emanations given off by the lavas and collected in the surface waters. Lane further suggests that the copper may have been derived from the solution of the copper that is disseminated in the freshest traps.

\section{MODE OF TRANSPORTATION}

Pumpelly supposed the copper to have been leached from the sandstones by surface waters and to have been carried into the underlying rocks by gravity. At the time of Pumpelly's study the deposits had been developed only to shallow depth, and the assumption of such a movement of the solutions seemed to offer no difficulties. Since then the deposits have been developed to a vertical depth of more than a mile or a distance down the dip of the lodes of more than 9,000 feet. The presence of strong mineralization far below present sea level can hardly be attributed to the action of ordinary gravity circulation under present conditions. Moreover, the deeper levels of all the mines are essentially dry. Pockets of water encountered on these levels quickly drain off and remain dry. Some deep drill holes, however, maintain a small flow of water for considerable periods at least, and in the Baltic and other mines the water is under some pressure. The region is one of moderate precipitation, and the upper levels of the mines contain abundant water. The failure of the surface water to sink through the lodes to the deep openings indicates that the ordinary gravity circulation to great depth is very slight. This conclusion, of course, corresponds with the general experience in other districts.

The position of the ore shoots beneath relatively impermeable barriers, such as that of the Osceola lode, the White Pine deposits, and the fissure deposit below the Allouez "slide," is also hard to reconcile with gravity circulation but suggests solutions rising from depth under pressure.

The fact should be kept in mind that concentration of the ores of iron in the neighboring iron country, where the deposits have been opened to considerable depths, is attributed to circulation of surface waters, but where the iron is concentrated near impermeable rocks it is above rather than below them.

The difficulties of attributing the movement of the mineralizing solutions to ordinary gravity circulation have been recognized by Lane, who has suggested the hypothesis of "imbibition." This hypothesis appar- ently supposes that the flows remained hot and the vesicles were filled with hot gases or liquids till the rocks were tilted to their present positions and were, in places at least, covered by desert lakes or playas containing copper in solution. As the rocks cooled the gases and liquids in the openings contracted and thus made room for the solutions that covered the outcrops to pass down the lodes. This hypothesis has the advantage over that of ordinary gravity circulation in that it accounts for the space necessary for the solution to enter at great depth. It only allows, however, for sufficient solution to fill the cavities and necessitates more highly concentrated solutions than are known as surface solutions in order to produce the deep ore shoots. Moreover, it encounters most of the difficulties of ordinary gravity circulation as to position of ore shoots under barriers and slight eirculation at depth. Lane points out that the tendency to form a vacuum as the gases contract would produce a "sucking" or "imbibition" effect. This, however, could help but little in overcoming the friction of deep circulation, as at best it could amount to only one atmosphere, or the pressure of a 33 -foot column of water.

Lane has also applied the idea of concentration by diffusion to the Michigan deposits. This idea apparently assumes that the rocks are saturated with essentially stagnant water or solution. This solution would dissolve some of the copper that is disseminated through the flows, and the copper so dissolved would tend to become uniformly diffused through the solution. It is supposed that certain of the rocks had a precipitating effect on the copper in solution. Where the copper was being precipitated, the solutions would contain less than elsewhere, but the diffusion force would cause more to come in to equalize the concentration. This in turn would be precipitated. By this process the copper disseminated through the traps would be concentrated in certain parts of the series.

This idea of concentration does not encounter the difficulties involved in that of deep gravity circulation. That the present-day deep waters contain copper is indicated by analyses. Water from a deep drill hole in the Baltic mine precipitates copper on scrap tin, and Mr. W. H. Schacht, general manager of the Copper Range Co., states that the same water dissolved the copper from fuse caps that chanced to fall into it.

The hypothesis of diffusion certainly has attractions in explaining the filling of amygdular cavities with copper and other minerals. It is difficult, however, to reconcile this hypothesis with some of the broader features of copper occurrence. If the hypothesis is valid, it is not easy to understand why a generally fragmental well-oxidized lode like the Osceola is not uniformly mineralized throughout its extent. Under this hypothesis there would seem to be nothing except the character of the lode rock that would tend to cause ore shoots, and there seems to be nothing in the proc- 
ess that would cause the precipitation to occur under impermeable barriers. In fact, it would be natural to expect that precipitation would occur throughout all amygdaloids and conglomerates, though varying in amount according to the character of the rock. The diffusion hypothesis fails to explain why the Calumet \& Hecla conglomerate is rich while, so far as known, most of the other conglomerates are lean or barren. The same difference in richness is shown by amygdaloids that appear equally well adapted for mineralization. It is difficult to explain the concentration in sandstone adjacent to fissures under the Nonesuch shale at a considerable distance from lava flows.

It seems, then, that although the hypothesis of diffusion avoids some of the difficulties presented by that of gravity crrculation or that of "imbibition" it encounters others that make it equally hard to accept.

\section{CAUSE OF PRECIPITATION}

Pumpelly considered that the copper was taken into solution in the oxidized form as sulphate or carbonate, as would be expected and is known to occur in the action of surface water. He further supposed that these solutions in passing into the trap beds encountered abundant ferrous minerals and that the copper solutions were reduced and the ferrous iron oxidized to ferric iron, resulting in native copper and the ferric minerals hematite, epidote, and chlorite. The abundance of hematite and other ferric minerals in the lodes evidently suggested this explanation.

The modifications of Pumpelly's idea likewise assume that the copper is in the oxidized state, though Lane considers it to have been carried as chloride in the waters of desert lakes that were sucked into the lodes; he supposes the copper to have been reduced and the iron oxidized essentially as outlined by Pumpelly.

\section{CHLORIDE WATER CONCEPTION}

At Lane's suggestion, G. Fernekes undertook what amounted to a laboratory demonstration of Pumpelly's method of copper precipitation. He found ${ }^{11}$ that under certain conditions ferrous chloride acting on cupric chloride will precipitate metallic copper and ferric oxide, one of the conditions being the presence of an alkaline mineral to neutralize the hydrochloric acid formed in the reaction. Prehnite and datolite were found to work satisfactorily as neutralizers, whereas with labradorite and laumontite no native copper was produced. Fernekes expressed these reactions by the following equations:

$$
\begin{aligned}
& 2 \mathrm{FeCl}_{2}+2 \mathrm{CuCl}_{2}=2 \mathrm{CuCl}+2 \mathrm{FeCl}_{3} \\
& 2 \mathrm{FeCl}_{2}+2 \mathrm{CuCl}=2 \mathrm{Cu}+2 \mathrm{FeCl}_{3} \\
& \mathrm{FeCl}_{3}+2 \mathrm{H}_{2} \mathrm{O}=\mathrm{Fe}(\mathrm{OH})_{2} \mathrm{Cl}+2 \mathrm{HCl} .
\end{aligned}
$$

These experiments, together with some made by H. N. Stokes ${ }^{12}$ slightly earlier, which showed that the ferrous iron minerals, siderite and hornblende, will precipitate metallic copper from cupric sulphate solutions, caused Lane to adopt the hypothesis that the

\footnotetext{
11 Econ. Geology, vol. 2, pp. 580-584, 1907
}

12 Econ, Geology, vol. 1, pp. 648-649, 1906 precipitation of the metallic copper was brought about by the reducing action of ferrous iron. He concluded that the common association of copper with prehnite and datolite and its rarer association with feldspar and laumontite are explained by Fernekes's findings, and he emphasizes the connection between the chloride waters of the mines, particularly those containing calcium chloride, which, as he points out, carry small quantities of copper, and the solutions from which the copper was precipitated. Lane rearranged and ex. panded Fernekes's equations into a single one, which he gives as follows:

$$
2 \mathrm{FeCl}_{2}+2 \mathrm{CuCl}+3 \mathrm{CaSiO}_{2}=
$$

$$
2 \mathrm{Cu}+\mathrm{Fe}_{2} \mathrm{O}_{3}+3 \mathrm{SiO}_{2}+3 \mathrm{CaCl}_{2} \text {. }
$$

\section{MINE WATERS}

Further discussion of Lane's ideas necessitates some specific consideration of the concentrated brines present in all the mines except near the surface. As Lane has discussed the matter fully, ${ }^{13}$ a brief summary will suffice.

The character of the water shows progressive changes from the surface downward. Lane makes the following classes:

(a) At and near the surface, soft and fresh, with sodium in quantities more than sufficient to combine with the chlorine present.

(b) At some distance (generally 500 to 2,000 feet before it attracts attention unless especially sought) the chlorine is higher and the water is charged with common salt.

(c) At great depth a strong solution of calcium chloride containing some copper.

The following analyses illustrate the composition of each of the three classes:

Analyses of mine waters

[Grams per liter]

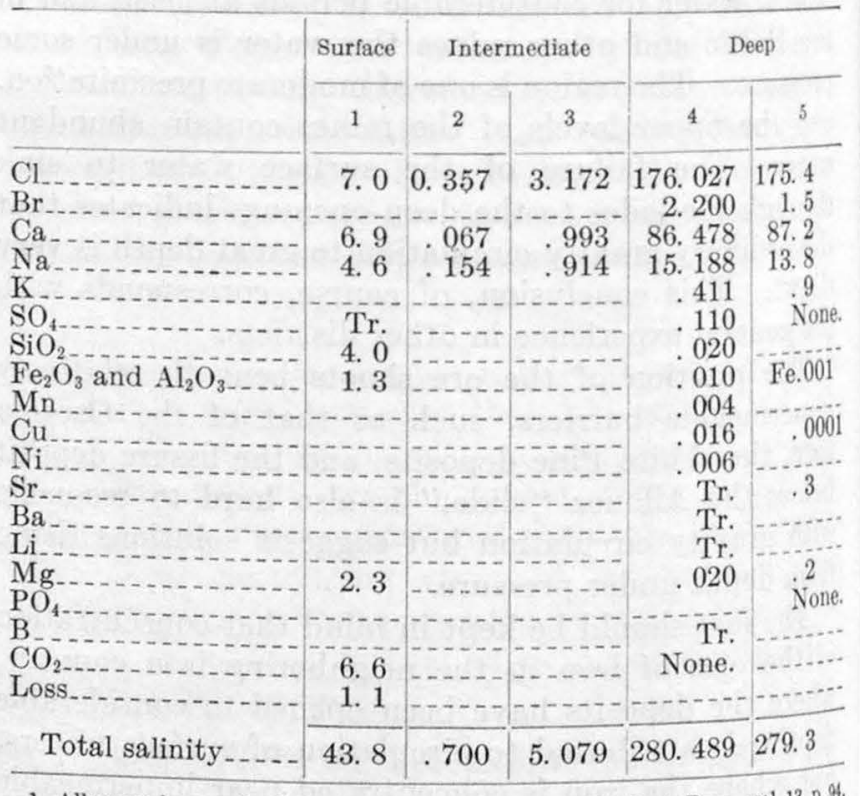

1908. Allouez mine pond. Lane, A. C., Lake Superior Min. Inst. Proc., vol. 13, p. th 1908. Dearborne Chemical Works, analyst.

2. Mohawk mine, No. 1 shaft, tenth level, dripping. Idem, p. 121.

3. Mohawk mine, No. 1 shaft, twelfth level, dripping. Idem, p. 121.

4. Quincy mine, dripping on fifty-fifth level north of No. 2 shaft. Idem, $p, 11$

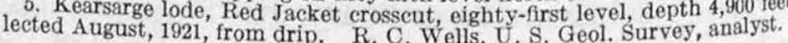

${ }^{13}$ Lane, A. C., Michigan Geol. Survey Pub. 6, vol. 2, pp. 774-846, 1911. 
The explanation proposed by Lane for the different types of waters is that the deep water was connatethat is, inclosed in the rocks when they were buried; that the water near the surface is water that was "sucked" into the beds and dissolved carbonates as it passed through the rock; and that the intermediate water resulted from reaction between the other two, the essential reaction being between $\mathrm{Na}_{2} \mathrm{CO}_{3}$ of the upper water and $\mathrm{CaCl}_{2}$ of the lower to produce $\mathrm{NaCl}$ and $\mathrm{CaCO}_{3}$. He believes that when the concentration of sodium chloride became sufficient in the middle water zone, sodium zeolites, like analcite, were precipitated. Lane explains the strongest brines as probably the residue left after most of the water had been absorbed in hydration of the rock.

Van Hise and Leith ${ }^{14}$ regard similar solutions encountered at depth in the iron region, as resulting from a condition of "deep stagnancy" in which the waters became progressively richer in the most soluble salts, and they do not believe that these solutions are related to any particular type of rock or to iron deposition in the region. In considering the solutions in the copper district, however, they suggest ${ }^{15}$ that these waters may represent the "residuum or brine" of the ore-depositing solutions, but why they are so regarded in the copper district and not in the iron district is not stated.

The following points may be regarded as facts or well-founded deductions:

1. The shallow waters are of surface origin and have derived their character from materials taken up from the air, the soil, and the rocks.

2. As greater depth is attained the waters become progressively less in amount.

3. The relative proportion of calcium chloride to sodium chloride increases with the downward decrease in the amount of water and increase in concentration.

4. It is probable that in the copper country a very considerable amount of erosion has taken place, so that the rocks now in the zone of fresh water were at one time much farther from the surface and possibly were in a zone that bore the same relation to the surface then existing that the present deep "dry" zone bears to the surface of to-day.

5. From the foregoing conclusions it is probably true that there has been a progressive downward migration of the upper zones.

The evidence seems indecisive as to whether these strong chloride waters are "connate" waters still further concentrated, as Lane supposes; "deep stagnant" portions of the general ground water; or the residual parts of ascending magmatic waters. Strong brines are found at depth in many parts of the world. Concentration has been explained as due to hydration, as Lane suggests, and to evaporation

\footnotetext{
"U, 8. Geol, Survey Mon. 52, p. 544, 1911.

HIdem, p. 588 .
}

by expanding gases in oil and gas regions. ${ }^{16}$ Their particular composition has been explained by reduced solubility of certain salts in presence of a common ion, ${ }^{17}$ which might cause sodium chloride to precipitate while calcium chloride remains in solution. As a matter of fact, stalactites of sodium chloride have been observed in the Quincy mine and have been reported to occur in other places where the waters are mainly calcic. There is, moreover, good resson to believe that in the deep levels, where the rocks are essentially dry, both calcium and sodium chlorides are present as solids. After a specimen of such rock has been wetted it will on drying accumulate a considerable crust of salts that have been dissolved and brought to the surface of the specimen. Specimens from deep levels, essentially dry when collected, become wet and even drip during damp or rainy weather, owing to their absorption of water from the air.

Of more concern in the present study than the origin and relations of the waters of the district is their possible connection with copper deposition. Lane's ideas in this regard have already been outlined. In the investigation here recorded no evidence indicating a close genetic connection between the salt waters and the deposition of copper has been recognized.

In general, the salt waters are as abundant and as concentrated in unmineralized as in mineralized portions of the lodes. There is practically no evidence that the mineralizing solutions were acid; a little calcite has been dissolved, but this result could have been accomplished as well by alkaline as by acid solutions, and the whole character of the mineralogy indicates that the solutions were not acid. No evidence of sodium zeolite deposition or copper deposition in zones that correspond to the present water zones has been found. Zeolites, except laumontite, which in places is abundant, are scantily present in both shallow and deep zones of the amygdaloid lodes but absent from the conglomerate lodes, and copper deposition shows no recognizable dependence on depth. The presence of traces of copper in the strong brines is not surprising when it is realized that these liquors have digested the copper-bearing rocks for untold years. Wells found that an artificial copper-free brine of otherwise the same composition as the deep waters (sample 5, p. 122), when put in contact with metallic copper, quickly dissolved copper in an amount comparable to that contained in the mine waters.

Pumpelly supposed that the oxidized copper solutions entered rocks rich in ferrous iron and were reduced, at the same time oxidizing the iron. But it is now established, as discussed in the oxidation of

16 Mills, R. V. A., and Wells, R. C., U. S. Geol. Survey Bull. 693, pp. 84-86, 1919

17 Idem, p. 73 . 
lava tops and ferric iron content of conglomerates, that the mineralized amygdaloids and the conglomerates were especially rich in ferric iron and low in ferrous iron before they were acted on by the mineralizing solutions. Furthermore, the ferric iron of the lodes in the vicinity of copper has been removed or chemically reduced to ferrous iron. This removal or change of iron is pretty clearly connected with the deposition of the copper. These facts not only cast grave doubt on any idea of origin that supposes the copper to have resulted from the reduction of oxidized copper solutions, as solutions of surface origin probably would be, and were assumed to be, but they strongly suggest that the direct opposite was true-namely, that the copper solutions were reducing in character.

The minerals, moreover, that accompany the copper and were formed at the same time are of a class that are believed to originate at moderately high temperature and certainly are not such as are formed by cool surface solutions. Altogether both the chemical changes and the character of the minerals seem opposed to the idea of formation from surface solutions.

There appears, however, no such chemical objection to the idea of concentration by diffusion. A part at least of the copper in the traps is in the form of sulphide, and it might be taken into solution and transported as such. When it entered the highly oxidized amygdaloids and conglomerates it might react with the ferric oxide, reducing that to ferrous oxide and in turn having its sulphur oxidized and the copper precipitated as metal, essentially in the manner set forth in the following section for ascending solutions. However, it is difficult to explain why so many amygdaloids, all rich in ferric iron and favorable physically and chemically to the process of diffusion, are barren.

From the foregoing discussion it appears that there are serious physical and chemical objections to the idea that the deposits were formed by descending surface waters. The hypothesis of concentration by diffusion avoids some of these difficulties but encounters others equally serious in regard to the distribution of the copper.

\section{DEPOSITION BY ASCENDING SOLUTIONS}

To show that the copper was deposited by ascending solutions would by no means fully account for the deposits. The hypothesis now to be discussed goes further and assumes that the copper-bearing solutions were expelled forcibly, at high temperature, from a magma chamber in which they originated. The probability of this assumption must depend largely upon the degree to which the chemical character of the solutions, as judged by the work they have done, resembles that of ore-forming solutions that have been active in other regions where there is virtual proof of their genetic relationship to igneous magmas.
A magmatic origin for the Michigan copper deposits was first proposed by H. L. Smyth in 1896. F. E. Wright, Van Hise, Leith, and Steidtman, R. E. Hore, T. S. Woods, and J. E. Spurr have since implied or asserted a similar origin.

The Coro Coro deposits, in Bolivia, which show many points of resemblance to the Michigan deposits, were ascribed to deep-seated causes as early as 1846 by C. A. de la Ribette and definitely to a magmatic origin in 1906 by G. Steinmann, and still later by Singewald and Miller and Singewald and Berry. For somewhat similar deposits in New Jersey J. Volney Lewis in 1907 proposed a magmatic source.

\section{SOURCE OF THE COPPER}

There is no direct connection between the main ore deposits of the district and the exposed intrusive rocks. However, certain associations of small copper deposits with the known intrusive rocks indicate what is thought to be true of the large ore bodies.

Copper sulphide veinlets cut the intrusive mass of Mount Bohemia ${ }^{18}$ and adjacent rocks and apparently terminate outward from the intrusive body; copper sulphides are concentrated also in the miarolitic carities of the aplitic phase of the intrusive gabbro. Wright appears to regard the intrusive mass as derived from the magmatic reservoir that furnished the somewhat older basalts and felsites and to consider the copper sulphides inclosed in it as related in source to the native copper and the copper sulphides and arsenides of the larger deposits of the region. Sul. phide veins are likewise associated with the intrusire gabbro near the Michigan-Wisconsin boundary and the quartz porphyry bodies north of Lake Gogebic.

Native copper, with some sulphide, occurs near tho Porcupine Mountains, where intrusive rocks that are probably of late Keweenawan age are thought to account for the uplift and faulting.

Arsenical copper with some sulphide occurs at the Indiana mine in felsite, which Lane ${ }^{19}$ regards 25 intrusive. Chalcocite is present also in probably intrusive felsite east of Allouez.

The Duluth gabbro, thought by most who have studied it to be of late Keweenawan age, may well be a part of the same intrusive mass with Mount Bohemia, the Porcupine Mountains, and the bodies of intrusive felsite and quartz porphyry known at many places throughout the district; this mass would thus underlie the whole lava series. Small copper sulphide deposits, ${ }^{20}$ with or without nickel, are found in the gabbro or just outside its contact.

Pegmatitic knots or lenses occur in some of the traps of the district, especially those of greater thickness, and some of these contain copper sulphides and native copper. These pegmatitic lenses are present

13 Wright, F. E., Michigan Geol. Survey Rept. for 1908, pp. 392-394, 1909.

10 Private report to the company.

${ }^{20}$ Nebel, M. L., Econ. Geology, vol. 14, p. 399, 1919. 
only well within the thicker flows. They seem to have resulted from a differentiation during the process of crystallization similar to that which produces the pegmatitic portion of intrusive bodies, though they are of small extent, and the differentiation has not progressed far. They do, however, show a differentiation toward increasing copper content that in a great intrusive body might well result in abundant copper-bearing solutions.

In nearly all these examples of close association of copper with intrusive bodies copper sulphides are present, and in most of them, except where the inclosing rock is red, sulphide predominates over native copper. Where the veins are within the intrusive rocks, only sulphides are usually present, though copper occurs in felsite at the Indiana mine.

\section{DIRECTION OF MOVEMENT OF THE SOLUTIONS}

The concentration of copper on the under sides of relatively impermeable barriers is perhaps the most direct indication that the solutions came from below after the rocks had assumed their present attitude, but it is not the most convincing evidence of ascending flow.

If, as most students of the problem now agree, the ores were deposited from hot solutions, they must have been hot either because they flowed through hot rocks or because they came from a heated source; the first assumption would imply precipitation within so short a period that the lavas had not cooled; the second, indicative also of rapid action, would probably require a magmatic source for both the solution and the heat. From what has been said in connection with gravity circulation (p. 121) it is clear that the permeability of the rocks was low when the driving force on the solutions was only gravity, or gravity plus one atmosphere. Greater fluidity and greater driving force would help to overcome low permeability, and both these advantages would exist if the solutions came from a magmatic source.

Marked decrease in viscosity of solutions attends rising temperature and undoubtedly continues as solutions pass from the liquid to the gaseous state. The solutions coming from a magma reservoir may be assumed to be under pressure sufficient to lift columns of molten rock thousands of feet to the surface. The more mobile constituents, the ore-forming solutions, should start out from the magma chamber, therefore, with pressure at least equal to that on a column of molten rock from the same source and should be able to maintain that pressure to higher levels in the crust because of their lesser weight and viscosity and their lower solidifying point. Recent Work at the Carnegie Geophysical Laboratory ${ }^{21}$ suggests that great pressure may be developed just at the

"Morey, G. W., The development of pressure in magmas as a result of crystallization: Washington Acad. Sci. Jour., vol, 12, p. 219, 1922. $58540-29-10$ time the volatile constituents are liberated and made available for migration. Altogether, the evidences of enormous forces associated with igneous activity, such as volcanic explosions, elevation of vast quantities of magma, and penetration of emanations into dense rocks, as in contact metamorphism, show that solutions from magmatic sources have a much greater ability to move through difficultly permeable rocks than waters impelled only by their own head.

Ascending solutions are never in want of an outlet, provided their pressure is great enough. The farther descending solutions penetrate the tighter they find the rocks; but rising solutions, which are least viscous and under greatest pressure at depth, where the difficulty of ascent is greatest, are continually reaching more permeable material above as their ability to flow becomes diminished through loss of temperature and pressure, and at the surface there is always a free outlet.

With great volumes of solution passing any given point on the upward journey there would tend to arise a uniformity of temperature for long distances along the channelway. Hot water starting through a long cold pipe would warm the near end of the pipe and emerge cold at the far end, whereas much hot water flowing continuously through the pipe would in due time warm it from end to end to about the same temperature. Where the rate of heat conduction is so low as it is in rocks, this tendency could doubtless afford essentially uniform temperatures throughout as great a vertical range as that represented by the mine workings and thus give the observed constancy to the character of mineral deposition throughout that range.

MEANS OF ACCESS OF THE SOLUTIONS

If the solutions ascended from some deep-seated source they must have had means of reaching the horizons where they are known to have precipitated copper. Two possible means of access may be considered-intersection of the productive beds by the underlying intrusive mass from which the ore solutions came; or ascent along fractures that cut these beds. More specifically, these hypotheses are that the solutions reached their horizons of precipitation from crosscutting contacts of the Duluth gabbro; or that they were brought to these horizons by the deep extension of the Keweenaw fault. A third means would be utilization of whatever avenues presented themselves in the regions lying near the magmatic source and the gradual and progressive collection of the solutions into the more permeable channelways at the higher levels.

\section{ASCENT FROM CONTACTS OF THE DULUTH GABBRO}

There is reason to suppose that the Duluth laccolith extends beneath this region at or near the contact of the Keweenawan and the underlying rocks. 
Grout and Hotchkiss have suggested, further, that the Lake Superior basin has resulted from slumping of the essentially horizontal crustal strata into an underlying magmatic basin, and that during this slumping the magma pushed into higher parts of the crust. Whether this or some other idea as to the cause of the basin is correct, it is to be expected that a mass of magma of the size of the Duluth or Lake Superior laccolith would send offshoots into the overlying rocks and show an irregular upper surface. That there are such offshoots may be inferred from the presence of intrusive rocks suggestive of Duluth gabbro parentage well above the base of the Keweenawan. That the main gabbro would actually inject its more mobile constituents into adjacent openings is indicated by the analogous occurrence of copper minerals in fractures near these minor intrusive masses.

If the main intrusive body, in working its way upward, intersected a permeable amygdaloid or conglomerate bed, the mobile constituents given off by the magma would pass upward along such a channelway, and where they encountered favorable physical and chemical conditions they would deposit certain of their constituents. This inference supposes that the beds now mineralized extend for long distances down the dip - a supposition that seems probable from the known extent along the outcrop of most of the productive beds and also from the less positive correlation of certain beds or groups of beds on Keweenaw Point and Isle Royal. It is perhaps also worthy of note that the productive parts of the Kearsarge, Baltic, and Osceola lodes coincide with the thickest portions of the flows as shown along the outcrop.

It is not likely, however, that all beds that extend to great depth will be equally favorable as solution channels. It is known that an amygdaloid or a conglomerate may change within a short distance along the strike from a relatively permeable to a relatively impermeable bed. To be favorable it must not only have been permeable at its intersection with the source of solutions but must have continued as a permeable channel to the level of the present surface at least, and doubtless to the original surface, in order to have an outlet that would permit the passage of a large volume of solution. It is obvious that not every bed that is favorable where cut by the present erosion surface or mine workings would be equally favorable for an indefinite distance down the dip any more than along the strike. Some beds, therefore, might be well mineralized while others that are of apparently equal promise where now exposed received only enough mineralization of the feebler kind to fill vesicles or cause cementation.

Beyond the analogy with the deposits adjacent to the subordinate intrusive bodies like that of Mount Bohemia and the intrusive mass which probably underlies the Porcupine uplift and with ore deposits on the margins of intrusive bodies in many other parts of the world, there is little direct evidence in support of this particular pathway of transfer for the magmatic solutions to the places where they acted. Perhaps the most suggestive fact relative to direct ascent along the permeable lodes from their intersection with the Duluth gabbro is the presence of the chief copperbearing beds in the lower part of the Keweenawan series. But even this may be due to the influence of the Keweenaw fault.

\section{ASCENT FROM THE KEWEENAW FAULT}

The Keweenaw fault has long been considered by Lane and others a possible channel for eruptive rocks. Attention bas been called by Lane to the several bodies of intrusive rock close to the fault, with the implication that the intrusive material may have risen along it. This implication suggests the fault as a possible channelway for the ore solutions.

That the copper mineralization followed the main fault movement seems to be indicated by the mineral. ization of the breaks in the highly shattered area near the fault. So far as known, however, no evidence of mineralization has been found on the fault itself; this would indicate that it was not particularly permeable as compared with fractures less filled by gouge or with open-textured amygdaloid or conglomerate beds.

The great horizontal extent of the fault and the magnitude of its throw indicate that it persists downward for a great distance-far enough, it is easy to believe, to tap the magmatic reservoir in which the mineralizing solutions origin ated. Although evidently less permeable than open fractures and porous beds, its greater accessibility and continuity may have made it the chief channelway by which the solutions passed upward in a direction transverse to the rock structure. The Keweenaw fault is a reverse fault, dipping with or slightly flatter than the beds, and there are smaller nearly parallel faults above it which probably branch from it. If the main fault and its branches truncate the higher beds down the dip, because the beds dip more steeply than the fault, solutions rising along the fault would tend to enter any porous bed and continue along it as affording a shorter and probably an easier channelway to the surface than the upper part of the fault fissure.

Essentially the same conditions would control the beds selected and mineralized in this ascent of the solutions in the beds from the Keweenaw fault as would control the beds entered directly from intersection with the Duluth gabbro.

It may be supposed that the fractures occupied by the fissure deposits reached down to the fault and thus furnished easy channelways for the upward movement of solutions. Where fissure deposits are abundant, as along the crest of the Keweenaw anticline in the north end of the district, no largely productive lode deposits have been developed, but in the central area, 
where fissures are less numerous, the copper occurs mainly in the lodes. This difference suggests that where plentiful fissuring furnished easy channels of escape for the solutions they did not traverse the lodes in sufficient quantity to form large deposits. Many of the smaller fissures, however, were fed locally from the lodes they cut, and the same thing may be true of some of the larger ones.

The presence of the copper in the Nonesuch lode at White Pine in close association with faults and fractures branching from a pronounced reverse fault which itself is not known to be mineralized, is suggestive of similar relations between the main copper deposits of Keweenaw Point and the Keweenaw fault.

If the Keneenaw fault down the dip cuts into higher beds than those which lie against it at the surface, there probably is some horizon in the folded beds to which it becomes tangent and below which it cuts back again to older beds. (See fig. 10.) If this is so, any of the favorable beds near the bottom of the series might receive solutions direct from the fault and become mineralized, but beds above the horizon of tangency would not be cut and so would receive only such solutions as were able to leak out from the major channelways and therefore would be only feebly mineralized. Several beds of the lower part of the series as high as the Ashbed lode carry considerable quantities of copper, but above that horizon there is nothing of known value save in the Porcupine region, where local conditions account for the exception.

Sulphides are more abundant in fractures that cut amygdaloid lodes near the fault than in those that cut lodes higher in the series. This difference would be explained if, as suggested under "Causes of precipitation" (p. 130), the solutions were originally sulphide solutions and were oxidized by long contact with the hematite of the lodes. At horizons near the fault the solutions may have followed the lodes for shorter distances and thus have been less completely oxidized, with more abundant sulphides as a result. But the Allouez conglomerate and some other conglomerates well above the fault carry widespread chalcocite, so that no great significance can be attached to this occurrence of sulphide.

The lodes farthest from the fault, the Ashbed, Pewabic, Calumet \& Hecla conglomerate, and Osceola, carry high-grade copper, exceedingly low in arsenic. The Kearsarge and Isle Royale lodes, nearer to the fault, and especially the Baltic, which is closest to it, contain more arsenic. This may likewise be an indication that the solutions became more highly oxidized as they travel farther from the Keweenaw fault. The Lake lode, which lies relatively low in the series and near the fault, contains nonarsenical copper, and this occurrence, although it may be an exception to the general rule through some special conditions not known, may indicate that the generalization is unfounded. It must be recognized, moreover, that there is much more fissuring of the rocks near the base of the series and that arsenical copper in fissures may, in part at least, account for the higher arsenical content of the lower lodes.

There is reason to believe that some of the lodes are fed by fissures that enter or cross them within the present range of observation. This seems especially evident in the Calico lode of the Michigan mine, which was largely mined above the intersection of the Branch fissure but is poor below the intersection. The similarity of the minerals in some of the strike fissures that cross the Baltic lode to the minerals in the lode and the local merging of fissure mineralization into lode mineralization are highly suggestive that the lodes were at least in part fed by the fissures.

\section{GRADUAL ACCUMULATION IN PERMEABLE CHANNELWAYS}

If solutions are forced against a body of rock varying in permeability from place to place, they will enter such openings as are first presented but will seek the avenues easiest to follow and eventually will flow in greatest volume through the most permeable portions of the rock. This principle may have governed the upward movement of the mineralizing solutions in Michigan. Aside from its plausibility and the certainty that it works on an important scale in movements of the shallow ground water, there is only one reason for thinking that it may apply here. It possibly explains more readily than the other suggestions the fact that the mineralizing solutions appear to have reached essentially all parts of the rocks of the lava series.

\section{CAUSES AND CONDITIONS OF PRECIPITATION}

Three contrasting views may be considered as to the nature of the copper-bearing solutions from which the ores were deposited-(1) that the copper was transported in an oxidized condition as sulphate, chloride, carbonate, or silicate and was deposited by chemical reduction of such compounds; (2) that the copper was transported actually or potentially in the metallic state and so deposited; (3) that the copper was transported actually or potentially as sulphide and arsenide and was deposited mainly as native metal as a result of the removal of the sulphur or arsenic by oxidation. These views may be called respectively the reduction hypothesis, the saturation hypothesis, and the oxidation hypothesis.

\section{PRECIPITATION BY REDUCING ACTION OF FERROUS IRON}

To Smyth ${ }^{22}$ belongs the credit of recognizing that the mineralogy of the deposits and certain structural features, such as the occurrence of copper in the fissure deposits on the under side of the Greenstone

${ }_{22}$ Smyth, H. L., Science, new ser.. vol 3, pp. 251-252, 1896. 
flow, are not in accord with the view that the solutions came from above, as Pumpelly had proposed, but indicated instead that they came from a deep-seated source, of which boron and fluorine are especially suggestive. Smyth concluded that each of the amygdaloid lodes had been weathered while exposed at the surface and so had acquired the ferromagnesian alteration products which Pumpelly had ascribed to the breakdown of the pyroxene and olivine of the basalts. The calcium and sodium minerals, however, which Pumpelly thought were similarly derived from the feldspar, Smyth said had been introduced, along with the copper that is found associated with them, from below, after the rocks had been tilted to their present attitude. Smyth accepted Pumpelly's explanation of the cause of precipitation as the one best in accord with known facts - namely, reduction of oxidized copper compounds by the ferrous iron minerals of the lodes. It is to be regretted that these ideas were recorded only in the most summarized form and therefore failed to receive the recognition that they deserved.

Smyth's account of the mineralogy, structure, and age of the deposits still seems correct. Since that account was published, however, it has been shown that chlorite, epidote, pumpellyite, and allied minerals are hydrothermal minerals rather than products of weathering, and, as set forth on page 38 , weathering is thought to have been of minor importance in producing red lava tops. The mineralization and rock alteration, therefore, represent a single period and a single cause rather than two widely separated periods and different causes. Again, Pumpelly's idea, accepted by Smyth, of copper precipitation by reduction is contradicted by the fact that copper is not closely accompanied by hematite but is intimately associated with bleached rock. It also fails to account for the copper in the conglomerates, particularly in the rich Calumet \& Hecla conglomerate. It is subject, in short, to exactly the same objections as the hypothesis that the solutions were descending. It postulates, moreover, the presence in ascending solutions of oxidized copper compounds, whereas ascending solutions, the world over, are now known to deposit copper in combination with sulphur or some similar element of antioxidizing character.

In describing the native copper and chalcocite deposits of New Jersey, Lewis ${ }^{23}$ noted the tendency toward concentration under barriers of low permeability, the bleaching of the red rocks around the copper, which had also been noted by Weed, ${ }^{24}$ and the close association of the copper with igneous masses. Lewis concluded that the copper had been deposited from ascending hot solutions, probably derived from the underlying source of the basic rocks of the region.

${ }^{23}$ Lewis, J. V., Econ. Geology, vol. 2, pp. 242-257, 1907.

24 Weed, W. H., New Jersey Geol. Survey Ann. Rept. for 1902 ,p. 135, 1903.
For the formation of native copper, Lewis cited experi. ments by Stokes ${ }^{25}$ and suggested that cupric sulphate contained in the ascending solutions had been reduced to cuprous sulphate by the action of minerals and solutions containing ferrous iron, and that native copper had been deposited from the cuprous sulphate where the solutions had become sufficiently cooled The bleaching he explained as resulting from leaching of the hematite by acid sulphate solutions.

In a later paper, read at the meeting of the Society of Economic Geologists in December, 1922, Lemi further emphasized the structural relations outlined above and the relation of the copper deposits to intrusive bodies. In this paper he recognized the probsbility that the solutions as they came from the mag matic source were reducing rather than oxidizing.

In general, Lewis's idea of the New Jersey occur. rences will apply equally well to those of Michigan.

Watson ${ }^{26}$ regards the native copper deposits of the South Atlantic States as derived from sulphides disseminated in the basic lavas. The copper was collected by circulating hot solutions and precipitated as metallic copper in areas rich in ferric iron by the oxidation of the solutions. Watson recognizes the possibility that the solutions may have been derived from deep-seated intrusive magmas.

Wright's reference to the presence of sulphides near intrusives and in the lower beds of the series and 0 native copper with little sulphide higher up ${ }^{27}$ indi. cates relations similar to those in New Jersey. He asserted that any theory of origin would have to explain these relations. Beyond implying that the copper near the intrusives is magmatic and that therefore all of it throughout the district may be magmatic, Wright did not go.

Van Hise ${ }^{28}$ cited the Michigan copper ores as examples of deposits formed by meteoric waters that had first descended, then moved laterally, dissolving copper as they went, and finally ascended and precipitated the copper as now seen. $\mathrm{He}$ adopted the Pumpelly idea of precipitation by ferrous iron.

Van Hise, Leith, and Steidtmann ${ }^{29}$ concluded that the ores were formed by hot solutions and that the type of rock alteration is unlike that accomplished by meteoric waters. As to the source of the water, they said: "On the whole the evidence is taken to point to a probable original concentration of copper by hot solutions, largely of juvenile contribution but more or less mixed, necessarily, with meteoric waters, and a later working over of the deposits by waters dominantly of meteoric source." As to whether the juvenile (that is, magmatic) waters were derived from the intrusive rocks or from the lava flows they were

2s Stokes, H. N., Econ. Geology, vol. 1, p. 645, 1906.

${ }^{28}$ Watson, T. L., Native copper deposits of South Atlantic States compared with those of Michigan: Econ. Geology, vol. 18, pp. 732-751, 1923.

${ }^{27}$ Wright, F. E., Michigan Geol Survey Rept, for 1908, pp. 392-394, 1909.

${ }^{28}$ Van Hise, C. R., Am. Inst. Min. Eng. Trans., vol. 30, pp. $189-98,1900$.

20 U. S. Geol. Survey Mon. 52, pp. 580-591, 1911. 
uncertain, but they somewhat favored the origin from the flows. The heat they thought was partly supplied by the hot magmatic waters and partly by the still hot flows. The copper they considered in part to have come as chloride from the same magmatic source as the hot juvenile solutions, along with boron, fluorine, $\mathrm{CO}_{2}$, and perhaps other magmatic emanations, but in part to have been derived from leaching of the basic wall rocks by the mingled hot solutions. The precipitation of the copper, they concluded, was accomplished through reduction of the copper solutions by ferrous iron minerals and by ferrous solutions derived from them, in essentially the way Pumpelly had proposed. Finally, they concluded that the brines of the deep levels are probably the residues of the ancient ore-forming solutions, possibly mixed with meteoric water.

The parts of these views of Van Hise, Leith, and Steidtmann that have to do with meteoric waters are discussed on page 120. The parts that deal with magmatic waters follow Smyth in large measure but go further in recognizing that the type of rock alteration contrasts entirely with that produced by weathering or by meteoric waters. If the magmatic waters came from the lava flows, there were presumably several periods of mineralization, as successive flows were in the proper condition to yield emanations. The presence of mineralized boulders of amygdaloid in what was considered unmineralized conglomerate was thought to mean mineralization before conglomerate deposition and apparently strengthened the belief that the lavas rather than the intrusives were the source of the mineralizing solutions.

Hore ${ }^{30}$ appended to an excellent summary of previous literature on the district his own ideas as to the origin of the deposits. He concluded that the copper and the Keweenawan igneous rocks had a common source; that the copper is essentially a primary deposit from ascending solutions which followed the extrusion of lava so closely that the rocks were still hot, although they had already been fractured; that tilting and faulting followed copper deposition; that the copper replaced the rocks and was precipitated from chloride solutions by the reducing action of ferrous iron. These conclusions were well presented and accompanied by shrewd and pertinent observations on other features of the copper deposits. The conceptions introduced are discussed above.

Woods ${ }^{31}$ emphasized the possibility that the felsite and quartz porphyry intrusive masses may have been the sources of the copper, which he thought may have been first deposited by ascending magmatic solutions and then enriched by downward-moving waters in Just the same way that the porphyry deposits of the West have been originally formed and later enriched.

\footnotetext{
"Hore, R. E., Michigan Geol. Survey Puh. 19, pp. 157-161, 1915.

"Woods, T. S., Eng. and Min. Jour., vol. 107, p. 300, 1919.
}

PRECIPITATION IN CONSEQUENCE OF SATURATION

It may be supposed that metallic copper was deposited, because that was what the solutions carried, and that it was precipitated by cooling of the solution or by some other cause, in the same way that calcium carbonate solutions precipitate calcite. Perhaps Spurr had some such idea in mind when, in his short article ${ }^{32}$ arguing for the magmatic origin of these deposits, he asked if the intercrystallization of copper with chalcocite does not indicate a deficiency of sulphur in the solutions.

The chief objection to this idea of precipitation by saturation is that in all but a few of the thousands of copper deposits that have been studied throughout the world it is apparent that the copper has been transported either as a sulphur, arsenic, or allied compound, as in most primary deposits, or as an oxidized compound, as in the secondary deposits. The native copper in many secondary deposits has clearly resulted from the oxidation of sulphides in place. On the other hand, the conception has certain attractions. Native gold may possibly be carried as such in solution and perhaps native silver also. In general, precipitation that takes place without evident attack of the solutions on the wall rocks may be thought to result from the fact that the solutions had reached the saturation point through decrease of temperature or other physical causes rather than from some chemical reaction that rendered the substances they carried less soluble.

In the Michigan deposits there is characteristically a pronounced chemical change in the inclosing rock, but locally copper is present in rock that shows little change, as in parts of the upper levels of the Calumet \& Hecla conglomerate, locally in the Kearsarge and Pewabic lodes, and in fissures. Doubtless the chemical reactions that caused the precipitation of native copper did not all take place just where the copper was precipitated. It is entirely probable that the reactions began as soon as the temperature and other physical conditions permitted, and they may have gone on for some time before any copper was precipitated. Once copper started to form, it would act as nuclei for further precipitation from solution that had been undergoing chemical reaction some distance away. In considering the immense masses of copper, hundreds of tons in weight, it is not reasonable to suppose that the entire chemical reaction was confined to the rock replaced by the copper or to that immediately surrounding it, and the supposition would be no more reasonable for the smaller masses.

\section{PRECIPITATION BY OXIDATION}

Most of the copper deposits of the world consist of sulphides ${ }^{33}$ or have been derived directly from sul-

${ }_{32}$ Spurr, J. E., The copper ores of Lake Superior: Eng. and Min. Jour., vol. 110, pp. $355-357,1920$.

${ }^{33}$ For brevity in expression the sulphide gronp is here used to include also the related compounds with arsenic, antimony, etc. 
phides by superficial oxidation. The relatively small class of primary deposits of native copper, of which the Michigan deposits afford the chief example, constitutes the only exception to the rule.

Although the transportation of copper in solutions that deposit it as sulphide or allied minerals is not yet well understood, the fact that it is so transported and deposited in by far the greater number of deposits must be accepted. It is advisable, therefore, to inquire whether the Michigan and similar deposits represent not an entirely different and independent scheme of copper transportation and deposition but rather a modification of the ordinary method through the influence of special conditions. What kind of special modifying conditions would serve to precipitate native copper from solutions that normally would deposit copper sulphide? The metallurgist, who transforms copper sulphide into metallic copper, would answer that if the copper sulphide solutions could be oxidized under the right conditions and to the proper degree, metallic copper would be formed.

Twenty years ago, G. Steinmann ${ }^{34}$ advanced the idea that the native copper and chalcocite deposits of Coro Coro, Bolivia, originated from ascending magmatic solutions that would normally have deposited only copper sulphides, but because the solutions entered hematite-bearing rocks, part of the sulphur was oxidized by the oxygen of the hematite and therefore part of the copper was precipitated as native metal in the midst of bleached areas of the rock, and the rest of the copper united with the remaining sulphur to form chalcocite.

How does this idea of precipitation by oxidation apply to the Michigan deposits? Several conditions must be met to make it seem applicable.

1. There should be definite evidence that sulphides had been present in the ore-forming solutions.

2 . If oxidation was the cause of the conversion of copper sulphide into native copper, the rocks in which the metallic copper was deposited must have been oxidizing in their nature.

3. At the places where copper was deposited the oxidizing power of the rock should have been lessened if not destroyed.

4. Oxidized compounds of sulphur might be expected.

The extent to which these requirements are met by the Michigan deposits is discussed below.

PRESENCE OF SULPHIDES

Sulphides and arsenides of copper in the Michigan district are subordinate in quantity but are of widespread occurrence. Copper sulphides occur in pegmatitic knots or lenses in certain of the thicker traps, and there is a close connection between sulphides and intrusive masses. Copper sulphide has been found in several of the lodes, especially in the Baltic and

34 Festschrift Harry Rosenbusch, p. 360, 1906.
Isle Royale, and in countless fissures, large and small, in and near the lodes. Copper arsenides have been observed sparingly in the Isle Royale lode and are plentiful in several large cross fissures. Copper sulphide and metallic copper (see pl. 68) or copper arsen. ides and metallic copper are in many places intimately intergrown. There is thus proof that practically tbroughout the district at least a part of the copper was transported in the manner common to most primary copper deposits elsewhere, and that the deposition of sulphide and arsenide of copper went on at the same time as the deposition of metallic copper.

If the sulphide and arsenide compounds of copper represent the minor residues of sulphur and arsenic that escaped oxidation, it might be expected that the copper sulphides and arsenides formed would be those lowest in sulphur and arsenic and highest in copper, and such is the case. The prevailing copper sulphide is chalcocite, with a molecular ratio of copper to sulphur of $2: 1$, the highest among all known coppersulphur minerals. Bornite, with a ratio of $5: 4$, is far less common; chalcopyrite, with a ratio of $1: 2$, less common still; and pyrite, the commonest sulphide in nature and the one that suggests an abundance of sulphur, is in the Michigan deposits practically absent.

The arsenides show a similar tendency. In other regions the common unoxidized copper-arsenic minerals are enargite and tennantite, with proportions of copper, arsenic, and sulphur of $3: 1: 4$ and $8: 2: 7$, respectively. In Michigan these minerals are absent and instead the arsenic is combined in the uncommon minerals domeykite, algodonite, and whitneyite, all high in copper, low in arsenic, and devoid of sulphur, with copper arsenic ratios of $3: 1,6: 1$, and $9: 1$, respectively. ${ }^{35}$ Moreover, certain of the lodes, notably the Baltic and Isle Royale and in less degree the Kerrsarge, carry "arsenical copper"- that is, metal containing small amounts of arsenic but enough to modify the mechanical and electrical properties of the copper.

Although sulphur doubtless exceeds arsenic in total amount in the district, there are no such massive and extensive occurrences of chalcocite as the $80^{-}$ called "mohawkite" arsenide veins of the Ahmeek and Mohawk mines, and arsenic is more abundant in proportion to sulphur than in other copper districts. The idea suggests itself that sulphur was oxidized with relatively greater ease than arsenic, and this idea accords with the behavior of these elements in copper smelting.

Finally, the oxidation hypothesis would suggest that the solutions that had traveled in the most intimate contact with the oxidizing agent would precipitate the least sulphide and arsenide, and vice versa. This suggestion likewise is borne out by the facts, as discussed below.

as The exact composition of these arsenides has not been worked out, because of the intimate intergrowths that prevent isolation of any single variety. The ratios given are those recorded in the textbooks. 
PRESENCE OF AN OXIDIZING AGENT

The conglomerate layers and the lava tops contained a noteworthy proportion of ferric iron, chiefly as hematite. This hematite was present in the rocks from the time of their formation and therefore long antedated the deposition of copper, which came only after the entire series had been accumulated and the filting and faulting had been accomplished.

Ferric compounds can part with one-third of their oxygen in the presence of a reducing agent. Hematite, therefore, may be regarded as a potential oxidizing agent toward a solution of reducing nature. The question then arises, Did hematite actually oxidize ore solutions bearing copper sulphide and thus cause the precipitation of metallic copper?

That rocks of normal composition contain copper sulphide ores, whereas red rocks rich in ferric oxide are likely to contain native copper, is shown by the following figures:

Ferric and ferrous iron content of inclosing rock of some copper deposits

\begin{tabular}{|c|c|c|c|}
\hline & $\begin{array}{l}\mathrm{Fe} \text { as } \\
\mathrm{Fe}_{2} \mathrm{O}_{3}\end{array}$ & $\begin{array}{l}\mathrm{Fe} \text { as } \\
\mathrm{FeO}\end{array}$ & $\begin{array}{c}\text { Total } \\
\text { Fe }\end{array}$ \\
\hline \\
\hline Butte, Mont., monzonite & 1. 47 & 2. 01 & 3. 48 \\
\hline Bingham, Utah, monzonite & 2. 27 & 1. 97 & 4. 24 \\
\hline Ely, Nev., monzonite & 2. 38 & 2. 69 & 5. 07 \\
\hline Bisbee, Ariz., limestone $\left(\mathrm{Fe}_{2} \mathrm{O}_{3}+\mathrm{FeO}\right)$ & & .24 & .36 \\
\hline \multicolumn{4}{|c|}{ Native copper: } \\
\hline $\begin{array}{l}\text { nearsarge lode, Migrigan } \\
\text { Osceola lode, Michigan }\end{array}$ & $\begin{array}{r}11.38 \\
7.15\end{array}$ & $\begin{array}{l}.33 \\
1.23\end{array}$ & 11. 38 \\
\hline Isle Royale lode, Michigan & 3.66 & 5. 30 & 8. 96 \\
\hline glomerate, Michigan & 3. 3 & .04 & 3. 34 \\
\hline $\begin{array}{l}\text { Iron-rich boulder, Calumet \& Hecla } \\
\text { conglomerate, Michigan }\end{array}$ & 8. 88 & 1. 01 & 9. 89 \\
\hline $\begin{array}{l}\text { Allouez conglomerate, felsite pebble, } \\
\text { Michigan }\end{array}$ & 3. 42 & .47 & 3. 89 \\
\hline $\begin{array}{l}\text { Puca sandstone, Coro Coro, Bolivia } \\
\text { (about) }\end{array}$ & 6.3 & & 6.3 \\
\hline Sandstone, New Jersey: & & & \\
\hline $\begin{array}{l}\text { Purple ore bed } \\
\text { Shale....................... }\end{array}$ & $\begin{array}{l}0.21 \\
9.61\end{array}$ & 1. 54 & $\begin{array}{r}6.21 \\
11.15\end{array}$ \\
\hline
\end{tabular}

Not only is the ferric iron higher in the rocks that inclose native copper but it is present as the oxide, whereas most of the iron in the rocks that contain sulphides is combined as silicate and thus probably is less available for reaction.

Native copper is common in the upper levels of deposits that have undergone sulphide enrichment. The conditions of occurrence and method of formation of this native copper are well understood; it is plainly an oxidation product of chalcocite. The oxidation is probably accomplished by atmospheric oxygen, but many believe ${ }^{36}$ that it is accomplished also by ferric sulphate, well known as an oxidizing agent. In the production of native copper by the action of ferric sulphate on chalcocite, the iron compound would be in solution and the copper compound solid, whereas the Michigan native copper is inferred to have been

\footnotetext{
"Lindgren, Waldemar, Mineral deposits, pp. 789-792, 1913.
}

formed by reaction between copper sulphide in solution and ferric iron in the solid state. Inasmuch as the first reaction certainly takes place, it would seem that the second might do so under the proper conditions; and it has actually been produced experimentally. ${ }^{36 a}$ The results of experiments relating to this problem and conclusions drawn from them are presented by R. C. Wells on pages 137-141.

Another indication that hematite acted as an oxidizing agent to precipitate metallic copper is seen in the field relations. The field evidence may be considered under two heads - the relation of native copper and copper sulphide to the proximity of hematitebearing rocks, and the effect upon hematite where metallic copper has been precipitated. The first of these topics is considered here; the second in the succeeding section on bleaching.

Where the ore solutions evidently traveled in most intimate contact with the oxidizing agent, the largest proportion of metallic copper and the smallest proportion of sulphide or arsenide are found; and conversely where the solutions appear to have moved mainly through rock of nonoxidizing character, the proportion of sulphide or arsenide to metallic copper is highest.

The first requirement for ore formation on a commercial scale was the presence of extensive through-going channels of relatively high permeability through which the ore solutions could pass. These permeable channels were of three sorts - the conglomerate layers; the vesicular lava tops, especially the brecciated tops; and large fractures relatively free from gouge, such as the cross fractures due to the tension on the anticlines, as the Allouez and Keweenaw anticlines, and strike fissures near the base of the series, as near the Baltic lode. Innumerable smaller fractures present throughout the district but especially abundant in the regions of major disturbances also acted as minor channels for the ore-forming solution.

The channels afforded by the conglomerate layers and the lava tops were relatively rich in hematite. If hematite exerted an oxidizing effect on the solutions that came into contact with it, then those that moved for the longest distances through the small openings of these hematite-bearing lodes had the greatest opportunity to become oxidized. The channels of the third type - the major cross fissures - cut mainly through the dark, unoxidized traps; only small parts of their walls consist of the hematite-bearing conglomerates or amygdaloids. Moreover, these fissures probably afforded readier and more direct passageways for the solutions than the more interrupted, more circuitous, : and probably smaller openings of the lodes. The solutions in the fissures were therefore not in such

36a If it is assumed that the copper was carried in solution as some compoundsulphide, for example $-\mathrm{a}$ condition in which it must have been carried in nature, then the action of ferric oxide was to prevent its deposition as sulphide through selective oxidation of the sulphur. The copper under these conditions could still deposit as native metal, whereas the more common process in the formation of ores is the change of native metal to sulphide. 
close contact with the adjacent rock as the solutions in the conglomerates and the lava tops, and consequently it might be expected that the solutions moving through the conglomerate and amygdaloid lodes would be more thoroughly oxidized than the solutions passing along the fissures. This in general is true; very little sulphide occurs in the amygdaloid lodes independent of fissures.

In the conglomerate lode practically no sulphide occurs in the cement in the way common for the metallic copper. The Allouez conglomerate in particular and some of the other conglomerates in less degree contain widespread chalcoeite in notable though noncommercial amount. But this chalcocite is not chiefly within the conglomerate rock itself, like the metallic copper, but is intergrown with calcite (see pl. 68) in fractures that cut the conglomerate at close intervals in all directions. The abundance of sulphide veins in the conglomerates may be due to the greater brittleness of the conglomerate, which made small-scale fracturing more easy, the lower hematite content of the conglomerate, and the greater chemical stability of the rock, which rendered its hematite less available.

Very little sulphide is present in the main ore shoot of the Calumet \& Hecla conglomerate, but sulphide is relatively abundant along the margins of the main ore shoot at Centennial and Osceola.

In the sandstone lodes of the Nonesuch formation and in the overlying shale a little chalcocite is present. Here the ore solutions probably did not move for long distances in the red sandstones but gained access to the beds from the White Pine fault and the related minor fractures, and so opportunity was not afforded for complete oxidation of the solutions by the hematite of the red rocks. The ratio of chalcocite to metallic copper, in the shales, which appears to be higher than in the sandstones, would be due to lack of hematite in the black shales. The amount of copper occurring as sulphide is relatively small: Samples in the White Pine mine indicated that only 2 per cent of the total copper is combined as sulphide, and by far the largest part of this is present in fissures and minor faults, where the opportunity for oxidation by the rocks was low.

Some of the amygdaloid lodes contain "arsenical copper," but in this the ratio of arsenic to copper is exceedingly low-a small fraction of 1 per cent. Definite copper-arsenide minerals are practically unknown as constituents of any of the lodes except in the immediate vicinity of some of the arsenide fissures.

Many fissures contain pure metallic copper, but many also carry arsenical copper, and the fissures are the chief source of the sulphides and almost the sole source of the arsenides of the district.

Moreover, the cross fissures of the Cliff-Central type have been found to carry notable quantities of copper only near their intersections with hematite-rich amygdaloid or conglomerate lodes. For the old fissure veins of Keweenaw County, one such horizon occurs under the Greenstone flow and another in the vicinity of the Ashbed amygdaloid. The relation of copper in the cross fissures to the intersection of a hematite-rich lode is well shown by the Mass fissure and the Kearsarge lode in the Ahmeek mine: The cop. per in the fissure is very distinctly concentrated in the neighborhood of its intersection with the lode, especially on the hanging-wall side of the lode; at many levels the Kearsarge lode is cut across by a solid wall of copper in the fissure. This suggests that the solutions that moved along the fissure would not have deposited copper in abundance in any form at this point had it not been for the effect of the amygdaloid.

The many small seams of copper that extend from the Kearsarge lode into the trap of the footwall or hanging wall as a rule contain copper for only short distances away from the main lode. It appears evident that they were fed by the solutions that flowed along the lode and that the reactions that caused the precipitation of copper occurred in the lode rather than in the fissures.

One further relation suggests the influence of long contact with red rock on the condition in which the copper was deposited. The copper of the lodes highest in the series, the Ashbed, Pewabic, Calumet \& Hecla conglomerate, and Osceola, is notably pure In the Kearsarge, Isle Royale, and Baltic lodes, which are low in the series, the copper becomes increasingly arsenical. The two lowest lodes, the Isle Royale and particularly the Baltic, contain more sulphide-bearing fissures than any other lode.

If the solutions gained access to the beds that are now the lodes from the Keweenaw fault as the main feeding channel, it would follow that the lodes highest in the series are at the present surface farther from their intersection with the Keweenaw fault than the lodes that lie deeper in the series and crop out closer to the fault. On the assumption that the fault continues downward at a dip $5^{\circ}$ flatter than that of the beds, it is found that the distance down the lode from the present surface to the intersection with the Keweenaw fault is about six times as great for the Ashbed, five times for the Pewabic, four times for the Calumet \& Hecla conglomerate, and between four and three times for the Osceola, Kearsarge, and Isle Royale as it is for the Baltic. This would mean that the solutions traveled six times as far from the connection with the fault in the oxidizing environment of the red lode of the Ashbed (and corresponding distances in the other lodes) as they did in the Baltic.

The result might be that in lodes in which the solutions traveled long distances nearly all the sulphur and arsenic was oxidized, but where the distance was 


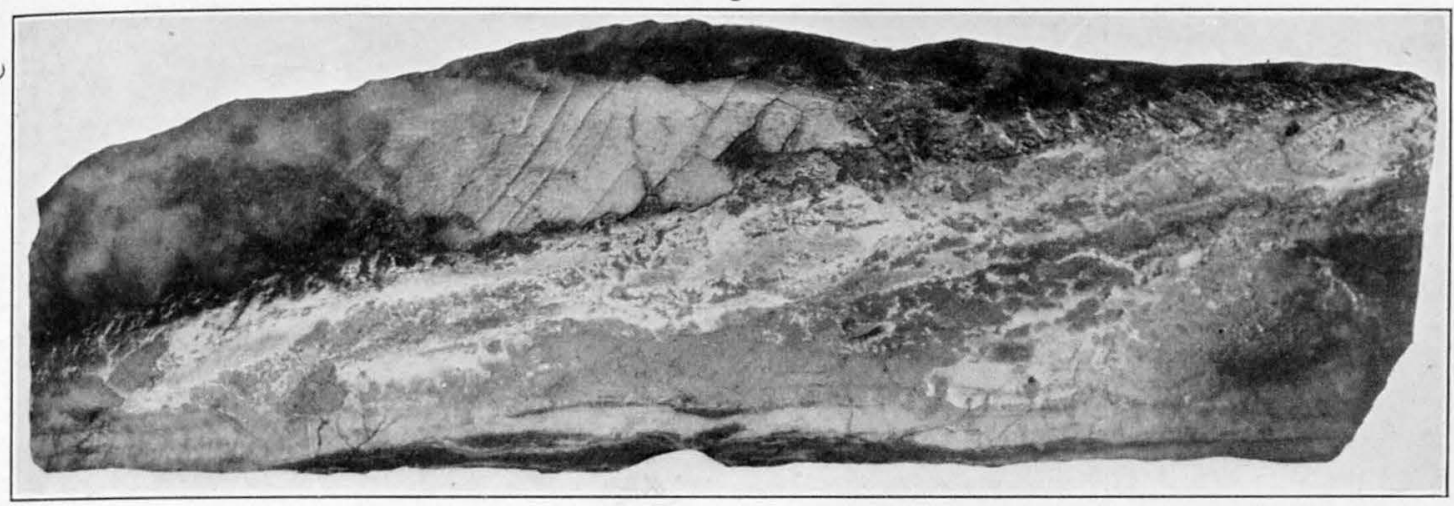

a

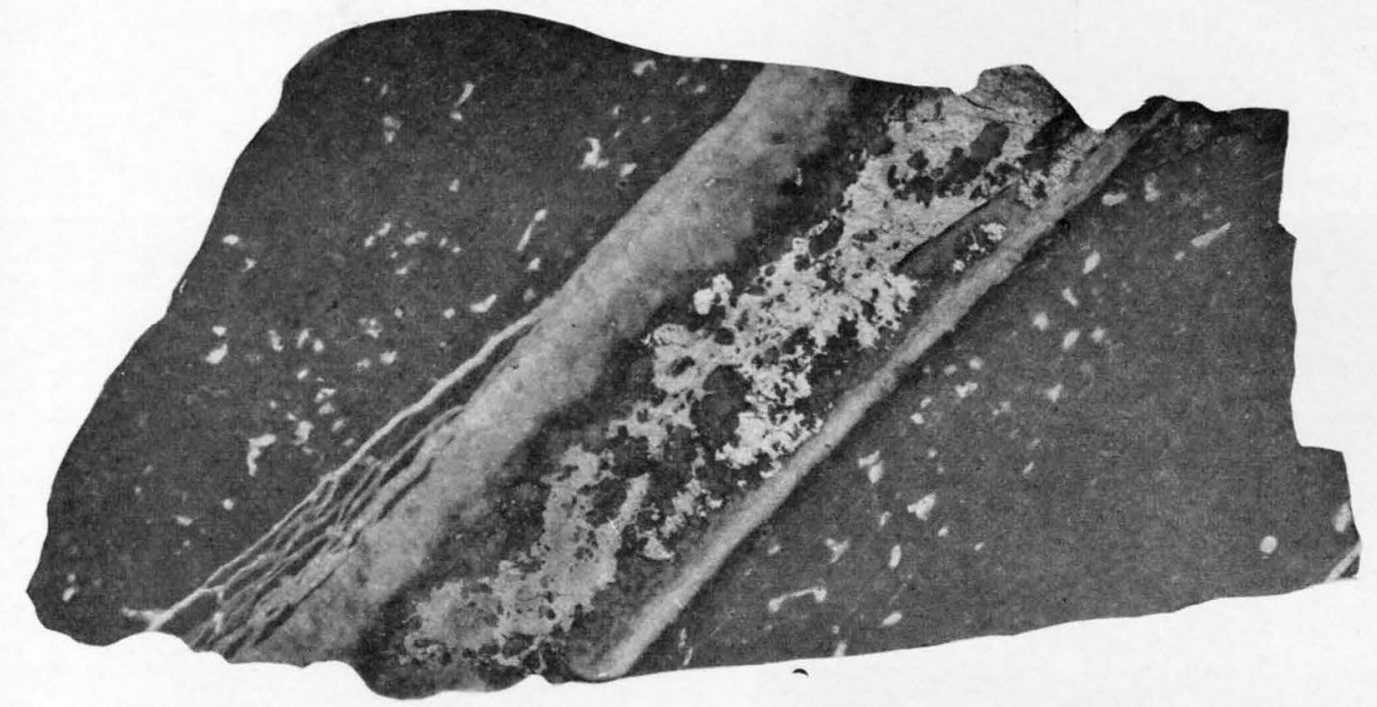

b

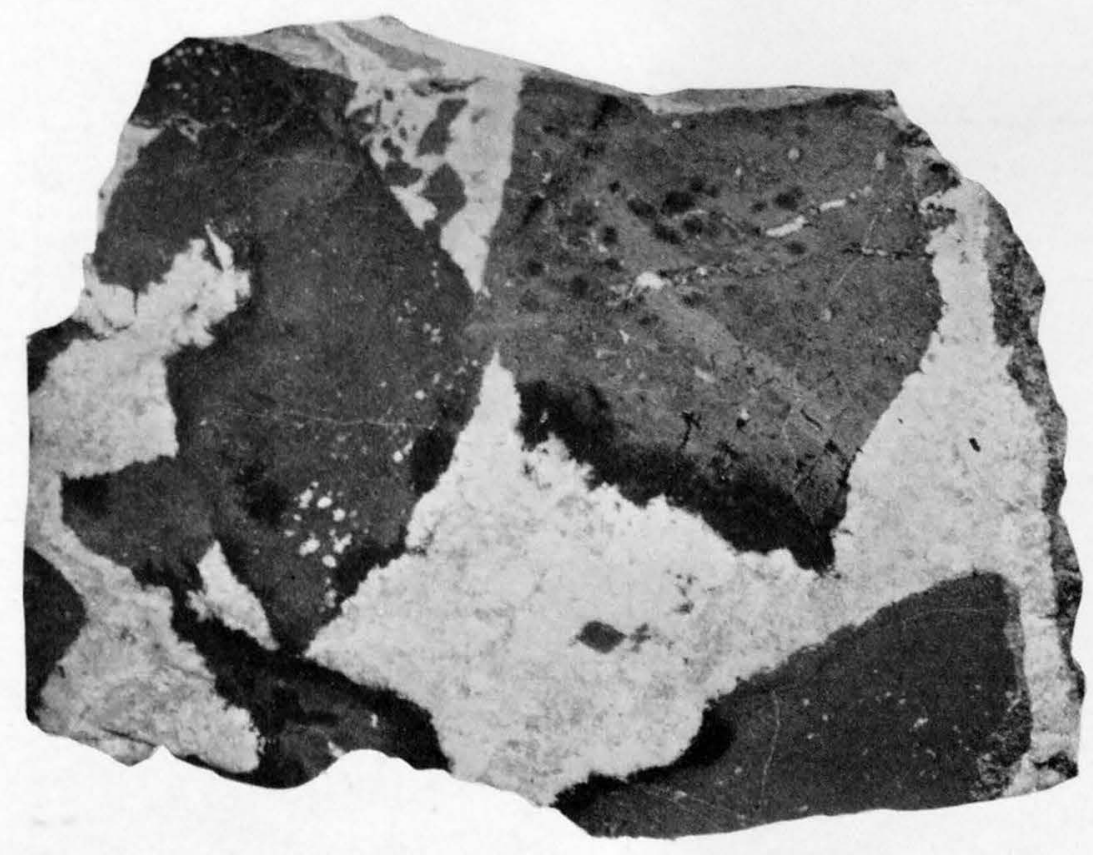

c

SULPHIDE VEINS

a, Vein of native copper (light) and chalcocite (dark), Baltic mine; b, chalcocite (light) and bornite (dark), gangue quartz and ankerite, Baltic mine; $c$, chalcocite (darkest areas) in amygdaloid, light areas iron-bearing carbonate, Trimountain mine 


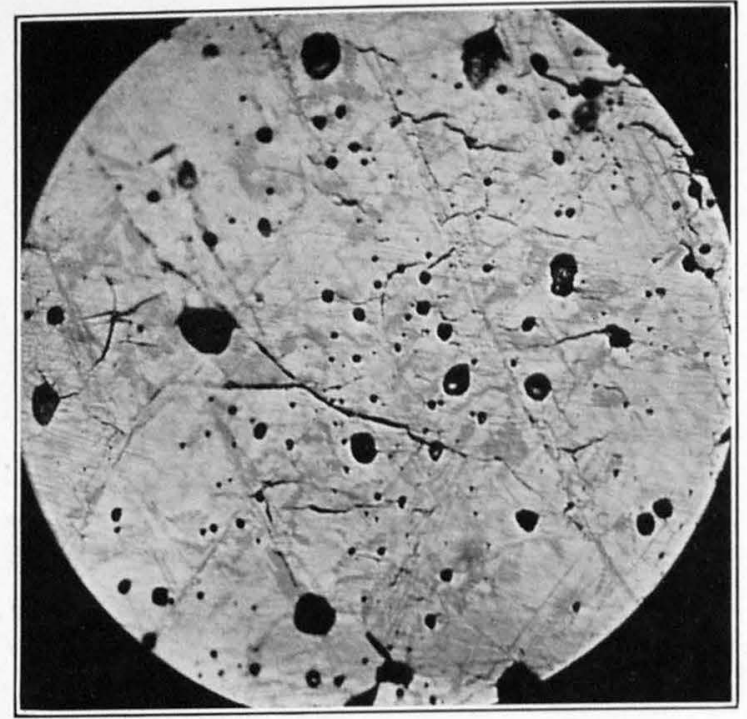

a
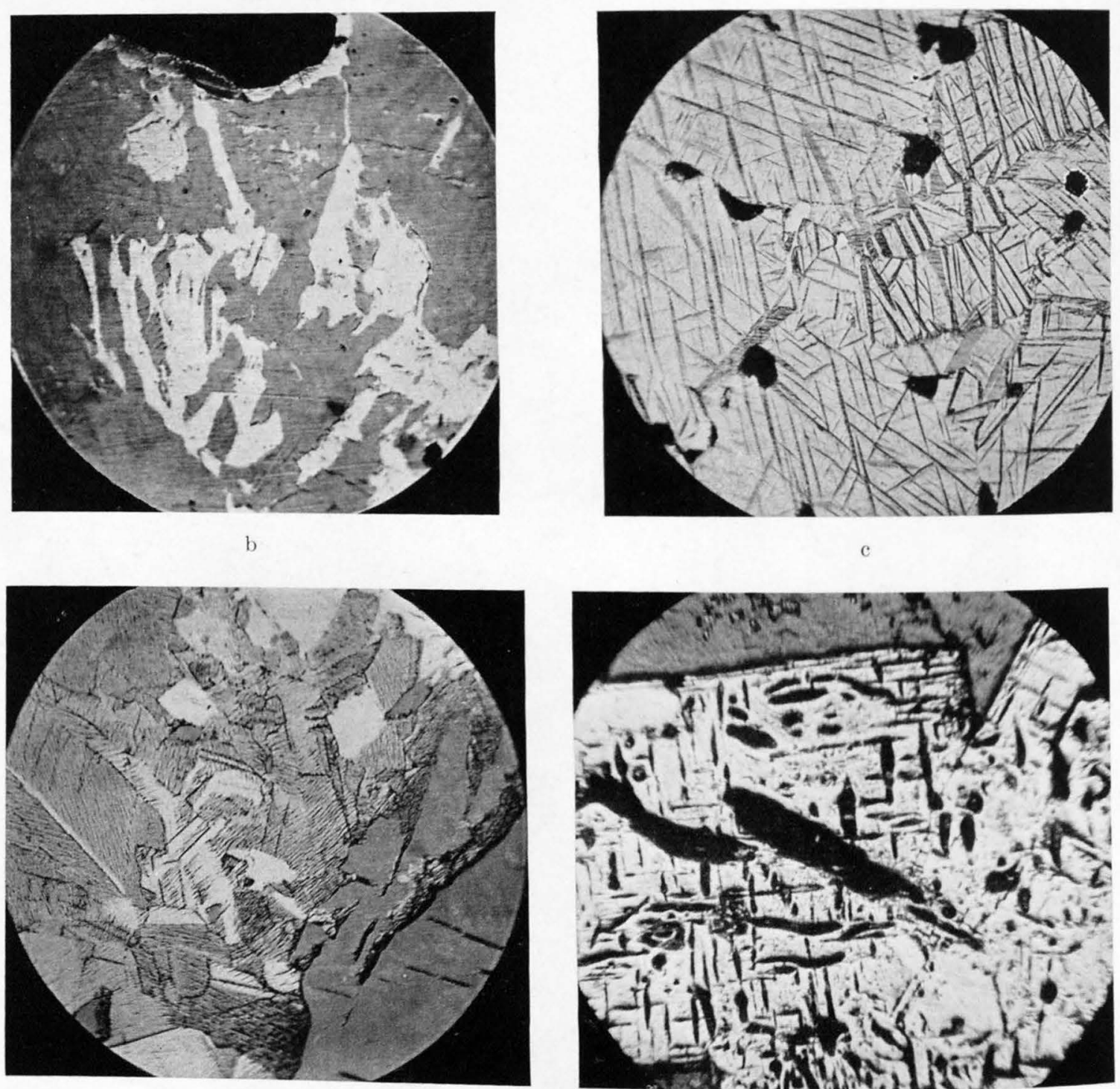

ARSENIDES OF COPPER

a, Domeykite etched with $\mathrm{NH}_{4} \mathrm{OH}$, at least four components present, $\times 242$; b the two varieties of algodonite intergrown, $\times 250 ; c$, algodonite etched with $\mathrm{NH}_{4} \mathrm{OH}$, whitneyite between grains of algodonite, $\times 250$; d, al adonite (two constituents) and unknown gray mineral, 


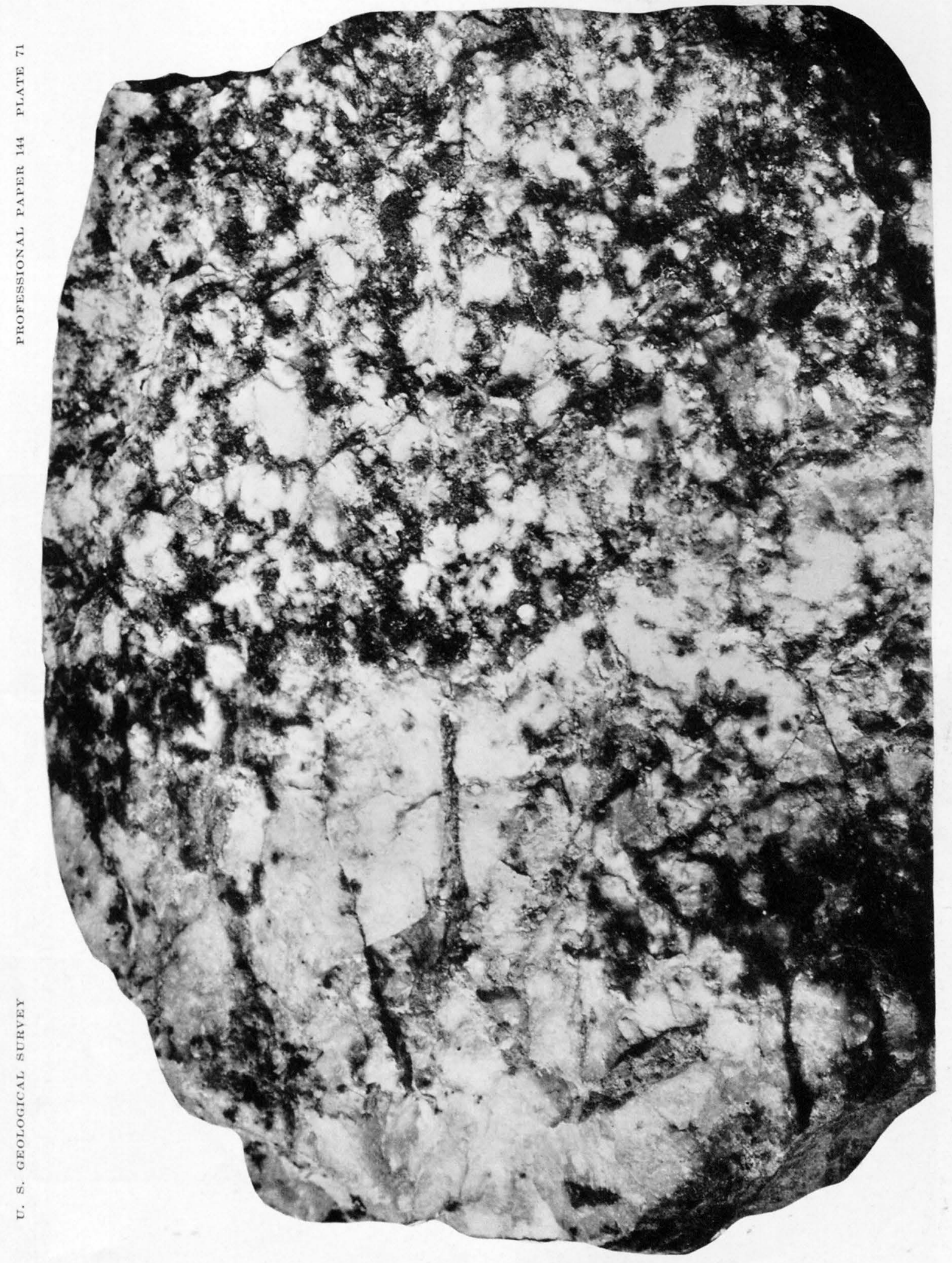



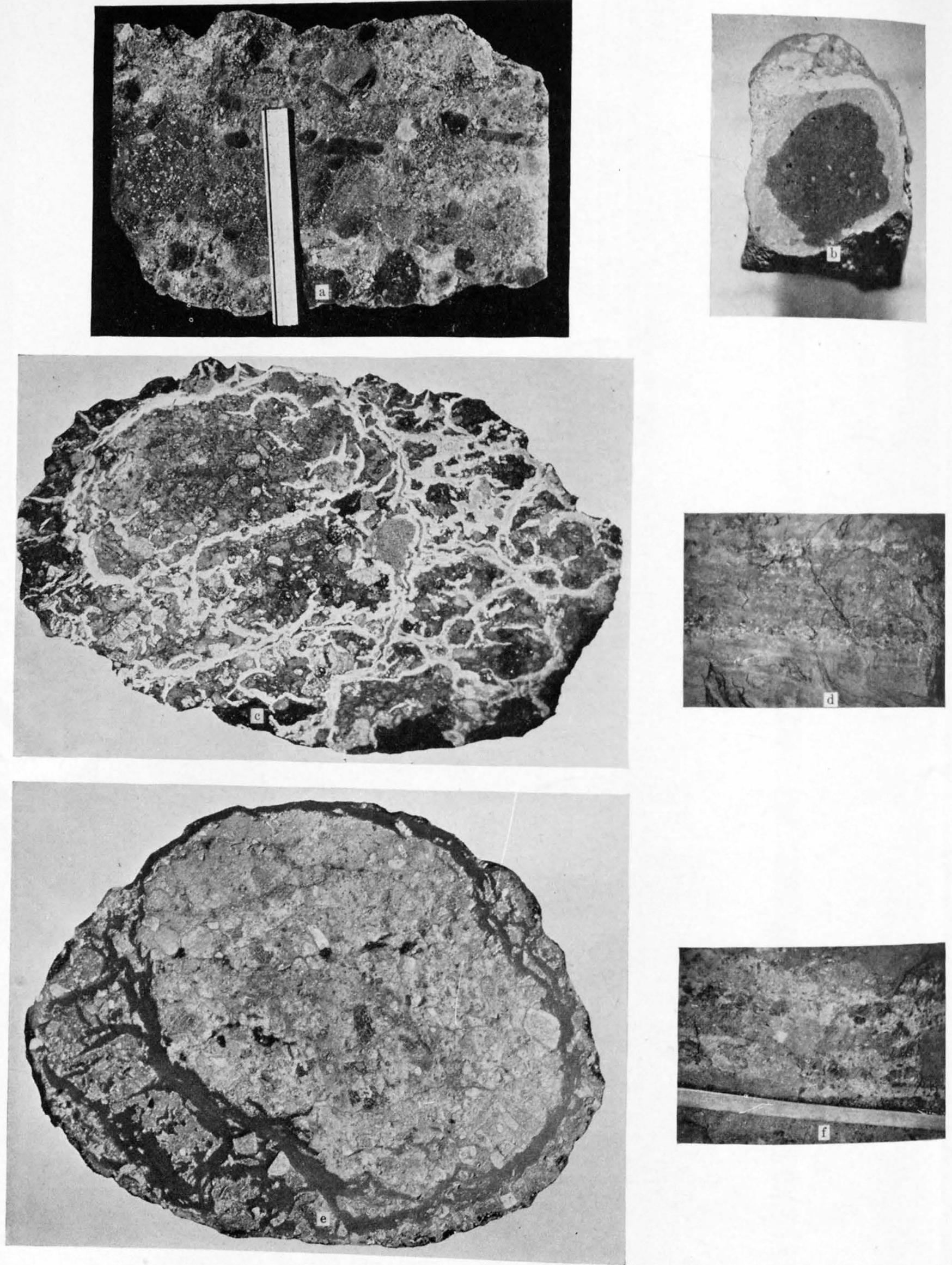

a, Bleaching of pebbles on

ground view of lode; e, conglomerate pebble partly replaced long; b, bleaching of pebble, $\times 11 / 2$; c, conglomerate pebble partly replaced by copper; $d$, under copper, light bands copper bearing pebble partly replaced by copper (dark bands); $f$, underground view of lote pebble partly replaced by copper; $d$, under- 

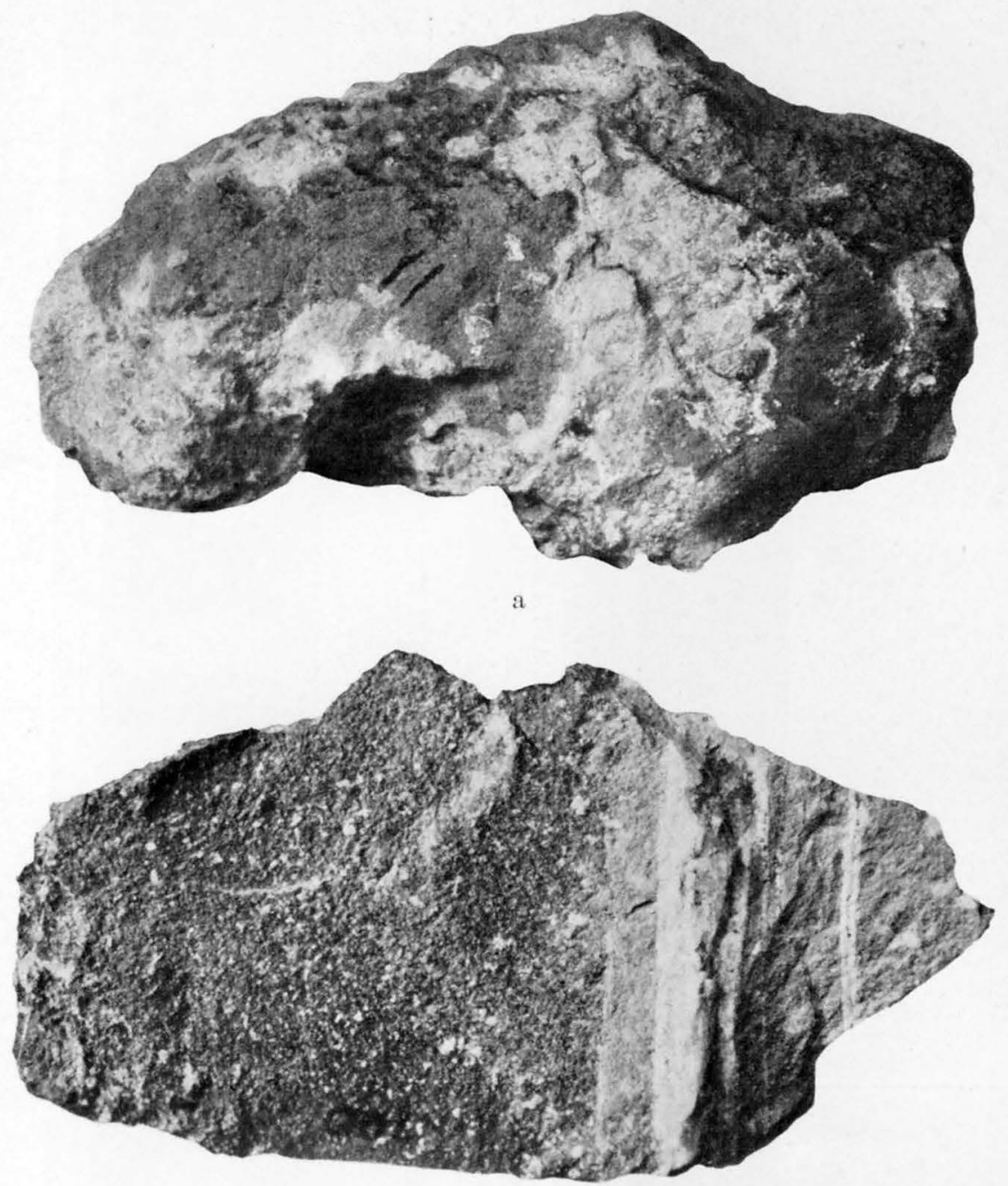

b

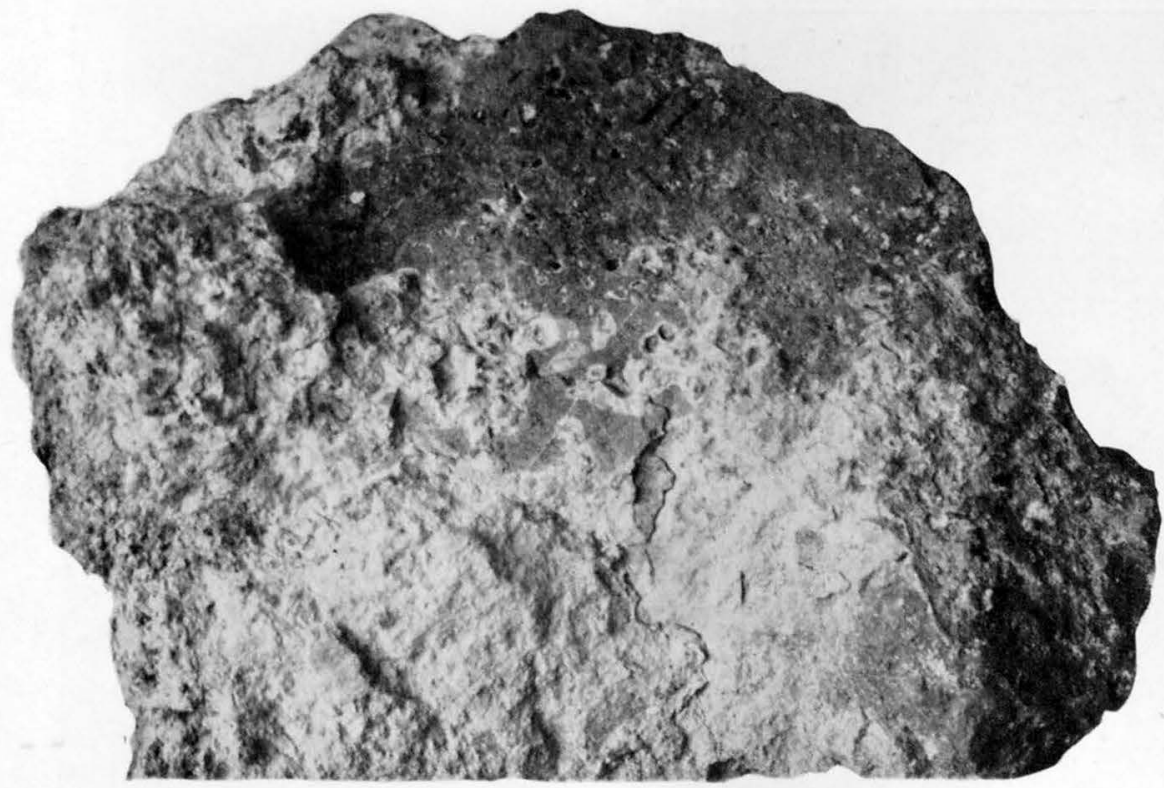

c

BLEACHING OF AMYGDALOID LODES

a, Bleaching of amygdaloid associated with copper, Osceola lode; b, bleaching of rock adjacent to sulphide vein, Baltic lode; c, bleaching of amygdaloid associated with copper, Kearsarge lode 

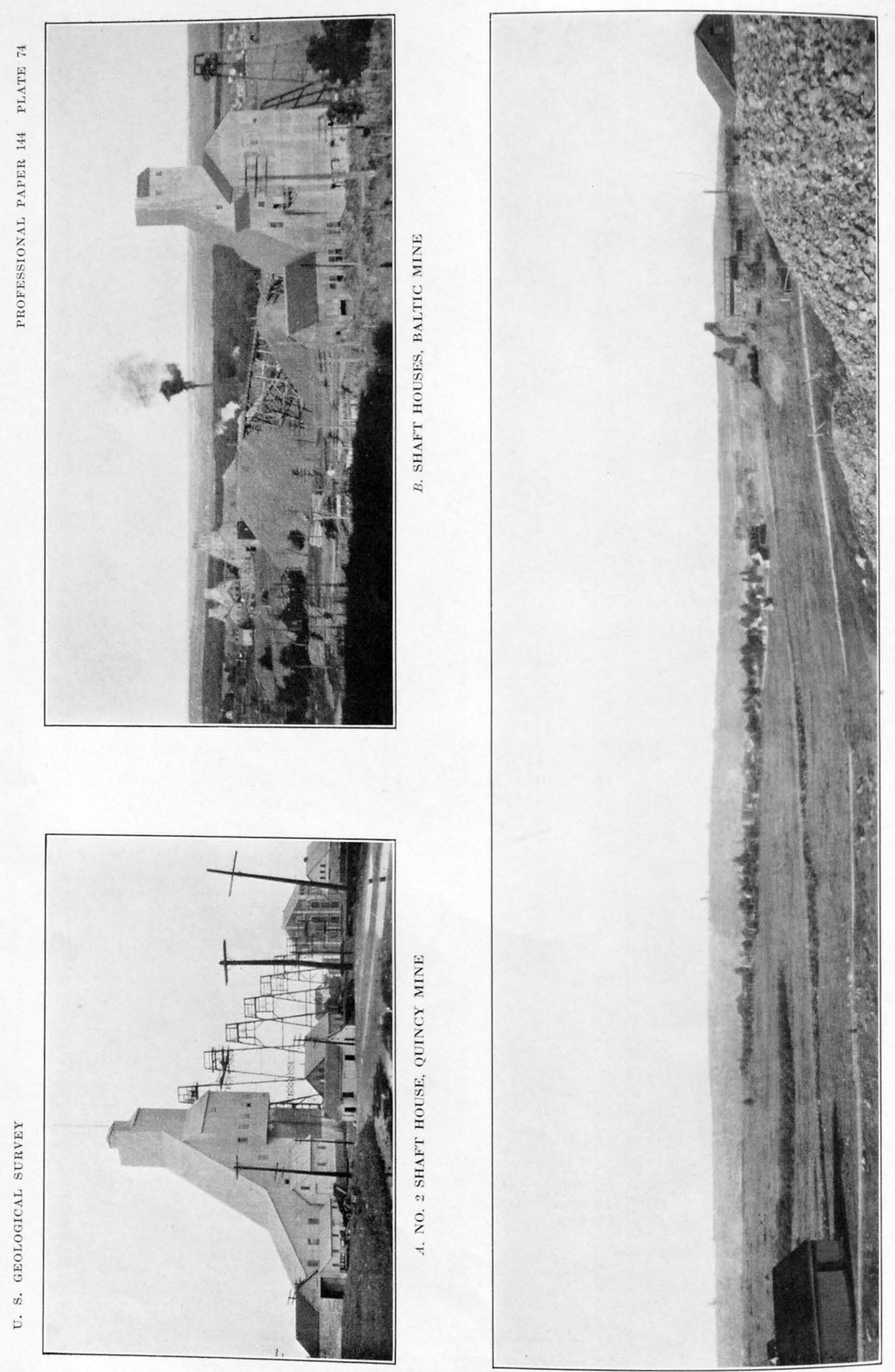
shorter some of the sulphur and arsenic would remain unoxidized. It might be expected that with increasing depth down a given lode - that is, toward the intersection with the Keweenaw fault-the proportion of grsenic and of sulphur would increase. There is a suggestion that this is true as related to arsenic, for it has long been believed that the arsenic content increases with depth; this relation, however, has not been proved. The Keweenaw fault is of course not proved to be the channelway for the ore solutions, but the relations outlined suggest that it was the channelway quite as much as they explain the distribution of sulphur and arsenic. They support the general hypothesis but without proving any part of it.

The copper contained in the pegmatitic streaks in trap occurs partly as sulphide; is this because the liquors that deposited it were never in contact with the oxidizing influence of red rock? Hematite is abundant in the pegmatite lenses, and it seems probable that as the rocks cooled these lenses went through much the same history as the copper deposits. At the proper temperature this hematite tended to oxidize the sulphur of the solutions but evidently was not sufficiently active to cause all of the copper to deposit as metal. Why the sulphur was not all oxidized is not clear. The copper occurring in fissures closely associated with intrusive masses, as at Mount Bohemia, and therefore deposited before having migrated far from its point of issue, is likewise chiefly or wholly in the form of sulphide, and the same lack of opportunity for oxidation may be the reason why it is not native.

Taken as a whole, the field evidence seems to indicate that metallic copper was deposited in abundance only in hematite-rich rocks or in close proximity to such rocks. Most of the sulphide and arsenide compounds of copper are confined to fractures that allowed the solutions to ascend either for long distances through trap or at any rate with less intimate contact with the hematite of the lodes. Further evidence of oxidation of the copper-bearing solutions is recorded in the following section.

\section{DESTRUCTION OF OXIDIZING AGENT-BLEACFING}

The amygdaloid and conglomerate layers have a red color because of their content of minute crystalline llakes of hematite that was formed before the deposition of copper. When copper was deposited the hematite was in part destroyed.

The following sets of analyses show the content of lemic and ferrous iron in the unaltered red rock and in the adjacent bleached equivalent close to metallic copper and the chemical change that has taken place in the rock during mineralization. This change is shown diagrammatically in Figures 17 and 18.

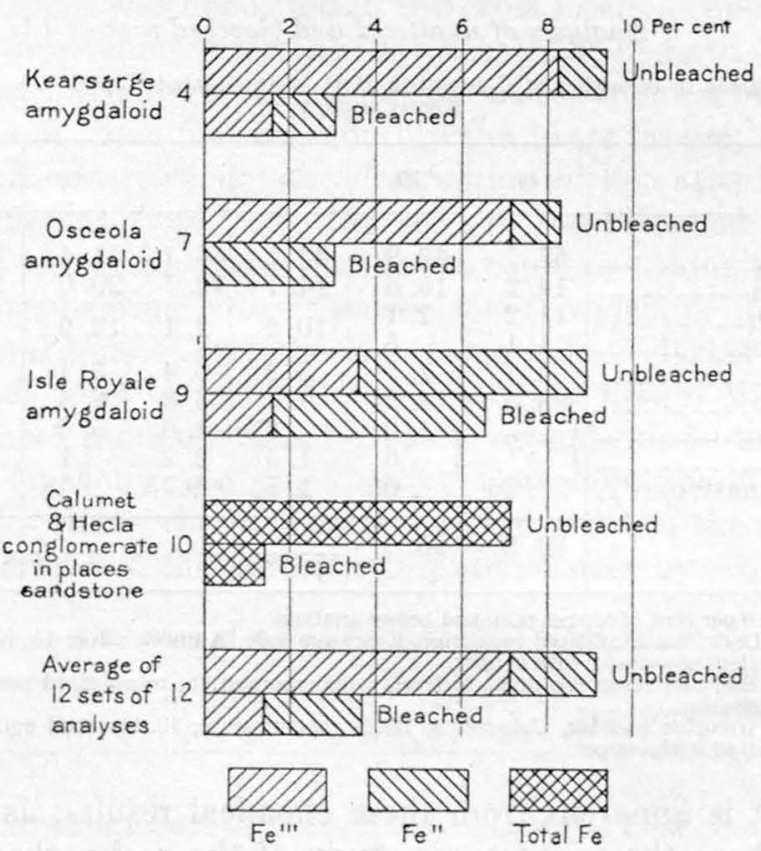

Figure 17,-Change in iron content of bleached rock associated with copper Numbers at left refer to table below.

Change in iron content produced by bleaching of rock associated with copper

[Specimens in collection of Calumet \& Hecla Consolidated Copper Co.]

\begin{tabular}{|c|c|c|c|c|c|}
\hline & \multirow{2}{*}{$\begin{array}{l}\text { Specimen } \\
\text { No. }\end{array}$} & \multicolumn{2}{|c|}{ Original rock } & \multicolumn{2}{|c|}{ Altered rock } \\
\hline & & $\mathrm{Fe}$ as $\mathrm{Fe}_{2} \mathrm{O}_{3}$ & $\mathrm{Fe}$ as $\mathrm{FeO}$ & $\mathrm{Fe}$ as $\mathrm{Fe}_{2} \mathrm{O}_{3}$ & $\mathrm{Fe}$ as $\mathrm{FeO}$ \\
\hline 1 & 1093 & 3. 42 & 0.47 & 0.57 & 0. 46 \\
\hline 2 & 1489 & 8. 88 & 1. 01 & .00 & 2. 32 \\
\hline 3 & 1593 & 11. 38 & .33 & .98 & .60 \\
\hline 4 & 1956 & 8. 28 & 1. 11 & 1. 65 & 1. 50 \\
\hline 5 & 1086 & 10.30 & .85 & .15 & 1. 53 \\
\hline 6 & 2141 & 8. 84 & 3. 31 & $\begin{array}{ll}\mathrm{A} & 5.54 \\
\mathrm{~B} & 2.65\end{array}$ & $\begin{array}{l}\text { 1. } 46 \\
\text { 2. } 22\end{array}$ \\
\hline & & & & C 1.26 & 3. 18 \\
\hline 7 & 1497 & 7. 15 & 1. 23 & .00 & 3.08 \\
\hline 8 & 1507 & 3.56 & 4. 69 & 1. 74 & 4. 03 \\
\hline 9 & 2165 & 3. 66 & 5. 30 & 1. 66 & 4. 92 \\
\hline 10 & 1552 & 7. 14 & $\ldots$ & 1. 47 & 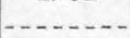 \\
\hline 11 & 1591 & 9. 03 & - - - & 1. 61 & $-1-2-1$ \\
\hline 12 & $\ldots$ & 7. 16 & 2. 03 & 1. 46 & 2.30 \\
\hline
\end{tabular}

Pebble from Allonez conglomerate, Allouez mine, T. M. Broderick, analyst. Iron-rich pebble, Calumet \& Hecla conglomerate, T. M. Broderick, analyst. 3. Amygdaloidal boulder in Calumet \& Hecla conglomerate, G. L. Heath, analyst.

4. Top of Kearsarge lode, Ahmeek mine, G. L. Heath, analyst.

Top of Kearsarge lode, South Kearsarge mine, G. L. Heath, anslyst.

6. Kearsarge lode, A hmeek mine, A, B, C, progressive stages of bleaching, G. L. Heath, analyst.

7. Osceola lode, Centennial mine, G. L. Heath, analyst.

8. Isle Royale, Isle Royale mine, H. C. Kenny, analyst.

9. Composite sample of Isle Royale lode and bleached equivalent, G. L. Heath, analyst.

10. Sandstone from lens partly mineralized, Calumet \& Hecla conglomerate, I. C. Kenny, analyst.

11. Iron-rich boulder, Calumet \& Hecla conglomerate, H. C. Kenny, analyst. 12. Average of 10 specimens representing lodes of different types. 
Figure 17 illustrates the change in iron accompanying mineralization for a number of typical examples. The principal constituents of the unaltered and bleached rock are shown in the following analyses:

Analyses of unaltered and bleached rock

[Specimens in collection of Calumet \& Hecla Consolidated Copper Co. H. C Kenny, analyst]

\begin{tabular}{|c|c|c|c|c|c|c|}
\hline & 1a & $1 \mathrm{~b}$ & $2 \mathrm{a}$ & $2 \mathrm{~b}$ & $3 a$ & $3 b$ \\
\hline \multirow{7}{*}{$\begin{array}{l}\mathrm{SiO}_{2} \\
\mathrm{Al}_{2} \mathrm{O}_{3} \\
\mathrm{Fe}_{2} \mathrm{O}_{3} \\
\mathrm{FeO} \\
\mathrm{CaO} \\
\mathrm{MgO} \\
\mathrm{H}_{2} \mathrm{O} \\
\mathrm{CO}_{2} \\
\mathrm{Cu} \text { (native) }\end{array}$} & $\begin{array}{l}57.7 \\
14.2\end{array}$ & $\begin{array}{l}62.8 \\
16.6\end{array}$ & $\begin{array}{l}63.1 \\
14.7\end{array}$ & $\begin{array}{l}53.1 \\
12.7\end{array}$ & $\begin{array}{l}51.4 \\
20.0\end{array}$ & $\begin{array}{l}55.3 \\
21.0\end{array}$ \\
\hline & $\begin{array}{l}14.2 \\
11.2\end{array}$ & $\begin{array}{r}\text { 10. } 1 \\
\text { 2. }\end{array}$ & 10. 2 & 2. 1 & 12. 9 & 2. 3 \\
\hline & 1. 1 & .5 & & & 3.4 & 4. 8 \\
\hline & $\begin{array}{l}6.7 \\
3.5\end{array}$ & & $\begin{array}{l}\text { 5. } 2 \\
\text { 1. } 7\end{array}$ & $\begin{array}{l}\text { b. } 4 \\
\text { 3. } 3\end{array}$ & 2. 8 & $\begin{array}{l}4.8 \\
3.8\end{array}$ \\
\hline & & $\{1.0$ & .6 & 1. 6 & 5. 0 & 7. 2 \\
\hline & .06 & $\begin{array}{l}.6 \\
.05\end{array}$ & $\begin{array}{l}\text { 1. } 4 \\
\text { 1. } 55\end{array}$ & a $\begin{array}{l}2.2 \\
9.75\end{array}$ & $\begin{array}{l}1 \\
.48\end{array}$ & $\begin{array}{l}.5 \\
.38\end{array}$ \\
\hline & 92.5 & 95.4 & & & & \\
\hline
\end{tabular}

a 15.0 per cent of copper removed before analysis.

1a, Dark, hard, oxidized rock from Kearsarge lode, Ahmeek mine; 1b, bleached

equivalent associated with copper.
$2 \mathrm{a}$, Red sandstone, Calumet \& Hecla conglomerate; $2 \mathrm{~b}$, mineralized portion of

same stratum. $3 \mathrm{a}$, Iron-rich boulder, Calumet \& Hecla conglomerate; $3 \mathrm{~b}$, bleached equivalent associated with copper.

It is apparent from these chemical results, as well as from the microscopic study of the rocks, that the copper-depositing solutions first attacked the hematite and that the iron was largely removed or recombined

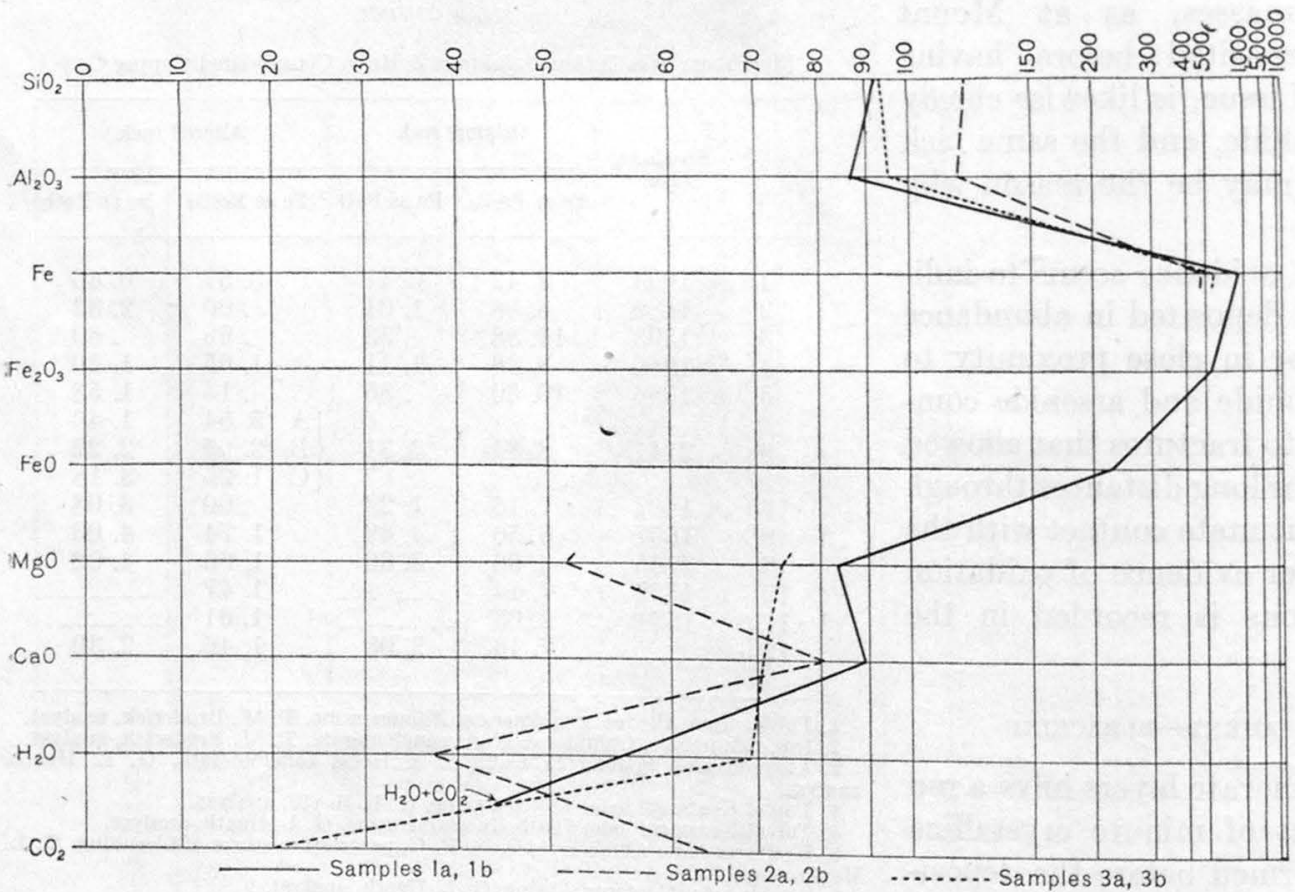

FIGURE 18.-Composition of bleached and unbleached rock. (For explanation of manner of constructing the diagram see fig. 5 , p. 40.)

before there was any conspicuous change in the other constituents. The copper replaced the rock substance as a whole, but in advance of this replacement the hematite was destroyed and the iron removed either entirely or in part, and whatever remained was combined into other minerals. (See pls. 72, 73.)

The general tendency in the alteration that produces bleaching is a removal of considerable ferric iron and a somewhat less marked conversion of ferric to ferrous iron. The fact that there has been some reduction of ferric to ferrous iron points to the probability that the iron that has been removed was also first reduced to the ferrous state, because under the conditions that probably existed ferrous compounds are more soluble than ferric.

If ferric iron was reduced to ferrous iron, there must have been an oxidation of the agent that accomplished the reduction, and it is of interest to know what that agent was.

Among the reducing agents that might have been present are carbon, carbon monoxide, hydrocarbon, hydrogen, and sulphur or some incompletely oxidized form of sulphur. As calcite is plentiful, it is possible that some less oxidized carbon-bearing material acted as the reducing agent and was itself oxidized to the carbonate condition. Lane has, indeed, suggested that the hydrocarbon which R. T. Chamberlin found in rocks of this district acted as a reducing agent, though Lane assumes that it acted on oxidized copper compounds. Hydrocarbons are, however, no more plentiful in the rocks here than in many other regions where no such peculiar results as deposition of native copper and destruction of hematite are found; there is no significant connection between the occurrence of calcite and either deposition of native copper or bleaching, and a the White Pine mine, where a solid hydrocarbon, most probably derived from the adjacent carbonaceous shale is present in fair abundance, the amount of bleaching is not conspicuously greater than where hydrucarbon occurs only in mere traces or not at all, but sulphides are more plentiful there in proportion to copper than at any other place in red rocks in the district.

It has been suggested that the bleaching around copper resulted from the reaction between the ferric oxide and the metallic copper and therefore occurred after the copper was deposited. Such a reduction of ferric oxide is readily accomplished and is, indeed, a difficulty in chemical analyses when ferric oxide is determined in the presence of metallic copper. Moreover, some of the copper ore when brought to the surface shows a thin film of green copper carbonate or of red oxide of copper surrounding the metal, and this has been suggested as the oxidized copper compound produced in the reaction cited. Examination and inquiry show, however, that the copper 
when the rock is first broken is not green but bright and metallic or at most covered by a mere film of ouprite. Moreover, the removal of hematite is not the only effect in the bleached areas. In the amygdaloid lodes in particular, the destruction of hematite was accompanied by an intense mineralogic, chemical, and textural breakdown of the rock surrounding the copper-an alteration that would not be likely to result from the mere action of the metallic copper on the rock.

There is no doubt that the metallic copper was replacing the bleached rock - that is, that the removal of iron, although everywhere going on at the same time as the deposition of copper near by, was accomplished st any given point in advance of the precipitation of copper; bleaching was the front of the alteration wave; replacement by copper was the end.

The practical absence of bleached spots without accompanying copper further indicates that deposition of copper and bleaching of rock were intimately asso ciated and that copper has not been removed since its deposition. The exceedingly low copper and iron content of the mine waters likewise proves that reaction between iron and copper is not now in progress, or, if at all, to only a very slight extent.

The hypothesis that copper sulphide solutions acted as the reducing agent that destroyed the hematite appears to fit the facts in a satisfactory way and at once explains both the bleaching of the rock and the deposition of copper in the native state. The power of the metallic sulphides as reducing agents is shown by the ease with which they take up oxygen to form sulphates-far more readily, for instance, than the ferrous iron minerals succumb to oxidation. In the oxidation of the "sulphide solution" the process has gone so far as to oxidize the sulphur, but the copper was deposited as metal.

The copper occurs generally in irregular masses rather than uniformly distributed through the lode. It is impossible to assume that the replaced rock itself could supply enough reactive agent of any kind to cause the precipitation of three times its own weight of copper, either in the small particles or in the great masses tons and even hundreds of tons in weight. It is more likely, as suggested in connection with the saturation hypothesis (p. 129), that the reaction was taking place as the solution passed through the lode until such a degree of concentration was reached that copper precipitation had to begin.

In places copper is accompanied by only slight if any immediately local bleaching. This is the case, for example, in parts of the Pewabic lode, in the upper levels of the Calumet \& Hecla conglomerate mine, and in the copper-bearing fissures that cut the Kearsarge lode.

Wells has found in his experiments that the metallic copper commonly does not replace the solid reagent that causes the precipitation but rather grows out into the free solution, often not in contact at all with the precipitant. The laboratory experiments thus appear to be in harmony with the natural occurrence.

Copper was deposited in the cross fissures chiefly at and near their intersections with thick hematite-rich lodes. Where in the Ahmeek and Mohawk mines some of these fissures, notably the Mass fissure, cross the Kearsarge lode, the destruction of hematite is of a different type from that seen in the bleached rock that so commonly surrounds the copper. Along these copper-bearing cross fissures for a width of 10 to several tens of feet the Kearsarge lode is darker and leaner than usual. Along the Mass fissure in the Ahmeek mine the dark lean zone extends for 80 to 100 feet on each side of the fissure. Determination of iron oxides shows the following contrast between the dark material and the normal red material near by:

Alteration of Kearsarge lode near Mass fissure

\begin{tabular}{l|r|r}
\hline & $\mathrm{Feas}_{2} \mathrm{Fe}_{3}$ & $\mathrm{Fe}$ as $\mathrm{FeO}$ \\
\hline Normal red lode__. & & \\
\hline Altered dark lode. 11 & 0.68 \\
\hline
\end{tabular}

The changes indicated by these analyses suggest that the solutions moving generally along the fissure but soaking into the Kearsarge lode were at that time and place able to destroy but little of the ferric iron but were, on the contrary, relatively highly charged with ferrous iron, which they precipitated. Microscopic examination of the dark material reveals a difference in two respects from the normal rock of the Kearsarge lode- $(a)$ much chlorite has been introduced throughout and accounts for about all the added ferrous iron; $(b)$ all the finer flakes and particles of hematite have been removed and with them the red color, but the larger grains of hematite, which make up the greatest part, by weight, are still present and account for the small decline in ferric iron content notwithstanding the marked change in color.

It seems probable that the solutions moved along the intersection of the fissure with the Kearsarge lode; the main avenue of flow was through the fissure, but there was always local penetration into the permeable lode, and in consequence the solutions, before reaching the levels now exposed in the mine, were oxidized at the expense of the hematite of the lode and became charged with ferrous iron and uncombined copper. Having undergone these reactions, the solutions deposited the constituents with which they had become saturated, but the copper was deposited mainly in the fissure itself as masses of native metal while the ferrous iron, which could not be precipitated alone, was deposited as chlorite partly along the fissure and partly in the lode. The lode rock, because of its glassy condition, was probably more susceptible to 
reaction than the trap that in the main bounds the fissure.

The channel afforded by the fissure and the immediately adjacent parts of the lode probably constituted an easier avenue for ascent than that offered by the lode alone. The solutions flowing along the fissure, therefore, should have reached the altitude of the present mine workings before those which moved up the lode and accomplished the normal mineralization characteristic of the Kearsarge. If so, the alterations just described had been accomplished, in part at least, near the fissure by the time the normal lode solutions reached that point. With the most finely divided and hence the most reactive of the hematite already gone, the lode near the fissure was less favorable for precipitating copper from the later solutions than the lode away from the fissure.

It is not definitely known whether such copper as occurs in the darkened zone along the fissure was deposited by the fissure solutions, by the lode solutions, or by both. The descriptions of certain of the fissure veins of Keweenaw County mined in earlier days, notably the Cliff and the Central, indicate that some lodes contained sufficient copper to warrant exploration of them outside the limits of the fissures or fissure zone; and as a rule the exploration of these "floors," as they were called, was abandoned not far from the fissures. The natural inference is that certain of the lodes close to the cross fissures had been mineralized by the solutions, which in the main were traveling along the fissures themselves.

The arsenide fissures that cross the Kearsarge lode carry iron carbonate in considerable abundance, and an iron carbonate is characteristically present in the sulphide fissures in and near the Baltic lode. It is evident, therefore, that the solutions that traversed the fissures were also relatively rich in ferrous iron.

PRESENCE OF SULPHATES

If copper sulphides were oxidized and in consequence precipitated native copper, the oxidation would obviously affect the sulphur. What condition or combination of sulphur might actually be expected?

Elemental sulphur is known to be formed from the oxidation of sulphide and from the oxidation of certain sulphur-bearing hot-spring waters, but these occurrences do not justify the inference that sulphur should have been formed in the Michigan copper deposits. Sulphur dioxide, which is present in volcanic emanations, may be produced in part by the oxidation of sulphides, directly or indirectly, and it is known to be formed in small quantity from the artificial oxidation of pyrite under certain conditions. The sulphite salts derived from it (or from sulphurous acid- $-\mathrm{H}_{2} \mathrm{O}+\mathrm{SO}_{2}$ ) are either easily soluble or unstable, and so it could not be expected that any of these sulphur compounds would now be present, no matter how much $\mathrm{SO}_{2}$ may have formed.

In nature oxidized sulphur occurs by far the most commonly as sulphate, and when solid sulphides oxi. dize, sulphates and sulphuric acid are formed from all or nearly all the sulphur of the sulphides; more. over, as has been indicated elsewhere, ${ }^{37}$ the sulphates present as gangue minerals in primary ore deposits have probably been derived by hypogene oxidation of sulphur-bearing solutions. Sulphates are the only oxidized compounds of sulphur that are likely to form minerals and be found in the deposits, but, as only a few of the sulphates are notably insoluble, it is not to be expected that even the sulphates will be found in abundance.

Sulphuric acid, if formed, would undoubtedly unite with one or more bases; so only sulphate salts would be expected. If copper sulphide were oxidized by hematite, one probable product of the reaction would be ferrous sulphate. It is certain, however, that if the solutions contained bases that form relatively insoluble sulphates such sulphates would form and be precipitated in accordance with their abundance and solubility. The sulphates of most of the common elements in the Michigan rocks are highly soluble. This is true of sodium, potassium, magnesium, and aluminum, and it is true of ferrous iron except when in contact with an oxidizing agent of stronger power than hematite. The present mine waters contain only slight and occasional traces of sulphates, though gypsum is being precipitated from mine waters in the Victoria mine; but unless it is shown that the present mine waters are part of those that deposited the ores, the presence or absence of sulphates in these waters is of no particular significance.

The barium and calcium sulphates barite, anhydrite, and gypsum occur in the Michigan deposits and are the only sulphates sufficiently insoluble to be expected. Barite accounts for all of the barium, so far as known, but the two calcium sulphates account for only a very small fraction of the total calcium present in the lodes. The total quantity of sulphate represented by these three minerals is far too little to account for all the sulphur of the solutions if the native copper came from sulphide. In explanation of this discrepancy, reference may be made to the behavior of the sulphate radicle in regions where sulphide ores undergo superficial oxidation. In camps like Bisbee and Globe, in Arizona, great quantities of sulphide ore contained in limestone have been oxidized near the surface, with the production of correspondingly great quantities of soluble sulphates and sulphuric acid; these have plainly enough reacted with the adjacent limestone and must have formed calcium sulphate on an enormous scale, yet the

2? Butler, B. S, Primary (hypogene) sulphate minerals in ore deposits: Bcon. Geology, vol. 14 , p. $581,1919$. 
mineral gypsum is present only sparsely in and near these oxidized ore bodies. This is due in part to the rather ready solubility of calcium sulphate in water.

A comparison with other districts where sulphate solutions are known to have formed in large quantity is doubtless the most reliable source of an explanation of the conditions in the Michigan district. Sufficient facts and experimental data are not available to afford a reliable interpretation of conditions so complex as those that affected the ore solutions in this district, though certain experimental facts may be pointed out. These are taken mainly from a paper by Stieglitz. ${ }^{38}$ In a saturated water solution of calcium carbonate and calcium sulphate, at $18^{\circ} \mathrm{C}$., the concentration of sulphate ionsis five thousand times greater than that of carbonate ions. $\mathrm{CO}_{2}$ increases the solubility of calcium carbonate in solution as bicarbonate, and this effect continues with increase in pressure of $\mathrm{CO}_{2}$. The presence of other sulphates decreases the solubility of calcium sulphates. The solubility of calcium sulphate and calcium carbonate is increased by the presence of sodium chloride up to a certain concentration, above which that of both decreases. Increase in temperature reduces the solubility of calcium sulphate, which is but slightly soluble at $200^{\circ} \mathrm{C}^{39}$ Increase in temperature also reduces the solubility of $\mathrm{CO}_{2}$ and in consequence probably that of calcium carbonate.

Too little is known of the influence of these several factors to warrant any definite conclusions, but perhaps the relatively high temperature of formation accounts for the fact that any calcium sulphate was precipitated. The argument with respect to oxidation products of sulphides may be summarized as follows. Such oxidation products were probably carried away for the most part in the form of gas or of soluble salt, either of which would be dissipated with relative ease soon after the mineralizing process had ceased. The only sulphates produced by sulphide oxidation that could be expected to remain are the sulphates of barium and calcium. Barite in fact is present perhaps as plentifully as the general scarcity of the element barium would permit, and anhydrite and gypsum are present as plentifully as the solubility of calcium sulphate would permit and as plentifully as they are found in other regions where calcium sulphate must have been produced in great quantity. All three sulphate minerals have been found only in the immediate vicinity of copper-a fact which may well be regarded as evidence that they are products of the reaction by which the metallic copper was formed.

The gypsum which is abundantly present, together with some barite and celestite, in and near the Coro

\footnotetext{
"Stieglitz, Julius, The relations of equilibrium between carbon dioxide of the strooshere and the calcium sulphate, calcium carbonate, and calcium bicarbonate 1" Tater solution in contact with it: Carnegie Inst. Washington Pub. 107, 1909.

"Melcher, A. F., $\Lambda \mathrm{m}$. Chem. Soc. Jour., vol. 32, pp. 50-66, 1910.
}

Coro deposits of Bolivia was likewise explained by Steinmann as formed from the sulphate radicle produced by the oxidation of the sulphur of the copper sulphide solutions. Carbonates are not abundantly associated with the Coro Coro deposits.

CHEMISTRY OF THE DEPOSITION OF NATIVE COPPER FROM ASCENDING SOLUTIONS

By R. C. WeLLS

As a very considerable weight of evidence indicates that the native copper in the Lake Superior district was deposited from solutions that may be characterized in a broad way as ascending, the chemical problem of accounting for the deposition of the copper as native metal is thereby delimited to a certain extent. Many of the conditions attendant on its deposition are unknown, as the solvents with all their more soluble dissolved matter have presumably disappeared, and the solids remaining are relatively few in number and simple in chemical character. But, on the other hand, the idea of ascending solutions, especially on the large scale exemplified in the Michigan district, implies certain general conditions, partly physical, partly chemical, which suggest a simple classification of the possibilities. The conditions, or rather the changes in conditions, that would naturally be expected to exist in association with ascending solutions, are, in the order of their probable importance, cooling, relief of pressure, oxidation, dilution, and reduction of acidity. Chemical suggestions based on old or new experimental evidence are offered herewith under each of these heads. The details of most of the new experiments are given in a separate publication, ${ }^{40}$ and what is presented here is largely a summary unencumbered with the chemical details. Needless to say, the experimental field is still far from covered, as neither melts, vapors, alkaline solutions, nor solutions above $300^{\circ} \mathrm{C}$. have been studied to any great extent. The results are such as could be obtained with workable solutions and the apparatus available. They are sufficient, however, both to supplement and to modify previous knowledge.

\section{DEPOSITION BY COOLING}

Hot solutions carrying cuprous sulphate deposit metallic copper on cooling. This action is believed to occur as the result of the change

$$
\mathrm{Cu}_{2} \mathrm{SO}_{4}=\mathrm{Cu}+\mathrm{CuSO}_{4}
$$

so that only part of the copper can be thus removed from solution. Cuprous sulphate may be formed in a number of ways-for instance, by the action of copper on cupric sulphate, by the action of various sulphides on cupric sulphate, or by partial oxidation of copper sulphides.

10 Wells, R. C., Chemistry of the deposition of native copper from ascending solutions: U. S. Geol. Survey Bull. 778, 1925. 
As metallic silver accompanies copper in a few deposits it is of interest to note that metallic silver is likewise deposited when certain solutions are cooled, as indicated by thə two following reactions:

$$
\begin{gathered}
\mathrm{Ag}_{2} \mathrm{SO}_{4}+\mathrm{Cu}_{2} \mathrm{SO}_{4}=2 \mathrm{Ag}+2 \mathrm{CuSO}_{4} \\
\mathrm{Ag}_{2} \mathrm{SO}_{4}+2 \mathrm{FeSO}_{4}=2 \mathrm{Ag}+\mathrm{Fe}_{2}\left(\mathrm{SO}_{4}\right)_{3}
\end{gathered}
$$

Gold behaves similarly, as shown by Stokes:

$$
\mathrm{AuCl}_{3}+3 \mathrm{CuCl}=\mathrm{Au}+3 \mathrm{CuCl}_{2}
$$

All these equations represent reversible reactions that proceed toward the right with falling temperature and in the opposite direction with rising temperature.

Vapors and melts would become more or less fixed by cooling also, but they can not be adequately discussed at present. Nor is it purposed to discuss in this place whether the theory here set forth or any of the other theories proposed would apply to a relatively local movement of the fluids from the interior of a lava flow to its cool top as well as to movement on a much larger scale.

\section{DEPOSITION BY RELIEF OF PRESSURE}

The solubility of most salts changes very slightly with pressure. For example, that of copper sulphate is known to increase with pressure some 3.2 per cent for 60 atmospheres, but that such a change could be significant in the problem under discussion seems doubtful. The solubility of gases, on the other hand, is affected to an enormous extent by changes in pressure, and, as gases like $\mathrm{CO}_{2}$ and $\mathrm{H}_{2} \mathrm{~S}$ increase the solubility of the carbonates and sulphides to a marked extent, it is evident that relief of pressure would favor the deposition of such compounds-that is, if the gases escape from solution. Carbonates are present in the copper lodes - in fact, copper and calcite are beautifully intergrown in some specimens. The escape of carbon dioxide through relief of pressure is a possible explanation for the formation of the calcite. Nothing is known as to the solution or precipitation of copper itself through changes in pressure, except that indirectly the reducing action of hydrogen and sulphur dioxide on copper compounds is increased by moderate increases in pressure, as much more of these gases is thereby held in solution. This fact would not account for precipitation through relief of pressure, however, and it probably has no application to the problem of the deposition of copper.

\section{DEPOSITION BY FRACTIONAL OXIDATION OF COPPER SCLPHIDE}

The theory that native copper was formed by the oxidation of copper sulphide in solution by ferric oxide in the rocks of the lodes has been advocated with confidence by the authors of this report, largely on the basis of field evidence. The formation of metallic copper by oxidation of the sulphide is a familiar operation in smelting practice. Analogous reactions, based on the oxidizing action of cupric salts and ferric salts, are cited in the literature. The action of acid. ified ferric salts on the sulphides of copper under ordinary conditions appears to result in the formation of ferrous and cupric salts, so that the problem resolves itself in part into a study of the oxidation of copper sulphide by cupric salts.

Considerable study has been given to these various possibilities. The theory here proposed implies chemical reaction. There are other grounds in the field relations for thinking that the solutions were ascending, and such solutions would be logical sources of copper sulphide. In the experimental work, however, it has not yet been possible to produce metallic copper merely by chemical reaction unaccompanied by cool. ing. In so far as cooling has been an essential part of the verification of the theory, the idea of ascending solutions receives support. The experimental evidence indicates, however, that at a still higher temperature than could be conveniently attained with the apparatus available, copper might be deposited by reaction alone and thus the theory rendered independent of the feature of cooling.

The steps by which ferric oxide may act on a solution of copper sulphide are as follows: Hot acid solutions containing copper and sulphur, assumed for the sake of simplicity to be equivalent in their chemical potentialities to acid solutions carrying cuprous sulphide, meet ferric oxide. The acid is decreased by solution of some ferric oxide. The ferric salt thus formed exerts an oxidizing influence, which is, however, at once balanced by the reducing action of cuprous sulphide, with the production of ferrous sulphate and cupric sulphate, as indicated by the following reaction:

$\mathrm{Cu}_{2} \mathrm{~S}+5 \mathrm{Fe}_{2} \mathrm{O}_{3}+11 \mathrm{H}_{2} \mathrm{SO}_{4}=10 \mathrm{FeSO}_{4}+2 \mathrm{CuSO}_{4}+11 \mathrm{H}_{2} \mathrm{O}$

The oxidizing action of the ferric salt seems to carry the copper to the cupric stage at first and rather rapidly. Further work is needed to see if the reaction can be sufficiently slowed down through the use of less acid to yield chiefly cuprous sulphate. However experiment shows that when further cuprous sulphide is available, its presence, as well as the decrease of acidity and the formation of water and cupric sulphate, favors the reactions

$$
\begin{aligned}
& \mathrm{Cu}_{2} \mathrm{~S}+8 \mathrm{CuSO}_{4}+4 \mathrm{H}_{2} \mathrm{O}=5 \mathrm{Cu}_{2} \mathrm{SO}_{4}+4 \mathrm{H}_{2} \mathrm{SO}_{4} \\
& \mathrm{Cu}_{2} \mathrm{~S}+3 \mathrm{CuSO}_{4}+4 \mathrm{H}_{2} \mathrm{O}=5 \mathrm{Cu}+4 \mathrm{H}_{2} \mathrm{SO}_{4}
\end{aligned}
$$

The second of this pair of reactions may possibly occur at a very high temperature but has not yet been realized experimentally. However, the first reaction yields cuprous sulphate, which deposits copper on cooling. The consumption of cuprous sulphide in these ways would obviously leave less of it to be deposited as the solutions cooled, whereas copper would still be deposited on cooling. Conditions favoring the deposition of copper would be an 
initial high temperature; the reduction of acidity to the point where no more ferric oxide would be attacked of the local exhaustion of the ferric oxide by the solution and reduction as outlined; and, lastly, cooling and dilution of the initially heated solutions. In this way the sulphur would make its exit as ferrous sulphate. A reaction that embraces all the steps mentioned would be

$$
\mathrm{Cu}_{2} \mathrm{~S}+3 \mathrm{Fe}_{2} \mathrm{O}_{3}+5 \mathrm{H}_{2} \mathrm{SO}_{4}=2 \mathrm{Cu}+6 \mathrm{FeSO}_{4}+5 \mathrm{H}_{2} \mathrm{O}
$$

Metallic copper has been obtained experimentally from the substances indicated in this equation after heating them with water in sealed tubes to $300^{\circ}$ and cooling.

It would be highly desirable to show that solutions of less acidity, such as those containing carbon dioxide under high pressure, would yield similar results, but the writer has not yet been able to do so. Some acid seems necessary to give the ferric iron sufficient sctivity to initiate the action, and the proper range sppears to be one in which some ferric oxide dissolves to give a definite oxidizing action, likewise insuring that a large excess of ferrous salt will not precipitate copper, so that only the sulphur and neither the ferrous ivon nor the copper shall be oxidized. Experiments at ordinary temperatures, at which the activities of the sereral reagents could be better regulated, would also be desirable, but the reactions involved occur too slowly at such temperatures for observation within the time available.

In view of the difficulties of reproducing the natural conditions exactly the writer feels that the experimental evidence makes this theory of the origin of the Lake Superior copper a tenable one aside from the strong field evidence in its favor.

\section{DEPOSITION BY DILUTION}

Solutions carrying considerable cuprous chloride, which is largely soluble in certain brines and other concentrated solutions, deposit copper on being gradually diluted. This mode of origin may account lor some of the "mass" copper in the Lake Superior mines where cross fissures have permitted the intermingling of the concentrated brines with more dilute solutions, although it is evident that such a view renders the deposition of the mass copper not necessarily contemporaneous with the deposition in the main lodes. The reaction for this change is

$$
2 \mathrm{Na}_{2} \mathrm{CuCl}_{3}=4 \mathrm{Na}^{+}+\mathrm{Cu}+\mathrm{Cu}^{++}+6 \mathrm{Cl}^{-}
$$

That is, a complex or double salt that exists in the concentrated solutions breaks up into single salts on dilution, with accompanying precipitation of some of the copper.

\section{DEPOSITION BY REDUCTION OF ACIDITY}

Moderate changes in acidity or alkalinity are generally characterized by the chemist as changes in the
Sorensen number or $\mathrm{pH}$ value, which defines the hydrogen-ion concentration of the solution by the equation

$$
\mathrm{pH}=-\log \left[\mathrm{H}^{+}\right]
$$

in which $\left[\mathrm{H}^{+}\right]$represents the concentration of the hydrogen ion in gram-equivalents per liter.

The $\mathrm{pH}$ number of ore-forming solutions is of considerable importance and has not been studied as much as it deserves to be. It is obvious that as solutions pass from an acid to an alkaline reaction the solubility products of the oxides will be reachedfor example, those of ferric oxide, copper oxide, and ferrous oxide - in the order of respective increasing solubility. The $\mathrm{pH}$ number likewise determines to a large extent the solubility of other ore and gangue minerals, such as the sulphides and carbonates. But the concentrations of the valuable metals in aqueous solutions that would be furnished by such compounds under ordinary conditions are extremely small-so small, in fact, that they are not within the range of ordinary analytical determination. It seems highly improbable, likewise, that such small concentrations have played any part in the transportation of ores; for if they had, ore deposits could not be formed at all. It is the task of the chemist who is seeking to explain the genesis of ores to point out special instances of solubility and the conditions that effect changes of solubility and to search for such conditions if they are not known.

In this investigation alkaline solutions with $\mathrm{pH}$ values much greater than 5.5 seemed to offer little aid toward solving the problem, inasmuch as ferrous salts, which were almost certainly present in abundance in the ore-forming solutions, would cause deposition of both copper and ferric oxide. In experiments with solutions saturated with ferric oxide at ordinary temperature, the writer has found that the $\mathrm{pH}$ number must be as low as 5.5 before a test for ferric iron can be obtained with potassium sulphocyanate. Solutions of even so low an acidity as this would therefore have geologic significance.

Precipitation of copper by ferrous salts, the agency long held to account for the formation of native copper in the Lake Superior district, can occur only if hydrolysis of the ferric salts to insoluble ferric oxide is brought about through continuous neutralization or continuously increasing heat - that is, by an increase of the $\mathrm{pH}$ number.

The writer's recent experiments on this method of deposition show that when ferrous hydroxide is used as the reducing and neutralizing agent, acting on cuprous chloride solutions, both of the following reactions occur:

$$
\begin{aligned}
& 3 \mathrm{FeO}+2 \mathrm{CuCl}=2 \mathrm{Cu}+\mathrm{Fe}_{2} \mathrm{O}_{3}+\mathrm{FeCl}_{2} \\
& 4 \mathrm{FeO}+2 \mathrm{CuCl}=2 \mathrm{Cu}+\mathrm{Fe}_{3} \mathrm{O}_{4}+\mathrm{FeCl}_{2}
\end{aligned}
$$


Deposition of copper from cuprous chloride solutions may be brought about even by ferrous chloride, however, when the $\mathrm{pH}$ number is carefully regulatedas, for instance, by means of definite proportions of acetic acid and sodium acetate. When ferrous chloride and cuprous chloride are introduced into such solutions, boiling in an atmosphere of nitrogen, no copper is precipitated if the $\mathrm{pH}$ value is initially less than about 5.0. In one experiment with a $\mathrm{pH}$ value of 5.2 a slight film, probably containing some copper, formed on the walls of the flask in the course of two hours' boiling. With a pH value of 5.38 the deposit showed some small particles of ferric oxide, each surrounding a nucleus of minute crystals of copper visible with a lens.

Repetition of the experiment with more ferrous chloride and less cuprous chloride, in a flask with a slight film remaining from the previous experiment, gave a deposit showing under a lens or a microscope numerous crystals of copper, some spicules, and some thick crystals showing triangular faces, most of them largely covered with iron oxide, which also adhered to the glass in the form of minute lumps and flocs without definite form. This iron oxide was not magnetic. The reaction occurring in this case may be written

$$
\begin{aligned}
& 2 \mathrm{FeCl}_{2}+2 \mathrm{CuCl}+ 6 \mathrm{NaCOOCH}+3 \mathrm{H}_{2} \mathrm{O}= \\
& 2 \mathrm{Cu}+\mathrm{Fe}_{2} \mathrm{O}_{3}+6 \mathrm{HCOOCH}_{3}+6 \mathrm{NaCl}
\end{aligned}
$$

These experiments show that the use of ferrous hydroxide is not absolutely necessary for the deposition of metallic copper but that more soluble ferrous compounds suffice; that copper is a recognizable product when the reaction is made to occur very slowly; and that the deposition of copper is not dependent on cooling, a point previously unsettled.

This mode of forming native copper can obviously not be left out of consideration entirely, because of the common association of ferrous and copper compounds, and it might be viewed as an adjunct to any theory in which mixtures of ferrous and cuprous salts are involved. On it Smyth based his theory of the deposition of copper from ascending solutions, which the writer has ventured to supplement with the process of neutralization. Neutralization is suggested in order that the initial solutions can be assumed to have been not very alkaline, so that appreciable concentrations of copper salts and ferrous salts could be present in them. If the initial solutions were alkaline in the presence of ferrous compounds it is difficult to see how significant quantities of copper could have been transported. But cooling must also usually occur in ascending solutions, and, as has been shown above, cooling alone will deposit copper from slightly acid solutions containing cuprous and ferrous sulphates, so that reduction by ferrous compounds is not absolutely needed as an explanation of the deposition of the copper.
The theory of reduction by ferrous compounds has been advocated by several geologists without regard to whether the cupriferous solutions were ascending or descending, and some study has been given to the neutralizing action of the lode minerals. For example, Lane and Fernekes found that prehnite and datolite were more active than labradorite and laumontite. Lane's equation for this action is

$$
\begin{gathered}
2 \mathrm{FeCl} \\
2
\end{gathered}+2 \mathrm{CuCl}+3 \mathrm{CaSiO}_{3}=2 \mathrm{Cu}+\mathrm{Fe}_{2} \mathrm{O}_{3}+3 \mathrm{SiO}_{2}+
$$

This equation is also an attempt to explain the calcium chloride waters now found in the deeper levels of the mines. Beyond calling attention to the small quantity of such waters in the mines, relative to the copper, the writer will only refer to the discussion of this feature of the problem in another section. All the reactions elucidated by Biddle, Stokes, Fernekes, and Lane, however, involve deposition of $\mathrm{Fe}_{2} \mathrm{O}_{3}$, whereas the present study has been devoted largely to the attempt to explain the dissolving of $\mathrm{Fe}_{2} \mathrm{O}_{3}$ in connection with the deposition of copper, which field evidence so strongly indicates.

In the light of present knowledge it appears difficult to decide whether ascending solutions would in general tend to become more acid or less acid in their reaction. In so far as they undergo oxidation they would probably become more acid, but the loss of such gases as $\mathrm{H}_{2} \mathrm{~S}, \mathrm{CO}_{2}$, and $\mathrm{SO}_{2}$ would have the opposite effect, so that it is difficult to be certain of the final result. A number of compounds, especially those of a saltike character, are decomposed by heat into free acids and bases, and such decomposition would certainly tend to occur to a greater or less extent at depth if such compounds are present. The acids, being volatile, could move into cooler regions, where they would recombine with any bases available, but the bases would be left at the point of decomposition. A somewhat similar result might be brought about through the action of silica as an "acid" in displacing the more volatile acids from their salts at high temperatures, but at low temperatures in aqueous solutions silica is an extremely weak acid in comparison with the strength of the bases with which it is generally associated. In other words, there seem to be several reasons for supposing that hot solutions and gases at depth would tend to be acid, whereas in cooler regions, except for the oxidation of sulphur compounds, alkalinity would become more pronounced.

This line of speculation favors the theory that copper might be deposited from ascending acid solutions through the agency of neutralization, but, if so, ferric oxide should accompany the copper, which does not generally appear to be the case in the Lake Superior ores. Moreover, this theory leaves sulphur compounds and the oxidizing action of ferric oxide out of consideration, and for that reason it can not be given 
first place as an explanation of the formation of the Lake Superior copper.

\section{CONCLUSIONS}

To recapitulate, five agencies that might effect the deposition of copper from ascending solutions have been considered-(1) cooling, (2) relief of pressure, (3) oxidation, (4) dilution, (5) reduction of acidity. Three of these agencies require specific constituents in the solution - the first, cuprous sulphate; the third, potential cuprous sulphide; the fourth, cuprous chloride. The third also demands an oxidizing environment for the incoming solutions, and the fifth is based on an environment that will neutralize acidity. Two of the agencies, however, may probably be excluded from consideration at once on account of the difficulty of defining the conditions with the necessary degree of certainty. These are the second and fifth.

The only application of the second agency that appears of importance as a possible cause of the deposition of native copper is the escape of certain acid gases, particularly carbon dioxide, which would leave the solutions more alkaline. This would tend to assist the deposition of copper by ferrous compounds, but other factors, such as oxidation, might tend to make the solutions more acid. It is extremely difficult to feel sure of the direction of the variation of acidity, so that it seems best to dismiss the fifth agency and with it the second from consideration. Another reason for doing so is the field evidence that the precipitating solutions seem to have dissolved ferric oxide rather than to have deposited it as required by the fifth agency for the deposition of native copper, and still a third reason is that sulphur compounds are not considered or their general absence explained by either the second or the fifth agencies.

The first and fourth agencies are so general that they might apply almost anywhere. They also require the presence of specific compounds, cuprous sulphate and cuprous chloride, respectively, and to call on them as explanations of a rather unusual type of ore, that of native copper, obviously requires some additional feature, such as, possibly, the large scale of the field. But this is as unwarranted as it is unnecessary. Thus the third agency is left as the only alternative explanation.

The third agency of deposition seems to fit the Lake Superior district best because the specific influence of ferric oxide in the gangue rocks is taken into account in determining the character of the copper mineral deposited, and it is probably unnecessary to delimit the character of the solutions further than to say that they were a potential source of cuprous sulphide and, so far as the necessities of the chemical experiments suggest, somewhat acid. The last statement might possibly imply nothing further than solutions containing large quantities of carbon dioxide. The general absence of sulphides is explained by the oxidizing action of ferric oxide, and the deposition of copper is explained by cooling of the resulting solutions at least, if not by a direct chemical reaction, which appears probable at moderately high temperatures.

\section{SUMMAR Y OF GENESIS}

In the preceding pages the several views regarding the origin of the native copper deposits of Michigan that have been advanced by previous investigators have been outlined, and the views held by the present writers have been elaborated in detail. A brief general summary of the argument may help the reader to judge the relative merits of all these proposed explanations. It will be emphasized in this review that the theory arrived at by the writers differs outstandingly from those of some others in postulating that the copper was deposited from ascending rather than descending solutions and was precipitated by oxidation of the ore solutions rather than by reduction. As in the fuller statement, origin, transportation, and deposition will be considered in turn.

\section{SOURCE OF COPPER}

If the deposits were formed by descending solutions the copper must have been derived from the general mass of the Keweenawan lavas, which are known to contain small amounts of copper-amounts comparable to those contained in similar rocks at many places. So far as known, this copper is pretty uniformly distributed. It is regarded by those who favor the view of descending waters as an ample source for the copper deposits. Those who favor the view of ascending solutions must also recognize this minutely disseminated copper as quantitatively sufficient, but they see no evidence that it has been concentrated. It is still contained in the traps to the extent of a few hundredths of 1 per cent. Is it reasonable to suppose that solutions would dissolve out a constituent present in minute quantity and concentrate it to the amount of 50 to 100 times without having a notable effect in dissolving the minerals that are present in much larger quantity?

Those who favor the view of an ascending origin consider the Duluth gabbro, which is believed to underlie the whole region, as the source of the copper. Copper in small amount is associated with the small offshoots of this igneous body, and to those whose experience has led them to look upon intrusive bodies as a source of ore deposits this source seems adequate, favorably located, and probable.

\section{TRANSPORTATION}

Gravity circulation of solution is regarded as the transporting agent in the theory of descending origin. Doubt is thrown on the sufficiency of that method by the very slow rate of gravity circulation as indicated by the dryness of the deep levels of the mines and by 
the difficulty of conceiving a gravity circulation as operative far below sea level, as it must have been under conditions at all like the present. Moreover, the position of many of the ore shoots beneath relatively impermeable rocks seems inconsistent with deposition by descending solutions.

The view of concentration by diffusion avoids some of the difficulties of gravity circulation but meets others in explaining why copper was not concentrated equally in all lodes of similar physical character and chemical composition and why the ore occurs so definitely in shoots.

In the theory of ascending origin the medium of transportation is regarded as the solutions given off by the crystallizing magma of the Duluth gabbro. These were heated liquids or gases and therefore very mobile and were under high pressure, which could force them in quantity through rocks where gravity circulation would be practically nil. The solutions either entered the lodes by the direct connection of the downward extension of the lodes with the igneous mass or were led into the lodes through faults or fissures that extended to the igneous mass. This explanation seems to furnish an entirely adequate means of transportation and one entirely similar to that believed to have been active in the formation of most primary copper deposits.

\section{CAUSE OF DEPOSITION}

The theory of descending origin assumes that the copper was carried as an oxidized compound and was deposited through reduction by ferrous iron.

The conglomerates and amygdaloids were very rich in ferric iron and poor in ferrous iron long before the copper was introduced. Moreover, the alteration of the rock associated with the copper indicates that when the copper was deposited the ferric oxide was actually reduced and ferrous oxide added-a fact which shows pretty clearly that reduction by ferrous oxide was not the process that formed the copper.

The theory of ascending origin assumes that the solutions were such as ordinarily deposit sulphides and were essentially reducing and that if they had encountered rocks of the ordinary composition they would have deposited sulphides. But because these solutions encountered rock with a high content of ferric iron there were chemical changes before precipitation. Ferric iron was reduced, sulphur was oxidized, and native copper was formed. The lodes rich in ferric iron would be the places most favorable for the precipitation of copper.

\section{OTHER RELATED DEPOSITS}

There are throughout the world other deposits of native copper in which the copper appears to have been deposited as nauve metal and not to have been formed by surface oxidation of some other mineral, such as chalcocite. The chief examples of such de. posits occur in Coro Coro, Bolivia; the Triassic areas of New Jersey and Connecticut; Cape d'Or, Nova Scotia; Oberstein, Germany; Commander Island, Russia; the Faroe Islands; Sao Paulo, Brazil; Upper Serbia; the Copper and White River districts, Alaska; the Comobabi Mountains, Arizona; Nora Zembla, Russia; and Coppermine River, Canada. The conditions of occurrence at these localities are set forth below:

Coro Coro, Bolivia.$^{41}$ - At Coro Coro occur the largest of a series of similar copper deposits that lie in a zone that extends across the Bolivian high plateau. The copper is found in the Puca red sandstone, of Creta. ceous age, in both vein and bedded deposits. Mineralization has occurred at a number of closely spaced horizons. The dominant copper mineral is the native metal, although the sulphide chalcocite and the arsenide domeykite are sparingly developed. Native silver is also found associated with the copper. Oxides of copper occur at the surface but give way to the native metal, which persists at least to 380 meters, the greatest depth attained by the present workings. The sandstone, which away from the ore has a distinctly red color tone due to iron oxide or hydroxide, is bleached in the vicinity of the ore. The copper is thus usually surrounded by a halo of whitish or greenish rock that grades into the red which is the prevalent color of the formation away from ore.

At Coro Coro we evidently have the essential conditions to produce native copper from ascending sulphide solutions. None of the complications of lava flows as possible sources of copper, of ferrous minerals as possible reducers of oxidized copper solutions, nor of zeolites, prehnite, datolite, feldspar, or other associated minerals, that have served to cloud the situation in Michigan, are present. The evidence indicates that the solutions were ascending and that they were of the type that ordinarily would deposit sulphides. They encountered a highly oxidizing environment (red sandstone) and deposited native copper and native silver with considerable copper sulphide (chalcocite) and some arsenides. The rock surrounding the metals was bleached, and sulphates were deposited. The conditions are essentially those that are found in the conglomerate and sandstone lodes of Michigan.

Triassic of New Jersey. ${ }^{42}$ - The Triassic of New Jersey consists mainly of characteristic red shale and sandstone but comprises also coarse conglomerate, black argillite, and gray or green flagstone. Both intrusive and extrusive rocks resembling the Lake Superior basalts in composition are also present. The main intrusive mass is that forming the Palisade diabase. The ore occurs in veins, which cut both igneous and sedimentary rocks, and disseminated in the

11 Singewald, J. T, Johns Hopkins Univ. Studies in Geology No. 1, 1922. ${ }^{42}$ Lewis, J. V., State Geologist New Jersey Ann. Rept. for 1906, pp. 131-164, 1901 
sediments either just below the base of the effusive rocks or close to the dikes.

The dominant copper mineral of the veins in the Palisade diabase is chalcopyrite. In the sediments close to intrusive rocks the copper occurs chiefly in chalcopyrite, bornite, and chalcocite, the native metal being absent. Away from the intrusive rocks native copper is the dominant ore mineral, although a little chalcocite is usually present.

Most of the native copper occurs in the red shale and sandstone just beneath the effusive rocks that constitute First Mountain. The deposit in the American mine, near Somerville, N. J., is typical of these occurrences. The ore bed is a purple rock with a texture between that of a fine-grained sandstone and a shale. This bed, which has been explored for a depth of 1,300 feet down the dip, is sparingly mineralized over a maximum thickness of $2 \frac{1}{2}$ feet. Wherever the copper occurs in this bed the rock has lost its purple color and is blanched to a pale gray or greenish white. Chalcocite is invariably associated with the native copper, which it apparently follows in age.

Triassic of Connecticut. ${ }^{43}$ - In the central part of Connecticut basaltic flows, some of which show red amygdaloidal tops, are interbedded with the red Triassic sandstone and shale. At the Newgate prison, Simsbury, disseminated bornite occurs in the sandstone, whereas the near-by trap carries native copper. at Meriden a core of native copper is inclosed by a shell of chalcocite, thus indicating the chalcocite to be the younger mineral.

Cap d'Or, Nova Scotia.4, ${ }^{44}$ The native copper at Cap d'Or, Nova Scotia, according to Sir William Dawson, forms masses ranging from some several pounds in weight down to the most minute grains in the veins and fissures that traverse the trap, interbedded with the red Triassic sediments. The trap is amygdaloidal and carries various zeolites, such as analcite, natrolite, and chabazite. The deposits were examined by A. C. Lane, who found them strikingly like those at Lake Superior. Lane notes that the copper is found in veins that cut the lavas.

Oberstein, Germany.-At Oberstein, Germany, amygdaloidal basalts are interbedded with red sandstones and shales of Permian and Triassic age. In the amygdaloidal cavities of the basalts and in the red sediments a little disseminated native copper occurs. Fissures cutting the traps also contain narrow veins of chalcopyrite, with which are associated pyrite, calcite, prehnite, a boron mineral (datolite?), and snalcite.

Commander Island, Russia. ${ }^{45}$-The deposits of Commander Island, Russia, are described at length by Morozewicz. The island consists of Tertiary effusive locks belonging to the soda rhyolite family, overlain

\footnotetext{
"Poye, W. G., personal communication, 1922.

"Dawson, William, Areadian geology, 1878.

"Morozewicz, J., Com. géol. Mém., new ser., livr. 72, p. 44, 1912.
}

by andesitic and basaltic tuffs and breccias. The effusive and clastic rocks are cut by basaltic and andesitic dikes. The basaltic tuffs are described as being of a gray-green color and are cut by basaltic dikes. The copper occurs in both the tuffs and the dikes and is associated with zeolites. The order of mineral formation is given as iron oxide, calcite, analcite, and wire copper.

Faroe Islands. ${ }^{46}$-The Faroe Islands consist of late Tertiary basalts with which are associated red tuffs and volcanic breccias. Between some of the flows are red shaly layers earrying plant remains. Dikes and sills are rare, and marked faults are missing. The effusive rocks are typical amygdaloidal basalts, in which the amygdules are rich in zeolites. Native copper appears sparsely disseminated in the tops of the youngest as well as in the oldest of these flows. The copper-bearing amygdaloidal portion of the flows is of a violet-gray color. Associated with and apparently later than the copper are the zeolites, stilbite, and heulandite. The copper also occurs in the interstices of the breccias intimately associated with the cementing zeolites. At Suderoe the copper occurs in the amygdaloidal portion of a dense black trap. The amygdaloidal cavities carry stilbite, mesolite, heulandite, and a fluorine-bearing apophyllite, as well as copper; the copper seems to be the oldest of these minerals and is found upon the walls of the cavities. At Vaag the copper occurs as thin plates in a dark-brown tuff.

Sao Paulo, Brazil.47-In the State of Sao Paulo, Brazil, diabasic rocks occur as dikes and stocks and as flows interbedded with Permian sandstone and shale. The flows are amygdaloidal, their vesicles having been filled with zeolites, chalcedony, and calcite. At Sorocabana the brownish-black diabase shows flattened open spaces that are now lined with chalcedony and filled with a hydrous iron silicate. Native copper occurs at the boundary between these two minerals.

Upper Serbia. ${ }^{48}$-The native copper of Upper Serbia occurs in the vuggy openings of a hornblende andesite, which shows dacitic phases, together with chabazite, heulandite, stilbite, apophyllite, and calcite. The copper is incrusted with the zeolites. It is of the leaf variety, although crystals are also found. The copper occurs also in certain highly propylitized portions of the andesite; it is here associated with chabazite, heulandite, stilbite, opal, chalcedony, and calcite, which are younger than the copper.

White River, Alaska. ${ }^{49}$-The copper minerals on White River, Alaska, occur in interbedded effusive and pyroclastic rocks of Carboniferous age. Both sulphides and native copper are present. The lavas

16 Cornu, F., Zeitschr. prakt. Geologie, 1907, p. 321.

"Hussak, E., Ueber das Vorkommen von gediegen Kupfer in den Diabasen von São Paulo: Centralbl. Mineralogie, 1906, pp. 333-335.

6 Lazarevic, M., Zeitschr. prakt. Geologie, vol. 18, pp. 81-82, 1910.

$6 \mathrm{Knopf}$ Adolph, Econ, Geology, vol. 5, p. 247, 1910. 
are slightly altered basalts of dark-brown, reddish, and green colors. The contact between two flows is as a rule easily determined because of a marked color difference. The copper minerals include both sulphide (usually chalcocite) and native copper; they are generally confined to the upper or amygdaloidal portions of the flows, although they also occur in veins and stringers. Associated with the copper minerals are zeolites, prehnite, quartz, and calcite. At the head of the Middle Fork of White River the country rock consists of stratiform basalts intercalated with beds of breccia and brick-red tuff. The native copper which occurs here is apparently limited to a certain definite volcanic sheet - a reddish lava, which is in places highly amygdaloidal. For 200 feet along the outcrop of the amygdaloidal rock metallic copper intergrown with prehnite, calcite, and zeolites can be found here and there in encouraging amounts. The copper occurs as irregular reticulating masses of metal several inches long and as small lumps and minute particles embedded in the minerals that line or fill vesicles in the lava flow.

Copper River district, Alaska.50-In the Copper River district of Alaska the copper occurs in the preTriassic basaltic and andesitic rocks, which attain a thickness of more than 3,000 feet. The native metal occurs at different horizons in different parts of the district, but nowhere in encouraging amounts.

On Glacier Creek, a tributary to Chitistone River, the native metal, associated with chalcocite, occurs in a greenstone filled with black amygdules. Masses of native copper weighing several pounds are found, but the metal is present chiefly as small specks in the greenstone and the black amygdules and as paperthin sheets or leaves.

On Fall Creek native copper occurs in a shattered grayish amygdaloidal greenstone. It forms small particles in both the altered and the seemingly unaltered greenstone and also in small veinlets of calcite and quartz.

On Nugget Creek a very little native copper occurs in the reddish, highly epidotized amygdaloidal portion of a basaltic flow. The copper is intimately associated with calcite and appears to be later than the chlorite, epidote, quartz, and prehnite.

Nova Zembla, Russia. ${ }^{51}$ - The rocks of the Nova Zembla islands are interbedded limestones, conglomerates, and basaltic lavas. The basalt is in part intensely epidotized and is also cut by calcite and epidote veins. Both sulphides and native copper are disseminated in the amygdaloidal portions of the basalt and in veins. The native copper occurs in a red-brown brecciated top of gray-green or black basalt; which may locally be bright red owing to the presence of iron hydrate. The copper is deposited in the epido-

\footnotetext{
so Moffit, F. H., U. S. Geol. Survey Bull, 345, pp. 143, 168, 1908.
}

$\$ 1$ Voit, F. W., Zeitsehr. prakt. Geologie, vol. 21, p. 42, 1913. tized rock. Copper also occurs in a green augite por. phyrite. The rock is strongly epidotized, and usually along with the copper this epidotization is marked, al. though abundant epidote does not always signify copper.

Zwickau, Saxony. ${ }^{52}$ - Native copper occurs in the red beds at Zwickau, Saxony. On both sides of minute copper veinlets the red rock is bleached yellowish owing to the reduction of the ferric hydroxide that colors the rocks.

Algodones, Chile. ${ }^{53}$-In the Mercedes mine, Algodones, Chile, a Mesozoic gray sandstone is cut by a diabase porphyry dike. In fractures in the dike there is a little native copper, with which a little native silver is associated. Native copper and cuprite in as. sociation with calcite and quartz replace propylitized portions of the rock, which is strongly impregnated with native copper. No ore appears to make in the sandstone. The amygdules of this dike rock contain calcite and delessite (?), and the mineral algodonite also occurs at this locality.

Comobabi Mountains, Arizona. ${ }^{54}$-In the eastern portion of the Comobabi Mountains, Arizona, there are lenses of altered greenish lava as much as 100 feet long, lying irregularly on lava. In this greenish lava quartz occurs as an alteration product of a red amygdaloidal basalt, and with the quartz in places there is native copper and cuprite. The altered rock that carries the copper is thoroughly epidotized and silicified. The amygdules usually show chlorite, epidote, quartz, and copper. The epidotized rock is cut by minute veinlets of quartz, epidote, and albite.

Permian "Red Beds" of the Southwest. ${ }^{55}$-In the "Red Beds" of the Southwest copper ore occurs in bituminous clay slate and marl in nuggets, nodules, or groups of irregular pockets, as carbonates, silicates, and siliceous carbonates. At Judge Kerr's farm, near Archer City, Tex., the green copper ore occurs in whitish-blue to dark-gray clays. At the Ball mine, about 7 miles northwest of Archer City, the ore consists of nodules and nuggets in a stiff white to gray bituminous clay slate or marl. This clay slate is interbedded with iron-rich clay and conglomerate. At the Isbell lead, half to three-quarters of a mile southeast of the Ball mine, the ore occurs as pseudomorphs after wood or as irregular lumps of black and green silicates in a slightly bituminous clay slate and marl.

In Oklahoma ${ }^{56}$ the ore occurs as sulphide and as the native metal in the "Red Beds," consisting of sandstone and shale of a prevailingly red color. The sandstone is fine grained and ranges in color through white and yellow to red. The sulphide has locally

82 Neues Jahrb., 1873, p. 64.

3 Märis While und ibre ${ }^{53}$ Möricke, W., Die Gold- Silber- und Kupfer-Erzlagerstätten in Chile und Ber. Abhängigkeit von Eruptivgesteinen: Naturf. Gesell. Freiburg im Breisgau Be Band 10, p. 180, 1897.

s Joralemon, I. B., report to Calumet \& Arizona Copper Co.

${ }^{6} \mathrm{Schmitz}$ E. J., Am. Inst. Min. Eng. Trans., vol, 26, pp. 97-108, 1896.

$\because \mathrm{T}$ \&11, W. A ., Econ. Geology, vol. 5,pp. 221-226, 1910. 
replaced the woody material at a definite horizon. Among the sulphides observed were chalcocite and chalcopyrite. Azurite, malachite, and chalcanthite are also present. At Coldwater, Okla., ${ }^{57}$ the copper occurs as very thin sheets in a bed of red shale.

In New Mexico ${ }^{58}$ the ores occur not necessarily in the red beds that give rise to the name, but in the light-colored sandstones which are interbedded with them. The most conspicuous ores are malachite and szurite, but these are merely oxidation products of chalcocite. With the chalcocite are small quantities of bornite, pyrite, and chalcopyrite. Near Estey the chalcocite ore replaces the calcite cement of a 500 -foot bed of red sandstone. The Copper Glance mine has sulphides, silicates, and carbonates of copper in a whitish, yellowish, or reddish sandstone. With the chalcocite a little hematite is associated. Of the copper minerals in the ore worked, about 60 per cent was chalcocite and about 40 per cent carbonate. dbout 5 per cent of the total copper content in most of the ore is present as native copper.

Montana.-Billingsley and Grimes ${ }^{59}$ describe an occurrence of native copper at Copper Hill on Baggs Creek, east of Deer Lodge, Mont. Copper Hill consists of a series of lava flows, basaltic at the base but andesitic toward the top. "Native copper in appreciable amounts is restricted to limited lenses within these flows. The metal occurs in the groundmass, in the augite phenocrysts, and in the amygdaloidal carities, in the latter case with quartz, calcite, and zeolites (rare)." The authors consider the deposits due to a concentration by comparatively cool waters of copper originally widespread as a constituent $(0.02$ per cent or less) of the original rock.

Arctic Canada.-It has long been known that native copper occurs on the mainland and islands of northern Canada over a wide area. These deposits have been visited by a number of men, but the best sccounts of them are one by Dr. James Douglas, ${ }^{60}$ based on an examination and reports by George M. Douglas, Lionel Douglas, and August Sandberg, who examined the Coppermine River region in 1911, and one by J. J. O'Neill, ${ }^{61}$ on the Arctic coast west of Kent Peninsula. The report by O'Neill reviews previous literature and contains maps showing what is known of the geology and geography of the region. The native copper occurs in a series of basaltic lavas interbedded with basic or amygdaloidal conglomerate. The regions about which most is known are those near Coppermine River and Bathurst Inlet. In the Coppermine River region, according to Sandberg, red "Haworth, Erasmus, and Bennett, John, Geol. Soc. America Bull., vol. 12, pp.
. 1800 .

"Lindgren, Waldemar, and others, U. S. Geol. Survey Prof. Paper 68, 1910.

"Billingsley, Paul, and Grimes, J. A., Ore deposits of the Boulder batholith, Mont.: Am. Inst. Min. Eng. Trans., vol. 58, p. 293, 1918.

"Canadian Min. Inst. Trans., vol. 16, pp. 83-144, 1913

"Canadian Arctic expedition, 1913-1918, Rept., vol. 11, Geology and geography, D. 1A-107A, 1924. rock occurs, and the rock associated with the copper is much altered. These conditions resemble those found in Michigan.

In bed No. 2 the rock, where exposed, has been very much altered in some places to epidote and a crumbling mass of lightcolored rock, in which nearly all the amygdules contain copper carbonates. Native copper in the form of chips and flakes is fairly abundant in this altered rock.

In the Bathurst Inlet region the copper occurs disseminated in the traps, in the amygdaloids, and in fissures. Copper sulphide, principally chalcocite, has replaced dolomite underlying basalt, and chalcopyrite and chalcocite are disseminated in some of the sills or dikes of the region. Chalcocite also occurs in fissures in both regions.

O'Neill sums up the evidence on the origin of the deposits as follows:

FACTS FAVORING A SYNGENETIC ORIGIN

1. The apparently uniform distribution of native copper in individual flows of lava of large extent, and the occurrence of such flows throughout so extensive a district.

2. The copper is abundant in some flows and apparently absent from others.

3. The copper occurs minutely disseminated throughout the dense, massive part of the flows, as well as in the upper amygdaloidal parts.

4. In many places the rocks containing the copper are apparently fresh and unfissured.

5. In many instances copper occurs in the dense groundmass of a flow, while apparently none occurs in the amygdaloidal portion of the same flow.

6. Copper sulphides occur disseminated through massive sills of diabase, which probably came from the same magma as did the surface flows.

7. No enrichment of native copper has occurred in flows cut by sills of diabase, although the flows contain native copper and the sills sulphides of copper.

$8 .{ }^{62}$ On the Coppermine River conglomerates interbedded with copper-bearing lava flows carry native copper in the contained pebbles, but copper was not observed in the matrix by the Douglas party. The copper therefore must have been in the amygdaloid before the immediately overlying conglomerates were deposited.

\section{FACTS FAVORING AN EPIGENETIC ORIGIN}

1. Specimens of the copper-bearing flows examined under the microscope show that minute grains of native copper replace the matrix or some of the minerals of the rock.

2. Native copper forms the outer edge and in some cases the center of amygdules, and in some instances replaces other minerals of the amygdaloid filling.

3. In places native copper occurs in thin fissures and in veins in the flows, and at some places the copper was found to be more abundant nearer minute fissures than through the rest of the rock.

4. Chalcocite occurs in some of the veins in the flows.

5. Dolomites immediately underlying the copper-bearing basalts in many places have been partly replaced by chalcocite. The chalcocite is intimately mixed with covellite, so that it is probable that secondary enrichment has taken place to some extent.

6. At one place, on Iglor-u-allik Island, copper occurs about the contact of two of the flows of basalt. The lower foot of the

62 See also No. 7 under "Facts favoring an epigenetic origin." 
upper flow contains considerable native copper, but no copper was seen throughout the rest of it.

7. A specimen of native copper in conglomerate was brought from the Coppermine River district to Dr. J. A. Allen, of the University of Alberta. The writer was shown this specimen and was immediately struck with the fact that the native copper in this case had replaced most of the matrix around the pebbles of amygdaloid.

\section{APPLICATION OF GEOLOGY TO MINING}

In the preceding pages and on the accompanying maps are presented in considerable detail the facts so far as they have been ascertained regarding the rocks of the district and the occurrence of the ores. The different theories of the way in which the ores were deposited have also been discussed. It has been hoped that both facts and theories would be of assistance in the search for new ore deposits.

This geologic report might perhaps wisely stop here and leave the practical application of its contents to be made by the mine operators of the district. Certain features that bear on the search for new ore, however, will be pointed out, but readers may draw their own conclusions, which may differ more or less from those presented in the following pages.

\section{LIKELIHOOD OF FINDING NEW ORE BODIES}

The advisability of searching for new ore bodies in the lodes is to be measured by the economic record of the ore bodies already mined and by the probability that similar bodies remain which can be found at reasonable cost. To the end of 1925 the mines of the district had paid in dividends about $\$ 290,000,000$. It is safe to say that before the present known ore bodies are mined out and the companies liquidated, the dividends will be at least $\$ 400,000,000$. There is no close record of capital expenditures, but from available data they are estimated at $\$ 150,000,000$. It is apparent, therefore, that the district has yielded a fair profit, probably better than the average for mining districts. A large part of the dividends have come from operations on a few ore shoots, and the capital expenditures in developing these shoots have usually been small, so that the profits on these particular operations have been large. Most of the capital expenditures, however, have been made in developments that have paid nothing. In this respect the Michigan copper district does not differ from most other districts.

Granted that several ore shoots have yielded large profits, how likely is it that there are similar shoots in the district as yet undiscovered? Most of the bedrock in the district is covered with glacial drift and therefore not open to inspection, yet although some deposits have been found by accident, most of the ore shoots have been discovered on the outcrops or by old Indian workings that doubtless started on outcrops. Once a shoot has been located, extensions have been traced. An inspection of the geologic map will give an idea of the amount of development work done outside the ore bodies and make it clear that the thoroughly prospected area is but a small part of the total. There seems no doubt that undiscovered ore shoots exist.

That these shoots are not easy to discover is indicated by past experience. At best a rather large expenditure must be made before the success of an enterprise can be established. This, however, should not discourage those in a position to undertake such operations, as it is a condition that now prevails in practically all mining districts. In other districts, as truly as in this, most deposits easy of discovery have already been found.

\section{CONDITIONS OF EXPLORATION}

DRIFT COVERING

Much of the district is covered by glacial drift, which adds greatly to the expense of exploration everywhere and which over considerable areas, where it is several hundred feet thick, has to the present largely prohibited extensive exploration. Only the massive or otherwise resistant beds, such as the Greenstone flow, crop out prominently. The amygdaloids are relatively weak rocks and are ordinarily eroded somewhat below the traps and covered even where the traps are exposed. Though the lodes are rarely exposed, it has been mainly by exposures that the ore shoots have been found.

\section{DISTRIBUTION OF DEPOSITS}

The copper deposits are distributed stratigraphically through several thousand feet of rock, and geographically the main productive portion occupies a belt 2 to 4 miles wide extending from Central to Victoria, a distance of about 75 miles, though the larger part of the production to date has come from the central portion of this belt, about 40 miles in length. This belt is among the largest mineralized areas in the world.

The production since 1845 has been comparable to that from the Butte district since 1880, which has come from a few square miles. Most of the copper produced in the Michigan district has come from a few large deposits, but these are widely scattered, and the ore forms but a very small part of the rock within the mineralized area. The location of the ore bodies, even though large, in so extensive an area is, of course, relatively difficult.

\section{GRADE OF ORE}

All the lode deposits are of relatively low grade. The average yield for all lode deposits from the Champion mine north has been about 26.9 pounds to the ton, and from 1906 to 1923 the average for all mines of the district was about 21.5 pounds to the ton. If the Calumet \& Hecla conglomerate is excluded, the average yield from the northern amygdaloid lodes 
has been 20.8 pounds to the ton from the beginning and 19.6 pounds from 1906 to 1923. Although the ore shoots are unusually large and regular as compared with those in other districts, nevertheless it is evident that in some the grade is not far above the economic limit, and a slight change in grade or in operating conditions suffices to put it below that limit.

After an ore shoot has been found, it is necessary to open a large mass of the lode to determine the size of the shoot and grade of the ore before it can be known whether or not a mine can be developed. To determine these questions is more difficult and costly in this district than in most others. The lodes must be opened by underground workings extending for thousands of feet, and mill tests must be made on the rock. Owing to the irregular distribution of the copper, no method of sampling that has been developed gives even a safe approximation of the grade of the ore. When the lode has been opened, those familiar with the ore can make a rough estimate of the copper content. If it is rich, the operators are warranted in going forward, but if it approaches the lower limit, only extensive mill tests will determine whether it is commercial or not.

In the past large sums have been expended in the development of shoots that proved to be below commercial grade, and it seems inevitable that this experience will be repeated in the future. It is not necessary, however, to erect an expensive mill in advance of proving a deposit, as has been done in some places in the past, for it is usually possible to make tests in existing mills, and in recent years this has been the custom.

\section{SIZE OF DEPOSIT AND GRADE OF ORE}

The belief is sometimes expressed that if ore of somewhat lower grade could be successfully mined, immense deposits would be available, but the increase would probably not be as great as is thought by some. Some ore shoots grade at the margins rather gradually into leaner and leaner ore, but it is far more common to go within a relatively short distance from profitable to hopelessly unprofitable ground. Within an ore shoot considerably more ground could be taken if the commercial grade were lowered.

It is perhaps common to think of high-grade deposits as necessarily small and of low-grade deposits as likely to be large. Whether or not there is any justification for such an idea as a general principle, it does not seem to hold good for the Michigan lode deposits. None of the great ore shoots have been mined out, nor are different shoots mined to the same extent, and therefore no final comparison is possible. Nevertheless there is a strong indication, as is suggested by the following table, that the larger shoots as measured by their content of copper, are consistently of the higher grade. The richer shoots have been most profitable and therefore most developed; if the leaner shoots had had the same amount of development they would probably show better than they do.

Yield from lode ore shoots through 1925

\begin{tabular}{|c|c|c|c|c|}
\hline \multirow[b]{2}{*}{ Shoot } & \multicolumn{2}{|c|}{ Copper (pounds) } & \multicolumn{2}{|c|}{ Dividends } \\
\hline & Total & Per ton & Total & $\begin{array}{l}\text { Per pound of } \\
\text { copper (cents) }\end{array}$ \\
\hline 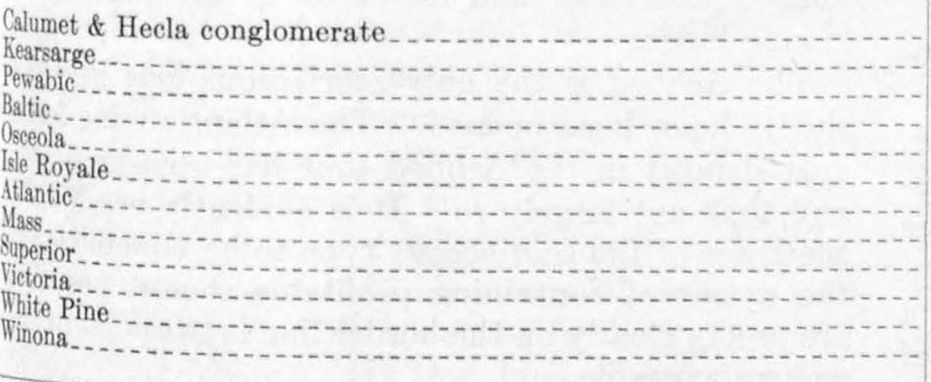 & $\begin{array}{r}3,375,000,000 \\
1,177,000,000 \\
873,700,000 \\
873,000,000 \\
416,400,000 \\
210,800,000 \\
142,800,000 \\
50,000,000 \\
31,000,000 \\
20,000,000 \\
18,000,000 \\
17,000,000\end{array}$ & $\begin{array}{l}\text { 49. } 07 \\
\text { 19. } 27 \\
22.11 \\
\text { a } 26.50 \\
\text { 16. } 75 \\
\text { 16. } 39 \\
\text { 13. } 55 \\
\text { b } 15 \\
\text { b } 19 \\
\text { b } 12 \\
20.3 \\
\text { b } 14\end{array}$ & $\begin{array}{r}\$ 148,700,000 \\
50,880,000 \\
29,242,500 \\
43,004,000 \\
14,700,000 \\
2,550,000 \\
990,000 \\
33,337.50\end{array}$ & $\begin{array}{r}4.41 \\
\text { 4. } 32 \\
\text { 3. } 35 \\
\text { 4. } 93 \\
\text { 3. } 55 \\
\text { 1. } 21 \\
.69 \\
\text { 2. } 10 \\
.18\end{array}$ \\
\hline
\end{tabular}

It is apparent that the relation between grade and size of deposit as indicated by mining to date is not entirely consistent, and of course the actual size is undetermined. Nevertheless there is an unmistakable indication that the larger deposits are the higher in grade. If, then, a low-grade ore is encountered in prospecting, it should be developed to make sure that the openings are not in a poor spot in or on the margin of a richer shoot, but when it is once established that the shoot is of low grade, there is little reason to believe that it will make up in size what it lacks in richness.

\section{SIZE AND GRADE NECESSARY FOR SUCCESS}

The size and grade of a lode deposit necessary for success in operation will of course vary with conditions.

An inspection of the preceding table will show that in the past the profits have been roughly in proportion to the amount of ore mined and the grade of the deposits. As a rule, the lode deposits that have produced more than $100,000,000$ pounds have been consistently profitable and those that have produced less have been rather consistently unprofitable, though 
the Superior and White Pine deposits, because of rather rich ore and other favorable conditions, have made earnings from a much smaller production. The lowest grade of ore that has generally been profitable in the past seems to be about 15 pounds to the ton, though the Atlantic shoot, which yielded a profit, averaged somewhat below that. It hardly need be said that relatively small mines located in rich parts of the large shoots, such as the South Kearsarge and Wolverine mines in the Kearsarge shoot, have been very profitable.

The profits from operations depend on many factors that will not be discussed here. The most detailed published discussion of the subject is one by Denton, ${ }^{63}$ who reaches the following conclusion:

It seems likely therefore that the minimum requirements for a profitable mine in one of our amygdaloids are, approximately, that 50 per cent of the lode must produce around 20 pounds per square foot of lode mined, concentrated into 1 ton of stamp rock. The mine one hopes for must show at least 60 per cent of the lode area producing 30 pounds of copper and 1 ton of stamp rock per square foot.

In other words, the minimum requirements where the rock is not sorted are that in one-half of the developed ground the lode must be 11 feet thick and yield 20 pounds of copper to the ton, and in the "mine one hopes for" 60 per cent of the developed ground must have a lode thickness of 11 feet and yield 30 pounds to to the ton. Where the rock is sorted the lode might be thicker and correspondingly leaner.

It is hardly necessary to say that an ore shoot must be considerably developed before any clear idea of the size and grade can be gathered. Where extensive development has been made on reasonably encouraging ground but failed to develop a mine, the resulting loss may be diminished by mining some of the best ground opened.

Fissures have yielded a comparatively small proportion of the copper and of the dividends for the district. In dividends per pound of copper, however, they compare favorably with lode deposits. The fissures that have proved profitable have been those that yielded mainly mass copper. and, with the exception of the Mass fissure of the Ahmeek mine, were rich and profitable from the surface. In deposits of this class it was not necessary to open extensively in advance of profitable extraction, and the fissures that proved profitable were so almost from the start of operations. The fissures commonly contain a considerable amount of stamp rock, but those in which the copper was mainly in stamp rock have not been profitable. There are numerous fissures on the $\mathrm{Ke}$ weenaw anticline that have been prospected but little

${ }^{63}$ Denton, F. W., Development and extraction methods for Lake Superior copper deposits: Lake Superior Min. Inst. Bull., August, 1922. or not at all, and the incentive for fissure exploration is much the same as that for lode exploration.

\section{EXPLORATION OF LODES}

Certain geologic conditions that have proved favorable to the formation of deposits may be briefly reviewed here in their bearing on exploration.

\section{CHARACTER OF AMYGDALOID LODES}

Amygdaloid lodes have been separated into four classes - cellular, cellular-coalescing, fragmental, and scoriaceous. The characteristics of these classes have been fully discussed in preceding sections and need not be restated here.

No mines or encouraging prospects have been developed in typical cellular amygdaloids, which appear unqualifiedly unfavorable. This applies equally to all cellular rock, whether the top of the flow is of that character throughout its extent or whether it is fragmental in places and cellular in places.

The fact that the lode is fragmental in one place increases the probability that it may be fragmental in other places. All but two of the largely productive amygdaloids of the district and most of those that have given some encouragement are of the fragmental type. There seems no doubt that this is the most favorable type. The fragmental amygdaloids form not more than 10 to 15 per cent of the total, and cellular amygdaloids make up most of the remainder. It is evident, therefore, that the physical character of the amygdaloids affords criteria by which a large proportion can be eliminated.

A considerable proportion of the copper from the Pewabic amygdaloid lodes of the Quincy mine has come from cellular-coalescing rock, though the lodes are in part fragmental. There is no doubt that valuable deposits can and do occur in the cellular-coslescing lodes.

The Ashbed is the only scoriaceous lode in which shoots have been opened. The Atlantic mine is the only deposit in the Ashbed that has been profitable, and that not largely so. It is evidently possible for the lodes of the scoriaceous type to be mineralized to the extent of containing profitable shoots, but they are pretty clearly on the border line between favorable and unfavorable.

The influence of hematite in causing the precipitation of metallic copper indicates that highly oxidized lodes are the most favorable for ore deposition. The same influences that tend to form fragmental lodes seem to cause high oxidation, so that in the main the lodes that are physically favorable are also chemically favorable. It may be pointed out, therefore, that cellular amygdaloid that is highly oxidized may be more likely to pass into fragmental amygdaloid than that which is poorly oxidized. 


\section{CONGLOMERATES}

Only two of the several conglomerates of the district have been shown to be extensively mineralized, namely, the Calumet \& Hecla, and the Allouez. Both, where mineralized, are moderately coarse, and the Calumet \& Hecla conglomerate, where it thins and changes to sandstone, quickly decreases in copper content. It appears that a moderately coarse conglomerate has the permeability requisite for forming an ore deposit. It seems probable that a moderately thin conglomerate that pinches out in places along the strike but is continuous down the dip is more farorable than a thick conglomerate continuous for long stretches that gives no opportunity for convergence of rising solutions. All the conglomerates have relatively abundant ferric oxide and are in this respect apparently chemically favorable to copper deposition.

The sandstone of the Nonesuch formation at the White Pine mine and neighboring prospects is the only sandstone known to be strongly mineralized and that is mineralized only relatively near to fissures. Sandstone therefore does not seem to be favorable to mineralization, though it is of course more favorable than shale.

\section{MINERALOGY AS A GUIDE IN EXPLORATION AND DEVELOPMENT}

A detailed study of the mineralogy and paragenesis of minerals has been a feature of all the more comprehensive geologic studies of the district, starting with Pumpelly's work and continuing through the present investigation. One of the objects of these mineralogic studies has been to find, if possible, minerals that would serve as indications of either the presence or the absence of copper in their neighborhood. It may be said at the start that these studies have not developed any very positive aids in either the general exploration stages or the later development and mining stages.

Mineralogic features, like textural features, are largely of local occurrence, and the best of ore shoots are known to contain patches of minerals that are regarded as unfavorable indications of copper; likewise many amygdaloids which so far as known contain no ore shoots may for long distances carry mineral combinations that are characteristic of some of the big ore shoots in the district. In the later stages of development observation of the copper itself is a better indication of the grade of the ground than a study of the gangue minerals.

\section{MINERALOGIC GUIDES IN AMYGDALOIDS}

The principal minerals that are regarded favorably as indications of copper in amygdaloids are the quartz-pumpellyite-epidote combination which is associated with copper, especially in the Isle Royale, $58540-29-11$
Baltic, Pewabic, and Evergreen lodes. However, many impermeable cellular amygdaloids that show alteration of this type are encountered in diamond drilling and crosscutting. The presence of these minerals should not lead to more extensive examination by underground openings unless other features, such as favorable physical character of rock or presence of copper, give additional cause for encouragement.

The rock bleached through the removal of iron, on the other hand, is much more rare and, so far as known, is invariably accompanied by copper. Furthermore, there is a distinct feeling that this bleached rock is indicative of a rather intense degree of mineralization, so that if a drill hole or a crosscut encounters a little copper surrounded by bleached rock, it is regarded more favorably than a similar quantity of copper without the bleached rock.

Red feldspar, prehnite, and datolite are to be regarded as more favorable than otherwise. The prehnite usually has some fine copper associated with it though prehnitized areas in the Osceola lode are rather poor. In general a fragmental lode showing these minerals, with perhaps some epidote and pumpellyite, is to be regarded more favorably than a lode of the same type with nothing but calcite in the interfragmental spaces. What probably amounts to the same thing is that the greater the variety of minerals the more favorable the appearance of the lode. Most of the commercial lodes have a greater variety of minerals than the average amygdaloid.

Calcite and chlorite are rather indecisive indicators. The intense chloritization in some places, such as adjacent to fissures in the Kearsarge lode and in the shattered areas near the Keweenaw fault, would seem to be an unfavorable sign.

Laumontite is generally regarded unfavorably. However, there are local patches of lean laumontitized rock in the best ore shoots.

The value of copper itself as an indication of an ore shoot needs some discussion. If copper is present in a drill core from an amygdaloid, it is of course always encouraging, but it is more encouraging under certain conditions than under others. The most favorable mode of occurrence is in association with rock bleached by the removal of iron in a fragmental amygdaloid. Copper associated with the pumpellyite-quartz-epidote combination is also favorable, especially if in a fragmental lode.

Copper in a fragmental lode leads to interest in the lode at that point, whereas copper in some quantity in a cellular lode encourages examination of that lode elsewhere to see if it changes into one of more favorable character, such as a coalescing cellular lode or a fragmental lode. Very fine copper in prehnite or calcite is pretty common and not very encouraging. Copper in small seams in amygdaloids of any type is in general of little interest. 


\section{MINERALOGIC GUIDES IN CONGLOMERATES}

The variety of introduced minerals in conglomerates is much less than in amygdaloids, but in general the same principles apply to the use of mineralogy in exploring and developing rock of both types. Many of the conglomerates seen in drill cores have practically none of these minerals, with the exception of a little calcite. As in the amygdaloids, the occurrence of rock bleached by iron removal as a rule probably indicates copper mineralization. Likewise, it is probable that a greater variety of secondary minerals in a conglomerate is a better indication than calcite alone.

\section{MINERALOGIC GUIDES IN FISSURES}

Little if any choice between two fissures can be made on the basis of mineralogy. The chief gangue mineral in the Mass fissure at the Ahmeek mine is calcite. The Owl Creek fissure at the Copper Falls mine in places had an abundance of datolite. Prehnite is common in many of the fissures of Keweenaw County. Some of the barren "crossings" in the lodes of the district are said to be mainly calcite. In many places the Mass fissure at the Ahmeek mine is merely a chlorite seam. In general, other things being equal, a fissure with a variety of gangue minerals is more encouraging than one with only a few.

In summary, although mineralogy is of value in exploration, its use must be accompanied by an understanding of its limitations. Some of the limitations are indicated. The best sign of copper is copper itself and the occurrence of copper in favorable lode rock is a much better sign than all the gangue minerals without copper in unfavorable rock. In development and mining mineralogy is of less use. In these operations the copper itself as seen in the openings is the best guide.

\section{ORE SHOOTS}

\section{EXTENT OF LODES}

In several of the lodes it is pretty clear that the ore-forming solutions have traveled upward for long distances in the lodes themselves. It may thus be assumed that a long downward extension of permeable lode is essential to the formation of an ore shoot. It might be supposed that long downward extension would accompany long lateral extension of flows and that therefore the relatively thick flows extending for long distances along the strike would be most favorable. There is some support for this idea in the fact that the Kearsarge, Osceola, and Baltic are all relatively thick flows and that the first two are known for long distances along the strike. The individual flows of the Pewabic amygdaloid are relatively thin and apparently not continuous for long distances. However, if the flows came from the central part of the basin, any that reach the present outcrop may be assumed to extend a long distance down the dip. It is questionable, therefore, whether thickness of flow should be given any weight in the matter of favorability.

\section{BARRIERS}

The concentrating effect of barriers is fully discussed on page 115 .

Barriers in the lode itself.- There are two general conditions in the lodes themselves favorable to concentration of solutions - (a) a lode that is prevailingly impermeable but contains permeable areas haring a long downward extension; (b) a lode that is prevailingly permeable but contains bars of impermeable rock so placed as to cause a concentration of rising solutions. The Calumet \& Hecla conglomerate and the Kearsarge amygdaloid are examples of the first type, and the Osceola lode of the second. Recognition of the first type should be of help in prospecting. In the second type, where the barrier in the lode is relatively small, it is probably quite as easy to find the ore shoot itself as it is to find the barrier. In the development of an ore shoot once found, however, the recognition of the barrier should be of decided help.

Folds.-It would be expected that solutions rising along a lode would tend to concentrate near the crests of the anticlinal folds that extend down the dip transverse to the general strike of the rocks. The presence of ore shoots on the Allouez, Baltic, Winona, Mass, and Michigan anticlines lends support to this idea. On the other hand, there are several deposits, such as the Calumet \& Hecla conglomerate, Osceola, and Quincy, that are not on folds, and the Isle Royale and Forest ("Victoria") are on synclines.

In the shoots studied in detail that are on anticlines the distribution of copper is more closely related to the character of the lode rock than to the crest of the anticline. The positions of the anticlines are well known, and if the idea proves to have any merit it can be easily applied.

Faults.-A fault offsetting a lode and making an angle with the dip of the lode would be a barrier that would tend to concentrate rising solutions the same as impermeable rock. Many faults are known that have sufficient throw to produce this effect, and there are doubtless many small unknown faults that might have this influence.

\section{FISSURE DEPOSITS}

The ore shoots in several fissures are at or near the intersection with thick, well-oxidized amygdaloids or conglomerates, and around the Keweenaw anticline they occur under the Allouez "slide," which probably acted as a barrier. These relations should be kept in mind in the prospecting of fissures. 


\section{GEOLOGIC DISTRIBUTION}

The ore deposits in general are distributed geologieally from a horizon near the lowest exposed part of the series to one well toward the top of the portion where flows predominate. The deposits in the Nonesuch formation are much higher but so far as known are present only near the Porcupine Mountain dome. There seems to be no very systematic arrangement in the geologic horizons at which the deposits occur. Near the central portion of the district, in a relatively short stretch from Quincy to Baltic, lodes occur from the highest to the lowest and at intermediate horizons. To the north the largely productive lodes are at intermediate horizons, though the Ashbed high in the series has been productive well to the north, at Copper Falls. In the south end of the district the productive lodes have been mainly near No. 8 conglomerate, at an intermediate horizon. From the distribution of the known deposits there seems little reason for favoring one horizon in the series over snother.

\section{GEOGRAPHIC DISTRIBUTION}

Geographically the most productive part of the district, from Champion to Mohawk, is centrally located. Lode production greatly predominates in this central portion. North of the more highly productive area there has been considerable output from fissures, and south of it from both lodes and fissures. There is some reason to think that mineralization decreases in amount north and south of the central area, but it is not to be supposed that the commercial limits are those indicated by the present profitable lode mines.

The assertion frequently made that only one deposit occurs in any section across the mineralized belt is not wholly supported by the facts. The Calumet \& Hecla conglomerate and Osceola shoots in part overlap. The Allouez conglomerate is mineralized and was mined above the Kearsarge shoot. The Atlantic in part overlies the Isle Royale and Superior. The Quincy has mined several lodes in the same section, and in the south end of the district the same is true of operations on the Evergreen and succeeding lodes. There seems no good reason for considering that an srea is distinctly less promising because an ore shoot has already been developed in the cross section of the belt in which the area lies or that a section in which ao ore shoot has been developed is particularly promising for that reason alone.

In no lode, up to the present time, have two widely separated profitable ore shoots been developed. Tidely separated shoots have been developed in the dshbed, in the Allouez conglomerate, and in the Evergreen and succeeding lodes of that series, but not more than one of those in a given lode has been profitable. There seems, then, to be no basis for supposing that a horizon at which productive deposits have been found in one part of the district is a particularly favorable horizon for prospecting in another part far distant, nor for prospecting a well-known and productive lode at a place far from an area where it is known to be productive, unless at this place it shows favorable character and signs of mineralization. Prospecting of well-known lodes at a distance from areas where they are known to be productive has been pretty thoroughly tried, and to the present time it has consistently resulted in failure. There seems no reason, however, why a lode should not contain more than one ore shoot, and if it is favorable in character at a distance from the known shoot, it should be considered as attentively as other equally favorable lodes. If it is physically unfavorable, on the other hand, it deserves no more attention than other unfavorable lodes.

In short, a given lode at a given place should be treated according to the local indications, and no money and effort should be expended on the basis of what the same lode may contain 20 miles away.

\section{RELATION TO PRESENT SURFACE}

All known important deposits appear to have reached the surface and to have been as rich at some places along the outcrop as at any greater depth. (See p. 112.) It would seem, therefore, that in prospecting the chance of striking a shoot at the richest point is probably as good at one depth as at another within practical limits. The depth at which general exploration should be carried on should be governed by the cost at the particular place considered. In new territory relatively shallow depth will usually be cheapest. Near old mines deeper exploration from existing openings may be just as cheap, and the deep openings may develop much less water and thus cause less future expense in pumping in case the prospect is abandoned. It is of course to be recognized that exploration for known or supposed shoots entering a property at depth constitutes a special case.

\section{EXPLORATION}

STAGES

Exploration in the Copper Range has now been in progress for more than 75 years and in different places has reached very different stages in its progress toward what may be regarded as complete exploration. For the portion of the range in Wisconsin the Wisconsin Geological Survey has now in progress the outlining of the broader geologic relations. For small areas in Michigan very detailed information is available. All stages between those extremes are to be found.

The problem to be solved in any given area and the method of attacking it depend on the information already in hand. In an area of which little is known the effective method is to proceed from the more 
general type of information to the more detailed. Lode exploration may be efficiently conducted in the following general order: (1) Geologic reconnaissance; (2) location of favorable lodes; (3) search for ore shoots; (4) development of prospects; (5) development of known ore bodies.

Geologic reconnaissance.-For most of the copper belt of Michigan the early stage has been passed, and the general distribution and relations of the rocks are known. Near the end of Keweenaw Point and toward the Wisconsin boundary there is still something to be gained from work of this type.

Location of favorable lodes.-With the general location and geologic relations determined, the next step is to find what are regarded as favorable lodes and conversely to determine unfavorable lodes.

For the area between Victoria and Breakfast Lake the accompanying geologic maps and sections give the character of the lodes and their position so far as known. For some areas this information is rather detailed, but for others it is very slight. It is evident that much remains to be done in this stage of exploration.

Search for ore shoots.-As is well known, no lode is mineralized to a commercial degree over more than a small part of its extent. Moreover, numerous beds that have all the properties that are regarded as favorable to mineralization are not known to contain minable ore at any place, though no lode has been thoroughly tested throughout. It is clear that the copper occurs in distinct shoots, only the larger and richer of which are of commercial importance.

It is always possible that a shoot may be discovered at any stage of exploration, and as a matter of fact most of those now known have been located in the early stages or entirely by chance. The probability of locating additional shoots by finding outcrops containing copper or by following up old Indian diggings is not great. Ore shoots are likely to be found in the future only by systematic search, implying an exploration program and the use of methods materially different from those that were cheapest in earlier stages.

Development of prospects.- Once a stretch of lode that contains an encouraging amount of copper is located, it must be developed to determine whether or not it is of a size and grade to make a mine. At this stage in particular an understanding of the behavior of the shoots in the developed mines is likely to be of assistance.

Exploration of ore shoots.- The mining of the great ore bodies, if it is to be carried out efficiently, must be planned far ahead of actual operation. The determination of the probable position and extent of a known ore shoot in undeveloped ground is an important function of exploration.

\section{METHODS OF EXPLORATION}

The several methods of exploration that have been commonly applied in the region, usually in the order named, are (1) examination and mapping of surface exposures; (2) trenching or digging test pits where the overburden is shallow; (3) diamond drilling; (4) under. ground openings. Other methods have been tried on \& far less extensive scale.

Examination of surface.-To get all the information that is possible from an examination of the surface is of course the first step in exploration work at any stage. It was early applied and resulted in outlining the broader features of the geology which have long been known. This method is particularly useful in the reconnaissance stages of exploration but may also be useful in later stages. Considerable detailed information may thus be obtained for small sreas, especially along stretches of lake shore and along river channels. Elsewhere only the more resistant beds are commonly exposed, and the amygdaloids, which are weak and easily eroded, usually occupy relatively depressed areas and are therefore commonly covered.

Trenches and pits. - The results obtained by digging trenches and pits in exploration are of course dependent on depth and character of overburden and on water conditions. In general this method is practicable only in areas covered by a few feet of overburden and is not applicable to swampy areas even where the overburden is thin. Wherever it can be effectively applied, this method is useful in all the earlier stages of exploration-namely, geologic reconnaissance, location of favorable lodes, and search for ore shoots.

Diamond drilling.-Diamond drilling has been employed in exploration in the copper country since 1882 and has probably furnished more detailed geologic information than all other methods combined. It is highly effective in determining the character of flows for general correlation, and where skillfully conducted it has proved very useful in determining the character of lodes. The medium-sized $11 / 8$-inch core from the " $\mathrm{A}$ " bit is much more informing than the $7 / 8$-inch core from the " $\mathrm{E}$ " bit and is well worth the difference in cost. Although diamond drilling is the most efficient method of getting information as to the kind of rocks and the character and position of lodes where outcrops or surface trenching will not furnish this information, the diamond drill has proved of rather doubtful service in the search for ore shoots. Owing to the very irregular distribution of copper in the average amygdaloid lode, a drill-core sample is likely to be equally misleading whether it contains copper or not, though the presence of copper should, of course, always be regarded as encouraging. Cores sufficiently encouraging to cause the sinking of exploratory shafts 
have been obtained at several places, as Mandan, Ojibway, Mayflower-Old Colony, and St. Louis, where disappointing results were encountered when the lodes were opened. The Lake lode, on the other hand, was located by diamond drilling and proved sufficiently mineralized to lead to rather extensive development. At the New Arcadian mine the lode that showed best in the drilling proved disappointing, but a near-by lode that was opened in the underground exploration has been extensively developed. Diamond drilling is thus a far less reliable guide in the search for ore shoots than trenching or underground openings, methods by which it is advisable, where indications warrant the expense, to expose considerable portions of the potential lode. Obviously, however, the information as to copper content obtained by diamond drilling is not to be neglected. Drill-core samples are more nearly representative of conglomerates than of smygdaloids, because the copper is more evenly distributed in the former rock than in the latter. The uniformity of distribution and the consequent reliability of drill-core samples is naturally even greater for finer sediments; the cores have been shown to give the copper content of the Nonesuch sandstone and shale, for example, with a fair degree of accuracy. The diamond drill has been used rather extensively in some mines to locate copper ground in known lodes. It bas been used most in the Quincy mine, where the lode is of the coalescing type, and for that type it is said to be effective. It was also used in the Osceola mine to locate "foot lode" copper, but here it produced rather indifferent results and was given up. In the arerage amygdaloid lode the advisability of its use for this purpose seems open to question.

Foot for foot, diamond drilling is, of course, much cheaper than underground opening. Probably at least 4 feet of drilling can be done at the cost of 1 foot of underground opening. In cross-sectioning inclined beds the ratio is even more favorable to the drill, which can cut the beds at right angles and traverse \& given stratigraphic thickness with a minimum lootage, as a crosscut can rarely do. It may thus be possible to section a lode or series of lodes several times with the diamond drill at the same cost as a single section with an underground opening.

Ohurn drilling.-Churn drilling, so far as known has been used only at the Laurium property. The, records of this work do not indicate that it is effective in giving any type of information in this district, and aill cuttings must obviously be far less informing than a core. The churn drill might be effective in ailling through overburden to bedrock.

Underground opening.-Underground opening, of course, gives, foot for foot, the most satisfactory information of all kinds. For general geologic information or the location of favorable lodes it is ordinarily too expensive. In the search for ore shoots where trenching is not practicable it is probably the most effective method. In the development of prospects it is the only effective means of determining the position of the ore shoot and the copper content of the ground.

Other methods.-The dip needle has been employed by the Wisconsin Geological Survey in working out the general distribution and structure of the copperbearing rocks. This method has been but relatively little employed in the Michigan copper district, and for much of the area more detailed data are already available than are likely to result from dip-needle work alone.

For certain problems, even in the more intensively developed areas, the dip needle will furnish geologic data at a lower cost than most other methods. In the less developed areas it has a larger field of usefulness. The possibilities of the use of the dip needle are discussed in the section on geophysical methods (pp. 156168). Other geophysical methods have been but little used in the Copper Range. Electrical methods have been tried as outlined on pages $158-160$ but have given as yet no very encouraging results.

\section{APPLICATION OF METHODS}

The results attaired with a given amount of money vary considerably with the skill used in choosing and applying the different means of exploration, even when the simplest methods are employed.

\section{SURFACE EXAMINATION}

A careful determination of the type and grain of the traps may give considerable information on the thickness and correlation of beds that are only slightly exposed and thus save more expensive work by restricting trenching and drilling to the vicinity of flow tops.

\section{TRENCHING}

In trenching across the strike of flows, if the grain of the rock is determined, it is possible to judge the approximate thickness of many flows and to avoid continuous trenching over the central portion of such flows.

\section{DIAMOND DRILLING}

Diamond drilling has been pretty thoroughly developed and systematized in the district, but there are certain features that may well be emphasized.

In making cross sections it is the general practice to drill the section across the supposed strike and, unless there are special reasons for doing otherwise, at nearly right angles to the supposed dip of the beds. This of course gives the maximum section for a given footage. It is worth going to considerable trouble, if necessary, to determine the strike of the beds before starting an extensive cross section. The purpose of a cross section is to determine not only the character of the beds but their attitude, and for this purpose a correlation between two holes is necessary. It is desirable, therefore, to find a characteristic bed that will permit correlation near the bottom of the hole farthest down the dip and to cut this same bed near the 
top of the next hole up the dip. It is well worth while to carry a hole some distance beyond what would otherwise be the most economical limit in length or to stop it short of that limit if such a correlation can be effected. A sedimentary bed is usually the best for correlation, but certain characteristic flows are satisfactory.

If beds of favorable character are encountered near the bottom of a hole, it is worth while to cut these in the next hole to determine their character at another point. To accomplish this, a hole may be stopped short of the most economic leng th after passing through favorable amygdaloids in order to start the next hole near the outcrop of those beds and cus them again.

Both the " $\mathrm{A}$ " bit, with $11 / 8$-inch core, and the " $\mathrm{E}$ " bit, with $7 / 8$-inch core, have been used in the district. The "A" bit has given a far better core recovery, especially of the amygdaloids, and therefore a better idea of the beds, and this advantage is well worth the difference in cost of operation. Larger bits have been used, but except under special conditions they are probably not justified by the additional information obtained.

A careful record should be made of every hole at the time of drilling, but in addition the core should be preserved, so that it can be reexamined when desired. A core may be stored at a cost of but a few cents a foot, and there is no justification for not preserving it. A few suggestions resulting from the examination of many thousand feet of core may not be out of place.

Cores are usually stored in wooden boxes ranging from 5 to 9 feet in length and containing from five to eight or nine rows of core each. The rows of core are commonly separated by wooden dividers. The size of box is not material, but pine lumber, even of poor quality, is preferable to even high-grade hemlock. Sheet zinc may be used for dividers in place of wood strips. This saves some space, and the cost per foot of core is about the same.

Marking of the depths within the box and marking of the box are highly important. For marking depths, 1-inch wooden blocks the width of the core should be used. The depth should be clearly marked in pencil on the top and one side of the block. A block should be placed at the end of each pull. It is convenient if the beginning of the box is marked with an arrow, and it is advisable to follow the general custom of placing the cores so that they are to be read from left to right as a book is read. Red marks on the dividing strips opposite places where copper is found in the core are helpful. The box, not the cover, should be marked both inside and outside with the name of the property, the number of the hole, and the depth. Metal tags with the numbers and letters stamped on are durable, but the box itself should be marked in addition.

Cores should be stored in a dry place and piled well above the ground. If left sut of doors or in a leaky building, they might as well be thrown out at once, as the boxes will soon be decayed. (See pl. 54, B.)

Some years ago the Michigan Geological Surver, recognizing that the matter was one of public inter. est, undertook to preserve such cores as were not being cared for by the companies. Unfortunately this effort was not continued, and those already col. lected were not given proper eare.

\section{UNDERGROUND EXPLORATION}

Depth.-The first question to determine in exploration is the most favorable depth. As an ore shoot is as likely to be found at one depth as another (see p. 112), the depth of exploration depends on the cost, and in most places the most economical depth would probably be shallow.

Horizontal versus vertical exploration.-In many of the explorations in the district, shafts have been sunk to a depth of 1,000 to 2,000 feet, and the vertical element of exploration has been emphasized, as contrasted with exploration along the lodes. Whether the chance of encountering an ore shoot will be greatest by opening down the dip of a lode or along the strike will depend on the attitude of the ore shoot. If the shoot extends directly down the dip, exploration in that direction will be least effective and drifting along the lode most effective, but if the shoot is horizontal the reverse will be true. Most of the known shoots trend more nearly with the dip of the lodes than with the strike, and therefore, in general, drifting should be preferable to sinking. Dritting, moreover, has the advantage of being cheaper; it also affords the easier method of following an irregular lode and of testing any lode by crosscuts.

If encouraging results are not encountered at one level, it is very questionable whether drifting at another level is justified in general prospecting, but if the extension of a known shoot is being sought, drifting at another level may be desirable.

Examples are cited in the discussion of ore shoots where a lode is poor in stretches near the surface and richer at depth, but as a rule drifting along the lode would have encountered the rich shoots with less effort than opening down the lode.

If an encouraging amount of copper is encountered, it is of course worth while to open the shoot down the dip as well as along the strike, but it is desirable to follow the shoot along the strike to its limits on each level opened in order to get the horizontal extent and probable attitude as early as possible. If a lode is rich, it is common practice to run levels in it during development, at the regular operating intervals of 125 to 150 feet. If the deposit is of doubtful grade or size perhaps the more common and better practice is to open it only at considerably greater intervals; the probable extent and grade are thus determined at a lower cost. 
Transverse versus longitudinal exploration.-In past exploration two practices have been more or less consistently followed-the examination of a lode or lodes known to be mineralized elswhere in the district, to the exclusion of the other lodes; and a preliminary cross sectioning of all the lodes in an area by diamond drill, trench, or crosscut and the further examination of any encouraging lodes that may be found. The information already available for much of the district gives a general idea of the character of the beds, from which it can be judged what method is likely to give the best results. Crosscutting would usually be employed where it is desired to investigate several adjacent lodes that are known to be of favorable character. If, on the other hand, diamond drilling has shown a promising lode in a series of unfavorable lodes the promising lode would of course be best examined by itself.

Prospecting fissures.-It has been pointed out that many of the known fissure deposits occur at the intersection of fissures with strong lodes and also that they may be under barriers like the Allouez "slide." These, then, are the places to be specially examined by the method that local conditions render easiest.

Where fissures are closely spaced it may be advantageous to drift on a strong amygdaloid across a number of such fissures, further developing any that show promise. Where they are widely spaced it will probably be advantageous to examine each fissure separately.

Equipment for prospecting. - It is obvious that no prospect in its earliest stages of development justifies the assumption that it will be a mine. Therefore, until a prospect is pretty well proved the equipment and the openings should be the cheapest that can be effectively employed. Certainly the building of a mill should wait till the ore for it is fully assured. Such a policy may lead to slight losses in the relatively few prospects that develop into mines, but the owners of such properties can stand the loss.

\section{SUGGESTIONS FOR FUTURE GEOLOGIC WORK IN THE COPPER RANGE}

The present report is but one of a series that have been made during the last 75 years. Each of the reports recorded the available facts concerning the geology of the district and expressed the opinions of the authors regarding the occurrence of the ores. With each succeeding report there has been a growing body of facts and a changing view regarding the occurrence of the ores. The change in view has been influenced by the accumulating facts, by the general increase in knowledge of ore deposits, and of course by the views of the different individuals who have been gaged in the several investigations.

Each of the previous reports has been helpful in the velopment of the district, and it is hoped that this one will also be helpful. The authors of the report probably realize more keenly than others its shortcomings, and they are well aware how much remains to be done and how important the continuance of geologic work in the district is likely to be. Many of the problems can be solved only by a steady, persistent collection and correlation of data from year to year, and the necessity for this work will not cease till mining in the district is definitely abandoned.

One of the first necessities for a geologic study is an accurate base map. A modern topographic map has been prepared for the central part of the copper district in Michigan, but this should be extended over the district as a base for accurately recording geologic data.

The district presents numerous geologic problems that are still unsolved or only partly solved. Among these are the problem of the Keweenaw fault and the associated problems, such as the depth and attitude of the Keweenawan lavas beneath the "Eastern" sandstone, and whether or not they contain valuable copper deposits east of the Keweenaw fault. Solution of these problems will involve the study of the South Trap Range and its relation to the Copper Range.

The Porcupine Mountain area, the portion of the Copper Range westward from the Victoria mine to the Wisconsin boundary, and the area near the end of Keweenaw Point, in Keweenaw County, are but little known. Throughout the district, in fact, there are rather large areas of which little is known, as can be seen by inspection of the maps. Much can doubtless be done toward filling these gaps by magnetic surveys and other relatively cheap methods. This work should be done on a scale and with an accuracy suitable to use in mining development. Much trenching and other exploration was carried on in the early days, especially in Keweenaw County, of which there is no record. The location of these openings on an accurate base map would give considerable information as to what has already been done and as to localities where additional exploration is most promising. In this same area there is considerable to be done in mapping outcrops when a suitable base map is available.

It is already demonstrated that dip-needle mapping of the formations can be carried on to advantage, and there is a considerable field for this work in further mapping of the general geology.

The possibility of the development and application of geophysical methods to the search for ore in the district should be kept constantly in mind. The fact that they have not been notably helpful to the present time should not discourage the study of such methods.

Likewise there should be a continuing study of the ore occurrences with the purpose of discovering additional guides to the search for ore. Progress has been made in this direction over a period of 75 years, and it is clear that the end has not yet been reached. 
To summarize, it may be stated that what is needed in this as in every other mining district is continuous geologic work with an accurate record and correlation of all data relating to the occurrence of ores and the steady and persistent attempt to apply new knowledge and new methods to the finding of new ore bodies and the exploration of those already known.

\section{GEOPHYSICAL METHODS APPLIED TO EXPLORATION AND GEOLOGIC MAPPING}

By T. M. Broderick and C. D. HoHL

\section{INTRODUCTION}

USE OF GEOPHYSICAL METHODS

During the last few years considerable interest has been aroused in the application of geophysical methods to the search for economic minerals. Well-authenticated cases of the discovery of deposits so diverse as iron ore, copper sulphide deposits, gold veins, and oil pools, either directly or indirectly as a result of the use of these methods, are on record. The recent widespread interest in this subject is the outcome of the rapid development of the methods in the last decade, particularly in Germany, Sweden, and France.

One type of geophysical observation has long been known and used in the Lake Superior region. Every geologist in the iron districts regards the magnetic dip needle as an essential part of his equipment, and a "magnetic survey" is in by far the greater number of explorations one of the first steps. Curiously enough, however, the possibilities of magnetic observations, regarded as essential in geologic mapping in the iron districts of the adjacent counties, were practically ignored in the copper country. It is safe to say that the present high degree of completeness of knowledge of the stratigraphy in this district could have been obtained at an enormous saving had magnetic surveying been used in the explorations of the old type. Thousands of feet of diamond drilling and trenching could have been dispensed with, preliminary shafts and crosscuts, poking around to "find the lode," would have been unnecessary, many miles of expensive transit work on the surface could have been saved, and mines such as the Ahmeek and Mohawk, long undiscovered because of a simple curvature in the strike of the lode, would have been found as soon as anyone with a dip needle had taken the trouble to work along the strike from the original discovery. However, the results were obtained, even though at unnecessary expense; but it is to be hoped that the futile "cut and try" exploration will be indulged in less and less as time goes on and scientific principles of exploration are followed. The present problem is to decide what use to make of geophysical methods, in the light of present knowledge of the geology of the district. No very positive statements can be made in the following discussion of this subject. However, some experimental work has been done and consider- able study has been given to the use of these methods by the geological department of the Calumet \& Hecls Consolidated Copper Co., and we feel that we are in a position to say what there is to be said on the present status of geophysical methods as aids to geologic work in this district.

\section{PRINCIPLES OF GEOPHYSICAL METHODS}

All geophysical methods depend upon a contrast in the physical properties of the mineral deposit itself with those of the surrounding rock, or upon the discovery or delineation by means of such contrasts of some geologic feature to which mineral deposits are related. Thus, magnetic deposits are more magnetic, massive chalcopyrite deposits are better conductors, and salt domes have a smaller gravitative attraction than the surrounding rock. Or a mineral body which of itself may have no outstanding physical property amenable to investigation by geophysical methods may be related to certain geologic features which could be outlined by such methods. Thus, oil pools are discovered by outlining salt domes, hematite bodies by their relations to magnetic dikes, or chalcopyrite deposits by their relations to a certain contact. The essential condition in all geophysical work is that there be a detectable contrast in certain physical properties of the feature that is being sought, be it the mineral deposit itself or some geologic structure or condition to which the deposit is related. The physical property upon which the method depends may be magnetic polarity, magnetic permeability, electrical polarity or conductivity, density, elasticity, or one of certain other properties that are used more rarely. The manner and degree in which this essential condition of contrast in physical properties is met by the rocks and ore bodies of this district will be brought out in the following paragraphs.

\section{THE THREE FUNDAMENTALLY DIFFERENT APPLICATIONS OF GEOPHYSICS}

There are three radically different methods of conducting geophysical investigations. (1) If the physical properties of certain ore bodies or mineral deposits themselves have the necessary contrast with those of the country rock, that method can be selected which takes advantage of this contrast, and the work can be carried on with the direct object of locating the mineral deposits themselves. (2) It may be possible to take advantage of the physical properties of rocks associated with the mineral deposits, enabling structural features known to be related to the mineral deposits to be determined. (3) Geophysical methods may be used in general geologic mapping where the immediate objective is not so directly the location of mineral deposits as it is to build up a general geologic map which it is hoped will ultimately be of use in exploration. The following discussion will take up in order these three methods. 


\section{DIRECT APPLICATION OF GEOPHYSICS TO COPPER FINDING}

\section{EXISTING CONDITIONS}

There are two general types of copper deposits in the Lake Superior district - the so-called lode deposits, which are in amygdaloid or more rarely in conglomerate, and the fissure deposits. The fissure deposits are unimportant as producers, having furnished less than 3 per cent of the copper of the district. A satisfactory geophysical method should be able to detect an amygdaloidal ore body having as little as 1 per cent of copper with as much as 30 feet of overburden, and it is therefore apparent at the start that the existing conditions are on the whole unfavorable. In the first place, the desirable degree of contrast between the ore bodies and the unmineralized lodes is not present. The sole difference, so far as we have been able to observe, between a mineralized lode and many unmineralized lodes is that the former has 1 per cent of its weight in native copper, which is $\frac{1}{300}$ of its volume, whereas the latter have less copper. Otherwise the mineralized lode is apparently the same in texture, mineralogy, porosity, permeability, water content, and chemical composition as dozens of unmineralized lodes, and for that matter many a lode is the same outside the boundaries of the ore shoot as it is within these boundaries, except for the small copper content.

The overburden of glacial drift, which covers almost the entire district, ranges from some hundreds of feet in thickness down to the vanishing point. Inasmuch as the prospecting in the last 80 years has involved a very thorough examination of the outcrops and the glacial drift, it follows that most of the undiscovered ore bodies are probably under rather deep overburden. There are probably none that crop out or are covered for any extent by less than 5 feet of overburden, and there are probably more covered by at least 20 feet of drift than by less than that amount. But with geophysical as with other methods applied on the surface, the thicker the overburden the less the chance of discovery.

The ore bodies are tabular and dip rather steeply, so that the outcrops, although of great length, are narrow, say from 10 to 20 feet on the average. The amygdaloid lodes are highly variable in width, some of them widening out from a few feet to 40 feet or more within a distance of 50 or 60 feet along the strike. These conditions reduce the chances of discovery by a geophysical method, because they introduce the possibility that the lines of observation may cross the lodes over the narrow spots. The conditions are very different from those in a district where the ore deposits are large, homogeneous, and equidimensional.

In most of the deposits the copper is very irregular in both size and distribution. Some of it is microscopic, being so fine that it gives a uniform pink tone to the including mineral, such as datolite or quartz. From these there are intermediate particles, nuggets, sheets, and masses weighing hundreds of pounds and even thousands of pounds. No physical continuity between the particles and masses exists to any degree, except possibly in the conglomerate ore, where the copper forms an interlacing cement in certain beds and is probably physically continuous over areas of some hundreds of square feet.

A very serious handicap to geophysical work in this district is the impossibility of making any exhaustive preliminary tests over known ore bodies. All such bodies have been worked from the surface downward, and very little "back" or unstoped ground was left at the surface. Furthermore, in most places there is a maze of power lines, pipe lines, tracks, and other artificial structures both on the surface and underground in the vicinity of the outcrops of the lodes, which would give much stronger "geophysical" effects than the modest copper content of the lodes themselves. In one or two places in the district it has been possible to make rather dubious tests over shaft pillars and old backs or roofs of ore bodies, but these have not been at all satisfactory nor convincing.

The conditions outlined above make it seem unlikely that geophysical methods can be of direct use in the exploration for copper deposits of the lode type. It is true that the fissure deposits present much more favorable conditions for geophysical work, but the history of the production of the district does not encourage the belief that fissure deposits of any great size could be found. Therefore exploration for fissures lacks the incentive that is offered by exploration for lodes.

The one outstanding feature that compels consideration of the possibilities of geophysics in this district is the fact that the ore mineral is native copper, which occupies a position in the series of natural electrical conductors far above that of the common sulphide minerals, such as chalcopyrite, which lend themselves so well to prospecting by electrical methods. It is possible that under certain conditions ore carrying 1 per cent of native copper would be as easily detected by electrical methods as ore carrying, say, 30 per cent of chalcopyrite. Because of the high conductivity of metallic copper, no such encouragement is offered to any other known method of geophysical exploration as there is to electrical methods. Of the other common methods the gravitometric and seismic have not been tried in lode exploration, simply because the conditions in the district seem to offer no hope for success. The possibilities of the use of magnetic methods in the search for copper deposits have been considered in conjunction with magnetic observations made for various purposes, and this work is described in succeeding paragraphs. 


\section{ELECTRICAL METHODS ${ }^{63}$}

Direct conductivity and resistance methods.-Long before the development of the technique of the modern electrical prospecting methods, tests were made of the conductivity of the copper-bearing lodes. In 1893 Prof. James Fisher, now of the physics department of the Michigan College of Mines, measured the resistance of stretches of copper-bearing lode in the Quincy mine and of the "Eastern" and Freda sandstones. Contact with the lode was made often by attaching the terminals to copper masses in the rock. The resistance was thus determined between points. About 1900 N. S. Osborne, at present with the United States Bureau of Standards, did some work along equipotential lines for the E. J. Longyear Co., both in the Lake Superior copper district and on the Mesabi iron range. Variable and apparently inconsistent measurements were obtained, and nothing of theoretical or practical importance resulted. Mr. F. N. Bosson, chief electrical engineer of the Calumet \& Hecla Consolidated Copper Co., has found that it is possible in the deep salt-water zones in one of the mines to operate electric trolley locomotives without the regular metallic ground return, the conductivity of the watersoaked lode providing an adequate return circuit.

Spontaneous polarization.-The method of spontaneous polarization depends upon the electrical currents set up at the outcrop of an ore body because of its chemical alteration in the zone of oxidation. Observations were taken across the Isle Royale lode and across the Kearsarge amygdaloid and Kearsarge conglomerate lodes at Ahmeek by means of two movable electrodes, at a fixed distance apart, in contact with the ground. Traverses were made by shifting the electrodes along lines at right angles to the ore bodies. The potential difference between the electrodes was determined at the different stations by means of a potentiometer in circuit with the electrodes. Absolutely no electrical effects were observed other than those due to the ordinary weak and irregular ground currents. This test was by no means, however, a conclusive elimination of this method as of possible use in the district. The rate of oxidation of native copper, on which this method depends, is very slow compared with the rate of oxidation of sulphide minerals and would therefore offer less chances for the method here.

Equipotential lines. - The method of equipotential lines depends upon the fact that if a direct current is sent through homogeneous ground between two electrodes the lines connecting the points having the

${ }^{63}$ We wish to acknowledge the assistance and cooperation of the experts in electrical prospecting who worked with us in what we regard as a piece of economic research. Without their technical skill and apparatus we could not have carried on the work. The experts who were in the district were Sherwin F. Kelly and Ingomar Tennberg with his assistant Mr. Roxtrom. In fairness to these gentlemen it should be stated that they regard the possibilities of their respective methods somewhat more optimistically than we state ther in the following discussion. same potential between and surrounding the electrodes are regular geometrical curves, of a character predeterminable by the theoretical considerations in. volved. If, however, a body of rock or ore having either higher or lower conductivity lies within the field between the electrodes, the points of equal potential do not lie along the regular theoretical curves of the homogeneous field, but the lines are found to be distorted in the vicinity of the body of different conductivity. If it is of lower conductivity than the surrounding rock, the equipotential lines are crowded together near it. If it is of higher conductivity, as most ore bodies are, the equipotential lines are spread apart over it and in its immediate vicinity.

A brief test of this method was made over the Isle Royale lode at a point where it was assumed to be mineralized. Although the lode itself appears to have distorted the equipotential lines, similar distortions were made by adjacent amygdaloids not known to be mineralized. It is felt that both the theoretical considerations and these experiments throw doubt on the possibilities of the successful use of this method in its present stage of development in the Michigan copper district. It is apparently able to indicate the locations of amygdaloids and would therefore be of use in general mapping of structure and stratigraphy. However, magnetic methods are so much more quickly, simply, and economically used for the same purpose that there would be no excuse for using the electrical methods for general geologic work where magnetic methods apply.

Inductive methods. - In the inductive methods a loop of insulated wire is laid out on the ground, usually in a rectangular form. An alternating current provided by a generator or by an induction coil operated with a storage batery is sent through the loop. Thus a primary alternating magnetic field is set up within the loop of an ideal predeterminable shape if the ground is homogeneous. If a conductor such as an ore body of certain types is in the field, however, a secondary field is set up about the conductor. This secondary field is opposed to the primary field and therefore causes a distortion of the ideal primary field above and near the conductor. By ingenious methods of amplification and observation of the electromagnetic field within the loop, the secondary currents due to certain types of ore bodies can be recognized.

After some preliminary laboratory tests with specimens of rock and ore, the results of which were of an indifferent character, attempts were made to carry out practical investigations over known lodes. These included tests over the Kearsarge, Pewabic, and Baltic amygdaloids and the Calumet \& Hecla conglomerate. All these trials showed the copperbearing lodes to give weak though detectable effects. The strongest effects were shown over the Calumet \& 
Heela conglomerate and the Pewabic amygdaloid. ffter critical analysis, however, these tests were not s satisfactory as appeared at first sight. Dipneedle readings were taken along the same sections on which the electrical traverses were run. The Kearsarge and Pewabic amygdaloids and the Calumet \& Hecla conglomerate showed varying degrees of magnetic disturbance in the vicinity of the lodes, and the electrical effects above the Kearsarge lode were definitely related to the magnetic anomalies rather than to the copper of the lode. The results the tests at the Baltic and Champion mines, over the Baltic lode, were unsatisfactory for several reasons, mong which were great thickness of overburden, esceptionally rough topography, wire fences, and the lact that where the conditions were most favorable and weak electrical effects were obtained over the ode similar effects were obtained away from the lode. The tests over the Pewabic lode, which may or may not be significant, indicated three mineralized lodes. It is possible that there are three mineralized lodes where the tests were made, inasmuch as mineralization in adjacent amygdaloids is a characteristic of the Pewabic ore body. Here again, however, there were complications due to magnetism of the traps and the possible presence of underground pipes, rails, wires, and ables. The conditions over the Pewabic lode were not such as to give a satisfactory test of this method. The most satisfactory test was the one over the Calumet \& Hecla conglomerate. Fortunately there ras a shaft pillar 200 feet wide at No. 12 shaft, Calumet \& Hecla. The shaft itself was not in operation, there being no shaft house nor machinery at the surface. The overburden is about 20 feet deep, the copper content of the rock is about 2 per cent, and the copper has the ramifying and connected form more common to conglomerate than to amygdaloid mineralization. The conditions for favorable results were the best to be expected in lode mineralization in his district. Furthermore, although the adjacent taps showed some magnetic disturbance, the effects were not strong nor sudden, the magnetie curves aring long, gentle slopes. The results of the electrical tests, though weak, were the strongest obtained in the district and were apparently due to the copper in the lode.

These tests over known lodes indicated that under the most favorable conditions of copper content, copper distribution, lack of complicating factors such is strong magnetism in the traps, and thinness of verburden the inductive method might detect an inknown copper-bearing lode. Furthermore, it was oped that with additional work in the district the lectrical prospecting experts might develop their wethods to the greater degree of refinement necessary or search for the Michigan type of copper deposit. lccordingly, the electrical prospectors were engaged if further field work. Exploratory crosscuts at shallow depths were being driven at the time on the lands of the La Salle Copper Co. and the Cliff Mining Co. On the La Salle ground $7 \frac{1}{2}$ miles of double traverse was run, and on the Cliff ground 4 miles. The traverse lines were run at right angles to the strike and ranged in length from a few thousands of feet up to 3 miles. Two parallel lines of observation 200 feet apart were run in each test. This was thought to be safer than a single line of observation, because of the many variable conditions which might allow an ore shoot to give no effect in one spot but a detectable effect not far distant. Some of these lines were run over the ground to be explored by the crosscuts. Dip-needle readings were taken wherever electrical observations were made, and in many places electrical effects were obtained, only to be eliminated from further consideration by finding that they were due to the local magnetism of the rocks. This ability to eliminate electrical effects due to the magnetite in the rocks by a method so simple and economical is a decided advantage. In order to make doubly sure that certain electrical effects were actually due to magnetite, the testimony of the dip needle was checked by digging a 170 -foot trench in one place where the electrical and dip-needle curves both showed disturbances. As was expected, no copper was found in the amygdaloids thus exposed. Certain electrical effects were apparently related to the water content of the overburden, weak disturbances being obtained where the traverse lines crossed from dry sand to wet swampy soil. No electrical indications were obtained which were suspected of being related to a copper deposit. However, no copper deposits were found in the crosscuts through a part of the territory covered by the electrical work.

Conclusions. - The conditions existing in this district seem to be distinctly unfavorable to the successful application of geophysical methods to the direct search for copper deposits. The electrical methods would seem to have the best chance of success, and several of these have been given brief and inconclusive trials. The inductive method gave most encouragement. The present situation may be summarized as follows:

1. Low-grade deposits, erratic distribution of copper, erratic variations in thickness of the lodes, which on the average are thin, lack of contrast between conductivity of the mineralized and the unmineralized rock, thick and irregular overburden, the chances that the greater number of undiscovered lodes are in the regions of thicker overburden, the interference of magnetite in the traps, and the high water content of the permeable amygdaloids, unmineralized as well as mineralized, are all features that tend to make electrical prospecting difficult.

2. There are practically no places in the district where conclusive tests of geophysical methods can be made over known ore bodies. 
3. Present electrical methods were developed chiefly to explore for massive sulphide deposits, which apparently give very much stronger and more definite results than the disseminated native copper deposits. Much greater refinement in technique seems to be necessary before these methods can be used with confidence in this district.

4. Those who are expert in these methods feel that they have passed the experimental stage, and this feeling is doubtless justified as regards massive sulphide deposits; but considerably more experimenting must be done before these methads can be applied in the Michigan copper country with the same degree of confidence. It is felt that there is enough of a chance of successful adaptation of these methods to the conditions of the district to warrant further research. The research should be carried on by men who are not interested in the commercialization of any particnlar method, and it should be financed as experimental work rather than as a method which has been demonstrated to be successful with ore bodies of this type. A Federal Government or State organization could undoubtedly handle the experimental work. At any rate, as experience is gained in the practice of the methods elsewhere, the tendency will undoubtedly be to become more and more expert in the detection and interpretation of the weaker effects due to lean disseminated deposits, thus approaching a solution of the problem of this district.

5 . Because of the weakness of the electrical effects which these copper deposits produce, other weak effects due to such features as topographic roughness, small quantities of magnetite, and irregularities in groundwater distribution, which are in districts of massive sulphide deposits of a small order of magnitude compared with the electrical effects of the ore body, become in the Michigan district of about the same order of magnitude as the effects due to the copper and therefore lead to confusion.

6. Too great a coincidence of favorable conditions seems to be required for positive results. The most satisfactory of the tests over known lodes was that over the Calumet \& Hecla conglomerate, where the copper content was exceptionally high, the copper distribution exceptionally favorable, and the overburden probably rather less than the average of that covering undiscovered deposits.

7. If it is true that such a coincidence of several favorable factors is required for a deposit to give a positive effect where the line of observation happens to cross it, then negative results do not go very far in condemning the ground explored by electrical methods.

8. The encouraging features are that the ore mined is native copper; that despite the fact that the methods have not been developed for the purpose of detecting such weak effects, trials over known ore where condi- tions are most favorable give detectable though minute effects; and that the dip needle offers a rapid, inexpensive, and simple means of eliminating one of the causes of uncertainty in the interpretation of electrical effects.

No attempt has been made in this discussion to present the technical side of geophysical prospecting. Some of the more important papers on the subject in the English language are listed in an article by Hans Lundberg. ${ }^{64}$

\section{INDIRECT APPLICATION OF GEOPHYSICS TO COPPER FINDING}

If there were surrounding the copper deposits a widespread zone of alteration characterized by excessive development of magnetite or the destruction of the magnetite already present in the traps, or if the copper deposits were related to certain structural features such as folds, fissures, faults, unconformities, or contacts, geophysical methods that could detect such features would be of indirect use in the search for the deposits. The copper-bearing series is by no means homogeneous magnetically. Different flows and different parts of the same flow vary in magnetite content. Furthermore, there are erratic concentrations of magnetite all over the district, some of them in the bedrock, others in glacial boulders. It would therefore be expected that irregularities in compass or dip-needle readings would be obtained somewhere in the vicinity of the copper deposits as well as elsewhere. Such erratic readings near the copper deposits naturally attracted attention, and it has even been asserted that "There is certainly a deflection in the vicinity of the richer copper belts." 65 Work thus far accomplished, however, indicates that the magnetic deflections in the vicinity of the copper deposits are simply those due to the primary magnetite concentration in the original rocks, unchanged by subsequent mineralization, and therefore in no way related to the copper deposits. Similarly, no structural relations, such as those suggested above, are known to exist. Some ore bodies are on synclinal and some on anticlinal cross folds; others occur where the strike is essentially a straight line for miles. Some have thousands of cross faults, strike faults, and fissures; others have practically none. Therefore, existing knowledge indicates that there is no present possibility of applying geophysics in this indirect manner. So far as now known, the only such application of geophysics likely to be feasible would be to determine the lateral extensions of a new deposit by tracing the strike of the lode in which it lies with the dip needle or by some similar means.

64 Practical points on electrical prospecting for location of mineral deposits: Min. Cong. Jour., vol. 12, pp. 737-738, October, 1926.

6s Meuche, A. H. The deverior an their geological relations: Michigan Geol Survey Pub. 6 (Geol. ser. 4), vol. 2, pp $887-931,1911$. 
APLICATION OF GEOPHYSICAL METHODS TO GEOLOGIC MAPPING

EARLY GEOLOGIC WORK

Very early in the history of the district fair geologic maps were made by following trap'and conglomerate ridges, thus making general_correlations of beds at certain horizons and determining the general structure. Thus it was a simple matter, for instance, to trace the Greenstone for many miles in Keweenaw County and the Evergreen flow in Ontonagon County because of the almost continuous outcrops along prominent bluffs. As one after another of the lode deposits were discovered, the idea that these few "master lodes" extend throughout the district took hold, and it persists to the present day. The great object of the explorers was to locate these "master lodes"- the Isle Royale, the Pewabic, the Calumet \& Hecla conglomerate, and the others - on their particular properties. This was a matter of stratigraphic mapping, and therefore infinite pains were taken to ascertain the stratigraphic relation of these beds to the more easily traceable key beds. Thus there followed a period of trenching based upon accurate surveying, in the attempt to follow from one end of the district to the other the lodes that were known to be mineralized at some point. The introduction of the diamond drill opened up great possibilities in the determination of stratigraphy, and extensive campaigns of drilling followed. It would be safe to estimate that a million feet of diamond drilling has been done in the district, a large share of it being chargeable to purely stratigraphic purposes, because few of the explorers were satisfied with the diamond-drill core as evidence of the presence or nonpresence of commercial deposits. The net result of all this drilling was a very detailed knowledge of the stratigraphy but no discovery of new ore bodies, with the possible exception of the Lake lode, which produced about $7,000,000$ pounds of copper before it was forced to shut down.

While all this drilling, surveying, trenching, and shaft sinking was going on in search of the "master lodes" in the copper district, magnetic instruments were being used just a few miles to the south, in the iron districts, not only in locating iron deposits but in tracing horizons of magnetic beds. Magnetism in the rocks of the copper district was noted on the plats of the original land survey, and in 1873 Brooks published an account of the use of magnetic observations in the Michigan iron districts. ${ }^{66}$

It is certain that the same knowledge of the structure and stratigraphy of the district could have been obtained much more economically had the dip needle been used in conjunction with the other methods, or, to put it another way, the same amount of money rould have furnished much more structural and strati-

"Brooks, T. B., Michigan Geol. Survey, pt. 1, vol, 1, pp. 205-243, 1873. graphic information had the dip needle been used in each locality before trenching, drilling, or shaft sinking. Many of the holes and shafts would never have been put down, and those that were sunk would have been more accurately located and directed. The present problem, however, is concerned with what should be done in the way of mapping geology by applied geophysics now and in the near future.

\section{IDEAL CONDITIONS FOR MAGNETIC WORK}

Magnetic contrasts in rocks.-Although gravitative, seismic, and electrical methods would undoubtedly serve to determine the geologic structure, the conditions for mapping by means of magnetic observations are so much more favorable that the other methods are not to be considered. The interbedded flows and conglomerates, many of them extending along the strike for tens of miles, carry magnetite in varying quantities. Thus there are the contrasts in adjacent rock bodies which form the indispensable conditions for any successful geophysical work. The variation in the magnetite content of adjacent beds causes distortions in the earth's magnetic field, and there are several types of instruments which can detect these distortions.

Simplicity of geologic structure.- The fact that the magnetite content and concentration is a property of many beds in which it occurs and that as a rule wherever one of these beds is crossed it can be depended upon to give a magnetic effect peculiar to itself makes it possible to trace certain beds for miles by the simple observation of this effect. Furthermore, the beds are parallel to a remarkable degree, so that once a positive correlation is established rather vague features in the near-by parts of the section, if they conform with the established correlation, can be related to other features at definite horizons with much more certainty than would be possible where the structure is more complex. These conditions make the interpretation of most of the magnetic data very simple.

Numerous geologic checks available.-One who undertakes to do magnetic work of the general reconnaissance type, crossing the mineral belt at regular intervals, should not, over the greater part of the district at least, be at a loss to know where he is geologically. It is possible in most places to tie in to known geologic features, because of the many diamond-drill sections and the extensive explorations. The question immediately arises why, if the geology is so well known, should any extensive magnetic mapping be undertaken? This is indeed a debatable question, and it will be considered throughout this discussion. The point to be made here is that if it should be decided to carry on any magnetic surveying, the existing knowledge of the district is sufficient to enable a close coordination between magnetic effects and known geology to be maintained during the work. 
Favorable geographic and topographic conditions.The country is very well adapted to the rapid methods of magnetic surveying. The copper-bearing formation as a whole occupies a long, narrow belt, in which the longer dimension is parallel to the strike. Roads and railroads extending along the belt within the limits of the series provide easy access to the belt almost from end to end. Over the greater part of the district a complete dip-needle traverse of the formation can be laid out at any place and completed with a few days. Numerous section corners, roads, diamond-drill holes, and mine shafts, abandoned and operating, provide convenient geographic tie points. United States Geological Survey topographic maps covering that portion of the district extending from Cliff to Globe are available.

THEORY AND PRACTICE OF MAGNETIC SURVEYING

Fundamental principles.-Over areas underlain by magnetically homogeneous rock material the earth's magnetic field is essentially uniform, the lines of magnetic force having a uniform inclination and spacing; or, expressed in another way, the magnetic field is uniform in direction and intensity. If a rock formation of different magnetic permeability lies within the otherwise magnetically homogeneous rock formations, the ideal or normal earth's field is distorted in the vicinity of the magnetically different formation. The lines of force are steepened or flattened and they are crowded together in some places and spread out in others; or, to put it more properly, there are local variations in the direction and intensity of the earth's field. Mapping geology by means of magnetic instruments, herein referred to as "magnetic surveying," simply involves the detection, tracing, and geologic interpretation of these local variations or anomalies in the earth's magnetic field.

Instruments.-A variety of instruments have been designed for this purpose. Sighting on a distant object and walking directly toward it, taking the magnetic bearing of the line traversed at intervals with an ordinary compass, may serve to detect variations in the direction of the horizontal component of the earth's field. Compasses equipped with sundials are used to determine the true meridian at a given station, and the deviation of the horizontal component of the earth's field, or the declination, is observed by reading the angle between the meridian and the position of the compass needle. The period of vibration of the needle from place to place can be determinea, and a measure of the variations in the horizontal intensity of the earth's field thereby obtained.

The most useful all-round instrument for magnetic surveying, in its simplicity, easy repair and adjustment, lightness in weight, sensitiveness, rapidity in taking observations, and satisfactory results, is the dip needle. Essentially it is a magnetized needle which swings in a vertical plane about a horizontal axis. Instead of swinging about its center of gravity, like the dip needles used in the study of terrestrial magnetism, it has a counterweight which is so ad. justed that the needle assumes a position most sensitive to magnetic variations of the normal field. Thus in the Lake Superior district the needles are adjusted to come to rest in a nearly horizontal position in the nor. mal field. In making an observation, the magnetic meridian is first determined by using the dip needle in the horizontal position, as with an ordinary compass. It is then tilted up into a vertical plane of the meridian and leveled by means of a leveling bubble, and the deflection of the needle from the horizontal is read in degrees. By standardizing this procedure, which is almost essential if readings that will be truly comparable are to be obtained, it is possible to make and record a dip-needle observation in 30 seconds.

More complicated and more sensitive instruments for making magnetic observations are available. There are, for instance, various types of magnetometers which determine all the elements of direction and intensity. The additional delicacy and refinement of the results yielded by such instruments in ordinary work, however, do not compensate for the clumsiness, need of transit surveys for locations of observation stations, liability to damage, difficulty in repairing, and time consumed in preparing for and making observations.

Plotting of results.- There are several methods of plotting dip-needle readings. A magnetic contour map may be made by connecting points which give the same dip-needle variations. Another method is to lay out the line of traverse on the map and plot a profile of the dip-needle readings from it as a base. This is the method used in showing the magnetic data on the accompanying map (pls. 6-9). The straight line represents the line of traverse, which may be either a transit line or a road. From it as a base the dip-needle readings in degrees are plotted. Where the north end of the needle is below the horizontal, the reading is plus, and the point is plotted at a distance above the traverse line proportionate to the number of degrees of deflection. Where the south end of the needle is below the horizontal the reading is minus, and the point is plotted below the traverse line. Where several men with different dip needles have taken observations in the same area, it is desirable to reduce all the observations to a common basis in order that they may be satisfactorily compared. In order to do this the needles are all read at a single station, preferably one where the earth's field is normal, and thus for each instrument a "normal" reading is obtained, and in plotting on the map all the readings in degrees above and below the horizontal are recalctlated to degrees above and below the "normal." This has not been done in the profiles on the accompanying 
map, because the readings were all taken with one instrument, so adjusted that the "normal" position of the needle was about horizontal, or approximately $0^{\circ}$. The curves are so plotted that they are correctly read by one facing north or east.

\section{HISTORY OF WORK IN THE LAKE SUPERIOR KEWEENAWAN ROCKS}

Early observations.-The earliest records of the observation of magnetic variations are those made at the time of the original land surveys. Some of these are noted on the township plats. While the land survey was still in progress geologic work by Jackson and his assistants was being carried on, and some attempt was made to find out whether there was any relation between the copper deposits and the magnetic snomalies. ${ }^{67}$ This work was not brought to a stage where any definite results one way or another could be announced.

Recent work.-During the many years in which systematic magnetic surveying has been carried on in the iron districts occasional traverses were made, intentionally or unintentionally, in areas underlain by Keweenawan traps. Magnetic lines of attraction, supposedly due to iron-bearing formation, after investigation by diamond drilling or otherwise have been found to be related to lava flows.

In recent years the State geological surveys of Minnesota and Wisconsin have conducted systematic investigations of the Keweenawan igneous rocks, using magnetic observations as one of the means of mapping the geology. So far neither organization has published a formal report of the work, although brief preliminary papers have been written presenting some of the results. ${ }^{68}$ The magnetic work in the Minnesota Keweenawan was done largely in the area of the great Keweenawan intrusive, the Duluth gabbro. Enough work was done over the traps to the south of the gabbro to show strong magnetic attraction at certain horizons in those beds. In more recent years the Minnesota Geological Survey has done some magnetic work in the Keweenawan lavas, but it was more or less incidental to other projects and has not been made the object of serious investigation.

By far the most comprehensive magnetic surveying in the Keweenawan has been done by field parties of the Wisconsin Geological and Natural History Survey under the immediate supervision of H. R. Aldrich. This work was started by W. O. Hotchkiss, at that time Director of the Survey, in 1922, and has

"Jackson, C. T., Report on the geological and mineralogical survey of the mineral lands of the United States in the State of Michigan: 31st Cong., 1st sess., S. Ex. Doc. 1, pt. 3, and H. Ex. Doc. 5, pt. 3, pp. 586-605, 1849

"Broderick, T. M., The relation of the titaniferous magnetite of northeastern Minnesota to the Duluth gabbro: Econ. Geology, vol. 12, pp. 663-696, 1917; Some katures of magnetic surveys of the megnetite deposits of the Duluth gabro: Idem, 10., 13, pp. $35-49$, 1918 . Aldrich, H. R., Magnetic surveying on the copper-bearing rocks of Wisconsin: Idem, vol. 18, pp. 562-574, 1923. been carried on by Mr. Aldrich from the beginning to the present time. Many hundreds of square miles of drift-covered Keweenawan rocks are being mapped structurally and stratigraphically by magnetic methods. The scattered outcrops are thus placed in their true relation to one another, and faults, folds, formation boundaries, unconformities, and individual beds are being mapped largely by magnetic methods. A few diamond-drill sections are available, and these, together with some good exposures of the section along streams, enable the observers to tie in the magnetic features to the geology from place to place. Except perhaps the land-classification work over possible iron-bearing lands, done by the same organization, ${ }^{69}$ this is, so far as we are aware, the most comprehensive magnetic survey ever made with no immediate application to ore finding as a direct objective. However, there are no known theoretical grounds which in any way discourage the idea that the possibilities of valuable copper deposits existing in Wisconsin are not as good as in Michigan, and the fact that they have been found in Michigan and not in Wisconsin is not conclusive. The members of the Wisconsin Geological Survey believe that

The areas away from Keweenaw Point may perhaps at once come in for new examination, but we feel that if not at present the attention will come within a very few years. **** Then the question comes, if the exposures are so meager and if the drift cover is so deep that geologists in the past have not been able to obtain the data necessary for a final conclusive opinion, what can a geologist do in such an area? So far as a thorough examination and testing of the rock is concerned, we of the survey fully agree that ordinary methods hold out little hope for an immediate solution of the problem. But we believe that there is much that may be done on the surface by means of a magnetic survey that will aid campaigns for the systematic disclosure of what lies below the drift..$^{70}$

Besides this magnetic work on the Keweenawan formations outside of the Michigan copper district, magnetic observations have been made in recent years within the district itself, the results of which are discussed below.

\section{RECENT WORK WITHIN THE COPPER DISTRICT}

We have no knowledge of any attempts at systematic magnetic work in the Michigan copper district between that at the time of Jackson and the present work by the geological department of the Calumet \& Hecla Consolidated Copper Co. This department has carried on some magnetic work at three different periods, with as many different purposes in view. The purposes and general results of the work in these periods are briefly as follows:

Work prior to 1925. - When the special geologic survey of the Calumet \& Hecla Mining Co. was

69 Hotchkiss, W. O., and others, Mineral land classification showing indications of iron formation: Wisconsin Geol. Survey Bull. 44, 1915.

70 Aldrich, op. cit., p. 574. 
started on the ground in 1920 , it was necessary to make tentative decisions as to the lines of research to be taken up first. The statements found in the literature that copper-bearing lodes caused magnetic disturbances were of course a challenge, and some observations were made with the dip needle in 1920 to check this statement. As a result of these observations and those made at a later date for the same purpose, it was decided that there were no obvious magnetic peculiarities in the vicinity of the copper deposits which could be detected by ordinary dipneedle practice in the light of present knowledge. Magnetic traverses have been run across the Calumet \& Hecla conglomerate and the Kearsarge, Pewabic, and Baltic amygdaloid ore bodies. On the other hand, we do not presume to state positively that a campaign of magnetic work carried out over a period of perhaps several years by competent geologists would not reveal magnetic peculiarities by which ore bodies might be detected. Our present position is just as it was after the tests in 1920 -that there are more promising lines of research, which therefore demand first attention. The brief magnetic work of the first summer likewise demonstrated the possibility of tracing the strike of certain beds by their magnetic characteristics.

Work in 1925.-The magnetic work done in 1925 was intended for the specific purpose of eliminating. effects that were due to magnetite of the traps and sediments from further consideration in the study of the results of electrical prospecting. The locations of the magnetic traverses thus were coincident with those of the electrical traverses. Eight sections, with a total length of 15 miles, were made on the lands of the La Salle Copper Co., and two sections, with a total length of 8 miles, on the lands of the Cliff Mining Co. All this work was in what may be termed the productive mineral belt. Magnetic observations were taken at all the stations where electrical observations were made. These were spaced 30 feet apart along surveyed lines at right angles to the strike. The magnetic traverses at La Salle are shown as dipneedle profiles on Plate 8 . Those at Cliff, made in connection with electrical prospecting, are the straightline traverses shown on Plate 7 . The results of this dip-needle work in eliminating electrical effects due to the magnetite of the rocks were most satisfactory. The observations made at this time also furnish data of use in the study of the possibilities of magnetic work in structural and stratigraphic geology.

Work in 1926.-As a preliminary to exploratory work about to be started in Keweenaw County, it was decided for various reasons to carry on some magnetic work in 1926. At this time 38 miles of traverses were run, and magnetic observations were made at 25 -foot intervals. This work was done in the autumn, and as it was desirable to get as many data as possible before winter stopped the work, it was decided to take the observations along the several roads crossing the formation, carrying locations by pacing and Brunton compass. The numerous possible tie-ins to well. located features, both geographic and geologic, made this a satisfactory method, although, of course, the plotting of results was more difficult than it would have been if section lines had been followed. The data so obtained, added to those of previous years, form the basis of the following discussion of the application of magnetic methods to structural and stratigraphic mapping in this district. We have made a total of over 60 miles of traverse and over 12,000 observations. These figures are by no means impressive when compared with similar figures of the larger State surveys or those of many iron companies. They become impressive, however, when it is realized how high a proportion of them can be tied up closely to the local stratigraphy because of the numerous diamond-drill explorations and outcrops.

\section{RESULTS}

Determination of strike.-One of the simplest and most easily obtainable deductions by means of magnetic work is the local strike. A magnetic bed is picked up and crossed at suitable intervals, and the line connecting that particular feature from section to section is the strike of the bed. It is desirable to know the strike in diamond drilling and in sinking inclined shafts. Examples of diamond-drill holes that would have been pointed differently and would have yielded more satisfactory information may be seen on the map showing the Cliff Mining Co.'s lands. Examples of shafts that would have been sunk differently had the strike been known are the Lake No. 1 and the New Baltic shaft, near the Keweenaw fault. Numerous examples of strike lines determined magnetically may be seen by reference to the magnetic sections on the maps. Those on the La Salle lands are especially good.

Tracing beds at specific horizons.- In earlier days, when certain lodes were known to be mineralized in different places, it was desirable to find the lateral extensions of the ore bodies, not only on the properties where development was going en but on adjacent properties. This work involved first tracing the strike of the lode itself, by trenching, surveying, diamond drilling, pit or shaft sinking, and crosscutting or by a combination of these methods. In many places the desired information could have been obtained at an insignificant fraction of the expense and time by dip-needle work. Such a problem would be solved by getting the horizontal distance from the lode to one or more near-by magnetic beds, tracing these beds with the dip needle onto the adjacent lands, and then measuring back to the position of the lode. Every engineer who has worked in the district 
can cite instances where time and money could have been saved had the location of some particular lode been known to the explorers. There are parts of the section where magnetic work of this type would be less successful than in other parts. For instance, the magnetic deviations are much weaker in some places toward the Keweenaw fault than higher in the section. Not enough magnetic data are available to reveal whether this is a secondary characteristic of ill rocks near the fault or a primary characteristic of that part of the section. At any rate, it would be much more difficult to trace lodes by dip-needle deriations of only $1^{\circ}$ or $2^{\circ}$ than it would by deviations of $6^{\circ}$ or $7^{\circ}$.

Location of faults, folds, and fissures.-Folds in the formation can be easily determined by magnetic methods, the magnetic lines following the curvature of the bedding. Similarly faults can be located by offsets in the magnetic lines, although in some localities the magnetic lines do not extend right up to the tault plane, which probably means that the magnetite has been altered in the zones of crushing adjacent to the faults. This apparent destruction of magnetite near faults suggests the possibility of locating fissures to be explored for copper deposits. Magnetic methods would probably have been of great aid in solving the structural problems where there are local complications, especially near the Keweenaw fault. Such sreas are present at the Mayflower-Old Colony, New dreadian, Lake, and elsewhere. The possibility that these areas are too close to the Keweenaw fault to rield traceable lines of magnetic attraction would make magnetic work of no avail, but so far as we are arare magnetic methods have not been tried in any of these places, and the explorers have had to feel their way along by means of expensive diamond drilling and underground work.

Other relations of magnetic features to geologic features.-The dip-needle profiles on the accompanying maps show certain recurring features, the recognition of which is of importance because they are the bases of correlation from one section to another. There are long stretches where the curve is essentially flat and rithout character; other stretches where the curve is rough, due to closely spaced areas of high, low, and normal attraction; other stretches where the curve is sbroad sag or an arch; and still others where the curve, though rough in detail, is in a broad way a succession of sharp rises, falling back to normal more gradually. The latter feature Aldrich ${ }^{71}$ likens to the teeth of a nipsaw. These peculiarities are the resultants of sveral factors, of which some are related to primary leatures of the rocks and others are not. The underying cause of the variations in the magnetic field at the present surface is the unequal primary distribu-

"Aldrich, H. R., op. cit., p. 566. tion of magnetite in the inclined succession of traps and sediments. To some extent this unequal distribution is related to differences in the magnetite content of successive flows. There are several types of extrusive rocks, varying chemically, mineralogically, and texturally. They range in composition from rather acidic felsites to the more basic members of the basalt group, and they vary widely in their magnetite content. Unequal distribution of magnetite is also the result of the unequal thickness of the flows. In general, the thicker flows give the stronger magnetic effects, probably in part because the slower cooling of the thick flows allows a more complete segregation of the magnetite to occur, and therefore a flow, say, 200 feet thick would have a greater magnetite concentration than five 40 -foot flows of the same composition as the 200 -foot flow. In general, the thicker ophites seem to cause the stronger magnetic effects. The La Salle profiles show this feature, the irregular curve from the neighborhood of the Calumet \& Hecla conglomerate to the Kearsarge conglomerate being due to a series of rather thick ophites. On the other hand, the more acidic glomeroporphyrites between the "Mesnard bed" and No. 17 conglomerate do not give much magnetic variation, nor do the thin feldspathic melaphyres and ophites just above and below the Kearsarge amygdaloid.

Local alterations, none of them so far recognized as being related to copper mineralization, have destroyed some of the primary magnetite so that its present distribution is probably more erratic than it was originally. The most notable of these alterations is the one which oxidized the ferrous iron of each flow while it was still hot, starting, perhaps, as soon as the flow reached the surface and continuing throughout the period of crystallization and even later. Thus there is very little magnetite left in the amygdaloidal tops of the flows, and the crystals of magnetite and other ferrous iron minerals deep within the flows are replaced to varying degrees by hematite. Even more erratic is the alteration of the magnetite in the vicinity of the faults and fissures. Little is known about this alteration at present, but there are strong indications that it exists. For instance, the traverses which crossed the thick Greenstone flow in Keweenaw County along the roads through the big gaps caused by fissure zones show flat magnetic curves, whereas those that crossed at the Ojibway and North American, away from any known fault or fissure zones, show violent magnetic effects in the Greenstone area.

Finally, there is the masking effect of the overburden and to some extent of the topography. In general, the thinner the overburden the more ragged the dip-needle curve, the effect of the overburden being to smooth out and generalize the curve, elimi- 
nating some of the minor variations and combining series of closely spaced magnetic highs and lows into broad areas of normal deflections or of uplift or depression. What is taken to be an effect of thick overburden is displayed by the northern part of the traverse running from Lac La Belle to Mandan. In the lower part of the section, just north of the point where it diverges from the section extending northwestward toward Delaware, the curve is rough and the overburden is thin, with many outcrops. Numerous correlations on the basis of magnetic observations can be made between the two profiles in their southern parts, but in their northern parts the two sections are very different. The western one, through the Delaware area, shows the magnetic characteristics of that part of the section as displayed in profiles run across it elsewhere. The eastern one, through the Mandan area, is much more smooth, and in parts of the section where the rocks in most places cause great magnetic contrasts the resultant curve is without marked characteristics. The sharp, strong magnetic effects especially characteristic of the thick ophites in the vicinity of the Calumet \& Hecla conglomerate are entirely lacking in the Mandan profile. Diamond-drill holes in both of these areas show that at Delaware the drift is much thinner than at Mandan, and it is thought that the thicker drift at Mandan is largely responsible for the lack of the usual strong magnetic contrasts in that section.

Abrupt changes in topography modify the magnetic curves to some degree, and the varying thickness of drift, together with abrupt topographic changes, may tend to make the correlation of geologic horizons with their related magnetic effects somewhat difficult.

Persistence of magnetic features.-The value of magnetic work in mapping stratigraphy is dependent upon the persistency of the magnetic properties of the beds at different horizons, which is pictured by a similarity in the dip-needle curves for different sections across the strike. If the concentrations of magnetite were haphazard and not characteristic of any particular geologic horizons, the magnetic lines would not be parallel to the strike or to any other feature, and therefore the magnetic observations would be of no use in geologic mapping. Such is not the case. The magnetite concentrations are characteristic of certain geologic horizons. Some of them are much more persistent than others, however, like the flows themselves. Some magnetic effects can be followed for many miles; other effects are difficult to find in a parallel section but a few hundred feet distant. The magnetic attraction at about the horizon of the Ashbed-lode is well marked in five out of the six sections that cross it in Keweenaw County. It is also present many miles to the south, in the La Salle area. This is an example of a very persistent and reliable magnetic line. Another persistent magnetic line is found about 1,300 feet horizontally above the Ashbed lode in Keweenaw County. In gen. eral, the closer the traverses the greater the number of possible magnetic correlations. The double traverse lines 200 feet apart in the La Salle area show in most places practically parallel magnetic curves, and correlations between them can be drawn at 100-foot intervals or in places even less. The distance between pairs is about half a mile, and the number of possible correlations between pairs is much less than that be. tween the two curves making each pair. In Keweenaw County, where the distance between traverses is still greater, the number of reasonable magnetic correlations is correspondingly less. The experience in correlating between diamond-drill sections is the same,

Inspection of the maps shows that where the drill sections are close together many more correlations can be made from hole to hole than where they are widely spaced. The flows thin out and disappear, and as a result the corresponding magnetic lines become weaker and disappear. Where one flow wedges out and is replaced along the strike by another flow, the two are generally of the same petrographic type. For instance, where one of the more basic flows, such as an ophite, wedges out, its place along the strike is not assumed by one of the more acidic flows, such as a glomeroporphyrite, but commonly by another ophite or a flow of similar composition. This means that the flows poured out during the same stages of the igneous activity were of a similar character. Thus there are portions of the section characterized by glomeroporphyrites, others characterized by ophites, and still others by intermediate types. The changes from a part of the section characterized by one rock type to a part characterized by another rock type are not abrupt, for there are in most places several flows of an intermediate type between the two extremes. Thus between a group of ophites and a group of feldspathic melaphyres there are likely to be a few feldspathic ophites and some feldspathic melaphyres with a faintly developed ophitic texture. Most of the accompanying maps and sections show this grouping of the various types of flows, and it is discussed elsewhere. The point to be considered here is to what extent this persistence of the belts of flows, in spite of the lack of persistence of the individual flows within the belts, is reflected in the magnetic profiles. An inspection of the magnetic profiles shows that the belt of glomeroporphyrites between the top of the Greenstone (or the base of the "Mesnard bed") and the Ashbed lode (or the overlying No. 17 conglomerate) is relatively homogeneous magnetically but that the ophites between the Calumet \& Hecla and Kearsarge conglomerates are not magnetically homogeneous as a belt. This difference causes smooth curves in the one case and rough curves in the other. Other belts have their characteristic magnetic effects. In general the persistence of magnetic effects bears a close rela- 
tion to the persistence of the beds which cause them. 1 given magnetic line probably weakens and disspears as the flow which causes it thins and wedges Ant. A broad general feature of the magnetic profiles lated to a group of flows of a given type is more persistent, just as the group is more persistent than the individual flows of which it consists. Aldrich ${ }^{72}$ inferred this wedging out of individual flows and the existence and persistence of the belts of flows of smilar composition in the Wisconsin Keweenawan amost solely from the details and broad features of his magnetic profiles.

Magnetic correlations. - The foregoing discussion will enable the reader to appreciate the many variable conditions which must be taken into account in the interpretation of magnetic observations in terms of stratigraphy and structure. The first step in this interpretation is to correlate the magnetic features of two or more adjacent cross traverses. The next step is to correlate the magnetic features with the local geology - to tie up certain magnetic lines with the formations which cause them, and to relate broad magnetic features to similarly broad geologic features. Finally, by working from areas where the geology is well known to areas where the geology is less certain, the determination of the geology from the magnetic features becomes possible. Some interpretations of these features are indicated on the maps. The most reliable magnetic correlations from section to section are shown. These are more numerous in the more closely spaced traverses. Other possible correlations are apparent, but most of these have not been indicated because they are less certain. Further data would of course allow more accurate interpretations to be made. It is thought that even the few traverses that are at present available are worth presenting, as they serve to show the possibilities of the method in a district where they form a simple, rapid, and economical means of obtaining valuable geologic information.

\section{PRESENT ATTITUDE TOWARD MAGNETIC SURVEYING}

As a result of this study of the application of magnetic methods to geologic problems in this district the conclusions set forth below have been reached. These conclusions are, of course, not to be regarded as final. Further data will undoubtedly strengthen or modify them or set up some others in their places, if any of them should prove to be unsound.

1. There is no reason to hope that the copper ore bodies in amygdaloids and conglomerates can be detected by magnetic methods. No feature of magnetite distribution is known to be in any way related to the presence of the copper. There may be zones of alteration adjacent to fissures and faults, in which some of the magnetite has been destroyed. Some of these zones may be mineralized, and it is conceivable that a search for fissure deposits in drift-covered country might be aided by magnetic surveying.

2. Magnetic methods are of use in the preliminary stages of the exploration of specific areas. Dip-needle traverses across the formation at closely spaced intervals give a great amount of detailed information concerning the geology, such as the strike, the presence of faults with amount of offset, a general idea of the thickness and character of the traps, and some idea of the thickness of overburden. For this purpose the traverses should be made at intervals of not more than a quarter of a mile, and they should be even more closely spaced where any structural complications are found. Readings should be taken at about 25 -foot intervals along the traverses.

3. Where it is desirable to trace the strike of a specific lode, magnetic methods will ordinarily serve. A traverse should be run across the formations where the position of the lode is known, thus determining its relation to the near-by magnetic beds. Then parallel traverses are made at intervals into the area where the position of the lode is to be traced, the lode being located by its determined position with respect to the magnetic beds.

4. Magnetic methods should help in solving local structural problems such as those pertaining to faulting or to pitching synclines and anticlines like those that occur at the Lake and New Arcadian mines.

5 . Since the beginning of geologic work in the district emphasis has been placed upon detailed stratigraphy. As a result the stratigraphy is especially well known. Individual conglomerates and traps have been traced for more than 50 miles along the strike. The character of the beds in the different parts of the section is known from one end of the district to the other. All this detailed information has been obtained by surface mapping, diamond drilling, and underground openings. There are some places in the district, of course, where the structure and stratigraphy are not so well known as in other places. Such areas occur south of Victoria and east of Mandan, and the next step in stratigraphic and structural mapping in the district might well be accomplished by a magnetic survey of these areas. Anyone who would enter into such a project should be convinced of its justification on the basis of its scientific or economic importance. It would be of considerable scientific interest to map the geology from the Victoria mine to the Wisconsin line, thus connecting in greater detail the geology of the copper district with that of the Wisconsin Keweenawan, now being mapped by the Wisconsin Geological Survey. Such a project would be especially valuable to the State of Wiscon$\sin$, because it would enable an interpretation of the Wisconsin geology to be made more closely in terms of the geology of the copper-producing portions of the Keweenawan series. 
One of the most interesting studies yet to be made in the Michigan Keweenawan is along the southern and eastern edges of the "Eastern" sandstone. The so-called South Range branches off from the main Keweenawan belt in the vicinity of Bessemer and Wakefield and extends southeastward for over 50 miles. It consists of northward-dipping Keweenawan traps and sediments, overlain by the "Eastern" sandstone. Also within the sandstone area are scattered outcrops of trap, as at Silver Mountain and in the Sturgeon River valley. A thorough study of the stratigraphy, petrography, and structural relations in this area would undoubtedly throw some light on the relations of the "Eastern" and "Western" sandstones and of the traps and the "Eastern" sandstone, and on some of the little understood features of the Keweenaw fault problem, such as amount of movement, thickness of sandstone, and rocks that underlie the sandstone. We have more than once heard practical men in the district seriously raise a question as to the economic possibilities of the Keweenawan formation southeast of the Keweenaw fault, beneath the "Eastern" sandstone. It is our opinion that a study of the South Range and the sandstone area to the north and east of it offers an almost certain chance of making important scientific contributions to some of the fundamental structural problems of the district, and that some of these contributions might have an economic bearing. Magnetic methods would be of use in this project, inasmuch as it is probable that the "Eastern" sandstone overlying the traps is very thin for some distance from the contact, therefore making it possible to trace the structure of the underlying traps by their magnetic effects.

So far as the part of the district between Victoria and Mandan is concerned, a project of general magnetic mapping is less attractive. The geologic maps accompanying this report furnish for that part of the district a degree of detail and accuracy far beyond the most extravagant ideas of successful outcome of a magnetic survey in a region such as that of the Wis- consin Keweenawan. In other words, the magnetic surveyor would start in this area with a map of more detail and greater accuracy than he ever could hope to make at the end of his work in the Wisconsin Keweenawan area. A certain amount of magnetic work in such well-mapped areas would be of use, however, in gaining an understanding of the way in which the various magnetic effects should be interpreted. Then when magnetic data from large unexplored driftcovered areas, such as those in Wisconsin, are studied, a much greater degree of certainty in their geologic interpretation would be possible.

The methods of magnetic surveying for general stratigraphy are fairly well standardized. Traverses across the formation, usually following land lines, are run at intervals, and the dip-needle readings are taken at equal intervals along the traverses. The distance between traverses should vary with the degree of detail of the information desired and the degree of detail already known. The interval between observations should vary in the same way. In order to make a contribution to the geology of the closely drilled areas, such as La Salle or Delaware-Mandan, magnetic traverses should be run at intervals of, say, one-eighth of a mile or less with readings taken every 25 feet. In the relatively unmapped country, such as that southwest of Victoria, traverses every half mile with readings every 50 feet would probably furnish a degree of detail which would serve as a basis for a fairly good contribution to the local geology.

6. Many problems of a topical rather than an areal nature present themselves as possible subjects of research in which magnetic methods could be used. Among those that have occurred to us are the mapping of the Lake Shore trap, a study of the felsites (present information not being sufficient to determine the intrusive or extrusive character of some of them), the relation of magnetic effects to character and thickness of trap, the distribution of magnetite in the flows, and the relation of magnetic effects to the tops and bottoms of flows. 


\section{PART 3. DETAILED DESCRIPTION OF LODES AND FISSURES}

In the following pages the ore deposits are described by lodes and fissures. A description by properties would in some cases cover deposits on several lodes and fissures, and a description by mines would in several cases cover but a part of a lode. The descriptions of lodes are arranged in order of stratigraphic position from higher to lower.

\section{NONESUCH LODE}

The Nonesuch lode is present throughout the Copper Range of Michigan, but prospecting and mining in it have been confined to the vicinity of the Porcupine Mountains, mainly around their east end. The White Pine mine is the only one that has made a notable production of copper from the Nonesuch lode. It was the only mine on the lode that was accessible at the time that this study was made, and therefore most of the statements regarding mineralization on the lode are based on observations made in that mine.

\section{STRATIGRAPHIC OCCURRENCE}

The Nonesuch lode is near the base of the Nonesuch shale, which lies between the Copper Harbor group and the Freda sandstone and is the highest formation known to be mineralized in the district. The Nonesuch formation is made up predominantly of red and black shales and red sandstone. Near its base is a persistent gray sandstone about 7 feet thick overlain by a thick black shale. Below the sandstone is about 4 to 6 feet of black shale followed by red sandstone and lenses of conglomerate. The gray sandstone underlying the thick black shale, the thin bed of shale below, and a few feet of sandstone below the shale are the most persistently mineralized strata in the formation, but where mineralization has been greatest it has extended to a maximum distance of 75 or 80 feet below the base of the black shale.

The black shale is a rather finely laminated, somewhat chloritic rock. Specimens of the shale from the White Pine mine, when heated in a closed tube, give off the tarry odor of hydrocarbons. The sandstone layers, which are predominantly red, range from medium-grained sandstone through grit to conglomerate, with pebbles several inches in diameter. The conglomerate consists mainly of pebbles of felsite and quartz porphyry and thus resembles the conglomerates of the principal copper district to the northeast. The sandstone of the beds in which the copper occurs is seen under the microscope to be made up of medium to coarse grained fragments, largely subangular. The constituents are quartz, feldspar, epidote, tour- maline, apatite, iron oxides, chlorite, micas, jasper, and fragments of felsite, trap, and volcanic glass in a matrix of finer grains of the same kinds, with calcite, silica, and iron oxides in considerable amount as cementing materials. Changes in the sandstone due to mineralization are mentioned on page 171 .

\section{STRUCTURE}

Structurally the Porcupine Mountain area is a domical uplift that constitutes a conspicuous irregularity on the south limb of the Lake Superior syncline. Felsite and coarser porphyry occupy the center of this uplift. Around and dipping away from them are the Eagle River group and younger formations, including the formation of particular economic interest, the Nonesuch. The uplift has not merely domed the beds upward but some of the beds have been broken across, so that although the felsite is in contact with the traps of the Eagle River group on the north and northwest sides of the mountains, it is brought against very steeply inclined younger rocks, including Nonesuch beds, on the southeast side.

Irving and later Wright and Lane explained the absence of the older rocks (like the Eagle River traps) on the southeast side of the felsite as due to a fault, called the "main Porcupine fault," along the margin of the felsite. Where the eastern end of this supposed fault is indicated on the original map of Wright and Lane, exploration between the White Pine and Nonesuch mines shows no fault to be present. If the felsite mass is an intrusive, this cutting out of certain beds along its border might be explained as a crosscutting intrusive contact.

The deformation in the Porcupine region may be a result of the injection of an igneous mass from below. The shape and nature of the uplift suggest that the intrusive body assumed the toadstool shape of the forms known as laccoliths. Over 40 years ago Irving recognized this structural similarity, but he concluded that "these mountains owe their existence in all probability to a fold," and thus he was left with the presumption that the felsite is a surface flow. Lane also concluded that both the narrow east-west belt of felsite south of the mountains and the larger body of felsite in the Porcupine Mountains region are effusive.

Lane, however, mentions several small intrusive masses just beyond the northwestern margin of the main felsite area (secs. 3 and 4 , T. 50 N., R. 44 W.), also intrusive rocks, including felsites similar in appearance to that in the Porcupine Mountain mass, a few 
miles to the southeast; and these felsitic masses may be offshoots from a common source.

The structure of the region is probably due to the intrusion of an igneous mass of later age than any of the rocks in which deposits of copper and silver are found. The indications of intrusive force acting upward and outward are not confined to the general doming of the overlying rocks and to the cutting out of certain beds west of the Nonesuch mine. Inspection of Wright and Lane's geologic map of the Porcupine region (see pl. 14) shows the presence of numerous faults disposed radially across the felsite contact on both the north and south sides of the mountains, and also the pushing outward from the east end of the felsite mass of a fan-shaped block some 3 miles wide from north to south, at the horizon of the base of the Nonesuch formation, and a mile wide at the top of the Lake Shore trap, south of the old Halliwell mine. As marked by the offset in the base of the Nonesuch shale, this block has been shoved eastward for nearly 2 miles.

The geologic details regarding this displaced block are known only along its southern edge, where the explorations of the White Pine mine have revealed certain features clearly. It seems evident that the outthrusting of the block was accomplished by a combination of faulting and of buckling or folding of the beds. Its south or southwest side is bounded by a nearly vertical fault, the White Pine fault, and as indicated on the map and shown by certain drilling explorations, its north side is likewise marked by a fault, which extends eastward from the old Halliwell mine. But on the south side, at least, these faults were developed only after the rocks had been folded so sharply that they broke across, and further dislocation was effected by faulting.

There is a suggestion from the map that farther north similar blocks between faults radially arranged with respect to the east end of the main felsite mass have similarly been shoved out away from the mountain, though to a somewhat shorter distance.

Branching from the reverse White Pine faults as shown in the White Pine mine are numerous minor faults that break the beds in the vicinity of the major faults. The details of these faults are given in the description of the White Pine mine (p. 172).

All the known features connected with this particular part of the region point to the production of the structural features by the intrusion of the igneous core of the Porcupine Mountains and the doming up and outward thrusting of the rocks that were invaded. This general setting helps to an understanding of the details of structure that have exerted a control on the ore deposition in the White Pine mine.

\section{MINERALIZATION}

ORE MINERALS

The ore minerals are native copper, native silver, and chalcocite. The native metals occur chiefly as cementing material in the sandstone lodes and as disseminated grains or as flakes lying along jointing planes in the shales. Subordinately they are present in fissures and fault gouges. Chalcocite occurs most conspicuously in small fissure veins, with calcite gangue. It is also sparsely disseminated in the sandstones and in the shales.

\section{FAVORABLE CONDITIONS}

The conditions that have been effective in localizing the ore minerals are the confining effect of relatively impermeable shales, proximity to fractures that acted as channels for the introduction of ore-carrying solutions, and favorable mineralogic or textural conditions of certain beds in the sandstones.

Influence of shale beds. - The lodes are in the sandstone close underneath the thick capping of shale, which acted as a barrier to the rising solutions that deposited the ore. The two beds most widely mineralized are immediately below the shale, separated from each other by a few feet of mineralized shale. At the White Pine mine, where mineralization has been most intense near fissures, certain beds have been mineralized for 70 to 80 feet below the heary overlying shale, but each of the lower beds has for its hanging wall or roof a bed of sandstone somewhat more shaly than normal, which seems to have acted as a barrier to the rising solutions.

Influence of fissures.-The deposits at the White Pine mine are closely connected with the White Pine fault and the associated branch faults, as is discussed in detail on page 173. Faults occur also in the ricinity of the Nonesuch and White Pine Extension mines, though there is no definite record of their relation to mineralization. Longyear, ${ }^{1}$ who was in charge of an exploration in T. 51 N., Rs. 41 and 42 W., north of the White Pine mine, says: "The drilling here has shown the principal mineralized areas to be in the immediate vicinity of the three northeast and southwest faults." Lane ${ }^{2}$ also some years ago pointed out the importance of prospecting along faults in the Porcupine Mountain district. Altogether the evidence seems to point very definitely to the association of mineralization with faults.

The ore-bearing solutions appear to have risen along the faults from a deep-seated source till they reached the heavy shale bed, in which the fault fissures were

1 Longyear, C. S., Michigan Geol. Survey Pub. 24, ser. 20, p. 20, 1916.

2 Lane, A. C. Unexplored parts of the Copper Range of Keweenaw Point: Lake Superior Mining Inst. Bull., vol. 17, p. 133, 1912. 
impermeable owing to the formation of gouge in these soft rocks. Below this impermeable bed the solutions soread out into the more permeable rocks and deposited the ore minerals.

Mineralogic and textural influences.-The third factor in controlling the distribution of the copper is the physical and mineralogic character of the beds impregnated. In so far as this factor may relate to differences between the particular beds mineralized and other near-by layers of the sandstone, it is believed to be of somewhat less importance than the tro factors just discussed-namely, proximity to one of the larger cross faults and an impervious cap rock. Vear one of these faults at the White Pine mine the mineralized layer is thicker than it is farther away. Tithin the lodes the copper is in many places confined to certain beds. Thus a lode 6 feet thick may have most of its copper in two or more layers that together make up not more than one-third of the total. In most hand specimens, and in thin sections as well, the copper is seen to follow certain bedding planes. This habit is undoubtedly due to some favorable textural or mineralogic features of the beds, but these have not been recognized except by the presence of copper associated with them.

The sandstones at the base of the Nonesuch shale, like most sandstones of the Keweenawan series of the Lake Superior region, are predominantly red. The ned color is due to the rather plentiful ferric oxide rith which the felsitic grains are impregnated and aso ferric oxide, which, together with calcite, forms the chief cementing material of the rocks.

The sandstone layers that carry copper have been bleached to a gray or greenish-gray color. Thin sections from the lode at the White Pine mine show that there is not much calcite remaining, but in its place as a cement is a pitchy black hydrocarbon, in an amount reaching a maximum of probably 2 per cent. The greenish tinge in this bleached rock is due to chlorite, which occurs largely as fringes about the sand grains and especially around the edges of the patches of hydrocarbon. The ferric oxide originally present in the unbleached rock has evidently been reduced to ferrous oxide and in part gone into combination as chlorite, but most of it appears to have been removed. This bleaching has occurred whether or not impregnation with copper has taken place just at that point. Many drill records show "gray sandstone" at the horizon of the lodes, but its copper content may be very low.

The impression gained from study of the sandstones in the White Pine mine is that the hydrocarbon, like the copper, has been introduced along the fissures and that its abundance has been determined by the same factors-namely, the presence of an impervious capping, proximity to a pronounced cross fault, and certain textural and mineralogic features of the beds.
The hydrocarbon, like the copper, occurs below the shale and shaly sandstone and is distributed through a greater thickness of beds and in greater amounts near the cross faults. It is more abundant in certain layers at these horizons, perhaps in those which were rich in replaceable calcite. The hydrocarbon occurs in the cross faults and fissures to an even greater proportionate extent than the copper; good-sized pieces of 10 to 20 pounds in weight made up largely of hydrocarbon have been obtained from such faults. The hydrocarbon is thought to have a greater horizontal distribution along the lodes than the copper, however, as it is found extending out along the beds farther than copper in commercial quantity.

The source of the hydrocarbon is not known with certainty, but inasmuch as the overlying black shale is bituminous, yielding a tarry distillate when heated in a glass tube, it seems probable that the hydrocarbon has been derived either from this shale or from some similar rock that may lie deeper in the series, by distillation under the heat and pressure attendant upon the intrusion and metamorphism of the region, or perhaps it was removed by the heated waters that carried the copper, although none of the shale seen in the mine appears to be leached or to have lost any of its black pigment.

The genetic relations of this carbonaceous substance and the copper are not entirely clear. Inasmuch as the same general conditions controlled the distribution of each, they are closely associated. The copper occurs in many places as a shell about the hydrocarbon, replacing the chlorite fringe. The period of deposition of hydrocarbon therefore was finished before that of the copper. Furthermore, the massive hydrocarbon of the fault zones is well impregnated with copper; whether this means replacement of the hydrocarbon by copper or simultaneous deposition of the two is not clear.

These relations might be thought to suggest that the hydrocarbon was active as a precipitant of the copper. In all the mines of the main productive region to the northeast, however, copper has been precipitated in the lodes that are high in ferric iron, and the precipitation has been attended by bleaching of the rock occasioned by reduction and removal of the iron but without the slightest evidence that any hydrocarbon has been involved. This is as true of the conglomerate lodes (parts of which are made up of sandstone like the lodes at the White Pine mine) as it is of the amygdaloid lodes. Bleaching of the rock through reduction and removal of the iron is likewise characteristic of the White Pine lodes. It is evident that the copper of the White Pine district entered an environment that would have been favorable for copper precipitation had there been no hydrocarbon present. The facts that copper occurs close to bituminous shale only in the Porcupine region and that so far as known 
hydrocarbon is associated with copper only in that region, and everywhere close to the shale, lend weight to the view that the hydrocarbon has been derived locally from the shale and at best exerted but a subordinate and modifying influence on the deposition of the copper, if indeed it had any influence at all.

In summary it may be repeated that the textural and mineralogic factors in the localization of the copper are of minor importance. The following generalizations may be made regarding the color of the sandstone and the presence of hydrocarbon and of copper:

1. No copper was seen in red sandstone, although copper occurs in gray bands in red sandstone.

2. No gray sandstone was seen at the White Pine mine without some hydrocarbon.

3. Little if any hydrocarbon was noted in red sandstone.

4. Gray sandstone without copper was noted.

5. The sandstone of the lodes may have been in part rendered gray by the hydrocarbon before the coppèr had all been deposited.

6. Although there seems to be a close connection between the hydrocarbon and the copper, it may be purely fortuitous; in any case the indications are that the copper solutions entered what would have been a favorable environment for copper precipitation had there been no hydrocarbon present.

7. Here, as in the larger deposits farther northeast, the deposition of copper is believed to have been accomplished by the oxidizing effect of ferric oxide in the rocks upon the copper sulphide solutions. In the fractures themselves, where the contact of the solutions with the rock was less intimate, part of the copper was deposited as native metal and part as the sulphide chalcocite.

\section{WHITE PINE MINE}

Location and topography. - The White Pine mine (pl. 33 ) is in secs. $4,5,8$, and 9 , T. 50 N., R. 42 W., Ontonagon County, a few miles east of the Porcupine Mountains, and is the most southwesterly producer among the mines of the copper district.

In the immediate vicinity of the mine the country, which stands about 200 feet above Lake Superior, is flat and monotonous. The bedrock is buried by glacial drift as much as 160 feet in thickness. The northward-flowing streams have cut rather shallow valleys into the drift and in places have exposed bedrock. These exposures and the drill records show that the rock surface also is one of little relief.

Production.-The White Pine Copper Co. was organized in 1909. Its production and dividends to the end of 1923 were as follows:

Rock stamped.

Refined copper produced:

887,654

Total_ _.

Per ton of rock ................... do

Silver produced ........................ ounces

Dividends paid:

20. 54

Total.

Per pound of copper.................... cent.

$\$ 33,438$

0.18
Rocks.-The following section is compiled from the notes of drill hole No. 162, 1,800 feet south of $\mathrm{N}_{0.3}$ shaft, supplemented by the data obtained in the mine concerning the rocks below the Second lode. The members of particular economic importance are indicated by indention.

\section{Section at White Pine mine}

Red shale... .

Red sandstone and shale_..................... 530

Black shale_.._.

Brown and black shale and gray sandstone.......... 200

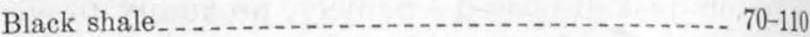

Gray sandstone (First lode) _........... 7

Black shale (parting shale)

Gray to red sandstone ${ }^{3}$ (Second lode) _........ 7

Red sandstone_............. 13

Gray to red sandstone ${ }^{3}$ (lower Second lode) ...... $\quad 6$

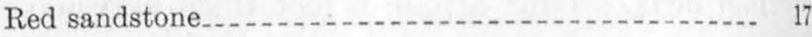

Felsite conglomerate _...

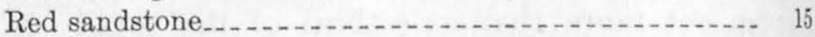

Gray to red sandstone ${ }^{3}$ (Third lode) _............. 8

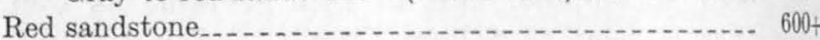

Structure.-The relation of the structure of the White Pine area to the general structural features of the region is shown on the map of the Porcupine Mountains and vicinity (pl. 14). In greater detail, the structure near the mine is shown in the small map of Plate 33, which shows the contour plan of the first lode, compiled from diamond-drill records and mine workings.

In the neighborhood of the White Pine mine the rocks have been dislocated along a soutkeast line 80 that those on the northeast side have been mored southeastward about 2 miles (as marked by the position of the first lode at the level of Lake Superior) and upward probably more than 1,500 feet. This digonal upward displacement has been accomplished partly by a buckling fold, which accounts for the strong curvature of the lode as it approaches the fault, and partly by faulting, which produces perhaps half of the total horizontal displacement and likewise about half of the total vertical displacement. The White Pine fault is of reverse throw; it dips steeply northeast, and its northeast side, containing most of the mine workings, is the upthrown side.

As this dislocation forms the southwestern boundary of the outthrust block, it is evident that the block on the northeast side of the fault-that is, the block that contains the principal mine workings-moved, and that on the southwest was stationary, relative to the country rock in general. It is probable that the block that moved would suffer greater stresses than the one that remained at rest, and it seems likely that the region of the present mine workings $(I, \mathrm{pl} .33)$ is a place of greater disturbance than the region on the opposite side of the fault (III). Faulting of the rocks appears favorable for the occurrence of ore in this locality, as is shown below.

\footnotetext{
3 Gray where mineralized; elsewhere red.
} 
The minor faults that are numerous in the developed portion of the mine are irregular in strike, dip, and throw, but certain generalizations concerning their hehavior can be made. Two principal ones ( $N$ and $K$, p. 33), from which many of the others are subordinate branches, are well exposed underground. The existence of another fault of apparently similar direction of strike and throw is suggested by the drill records in the neighborhood of $S$, some 1,500 feet east of No. 5 shaft. The known faults, like $N$ and $K$, decrease in mount of throw as distance from the White Pine fault increases. The place at which the suggested dislocation $S$ is revealed is distinctly farther from the supposed continuation of the White Pine fault than the farthest known extensions of $N$ and $K$, yet the displacement at $S$ is greater than the maximum at $N$ and $K$. There is a possibility, therefore, that $S$ is a larger fault than the others and that nearer to the White Pine fault along $S$ there may exist either a single strong fault or a region of disturbance similar to that in the $N-K$ block and of eren greater intensity.

The known cross faults, with the exception of $K$ and sfew smaller ones, have their downthrown side to the southeast. As the fault $K$ has its downthrown side to the northwest, the greater part of the block of ground between No. 3 and No. 4 shafts has been dropped with respect to the blocks on the northwest and southeast. The faults $N$ and $K$ have caused a greater displacement of the lodes than any of the others that were traceable for any considerable distance through the mine. Their displacement is rariable, but in general they bring the First lode on one side well down toward the Third lode on the other side; this implies some 40 to 50 feet of vertical displacement. Most of the cross faults cause a displacement of less than 10 feet.

These cross faults as a rule are curved rather than straight, and many of them twist surprisingly. They are probably contemporaneous with the major dislocation represented by the folding and by the White Pine fault. The curvature is convex in dip as well as in strike toward the southeast until the faults finally become tangent to the White Pine fault. They branch, borsetail fashion, on the convex side as they swing away from the White Pine fault, and they decrease in amount of throw outward from it. All these facts suggest that these minor cross faults are due to drag along the major White Pine fault in or near a semiplastic material such as the thick overlying shale.

Mineralization.-The general features of the mineralization of the Nonesuch lode are described on pages 169-171, but the special relation of the faults branching from the White Pine fault may be pointed out. The evidence of the premineral age of the cross faults lies in the facts that the lodes are thickest and nichest in the immediate vicinity of the larger cross faults, and that the cross faults themselves are well mineralized, even the smallest joints and fissures in the sandstone and adjacent shale carrying copper.

The richest ground in the mine is in and immediately adjacent to the block between the principal cross faults, $N$ and $K$. Here the lodes are both thickest and richest.

The records of the diamond drilling from the surface give the copper percentages for the several mineralized beds. Multiplying each of these percentages by the number of feet of rock which it represents and adding together these products gives a percentage-foot figure for each hole that represents what may be termed the "intensity of mineralization" of the ground penetrated. To obtain these figures, only the footages of ground that assayed 0.5 per cent or more of copper were considered. For example, the intensity of mineralization of a given hole is computed thus:

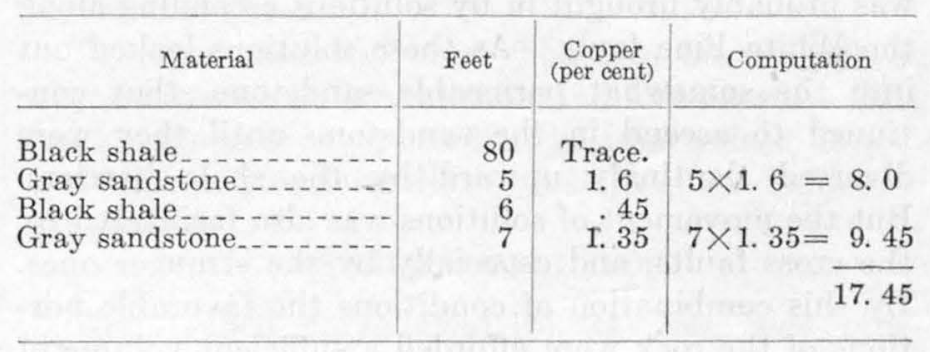

Plate 33 shows the position of each drill hole together with the intensity of mineralization as thus obtained for it, also contours drawn at 25-unit intervals over the entire area drilled. It is apparent that the block between faults $N$ and $K$ and the immediate vicinity is by far the richest ground drilled, copper contents and thickness of lodes both being considered.

The evidence of the drill records was confirmed by sampling in the workings of the mine at different intervals, chiefly east of the fault $K$. Over 50 samples were taken, assays for which were furnished by Mr. C. H. Benedict. The places for sampling the several lodes were selected as nearly along the same vertical line as the exposures in the workings allowed. Thus the same method of multiplying percentage of copper by thickness of lode and adding the products gives figures which represent "intensity of mineralization" at different places. These figures likewise show that mineralization is most intense near the fault $K$, grading outward from it toward No. 5 shaft. Minor deviations from the general rule are probably due to the enriching effect of subordinate fractures near points where the assay samples were taken.

Plate 33 shows that shafts Nos. 3 and 4 are in the heart of the only noteworthy ore body penetrated by the drilling. The holes to ther northeast and northwest along the outcrop of the lodes indicate that the mineralization is slight there as compared with that in the present workings. 
Other evidence indicating that faults $N$ and $K$ were channels for the mineralizing solutions is afforded by a series of small but very rich ore bodies, including all the rich silver bodies seen, which eling very close to these faults. They are in the nature of thickenings of the normal lodes, and mineralization of two lodes that are not mineralized generally through the mine-namely, the Lower Second lode and the Third lode. The mineralization of the Third lode, so far as now known, is confined to the highly mineralized part of the area, centering about $N$ and $K$.

Plate 33 shows that in places outside of the present mine workings where there are breaks in the structural contours, indicating cross faulting, there are increases in the mineralization. Such places are found in the NE. $1 / 4$ sec. 6 and the NE. $1 / 4$ sec. 9 (fault $S$ ).

To summarize: In the White Pine mine the copper was probably brought in by solutions ascending along the White Pine fault. As these solutions leaked out into the somewhat permeable sandstone, they continued to ascend in the sandstone until they were diverted slantingly upward by the shale barriers. But the movement of solutions was also facilitated by the cross faults, and especially by the stronger ones. By this combination of conditions the favorable portions of the rock were afforded a sufficient volume of solution to become commercial lodes, whereas farther away from the faults the richness falls below the economic limit. Copper or chalcocite was also deposited in the faults and fractures themselves. This relation between faults and the best mineralization is in accord with the experience of those who have worked elsewhere in the Porcupine Mountain district.

Extensions of ore bodies.-Development of the lodes at the White Pine mine has been carried from the outcrop down to the White Pine fault. The lode has been located on the downthrown side of the fault, but development of it has been very slight, and principally at No. 2 shaft. As indicated in the discussion of structure there are some reasons for supposing that the downthrown block may be less broken by branch faults than the upthrown block and therefore less favorable to mineralization. If the solutions were rising along the White Pine fault it also seems probable that the beds on the upthrown side were more favorably situated to receive them.

Diamond drilling shows that the beds associated with the branch fault east of the White Pine mine workings are mineralized at some distance from the main fault, and it seems, possible that this mineralization may be more intense nearer the main fault.

\section{WHITE PINE EXTENSION MINE}

The following statements regarding the White Pine Extension mine are largely compiled from the records of the company. The mine is in T. 50 N., R. 44 W., about 8 miles west of the White Pine mine. The workings are in the Nonesuch formation south of the Porcupine Mountain uplift. The property has been developed by diamond drilling across secs. 7, 12, 13, and 14, with a total of 45 holes ranging in depth from 80 to 1,400 feet. A shaft has been sunk to a depth on the incline of 438 feet, and drifts have been opened on the No. 2 shale on the second and fourth levels for a maximum distance of 3,380 feet.

The rocks belong to the Nonesuch formation, which, as shown in the drill cores from the Freda sandstone downward, includes the following beds:

Brown shale and sandstone
Upper grit_.
Bedded gray shale group
Lower grit_.
No. 1 shale
No. 1 sandstone
No. 2 shale
No. 2 sandstone.
Red sandstone.

The beds dip away from the Porcupine Mountain uplift at an angle of $83^{\circ}$ in the mine workings. They appear to be regular in the main, though there is minor faulting across the lodes.

Mineralization has occurred mainly in No. 1 shale, No. 2 shale, and a bed in the sandstone about 9 feet below No. 2 shale, known as No. 3 sandstone. At 33 feet from No. 2 shale a crosscut on the fourth evel encountered "quartz-banded shale" with disseminated sulphide which assayed 20 pounds of copper to the ton for a thickness of 3 feet. The copper occurs in the shale mainly as thin sheets and flakes in the bed partings and joints.

Drifts have been opened on No. 2 shale with crosscuts at 100 -foot intervals to No. 1 shale and at 200 foot intervals to No. 3 sandstone. When operations ceased in May, 1918, the following work had been accomplished:

First level, incline depth . .

Second level, incline depth . . .

Third level, incline depth _........ 320

Fourth level, incline depth

Drifts:

First level, 14 feet north, 11 feet south .......... 25

Second level, 1,542 feet north, 1,838 feet south _..... 3,380

Fourth level, 1,138 feet north, 1,080 feet south .... 2, 218 Crosseuts_................

7,383

No. 2 shale for a width of 4.8 feet, including some barren shale that breaks with the ore, has an average copper content of 21 pounds to the ton. North of the shaft there is some relatively poor ground averaging about 13 pounds to the ton. If this is eliminated, the south ends of the drifts average between 23 and 24 pounds to the ton. 
A total of 23 samples of No. 1 shale assaying from 6 to 20 pounds to the ton gave an average of 12 pounds for a thickness of 5.7 feet.

A total of 10 observations on No. 3 sandstone on the second level showed a width of 1.6 to 3 feet and s copper content of 0 to 28 pounds. On the fourth level the sandstone showed no mineralization and in some crosscuts could not be identified.

When the mine was closed water was being pumped st the rate of 92 gallons a minute.

\section{NONESUCH MINE}

The Nonesuch mine, about 3 miles west of the White Pine, was productive intermittently from 1868 to 1885 , and its recorded production is 389,556 pounds of copper. The mine is developed by four shafts. ${ }^{4}$ No. 3, the deepest, went to the fifth level, a depth of 460 feet. The occurrence of the ore, apparently, is similar to that of the neighboring White Pine mine.

\section{ONONDAGA EXPLORATION}

The Nonesuch formation was examined by diamond drilling by the Onondaga Copper Co. in Tps. 49 and $50 \mathrm{~N}$., Rs. 42 and 43 W., on the south side of the structural basin south of the Porcupine Mountains. The formation is similar to that on the north side of the basin, but the copper content as revealed by the drilling did not warrant development.

\section{OTHER PROPERTIES}

North and northeast of the White Pine mine pits have been sunk in days past on bunches of copper or silver ore in the sandstone, apparently associated with faults. Some of these faults may be of a magnitude corresponding to that of the White Pine fault. (See pl. 14.)

The rocks at the Nonesuch horizon were examined by diamond drilling in T. 51 N., Rs. 41 and $42 \mathrm{~W}$.
Some copper was found, and the best ground was reported to be near the faults, ${ }^{5}$ but it was not further developed.

\section{LAKE SHORE TRAP HORIZON}

The sandstone immediately under the Lake Shore trap is mineralized at several points on the north side of the Porcupine Mountains and was developed years ago in the Carp Lake mine. From 1860 to 1865 there was a recorded production of 33,935 pounds of copper. The copper of this mine has replaced red sandstone immediately below the Lake Shore trap. The sandstone is mineralized from a few inches to a few feet from the trap. Where mineralized, the red sandstone is bleached to gray. No hydrocarbon was noted in this sandstone. On the dump of the Carp Lake tunnel is vein material consisting mainly of calcite and in part an iron-bearing carbonate with included chalcocite.

The sandstone has been shown to be mineralized over a distance of several thousand feet near the Carp Lake mine and is reported to be mineralized at sereral other points along the north slope of the Porcupine Mountains.

\section{ASHBED AMYGDALOID}

The Ashbed amygdaloid (pl. 34) has been prospected from the Atlantic mine, south of Portage Lake, nearly to the end of Keweenaw Point. Whether the developments on this stretch are on the same bed is not known, but they are at the same general horizon, a little below No. 17 conglomerate. The most extensive developments have been made at the Copper Falls, Arnold, and Phoenix mines, in Keweenaw County, and the Atlantic mine, south of Portage Lake.

\section{PRODUCTION}

The following table shows the production from the Ashbed amygdaloid to the end of 1925 :

Production and dividends from Ashbed lode to end of 1925

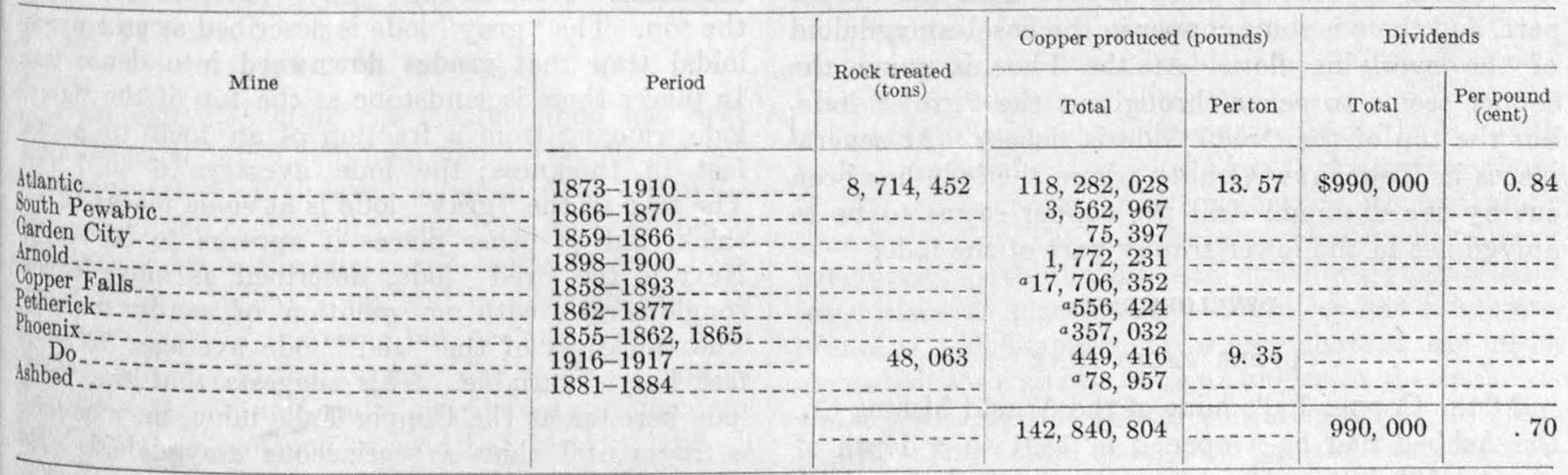




\section{CHARACTER OF ROCK}

The Ashbed flows are toward the andesitic end of the basaltic series and are everywhere porphyritic, containing rather abundant small feldspar phenocrysts, which are usually collected in nests.

The amygdaloid is prevailingly of the scoriaceous type and is ordinarily cited as the typical example of scoriaceous amygdaloid. There is, however, a notable variation in the amount of the clastic material in the Ashbed at different places. At the Atlantic mine, so far as indicated by the dump material, it is distinctly of the scoriaceous type with pebbles and boulders of amygdaloid in a sandy matrix. At the Phoenix mine the upper part, or "gray" bed, is of the same character, but the lower part, or "red" bed, is not described as scoriaceous. At the Copper Falls mine the bed is locally sandy and approaches the scoriaceous type, but for the most part it is rather typically fragmental. At most of the places in Keweenaw County where it has been cut by the diamond drill the lode is scoriaceous. At the Copper Falls mine it is well oxidized, and at the Atlantic it is said to be chocolate-colored. The Ashbed seems, therefore, to be a fairly well oxidized amygdaloid.

\section{MINERALIZATION}

The mineralization of the Ashbed does not seem to differ materially from that of other lodes. The more abundant minerals at the Copper Falls mine are calcite, quartz, epidote, and pumpellyite. Near the fissures datolite is apparently abundant, and in Keweenaw County it appears to be generally more abundant on the Ashbed than on the other lodes.

At the Phoenix mine the basal portion of the lode is chloritized. Not enough of the Atlantic lode has been seen to give a very clear idea of the mineralization. At the Copper Falls mine much of the bleaching associated with copper is of the iron-removal type.

At the Copper Falls mine the upper part of the lode seems to contain more copper than the deeper part, and there is some copper in the basal amygdaloid of the overlying flow. At the Phoenix mine the copper seems to occur throughout the "gray" lode, but the top of the "red" lode is richest. At several places in Keweenaw County where the lode has been cut by the diamond drill the copper seems to be in amygdules in the lower trappy part of the lode.

\section{DEVELOPMENTS}

COPPER FALLS MINE

At the Copper Falls mine of the Arnold Mining Co. the Ashbed had been opened in 1891 to a depth of about 1,500 feet and had been opened and stoped for about 2,400 feet along the strike. The workings extend about 1,000 feet east and 1,400 feet west of the Owl Creek fissure. Work continued for a year or so after 1891, but the extent of the latest openings is unknown. The Ashbed was also opened adjacent to the Petherick fissure but to what extent is not known.

The Ashbed lode as seen in the upper levels of the Copper Falls mine is of the fragmental type of amygdaloid with some sandy material and is well oxidized. The width stoped varies greatly but probably averages 6 to 8 feet. The lode seems richest near the top.

A report by Wadsworth states that the lode averaged 10 to 12 feet in thickness and yielded about 1 per cent of copper. The yield in 1859 is given as 22.8 pounds to the ton. There is no record of the output from the Ashbed separate from the output from the Owl Creek fissure, which was operated at the same time, but the production from the Ashbed was certainly considerable.

The relation between the Owl Creek and other fissures and the mineralization of the Ashbed is not very clear, but the mineralization seems to have been strongest near this fissure.

\section{ARNOLD MINE}

At the Arnold mine the lode has been opened by No. 1 shaft to the eighth level. On the fifth level a drift has been carried 210 feet to a fissure, which was opened for a short distance. The drift has been extended also about 300 feet south, to a fissure which was opened for about 400 feet. The levels above the fifth were not carried far from the shaft.

\section{PHOENIX MINE}

The Phoenix mine of the Keweenaw Copper Co, on the Ashbed lode, was not operating when this report was in preparation. The following notes are taken from the company records and statements by Mr. C. A. Wright, superintendent.

The hanging wall is marked by a clay slip that dips and strikes with the formation. This possibly represents No. 17 conglomerate. Below the clay slip is the amygdaloid of a trap averaging about 15 feet in thickness. Next is the "gray" lode, with a slip at the top. The "gray" lode is described as an amygdaloidal trap that grades downward into dense trap. In places there is sandstone at the top of the "gray" lode, ranging from a fraction of an inch to several feet in thickness; the lode averages 6 to 7 feet. The trap of the "gray" lode is at some places 15 feet thick, but at other places it appears to be absent. Next is the "red" lode, described as amygdaloidal conglomerate with no mention of sandy material. The thickness of the "red" lode averages 15 to 20 feet but is variable. This suggests that the "red" lode here, as at the Copper Falls mine, may be more a fragmental than a scoriaceous amygdaloid. The trap of the "red" lode is about 60 feet thick. The next amygdaloid is described as narrow, and reddish gray; it is mineralized in spots but seems very "bunchy." 
The Ashbed is crossed in the Phoenix workings by Phoenix and Armstrong fissures, and near the urface a third fissure was opened. A fault west of Phoenix fissure offsets the beds to the east of the ssure about 60 feet to the north.

The Ashbed has been opened at the Phoenix mine a depth on the dip of 1,600 feet and along the irrike for about 2,500 feet. Most of the development Las been on the "gray" lode, and most of the prounction has apparently been from this lode. The copper in the "gray" lode is said to be fine.

From October 13, 1916, to December 31, 1917, 67,215 tons of rock was hoisted, of which 18,993 tons ras discarded; 48,063 tons stamped yielded 449,416 pounds of copper, a recovery of 9.35 pounds to the ton, with a loss in tailings of 5.65 pounds to the ton. This can probably be taken as representing the grade of the "gray" lode.

The "red" lode has also been opened in several places, at most of which it is reported to show an encouraging amount of copper near the top of the bde, in a zone as much as 4 feet in thickness. It is said that the copper is coarser than that in the "gray" lode. Some mineralization is reported to have occurred also near the base of the lode. Apparently not enough stoping has been done on the "red" lode to give a clear idea of the copper content. The lode close to the fissures is said to be poor, but there is some suggestion that it may be better in the general ricinity of the fissures than it is away from them.

The Ashbed was also opened at Garden City, east of the Phoenix workings. Old reports indicate that amygdaloids similar to those at the Phoenix were present and that the copper content was encouraging. The production, however, was small. The "red" lode appears to have been the one most worked at Garden City.

\section{HANCOCK MINE}

The Ashbed has been opened at the Hancock mine but is described with the other lodes of that mine on pages $177-178$.

\section{ATLANTIC MINE}

At the Atlantic mine the Ashbed lode has been opened for about 5,800 feet along the strike and down to the thirty-fifth level. (See pl. 34.) Here the lode was of the scoriaceous type, was soft, averaged 12 feet or more in thickness, and seems to have been rather uniform in character and in mineralization in the central part of the mine but became poorer both to the north and to the south. The copper is said to have been rather uniformly distributed through the lode, and the developed ground has been nearly all stoped.

The only structural feature of importance at this mine is a strong fissure or "crossing" with a steep northerly dip extending through the mine just north of No. 2 shaft. The filling of this fissure, as judged by descriptions and some material on the dump, was a coarsely crystalline calcite, in places at least with a pinkish tinge.

It is said that in the upper levels the lode near the fissure was poor, and a rather wide pillar was left. In the lower levels the pillar left was much narrower. In the early years of operation of the Atlantic Mining Co. the rock averaged 18 to 20 pounds of copper to the ton, but for much of the productive period it did not exceed 15 pounds and dropped almost to 11 pounds. For the last years of operation it was as follows: 1902, 11.09 pounds; 1903, 12.78; 1904, 13.63; $1905,13.72 ; 1906,14.69$. When the mine was closed by caving in 1906 it was reported that the central portion in the deeper levels shows no indication of a decrease in the grade of ore. The profitable operation of the Atlantic mine on a lode that averaged so low was due partly to the rather uniform mineralization, which made mining cheap, and partly to the softness of the lode, which was favorable to cheap mining and milling.

\section{LODES OF THE HANCOCK MINE}

Production from the lodes of the Hancock mine (pl. 35) began in 1861 and continued with interruptions till 1918. The total production from these lodes, together with a considerable production from the Pewabic lodes by the Hancock Consolidated Mining Co. that has not been separated is $17,559,557$ pounds. The earlier production, from 1861 to 1886 , $5,360,000$ pounds, was derived from lode No. 1 ; and the later production, from 1911 to $1918,12,199,000$ pounds, mainly from lodes Nos. 3 and 4 and the Pewabic lodes. In the later years the yield averaged about 13.5 pounds copper to the ton.

The writers had no opportunity for an examination of the Hancock mine, and the following statements and the accompanying maps and sections are based on data furnished by the Hancock Consolidated Mining Co.

The lodes of the Hancock mine lie between No. 17 conglomerate and the Pewabic lodes. The old No. 1 lode is, to judge from the descriptions and from the course of the drifts along it, apparently on the Hancock fault, a reverse fault which strikes at the surface about N. $54^{\circ} \mathrm{E}$. and dips at a considerably steeper angle than the beds. The fault fissure evidently curves very irregularly, both the dip and strike varying greatly from place to place, and it doubtless has numerous branches. The apparent displacement of the beds, measured horizontally at right angles to the strike, is about 600 feet but differs considerably at different points. The actual movement on the fault to produce this apparent displacement was certainly much greater.

No. 1 lode has been opened along the strike for about 1,200 feet and to the fourteenth level. Most of the 
stoping was done between the surface and the tenth level. There is a strong suggestion of a southerly pitch to the ore shoot.

No. 3 lode is the amygdaloid of the third flow below No. 17 conglomerate and is therefore at the general horizon of the Ashbed amygdaloid. It is, in places at least, scoriaceous and in this respect resembles the Ashbed. The No. 3 lode has been opened for about 1,500 feet along the strike and has been stoped mainly between the tenth and eighteenth levels.

No. 2 lode is the amygdaloid next below No. 3 lode. The lode called No. 9, above the eighteenth level is probably No. 2 repeated below the Hancock fault. No. 2 lode has been opened for about 1,000 feet along the strike and stoped mainly between the sixth and eleventh levels. The stoping on the part known as No. 9 is mainly between the twelfth and eighteenth levels.

The true No. 9 lode, as it may be called, below the eighteenth level is above the fault and below No. 16 conglomerate. No. 4 lode is a little below this No. 9 lode and probably a little above the Pewabic Far West lodes.

There are, then, two general horizons of mineralization-one represented by lodes No. 2 and No. 3, lying near the horizon of the Ashbed amygdaloid, and the other represented by No. 4 and the true $\mathrm{N}_{0.9}$ which lie below No. 16 conglomerate. In addition No. 1 lode is apparently on the Hancock fault. Most of the ore thus far developed occurred above the Hancock fault.

\section{PEWABIC AMYGDALOID LODES}

\section{IOCATION AND PRODUCTION}

The Pewabic amygdaloid lodes (pl. 36) have been mined mainly in the properties that now form the Quincy mine. The present Quincy mine (see pl. $74, A$ ) includes the Old Quincy, Pewabic, Franklin, Mesnard, Pontiac, and others. Outside the Quincy mine the lodes have been mined in the Hancock mine, adjoining the Quincy on the south and in the Franklin Junior mine to the north. To the south the rocks at this horizon were extensively explored by the Naumkeag Copper Co. and to the north they were opened at the Rhode Island mine and have been cut by the vertical shafts at Calumet but only slightly explored.

The following table shows the production of the Pewabic amygdaloid lodes from the beginning of operations to 1925 :

Production and dividends from Pewabic amygdaloid lode, 1855-1925

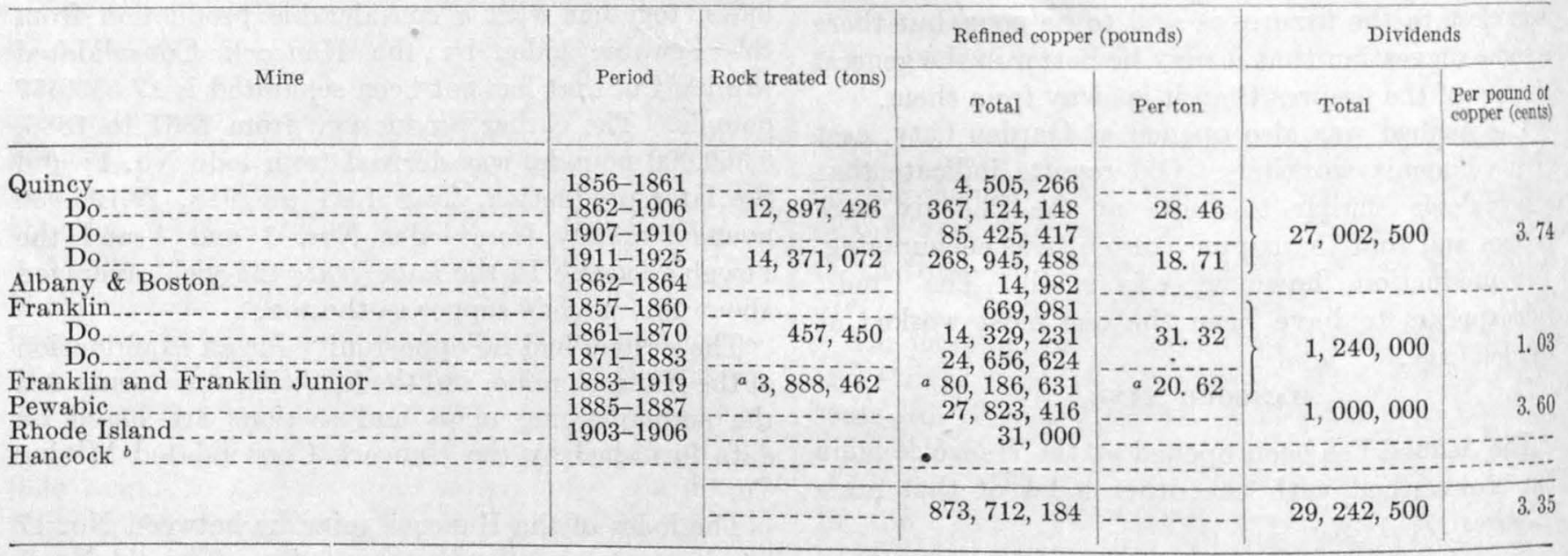

a Estimated.

Much of the production from the Hancock mine for 1911 to 1918 , amounting to $12,199,000$ pounds of copper, was derived from the Pewabic lodes.

\section{CHARACTER OF FLOWS}

The Pewabic amygdaloid lodes at the Quincy mine consist of a group of relatively thin flows. These overlap so that it is possible to follow amygdaloid continuously and still pass from the amygdaloid of one flow to that of another. It is difficult to correlate the flows certainly from one point to another unless the top of the flow has been actually followed, as one flow may give place to another within a few hundreds or, in the thinner flows, a few tens of feet.

In composition the Pewabic flows fall toward the andesitic end of the basaltic Keweenawan series. Texturally they are glomeroporphyrites and feldspathic melaphyres, with ophitic texture in some of the thicker beds, such as the one below the Pewabic Far West lodes in the lower 50 levels at No. 2 shaft. All or nearly all the beds are porphyritic, containing well-developed feldspar phenocrysts.

\section{CHARACTER OF AMYGDALOIDS}

The amygdaloids of all the flows of the Pewabic lodes are characteristically of the coalescing type, though different lodes vary in the degree to which this character is developed, and there may also be a decided difference in its development in different parts of a single flow. Where it is well developed there are from 2 or 3 to as many as 8 or 10 cavernous bands or layers 
in a lode from 3 to 5 feet thick. It is not uncommon to see these bands continuous along a cross section of the lode for 10 to 15 feet or even more, and in the plane the lode such layers must form connected openings for tens and probably for hundreds of feet. There is every gradation from the well-banded or layered lode to that in which the vesicles show only a moderate tendency to collect in layers and do not form continuous openings.

Fragmental tops are not characteristic of the Pewabic lodes as a whole. A little fragmental rock occurs at the top of the amygdaloids in many places, and over considerable areas the lode is typically fragmental, though more uniform in thickness than most of the fragmental lodes. A large area of this character is present in the south end of the mine, extending from the seventy-sixth to the eighty-first level and covering an area of 400,000 to 500,000 square feet. A smaller area, so far as opened, is present in the bottom (eighty-first to eighty-fifth level) near No. 2 shaft. So far as observed in the lower levels, the East branches of the series show more fragmental amygdaloid than the West branches. The upper and intermediate levels were seen in only a few places, but it is stated in old descriptions and by those familiar with the upper levels that the "main" lode was a thick, soft, chocolate-colored lode. Some of it was seen on the twenty-second level between No. 2 and No. 6 shafts, where for the most part it is a typical fragmental lode, showing all the characteristics of that type. The lode thins and thickens from place to place with bulges into the hanging wall and the footwall. There the lode is thin it tends to become cellular and coalescing.

On the twenty-seventh level between No, 2 and No. shafts the character of the lode alternates between rather tight cellular, tending to coalescing, broken in places into large blocks, and fairly well developed fragmental. The fragmental portions have been stoped and doubtless were considerably mineralized. From observations in and descriptions of the lode in the upper levels it seems probable that large areas of the "main" lode above, say, the thirty-fifth level were fragmental. Some of the other lodes where seen in the upper levels are as distinctly coalescing as any on the lower levels.

The oxidation of the coalescing lodes is less than that of the fragmental lodes, though the tops are distinetly reddened. The fragmental portions of the lodes are moderately well oxidized, though not so highly as many fragmental lodes elsewhere.

\section{MINERALIZATION}

The mineralization associated with the deposition of copper in these lodes was simple. Silicification of the lode is pronounced, and quartz is abundant, commonly as well-formed crystals in the open cavities.
Calcite is also nearly everywhere present and rather abundant. Pumpellyite is present as a product of rock alteration and also in open cavities, and epidote is common but less abundant than pumpellyite. Chlorite is abundant in amygdules in the base of the flows and throughout the trap part of some of the flows. Near fissures the chlorite may be replaced by the light-colored minerals, quartz or calcite, which gives the rock adjacent to the fissures a much more amygdular appearance. Zeolites are sparsely represented. Laumontite is present in the Main Spar crossing and was noted in other small fissures. In the lode it is rarely seen on the lower levels but is rather abundant for a considerable distance from the Spar crossing on the upper levels. No other zeolites were noted. Prehnite is present but not common. Nodular masses of porcelanic datolite are said to have been of common occurrence in the upper levels of the mine, but no datolite was seen in the lower levels.

\section{ROCK ALTERATION}

The bleaching and alteration of the rock is characteristically of the quartz-pumpellyite type common in the coalescing lodes. In the well-oxidized fragmental portions, especially where seen in the upper levels, the quartz-pumpellyite alteration is less conspicuous and the bleaching is due more to the removal of iron, as in the Kearsage and Osceola lodes.

Before the mineralization, when the cavities were empty, the well-developed coalescing amygdaloid was much more permeable than the cellular amygdaloid and would permit the passage of much more of the mineralizing solutions than the cellular type. It is evidently for this reason that the richer copper ground is in the well-developed coalescing lodes, and although these are not everywhere rich, the poorly developed coalescing and cellular lodes are pretty consistently poor.

Considered in more detail, the coarse copper and masses very commonly are associated with strongly developed bands in an amygdaloid, though the copper and associated minerals generally replaced the rock adjacent to the openings. The finer copper also is as a rule closely associated with well-developed bands, though it may extend some distance from them; and some copper is of course found in cellular amygdaloid and even in amygdules in the trappy portion of the lode.

Fragmental lode rock is of course distinctly permeable and readily replaceable and therefore favorable to mineralization. The masses of such rock exposed in the bottom of No. 2 shaft are pretty consistently rich. The fragmental amygdaloid in the "main" lode in the upper levels of the mine was evidently well mineralized, and in places it was rich. Smaller areas of fragmental lode and areas where a foot or so of the top of the lode is fragmental are commonly good to rich ground. 
It is pretty clear, therefore, that a fragmental lode in this series can be as favorable and possibly more favorable than a well-developed coalescing lode.

There is some minor fissuring both parallel to and across the lodes. The fissures are commonly mineralized and evidently were favorable to the movement of solution.

\section{MINERALIZATION IN DIFFERENT LODES}

The Pewabic lodes are separated into three groups by the Quincy Mining Co. for the purpose of the underground mapping. The grouping is based on position, and the three groups are called the East lodes, the West lodes (including the "main" lode), and the Far West lodes. The East lodes are east of No. 2 shaft in the upper levels. The shaft was in the "main" lode, which apparently corresponds to the West lodes in the lower levels. The Far West lodes are stratigraphically above or west of the West lodes.

The East lodes are the most persistent and regular in the lower and middle levels. They consist of a lower or foot branch and an upper or west branch. The flow whose top forms the lower branch lode rests on the Old Pewabic flow. It is usually not more than 30 to 40 feet thick. It consists in places of one flow, and in places apparently of more than one. The upper flow is even thinner; in places only 10 feet of trap, or even less, separates the two branches, and it is possible that the upper flow is not everywhere present.

In the south end of the mine the upper branch of the lode has been most extensively opened. Stoping on this branch extended from the tenth level, between No. 7 and No. 2 shafts, to the bottom of the mine. To the north there is little work on this branch to the twenty-seventh level in No. 6 shaft, and somewhat lower in No. 8. Below this to about the sixty-fifth level in No. 8 and No. 6 shafts not more than 50 per cent of the lode has been taken. From about the sixty-fifth level to the bottom in the north end more of the upper branch has been taken, and in the south end it has been very largely stoped.

The lower branch was mined but little to about the fortieth level. From the fortieth to about the sixtyfifth level it was extensively mined north of No. 6 shaft, and considerable was taken in the south end of the mine. Below the sixty-fifth level this branch has been mined very little in the south end but some has been taken between No. 6 and No. 8 and considerable north of No. 8 .

Above the sixty-third level both branches have in places been mined in the same area, though not as a rule. Below this level in the north end of the mine both have been mined. This difference apparently is due in part to a change in mining method rather than to a sudden change in the character of the lodes.

\section{"MAIN" BRANCH}

Down to about the thirtieth level the "main" branch was the one most extensively mined. This is above the East lodes and apparently corresponds to the West lodes in the lower levels. In the lower levels it has been but slightly developed to the north of $\mathrm{N}_{0}$. 8 shaft and to the south of No. 7 but has been rather extensively mined from No. 6 and No. 2 in the central part.

There is more than one lode in this West group. What is known as the hanging-wall branch has been most extensively mined. These branches in the lower levels do not seem to have the long stretches of continuous favorable rock that are present in the East lodes, but where favorable rock is present it is very well mineralized.

\section{PEWABIC FAR WEST LODES}

The Pewabic Far West lodes have been developed principally below the fiftieth level near No. 2 and No. 6 shafts. In the upper part of the developed area at No. 2 shaft they are separated from the West lodes by an ophitic trap, which is as much as 130 feet thick in this part of the mine, but apparently thins very much down the dip, up the dip, and toward No. 6 shaft. The Far West lodes are above this trap, in the coalescing amygdaloidal tops of several small flows. So far as opened, these tops appear to have shorter stretches of favorable amygdaloid than the East or West lodes, but where their character is favorable they are well mineralized.

In the preceding paragraphs the changes in the lodes in different parts of the mine have been noted in some detail to bring out the idea that in a series of lodes like the Pewabic too much emphasis should not be placed on local changes in character of amygdaloid and copper content of individual lodes in their effect on the favorability of the series as a whole. It is apparent, so far as the present extensive developments show, that some of the lodes were richer in the upper levels, some in the intermediate levels, and some in the lower levels. Some were most extensively mined in the north end of the developed area and some in the south end. The series as a whole appears to have been about equally productive in the upper and in the lower levels of the mine.

\section{FISSURES OR "CROSSINGS"}

A strong cross fissure extends through the mine, dipping north at a high angle (see pl. 36) and crossing No. 6 shaft at the fifty-fifth level. The strike of the fissure, as indicated in the fifty-first level footwall crosscut, is about $10^{\circ}$ from right angles with the strike of the lode. This crosscut intersects the Allouez conglomerate and in fact all the lodes cut by it only a short distance from the fissure. Where it crossed 


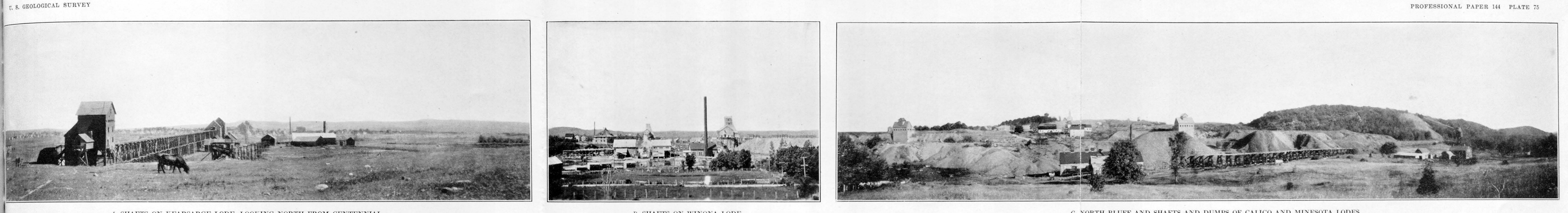
SHAFTS ON KEARSARGE LODE, L.OOKING NORTH FROM CENTENNALI SHAFTS ON WINONA LODE
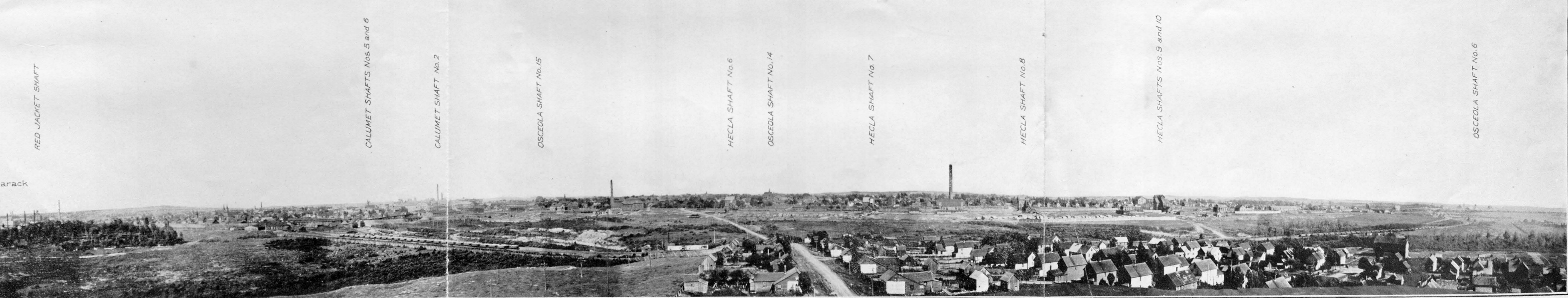
the "main" lode in the upper levels little stoping was done adjacent to this fissure, and the lode was evidently poor. This condition continued to about the fiftieth level. Below that stoping was carried close to the fissure, which is said to have had little effect on the copper content of the lode for more than a few feet on each side, and in places good ore is present against the fissure. Where seen in the lower levels the fissure has displaced the lode very little, though the rock is broken for several feet. The fissure filling consists mainly of calcite, laumontite, and quartz. Chloritization and pumpellyitization of the wall rock are conspicuous in and near the fissure but extend only a short distance. Where the "Spar crossing" was seen on the upper levels, laumontite is abundant in the bodes for a considerable distance from the fissure. Pink calcite is the most abundant mineral in the fissure; quartz and epidote are present locally. Copper is present in the fissure wherever examined, and at one place a good-sized mass was seen. The copper content of the fissure has not been sufficient to encourage work on it.

Two other crossings are noted on the mine maps; one of these passes between No. 6 and No. 8 shafts and is about parallel to the main erossing; another crosses No. 8 shaft at the twelfth level and dips about with the north boundary of the ore shoot. Neither of these were seen. The first seems to have had no notable effect on the grade of the lode adjacent to it. The second is mainly outside the stoped area.

\section{FAULTS}

The only fault of note that affects the Pewabic lodes is the Hancock fault, which cuts the lodes in the south end of the Quincy mine and in the Hancock mine. This fault is represented in the cross section of No. 7 shaft as crossing the shaft at the fifteenth level and reaching the surface in the hanging-wall side of the shaft. These two points give the fault a dip of sbout $75^{\circ}$. At the fifteenth level it is marked on the map as having a dip of $76^{\circ} 30^{\prime}$ and a strike of S. $17^{\circ}$ $48^{\prime} \mathrm{W}$. for a short distance. The fault is more fully described in connection with the lodes of the Hancock mine (p. 177) and shown in the cross section of that mine.

The Allouez ("Albany \& Boston") conglomerate, is represented in the old adit, is offset approximately 600 feet on the level. The Pewabic lode on the sixteenth level is indicated as having a similar offset.

\section{FRANKLIN JR. MINE}

The production from the Pewabic lode and that rom the conglomerate lode in the Franklin Jr. mine ere not separately recorded for part of the time. fiter the closing of the conglomerate lode in 1909 the ewabic lode produced about $16,000,000$ pounds of $58540-29-13$ copper. During this period the yield was about 9 to 12 pounds of copper to the ton of rock.

The writers have had no opportunity to examine the lode in the mine.

The lode has been opened by four shafts, but most of the operations have been conducted from the No. 1 shaft, which extends to the thirty-seventh level. No. 3 shaft goes to the fifteenth level. The lode has been opened for about 3,800 fest along the strike, but most of the development has bаan within 1,500 feet north and 1,000 feet south of No. 1 shaft.

In the upper levels most of the ground stoped was north of No. 1 shaft; in the lower levels the productive ground extended south of the shaft, suggesting a southward pitch of the south boundary of the ore shoot. The ground was stoped over a longer stretch in the lower levels than in the upper, and between the upper and lower levels there was an area in which comparatively little of the lode was stoped.

\section{RHODE ISLAND MINE}

The Pewabic amygdaloid has been opened at the Rhode Island mine by two shafts-No. 1 to the fourth level, No. 2 to the tenth level. The openings extend about 2,700 feet along the strike for about equal distances north and south of No. 2 shaft. A few tons of mass and barrel copper has been shipped from the Rhode Island mine. There has been no opportunity for the writers to examine the lode in the mine.

\section{ALLOUEZ CONGLOMERATE ("ALBANY \& BOSTON")}

The Allouez conglomerate (pl. 37) has been opened and mined at three widely separated localities-at Delaware, at Allouez, and at Franklin.

\section{PRODUCTION}

The first production from this conglomerate was made by the Albany \& Boston Co. in 1862 at the present Franklin Jr. mine. In 1882 the mine was sold to the Peninsula Copper Co., which operated it till 1892. In 1895 it was sold to the Franklin Mining Co. The Pewabic lode was being mined for part of the period, and there is no accurate record of the total production from the Allouez conglomerate, but it was about $34,500,000$ pounds. The average grade of the rock in the later period was between 11 and 12 pounds of copper to the ton.

Work was begun on the conglomerate by the Allovez Mining Co. in 1869. From that time there was alternation of company operation and work by tributers till 1892, when production ceased. The total recorded production from the Allouez mine was $25,786,000$ pounds. During the later part of the period the yield ranged from 13 to 19 pounds of copper to the ton of rock. 
From 1847 for many years the fissures and the conglomerate lode were worked at Delaware by different companies, usually in the most inefficient manner. Altogether a large amount of money was expended to little purpose. Mills were built near Delaware, and later a railroad was extended to Lac La Belle, where a mill was built. There is no accurate record of the production from the conglomerate separate from the fissures, but it is estimated at about 1,770,000 pounds. The largest output was made in 1883 and 1884, when the rock yielded from about $91 / 2$ to 11 pounds of copper to the ton of rock. The recovery was poor, however, and the tailings probably contain as much or more than was recovered.

Production from Allouez conglomerate

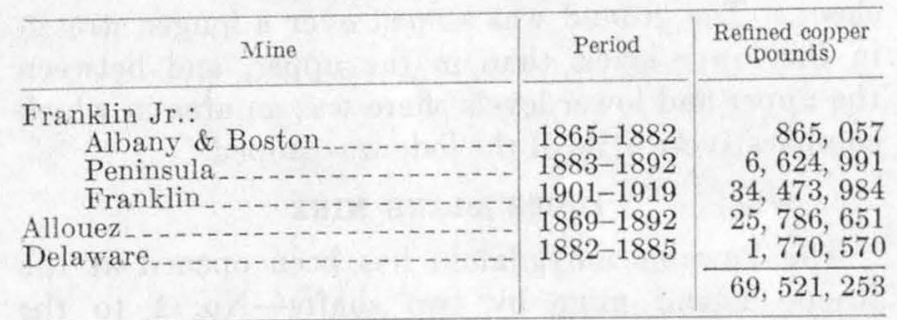

\section{CHARACTER OF CONGLOMERATE}

There has been no opportunity for the writers to examine the Allouez conglomerate as exposed in the mine workings. As seen on the dumps at all three localities it is a moderately coarse felsite conglomerate similar to the Calumet \& Hecla conglomerate. From descriptions it appears that lenses of the Allouez conglomerate were well mineralized and some were rich but that much of it was poorly mineralized or barren.

The character of the mineralization and of the rock alteration seems to be similar to that of the Calumet \& Hecla conglomerate. A feature that is pronounced in the Allouez conglomerate at all three localities is the presence along joints and seams of many dark veins of calcite containing finely divided chalcocite. Similar veins are present on the margins of the Calumet \& Hecla conglomerate ore shoot, as at Centennial, but are not common in the main shoot.

\section{FRANKLIN JR. MINE}

The Allouez conglomerate has been opened at the Franklin Jr. mine by two shafts from the outcrop-in No. 1 to the twenty-fourth level and in No. 2 to the nineteenth level. The openings extend for about 2,500 feet along the strike, and within this area most of the ground has been stoped. The conglomerate has also been opened below the shaft workings by crosscuts from the Pewabic No. 1 shaft from the twentysixth to the thirty-seventh levels and here also for a maximum distance along the strike of about 2,500 feet, but the proportion of the ground stoped in this area is not so great. The stope map suggests that the main ore shoot in this area pitches south.

\section{RHODE ISLAND MINE}

A little shallow work was done on the Allouez conglomerate by the Rhode Island Co.

\section{ALLOUEZ MINE}

A map in the report of the Commissioner of Minera Statistics for 1882 gives developments on the Allouez conglomerate to January, 1883. Three shafts had been opened and the lode developed for a maximum distance along the strike of about 1,700 feet. $\mathrm{N}_{0.2}$ shaft extended to the fourteenth level.

The production was derived mainly from a shoot lying north of a "slide" that reached the surface about 200 feet south of No. 1 shaft and intersected No. 2 shaft at the thirteenth level. The northem boundary of the shoot, which was mined for $700 \mathrm{t}$ 1,000 feet north of the "slide," appears to have been indefinite,

The mine produced as much copper after 1882 as it had before, but there is no map available showing the position and extent of the later openings.

\section{DELAWARE}

At Delaware the Allouez conglomerate has been opened by three main shafts and two shallow ones. No. 1 shaft extends to the ninth level, No. 2 to the tenth level, and No. 3 to the fifth level. The openings extend for a maximum distance along the strike a about 2,500 feet, but the main development has been confined to a distance of about 1,200 feet adjacent t No. 1 and No. 2 shafts. Only a small proportion the lode within the developed area has been stoped.

\section{LODES IN CLIFF MINE}

In the early operations in the Cliff mine considerabl attention was given to the ninth amygdaloid "floor," which was opened to the 90 -fathom level an followed by drifts for short distances on most of th levels; on the 80 -fathom level a drift was extend west about 500 feet and east about 400 feet. Th early reports spoke favorably of the showing in the drifts, but in 1864 a test run showed the rock to are age less than 15 pounds to the ton, and work w abandoned. In the report for 1864 it is stated th the copper content decreases away from the fissu The thirteenth "floor" is also spoken of in the ear reports as well mineralized, but very little work seet to have been done on it.

When the mine was reopened in 1906 short drit were run on amygdaloids in the south end of the min Whether all looked favorable or not is not evide It is stated that some fair rock was taken, but average was evidently poor.

Later some work was done on amygdaloids in north end without encouraging results. Apparen no work was done at this time on the ninth thirteenth "floors," which were regarded as m favorable in the early days.

\section{CALUMET \& HECLA CONGLOMERATE LODE LOCATION AND EXTENT}

The Calumet \& Hecla conglomerate (pl. 38) been opened at numerous places from Portage nearly to the end of Keweenaw Point. In most plis it is a scoriaceous amygdaloid with a few inches th 
few feet of overlying felsitic sand or grit. Only in the Calumet area has it been shown to be a welldeveloped felsite conglomerate.

The lode has been developed in the Osceola, Calumet \& Hecla, Tamarack, Tamarack Junior, and Centennial mines, now all owned by the Calumet \& Hecla Consolidated Copper Co., for a distance of about
18,000 feet along the strike and to a maximum depth of 9,300 feet down the dip. (See pl. 75, D.)

\section{PRODUCTION}

The Calumet \& Hecla conglomerate was discovered in 1864, and production from it began in 1865 . The following table shows the production from the lode to the end of 1925 :

Production and dividends from the Calumet \& Hecla conglomerate, 1865-1925

\begin{tabular}{|c|c|c|c|c|c|c|}
\hline \multirow[b]{2}{*}{ Mine } & \multirow[b]{2}{*}{ Period } & \multirow[b]{2}{*}{ Rock treated (tons) } & \multicolumn{2}{|c|}{ Refined copper (pounds) } & \multicolumn{2}{|c|}{ Dividends } \\
\hline & & & Total & Per ton & Total & $\begin{array}{l}\text { Per pound of } \\
\text { copper (cents) }\end{array}$ \\
\hline Centennial & $\begin{array}{l}1869-1882 \\
1897-1898\end{array}$ & 6,285 & $\begin{array}{r}1,966,083 \\
119,190\end{array}$ & 18. 96 & & (n) \\
\hline Tamarack & $1885-1917$ & 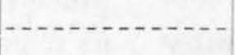 & $379,971,101$ & & & \\
\hline $\begin{array}{l}\text { Mine } \\
\text { Reclamation plant } \\
\text { Osceola } \\
\text { Tamarack Junior: }\end{array}$ & $\begin{array}{l}1866-1925 \\
1915-1925 \\
1873-1880\end{array}$ & $\begin{array}{r}57,229,052 \\
12,374,823 \\
358,450\end{array}$ & $\begin{array}{r}2,831,092,153 \\
127,686,924 \\
12,652,028\end{array}$ & $\begin{array}{l}\text { 49. } 47 \\
\text { 10. } 32 \\
35.30\end{array}$ & $a \$ 148,726,051$ & 4. 44 \\
\hline $\begin{array}{l}\text { Tamarack Junior Mining Co } \\
\text { Osceola Consolidated Mining Co. }\end{array}$ & $\begin{array}{l}1892-1896 \\
1897-1902\end{array}$ & 619,478 & $\begin{array}{r}9,462,191 \\
12,404,000 \\
\end{array}$ & 20.02 & & \\
\hline $\begin{array}{l}\text { Total production omitting figures for } \\
\text { which no corresponding tonnage is } \\
\text { given: } \\
\text { Mine production } \\
\text { Including copper reclaimed from } \\
\text { tailings }\end{array}$ & - & $\begin{array}{l}58,213,265 \\
58,213,265\end{array}$ & $\begin{array}{l}2,856,267,371 \\
2,983,954,295\end{array}$ & $\begin{array}{l}\text { 49. } 07 \\
\text { 51. } 26\end{array}$ & $148,726,051$ & 4. 41 \\
\hline
\end{tabular}

- Estimated.

\section{COMPOSITION}

The conglomeratic portion of the Calumet \& Hecla conglomerate is made up of several kinds of rock varying somewhat in proportion from place to place. The common varieties are felsite, feldspar porphyry, quartzfeldspar porphyry, amygdaloid, and trap, with other types of rock such as quartzite in small amount. The siliceous rocks make up probably more than 95 per cent of the lode. Amygdaloid boulders, which are most plentiful near the base of the lode, appear to have been derived from the amygdaloid immediately beneath the conglomerate and to have moved but a very short distance. A few boulders of more highly oxidized amygdaloid and of trap are present that may have come from other sources. No indication has been found that the siliceous pebbles were derived from earlier conglomerates. This and the absence of basic pebbles except of the amygdaloid immediately below makes it seem that the conglomerate must have been derived from sources outside the series of flows and conglomerates that make up the immediately underlying part of the series. Nearly all the material of the conglomerate is red to brown in color, so that the general color effect of the unmineralized lode is dark red to brownish red. There is considerable variation in the quantity of the different types of rock in different parts of the lode. For example, felsite and feldspar porphyries are relatively abundant south of the bar between No. 6 and No. 10 Hecla, whereas north of that bar quartz porphyry is relatively abundant. In the lower part of the mine, to the south, the quartz porphyry also seems less abundant. In the upper levels in No. 5 Calumet a light-colored variety of felsite porphyry is especially abundant. This rock resembles in color the felsite intrusive south of Ahmeek, although it is not thought to have furnished material for the Calumet \& Hecla conglomerate. A few quartzite boulders were noted in the region of the slope shaft and in North Tamarack. Such a local variation in the composition suggests rather near-by sources for the material.

IRON OXIDE OF THE FELSITES AND QUARTZ PORPHYRIES OF KEWEENAW POINT

The following notes relate to the source of the rather abundant ferric oxide in the lode. The chief purposes of the examinations here summarized were to determine whether the bulk of the iron oxides in the Calumet \& Hecla conglomerate were there when the mineralizing solutions entered, or were introduced at an early stage of the mineralization, and to determine what oxides they are.

It is believed that the type of iron oxide and its abundance in the several felsites in place along Keweenaw Point throw considerable light on these questions. Polished surfaces of these felsites show that they all contain hematite to a greater or less extent. In several specimens where the reticulate structure characteristic of the magnetite-ilmenite intergrowths suggested that magnetite might be present, its absence was definitely established by such tests as treating the polished surface with hot concentrated hydrochloric acid and powdering the rock and testing with a magnet. It was shown that beyond a reasonable doubt the chief iron oxide of the felsites from the end of Keweenaw Point to the Porcupine Mountains is hematite. 
There is evidence that this hematite is a primary mineral of the felsites. It appears homogeneous under the highest magnification available both before and after treatment with hot concentrated hydrochloric acid, showing no islands of unreplaced magnetite such as are common where hematite has replaced magnetite. The rock contains intergrowths that resemble those of magnetite and ilmenite, but such forms are also assumed by hematite and ilmenite. Many examples of hematite with lathlike form were noted, suggesting cross sections of tabular hematite crystals; these are probably identical with the elongated opaque reddish forms in the felsites and acidic porphyries described by Irving under the name "ferrite." Hematite as a primary mineral occurs at many localities in siliceous and feldspathic rocks, where ferrous iron is absent or present in small amounts. That the ferrous iron in some of the Keweenaw Point felsites is low as compared with the ferric iron is shown by the following analyses.

\begin{tabular}{|c|c|c|}
\hline & $\mathrm{Fe}_{2} \mathrm{O}_{3}$ & $\mathrm{FeO}$ \\
\hline $\begin{array}{l}\text { Felsite pebble from Allouez conglomerate, } \\
\text { unaltered. }\end{array}$ & 4. 88 & \\
\hline Mount Houghton quartz porphyry ......... & 2. 27 & .15 \\
\hline Do & $\begin{array}{l}\text { 1. } 72 \\
1.44\end{array}$ & $\begin{array}{l}18 \\
66\end{array}$ \\
\hline Daly's average quartz porphyry & 1.57 & 1. 02 \\
\hline
\end{tabular}

IRON OXIDES IN THE CALUMET \& HECLA CONGLOMERATE

The chief modes of occurrence of iron oxides in the Calumet \& Hecla conglomerate may be classified as follows: (1) Disseminated in rather fine particles in the felsite and quartz porphyry fragments and boulders; (2) in rounded grains in the sandy matrix of the conglomerate and particularly in black bands in the sandstone; (3) as hematite in soft, considerably altered boulders, many of which are iron-rich and form the familiar copper skulls when replaced; (4) as specular hematite in vugs and along planes of weakness.

The available information on these modes of occurrence may be summarized as follows:

1. All the polished sections show that the comparatively unaltered fragments of felsite and quartz porphyry - that is, those that are not softened or bleached-contain hematite in varying amounts, as seattered fine grains. In this respect they are the same, as closely as could be determined, as the felsite in place. The same tests to establish the absence of magnetite were made on such material with negative results.

2. Rounded grains of iron oxide occur plentifully throughout the finer material of the conglomerate. As very little or no magnetic material was found in repeatedly testing the powdered rock with a magnet, it is concluded that these grains consist of limonite, hematite, and ilmenite. This conclusion accords with Palache's determination on the black table concentrates of the conglomerate. It also agrees with the statement of one of the company's chemists who ana. lyzed the dark material of the flotation slimes of the conglomerate, that it is a "dark-red powder and but slightly magnetic." His analysis is as follows:

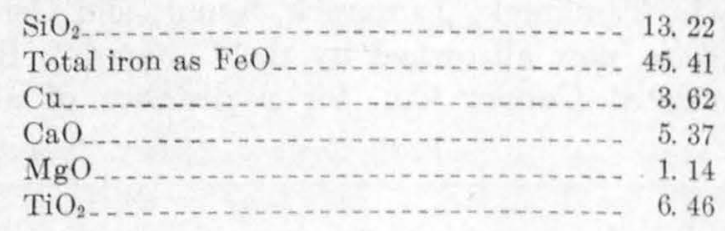

Many of the larger of these clastic grains of oxide consist of limonite through which run reticulate bars of ilmenite. Two possibilities as to the mineral replaced by the limonite present themselves. In so far as it is detritus from traps, it was probably magnetite. If it is felsite detritus, it may have been originally hematite, as hematite-ilmenite intergrowths are common.

It is important in a consideration of the chemical aspect of the origin of the native copper to determine when and how this oxidation of the ferrous iron in the small quantity of magnetite in the conglomerate took place. The outstanding chemical alteration of the rock surrounding copper, both in conglomerates and amygdaloids, is the reduction and removal of ferric iron. Therefore, if oxidation of magnetite took place during the mineralization, it is a reversal of the commonly observed reaction. To test this point the iron oxide in some of the sediments, such as the Great conglomerate at Eagle Harbor, far away from copper deposits, was studied, and the magnetite was found to show the same oxidation to a varying degree, as the magnetite in the Calumet \& Hecla conglomerate. Hence the change is independent of copper mineralization and probably took place in part soon after the crystallization of the magnetite in its parent lava flow (see p. 42) and in part during the time it was exposed to weathering.

3. Many pebbles and boulders, soft and much altered, are red with ferric oxide. Some of them contain feldspar and quartz phenocrysts. This hematite seems different, on the one hand, from the finely disseminated primary hematite of the hard felsite and, on the other hand, from the shiny black specular hematite which is to be associated with the recrystallizing effects of the mineralizing solutions acting on the rock. The explanation of the occurrence of these soft oxidized boulders is not clear. That there were phases of the porphyries with more abundant iron-bearing silicates than the prevailing types is probable. Irving describes many Keweenawan quartz porphyries as containing altered augite and says that there are gradations from the highly siliceous phases to the diabase porphyries. Hence, a possible source of these iron-rich boulders is not hard to imagine. The chief difficulty comes in explaining their presence in such a soft oxidized state in the conglomerate. If they were oxidized before deposition, how could they stand up under the rather severe mechanical abrasion to which they would be 
subjected? If they came to rest as hard unaltered pebbles but were later softened and oxidized, it would mean more intense weathering than is indicated for most of the conglomerate material, though such pebbles would be presumed to be relatively susceptible to oxidation.

4. Specular hematite is not uncommon in open spaces of various sorts in the conglomerate. It is regarded as a result of the rearrangement of ferric oxide, shown to have been present in abundance before the ore-bearing solutions entered.

\section{CHANGES IN THE IRON OXIDES DURING MINERALIZATION}

The effect of the ore-bearing solutions upon the iron oxides is notable. Chemical analyses of bleached and unaltered felsite, study of polished sections of pebbles with bleached portions, examination of hand specimens and the interiors of copper "skulls," and observation of the bleaching on a large scale underground all point to the same conclusion - that the introduction of copper has been accompanied by the removal of ferric iron. Polished sections show that the bleached portions of pebbles, whose unaltered parts have swarms of tiny hematite crystals, are entirely lacking in ferric oxide. Hand specimens show that black iron oxide bands in the unbleached sand largely disappear on passing into a mineralized portion. Similarly, the soft iron-rich boulders, which analyses show may run over 12 per cent of ferric oxide, are bleached and contain practically no ferric oxide where the copper has been introduced.

The effect upon the ilmenite has not been observed in polished section, but the petrographic examination of thin sections indicates that much of it changes to titanite. In an epidotized sand nothing is left of many iron oxide grains but the skeletons of reticulate ilmenite surrounded by a transparent mineral, suggesting that the hematite or limonite went to build the epidote, leaving the ilmenite.

Therefore, while it seems clear that the ore solutions had the power of rearranging the iron oxide, the evidence indicates that the bulk of the iron oxide came in at the time of sedimentation as ferric oxide, much of it as primary hematite from and in the felsite and quartz porphyry. It was removed by the ore-bearing solutions, and this removal bleached the rock and was closely associated with the precipitation of copper.

\section{THICKNESS}

The conglomeratic portion of the Calumet \& Hecla conglomerate, so far as developed, is distinctly lenticular. The longitudinal axis of greatest thickness extends almost due north from about the collar of No. 1 conglomerate shaft, Osceola mine. Both east and west of this medial line the lode thins but not uniformly. There are several minor axes to the east coming to the surface at No. 5 Hecla, No. 1 Hecla, and No. 2 Calumet. (See pl. 38.)
The lens thins not only to the east and west but to the south or toward the outcrop. As far south as No. 8 Hecla the lode has nearly feathered out to the east, and at most but a few hundred feet appears to have been eroded. South from No. 10 much more of it has been eroded. Along the main axis the conglomerate thickens toward the north, or down the dip, the thicker portion being found around No. 5 Tamarack and in North Tamarack. In passing from south to north the thicker part of the conglomerate lens widens notably, so that a cross section through No. 5 Tamarack would include a width of conglomerate having a thickness of 10 feet or more, at least four or five times as great as a similar section passing through the collar of No. 10 Hecla.

It is apparent that in passing downward from the surface successive sections across the entire lode would contain an increasing amount of rock. This is equally true whether the section is taken parallel to the present surface or at right angles with the major axis of the lode. A rough estimate of the relative amount of lode exceeding 5 feet in thickness at the surface and at the twenty-fifth, fiftieth, and seventy-fifth levels gives the approximate ratio $3: 4: 7: 10$.

Sections at right angles to the axis of the lode at equal intervals passing about through No. 10 Hecla and No. 1 Hecla and near Red Jacket shaft give a ratio of about $4: 8: 11$.

\section{TEXTURE}

The texture of the lode, like the thickness, varies from place to place, and in a broad way there is a rather close correspondence between thickness of lode and texture. Where the lode is thick coarse material is relatively abundant, and where it is thin fine material is relatively abundant. Thus, where the lode is less than 5 feet thick it is composed largely of coarse to fine sand; where it is more than 10 feet thick it is prevailingly a pebble to boulder conglomerate. The portion of intermediate thickness, over considerable areas at least, as is seen in the upper levels of the Calumet and of Hecla shafts Nos. 1 to 5, is intermediate also in texture, the prevailing rock being a coarse grit to fine pebble conglomerate. In the coarser parts of the conglomerate there is a varying but usually rather large percentage of coarse to fine grit that forms the matrix for the pebbles. The coarse and fine phases of the conglomerate, including sandstone, do not differ greatly in composition except that the finer portions contain considerable ferric oxide and ilmenite in grains. In the sandstone these form definite bands that are practically everywhere noticeable, but the grains are also present in the fine matrix of the coarse types of the conglomerate. The finer parts of the conglomerate are therefore richer in ferric oxide and in ilmenite than the coarser parts. 
There are coarser and finer phases of the conglomerate present in practically every section. Thus, it would be hard to find a section that did not contain some bands of sandstone, and in the finer beds there are lenses of coarser material. There is no very clearly recognized regularity as to the stratigraphic position in the lode of the fine and coarse material. It is common to find sandstone on the footwall, on the hanging wall, or in intermediate positions, and, on the other hand, the coarser phases may occupy all these positions.

The general impression gained from looking at the lode as exposed in drifts is that the bedding is essentially parallel to the walls. Where mineralization has followed the bedding, however, so that the mineralized rock is prominent for relatively long distances, there is a distinct appearance of cross-bedding of large pattern. Where best seen the divergence of bedding planes is to the north, parallel to the axis of the conglomerate. Cross-bedding of small pattern is seen here and there but is not common.

\section{HANGING WALL}

The hanging wall of the conglomerate over a large part of the developed area is a dense trap with a rather pronounced basal amygdaloid, from 2 to 6 ${ }_{i}$ nches in thickness, and with pipe amygdules extendng upward from the contact of the conglomerate. The basal amygdaloid is commonly slightly oxidized for 1 inch to 6 inches from the contact. The actual contact is slightly irregular, the lava being molded around boulders in the conglomerate.

In the northeastern part of the mine there are frequently 1,2 , or possibly 3 small flows above the main conglomerate lode. In places felsitic sand or conglomerate overlies the small flows. On the twentyninth level, south of No. 5 Calumet, the drift follows a 3 to 4 foot bed of felsitic sand resting on a 3 to 4 foot lava flow that in turn rests on the main conglomerate lode. In No. 4 Calumet the hanging-wall flow was recognized as low as the forty-ninth level. The flows have been recognized to the south as far as No. 2 shaft. A small hanging-wall flow (about 15 feet thick) is also present on the sixty-sixth level of the slope shaft where the crosscut extends to No. 3 Tamarack.

It would appear that small flows are present, locally at least, over a considerable part of the area north of No. 2 Calumet and above the sixty-sixth level. The small flows commonly show some oxidation and in places are rather well oxidized.

\section{FOOTWALL}

The footwall of the conglomerate is everywhere a scoriaceous amygdaloid, but it differs notably in different places. Over considerable areas there may be from 6 inches to 4 feet of soft red basic sandstone or shale immediately beneath the felsitic conglomerate.
Nearer its base this sandstone or shale begins to contain pebbles or boulders of amygdaloid, which gradually become more abundant, and within 3 or 4 feet it passes into scoriaceous amygdaloid filled with sandstone and shale; this in turn gives place to amygdaloid with decreasing amounts of clastic material, and the amygdaloid passes into the footwall trap. The felsite conglomerate may rest on rock of any one of these lower types, suggesting that where the upper members are lacking they have been removed by erosion. The data available do not indicate any very definite distribution of the different types where they form the immediate footwall. The sandstone and shale are, however, rather abundant where the lode thins out to the northeast and also to the south where the lode has been observed-namely, on the fortyninth and fiftieth levels; south of No. 12 Hecla; likewise where the lode is thin on the seventh level east and west of No. 6 Hecla. These occurrences suggest that in a broad way erosion has been relatively slight where the conglomerate lode is thinnest.

The footwall along the main axis of the conglomerate however, does not seem to show vigorous erosion, as the scoriaceous amygdaloid is present. There seems, indeed, to be little evidence of vigorous erosion at the base of the conglomerate, although the scoriaceous amygdaloid is itself evidence of erosion and deposition at this horizon. The line of separation between the felsitic sediments and the underlying amygdaloid is usually sharp. Pebbles and boulders of the underlying amygdaloid are present in the lower part of the conglomerate, but rarely is felsitic material mingled abundantly with the basic sands of the footwall. The presence of the boulders of amygdaloid in the base of the conglomerate suggests that there has been some erosion and that the finer portions have been carried away or so disseminated through the conglomerate that they are not recognized. Beneath the thicker parts of the conglomerate the amygdaloid is usually dark and shows little oxidation. Where the conglomerate is thin, the amygdaloid is commonly distinctly reddened by oxidation.

\section{STRUCTURE}

Faults.-But one pronounced fault zone crossing the conglomerate lode has been recognized. This zone is at the surface between Nos. 3 and 4 Hecla and crosses the seventy-ninth level about 400 feet north of No. 6 shaft. The fault has not been cut outside the lode, and the strike can not be closely determined, but it seems to be essentially at right angles to the strike of the lode. The dip is everywhere steep but not uniform. If the strike is at right angles to the lode the average dip is about $82^{\circ} \mathrm{S}$. The horizontal offset on this fault on the upper and lower levels is about 8 feet. The same is reported for the upper levels of Tamarack No. 1. The block south of the fault moved to the west. There is a rather strong gouge on the fault in 
the hanging-wall trap, which has been mineralized with calcite, laumontite, and copper.

Over a zone of 100 feet on each side of this fault there are minor faults with a throw of not more than few inches where observed. Another fault, which has been traced for several hundred feet, crosses the lode at the crosscut from No. 5 Tamarack on the eighty-first level. This fault strikes at a low angle with the lode, about N. $45^{\circ} \mathrm{E}$., and dips northwest. Where observed, the dip is irregular, ranging from $60^{\circ}$ to $90^{\circ}$. The hanging wall is up about 6 feet; therefore the fault is reverse.

Not uncommonly there is a slickensided zone on the footwall or hanging wall of the conglomerate. This indicates some movement, but nowhere is the amount known.

Fissures and joints.-Fissures and joints are abundant throughout the conglomerate lode. Many of them can be traced into the footwall or hanging wall, but show no displacement. They are commonly nearly rertical and at right angles to the lode. They are more abundant in certain areas, but close inspection over a few feet of lode almost anywhere will disclose fissures or joints. Many of them contain copper and calcite, and the adjacent rock is bleached, indicating that they are earlier than the mineralization. On a lew of these joints a little chalcocite occurs, closely associated with the calcite, and where the lode was opened at Centennial small calcite-chalcocite veins were rather abundant.

\section{ALTERATION}

The conglomerate, where unmineralized, is dark reddish brown, the prevailing color being due to the presence of ferric oxide both in the pebbles and as small grains in the finer matrix and in the sand. Where copper is not present the lode has a rather uniform appearance and seems to have suffered little alteration since its burial by the hanging-wall flow. The epidotization of some of the lean ground, especially along the borders of the ore shoots, is an exception which is mentioned on page 188 .

\section{SOFT BOULDERS}

In parts of the conglomerate soft boulders are rather numerous. These usually contain phenocrysts of red feldspar and quartz and appear to have been similar to the quartz-feldspar porphyry that is abundant in the conglomerate, as pointed out by Pumpelly and others. At present they show rather diverse characteristics. In many of them a soft reddish-brown to dark greenish-brown material incloses the phenocrysts. These appear to be rich in iron, much richer than any of the fresh quartz-feldspar porphyry pebbles. In other pebbles a soft green chloritic material incloses the phenocrysts.

Nearly all the pebbles are softened and altered to the center and give no evidence of the original charac- ter of the rock except for the phenocrysts. A few have relatively hard centers. In some of these epidote is abundant, suggesting that the original rock. was first highly epidotized and later altered to its present condition. In others there appears to be little or no epidote. Magnetite, barite, and secondary specularite have been noted in these hard centers.

As the soft pebbles appear to be as abundant in the rock that contains no copper as in that which is well mineralized with copper, there seems no reason to connect this alteration of the pebbles intimately with copper mineralization.

The soft pebbles are usually in close proximity to other pebbles of quartz porphyry that show no similar alteration. This must mean either that there was some strong selective action or that the soft pebbles were altered in whole or in part before they were incorporated in the conglomerate. That they were incorporated in their present soft condition seems hardly possible. It may be that they had undergone some alteration and were in a condition to be further altered readily when they were incorporated, and that they were softened and oxidized before the conglomerate was buried. No satisfactory explanation of these pebbles has yet been suggested.

\section{MINERALIZATION}

\section{CHARACTER}

The most striking and characteristic feature of the mineralization is the pronounced bleaching of the rock that accompanied the deposition of copper. At nearly every place where the lode is exposed the presence of copper is indicated by the pale brick-red or salmon color of the mineralized portion as contrasted with the dark brownish red of the unmineralized lode. In the finer material the small pieces of rock may be largely bleached to the center, so that the lode has a rather uniform color. In the coarser material the pebbles have been bleached for a short distance from the surface, but the inner part retains its original color.

The coarser copper is commonly in the cement where it has partly replaced the rock material. Where the rock is bleached, an examination of the polished surface generally discloses the presence of copper.

Bleaching not plainly connected with copper has been noted only in lenses of epidotized sandstone. In such lenses pebbles may show a bleaching similar to that associated with copper, and such lenses are commonly surrounded by a narrow zone, rarely more than 1 inch wide, of bleached rock.

The bleaching associated with the deposition of copper has resulted from a removal of ferric oxide. Commonly there is no evidence of the ferric oxide having been converted to another mineral that has remained. There are, however, two exceptions. Sandstone lenses have been almost completely changed to epidote, apparently from a combination of the ferric oxide with other constituents of the sandstone 
to form epidote, though some of the epidotized sandstone is higher in iron than the corresponding unepidotized sandstone. Copper is commonly present in these lenses, but it is rarely abundant.

The second exception is possibly the alteration of the iron-rich boulders to form "skulls" of copper. In this replacement the portion of the boulders rich in ferric oxide close to the copper has been altered to a soft gray to green material that appears chloritic. There has been a large removal of iron, but some remains as ferric or ferrous silicate.

\section{MINERALS}

There are few minerals in the conglomerate that can be regarded as gangue minerals in the sense that they were deposited with the copper.

Calcite is abundant in the lode, but its distribution does not seem to be closely connected with the distribution of copper.

Epidote, like calcite, is rather abundant, though usually not in the rich ground. It is in places plentiful near the margins of ore shoots, and it occurs around many areas of calcite, suggesting that the lime was obtained from the calcite and the ferric oxide from the conglomerate. It is perhaps most conspicuous where it has replaced lenses of sandstone. Such lenses are present in many parts of the mine, though they are decidedly more numerous where the ground is poor. In the conglomerate lode there is no indication of close association of epidote with rich copper ground.

Red feldspar is present throughout the mine in variable amounts. Like calcite and epidote, however, it shows no close association with rich ground, though copper is commonly present with feldspar. It seems rather more abundant on the lower levels.

Barite occurs characteristically in the soft iron-rich pebbles, locally in their bleached portions, associated with copper. Barite in such pebbles is common in the lower levels of the Hecla, but it was rarely seen in the north end of the mine.

Chlorite is rare in the conglomerate except in the soft iron-rich pebbles, where chloritic minerals of undetermined composition are common; also in the altered amygdaloid pebbles.

Zeolitic minerals are characteristically absent from the conglomerate lode. Fissures passing from the lava to the conglomerate lose their zeolites at the contact.

\section{DISTRIBUTION OF THE COPPER}

The characteristic occurrence of the copper is in lenticular shoots flattened in the plane of the lode. The mineralized beds may occur in any part of the lode, as near the hanging wall, near the foot wall, or in intermediate positions. In the upper part of the mine, where the lode is relatively thin, the mineralized portion may form a large percentage of the lode. In the lower levels, where the lode is thick, the mineral. ized portion may be only a relatively small part of the total thickness.

There are no obvious differences in the origind characters of the mineralized and the unmineralized parts of the lode, and it seems probable that slight differences in permeability may have been the chief determining factor in producing the deposits. Mineralization may be influenced, however, by variations in composition, the effect of which may conflict in places with that of permeability. For example, it has been pointed out that the finer material contains more ferric oxide and ilmenite as grains than the coarser material. In the alteration of the lodes the smaller particles are completely bleached, while the pebbles are but partly bleached. It would follow that the finer sediment contains more ferric oxide available for reaction, and if this is a factor in the precipitation of copper, it would seem that, other things being equal, the finer-grained parts of the lode would be more favorable. On the other hand, the sandy portions are presumably not favorable to free circulation of solutions. There is then probably some combination of sufficient permeability and abundant iron oxide that is most favorable to precipitation o copper.

\section{INFLUENCE OF FAULTS AND FISSURES}

The lode is crossed by one rather strong persistent fault and by a great number of joints and fissures that show little or no displacement. The large fault and many of the joints and fissures are mineralized. Some very handsome specimens of arborescent copper have been taken from the large fault. There is no good evidence, however, that any of these were channels that admitted the ore-forming solutions to the lode. A zone of poor ground lies immediately north of the large fault, through part of the mine at least, but the ground to the south of it is generally good. This difference suggests that the gouge may have acted as a dam against ore solutions moving from the south through the conglomerate and thus caused a lean area north of the fault. There is little recognized evidence that the ground is particularly rich where the joints and fissures are abundant or particularly lean where they are few. Many of the fractures, however, are bordered by a zone of bleaching and were evidently channels for mineralizing solutions within the lode.

The crosscuts disclose many strike fissures outside the conglomerate that contain calcite, quartz, chlorite, laumontite, red feldspar, prehnite, and copper. A few cross fissures similarly mineralized have been noted.

The position of the lenses of mineralized ground in the lode is distinctly suggestive of solutions moving upward through the conglomerate. 
MINERALIZATION OF WALLS

The basal amygdaloid of the hanging-wall trap locally contains some copper. It is said that in the northeastern part of the mine the thin amygdaloida beds were in places sufficiently mineralized to have been taken for ore. Certain joints in the hanging wall contain sheet copper.

Ordinarily there is no copper in the footwall immediately below the conglomerate. Where mineralized conglomerate rests on the basic sand or on the scoriaceous amygdaloid the mineralized rock cuts off sharply at the contact. In the lower part of the amygdaloid, however, there is in many places a little copper. This is associated with chlorite, and the occurrence is similar to that near the base of the Kearsarge amygdaloid.

Where the conglomerate is very thin or lacking and the amygdaloid is moderately oxidized, as on the forty-ninth level south of No. 12 Hecla, the amygdaloid may contain more copper. Here it is associated with bleached areas, and the occurrence, in general, is similar to that of the amygdaloid lodes.

\section{CHANGE IN GRADE OF ORE}

From the surface to the lower levels there has been a very pronounced decrease in the grade of the rock. Several possible causes for this decrease are suggested - that the precipitation of copper was controlled by distance below the surface that existed when the deposits were formed; that the decrease is due to a change in character of the conglomerate; or that deposition was influenced by the contraction of the conglomerate body upward. It is possible that all these causes and perhaps others have been operative.

There is little doubt that distance below the surface existing at the time of mineralization was a factor in determining where deposition of copper began. Doubtless there was a range of depth in each lode that furnished the conditions of heat and pressure most favorable to deposition, and probably the deposition was less both above and below that region.

Parts of the lode are physically and chemically more favorable than others. The finer rock, provided it permitted free passage of the solutions, would seem to be more favorable than coarse conglomerate. This may, in part, account for the very rich ground in the upper levels of the Calumet mine, where the conglomerate is fine, and it may likewise account for the low grade in some of the thick parts of the lode.

The conglomerate as developed is a tapering body, increasing both in thickness and in width, and consequently in volume, down the axis. It is roughly estimated that the relative amounts of the conglomerate at the surface and the twenty-fifth, fiftieth, and seventy-fifth levels are in the ratio $3: 4: 7: 10$. This upward contraction of the body and consequent decrease in the volume of conglomerate suggest that $58540-29-14$ the change in grade may be due in part to the converging of the ore-depositing solutions through a steadily decreasing volume of rock. It has been found that sections across the shoot at different levels, as the twenty-fifth, fiftieth, and seventy-fifth, contain approximately the same amount of copper, but that in the lower levels the ore, being distributed through more rock, is of lower grade.

The grade map (pl. 38) shows very clearly that there is a steady decrease in the grade of the rock from the surface downward and that in general the successive belts of different grade lie roughly parallel to the present surface.

By far the richest rock in the mine is in the "pocket" lying between the north boundary of the ore body and the bar of thin conglomerate between No. 5 and No. 10 Hecla shafts. From this bar north rich shoots come to the surface between the small bars of thin conglomerate. This relation suggests that there were minor outlets through these channels. Below the bar of thin conglomerate-that is, below the twenty-fifth level-the grade belts are nearly horizontal except in the South Hecla, where good ground extends up along the main axis of the conglomerate body.

In the lower levels of the mine a bar of poor ground with a general northerly trend lies just south of No. 5 Tamarack shaft. This broadens to the north. Likewise, a bar of poor ground seems to come in at the northern extension of the North Tamarack workings, though the facts necessary to outline this ground are not available.

\section{MAP SHOWING "COPPER PER UNIT AREA OF LODE"}

The data on which the maps showing grade of rock and thickness of lode are based have been combined on Plate 38 by multiplying pounds of copper to the ton of rock at each point by the thickness of lode at the same point and dividing the product by the number of cubic feet of rock to the ton, thus obtaining figures that represent the amount of copper per square foot of lode at the different points.

An examination of this map indicates that the areas of maximum mineralization do not coincide with the areas of richest rock. The area of maximum mineralization trends northward and down the lode, roughly parallel to the main axis of the conglomerate body but somewhat above it, and the mineralization decreases in intensity northward and down the axis. There are some exceptions to these general tendencies. The most pronounced are a tendency for the intensity to increase in the pocket toward the outcrop of the Hecla, and the presence of a rather large area of relatively low mineralization in the vicinity of the lower workings of the Tamarack.

An attempt has been made to determine the relative amounts of copper in different horizontal cross sections 
of the lode. This has been done by multiplying the "foot-pound" figure (obtained by multiplying pounds per ton by thickness of lode) by the length of lode on the sections at the different levels. One estimate took the general average for the level as the "footpound" figure; another estimate calculated each line in several sections, which were combined to obtain the "foot-pound" figure. The greatest difference, on the seventy-fifth level, resulted from differences in estimate on the undeveloped area at the north end of that level and may be taken as representing the uncertainty as to that area.

The average of the two estimates gives the following relative amounts of copper on the different levels, in a unit section: Twenty-fifth, 133 ; fiftieth, 133 ; seventyfifth, 115; average, 127. The seventy-fifth level thus shows 10 per cent below the average.

It is apparent, then, that so far as these data are trustworthy they indicate a decrease in mineralization with increase in depth, though the decrease shown is certainly not beyond the limits of error in the data used. What they seem to show with considerable certainty is that the tendency toward a decrease in total mineralization with increase in depth is not marked, but that the large decrease in grade is due mainly to the dissemination of approximately the same amount of copper through a larger volume of rock.

A calculation of the amount of copper in the lode from the data indicated on the maps, with the assumption that 75 per cent of the lode has been stoped, gives approximately the amount that has been actually recovered and thus tends to corroborate the approximate accuracy of the data used on the maps.

If it is assumed that the same amount of copper is disseminated through the lode at each level and further that the grade at the seventy-fifth level is 30 pounds to the ton, then at the fiftieth level it should be 43 pounds, at the twenty-fifth 75 pounds, and near the surface 100 pounds. The recorded grades show a rather surprising approach to these figures.

There seems no reason to expect a change in these general relations with increased depth. The lode appears to be increasing both in extent and width, and it would follow that there should be a decrease in grade of ore. There does, however, appear to be some tendency to break up more with depth into poor and rich shoots. The appearance of the lode underground suggests this rather more strongly than the data brought out on the map.

CAUSE OF CONVERGENCE OF SOLUTIONS AND INFLUENCE OF BARRIERS

As pointed out on page 101 and indicated on the map showing thickness of lode (pl. 38) the part developed is a projection from a much larger body of conglomerate. As no striking relation has been found between fissures and mineralization, it is believed that the solutions gained entrance at some point below the area developed and rose along the lode. If movement were unimpeded the solutions would probably rise directly along the lode toward the outerop. If, however, they met a barrier they would be deflected and move upward below the barrier.

It is of interest, then, to note what such barriers may be. As is well known, the finer a sediment the less readily a solution moves through it. Toward the edges of the conglomerate lenses the material becomes finer, and where the lode is less than 5 feet in thickness it is mainly sand. There appears to have been little movement of the solutions through these sandy parts, and they may be regarded as under the circumstances effective barriers to the movement of the solutions. The favorable influence of the converging barriers on the grade of ore is discussed under "Ore shoots" (p. 115).

\section{COPPER BOULDERS AND SKULLS}

Many of the pebbles of porphyry rich in iron and others largely altered to a chloritic material that lie in the ore shoots have been very favorable to replacement by copper. Pumpelly long ago described the characteristics of the pebbles thus replaced. The inner part of the pebbles and presumably the part least affected by the copper solutions is a red porphyry. The material varies considerably but is commonly rather soft and friable, dark red-brown to greenish black, and evidently rich in ferric iron. Next to the copper of the "skulls," which are only thin envelopes of copper surrounding the pebbles, is a zone of graygreen soft chloritic rock, which grades into the red central part. There is much less iron in the chloritio part of the pebbles, and much of that present is ferrous iron.

In other pebbles the copper penetrates to the center and only a small proportion of the rock material remains. This consists of phenocrysts of feldspar and quartz and some green chloritic material similar to that described above. The feldspar is somewhat altered, but the nature of this alteration has not been determined.

Very little silver was seen in the conglomerate lode. That observed, principally in the southern stopes on the lower levels of No. $10 \mathrm{Hecla}$, is similar in mode of occurrence to the amygdaloid. It seems to be slightly later than the copper. It is said that silver was much more abundant in the upper levels of the Hecla shafts.

\section{OSCEOLA LODE}

\section{HISTORY AND PRODUCTION}

Important production from the Osceola lode in the Osceola mine began in 1879 and continued without interruption for any whole year till 1920 . Exploration on the Osceola lode by the Calumet \& Hecla Co. began in 1895 and steady production in 1904. The following table shows the production from the lode from the beginning of operations till the end of 1925 . 


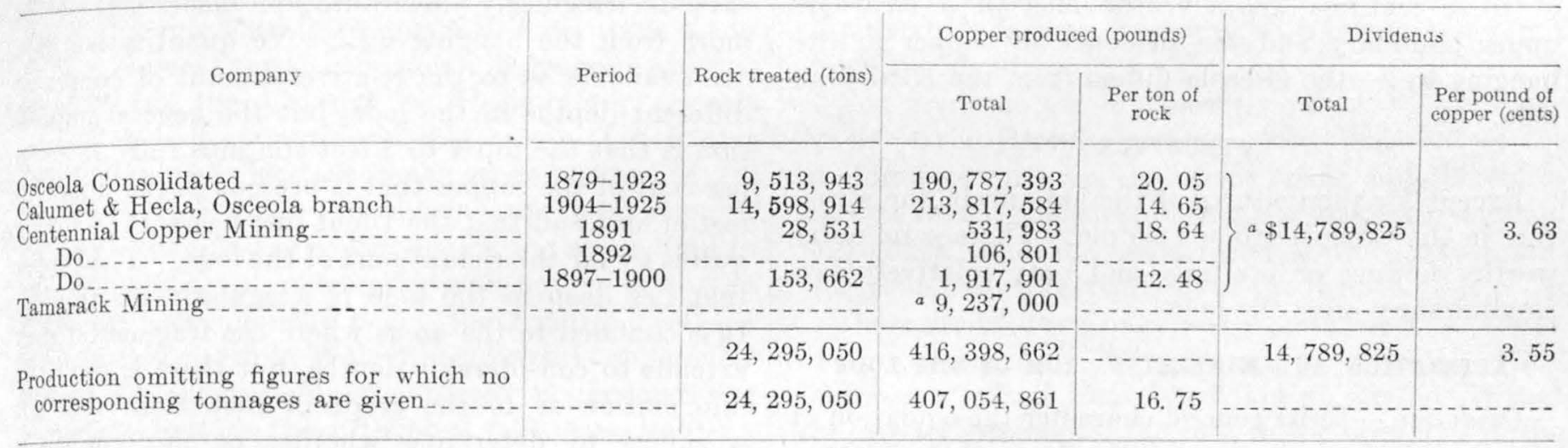

- Estimated.

\section{OSCEOLA FLOW}

The Osceola flow (pl. 39), which is a well-marked ophite, has been traced with a reasonable degree of certainty from the Arcadian to the Cliff mine. Outside this stretch there is doubt of the accuracy of suggested correlations.

At the Cliff mine the flow is 35 feet thick; at the Ahmeek, 130 feet; at the Red Jacket shaft, seventyeighth level, 210 feet; at the LaSalle, 180 feet; at the Franklin Jr., 98 feet; and at the Arcadian, 129 feet. It is the thickest part of the flow, near Calumet, that thus far has been productive. In this respect the Osceola is like the Kearsarge flow.

\section{CHARACTER OF THE OSCEOLA AMYGDALOID}

The Osceola flow throughout the area that has been extensively developed, and probably over a much larger area, has a distinctly rough or fragmental top. Its surface, which is much more irregular than that of the Kearsarge flow, consists of a series of hummocks and depressions of very irregular shape and variable size. Perhaps the tops of the hummocks and the bottoms of the depressions would average 12 to 15 feet above and below an average plane, or 25 to 30 feet from top of hummock to bottom of depression. In places the variation is considerably greater, and of course in other places it is less.

The lode is distinctly of the fragmental type. There is less of the nonfragmental, cellular lode rock than in the Kearsarge flow, but where present it commonly underlies the fragmental rock, as in the Kearsarge. The coarse cellular rock that is very common in the lower part of the Kearsarge lode is also less abundant in the Osceola. In many places the lode passes directly from fragmental lode to fine foot trap. There are areas where the lode is mainly of a rather thin cellular type.

There are considerable areas of the lode that contain much sandy material and are of the "scoriaceous" type.

Inclusions of partly resorbed amygdaloid are present below the lode, but they are scattered and not a con- spicuous feature of the footwall as they are of the Isle Royale lode.

\section{THICKNESS}

The lode ranges in thickness from as little as 1 foot to as much as 60 feet; perhaps in a few places it is even thicker. In general, the lode is thicker in the hummocks, consisting mainly of fragmental rock, that rise above the average level of the top of the flow, and is thinner in the depressions below the general level, as the fragmental material commonly extends deeper under the hummocks than it does under the depressions. This is what would be expected if the fragmental material floated in irregular masses on the lava - the higher the loose solidified material was piled above the general level the deeper it would sink into the liquid or plastic part of the flow, and it would remain there when the whole came to rest and solidified. It is the lower portion of these downward bulges that constitutes the so-called "foot lode."

In places the lode contains a bar of "vein trap" with fragmental rock above and below. This, however, has rarely been seen to be continuous over very large areas. Ordinarily the fragmental material underlying the thin trap layer is connected near by with that on the top of the flow, and in most places the lode is simply a continuous thick mass of fragmental rock.

The lode also shows variations that are on a larger scale than those mentioned above. Bands of relatively thick and thin breccia pitch in a southwesterly direction, in general, parallel to the southern boundary of the Osceola ore shoot. Such a thin band is rather consistently present along the south boundary of the Osceola shoot, and similar bands are present in both the Osceola and the Calumet \& Hecla portions of the lode. Within these thin and thick belts the minor variations of hummocks and depressions are present.

\section{HANGING WALL}

The hanging wall of the Osceola lode is a heavy trap with a rather indistinct contact between its thin basal amygdaloid and the upper surface of the Osceola lode. In many places the hanging wall is jointed 
and sheet copper is present on the joints. In both of these features-namely, the lack of a clear-cut upper boundary and the presence of copper in the hanging wall-the Osceola differs from the Kearsarge lode.

\section{STRUCTURE}

Except for the features of the lode itself, the structure in the Osceola mine is simple. There is no noteworthy folding or faulting; and only relatively few small fissures cross the lode.

\section{ALTERATION AND MINERALIZATION OF THE LODE}

Oxidation.-In its general character the oxidation of the Osceola lode does not differ from that of other fragmental lodes. As in the other lodes, it is earlier than and independent of the copper mineralization and varies with the character of the rock. The highly fragmental lava is consistently well oxidized; the cellular and trappy rock is much less oxidized.

There is not the same change in degree of oxidation from the hanging wall toward the footwall in the Osceola that there is in the Kearsarge lode. The Kearsarge lode is most highly oxidized near the trap, but the Osceola lode is highly oxidized throughoutsome of its fragmental "foot lode" is apparently oxidized as much as any other rock in the lode. Oxidation has extended rather deeply into the "foot trap," which for some distance from the lode is distinetly redder than the "hanging trap." In this respect, as in some others, this lode resembles the Isle Royale lode.

Alteration and mineralization later than oxidation.The results of the alteration and mineralization of the lode that were later than the oxidation do not differ in general from those of the Kearsarge lode. Prehnite and datolite are more abundant than in the Kearsarge. Epidote is distributed throughout the Osceola lode, whereas in the Kearsarge it is largely confined to the upper part. This is apparently a result of the deep oxidation of the Osceola lode.

Bleached rock very similar to that of the Kearsarge lode is associated with the copper and differs from that found in the Pewabic, Isle Royale, and Baltic lodes in containing a relatively small amount of pumpellyite.

The more abundant minerals are feldspar (rather irregularly distributed), calcite, quartz, epidote, pumpellyite, chlorite, and prehnite. Prehnite is most abundant in the sandy areas. The less abundant minerals, which are rather unevenly distributed, are datolite, most plentiful toward the south boundary of the ore body; laumontite, mainly in fissures; analcite, also largely in fissures; and a little saponite in the lode.

\section{DISTRIBUTION OF COPPER IN THE LODE}

Distribution through thickness of the lode.-In the Osceola lode, as in the Kearsarge, by far the richest and most uniformly mineralized portion lies against the hanging wall. The mineralized rock, however, extends irregularly downward, in places 50 feet or more from the hanging wall. No quantitative data are available as to the relative amount of copper at different depths in the lode, but the general impression is that the top 4 to 5 feet contains fully 75 to 80 per cent of the copper that is present in the upper 10 feet of lode and that the 1 foot just below the hanging wall is by far the richest part of the lode. The copper that lies deep in the lode is irregularly distributed. It is confined to the areas where the fragmental rock extends to considerable depths, but there is too little information as to the grade of rock from the foot workings to determine whether or not copper is always or usually present in commercial quantities in those areas.

Five samples of red lode rock that showed no copper on ordinary inspection were taken to determine if copper is present in rock in which it is not readily seen, and, if so, in what amount. Assays of these samples ranged from 2.8 to 4.8 pounds to the ton, with an average of 3.76 pounds.

As a general rule, "thick lode" and "deep foot lode" occur where the lode bulges up into the hanging wall and, conversely, are not to be expected where the hanging wall bulges down into the lode. If experience shows that copper in commercial quantity is present in a sufficient number of places where "deep foot lode" occurs to warrant prospecting for it, then this relation to the hanging wall would seem to offer a very economical method for locating the areas of thick lode.

Distribution in the plane of the lode.-It has already been noted that there are bars of thin amygdaloid pitching southwest in the lode. These bars are usually poor in copper, though their thicker portions contain some commercial ground. Along the south boundary of the ore shoot, where it has been examined, the lode seems to be rather uniformly thin and tight. This thin streak is regarded as an inclined barrier that has prevented the direct upward movement of the ore solutions along the lode and caused a concentration beneath it. This belief is supported by the fact that south of this barrier the lode is lean, even though it is moderately or even in places decidedly thick and has the other physical characters that are regarded as favorable.

The best ground in the shoot has in general been found close to the barrier, and the grade has decreased with increasing distance from it; but the grade varies notably with the character of the lode, and too little definite information is available to give a very clear picture of the variations and their causes. The following facts, however, have a bearing on the matter.

In the lower levels there is a notable change in the grade of rock northward from the south boundary. The area south of Osceola No. 6 shaft is of decidedly better grade than that of No. 5 shaft. In the accessible levels near the bottom of No. 5 the lode is of 
only medium thickness, a condition which was probably a factor in producing the lower grade, but regardless of the difference in character of lode, there seems to be a decrease toward the north in general, which is observed in the Calumet \& Hecla Co.'s Osceola ground as well as in the Osceola mine. Taken as a whole, there is a decrease in the grade northward, till in No. 18 shaft there is a much lower proportion of pay rock than in the south side of the shoot, and in the Centennial it apparently was not sufficient to encourage development below the twelfth level. A shaft farther north in Wolverine ground is apparently out of the shoot and encountered no encouraging copper content to the fifth level. Tamarack No. 1 in its upper levels encountered some commercial rock, but this continued for only a few levels, when the rock became of too low grade to pay.

The available facts thus suggest that the commercial rock will be found to fail toward the north along a line roughly paralleling the southern boundary of the ore shoot. This means, of course, that the shafts from the north to south will reach unprofitable ground at progressively greater depths. No. 18 even at the outcrop is at about the margin of pay ground. No. 17 averaged poor below the tenth level. No. 16 seems to be getting leaner in the lower levels. If this trend continues, No. 15 will soon be getting into poorer ground, though the Tamarack found some good ground between Nos. 15 and 14 at considerably greater depth. Nos. 14 and 13 would seem to have a good distance to go before they encounter poor ground.

No. 5 Osceola is bottomed in rather poor ground, and the question naturally arises whether this is the bottom of the shoot. The general trend would suggest that it is not. Furthermore, there is a rather wide bar of thin lode in Calumet \& Hecla ground that, if projected, would about intersect the bottom of No. 5 shaft, and it is possible that the poor grade in the bottom of No. 5 is in part due to this bar of poor, thin lode rock, and that the bottom of the shoot is at very considerably greater depth.

\section{VARIATION IN COPPER CONTENT WITH DEPTH}

In any discussion of the variation of the copper content, of the Osceola lode with depth, it is necessary to consider the ore shoot as a whole and not a section as represented by any single shaft. Considering individual shafts, there is little doubt that all the Calumet $\&$ Hecla shafts and Nos. 1,2 , and 3 Osceola would eventually show a decrease in copper content with increase in depth. Nos. 5 and 6 Osceola, on the other hand, pass through lean or nearly barren ground for several hundred feet before entering the ore shoot, and there are indications that the ground along No. 5 shaft is growing leaner in the lower levels.

If, however, an inclined belt parallel to the trend of the ore shoot is examined - for example, a belt 1,000 ,
2,000 , or 3,000 feet north of and parallel to the south boundary of the ore shoot-no clear evidence is found of a decrease in copper content with increase in depth down the shoot.

The grade of the ore recently mined in the lower levels of the Osceola mine is lower than that of the ore formerly mined in the upper levels, but this is, in part at least, a* matter of changes in mining method and policy, as is discussed below, rather than a real change in the copper content of the lode.

There are no exact data available to check the grade of the ore in different parts of the mine, but the impression gained from inspection of the lode is that the copper content of the rock in the ore shoot in the lower levels south of No. 6 shaft compares favorably with that in the higher levels of the mine.

\section{CHANGES IN METHOD OF MINING}

There have been decided changes in the method of mining lodes of this type in the district and in the Osceola mine itself, as is very evident to one going through the workings of different periods and of different depths of mining. In the early days of mining on the Osceola lode the method seems to have been to make the highest possible recovery from the hanging side of the lode; the hanging wall was stripped clean, and the pillars were small. No great effort was made at that time to get a high recovery of the copper deep in the lode. A relatively narrow stope was carried against the hanging wall, and where copper was exposed near the footwall it was apparently followed; but where it was not exposed little if any effort was expended in search for it. Thus there was a high percentage of recovery from the hanging side of the lode and a low recovery from the foot side.

Moreover, in the early mining a much larger proportion of the thin and poor portions of the lode was left untouched than in the later operations. The ore under this early type of mining over a distance of 2,000 to 3,000 feet north of the south boundary of the shoot yielded 22 to 29 pounds of copper to the ton.

In the lower levels of the mine south of No. 6 shaft, for example - the width stoped averages distinctly greater than in the upper levels, and more of the lode has been mined, despite the facts that there has not been the former high recovery of the rock just below the hanging wall, a few inches to a foot of lode being commonly left on the hanging wall, and that the pillars are more numerous and larger than in the upper workings, as is required by the greater depth.

The results of this change from the earlier method are not very certain, but the impression is that considerably more lode rock has been mined per unit area, with perhaps little if any greater recovery of copper per unit area. For example, say the average thickness mined in 1920 was 12 feet, including foot work, with a recovery of 18 pounds to the ton, or 
about 18 pounds to each square foot of lode; in the early mining 8 feet of lode was mined with a recovery of 27 pounds to the ton, or 18 pounds to the square foot.

\section{KEARSARGE LODE}

\section{HISTORY AND PRODUCTION}

The earliest notable production from the Kearsarge lode was made in the Kearsarge mine; now the North Kearsarge, in 1887, though development had begun some years before. Production from this mine was followed by that of neighboring mines - namely, the Wolverine in 1895, the South Kearsarge in 1900, and the Centennial and Calumet \& Hecla in 1904. At the north end of the lode the Mohawk began production in 1903, followed by the Ahmeek in 1904, the Allouez in 1905, the Gratiot in 1910, and the Seneca in 1921. Prospecting has been extended to the north by the Ojibway, Cliff, Miskowabic, Manitou-Frontenac, and Keweenaw Copper (Mandan) companies and to the south by the Laurium, La Salle, and Franklin Jr.

Production and dividends from Kearsarge lode to end of 1925

\begin{tabular}{|c|c|c|c|c|c|c|}
\hline \multirow[b]{2}{*}{ Mine } & \multirow[b]{2}{*}{ Period } & \multirow[b]{2}{*}{$\begin{array}{l}\text { Roek treated } \\
\text { (tons) }\end{array}$} & \multicolumn{2}{|c|}{ Refined copper (pounds) } & \multicolumn{2}{|c|}{ Dividends } \\
\hline & & & Total & Per ton & Total & $\begin{array}{l}\text { Per pound of } \\
\text { copper (cents) }\end{array}$ \\
\hline $\begin{array}{l}\text { Ahmeek } \\
\text { Do } \\
\text { Cllouez } \\
\text { Calumet \& Hecla, Kearsarge branch } \\
\text { North Kearsarge } \\
\text { South Kearsarge } \\
\text { Gratiot } \\
\text { La Salle } \\
\text { Mohawk } \\
\text { Ojibway } \\
\text { Seneca } \\
\text { Do } \\
\text { Wolverine } \\
\text { Do }\end{array}$ & $\begin{array}{l} \\
\\
\\
\\
\\
\\
\\
1887-1925 \\
1910-1920-1920 \\
1902-1925 \\
1911 \\
1920-1924 \\
1925 \\
1882-1886 \\
1891-1925\end{array}$ & $\left\{\begin{array}{r}10,801,252 \\
4,918,843 \\
2,261,890 \\
2,331,524 \\
\hdashline 10,344,447 \\
6,427,605 \\
30,315 \\
739,624 \\
14,014,050 \\
7,448 \\
148,530 \\
17,313 \\
8,468,263\end{array}\right.$ & $\begin{array}{r}16,795,681 \\
241,492,186 \\
82,222,989 \\
33,033,675 \\
67,351,569 \\
21,237 \\
160,862,279 \\
115,156,251 \\
313,848 \\
7,814,730 \\
259,114,348 \\
49,662 \\
3,561,922 \\
284,241 \\
1,979,378 \\
186,817,729\end{array}$ & $\begin{array}{r}22.36 \\
16.72 \\
14.60 \\
28.89 \\
15.55 \\
17.91 \\
10.35 \\
10.57 \\
18.49 \\
6.63 \\
23.98 \\
16.4 \\
22.06\end{array}$ & $10,750,000$ & 5. 48 \\
\hline $\begin{array}{l}\text { Production omitting figures for which } \\
\text { no corresponding tonnages are given.- }\end{array}$ & & $\begin{array}{l}60,511,104 \\
60,511,104\end{array}$ & $\begin{array}{l}1,176,871,725 \\
1,158,075,429\end{array}$ & 19. 14 & $50,882,000$ & 4. 32 \\
\hline
\end{tabular}

a Mines now belonging to the Calumet \& Hecla Consolidated Copper Co.

B Estimated.

\section{KEARSARGE FLOW}

EXTENT AND CRITERIA FOR RECOGNITION

The Kearsarge flow (pl. 40) has been recognized from Atlantic to Mandan, in Keweenaw County, a distance of about 35 miles. The rock is a well-developed ophite. The identification of this flow is commonly based on the porphyritic character of its upper portion and on its position immediately above the Wolverine sandstone. With these aids it can be recognized more easily and certainly than most of the other flows.

The plagioclase phenocrysts are usually most abundant in the trap just below the amygdaloid, though they are present in the amygdaloid. They vary considerably from place to place, both in size and in abundance. Usually the tabular crystals do not exceed half an inch in length and make up but a small part of the rock. Locally, however, they reach an inch in length and over short stretches may form a considerable percentage of the rock. In the "west flow" they are less abundant than in the main flow. The concentration of phenocrysts at the base of the amygdaloid appears to have [resulted from the rising of the crystals through the molten lava till they reached the solid or viscous portion near the top, where they were stopped. The lesser numbers in the thin "west flow" may be due to the fact that they collected from a smaller volume of lava.

What is classed as the Kearsarge flow does not everywhere consist of a single flow; in many places there are two or more flows at the Kearsarge horizon that contain feldspar phenocrysts and are grouped as Kearsarge. In the principal productive area, from the Centennial mine to the Gratiot mine, the amygdaloid of the lowest flow of the series has been mined, and only locally have the amygdaloids of the "west lodes" been shown to contain copper in paying quantity. In this area the higher flows are relatively thin, phenocrysts are few, and the amygdaloidal tops are of the cellular type and usually but little oxidized.

\section{THICKNESS}

At No. 2 shaft, Ahmeek, the basal Kearsarge flow is 200 feet thick at the surface and has essentially the same thickness in the crosscuts on the Mass fissure in the lower levels. On the twelf th level, Centennial, the Kearsarge trap is 179 feet thick, with 6 feet of amygdaloid, a total of 185 feet. At the surface the total thickness of the flow as scaled from a cross section is 170 feet. The crosscut in the Wolverine mine shows 
the Kearsarge bed about 200 feet thick. Between No. 1 and No. 2 shafts, Mohawk, on the twenty-first level, the flow is 185 feet thick. It thus seems that in the main productive area this basal flow has a thickness of 170 to 200 feet. Locally overlying the basal flow are thin flows of the Kearsarge type. How much of the lode is covered by such flows is not known, but there are certainly places where none are present, and in other places as many as half a dozen flows are present between the basal Kearsarge and the next heavy trap. These flows are usually thin, but a flow 85 feet thick, with phenocrysts, lies on the main Kearsarge flow at No. 4 shaft, North Kearsarge, and a flow of similar thickness has been noted in a crosscut on the Mass fissure in the Ahmeek mine. It appears, therefore, that in the productive area the Kearsarge flows may reach a total thickness of 300 feet.

The following observations were made north of the more developed area:

Gratiot: No. 2 shaft, amygdaloid 29 feet, trap 169 feet, total 198 feet; No. 1 shaft, amygdaloid 9 feet, trap 193 feet, total 202 feet.

Seneca No. 1 shaft: Diamond-drill hole No. 6, more than 127 feet in five flows; basal trap 63 feet. Diamond-drill hole No. 3, 74 feet from top cut, five amygdaloids and base of series not reached. Diamond-drill hole No. 1, basal trap more than 84 feet, sandstone not reached. Diamond-drill hole No. 5, 950 feet north of No. 1 shaft, 113 feet of Kearsarge flows with four amygdaloids, basal trap 24 feet. The old Seneca No. 1 shaft is sunk near the Wolverine sandstone, and crosscuts were extended from it into the hanging wall. First level, crosscut 150 feet; second level, crosscut 50 feet, drift on an amygdaloid; third level, crosscut about 350 feet, apparently cutting the entire series of Kearsarge flows, drift about 700 feet, apparently on top amygdaloid; fifth level, crosseut about 230 feet, drift on an amygdaloid, possibly the top amygdaloid.

Ojibway: Kearsarge apparently consists of two or more flows. Basal flow at No. 1 shaft reported 35 to 85 feet, at No. 2 shaft 260 to 360 feet.

Cliff: Diamond-drill hole No. 1 at shaft, Wolverine sandstone 33 feet, trap 93 feet, amygdaloid 6 feet, trap 28 feet, amygdaloid 7 feet (west lode?). Diamond-drill hole No. 11, 1,900 feet along strike from south boundary, Wolverine sandstone 2 feet, basal trap 107 feet, amygdaloid 22 feet, second trap 7 feet, second amygdaloid 10 feet, followed by a series of small flows. Diamond-drill hole No. 12, Wolverine sandstone 3 feet, basal trap 46 feet, amygdaloid 5 feet, second trap 12 feet, amygdaloid (Kearsarge) 14 feet, third trap 7 feet, amygdaloid (Kearsarge) 8 feet. Diamond-drill hole No. 3, 5,200 feet north of south boundary, Wolverine sandstone 19 feet, basal trap 174 feet, amygdaloid (Kearsarge) 24 feet, second trap 81 feet, amygdaloid 11 feet. Diamond-drill hole No. 4, 5,600 feet north of south boundary, Wolverine sandstone 5 feet, basal trap 113 feet, amygdaloid 18 feet, second trap 77 feet, amygdaloid 13 feet.

Central mine: Kearsarge as scaled from a cross section, 235 feet in three flows. Diamond-drill hole No. 2, Wolverine sandstone thin, basal trap 70 feet, amygdaloid 5 feet, second trap 57 feet, amygdaloid (Kearsarge) 33 feet.

Manitou-Frontenac: Diamond-drill hole No. 7-4-S, Wolverine sandstone 6 feet, basal trap 28 feet, amygdaloid 4 feet, Diamond-drill hole No. $3-5-\mathrm{S}$, Wolverine sandstone thin, hasa] trap 19 feet, amygdaloid 5 feet, second trap 63 feet, amygdaloid
3 feet, third trap 39 feet, amygdaloid 5 feet, fourth trap 21 feet, amygdaloid 14 feet, total Kearsarge flow 169 feet.

Mandan: Diamond-drill hole No. 9, Wolverine sandstone thin, basal trap 55 feet, amygdaloid 6 feet; appears to be one flow.

From the records given above it is apparent that north of the Gratiot mine the basal Kearsarge flow becomes decidedly variable in thickness, ranging from 24 feet in diamond-drill hole No. 5, Seneca, to 260 feet or more in No. 2 shaft, Ojibway, 19 feet in the Frontenac, and 27 and 45 feet at Mandan. In contrast with the main productive area, the basal flow is in most places thin, and the whole series does not maintain the thickness of the basal flow in the area from the Gratiot to the Centennial mine.

The following observations were made south of the productive area:

Laurium: Diamond-drill hole No. 3, 1,700 feet south of north boundary, Wolverine sandstone 10 inches, basal trap 110 feet, amygdaloid 10 feet, second trap 4 feet, amygdaloid 2 feet. Diamond-drill hole No. 2, 800 feet north of shaft, Wolverine sandstone 3 feet, basal trap 141 feet, amygdaloid $81 / 2$ feet. Diamond-drill hole No. 4, 900 feet from extreme south boundary, Wolverine sandstone 10 feet, basal trap 144 feet, amygdaloid 11 feet, second trap 4 feet, amygdaloid 7 feet.

Calumet \& Hecla: Eighty-first level crosscut, Red Jacket shaft, two small flows over the main Kearsarge lode; basal flow 181 feet.

La Salle: Diamond-drill hole No. 12, opposite No. 2 shaft, Wolverine sandstone 2 feet, basal trap 131 feet, Kearsarge amygdaloid 9 feet, trap 75 feet. No. 2 La Salle shaft is on first amygdaloid. Diamond-drill hole No. 13, 1,700 feet south of No. 2 shaft, from top down, hanging-wall trap 60 feet, top Kearsarge amygdaloid 4 feet, trap 15 feet, amygdaloid 4 feet, trap 20 feet, amygdaloid 14 feet, trap $20+$ feet; Wolverine sandstone not noted. Diamond-drill hole No. 14, 250 feet down dip from No. 13, hanging-wall trap 65 feet, Kearsarge amygdaloid 4 feet, Kearsarge trap $33+$ feet. Diamond-drill hole No. 1, 5,200 feet south of No. 2 shaft, at No. 5 La Salle, Wolverine sandstone 7 feet, basal trap 28 feet, amygdaloid 4 feet, second trap 28 feet, amygdaloid 6 feet, third trap 10 feet, amygdaloid 12 feet, fourth trap 29 feet, amygdaloid $1 \frac{1}{2}$ feet, fifth trap $21 / 2$ feet, amygdaloid 6 inches, sixth Kearsarge trap $41 / 2$ feet, amygdaloid 7 feet. Diamond-drill hole No. 4, at No. 6 La Salle, Wolverine sandstone, first flow, lowest Kearsarge trap 42 feet, amygdaloid 3 feet; second flow, trap 8 feet, amygdaloid 7 feet; third flow, trap 14 feet, amygdaloid 4 feet; fourth Kearsarge trap 14 feet, amygdaloid 7 feet; hanging-wall trap 14 feet. Diamond-drill holes Nos. 6, 9, 10, 1,500 feet south of No. 6 La Salle; diamond-drill hole No. 9, Wolverine sandstone 1 foot, basal trap 96 feet, amygdaloid 2 feet, second trap 37 feet, amygdaloid 4 feet, hanging-wall trap 62 feet.

Franklin Jr. mine, thirty-second level crosscut: Wolverine sandstone 10 feet, basal trap (broken) 10 feet, amygdaloid 16 feet; second flow, trap 22 feet, amygdaloid 30 feet.

Franklin Jr. new shaft: First Kearsarge amygdaloid 7 feet, trap 28 feet; second Kearsarge amygdaloid 6 feet, trap 33 feet; third Kearsarge amygdaloid 9 feet, trap 2 feet; Wolverine sandstone(?) 4 inches.

Arcadian No. 1: Total flow 109 feet; No. 2, total flow 101 feet.

Naumkeag: Diamond-drill hole J, Wolverine sandstone 1 frot, trap 57 feet, amygdaloid 17 feet.

Isle Royale mine: Wolverine sandstone 1 foot, trap 49 feet, amygdaloid 5 feet.

Atlantic: Wolverine sandstone 6 feet, trap 40 feet, amygdaloid 17 feet. 
From these observations it is apparent that south of the Centennial mine there is a thinning of the Kearsarge flows, and that south of Nos. 1 and 2 La Salle the basal flow is thin and the series generally consists of a succession of thin flows.

\section{CHARACTER OF KEARSARGE AMYGDALOID}

\section{GENERAL FEATURES}

Next to the Pewabic, the Kearsarge lode is the most regular of the large productive lodes of the district, yet it varies notably in character from place to place. In the main productive area the amygdaloid can be roughly separated into material of three types-namely, "fragmental lode," banded amygdaloid, and "foot lode."

The "fragmental lode" consists of irregular angular to subangular fragments of amygdaloid. The amygdaloid fragments are predominantly fine and contain very numerous but small amygdules, indicating relatively rapid solidification; but mixed with the fine fragments are some of coarser texture.

In the Kearsarge lode as a whole individual fragments rather rarely exceed a foot in greatest dimension, and most of the fragments range from 6 inches to a fraction of an inch. In the top portion the fragments average smaller than toward the base. In position "fragmental lode," if present, is always at the top, immediately beneath the hanging-wall trap. It gives place downward either to cellular banded amygdaloid or to "foot lode;" if the former, the transition is likely to be gradual; if the latter, it is more likely to be abrupt.

The thickness of the "fragmental lode" probably averages 5 to 6 feet but ranges from 20 feet down to the vanishing point. Very commonly, where the "fragmental lode" is thickest it bulges into the hanging wall, indicating that it formed slight elevations on the surface that was buried by the overlying flow, and it also extends deeper in to the underlying material at such places.

The banded amygdaloid, as contrasted with the "fragmental lode," is an unbroken rock body over considerable areas. The amygdules are commonly more abundant at certain horizons, giving the rock a banded appearance in cross section. In texture it varies with distance from the surface of the lode. Where it forms the top of the lode the upper portion is fine textured and it increases in coarseness with increase in distance from the surface. Where it is covered by "fragmental lode" the finer-textured part is not present. Evidently the "fragmental lode" offered the same protection from rapid cooling as the chilled upper portion of the banded amygdaloid.

The banded amygdaloid may lie immediately below the hanging-wall trap or it may grade upward into "fragmental lode." Downward it grades into "foot lode." In most places it is less than 6 feet thick, but it may exceed that thickness locally, as in some parts of the upper levels of the Wolverine, North Kearsarge, Mohawk, and other mines.

The rock in the zone between the banded amygda. loid and the footwall trap is called "foot lode." It differs from the banded amygdaloid in having a coarser texture, with larger and fewer amygdules and less tendency for the amygdules to form in bands. It grades upward into cellular amygdaloid or underlies "fragmental lode." In a very few places it immediately underlies the hanging-wall trap. Downward it grades into the footwall trap. Locally it contains a few fragments of cellular amygdaloid. It rarely exceeds 6 feet in thickness.

From the foregoing statements it is apparent that the lode may consist of "fragmental lode," banded amygdaloid, and "foot lode"; of "fragmental lode" and "foot lode"; of banded amygdaloid and "foot lode"; or rarely of "foot lode" alone. The thickest parts of the lode always comprise a fragmental layer and in many places all three types. The thin parts probably consist most commonly of banded amygdaloid and "foot lode," though a lava-cemented fragmental thin lode is a common type.

The average thickness of ground stoped varies somewhat in the different mines of the Kearsarge lode. In several of the mines the lode has been so largely removed from the part developed that it is possible to estimate roughly the average thickness stoped from the quantity of rock produced and the area mined. Such estimates are shown on page 199.

The amount of ground left in stoping differs considerably in different mines; it probably ranges from 10 to 35 per cent. The South Kearsarge has one of the highest recoveries, and its greater stoping width as calculated is probably due in part to that fact. For the Mohawk the actual stoping width is said to be about 12 feet, whereas the calculated width is 9.5 feet, indicating that about 20 per cent of the lode is left.

It appears from the calculations that the average thickness of lode stoped decreases from the South Kearsarge northward. That this difference can not be attributed to stoping wider than is warranted in the South Kearsarge and part of the Wolverine is indicated by the average high yield in copper per ton of rock from these mines. It must of course be recognized that there is a decided variation in the thickness of lode in different parts of individual mines. In the Mohawk, for example, the lode averages distinctly thicker at the south than at the north end.

The largest area of thin and cellular amygdaloid in the productive part of the Kearsarge lode extends along the outcrop from about the north boundary of the South Kearsarge to the Mohawk mine. For much of the distance it extends but a few hundred feet 
below the outcrop, but in the North Kearsarge and Wolverine mines it reaches as deep as the twentieth level. (See pl. 40.)

Another large body of cellular rock is present in the north end of the Mohawk mine. At the surface it extends from about No. 4 shaft to the north boundary, and in the bottom levels from about No. 2 shaft to the boundary. Interspersed with fragmental rock the lode rock of this type apparently extends beyond No. 1 Gratiot shaft, though the lode in that area ias been less developed. It is also predominant north of the new Seneca shaft in the deeper levels. Fragmental lode rock occurs along the Mohawk-Gratiot boundary in the upper levels of No. 2 Gratiot, and smaller areas in the upper and intermediate levels of No. 1 Gratiot and in the lower levels of the new Seneca shaft. A third body of cellular lode is found in the lower levels north and south of Allouez No. 1 shaft, and a smaller body is present north of No. 2 Allowez. Another stretch of thin lode is present in the North Ahmeek, extending from No. 4 shaft northward along the Mohawk boundary beyond No. 4 Mohawk. The bodies of thin lode included in the general area of thick lode thus far outlined have their greatest extent along the strike of the lode and relatively small extent on the dip. If this pattern proves to be typical, it may be possible to get some idea of the distance through a thin bar from its extent along the strike.

\section{LOCAL OBSERVATIONS}

At Ojibway, according to Hubbard, ${ }^{6}$ there is an east lode and a west lode that are copper bearing. Both seem to be irregular in thickness and to be cut out in places. Hubbard suggests that the lode has been eroded and that the old stream channels are recognizable. According to bis description the lode is present in the channels and absent from the bounding ridges. To account for this Hubbard ${ }^{7}$ suggests that after the erosion of valleys they were partly filled with rock material, which was later covered by the flow. Apparently there are two rather persistent copper-bearing lodes separated by trap. The report for 1909 states that at No. 1 shaft "the east lode is from 24 feet in width on the 500 -foot level to 17 feet on the 650 -foot level and contains copper on both wels. The west lode was reached by crosscutting through 17 feet of trap rock. The west lode is about 17 feet wide horizontally on both levels and contains copper."

Little information is available as to the character of the lode at the Cliff shaft. From an inspection of the dump the impression was gained that the lode is mainly of the cellular type, though some breccia is present. The diamond-drill hole at the shaft shows

Ojibway Mining Co., Repts., 1909-1912.

'Lake Superior Mining Inst. Proc,, vol. 17, p. 234, 1912. two flows, the bottom one 134 feet thick, with a 6 -foot amygdaloid, and the top one 30 feet thick, with a 7 -foot amygdaloid. In the main the lode seemed rather poorly oxidized. Feldspar phenocrysts are present but rather sparingly. Most of the work was done on the lower amygdaloid, from which most of the material on the dump was probably derived.

At the Rhode Island mine 10 feet of breccia lode, almost a "conglomerate," was noted by Lane. The thickness of the basal bed is 19 feet; the wes flow is 86 feet thick, with 11 feet of red amygdaloid.

At the Franklin Jr. mine the Kearsarge amygdaloid was located, ${ }^{8}$ and the cores show a little copper. ${ }^{9}$ The thirty-second level crosscut showed enough copper on the footwall side of the lode to warrant further exploration, according to the report of the company. The explorations in the new Kearsarge shaft show three Kearsarge flows with cellular tops.

In the Delaware drill section the Kearsarge amygdaloid has been eut in several diamond-drill holes. In all it is a thin ( 3 to 4 feet), nonfragmental, poorly oxidized amygdaloid. Some of the holes cut "west" lodes also with thin, nonfragmental, poorly oxidized amygdaloids.

South of the main productive area the lode, so far as known, seems to be thinner and less fragmental than in the productive area. This change is apparent in the south end of the Centennial mine. Little is known of the character of the lode in the Calumet \& Hecla, but farther south, in the La Salle mine, it is only locally fragmental and in general only moderately oxidized. The diamond-drill records show that the Kearsarge flow in La Salle ground consisted of three to five thin flows with amygdaloids. In the south shafts the development seems to have been on the upper amygdaloid of this series. The north shafts are evidently on the first amygdaloid above the Wolverine sandstone. In the Laurium ground the diamond-drill record indicates but one thick flow.

In the productive area of the Kearsarge lode the copper has practically all come from the first amygdaloid above the Wolverine sandstone.

From these notes it appears that nowhere outside of the main productive area have large areas of thick "fragmental lode" been discovered.

\section{STRUCTURE}

\section{ALLOUEZ ANTICLINE}

The major structural feature of the productive part of the lode is the Allouez anticline. The axis of this arch passes near No. 1 Ahmeek shaft; the beds flatten out at the south near the Centennial shafts and at the north between Nos. 3 and 4 Mohawk. Within these limits the average divergence from a

\footnotetext{
s Franklin Mining Co. Rept. for 1905, p. 12.
}

Idem for 1916 , p. 8 . 
plane in the position of the Kearsarge bed outside this fold is about $5^{\circ}$ for both limbs, or about 9 feet in 100 feet. The steepest dips are at the crest of the anticline, and if the dips continue down the lode at the same angle as at the surface, the anticline must gradually flatten, and at 10,000 feet down the dip it must nearly disappear. The anticline is much less pronounced in the higher beds of the series than it is toward the base.

FAULTS AND FISSURES

By far the most prominent series of fissures strike a little west of north and as a rule dip steeply eastward. Among these are the shatter zone, the Mohawkite, Mass, and Fulton fissures, and half a dozen fissures in the Mohawk mine. Fissures of this series are less abundant to the south but are present throughout the developed area.

There has been some movement on many of the fissures. The shatter zone passing through Ahmeek and Allouez has the greatest displacement. It is a belt 200 to 400 feet wide that contains many fissures. It has been traced through the Ahmeek and Allouez workings, and its persistence to the north and south is indicated by the low Allouez Gap, which doubtless has resulted from erosion of the weakened rocks of this zone. The displacement is about 100 feet, the lode to the north of the zone being that distance to the west of the portion to the south. Both the north and south boundaries of the zone are marked by strong red clay gouges; that to the north is the thicker, measuring from 6 inches to several feet. Associated with the north gouge is a strong prehnite-epidotecopper vein that has been greatly shattered, seemingly by the movement that produced the fissure.

The shatter zone that passes along the boundary between the North Ahmeek and Mohawk mines offsets the lode in the upper workings of the Mohawk, but this offset decreases with depth till in the North Ahmeek it is little more than the width of the lode. This shatter zone is narrower than the AhmeekAllouez zone but resembles it closely in other respects. It is considerably wider in the Mohawk than in the North Ahmeek. The fault south of No. 1 Gratiot offsets the lode about 50 feet to the west on the north side.

The other prominent fissures commonly show a little gouge, and in places there is some brecciation of the adjacent rock. Not uncommonly the fissure zone widens out to 2 to 3 feet.

Another set of fissures strikes approximately east, or nearly at right angles to the north-south fissures, and usually dip steeply south. None of these are prominent, and few can be traced for more than a few hundred feet. There are numerous fissures in the mines that do not seem to fall into any well-developed regional system, but they are commonly small and traceable for only short distances.
ALTERATION AND MINERALIZATION

OXIDATION

Oxidation was the earliest alteration of the lode. The oxidation of the Kearsarge and other lodes is fully discussed in the general section of the report (p. 34). The fragmental portions of the Kearsarge lode are highly oxidized and unusually high in ferric oxide. The oxidation is believed to have taken place during the cooling of the lava, earlier than and quite independently of the deposition of copper.

\section{ALTERATION ACCOMPANYING MINERALIZATION}

The alteration that took place subsequent to the oxidation may not all have occurred at the same time, but to separate it clearly is not easy. Much of it seems to have been closely associated with the deposition of copper, but certain phases of the alteration seem to have been more widespread than the copper deposition and not necessarily closely tied to it. For example, red feldspar, though present nearly everywhere in the Kearsarge lode, is distinctly variable in amount. In La Salle North Kearsarge, North Ahmeek, and Mohawk ground it is rather abundant, but in South Ahmeek ground there is less. Epidote is also far more widely distributed in the lode than important copper deposits. It may be added that what is true of the Kearsarge lode is also true of other lodes. Some that have very little copper show a more or less pronounced epidotization. This suggests that some of the changes may not have been due primarily to the copper-bearing solutions but probably to the general temperature conditions that accompanied the mineralization.

The mineralization that followed the oxidation of the lode bore a distinct relation to the compositions of the lode after oxidation. Thus epidote, a ferric silicate, is abundant in the more highly oxidized portion of the lode but is much less abundant in the "foot lode" that was less highly oxidized. Chlorite and pumpellyite, ferrous-ferric silicates, are characteristic of the less oxidized "foot lode" and also of the basal amygdaloid of the hanging-wall trap, though they are also present in the more highly oxidized portion of the lode.

The change from epidote to chlorite in passing from the Kearsarge lode to the basal amygdaloid of the overlying trap is very sharp. Areas of these rocks but a fraction of an inch apart show the characteristic mineralization of each. In the west lodes, which are much less oxidized than the main lode, pumpellyite is relatively abundant. Minerals that do not contain iron show no such control as indicated above. Thus, quartz and feldspar are distributed throughout the lode, and so is laumontite where present; in fact, $\mathrm{s0}$ far as recognized, the control is confined to the iron minerals.

The most conspicuous and striking change that is closely associated with copper is a pronounced bleaching of the rock around the copper in the upper highly 
oxidized portion of the lode. In this portion the copper has replaced the rock in masses of diverse sizes, the largest weighing several hundred pounds. Surrounding the copper is an area of light-gray rock in which the hematite of the red lode has largely disappeared. Quartz, pumpellyite, epidote, calcite, and some of the feldspar of the rock are the most abundant minerals. The relation of the copper to these minerals indicates that it is later and that it continued to replace these minerals after they were formed. In the lower part of the lode, especially in the "foot lode," where the rock is much less oxidized, bleaching is less pronounced, epidote decreases in amount, and chlorite becomes abundant. The copper has replaced the rock to a less extent and is more abundant as an amygdule filling.

\section{YIELD}

In general, the Kearsarge lode is richest near the hanging wall; the richest ore is not always, perhaps not usually, at the very top, but the first 3 to 5 feet is the richest part of the lode and grades downward into leaner rock. In the Wolverine mine the "foot lode" was not extensively mined in the earlier years, but it is said to have been in the last few years a rather large factor in the production. In the earlier years the rock mined averaged 25 to 30 pounds to the ton; in the last few years it has averaged 15 to 16 pounds, indicating that the "foot lode" is much lower in copper than the upper part, though some low-grade material from the top part has been mined at the same time. A similar but much less marked change occurred in the South Kearsarge when the "foot lode" began to be more extensively mined.

The copper derived from a given area of lode varies to a considerable extent with the thickness of the lode, though there are notable exceptions. For the larger mines on the Kearsarge as to which data are available, the following table shows the average calculated thickness of lode stoped, the average quantity of rock mined per square foot of lode area, and the average yield of copper.

Rock mined and copper produced per square foot of Kearsarge lode

\begin{tabular}{|c|c|c|c|c|}
\hline \multirow{2}{*}{ Mine } & \multirow{2}{*}{$\begin{array}{c}\text { Thickness } \\
\text { of lode } \\
\text { (feet) }\end{array}$} & \multirow{2}{*}{$\begin{array}{l}\text { Rock (tons } \\
\text { per square } \\
\text { foot) }\end{array}$} & \multicolumn{2}{|c|}{ Copper (pounds) } \\
\hline & & & $\begin{array}{c}\text { Per square } \\
\text { foot }\end{array}$ & $\begin{array}{l}\text { Per ton } \\
\text { of rock }\end{array}$ \\
\hline $\begin{array}{l}\text { South Kearsarge } \\
\text { Allouez } \\
\text { Ahmeek Nos. } 1 \text { and } 2 \\
\text { Ahmeek Nos. } 3 \text { and } 4 \\
\text { Mohawk } \\
\text { Wolverine } \\
\text { North Kearsarge } \\
\text { Centennial }\end{array}$ & $\begin{aligned} \text { 12. } 6 \\
\text { 10. } 9 \\
\text { 10. } 1 \\
9.3 \\
9.5 \\
8.69 \\
\text { 7. } 64 \\
6.3\end{aligned}$ & $\begin{array}{r}1.05 \\
.91 \\
.84 \\
.77 \\
.79 \\
\end{array}$ & $\begin{array}{l}\text { 18. } 8 \\
\text { 15. } 23 \\
\text { 17. } 26 \\
\text { 13. } 8 \\
\text { 17. } 19 \\
10.4 \\
7.72\end{array}$ & $\begin{array}{l}\text { 17. } 98 \\
\text { 16. } 74 \\
\text { 22. } 15 \\
\text { 17. } 48 \\
\text { 23. } 2 \\
\text { 15. } 62 \\
\text { 14. } 6\end{array}$ \\
\hline
\end{tabular}

The relatively large amount of unprofitable ground in the Wolverine, Centennial, and North Kearsarge make the figures for these mines less accurate.

There is a rather regular decrease in the average stoping width from the South Kearsarge mine northward to the Mohawk, the average in the latter mine being fully 3 feet less than that in the former. Except in the South Ahmeek (Nos. 1 and 2) there is also a decrease in the copper per square foot of lode. The Wolverine has the highest-grade rock, and in part of the mine the lode is as thick as in the South Kearsarge, so that this part probably has the highest yield per square foot of lode. The grade of rock in the Ahmeek has averaged distinctly higher than that in the South Kearsarge, but the average thickness stoped is 2 feet less, so that the average per square foot of lode is slightly less.

It appears that although the lode is mineralized from the Centennial to the Mohawk, two areas richer than the average have been developed. One includes the South Kearsarge and Wolverine with adjacent parts of the Centennial and North Kearsarge; the other includes the South Ahmeek, South Mohawk, and parts of the Allouez. There are also certain poor areas that in general correspond to the areas of thin and cellular lode already outlined and associated with the strong fissures and fissure zones. (See pl. 40.)

\section{PROBABLE CAUSES OF RICH AND POOR GROUND}

Three principal causes seem to have been operative in determining the richness of the ground-character of rock, structural relations, and relation to strong fissures. Of these the character of rock and relation to strong fissures are the more conspicuous.

\section{CHARACTER OF ROCK}

Within the productive portion of the Kearsarge lode the thin parts of the lode and those consisting of dense, trappy amygdaloid are consistently poor. In the larger areas where the lode is poor it is thin or tight and relatively impermeable. The richest ore has been formed in thick masses of strongly developed fragmental top. The thick parts of the lode are not all rich, nor are parts of apparently equal thickness similarly rich, but rich parts of the lode are always thick or loose and fragmental in texture. Outside of the main productive area there are, so far as available data indicate, no large areas of thick fragmental top, most of the outside exploration having disclosed only thin or cellular amygdaloid.

The parts of the lode that are above the average grade in the Ahmeek mine and the south end of the Mohawk are decidedly of the fragmental and welloxidized type. The same is apparently true of the Wolverine-South Kearsarge shoot. In the North 
Kearsarge mine and in the upper levels of Gratiot No. 2 shaft there is some good-looking rock that carries only a fair quantity of copper. The lode in the north end of the Mohawk mine is prevailingly cellular to trappy, moderately thick, and moderately oxidized. It contains some very good ground, but much of it is only fair, and a considerable amount is poor. The same is true of the thin and trappy portions of the lode in the North Kearsarge, Wolverine, Allouez, and Seneca mines.

INFLUENCE OF STRUCTURE AND TEXTURE

The structural and textural features that had an influence on the movement of solutions may also have been an important factor in directing solutions to or from certain parts of the lode. The structural features are independent of the lode; the textural features form a part of the lode.

Structure.-The structural features that have affected the movement of solutions in the lode are folds, faults, and fissures.

The Allouez anticline is the most pronounced fold in the productive area of the lode. If the solutions were traveling upward through the lode, they would have a tendency to move toward and concentrate along the crest of the anticline, and, other things being equal, this should be relatively rich ground. Nos. 1 and 2 shafts in the Ahmeek mine are essentially on the crest of the anticline, and although the stoping width here is less than in some of the mines farther south, the grade of the rock averages higher than in any other mine except the Wolverine.

Faults that offset the lode by more than its thickness and that intersect it in a line whose course is not directly down the dip constitute barriers beneath which the solutions may be concentrated and thus produce rich shoots of ore. The shatter zone is the only fault on the Kearsarge lode that seems likely to have had such an influence, and the extent of its influence is not very clear. Some rich ground was found close under it in the Allouez mine, but to what extent this ground was due to the shatter zone can hardly be stated. The rich ground of Nos. 1 and 2 Ahmeek shafts is in an area of strong fissures, including the shatter zone and the Mohawkite and Mass fissures, but convincing evidence that these fissures were a factor in the enrichment of the lode in this area has not been found. Sulphides are present in small amounts in numerous places in the lode but are most abundant near the shatter zone.

The lode is crossed by many fissures, the most prominent of which strike west of north and dip steeply east. Many of these fissures contain copper as native metal, as arsenides, or as sulphides. The Mass fissure has been by far the most extensively developed, but copper is present at the crossing of the lode in many of the fissures.
The fissures vary considerably in the character of their mineralization. In the Mass fissure calcite is the most abundant gangue mineral, though quartz and epidote are locally abundant. In the Mohawkite fissure quartz is relatively plentiful. In the arsenide fissures in the north end of the Mohawk mine ankerite (iron-calcium-magnesium carbonate) is a very abundant constituent, and specularite was noted in small amount at one point. Even where the ankerite is the predominant gangue mineral in the arsenide fissures, the mineral most intimately associated with the arsenide is quartz.

In the Mass fissure there is a decided concentration of the copper at the crossing of the Kearsarge lode and for a few hundred feet above the crossing, beyond which it falls off rapidly, though copper is present as much as 1,100 feet from the lode. Few of the other fissures have been followed far enough away from the lode to show the relations clearly, but so far as the evidence goes it indicates a strong tendency for copper to be precipitated in and near the Kearsarge lode. This is shown in many of the small fissures, which contain masses of copper in the lode but little or no copper even a few feet away. A drift has been extended into the hanging wall on a fissure (Mohawk No. 4 shaft, 22d level south, near No. 5) for several hundred feet. For a short distance in the hanging wall there was considerable mass copper, but it seemed to decrease with distance from the Kearsarge lode, though the drift has not been extended far enough to demonstrate this conclusively.

The arsenide fissures, such as the Mohawkite, have been prospected but a few feet from the lode in the Ahmeek mine, and the influence of the lode on the precipitation of the arsenides is not known. The arsenide fissure near the north end of the Mohawk mine has been followed by drifts in the upper levels. The mineral seemed to occur at the crossing and for a short distance in the hanging wall, as on the Mass fissure. A number of the less prominent fissures, such as the Fulton and some unnamed fissures in the Ahmeek and Allouez mines, contain arsenical copper, and these seem to correspond in habit to those that carry copper, so that there appears to be a very close relation between the copper fissures and the arsenide fissures. A relation between copper in the fissures and in the lode is indicated by the presence of some arsenical copper in the lodes near the arsenide fissures. The fissures that contain arsenide are either strong themselves or are closely associated with strong fissures.

Texture.-The textural features within the lode that have been effective in diverting and converging the mineralizing solutions are the areas of relatively impermeable amygdaloid. The rock in these areas is by no means absolutely impermeable, but its permeability is sufficiently low to cause some of the solu- 
tion that would naturally pass through it to move by easier channels through the areas of thicker and more fermeable rock.

A long bar of thin or cellular lode extends from the Ahmeek to the South Kearsarge in the upper levels of the mines. In the lower levels of the Allowez there is another bar of thin lode that reaches the bottom of the mine and has not been completely outlined, but there is a suggestion that at deeper levels it may extend pretty nearly across the Allouez and into the North Kearsarge. Between these bars of thin lode is an area of fair to thick lode in the North Kearsarge that is partly pocketed by the thin lode. At the south end of the barrier is the thick lode of the South Kearsarge, which reaches the present surface.

It seems possible that these two bars of thin lode have together tended to divert the solutions that were rising along the anticline southward through the thick lode of the Wolverine and South Kearsarge and that such a convergence of the solutions has resulted in the Wolverine-South Kearsarge shoot. Much of the lode that lies between these two bars in the North Kearsarge mine is of good thickness and looks favorable, and copper is well distributed through it, but the masses are small, and little of the lode rock is above average tenor and a considerabie part is below average. It seems possible that owing to the barrier above, which prevented free passage out, and to some extent to the barrier below, which diverted the solutions southward, there was not a normal flow of mineralizing solutions through this part of the lode and therefore, though favorable in character, it was not heavily mineralized.

The Wolverine-South Kearsarge area is favorable because it contains the thickest part of the lode, and probably also because the bars of thin lode have diverted solutions through it that would otherwise have passe 1 toward the outcrop through ground farther north.

A somewhat similar condition is present in Gratiot No. 2 shaft. The upper levels of that shaft are in a moderately thick, favorable lode but show little copper. From the tenth to the fifteenth level near the Mohawk boundary the lode is of good character and from fair to rich in copper. Between these areas of favorable rock is a bar of thin lode showing in the shaft from the eighth to the twelfth level. This bar has apparently diverted the solutions that mineralized the favorable rock below it; and the favorable rock above the bar, so far as developed, is poor in copper.

\section{INFLUENCE OF FISSURES ON THE LODE}

The influence of fissures on adjacent parts of the lode is striking and very generally recognized by the operators. Except in a very few places the lode in the immediate vicinity of strong fissures is decidedly lower in copper than the average at greater distance.
Strong fissure zones are most abundant in the Ahmeek and Mohawk mines. In both the change in appearance of the rock near the fissures is well recognized. In the Mohawk two general types of lode rock are recognized - "gray lode" and "brown lode." The "gray lode" is most extensive in the north end of the mine and the "brown lode" in the south end, though "gray lode" is present near the fissures in the south end. In the Ahmeek mine dark or chloritic lode rock is present along the Mohawkite, Mass, and Fulton fissures. The change in the lode along these fissures is due to a chloritization and to some extent a sericitization of the lode rock. Alteration of the same type has resulted in the "gray lode" near the fissures in the Mohawk mine.

It seems to be a general rule that the portions of the lode adjacent to the strong fissures in the Ahmeek and Mohawk mines are relatively poor. What seems to be an exception was seen south of Mohawk No. 4 shaft, on the twenty-second level near No. 5 shaft, where a "mass" fissure cuts exceptionally thick and highly oxidized lode. Here the lode is said to be well mineralized and carried considerable mass copper. Apparently mass copper was not encountered in notable quantity on this fissure in the higher levels.

The shatter zone seems to be similar to the fissures, except that in this zone there has been more movement of the rock and thick gouge has resulted. The rocks of the shatter zone seem to have been altered like those near the fissures, but in addition there is strong laumontitization. The gouge, however, is decidedly red, and the rock near the gouge is commonly red also, giving to the shatter zone a distinctly red tone. This zone is everywhere poor in copper.

In the Ahmeek and Mohawk mines the copper in the lode near the arsenide fissures is arsenical. In the Mohawk arsenical copper was found in the "gray lode" 35 feet from an arsenide vein.

\section{CONDITIONS FAVORABLE TO MINERALIZATION IN THE KNOWN PRODUCTIVE PORTION OF THE KEARSARGE LODE}

Several conditions that are regarded as having been favorable to mineralization are present in the productive part of the lode that are not known to be present outside of the productive area, and there are others that should be considered possibly favorable.

The lode is of the fragmental type throughout the productive area. Outside of the productive area, so far as indicated by data now available, there are no large bodies of thick fragmental lode.

The lode has suffered an unusually high degree of oxidation throughout the productive area.

The productive area is on the Allouez anticline, which may have been a factor in the convergence of the mineralizing solutions.

The north end of the productive area is crossed by a series of strong fissures. This is not regarded as among the favorable conditions, but it may be so. 
In the same cross section as the central portion of the productive part of the lode but at a lower stratigraphic horizon is a body of intrusive felsite. This is another factor which is not regarded as essential but which may be favorable.

\section{EFFECT OF DEPTH ON THE COPPER CONTENT OF THE LODE}

The study of the Kearsarge lode has shown no evidence of leaching of copper near the surface and reprecipitation at greater depth. Where the lode is poor at the surface, as in parts of the Wolverine and North Kearsarge mines, the rock is impervious and unfavorable, and there is no indication that it was ever well mineralized. Where similar rock is encountered in the deeper workings, as in the lower part of the Allowez and in part of the North Ahmeek, the low copper content is encountered.

Where favorable lode rock reaches the outcrop, as in the south end of the Mohawk mine, it is well mineralized, and the same is true of favorable rock at greater depth.

If the mineralizing solutions in the main were traveling up the lode, the lode in general must continue permeable down to the connection with the source of the solutions, otherwise they would not have found their way to the level now developed. That mining will disclose areas of unfavorable rock and variation in the copper content at greater depth is to be expected from the known conditions in the developed areas. The encountering of an area of unfavorable rock should not be regarded as discouraging for the lode as a whole, though it may be so for an individual property. Poor ground, due both to character of rock and to the influence of fissures, is likely to be found here and there at greater depth as it has been to the present depth.

It is not intended to imply that a general decrease in the copper content of the Kearsarge lode will not be found at depth, but there is no reason to think that it will be other than a gradual falling off for the lode as a whole. So far as known, the causes that resulted in a decrease in the grade of the rock on the Calumet \& Hecla conglomerate lode-namely, an increase in the thickness and extent of the lode with increased depth - will probably not affect the Kearsarge lode. The conditions are more likely to approach those of the Quincy lode, where a depth nearly as great as on the Calumet \& Hecla conglomerate has been attained with no notable decrease in copper content.

\section{MAYFLOWER-OLD COLONY MINE}

The Mayflower-Old Colony Co. was formed by a consolidation of the two properties indicated in the name. The property covers the portion of the copperbearing series extending from a horizon a short distance below the Wolverine sandstone to the Keweenaw fault. It lies east of the Calumet \& Hecla (Centennial and South Kearsarge) and Mohawk (Wolverine) ground.

\section{STRUCTURE}

The rocks conform to the general strike and dip of the beds in this part of the range down to about the horizon of the "St. Louis" conglomerate, where the normal structure is interrupted by the Mayflower fault. This fault is apparently a branch of the Keweenaw fault, which it seems to join a short distance south of the Old Colony tunnel. The Keweenaw and Mayflower faults diverge from a point south of the Old Colony tunnel (see pl. 8) to a maximum known separation of about half a mile in the north end of the Mayflower-Old Colony property.

At the Old Colony tunnel the Mayflower fault is about 700 feet east of and several hundred feet stratigraphically below the "St. Louis" conglomerate. To the north the fault approaches the "St. Louis" conglomerate, and in the north end of the property near the surface it cuts out that conglomerate and some of the overlying "Big" trap. The dip of the fault is slightly steeper than that of the beds, and at depth the "St. Louis" conglomerate is present in the north end of the property, as indicated by diamond drilling. The continuation of this fault north of the area drilled can only be inferred. The "St. Louis" conglomerate crops out about half a mile north of the northern drill holes, and it is pretty certain that the fault lies east of the conglomerate and very probably connects with the area of felsite in that region (see pl. 8), with which, indeed, it may be associated in origin.

In the block between the Keweenaw and Mayflower faults the rocks are broken and displaced by minor faults of diverse attitude, but in general the beds are horizontal or have a gentle eastward dip - the reverse of that normal for the formation west of the faults. The block contains many beds of melaphyre and glomeroporphyrite, with some rather thick ophitic beds and two persistent beds of conglomerate. It is not positively known where these rocks belong in the general series, but there can be little doubt that they are higher in the series than the rocks adjacent on the opposite side of the Mayflower fault. Similar traps are present in the series above the "Big" trap, but in the nearest sections observed there are no conglomerates above the "Big" trap that correspond with those below the fault. There áre, however, sedimentary beds in the series both to the south and north that might have developed into conglomerates. Rocks similar to the series of melaphyres and glomeroporphyrites immediately above the "Big" trap do not again appear till the Greenstone flow has been passed, and it seems more probable that the rocks in the fault block correspond to the series above the "Big" trap than to the series above the Greenstone flow. 


\section{DEVELOPMENTS}

The earlier development of the Old Colony or southern portion of the property consisted of several shafts and a tunnel. The Old Colony tunnel starts near the Keweenaw fault and was driven across the series a distance of about 2,500 feet, or to the fourth flow above the "Big" trap. The No. 1 and No. 2 shafts were on amygdaloids about midway between the Kearsarge amygdaloid and the "Big" trap. No. 2 was on a bed a little higher in the series than No. 1.

No very clear record is available of the results of these earlier operations, though so far as known no copper was produced. On the dumps of No. 1 and No. 2 shafts there is some fragmental lode rock with a little copper. The pump shaft is on an amygdaloid a few hundred feet lower than No. 1 shaft. The North shaft, in the northern part of the Old Colony property, was in the area between the Keweenaw and Mayflower faults. The Haddy shaft opened two amygdaloids a little higher in the series than the No. 2 OId Colony shaft. The several operations apparently failed to open a lode that gave much encouragement.

About 1910 an extensive drilling campaign was undertaken by both the Mayflower and Old Colony companies to prospect the lower portion of the copperbearing series on their properties. After this tract had been more intensively drilled than any other area in the Copper Range, the two companies were merged, and the present No. 1 shaft was sunk to a depth of 1,760 feet to prospect the Mayflower lode. The shaft starts in the "Big" trap, but the prospecting has been in the rocks below the Mayflower fault, on the 1,450 and 1,700 foot levels. The Mayflower amygdaloid occurs above two well-defined conglomerates, which have been a great help in working out the structure of this much-faulted block of ground. At the end of 1924 a crosscut was being run N. $70^{\circ} \mathrm{W}$. from the seventeenth level, No. 1 shaft, to prospect above the "Big" trap at the horizon of the "St. Louis" amygdaloid.

\section{ISLE ROYALE LODE}

\section{HISTORY AND PRODUCTION}

Production from the Isle Royale lode (pl. 41) began in 1855. The present Isle Royale Copper Co. is a consolidation of several companies, including the old Isle Royale, Huron, Grand Portage, and Miners.

Production and dividends from Isle Royale and Arcadian lodes, 1855-1925

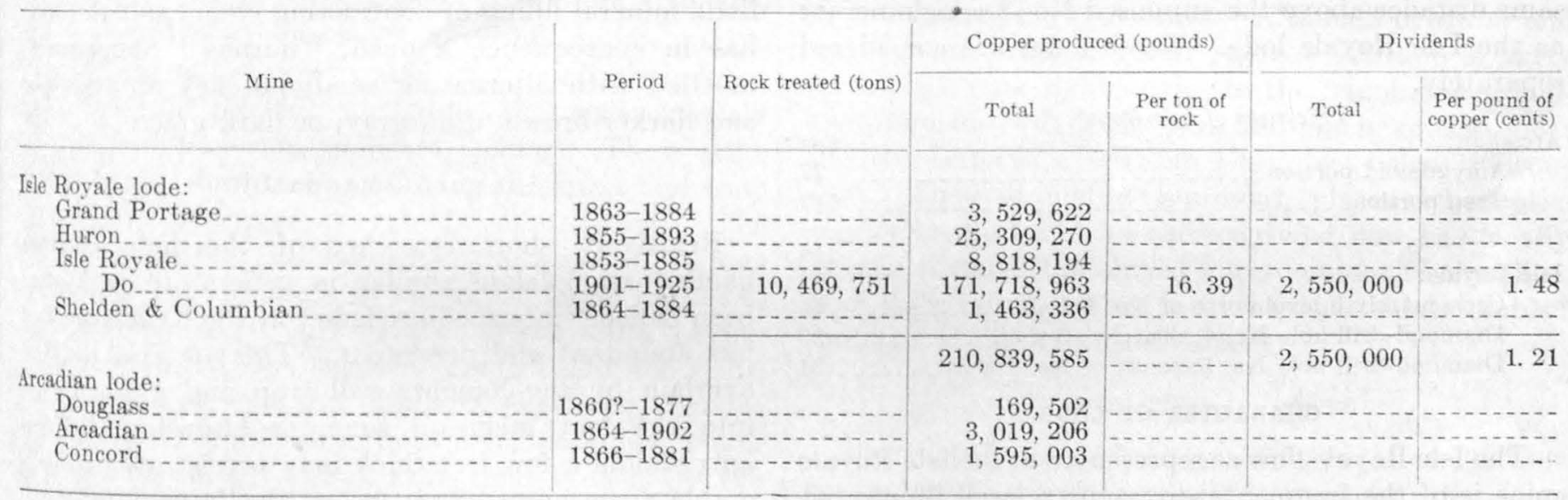

\section{EXTENT AND CORRELATION}

What is now generally regarded as the Isle Royale amygdaloid has been known under several names. In the Isle Royale mine, from a point south of No. 7 shaft to a point north of No. 1, it is known as the Isle Royale lode. From a point north of No. 1 shaft to Portage Lake is what was known as the Grand Portage lode. Until recent years the identity of the Isle Royale and the "Grand Portage" lodes was not established. In the Isle Royale mine the part north of the fault Was known as the West lode, but it is now evident that the two are faulted portions of the same bed, the Grand Portage or northern section being displaced westward about 175 feet, as is clearly shown in the mine workings.
North of Portage Lake the Arcadian lode, from its position relative to No. 8 conglomerate which lies below it, has been regarded as equivalent to the Isle Royale lode. The character of the lode material as seen on the Arcadian dumps shows a close similarity to the Isle Royale lode; the Arcadian, like the Isle Royale, is highly and coarsely brecciated and carries numerous inclusions in the lower part; its oxidation is comparable to that of the Isle Royale; and both sericitization and pumpellyitization are factors in its alteration. It was long supposed that the beds on opposite sides of Portage Lake were offset by a fault concealed by the lake. Marvine ${ }^{10}$ assumed a horizontal throw of 720 feet, the north side being displaced

10 Marvine, A. R., Michigan Geol. Survey, vol, 1, pt. 2, D. 61, 1873, 
westward. Hubbard, ${ }^{11}$ however, has shown by the position and strike of No. 8 conglomerate at two points 15,000 feet apart on opposite sides of Portage Lake, that the horizontal displacement on this supposed fault could not exceed 275 feet. Furthermore, it is now known that the fault already mentioned as occurring north of the Isle Royale No. 1 shaft intervenes between the two positions used by Hubbard and accounts for 175 feet of the total, thus reducing to a maximum of 100 feet the displacement of a fault under Portage Lake. So small a displacement over so great a distance may be due simply to a slight bend in the strike of the formations.

Farther north the "St. Louis" lode is at about the same horizon, but neither this nor any other known lode north of the Arcadian bears close resemblance to the Isle Royale.

To the south a lode in the stratigraphic position of the Isle Royale has been opened in the Elm River (Contact) property near Twin Lakes, and also in the Winona mine, where it is known as the Winona lode and has a thick breccia top with pumpellyitic alteration like that of the Isle Royale. Identification still farther south is less certain; the Evergreen and succeeding lodes and the Forest ("Victoria") lode are at about the same distance above the supposed No. 8 conglomerate as the Isle Royale lode. These lodes are considered separately.

Areadian: Thickness of Isle Royale flow
Amygdaloid portion
Trap portion
Isle Royale:
Crosscut, sixth level north of No. 4 shaft_...
Diamond-drill hole No. 4, near No. 6 shaft
Diamond-drill hole No. 5, south of No. 7 shaft

\section{CHARACTER OF LODE}

The Isle Royale flow as represented at the Isle Royale mine is of the fragmental-top type so well illustrated elsewhere in the Baltic, Kearsarge, and Osceola lodes. The lode or top portion of the flow may in turn be separated into several phases or types that are easily recognized but that show gradation from one to another. These may be designated, from the top down, fragmental zone, banded amygdaloid, "vein trap," and foot-inclusion zone. The last forms the transition to the main trap portion of the flow. In addition, irregular small tongues or stringers from the overlying flow extend down in many places from a few inches to a few feet into the upper portion of the lode and are distinguishable only with some care from the lode proper.

\section{FRAGMENTAL ZONE}

The fragmental portion of the lode consists of irregular fragments of amygdaloid and fine-grained

"Hubbard, L. L., Michigan Geol. Survey, vol. 6, pt. 2, p. 108, 1898. trap ranging from small grains to tabular blocks ser. eral feet in greatest dimension. In form the frag. ments range from sharply angular through subangular to fairly well rounded. In general, the larger fragments are more angular than a large proportion of the smaller fragments. The top portion of the fragmental zone is composed of fragments of a little smaller average size than the bottom portion. In any given section of the lode, however, there is a mingling of fragments of varying size. In texture the fragments may be very finely amygdular, or more coarsely amygdular with distinct "chilled" or finergrained margins, or trappy and virtually uniform in character. The more traplike fragments are in general commoner near the base than near the top of the fragmental part of the lode.

As a rule the vesicles are filled with minerals, though they may be only partly filled, especially if epidote is the filling material. The spaces between the fragments likewise contain minerals. In general, the color of this mineral filling, whether in the interstices or as amygdules, contrasts plainly with the usual red color of the rock fragments themselves; but in many places near the overlying trap, especially where the lode is thin, the rock, although clearly brecciated, contains little mineral filling of contrasting color, and the lode has in consequence a dead, "burned" appearance, mottled with alternating small patches of brick-red and darker brown, dark gray, or dark green.

\section{BANDED AMYGDALOID}

Relatively short stretches of the lode contain banded amygdaloid similar in general to what has been called "intermediate lode" in the Kearsarge but less abundant and persistent. This material may be overlain br the hanging-wall trap and grade below into the foot inclusion zone, or elsewhere banded amygdaloid a few feet thick may persist over considerable areas immediately below the fragmental zone. In other places large slabs of banded or cellular amygdaloid lie in the midst of the fragmental material. Most commonly the fragmental zone gives place to the foot inclusion zone without a distinct intervening layer of cellular rock.

\section{FOOT INCLUSION ZONE}

Directly below the fragmental zone, or the banded amygdaloid, is a brownish-gray rock of rather fine trappy texture, known in the mine as "foot trap." It commonly contains somewhat indefinite patches or inclusions of amygdaloidal rock; the amygdules in these fragments consist usually of chlorite, though less commonly of calcite or some other light-colored mineral, with or without chloritic amygdules near the outer margins of the inclusion. Some inclusions are sharply angular, essentially like the amygdular fragments of 
the brecciated portion of the flow, but far more are rounded, in consequence of partial melting by the inclosing material, and in extreme cases of melting or resorption the position of the original inclusion is marked by an area containing amygdular cavities but possessing no recognizable boundaries. The inclusions range, in general, from an inch or less to 6 or 8 inches in diameter; a few reach 2 or 3 feet. They are most abundant and most conspicuous in the upper part of this zone and decrease in number and become more completely resorbed and smaller farther down. They cease to be abundant 10 to 12 feet below the upper limit of the zone. These amygdular inclusions are regarded as pieces from the fragmental zone sunk or dragged into the lower, still molten, and moving portion of the flow and partly remelted by it.

In contrast with the amygdules of these inclusions, the trappy rock of this zone contains amygdules of its own, but these are commonly sparsely distributed and noticeably large, as is usual in the lower portions of the lodes throughout the district:

\section{VEIN TRAP}

Slabs of trappy rock included in the fragmental zone are known as "vein trap." In general this material shows no notable differences from that of the foot inclusion zone, though in places it exhibits a slightly chilled border. Some slabs have an under margin marked by notably elongated or "pipe" amygdules, and, as a rule, the large amygdules that occur sparsely in the foot inclusion zone are lacking. These slabs range from 1 foot to 4 or 5 feet in thickness and from a few feet to several scores of feet in extent. The smaller slabs may lie parallel to the walls of the lode or be tilted at any angle to them; the larger masses of necessity are essentially parallel to the walls. Fragmental material lies both above and below the slabs. These slabs of vein trap probably represent parts of the flow that solidified without brecciation just under the fragmental layer but were then broken by the continued movement of the flow and had fragmental material dragged or formed underneath them.

\section{MAIN TRAP}

The foot inclusion zone passes gradually into a monotonous trap rock, practically devoid of amygdules and of amygdular inclusions, which constitutes the main lower part of the Isle Royale flow; this trap is greener and less brown than the trap of the foot inclusion zone.

\section{HANGING-WALL TRAP}

The trap immediately overlying the Isle Royale flow is a dark greenish-gray and distinctly crystalline rock that commonly may be distinguished readily from the more brownish and finer-grained trap of the flow itself. Pipe amygdules in the trap just above the Isle Royale lode are present in places, but they are by no means so common or so characteristic as in the corresponding position above the Kearsarge lode. The hanging-wall flow above the Isle Royale lode ranges in thickness from 195 to 225 feet. At Winona the flow above the Winona lode is 310 feet thick.

The trap has invaded the top portion of the fragmental zone as small tongues and irregular stringers that range from less than an inch to a few inches or even a foot or more in width. These tongues and stringers are distinctly reddish, and in this respect as well as in their finer grain they differ notably from he main mass from which they branch; they are thus more like the Isle Royale trap, from which, however, they may be distinguished by their denser texture, their amygdules, and their red rather than brownish color. These invading tongues are not everywhere readily distinguishable from the fragmental material that they penetrate, for the two are not unlike in texture and are closely similar in color. Ordinarily, however, the tongues are slightly redder near their margins, and at their very edges they may be marked by a faint lighter-colored line apparently due to incipient bleaching or else to the deposition of a colorless mineral. These invasions are rarely of such regularity as to be mistaken for dikes; they penetrate irregularly into and ramify through the fragmental material, parts of which they may surround. Although irregular and variable in direction, their average attitude is likely to approximate right angles to the hanging-wall contact, and they gradually fork and pinch, so that most of them terminate less than 4 or 5 feet below the contact. They probably represent places where the relatively fluid melt of the overlying flow has locally broken through the chilled lower contact of that flow and thus found access into the loose and jumbled material of the fragmental zone.

\section{DISTRIBUTION OF TYPES}

The distribution of the several phases of the lode seems most unsystematic. Throughout the mine areas of thick fragmental rock are interspersed with areas of thin, denser fragmental rock, of banded amygdaloid, or of vein trap. The foot inclusion zone is everywhere present, though its thickness and the number of its inclusions may vary.

The areas of thick fragmental rock are very irregularly distributed; at many places where the fragmental material was piled above the general level of the flow surface it now bulges into the overlying trap. Where these bulges are pronounced there may be an apparent local change in the dip of the lode, the dip seeming to flatten on the up-dip side of these bulges and to steepen on the down-dip side. A similar local modification of the footwall dip is effected by abrupt reentrants of the thick fragmental rock into the basal trap, the footwall dip being steeper on the up-dip side and flatter on the down-dip side of these reen- 
trants. On the other hand, where the fragmental material is notably thin, the hanging wall appears to bend in toward the footwall and the footwall to rise from its normal position. In these thin places the fragmental rock commonly loses something of its brecciated appearance, becoming more dense and massive, but it retains its red color, which chiefly serves to distinguish it from the rock of the footwall.

There is thus a tendency toward alternate divergence and convergence of hanging wall and footwall - that is, toward alternate thickening and thinning of the lode. But not every swing in one wall is accompanied by an opposite swing in the other wall. Moreover, the bulges into the hanging wall, which may measure as much as 10 or even 20 feet, are more extreme than the bulges into the footwall, which ordinarily do not exceed 5 to 8 feet. The bulges of fragmental material into the lower part of the lode may be more abrupt, so that locally the boundary between the fragmental zone and the foot inclusion zone may be almost at right angles to the plane of the lode. The bulges into the hanging wall are marked by slopes which appear to have been, when the flow was in its original horizontal attitude, of less than $40^{\circ}$ and which thus may have been limited to the angle of repose of loose fragments. Vein trap is naturally commonest where the fragmental layer is thick but is not present in all thick places.

The various kinds of lode rock are not only irregularly intermingled but occur in decidedly different proportions in different parts of the mine. In the workings of No. 4 and No. 5 shafts the fragmental zorie is relatively thick and the areas of thin lode and banded lode are comparatively small. In the No. 7 shaft region, down to the 7 th or bottom level, the lode is relatively thin, and areas of thick fragmental rock are small. The ground south of No. 6 shaft is intermediate in character between that of No. 5 and that of No. 7 .

In the old Huron workings, especially about No. 6 and No. 8 Huron shafts, the lode averages thinner than in the neighborhood of Isle Royale shafts Nos. 4 and 5, and the alternations between thick and thin lode are numerous and abrupt, especially in the upper levels. At certain of the thicker places, especially south of No. 8 old Huron shaft, the lode is double through the presence of a relatively large mass of "vein trap" between two layers of fragmental rock. Here both the upper and the lower fragmental layers were ore-bearing, but as a rule only the upper layer was thoroughly explored by the Huron management.

South of No. 2 shaft, in the upper levels, the lode is of good thickness and grade, but in depth, down to the Grand Portage fault and especially northward to the limits of the workings beyond No. 1 shaft, thin lode predominates, though with numerous local exceptions. The Grand Portage or faulted portion of the lode has essentially the same character as the main section south of the fault, but the average thickness of the fragmental zone seems to be a little greater than around No. 1 and No. 2 shafts, on the main section of the lode.

The distribution throughout the mine of areas of thick and thin fragmental material interspersed with cellular rock and of areas of trappy material overlain and underlain by fragmental rock, though suggesting complicated and varied modes of origin, is believed to result from comparatively simple conditions of movement and solidification while the flow was in progress, as is discussed in connection with character of tops on page 31 .

\section{STRUCTURE}

\section{ISLE ROYALE SYNCLINE}

Aside from the tilting of the entire series, the laroest structural feature revealed in the mine is the Isle Royale syncline. This is a gentle fold which accounts for the curvature of the lode. Its axis is at about No. 4 shaft. The fact that the best ground centers about the axis suggests that the presence of the fold had something to do with the localization of the copper. The dip of the lode at the north and south, as near No. 2 and No. 6 shafts, respectively, is steeper, about $56^{\circ}$, than near No. 4 and No. 5 shafts, where the dip is about $51^{\circ}$. If a similar difference in dip were maintained downward the fold would become less and less marked, and at a depth of about 10,000 feet down the lode from the outcrop it would disappear. Indeed, at the present deepest levels the curvature of the lode is notably less than at the surface, that is, the levels are straighter than those above. On the other hand, the beds higher in the series, exposed to the west as far as the Ashbed or Atlantic lode, retain the synclinal structure. As these higher beds where they reach the surface overlie (stratigraphically, or perpendicular to the bedding) deeper parts of the Isle Royale lode and therefore are likely to reflect the structure existing at depth on that lode, it would seem probable that the Isle Royale syncline persists downward for a long distance.

\section{FAULTS}

The only large fault recognized in the mine is the Grand Portage fault, encountered in the north end. It strikes N. $35^{\circ}-60^{\circ}$ E. and dips $60^{\circ}-80^{\circ} \mathrm{NW}$. The section north of the fault is the "West lode," known as the "Grand Portage lode" before its identity with the Isle Royale was established. Where each section of the lode meets the fault, it is bent or dragged around so as to point somewhat in the direction of the other section. This attitude confirms the conclusion as to the direction of displacement caused by the fault and strengthens the correlation of the two sections as parts of the same lode. The fault offsets the northern section of the lode about 175 feet toward the west, as measured on the level. This is the distance at right 
sngles to the lode, but the actual amount of displacement must have been greater, ranging from some 300 feet to very much more, depending on the direction of the movement. On the assumption that the fault is an overthrust the Grand Portage section moved relatively upward and slightly to the southwest. If that is assumed as the true direction of displacement, then any point in the lode south of the fault would find its equivalent in the Grand Portage block some four or five levels higher up. But in any case, except that special one in which the displacement had been entirely in a horizontal direction, equivalent portions of the lode on opposite sides of the fault would not be st the same level. This relation may explain differences in the lode on the two sides of the fault on any given level.

The character of the Grand Portage fault varies from place to place. In the upper levels north of No. 1 shaft it is a clean-cut break, carrying from a few inches up to 2 feet of gouge and brecciated rock, with pronounced dragging of the lode but only minor fracturing parallel to the fault. Toward the bottom of No. 1 shaft, however, and in the workings north of No. 2 the fault is less definite and simple; it tends to fray into a series of fractures of somewhat variable dip and strike but conforming on the whole to the general direction of the fault; these fractures are more likely to carry veins of either light or dark colored calcite than to contain a notable amount of gouge. Another fault of approximately the same strike and dip and with the same direction of displacement was observed from the eighth level of No. 4 shaft dose to the old Huron workings to the sixteenth level south of No. 4, or beyond. Its horizontal displacement is not over 30 feet as measured on the levels. In character it resembles the Grand Portage fault, being well defined and only a few inches to a foot in width in the upper levels but breaking into branches that form a fractured zone in the deeper workings. It carries quartz, calcite, pumpellyite, copper, and chalcocite.

In contrast with these two faults, which appear to belong to the same series, there are other faults and fractures that strike nearly parallel to the lode but generally a little more to the north. More than half of these dip against the lode; the others dip with it, all at angles steeper than the inclination of the lode. The small divergence in strike between these fractures and the lode might permit considerable displacement along them to escape recognition, but so far as can be seen there is only slight displacement along any of hese breaks and none whatever along many. They re rendered conspicuous chiefly by the vein minerals eposited in them, which consist mainly of laumontite, alcite, and quartz, in places with a little chalcocite copper.
All these faults for which the direction of displacement is evident appear to be reverse faults - that is, the hanging-wall side of the fault has been raised relative to the footwall side. This is the same type of faulting as that shown by the Keweenaw fault. Diamond drilling has disclosed, according to Lane, several other faults between the Isle Royale lode and the Keweenaw fault and parallel to the Keweenaw; these he has interpreted as probably reverse faults also. It thus seems reasonable to assume that the hanging-wall block of the Keweenaw fault, up to and beyond the Isle Royale lode, suffered distortion at the time of the main faulting and had relatively subordinate sympathetic faults and fractures developed in it.

The faults carry minerals of the general period of copper deposition and thus are believed to have been formed before the mineralization.

\section{FISSURES}

Fissures are abundant in the mine and vary greatly in their attitude. Some of the larger ones are discussed above in connection with faulting. Most of the fissures can be grouped into a few systems. Those of one system strike N. $50^{\circ}-65^{\circ} \mathrm{E}$., and most of them dip southeast at rather steep angles, although some of them dip northwest. This system is best developed in the south end of the mine and is more sparsely represented in the north end. Another system strikes N. $25^{\circ}-45^{\circ} \mathrm{W}$. and has steep dips. It is represented in both the north and the south ends of the mine. A third series strikes nearly parallel to the lode and dips in the same direction as the lode but perhaps on the average a little more steeply. This system apparently changes strike with the main curvature of the lode and so keeps essentially parallel with the lode throughout the mine. A slight amount of displacement of reverse-fault direction can be seen along some of these fissures.

These fissures are present in the main trap under the lode, and some of them pass through into the hanging-wall trap where this is exposed by the workings. As a rule only the stronger fractures persist from the trap of the footwall into the fragmental zone, and many of these are deflected upon entering the lode to a course approximately parallel or more nearly parallel with it. In general, then, fissures are most common in a zone a few feet thick that occupies the basal portion of the lode and constitutes the main copper zone. In places this concentration of fissures near the base of the lode gives to it a distinct appearance of sheeting approximately parallel to the walls, as is well shown in many of the old stopes, where in the blasting the rock has broken clean along these joints. On this account, and because of the position of the best copper along the base of the lode, in contrast with most of the other amygdaloids in which the 
best ground is near the hanging wall, it is desirable to ascertain the nature and cause of this fracturing and its effect on copper localization.

Copper mineralization is often found to have terminated downward at a fracture plane essentially parallel to the lode, known by the miners as the "foot slip" and regarded as the boundary between the lode and the underlying "foot trap." The readiness with which the blasting breaks to such a fracture plane would seem to indicate that sheeting nearly parallel to the lode is indeed a characteristic of the zone just at the bottom of the fragmental layer.

The assumption of this condition of sheeting along the foot of the lode must not be carried too far, however. For example, where the fissuring essentially parallel to the lode is best shown, two or three other systems of joints are likely to be well developed also, and the question arises whether, if there were occasion to carry the mining in a different direction, one of these other joint systems might not seem the prominent one to the miners and be as conspicuous after blasting as the "foot slip" is now. In the crosscuts from shafts to lode it can not be seen that fractures or joints parallel to the lode are notably more common or stronger than those in other planes, and when the lode is reached it is not commonly marked by a conspicuous concentration of fracture planes parallel to it. Where the lode pinches and the footwall rises perceptibly from its normal position the "foot slip" tends to swing with the footwall, but it is less conspicuous where the footwall is high and the lode is thin than it is where it lies farther down from the hanging wall under a thick fragmental zone. The change in direction of the slip is also less extreme than that of the bottom of the fragmental lode. The slip is therefore deeper in the foot inclusion zone where passing over the upward bulges of the footwall than where the lode is thick, for there it is either close to or actually within the fragmental part of the lode.

The relative importance of the fractures that are approximately parallel to the lode as contrasted with fractures of other directions is not very definitely known. Their effect, however, in guiding and in limiting the flow of mineralizing solutions to the horizon close to the footwall can not be overlooked. It is not unreasonable to suppose that fissuring along the base of the lode and especially in a plane about parallel to the lode may be noticeable in the Isle Royale mine because of proximity to the Keweenaw fault to which this fissuring may be related. Another possible cause of the fracturing parallel to the lode is slipping of the beds when the Isle Royale syncline was formed.

Altogether, the origin and the importance of the foot slip at the Isle Royale mine are not at all clearly understood.
Many of the fissures are mineralized; the details are given under the next heading.

\section{ROCK ALTERATION AND ORE DEPOSITION}

The effects of two distinct periods of alteration car be recognized in the lode one earlier than coppe deposition and independent of it, the other believed to be closely associated with the formation of the ore

FIRST PERIOD

Oxidation was the earliest alteration to affect the lode. This change probably took place before the lode was buried by the overlying flow. All of the fragmental part of the lode was decidedly oxidized and reddened, apparently about the same degree throughout its thickness. This porous material was apparently rather strongly affected by oxidation, even where overlain by a layer of "vein " trap. The cellular amygdaloid and the denser material that characterizes places where the lode is thin were also oxidized and reddened though to a less intense degree, and the oxidation and reddening extended with further decrease of intensity into the trap of the foot inclusion zone. In general, the fragmental portion of the lode has been more highly oxidized than the nonfragmental portion, but the fragments in the foot inclusion zone rarely show more oxidation than the surrounding trap.

The tongues of overlying trap that extend into the lode, as well as the bottom portion of the main hanging. wall flow for a few inches above the lode are red and oxidized, in distinct contrast to the main portion of the mass. This oxidation may have been accomplished at the time of or shortly after the outpouring of the hanging-wall trap by means of the oxygen included in the porous lode on which it was spread.

Although the oxidation of the main lode undoubtedly produced a notable change in color of the rock, through the development of hematite, the texture of the rock was unaffected, and feldspar, the chief constituent, was not altered.

\section{SECOND PERIOD}

The second period of alteration came long after the surrounding rocks had been formed, and probably after the lode had been tilted into approximately its present position. In contrast with the early alterstion, a main feature of which was the conversion of ferrous iron to ferric, the alteration of the second period was complex and more intense, causing in many places a profound change in both appearance and character of the rock. Fmbraced in this com posite alteration were the successive but somewhat overlapping developments of epidote, pumpellyite, quartz, sericite, calcite, metallic copper, and copper sulphides and arsenides, as well as several other minerals of less common or less abundant occurrence. 
This second period itself seems divisible into at least two and possibly three stages - an early stage intimately connected with the deposition of most of the metallic copper and producing epidote, pumpellyite, quartz, and calcite; a later stage subsequent to the deposition of most of the copper and characterized by the development of sericite with quartz, calcite, anhydrite, gypsum, and a little barite; and a final stage or else the concluding phase of the second, in which the minerals of the sericite stage occur along with copper sulphides and arsenides or arsenical copper, chiefly in veinlets through the lode.

The stage of copper deposition is marked by the production of a greenish or grayish rock, a result of the quartz-pumpellyite type of bleaching, in which pumpellyite is the most prominent mineral produced, with less abundant quartz, calcite, and epidote. A little prehnite, alkali feldspar, or laumontite may be present here and there. This greenish rock, dense and usually harder than the unbleached red breccia, is the characteristic associate of most of the metallic copper of the lode. It may occur in patches and streaks or may persist in long stretches of the lode, but it is generally confined to a layer embracing the lower part of the fragmental zone and the uppermost part of the foot inclusion zone; and it is from this layer that most of the copper is obtained in the mine. Little copper occurs in this layer that is not inclosed in the green, pumpellyitized rock, but there may be considerable masses of the green rock that contain little or no copper. As a rule, however, copper and the bleached rock are close companions.

This green copper-bearing layer coincides closely with the zone of fracturing along the footwall described above under "Fissures." Many of the fissures either carry copper or are marked by especially pronounced pumpellyitic alteration along them. It may be that the concentration of copper and the accompanying bleaching was localized near the base of the lode by reason of this belt of fracturing, which added to the normal permeability of the fragmental part of the lode.

In places in this pumpellyitic zone the minerals and the texture of the original rock are entirely destroyed. Such alteration with attendant copper deposition is scanty in the thin parts of the lode, where there is little breccia, and is strongest where well-marked littlealtered fragmental rock lies above the pumpellyite zone.

On the under side, where the mineralized zone is in contact with the trap of the foot inclusion zone, the bleached rock is likely to terminate abruptly and in places is bounded by a break or fracture that separates it sharply from the darker rock underneath. It is probable that this green rock is formed mainly by alteration of the breccia and to a less extent by alteration of nonfragmental amygdaloid or of trap.
At many places residual traces of the fragmental structure can be seen in the green rock, and it fades out gradually upward to typical red fragmental amygdaloid; in the main the alteration has obliterated the breccia structure, so that the part derived from breccia and that derived from the underlying trap are indistinguishable.

In places this pumpellyitic zone and the accompanying copper extend above their usual upper limit into the main fragmental portion of the lode, even to the hanging wall and rarely for a few inches into the overlying trap. In such places the alteration is less, the bleaching or removal of the red color and replacement by green not so marked, the destruction of the brecciated structure less thorough, and the amount of copper smaller than in the principal zone. These upward extensions of the copper-pumpellyite zone are generally in places where the lode is widest and the fragmental layer thickest-in short, probably places of greater than average permeability. In some of the old Huron workings, where a tendency toward double lode is to be seen, this bleaching is present in both hanging-wall and footwall portions, though it is not very intense in either.

Sericite is the most characteristic or distinctive mineral of the later stage of rock alteration. It is very abundant in some of the red fragmental parts of the lode, but its distribution is irregular, contrasting in this respect with the pervasive distribution of the pulverulent hematite that gives the red color to the breccia. In parts of the Isle Royale mine the breccia is well sericitized, as in the upper and intermediate levels of No. 6 shaft and in parts of No. 7 shaft and of the Grand Portage lode. In other parts of the mine, as in No. 2, No. 4 , and No. 5 shafts, the sericitization was much less intense. The mineral occurs chiefly as a cement to the fragments, formed in part by filling of interfragment spaces and in part by replacement of the smaller fragments that lay between the larger ones. In many places where sericite was deposited, rock solution went on more rapidly than mineral deposition, the result being to produce a vuggy texture in the brecciated material. This is shown particularly well in the lower levels of No. 2 shaft, where pumpellyite and later sericite have replaced the breccia; leaving vugs that are now lined with crystals of calcite and quartz. Where present abundantly the sericite may be identified by its softness and rather greasy feel, also by its light color, ranging from white to pinkish or pale green, which contrasts with the strong red color of the breccia fragments cemented by it. In smaller quantity also it has partly replaced the larger fragments, but generally this replacement was not so extensive as to destroy either the texture or the red color of the fragments.

By deposition chiefly in the spaces between the fragments, the sericite appears to have luted or 
plugged up the breccia and thus to have decreased the permeability of those portions of the lode in which it is plentiful. Because of its soft and somewhat plastic character, the sericite would probably be more effectual in this respect than quartz, calcite, or the other brittle minerals that were deposited in similar relation to the breccia fragments.

It was at first thought that the deposition of the sericite with its plugging effect had taken place in the highly brecciated portion of the lode because that was the most permeable, before the pumpellyite-quartzcopper mineralization. Subsequent study, especially with the microscope, shows that this conclusion was ill founded. Nearly or quite all the sericite is found to be younger than the pumpellyite and to have replaced it in part. It is thus necessary to conclude that the solutions from which pumpellyite and metallic copper (and accompanying minerals) were deposited entered the lode before the fragmental portion was sealed up by sericite, that they therefore chose the zone near the base not by necessity but by preference, and consequently that this zone, because a site of fracturing, was actually more permeable at the outset than the highly fragmental but less fissured material overlying it. At places where the fragmental stuff was especially permeable, however - and apparently this is where it was thickest--some copper and zoisite did find their way up into it toward the hanging wall. Later, when the sericite-forming solutions came along, they had to content themselves with the main mass of the breccia, which was then the most permeable material available; they were excluded from the fractured zone near the base, which had already been occupied by copper and pumpellyite; they attacked the margins of the pumpellyite zone but were unable to penetrate far into it; and they gained little access to those thick places in the fragmental lode where copper and pumpellyite had been formed.

In much of the best ground in the mine, especially near the No. 4 and No. 5 shafts, calcite, accompanied by more or less quartz and by smaller amounts of prehnite, strongly predominates over sericite as the cementing material of the fragmental zone. In certain areas, moreover, notably on the fourteenth level south and nineteenth level north of No. 5 shaft, on the twenty-sixth and twenty-seventh levels of No. 2 shaft, and on the fifteenth level at the south end of the Grand Portage section of the lode, anhydrite, with or without gypsum, occurs in a similar cementing relation to the breccia, locally forming patches several inches across. Scattered here and there through the lode also is a very little barite. The possible significance of these sulphate minerals is considered on page 136 in connection with the general hypothesis that the metallic copper was deposited as a result of the oxidation of copper sulphide solutions by hematite.

Copper sulphides and arsenical copper, accompanied by calcite, sericite, quartz, chlorite, and specular hematite, occur in numerous veinlets that cut the lode. Possibly contemporaneous with these are the copper arsenides that have been found on the twelf th level at the very north end of the Grand Portage section. These occur in fragmental material near but not actually in veinlets. The arsenide patches are bordered by rock that shows bleaching of the iron-remoral type and that under the microscope is found to contain sericite in addition to the usual quartz, epidote, calcite, and laumontite.

In general the sulphide veinlets are narrow, being rarely more than 3 inches in width and commonly much less. In some, as one on the fourteenth level north of No. 5 shaft, the chalcocite occurs in short lenticular masses from which specimens weighing \& pound or two may be collected. The gangue constitutes the chief filling or replacing material of the vein, so that it is frequently necessary to search carefully before finding the sulphide which the gangue minerals suggest is present. The wall rock of these veinlets is chloritized, sericitized, and calcitized. For a width of an inch or two the red wall rock may be bleached by the bodily removal of the iron and replacement by sericite and calcite; or the immediate walls may be dark green, owing to the removal of the ferric iron and the development of chlorite. In the vein proper calcite and quartz are the chief minerals, although ankerite, a carbonate of lime, magnesium, and ferrous iron, is also common. Where ankerite forms the gangue, both bornite and chalcopyrite may be very sparingly developed and specular hematite, magnetite, and metallic copper are also to be found. The central part of the vein may carry massive sulphide, which has replaced the carbonate.

As a rule the chalcocite is confined to the veins, but in the Grand Portage section as well as on the second and third levels north of No. 7 shaft it has been found sparingly developed within the sericitized lode.

The distribution of arsenides and arsenical copper has not been studied in detail. At one place arsenical copper, domeykite, and whitneyite are associated with chalcocite; the age relations are not clear, but there is a suggestion that the arsenides preceded the sulphide. Arsenical copper has been found in highly sericitized fragmental rock; there may be in this mine a relation between arsenic and sericite, such as is shown by the sericitic alteration along the Mohawkite fissure in the Ahmeek mine, but the Isle Royale sericite is by no means invariably associated with arsenide or arsenica copper.

\section{CHEMISTRY OF ORE DEPOSITION}

The chemical changes that accompanied the deposittion of copper in the Isle Royale lode appear to hare tended in the same general directions as in the other important amygdaloids. In the main, the red lode rock seems to have been favored for replacement by copper. The rock alteration attending the precipita. 
tion of copper has been relatively profound. There has been a notable decrease in total iron and a reduction of ferric to ferrous iron. As compared with the rock alteration accompanying the deposition of copper in the Kearsarge lode, there has been less removal of the iron, and more of what remains has been converted from the ferric to the ferrous condition; there has also been more deposition of quartz. The physical result is seen in the difference between the Isle Royale type and the Kearsarge type of bleaching.

Potash was a notable constituent of the solutions, as indicated by the abundant sericite and the smaller amount of orthoclase feldspar, the former more and the latter less plentiful than in the Kearsarge and Osceola lodes.

Sulphides are more abundant in this lode than in the Kearsarge and Osceola lodes and indicate that in the later stages of the ore-depositing period, when subordinate open fractures were followed by the solutions, sulphur compounds were the stable form for copper deposition. It is not clear why hematite was destroyed on a large scale at the time when most of the copper was deposited and was later precipitated in minor amounts along with chalcocite. Arsenic as arsenical copper and arsenides may, like the sulphides, be products of the later stages of the period of mineralization, but the evidence on this point is meager and inconclusive.

Throughout the second period of mineralization as described above, various rock elements were taken into solution as the rock was attacked. The deposition of copper that bodily replaced the rock would also naturally foree into solution such rock constituents as calcium, sodium, aluminum, and silica. It seems altogether probable that the gangue minerals formed by the mineralization, such as quartz, epidote, pumpellyite, sericite, calcite, and laumontite, represent in the main recombinations of these rock constituents in forms that were stable at the successive stages of the mineralizing period.

\section{ARCADIAN LODE}

The Arcadian lode (pl. 42) was first opened by the Arcadian and Concord companies, which produced a small amount of copper. The most extensive developments were made by the Arcadian Copper Co. within a period of a few years, beginning about 1898. The lode was opened for about 8,000 feet along the strike by five shafts. North and south of this developed area are shallow shafts. The principal shafts from north to south are No 4, opened to the sixth level; No. 3, to the seventh level; No. 2, to the eighth level; No. 1, to the fifth level; and shaft A, to the ninth level. The most extensive stoping was done from No. 2 shaft, near the center of the developed area, and from shaft $\mathrm{A}$, at the south end of the developed area. From 1899 to 1902 the Arcadian Copper Co. produced
2,950,000 pounds of copper. There is no available record of the grade of the ore, but it was not, sufficiently high to justify continued mining of the lode.

The Areadian lode is a few hundred feet above No. 8 conglomerate and is believed to be the northward extension of the Isle Royale ("Grand Portage") lode. It was said to average about 13 feet in thickness. The material on the dump indicates that the lode is well oxidized, and that, like the Isle Royale, it is strongly fragmental. The mineralization appears to be in general similar to that of the Isle Royale, though there is considerable feldspar in the Areadian lode and little of the sericite that is locally abundant in the Isle Royale lode.

\section{NEW ARCADIAN LODE}

The New Arcadian lode is a short distance above No. 8 conglomerate and below the Arcadian lode. It has been developed by the Arcadian Consolidated Copper Co. through the New Arcadian and New Baltic shafts. From the New Arcadian shaft the lode has been opened along the strike for a minimum distance of about 2,500 feet on the 600 -foot level, and the shaft goes down to the 1,850-foot level. From the New Baltic shaft it has been opened for about 1,500 feet along the strike and down to the 1,250-foot level; the most work has been done on the 950 -foot, 1,100foot, and 1,250-foot levels.

The New Arcadian lode is in general of the fragmental type, but stretches of fragmental rock alternate with stretches of cellular rock. The fragmental areas show encouraging mineralization, which is mainly of the quartz-pumpellyite-epidote type with some fairly coarse copper. Areas of cellular amygdaloid in this, as in other lodes, are characteristically poor.

No heavy faulting of the lode has been recognized, but there are some faults of small throw that offset the lode and have caused some difficulty in following it. To the present time (1925) there has been only a little test stoping and no production on a commercial scale. In 1915, according to the annual report of the company, 3,845 tons of rock yielded 79,209 pounds of copper, or an average of 20.62 pounds to the ton. In 1916, 1,391 tons of rock yielded 32,307 pounds, or 23.23 pounds to the ton. In $1917,4,900$ tons of rock yielded 53,278 pounds, or 10.87 pounds to the ton. The average for the three years was 16.3 pounds to the ton.

\section{WINONA LODE}

\section{PRODUCTION AND CHARACTER}

The main output from the Winona lode (pl. 42) has been derived from the Winona mine, which includes the King Philip mine. The lode was opened by old Indian pits and therefore discovered early. Operations by white men began about 1864, and a little copper was produced in succeeding years. In the earlier part of the productive period the recovery was not very high, 
because much of the copper is in rather fine particles. From 1902 to 1907 about $3,350,000$ pounds of copper was produced. The mine was then idle till 1911, when the company was reorganized as the Winona Copper Co., and it was then active till 1920, when operations were suspended except for a little development work. Its total recorded production, from 1902 to 1920 is $1,262,678$ tons of rock, yielding $17,684,234$ pounds of copper-an average of 14 pounds to the ton.

The Winona lode is about 400 feet above No. 8 conglomerate, at the general horizon of the Isle Royale lode.

On the Winona property the Winona lode is developed by six shafts-from north to south Nos. 1 to 4 Winona and Nos. 1 and 2 King Philip. Development has been carried for about 9,000 feet along the lode.

The northern part of the developed portion of the lode crops out just at the base of a prominent bluff. On this outcrop the Indians dug shallow pits, and it was eventually opened by the northern Winona shafts. The southern part of the developed portion of the lode, which is opened by the southern Winona shafts and the King Philip shafts, was covered by glacial drift.

The writers did not examine the mine. The following description is made up from the mine maps, from examination of the dump, and from descriptions by Messrs. T. S. Woods and R. R. Seeber.

The lode, which is of the fragmental type and fairly well oxidized, appears to be very irregular, changing from thick to thin within short distances. There is a persistent "slide" or gouge zone a few feet above the lode-Mr. Seeber says about 14 feet. In places the lode extends to this "slide."

The mineralization was of the same general type as that of the other lodes. Pumpellyite, quartz, epidote, and calcite are plentiful. Prehnite, laumontite, and probably other minerals are present. The copper is associated with quartz and pumpellyite.

As indicated by present developments, the ore lies in a flat southward-dipping shoot (see pl. 42) that crops out near Winona No. 2 shaft. The northern Winona shafts seem to pass through the shoot, but in the King Philip shafts it is several hundred feet below the surface. The ore-bearing ground is apparently made up of a series of small nearly parallel shoots, interspersed with poor streaks. Even the smaller shoots contain areas in which the lode is thick and relatively high in copper and areas in which the lode is thin and poor. Where the lode extends to the hanging-wall slip it is said to be thick and rich.

The Winona lode in many ways resembles the Isle Royale lode with which it is commonly correlated. So far as learned, however, it does not show the tendency for the ore to form near the footwall, which is so persistent and unusual a feature of the Isle Royale lode.
WYANDOT MINE

The Winona lode was opened at the Wyandot mine by a shaft to the 1,000-foot level, from which short drifts were run. The lode was reported as carrying some copper, but operations in this mine were soon discontinued.

\section{ELM RIVER MINE}

The Elm River Copper Co. opened a lode at the general horizon of the Winona by a shaft to the 500 foot level, where drifts were extended for about 1,000 feet. The lode was also opened on the first level for a few hundred feet. The results were apparently not very encouraging. At No. 6 shaft the lode was entered by a crosscut at a depth of about 250 feet and was followed for about 700 feet.

\section{CHEROKEE MINE}

The Cherokee Copper Co. opened a lode that is farther from No. 8 conglomerate and possibly stratigraphically higher than the Winona lode. A shaft was sunk to the fourth level and short drifts carried on each level. It was reported that some stretches of commercial ground were opened. There is a fault south of the shaft (see pl. 12) that displaces the rocks on the south about 500 feet to the east.

\section{WYANDOT NO. 8 LODE}

The Wyandot Copper Co. opened a lode in a crosscut from the 700 -foot level, No. 11 shaft, about 1,100 feet horizontally (950 feet stratigraphically) below the hanging wall of No. 8 conglomerate. The lode was opened on this level and by a winze to the 800,900 , and 1,000 foot levels, on each of which drifts were carried. The lode is fragmental in character, and the results were reported as somewhat encouraging. I test shipment of 1,605 tons of rock made in 1917 yielded 12.54 pounds of copper to the ton.

\section{EVERGREEN AND SUCCEEDING LODES}

All the mines on the Evergreen and succeeding lodes were idle at the time the region was examined, and only very meager observations underground were made at the Mass and Adventure mines.

\section{OCCURRENCE}

From the Lake mine at the north to the Victoria mine at the south there have been rather extensive developments on a series of lodes whose base is about 400 to 500 feet above No. 8 conglomerate and which extends through a thickness of about 500 feet of flows. This series is at the general horizon of the Winona and Isle Royale beds, to the north, and of the Forest ("Victoria") lode, to the south. The correlation of individual flows from one development to another is probably somewhat uncertain, but in each of the openings in the Lake, South Lake, Adventure, Mass, and Michigan mines there are several lodes that carry 
sufficient copper to have encouraged extensive development, and a substantial amount of copper has been produced from the series as a whole.

From higher to lower horizons the lodes are the Knowlton, Merchant, Mass, North Butler, Butler, South Butler, Ogima, and Evergreen, with other amygdaloids present in places. (See pls. 43-46.) The position of these lodes is shown in Plate 13. The lodes that have been most developed and most productive are the Butler, Evergreen, and Knowlton. The Butler lode has yielded the largest amount, but the Evergreen and Knowlton lodes have made a considerable output.

\section{PRODUCTION}

The records of production from the several lodes of the series have not usually been kept separate by the mining companies, but the total for the series is essentially the production of the companies mentioned below, with the exception of the production from the Minesota fissure and the Calico lode by mines that have become a part of the present Mohawk Mining Co. (Michigan mine) and from the Lake lode by the Lake Mining Co., which is not here included with the group.

Production from Evergreen and succeeding lodes to end of 1925

\begin{tabular}{|c|c|c|c|c|}
\hline \multirow{2}{*}{ Mine } & \multirow{2}{*}{ Period } & \multirow{2}{*}{$\begin{array}{c}\text { Rock } \\
\text { treated } \\
\text { (tons) }\end{array}$} & \multicolumn{2}{|c|}{ Copper produced (pounds) } \\
\hline & & & Total & Per ton \\
\hline $\begin{array}{l}\text { Lake- } \\
\text { South Lake. } \\
\text { Adventure... } \\
\text { Mass } \\
\text { Michigan.... }\end{array}$ & $\begin{array}{l}1909-1923 \\
1915-1923 \\
1851-1923 \\
1916-1920\end{array}$ & 80,075 & $\begin{array}{r}a \text { Small. } \\
1,042,211 \\
10,783,889 \\
50,616,877 \\
{ }^{b} 4,065,175\end{array}$ & $\begin{array}{r}13.02 \\
\end{array}$ \\
\hline & & & $66,508,152$ & -........ \\
\hline
\end{tabular}

- Does not include production from the Lake lode.

Bstimated; does not include production from the Minesota fissure and Calico lode.

\section{CHARACTER OF FLOWS}

The flows of the Evergreen and succeeding lodes are intermediate in composition, falling toward the andesite end of the basaltic series. Texturally they are chiefly melaphyres and glomeroporphyrites, but ophitic texture occurs in some of the thicker flows.

\section{STRUCTURE}

Next to the general tilting of the beds and the Keweenaw fault the largest structural feature affecting this series of beds is the pronounced anticline with its crest at Mass. This fold extends southward nearly to Flintsteel River and northward to the Lake mine. Like the Baltic anticline, it does not show a gradual change in strike around the fold but a very sharp change at Mass City of about $35^{\circ}$.

The Lake mine syncline extends into this region, and this series of beds are involved in that fold, but the correlation of the individual beds in the Lake $58540-29-15$ mine basin with the normally dipping bedis to the north is somewhat uncertain, and the lodes have therefore been considered separately. There are many fissures and faults with small throw on the Mass anticline, as is usual where the rocks have been folded to that extent. The opportunity for observing these fissures has been too meager to warrant any generalizations regarding them. It may be noted, however, that many of them are probably tension fissures resulting from the folding, though some are essentially strike fissures that dip in an opposite direction to the lode. All the fissures noted are mineralized and were evidently formed before the period of mineralization, though there has been movement on some of them since mineralization.

\section{CHARACTER OF AMYGDALOIDS}

Wherever seen the amygdaloids of this series of flows are fragmental to some degree. Very commonly the fragmental material is rather coarse and trappy. Like all other fragmental amygdaloids these differ greatly in different places, but characteristically areas in which the lode is moderately thick and fragmental alternate with areas in which it is thin and cellular or trappy and fragmental. The relative extent of these areas varies from place to place.

Some of the lodes, especially parts of the Evergreen lode opened in the Mass mine, show locally a distinct tendency to pass into amygdaloid of the coalescing type, though this tendency was not seen to persist over very large areas.

\section{MINERALIZATION}

The result of mineralization in all the lodes of the series is similar. The abundant minerals are quartz, feldspar, pumpellyite, chlorite, calcite, and epidote. Red feldspar is usually abundant in all the lodes. The less abundant minerals are prehnite, datolite, and laumontite. Zeolites other than laumontite were not noted though possibly present. Anhydrite was found on the dump at the Mass mine, but this mineral seems to be relatively rare in these as in other lodes.

Copper in small and large masses is irregularly distributed through the lode. In the Evergreen lode, in the Mass mine at least, much of the copper is present in masses - in fact a rather large percentage of the copper in all the lodes is coarse.

\section{ROCK ALTERATION}

The quartz-pumpellyite rock is the characteristic product of rock alteration associated with the copper, though there has been much replacement of rock by red feldspar and less by chlorite and epidote.

\section{RELATION OF MINERALIZATION TO CHARACTER OF LODE}

A close relation between character of lode and mineralization is evident wherever the lodes have been examined. Rich ground is wholly confined to frag- 
mental parts of the lode, and the areas of good ground usually coincide with areas in which the lode is also relatively thick. The thin, cellular, and trappy parts of the lode are consistently poor. There is apparently some tendency for the favorable rock to form belts or "shoots," but observation in the mines has been too scanty to make this certain.

\section{BUTLER LODE}

\section{MASS MINE}

The Butler lode (pl. 45) has been the most productive of the lodes of this series and has been most extensively developed in the Mass mine, where it has been opened for about 5,000 feet along the strike and rather extensively to the thirteenth level. Large areas have been stoped in the ground adjacent to shaft C. Near shaft $\mathrm{B}$ and, more especially, near shaft A the stoping has not been as continuous, and presumably the ground is less regularly mineralized.

Lithologic character.-Where examined, as it has been over small areas only, the lode is generally fragmental but largely of rather coarse trappy character. As in most other fragmental lodes, areas of definitely fragmental rock are interspersed with areas of thin trappy or cellular rock. Mr. E. W. Walker, the superintendent, states that in places the lode was unusually wide and was mineralized near the footwall and hanging wall but barren in the middle. In such places two stopes were carried.

Structure.-The main structural feature of the lode in this mine is a series of mineralized fissures. Locally these may show slight displacement, but they rarely offset the lode as much as its width. A "crossing" near shaft $A$ is said to displace the lode along a brecciated zone. No mapping of the fissures has been carried over the area, but there is one series striking northeast and one northwest. There are also fissures striking approximately with the lode, some of which dip with the lode and others across the lode at a high angle. All the fissures contain essentially the same minerals as the lode and were evidently formed before the mineralization, though there has been movement on some of them since mineralization. According to Mr. Walker, no close relation between fissuring and mineralization of the lode has been recognized, though the fissures have evidently rendered the lode more permeable.

Mineralization.-The most abundant minerals of the lode are quartz, calcite, pumpellyite, epidote, and feldspar. Datolite is not uncommon but apparently not abundant. The pumpellyite type of bleaching was the characteristic alteration associated with the deposition of copper. The fine copper of the stamp rock is said to be more evenly distributed in this lode than in the Evergreen lode. That there is considerable coarse copper, however, is indicated by the fact that mass copper constituted about 26 per cent of the total mine production. In the present stage of develop. ment, no definite trend of ore shoots has been recog. nized on a large scale. Minor shoots of good and poor ground are recognized.

Yield.-D During the late years of mining by the Mass Consolidated Mining Co. the yield was about half o ton of stamp rock per square foot of lode. As about 50 per cent of the rock was discarded underground, about a ton of rock per square foot of lode was broken, or an average thickness of around 12 feet. The rock milled yielded 15 to 17 pounds of copper to the ton.

ADVENTURE MINE

In the Adventure mine the Butler lode has been opened for about 2,500 feet along the strike and down to the eighth level, but only relatively small areas have been stoped. Where seen in the upper levels fragmental rock seems to form a relatively small pro. portion of the lode, and the areas between the frag. mental portions are "tight" and poor. The mineral. ization was similar to that in the Mass mine. No records of the grade of rock or production are available.

SOUTH LAKE MINE

The Butler lode has been opened to a small extent in the South Lake mine from the surface to the 600 . foot level. It is stated in the company reports that the openings made on the lode before operations were suspended were encouraging and that it gave the most promise of all the lodes in the mine. Rock milled in 1918 amounted to 7,694 tons and averaged 28 pounds of copper to the ton. It is not stated to what extent this rock was selected.

\section{LAKE MINE}

Development work on the Butler lode was done in the Lake mine from 1917 to 1919 through a crosscut on the 600 -foot level of the Knowlton shaft. The lode was opened for about 1,400 feet along the strike and was reported to contain stretches of fair copper ground. The lode had been earlier opened by the No. 1 and No. 2 Butler shafts from the surface to the third level and for about 1,000 feet along the strike. Some stoping was done on the first and second levels, but no record of the results is available.

\section{NORTH LAKE MINE}

The North Lake Co.'s report for 1918 states that the Butler lode was cut in the 800 -foot crosscut and followed by a drift for 30 feet. It was said to contain an encouraging amount of copper.

\section{EVERGREEN LODE}

MASS MINE

In the Mass mine the Evergreen lode (pl. 46) has been opened for about 3,500 feet along the strike. I has been rather extensively opened down to the eleventh level from shaft $B$ and to a lesser depth an 
lateral extent from shaft A. There was no good opportunity to examine this lode in its best-mineralized portions. It is evidently fragmental, though not so highly fragmental as the Butler lode, and in places is coalescing. The fragmental part of the lode is of the rather coarse trappy type. Its mineralization was similar to that of the other lodes of the series. Quartz, calcite, pumpellyite, epidote, and feldspar are the common minerals. Like the adjoining lodes, this lode is cut in the Mass mine by numerous fissures. All are mineralized, and some contain considerable copper. The copper is coarser than in the Butler lode, yielding a larger proportion of mass - in fact, stamp rock is relatively unimportant. The copper is said by Mr. Walker to show a slight tendency to occur in shoots with a southwesterly pitch.

The production from this lode, in recent years at least, has been much less than that from the Butler lode.

\section{ADVENTURE MINF}

In the Adventure mine the Evergreen lode has been opened for a few hundred feet on the adit level and to a slight extent on the sixth level. Little stoping has been done in this mine. The lode where seen in the adit level is fragmental but relatively thin. It contained copper rather persistently for a foot or so near the hanging wall.

\section{SOUTH LAKE MINE}

The Evergreen lode was eut in the South Lake workings, but no record of its character as there shown has been found.

\section{LAKE MINE}

In the Lake mine the Evergreen lode was cut on the 600 -foot level from the Knowlton shaft and opened for about 700 feet along the strike. The report of the company for 1919 states that the lode as opened is very encouraging and is considered the best of the series as opened in the Lake mine. A stope over 200 feet long was started. Small test shipments, roughly picked at the surface, yielded from 18 to 34 pounds to the ton.

\section{NORTH LAKE MINE}

The Evergreen horizon was reached in the North Lake workings, but no description of the character of the lode is available.

\section{KNOWLTON LODE}

The Knowlton lode (pl. 43) has been most extensively opened in the Mass, Adventure, and Lake mines. It was seen in only a few places in the Mass mine, where it is of the fragmental type. As judged from the material on the dumps, it is fragmental in the other places where it has been opened.
MASS MINE

In the Mass mine the Knowlton lode has been most extensively opened from shaft C. On the third level a drift has been carried on the lode for about 2,000 feet. The lode has been largely stoped for 200 to 300 feet each side of shaft $\mathrm{C}$ to the eighth level. In shaft B the lode has been opened on the fourth, seventh, tenth, and eleventh levels, but little ground has been stoped. From shaft $\mathrm{A}$ it has been opened on the tenth level only. Near shaft C, according to Mr. Walker, it was of good grade.

\section{ADVENTURE MINE}

The main operations of the Adventure mine were on the Knowlton lode. In Nos. 1, 2, and 3 shafts the lode was opened for about 2,000 feet along the strike, and in No. 3 shaft it was opened to the thirteenth level. Only a relatively small proportion of the ground opened was stoped. The largest areas stoped were near No. 2 shaft to the tenth level and midway between Nos. 3 and 4 shafts on levels 7 to 10 .

No. 4 shaft was supposed to be located on the Knowlton lode, but later a lode was found about 60 feet from the hanging wall of the one on which the shaft was sunk, and it was thought that this might be the Knowlton. The lode as opened in the Adventure mine has averaged rather low in copper. Prior to 1906 , according to the company's report of 1907 , all rock stamped averaged 12.29 pounds to the ton; in the first half of 1907 it fell to 8.7 pounds, but it improved during the second half of that year, when the mine was closed. The mine was operated for a short time in $1916-17$ but was soon closed again.

\section{LAKE MINE}

The Knowlton lode has been opened at the Lake mine for about 1,200 feet along the strike and as deep as the sixth level in the main Knowlton shaft. Stoping has been done near this shaft from the first to the sixth levels. Some areas of fair ground were said to have been opened.

\section{MICHIGAN MINE}

A lode that is locally known as the Butler lode but appears to be higher, possibly at the Knowlton horizon, has been opened by shaft $\mathrm{E}$ of the Michigan mine to the eighth level and for a maximum distance along the strike of about 1,400 feet. The most extensive stoping has been done in what appears to be a westward-pitching shoot that crosses the shaft below the fifth level. (See pl. 43.) As indicated by material on the dump the lode is fragmental, and the character of mineralization is similar to that at other places where the lode has been opened. 


\section{OGIMA LODE}

The Ogima lode (pl. 44) has been opened to a slight extent in shafts $\mathrm{C}$ and $\mathrm{B}$ of the Mass mine and in the Adventure mine. It contains patches of fragmental rock, and some of these are fairly well mineralized. The openings on the whole have apparently not been encouraging.

\section{OTHER LODES}

There has been slight development of the Merchant and North Butler lodes in the Mass and Adventure mines and of a lode in the foot of the Evergreen at the Lake mine. These lodes are somewhat fragmental and in places carry copper, but as yet they have offered little encouragement to extensive development.

\section{FOREST ("VICTORIA") LODE}

The statements regarding the Forest lode (pl. 47) are based on a brief visit to the Victoria mine in August, 1923 , on the mine maps and records, and on statements by the late George Hooper, superintendent during the later operations, and by Charles Hooper.

\section{PRODUCTION}

The Victoria mine, on the Forest lode west of Ontonagon River, is the westernmost mine on the main range that has made a notable production. It was also one of the earliest producers in that part of the district.

Production of Forest lode in Victoria mine to end of 1923

\begin{tabular}{|c|c|c|c|}
\hline \multirow{2}{*}{ Period } & \multirow{2}{*}{$\begin{array}{l}\text { Rock } \\
\text { treated } \\
\text { (tons) }\end{array}$} & \multicolumn{2}{|c|}{ Copper produced (pounds) } \\
\hline & & Total & Per ton of rock \\
\hline \multirow[t]{2}{*}{$\begin{array}{l}1855-1878 \\
1904-1923 \ldots\end{array}$} & 700518 & $\begin{array}{r}375,279 \\
19,649,134\end{array}$ & 11. 55 \\
\hline & & $20,024,413$ & \\
\hline
\end{tabular}

\section{GEOLOGIC HORIZON}

The Forest lode is one of the series a short distance above No. 8 conglomerate, but with which one, if any, of those developed to the east it is to be correlated is not certain, and it is therefore considered separately. It is low in the series and probably near the Evergreen horizon. This lode has been slightly prospected for several miles to the south on the Tremont-Devon, Cass, and other properties but not extensively developed.

\section{CHARACTER OF AMYGDALOM}

Where seen in the Victoria mine the lode shows alternations of areas of rather thin cellular to coalescing amygdaloid with smaller areas of fragmental rock. The areas of fragmental rock seemed to bulge rather deeply into the underlying material, but Mr. Hooper stated that there were bulges of this character into the hanging wall also. The fragmental parts of the lode are 50 feet thick in places. The thicker masses of fragmental rock are irregularly distributed in the developed area, though they show some tendency to form shoots.

\section{MINERALIZATION}

Quartz, pumpellyite, epidote, and calcite are the most abundant minerals associated with the copper. Prehnite is fairly abundant. The rock alteration is mainly of the quartz-pumpellyite type.

Much of the copper occurs as relatively large masses. $\mathrm{Mr}$. Hooper stated that in the later operation mass copper had run as much as 50 per cent of the total production and that the stamp rock was of low grade, carrying less than 10 pounds of copper to the ton. The thick bulges of fragmental rock are by far the richest portions of the mine, though $\mathrm{Mr}$. Hooper stated that such rich areas have not yielded a very large proportion of the total output. The richness of the ground seems to show a close relation to the degree to which the lode is fragmental.

\section{EXTENT OF DEVELQPMENT}

The lode has been opened in the Victoria mine for about 3,800 feet along the strike and to the twenty. eighth level. The area in which extensive stoping has been done is considerably less, as can be seen by reference to Plate 47.

Some work was done in the early days on the Tremont-Devon property, west of the Victoria, and more recently diamond drilling has been done in order to locate the Forest amygdaloid. An amygdaloid that was thought to be the Forest was encountered and was reported to contain some copper.

\section{LAKE LODE}

\section{PRODUCTION}

The Lake lode (pl. 48) was located by diamond drilling in 1907. Development began in 1908, and the first production was made in 1909. From 1909 to 1918, when production was suspended, the Lake lode had yielded $7,326,227$ pounds of copper. The rield ranged from about 16.0 to 26.5 pounds per ton of ore milled and averaged about 23 pounds. The rock was sorted to a varying degree. The company's report for 1918 states that "All new stopes opened in the Lake shaft showed a steadily decreasing copper con. tent of rock. *** In the newer stopes 5 or 6 tons had to be discarded for every ton shipped."

\section{LOCATION}

The Lake lode was discovered and first opened near the Keweenaw fault. Developments on the lode in the Lake and South Lake mines show that this portion of the lode is on the north end of a synclinal basin pitching southwest.

The openings on the lode were not accessible when the writers visited the region, and the statements concerning the lode are taken largely from the records 
and reports of the Lake and South Lake companies and from descriptions by Mr. C. J. McKie, manager of the Lake mine when operations on the lode were suspended.

\section{STRUCTURE}

The general structure of the area is that of a broad syncline lying between the northward-dipping series of the Evergreen Bluff, to the north, and the Keweenaw fault, to the south. The main workings of the Lake mine are around the north end of this basin, and those of the South Lake mine are on the north side of the basin, where the beds dip to the northwest and southeast from the axis of an anticline that strikes about with the general trend of the range.

\section{CORRELATION}

In the present stage of development there is possibly some uncertainty as to the exact correlation of the Lake lode with the lodes north of the anticline, which have the normal northerly dip of the range. It seems clear, however, that the Lake lode is one of the series of lodes above No. 8 conglomerate, and probably it is near the Evergreen lode of that series. A lode which may or may not be the Lake lode has been opened at the Algomah mine, west of the Lake mine, on the south side of the Lake mine basin, at the general horizon of the Lake lode.

\section{CHARACTER}

The Lake lode is distinctly of the fragmental type, and, like the Evergreen and most of the succeeding lodes, where they have been opened, it shows great variation in thickness from place to place. In some places it is apparently thick and fragmental; in others the amygdaloid has nearly disappeared.

The lode has been developed in the Lake mine for a distance of about 3,500 feet along the strike and down to the eleventh level. Some copper is said to be present throughout these openings, but the copper content was highest for a distance of 500 to 600 feet north and south of the main shaft, where 25 to 30 per cent of the rock has been stoped. It is reported that some copper was found in the drift on the Lake lode in the South Lake mine, but no stoping was done.

The fragmental amygdaloid of the Lake lode was brown and well oxidized. The principal minerals associated with the copper are quartz, pumpellyite, and calcite, which are accompanied by some epidote and a little red feldspar. The alteration of the lode rock was typically of the quartz-pumpellyite type.

\section{ALGOMAH LODE}

Operations on the Algomah lode began in 1910, but the only production has consisted of test shipments. A shipment of 74,560 pounds of ore made in 1914 yielded 18 per cent of copper, according to the company's report for that year.

The shaft on the Algomah lode is on the south side of the Lake mine basin, at the general horizon of the Lake lode and only 60 feet from the Keweenaw fault. Whether or not this lode is the same as the Lake lode has not yet been determined. Near the surface the lode dips $60^{\circ} \mathrm{N}$. The shaft was not accessible at the time of the writers' visit to the district. In a short level about 30 feet below the collar of the shaft the lode is mainly cellular, with small areas of fragmental amygdaloid. The rock showed the pumpellyite rock alteration characteristic of many of the lodes in this part of the district. The company's reports, however, state that little native metal was found but that the copper was nearly all combined as black oxide, melaconite, green carbonate, malachite, and silicate. The ore seen on the dump corroborates this statement.

The lode has been developed for about 2,000 feet along the strike on the first level. About 1,000 feet north of the shaft the drift on the amygdaloid entered the Keweenaw fault, which was followed for some distance. The shaft was sunk to a depth of 558 feet, and a crosscut was driven north from the second level for about 950 feet to explore for other lodes.

\section{BALTIC LODE HISTORY AND PRODUCTION}

Important development of the Baltic lode (pl. 49) began at the Baltic mine about 1898 . The Trimountain mine and the Champion mine began production in 1902. Originally the three mines were operated under separate organizations, but at present the Copper Range Co. owns the Baltic and Trimountain and one-half of the Champion; the other half of the Champion is owned by the St. Mary's Mineral Land Co. The Copper Range Co. also owns the Atlantic mine. The following table shows the production from the mines and dividends from the beginning of operation to the end of 1925. A more detailed statement of production is given in the statistical section.

Production and dividends from the Baltic lode, ${ }^{a}$ 1898-1925

\begin{tabular}{|c|c|c|c|c|c|c|}
\hline \multirow[b]{2}{*}{ Mine } & \multirow[b]{2}{*}{ Period } & \multirow[b]{2}{*}{ Rock treated (tons) } & \multicolumn{2}{|c|}{ Refined copper (pounds) } & \multicolumn{2}{|c|}{ Dividends } \\
\hline & & & Total & Per ton & Total & $\begin{array}{l}\text { Per pound } \\
\text { of copper } \\
\text { (cents) }\end{array}$ \\
\hline $\begin{array}{l}\text { Baltic } \\
\text { Do. } \\
\text { Trimountain } \\
\text { Do } \\
\text { Champion... }\end{array}$ & $\begin{array}{l}1898-1916 \\
1917-1925 \\
1924-1925 \\
1902-1923 \\
1902-1925\end{array}$ & $\begin{array}{r}8,672,553 \\
1,820,612 \\
43,625 \\
6,703,079 \\
14,156,309\end{array}$ & $\begin{array}{r}200,584,164 \\
62,939,547 \\
1,343,303 \\
139,697,289 \\
438,403,286\end{array}$ & $\begin{array}{l}23.13 \\
34.57 \\
30.79 \\
20.84 \\
30.97\end{array}$ & $\begin{array}{c}\$ 7,950,000 \\
\text { s } 2,084,772 \\
3,250,000 \\
29,070,260.96\end{array}$ & $\begin{array}{l}\text { 3. } 96 \\
\text { 3. } 23 \\
\text { 2. } 33 \\
\text { 6. } 75\end{array}$ \\
\hline & & $31,396,177$ & $842,967,589$ & 26. 91 & $42,355,032$. QR & 5. 02 \\
\hline
\end{tabular}


The relatively high copper content of the rock treated from the Baltic lode as compared with that from the other amygdaloid lodes of the district is due mainly to the present method of mining, which permits discarding underground a relatively large percentage of poor rock. The table of production by years (pp. 79, 82) shows the change in copper content of rock treated resulting from the development of this method of mining. The method has been described and the results discussed by Denton and Schacht, ${ }^{12}$ of the Copper Range Co., who show that for the period 1915-1921 as compared with 1908-1914 the yield per ton of rock treated increased from 24.8 to 37.2 pounds, or 50 per cent. The rock recovered per square foot of lode decreased from 1.54 to 1.40 tons.

The lode has been developed in the three mines for about 20,000 feet along the strike and in depth to the twenty-seventh level in the Champion mine, the thirtysixth level in the Trimountain mine, and the thirtyninth level in the Baltic mine.

\section{EXTENT AND CORRELATION}

The Baltic lode has been opened through the three mines of the Copper Range Co.- the Baltic, Champion, and Trimountain. North of these the Atlantic Mining Co.'s Section 16 explorations were presumably at this horizon, and farther north the Superior and Houghton Copper mines are at the general horizon of the Baltic lode and probably on that lode. Still farther north an amygdaloid at this horizon has been prospected by the Isle Royale Copper Co., and north of Portage Lake by the Arcadian Consolidated Copper Co. The identification and correlation of the Baltic lode becomes increasingly uncertain with increasing distance from the principal mines on the lode.

South of the Copper Range Co.'s mines an amygdaloid at the Baltic horizon has been prospected at the Globe and Challenge mines. The No. 3 conglomerate is not developed at these localities, and the correlation is somewhat doubtful, but the horizon has certainly been reached at the Globe, not so certainly at the Challenge.

\section{BALTIC FLOW}

The Baltic flow at the Copper Range Co.'s mines is an ophite 150 to 200 feet thick. It varies considerably in thickness from place to place.

Resting on the Baltic flow in the developed area are a number of thin disconnected flows. Some of these seem to thin out both up and down the dip and along the strike; others are as yet only partly outlined. Examples of those that seem to thin out are found in the upper levels of the Trimountain mine, and examples of both kinds in the south end of the Champion mine.

12 Denton, F. W., Development and extraction methods for Lake Superior copper deposits: Lake Superior Min. Inst. Bull., 1922, ppor methods of the Copper Range Co.: Am. Inst. Min. and Met. Eng. Trans, vol 72, pp. 346-370, 1925; Lake Superior Min. Inst. Bull, 1922, pp. 56-79.
These small flows apparently occupy and tend to fill depressions in the surface of the main flow. This is indicated by the fact that the distance from the No. 3 conglomerate, beneath the Baltic flow, to the top of the highest of these flows and to the top of the Baltic flow where they are absent, is far more uniform than the distance from the conglomerate to the top of the Baltic flow measured both where the overlying flows are present and where they are absent. The relations suggest that these small flows may be gushes from the main flow that were forced out after a considerable crust had formed on it but while most of the interior was still fluid. The gushes tended in part to fill hollows in the original surface of the flow, and in part they possibly caused the crust on which ther flowed to settle into the fluid portion beneath, thus lowering the top of the main flow at these places.

Above the main Baltic flow and the "gush" flows resting on it is a flow that has a thickness of 40 to 60 feet where it has been cut in the developed area. The Baltic West lode is at the top of this flow.

\section{STRUCTURE}

FOLDS

The most pronounced structural feature in the Copper Range Co.'s mines is a broad anticline whose crest passes between the Baltic and Trimountain mines. This fold causes a very sharp change in strike, amounting to about $30^{\circ}$, between these two mines and in the south end of the Baltic workings. In this ares the ground is much broken by faults and slips, and these probably displace the lode considerably, though present developments do not make this certain. In the south end of the Baltic mine the lode swings around in a zone of considerable fissuring and assumes the general strike that it has in the Trimountain mine, but if continued on this strike it would not meet the lode in the Trimountain mine. This suggests an offset between the Baltic and Trimountain mine. (Seet pl. 10.)

\section{CROSS FAULTS AND SLIPS}

In all the mines there are faults or slips with strong clay gouges striking nearly across the lode; most of these have steep dips, though a few dip as low as $30^{\circ}$. The smaller slips have caused but little displacement of the lode, and a drift carried on the general strike usually reenters the lode a short distance beyond such a slip, or the displacement may be so slight that the lode is not lost.

On some of the slips, however, there is a displacement of as much as 60 to 70 feet-for example, in the lower levels of the Baltic mine between No. 4 and No. 5 shafts and in the south end south of No. 2 shatt. The faults do not show a uniform direction of displacement. In many of the smaller faults the block north of the break is offset to the west, but a strong fault 
south of Baltic No. 2 shaft has moved the south block relatively westward.

Examples of the cross breaks with heavy clay gouges, together with vein minerals, are to be seen at the south limit of developments in the Champion mine and the north end of the Baltic mine. Some of the fissures in the Trimountain mine also have strong gouges, and, as already noted, there is apparently much fissuring with gouges in the srea between the Baltic and Trimountain mines, where the lode makes a sharp change in strike, and the area of the Atlantic Co.'s Section 16 exploration north of Baltic is said to be much broken and fissured.

\section{STRIKE FISSURES}

Throughout the mines there are numerous fissures that strike with the lode or nearly so and dip more steeply than the lode, or from $75^{\circ}$ to $90^{\circ}$ where the lode dips $70^{\circ}$. These fissures are seen in the openings in the lode and in the crosscuts on both sides of the lode. In the long hanging-wall crosscut on the seventh level of the Champion mine such fissures are numerous near the lode but become less numerous with increasing distance from it. They are numerous and strong in the crosscut back of No. 4 shaft in the Baltic mine, but less numerous and weaker above the Baltic lode. This increase in abundance of strike fissures toward the Keweenaw fault, which is a few hundred feet southwest of the Baltic lode, suggests that the fissures may have been formed at the same time and by the same forces that produced the fault.

\section{CHARACTER OF BALTIC AMYGDALOID}

Although the writers were not able to examine the Baltic lode over large areas in the older worked-out portions of the mines, it is fairly clear from the examinations made and from descriptions by those familiar with the older workings that the lode is of the fragmental type.

Like all the other fragmental amygdaloids, the Baltic lode shows notable variations in the quantity of fragmental material from place to place. In many places the lode is 50 feet or even more in thickness and is composed of fragmental amygdaloid throughout; in other places it is but a few feet thick and is composed of rather coarse trappy fragments. Locally the spaces between the large fragments are filled with tongues from the hanging flow that extend for some distance below the top of the amygdaloid. In still other places the lode is cellular, with slight tendency to fragmental character. As in the other fragmental amygdaloids, unusually thick parts of the lode tend to bulge both to the hanging wall and the footwall.

This variation appears in both a small and a large pattern. In an area of prevailingly thick, notably fragmental amygdaloid, there are areas of thin and trappy or cellular amygdaloid, and in an area of pre- vailingly thin trappy amygdaloid there are areas of fairly typical fragmental amygdaloid. In the larger pattern the largest areas of thick fragmental amygdaloid occur in the Champion mine and in the upper levels of the Baltic mine. In the lower levels of the Baltic, in the Trimountain, and in the lower levels of the northern part of the Champion mine the lode contains on the average less fragmental material, though there are areas of markedly fragmental amygdaloid. In the smaller pattern there is a distinct tendency for the areas of abundant and less abundant fragmental material to form "belts" or "shoots" with a rather low southerly pitch. This tendency is particularly apparent in the Trimountain mine but is also evident in the Baltic and Champion mines. Whether or not this tendency is also present in the larger pattern is not clear in the present state of development. There is, however, a suggestion of it in the lower levels of the Baltic mine, where the lode contains a relatively small proportion of fragmental rock.

Where the small overlying flows or "gushes" are present, the lode beneath them seems to average thinner than where they are lacking. In places, at least, there seems to be especially thick fragmental amygdaloid around the margins of such flows, as if they had filled in depressions underlain by relatively thin amygdaloid surrounded by ridges of thick amygdaloid. The amygdaloid of these "gush" flows averages thinner and is more cellular than that of the main flow, which is probably to be expected from their origin.

The lode varies greatly in thickness. In the Champion mine in numerous places it is 50 feet thick and in some places even more; the average stoping width is about 26 feet. $^{13}$ In the Trimountain mine the average is about 16 feet. In the upper levels of the Baltic mine the lode averaged 20 to 23 feet, but in the bottom of the mine it is relatively thin and cellular.

\section{OXIDATION}

The Baltic lode is well oxidized though distinctly less so than the Kearsarge lode. The markedly fragmental rock, where not bleached by mineralizing solutions, is brown to reddish and well oxidized throughout. Trappy fragmental rock and cellular rock are usually less oxidized, though the tongues from the overlying flow that fill the spaces between coarse, trappy fragmental rock are commonly distinctly oxidized and give the lode a reddish appearance.

\section{MINERALIZATION}

MINERALS

The minerals of the Baltic lode are few. The abundant minerals associated with copper are quartz, pumpellyite, epidote, and carbonate -both calcite

13 Schacht, W. H., op. cit., p. 5 
and an iron-bearing carbonate. Locally sericite is plentiful as in the south end of the Champion mine on the ninth and tenth levels. It is present but not abundant in many other places in all the mines. Laumontite is present in many fissures and locally in the lode. Other zeolites were not noted and certainly are relatively rare. Prehnite is present but is not abundant except in some fissures. Orthoclase, which is abundant in many other lodes and in the Superior mine, to the north, is almost entirely lacking in the Copper Range Co.'s mines. Datolite was not noted. Sulphides of copper are unusually abundant in all three mines. Their characteristic occurrence is in the fissures that dip $75^{\circ}$ to $90^{\circ}$ and strike nearly parallel with the lode, and they are likewise present in cross fissures. They also occur in the lode in the same manner as the copper, but this type of occurrence is rare. It was seen best in the Trimountain mine, on the twelfth level, in the stope south of No. 4 shaft from the end of the stope to No. 2 mill, where most of the copper in the lode is chalcocite associated with iron carbonate of the same type as occurs in the fissures. Chalcocite is by far the most abundant sulphide in the fissures, but bornite is not rare. Chalcopyrite is reported to occur in a few places.

The mineral most characteristically associated with the sulphides, both in lode and in fissures, is an ironbearing carbonate. This mineral usually forms on the walls of the fissures, with the sulphides in the center. A similar relation exists where sulphide forms in the lode; the sulphide is surrounded by the iron carbonate. The iron carbonate is far more widespread than the sulphide. Over large areas it has permeated and replaced the amygdaloid, so that the rock, when exposed on the dumps, quickly turns brown from oxidation of the iron in the carbonate, as can be readily seen on the dumps of the Baltic mine. In many places copper is associated with the sulphides. Usually it occurs at the margins of the sulphide veins, but it may occur with quartz in the center of a vein. Where a vein branches and dies out in fragmental lode rock, chalcocite may give place to copper in the extreme ends. In the mass copper fissure in Trimountain No. 2 shaft, twenty-fifth level south, the mass copper was found near the intersection with the lode; where the fissure was followed into the footwall trap chalacocite appeared, though copper was still present. Only a relatively small amount of copper was present in both forms away from the lode.

Barite has been found in the Baltic lode but here as elsewhere is rare except in some of the fissures. The principal commercial occurrence of copper is in the lode, where it is irregularly distributed through the amygdaloid in bodies ranging from minute specks to masses several tons in weight. Most of the copper in this lode is in relatively small masses. Schacht ${ }^{14}$

14 Op. cit., p. 5. gives the percentage of the various sizes of copper produced as follows:

20 pounds or more
Less than 20 pounds but over $1 / 2$ inch
$1 / 2$ to $1 / 4$ inch.
$1 / 4$ inch to 20 mesh
20 to 60 mesh
Below 60 mesh

Large masses of copper have been found in tho fissures at and near their intersection with the lode Near Trimountain No. 2 shaft a mass fissure wa mined from above the twenty-fifth level to the twentr. seventh. It is said that most of the copper was found just below the Baltic lode. Mas's copper has also been mined from a fissure in the West lode of the Baltic mine, above the twentieth level. The fissure strikes nearly parallel with the lode but dips more steeply The copper was in the hanging wall of the West lode. The fissure is of the same system as those that carry chalcocite, but it carried no sulphide so far as was noted. Mass copper in considerable quantity is said to have been recovered from strike fissures in the Champion No. 2 shaft. The copper is said to hare occurred mainly in the trap below the lode.

\section{ROCK ALTERATION}

The characteristic rock alteration is of the quartz pumpellyite type, with varying amounts of epidote Wherever copper is present the lode is bleachel usually to the light-green color characteristic of abm dant pumpellyite. This type of rock alteration more fully discussed on page 107. Alteration of the same type occurs along the fissures both in the lod and in the adjacent trap rock.

\section{RELATION OF MINERALIZATION TO CHARACTER OF LOD}

In a broad way there is a close relation betreen character of amygdaloid and degree of mineralization Rich ground is formed in thick fragmental amygdaloid Thin trappy fragmental amygdaloid and cellular amygdaloid are commonly poor. The thick fros: mental amygdaloid is not invariably rich, but thin or cellular lode is nowhere known to be rich over more than small areas.

The largest areas of thick fragmental amygdaloi opened are in the Champion mine and in the uppet part of the Baltic mine. These are also the riches areas developed on the lode. In the Trimountain mine and in the lower part of the Baltic the lode is les fragmental and is not so well mineralized. In this respect the Baltic lode does not differ from othe mineralized fragmental lodes.

\section{RESULTS OF OPERATION}

The variation of copper content with thickness o lode is shown by the data published by Denton ${ }^{15}$ an

13 Denton, F. W., op. cit., p. 42. 
Schacht ${ }^{16}$ on the results of operations to 1921 on the richest and poorest units of operation on the Baltic lode.

Results of operation of mines on Baltic lode

\begin{tabular}{|c|c|c|}
\hline & Champion & $\underset{\text { tain }}{\text { Trimoun- }}$ \\
\hline $\begin{array}{l}\text { Average thickness of lode } \\
\text { Ore per square foot of lode } \\
\text { Copper per square foot of lode_to pounds.- } \\
\text { Productive lode area }\end{array}$ & $\begin{array}{l}26 \\
1.36 \\
44 \\
66\end{array}$ & $\begin{array}{l}16 \\
0.98 \\
21 \\
48\end{array}$ \\
\hline
\end{tabular}

It is readily seen that the thicker parts of the lode have been the more productive. The Baltic mine is intermediate in character and productivity between the other two.

\section{BALTIC WEST LODE}

The Baltic West lode is the first amygdaloid above the Baltic lode. The underlying trap is from 40 to 60 feet thick, fine grained, and brownish. The amygdaloid of the portion opened, mainly in the Baltic mine, is of the fragmental type and is similar in character to the thinner parts of the fragmental amygdaloid on the main Baltic lode.

There have been no large areas developed on this lode comparing in thickness with the thick fragmental Baltic lode of the Champion and upper levels of the Baltic mine. There is some suggestion in this lode, as in the main lode, that the amygdaloid is in areas or belts of moderately fragmental and slightly fragmental or cellular lode. The present developments do not give much idea of the trend of such belts, but apparently if present they do not pitch very steeply.

The results of mineralization and rock alteration are entirely similar to those shown in the main lode, and there is the same general relation between mineralization and character of rock.

\section{RELATION OF FISSURE MINERALIZATION AND LODE MINERALIZATION}

Hubbard ${ }^{17}$ long ago suggested that the strike fissures in the Baltic lode were the main channels through which the mineralizing solutions passed. He regarded the deposit as a true lode in the sense that it is a zone of closely spaced mineralized fissures rather than a mineralized amygdaloid.

The close similarity of the minerals of the fissures and of the amygdaloid-the presence of abundant iron carbonate and quartz in both, and the same type of rock alteration in both-certainly gives good reason for supposing that the solutions that produced the fissure mineralization and the amygdaloid mineralization were very similar. The main differencenamely; the relative abundance of sulphides in the

\footnotetext{
16 Schacht, W. H., op. cit., p. 5.

"Hubbard, L. L., Lake Superior Min. Inst. Proc., vol. 17, p. 229, 1912. $58540-29-16$
}

fissures and their relative scarcity in the amygdaloidmay be due to the oxidizing effect of the ferric iron of the amygdaloid, as has been discussed on page 129 . This is particularly indicated where fissures finger out and are lost in fragmental amygdaloid. The mineral in some such fissures changes near the ends from chalcocite to native copper. It is also suggested by the presence in the amygdaloid over small areas of chalcocite instead of native copper, as has been noted especially in the Trimountain mine. These relations also suggest that the minerals in the veins and in the amygdaloids were formed during the same general period of mineralization, but there can be no doubt that some of the minerals in the fissures were deposited later than some of the minerals in the amygdaloid, and the minerals that now fill the fissures may have been deposited largely after the mineralization of the amygdaloid. Indeed, this must have been the case if the fissures were really the channels through which the mineralizing solutions entered the amygdaloid. The general subject of lode mineralization is discussed on page 124, where it is pointed out that in some of the lodes of the district there is no evidence to the present depth of development as to how the mineralizing solutions entered the lodes, but the mineralization seems to have been effected by solutions rising along the lodes.

It is entirely possible that solutions may have entered the Baltic and other amygdaloids with which mineralized fissures are associated, in part through the fissures that are now exposed and in part through fissures that entered the lode below the present depth of the mines.

\section{SUPERIOR LODES OCCURRENCE}

The main Superior lode (pl. 48) is approximately at the same horizon as the Baltic lode and may be identical with it. It has been developed by the Superior Copper Co. and the Houghton Copper Co. Between the Superior mine and the Copper Range Co.'s mines, to the south, on the Baltic lode, are the Copper Range Co.'s Section 16 explorations, which are in a zone of considerable faulting, and no positive correlation of the beds has been carried across this zone.

Here as on the Baltic lode, both a main lode, called the Superior lode, and a west lode, called the Superior West lode, have been worked. The main lode has been opened in the two mines for a horizontal distance of about 6,000 feet and down to the thirty-first level in the Superior mine and about the fourteenth level in the Houghton Copper mine.

\section{PRODUCTION}

The following table gives the result of operations on the lodes to the end of 1925 . 


\begin{tabular}{|c|c|c|c|c|c|c|}
\hline \multirow[b]{2}{*}{ Mine } & \multirow[b]{2}{*}{ Period } & \multirow{2}{*}{$\begin{array}{l}\text { Rock treated } \\
\text { (tons) }\end{array}$} & \multicolumn{2}{|c|}{ Refined copper produced (pounds) } & \multicolumn{2}{|c|}{ Dividends } \\
\hline & & & Total & Per ton & Total & $\begin{array}{l}\text { Per pound } \\
\text { copper (osed) }\end{array}$ \\
\hline \multirow[t]{2}{*}{$\begin{array}{l}\text { Houghton Copper Co } \\
\text { Superior Copper Co }\end{array}$} & \multirow[t]{2}{*}{$\begin{array}{l}1915-1917 \\
1908-1920\end{array}$} & $\begin{array}{r}49,729 \\
1,550,474 \\
\end{array}$ & $\begin{array}{r}540,052 \\
30,018,271\end{array}$ & $\begin{array}{l}10.86 \\
19.36\end{array}$ & $\$ 649,000$ & 2.18 \\
\hline & & $1,600,203$ & $30,558,323$ & 19. 09 & 649,000 & 2.12 \\
\hline
\end{tabular}

\section{CHARACTER}

The main Superior lode, as indicated by the material on the dumps of the two mines and from descriptions, is a fragmental lode of distinctly scoriaceous character, with some shaly to sandy rock above the lode in the Superior mine.

The Superior West lode where mined is prevailingly fragmental but contains areas of cellular top. Outside of the main ore shoot the fragmental areas appear to be small as compared with the cellular.

\section{MINERALIZATION}

The most abundant minerals associated with copper in the Superior West lode are quartz, pumpellyite, epidote, calcite, and feldspar. Feldspar is unusually abundant in this lode, as contrasted with its scarcity on the Baltic lode. Laumontite is present in fissures and locally in the lode. Chalcocite and barite are present in small amount in fissures crossing the lode. The writers had no opportunity to examine the main Superior lode.

\section{ORE SHOOTS}

The ore shoot in the main Superior lode was developed in the Superior mine from the surface to the nineteenth level, but little of it was mined below the seventeenth level. The productive ground extended for 1,200 to 1,500 feet along the strike, but less than 50 per cent of the lode within the shoot was mined for ore. The general pitch of the shoot in the lode was to the north.

In the Superior West lode a shoot pitching south at a low angle was opened from the twelfth to the thirty-first level, but most of the ore mined was obtained between the twelfth and twenty-third levels. This shoot was developed along the strike for 1,000 to 1,500 feet, and in the most productive part between the twelfth and eighteenth levels a rather high percentage of the lode was mined. In the lower levels the shoot was small and "binchy."

In 1920 the mine was closed, and the management stated that ore reserves had been exhausted and that prospecting for new ore had not been sufficiently encouraging to warrant further expenditure.

The Houghton Copper mine is north of the Superior mine, and the main openings are thought to be on the main Superior lode. The shaft is in the foot of the "East lode," which is probably the main lode. There has been some development in the upper levels on 8 lode lying farther east, and the Superior West lode has been opened in the Houghton ground to a slight extent by a drift from the nineteenth level of the Superior mine.

Only relatively small areas of the lode were stoped. The discard of rock broken in 1912 was 41 per cent, and the copper yield was low.

\section{ISLE ROYALE}

On the Isle Royale property an amygdaloid at the horizon of the Baltic lode has been opened by the $A$ and Section 12 shafts, but without encouraging results.

\section{FELSITE OF INDIANA MINE}

\section{DEVELOPMENT}

The No. 1 Indiana shaft was begun in 1910 to explore an area of felsite which had been cut in diamond-drill hole No. 2 and from which a very rich core had been taken at a depth of about 1,400 feet. This exploration was carried on till 1916. The shaft was sunk below the fourteenth level, and openings were made at the 600 -foot, 1,150 -foot, and 1,400-foot levels.

The results of this work indicated that the felsite is an irregular body intruded into the traps. The felsite on the dump is a reddish fine-grained rock with scattered phenocrysts of quartz and feldspar. It is all much shattered, and there is also much felsite breccia, which probably came from the vicinity of the contact with the trap, where a considerable part of the exploration was carried on.

\section{MINERALIZATION}

Calcite is everywhere present along seams in the rock, and the felsite is bleached to a light gray. In someof the rock this bleaching has included the whole ares between fissures. Oxidized copper minerals, carbonate (malachite), and silicate occur along many of the fissures. Where the oxidized minerals are present the original minerals have usually been entirely altered, but in some of the least altered portions chalcocite and "brittle" arsenical copper are present. It is probable that the oxidized minerals have been derived from both of these. In the larger fissures rather massive copper was found. There are masses several hundred pounds in weight on the dump. 
No. 2 drill hole, from which the rich core was taken, was not identified underground, but the management believed when operations were suspended in 1916 that the core had come from a mineralized fissure or vein, like those encountered in the workings, and that the vein was probably not of great extent.

\section{FISSURE DEPOSITS}

\section{HISTORY}

Apart from the incidental extraction of copper from fissures in mines that exploit the amygdaloid and conglomerate lodes, there are some mining operations devoted primarily to fissure deposits. The first copper produced in the district was taken from the fissure deposits of Keweenaw and Ontonagon Counties. (See pls. 50-52.) Production began in 1845, and fissure mines were operating till about 1890 . Except for the production from the Mass fissure by the Ahmeek Mining Co., beginning in 1909, there has been little operation on fissure deposits since that time.

\section{PRODUCTION}

The total recorded production of copper from fissures to the end of 1925 amounted to $199,853,000$ pounds; of this total $61,315,000$ pounds came from the Minesota fissure, of Ontonagon County, leaving a total of $138,538,000$ pounds from the fissures of Keweenaw County. (For the production of individual fissures see p. 72 and the reports on mining companies in the statistical section, pp. 76-98.)

Of all the fissures that have been worked independently of the lodes in the district, only three have yielded a profit - the Cliff, Central, and Minesota. The Cliff paid $\$ 2,518,620$ in dividends; the Central $\$ 2,130,000$; and the Minesota $\$ 1,820,000$, plus $\mathrm{Na}$ tional $\$ 320,000$, or $\$ 2,140,000$. The Copper Falls paid $\$ 100,000$ in dividends, but that was less than the assessments collected. The Phoenix paid $\$ 20,000$. The Mass fissure in the Ahmeek mine has undoubtedly been profitable and probably would have been profitable if worked alone.

\section{DISTRIBUTION}

Plate 50 shows the relation of the Greenstone flow and the Allouez conglomerate to the principal fissures worked in Keweenaw County from Ahmeek to Delaware.

The fissures in the north end of the district are tension cracks on the folds. Thus there is a series of fissures near the crest of the Allouez anticline. From the Gratiot River gap nearly to the North American gap the Greenstone flow, which is perfectly exposed, is massive and almost without fissuring. Near the North American gap the great Keweenaw anticline begins, and fissuring of varying degrees of intensity is present from that locality to the end of Keweenaw Point.

\section{DISTRIBUTION OF COPPER IN THE FISSURES}

The only fissures that the writers have been able to study in any detail are those that cross the Kearsarge lode in the Ahmeek and Mohawk mines. Some of these contain native copper, others arsenides. On the Mass fissure only has drifting been carried far from the Kearsarge lode, though on a few others drifts have been extended as much as 200 or 300 feet from the lode.

There is strong evidence that the Kearsarge lode has been a large factor in causing the precipitation of the copper in the Mass fissure. This evidence consists first in the distribution of the copper in the fissure. The copper is most abundant at the intersection of the amygdaloid and the fissure and decreases with increased distance from the amygdaloid. On the footwall side it extends but a short distance, but on the hanging-wall side it extends much farther. Between the Kearsarge amygdaloid and the Kearsarge conglomerate there are no thick amygdaloid lodes, and no relation between copper and any amygdaloid but the Kearsarge has been noted. The second evidence of relationship is the alteration of the lode adjacent to the fissure. In general the lode near the fissure is chloritized and sericitized and contains less copper.

So far as can be determined from the meager amount of development, the same conditions hold true for the other fissures that cross the Kearsarge lode, both copper and arsenide fissures. The parts of the lode adjacent to the arsenide fissures contain some arsenides, and there can be little doubt that the copper arsenic solutions were traveling along these fissures and precipitated their burden at the crossing of the Kearsarge lode. The gradations from fissures high in arsenic to those low in arsenic, like the Fulton and other fissures, strongly suggests a common age and origin for all the fissure deposits.

The Mass fissure is crossed by a bedding fault about 200 feet stratigraphically above the Kearsarge amygdaloid. Most of the copper is found below this fault, but no sharp change in the amount of copper in the fissure after passing the fault has been recognized.

The most productive fissure deposits in the north end of the district have been found beneath the Greenstone flow, though some copper has been produced from fissures above the Greenstone flow. There has been no opportunity for direct study of these deposits, and the descriptions in the literature are far from complete. From such information as is available, however, there seem to be at least two possible causes for the special richness of the fissures beneath the Greenstone flow. The first is the presence of a fault or "slide," immediately beneath the Greenstone flow, at the horizon of the Allouez conglomerate, whether the conglomerate is present or not. This movement has produced a rather thick gouge, which may have 
acted as a dam to rising solutions and caused them to concentrate just beneath the Greenstone flow. Locally there is a displacement of the fissures along this fault, which causes the fissures to end against the gouge and would favor concentration of solutions.

The second possible cause is the same as already discussed for the fissures crossing the Kearsarge lodenamely, that the amygdaloid lodes intersected by the fissures were an influential factor in causing the precipitation of the copper.

From drill-core records at the Delaware, Cliff, and Central mines and descriptions of the Cliff mine, as well as from material on the mine dumps, it appears that there are favorable amygdaloids in the belt under the Greenstone flow. In some reports mention is made of the favorable influence of amygdaloids on the vein, which seems to have been pretty clearly recognized by the early operators. Furthermore, some of the veins above the Greenstone flow are correlated, though not certainly, with those below, as the Petherick and the Northwestern, the Cliff and the North Cliff; and doubtless others have continuations above the Greenstone flow. Above the Allouez conglomerate horizon the veins seem to be poor or barren until they reach the amygdaloids at the horizon of the Ashbed lode, which are the next higher thick amygdaloids. The fissure deposits associated with the Ashbed are not as large as those below the Greenstone flow, but it seems likely that the solutions passed through the Greenstone flow and overlying beds but did not deposit much copper till they reached the favorable environment of the amygdaloids at the horizon of the Ashbed lode. If this is true, it would seem that neither the Greenstone flow nor the "slide" beneath it was everywhere a very effective barrier to the passage of ore solutions along these fissures. It may be noted, however, that apparently in neither the Cliff nor the Central mine has a largely productive deposit been found on the extension above the Greenstone flow. The extension of the Central fissure above the Greenstone flow has not been identified, but the supposed extension of the Cliff has been prospected without finding valuable deposits, though the fissure contains some copper where it crosses the Ashbed. The Cliff fissure is offset by a fault at the horizon of the Allowez conglomerate, and the same may be true of the Central. Such offsets would doubtless tend to limit the mineralization to the sections below the faults. From the detailed descriptions of the different fissure deposits beneath the Greenstone flow it appears that the fissures are not everywhere and probably not generally mineralized up to this flow or to the "slide" but have the maximum mineralization a short distance below the slide. The diamond-drill sections at the North American, Cliff, and Central mines show that the amygdaloids imme- diately beneath the Greenstone flow are not very thick or favorable as compared with those below the Houghton conglomerate. The fissures, however, prob. ably averaged richer above the Houghton conglomerate than below it, so that while there is a general relation between thick amygdaloids and copper in the fissures, this relation is not close.

At several localities a slide has been reported at the horizon of No. 17 conglomerate and may hare been a factor in the formation of fissure deposits in the Ashbed amygdaloid flows.

It appears that there is a very notable difference in the effect of the fissures on the amygdaloids near the crossing in the Kearsarge and on the amygdaloids to the north, under the Greenstone flow. The Kearsarge lode is relatively poor in copper near the fissure intersections, whereas both the Ashbed and the amygdaloids below the Greenstone flow are said to be best near the intersections of fissures. This difference is not necessarily inconsistent with the operation of the same causes. Apparently both the Kearsarge lode and the amygdaloids to the north were mildly mineralized near the crossings by the solutions that traveled along the fissures. To judge from what can be observed in the mines on the Kearsarge lode, these early solutions also altered the lodes where they mineralized them, destroying much of their favorable chemical character, so that when the later mineralizing solutions came up along the Kearsarge lode they encountered unfarorable ground near the fissures and hence did not deposit much additional copper in those parts of the lode.

In the Ontonagon district the fissures are nearly parallel with the strike of the beds. In the main Minesota or North branch, mineralization occurs in the fissure at and above the supposed intersection with the Minesota conglomerate, suggesting that in this deposit the character of the bed crossed by the fissure is the controlling factor. The position of the downward extension of the fissure is not certain. If the dip and strike of its known portion are maintained it cuts across the beds; but there is a possibility that it curves into the conglomerate bed and becomes \& bed fissure.

From the foregoing statements it is apparent that a clear understanding of the cause of the localization of the copper in the fissures is of great importance in prospecting for this type of deposit. In the deposits at the Kearsarge lode crossings, for which the most definite information is available, the character of the lode seems to be the controlling factor. The deposits of which less is known, such as those under the Greenstone flow, afford reason to believe that the character of the lode is an influential factor, though the presence of the "slides" and the offsetting of the fissures, forming barriers, have aided in concentrating the flow of the solutions. 


\section{STATE OF DIVISION OF COPPER}

The Mass fissure of the Ahmeek mine (pl. 51) differs from most of the other known fissures in the district in that it contains practically no stamp rock, whereas from the others the recovery from stamp rock was large. The approximate percentages which the several kinds of copper made of the total production from the different fissures are as follows:

Cliff, 70 per cent mass, 15 per cent barrel, 15 per cent stamp Phoenix, 50 per cent mass and barrel, 50 per cent stamp. Central, 50 per cent mass, 50 per cent barrel and stamp.

Northwestern (1854), about 30 per cent stamp.

Minesota (1866), 30 per cent mass, 43 per cent stamp.

Copper Falls, a large amount of stamp copper.

Robbins, mainly stamp rock.

At nearly all the mines stamp mills were regarded as essential parts of the plants. Rock was stamped from the Stoutenberg, Clark, Eagle River, Madison, Amygdaloid Mining Co., St. Clair, and other fissures, in addition to those mentioned above. In the early days rock was calcined in stone kilns before being stamped.

\section{EXPLORATION OF FISSURES}

\section{INCENTIVE TO EXPLORATION}

The total production of copper from fissures has been small as compared with that from lodes. Each of the principal lodes of the district has produced nearly as much as all the fissures together, and most of them much more. The total amount of the dividends from fissure deposits has also been modest as compared with those resulting from lode mining. The dividend per pound of copper, however-about 3.5 cents - is about the same as that of the lode mines. It is worth while, therefore, to consider whether any considerable veins remain unopened or but partly developed.

Examination of the records and of the field indicates that by no means all the wide fissures that are exposed in the Greenstone bluff have been extensively explored; that almost nothing is known of the extensive areas comprised in the "gaps" in the Greenstone flow; that the experience gained in the Central exploration indicates that valuable deposits may be found in fissures that make little show where they cross the Greenstone bluff; and that a second favorable belt for fissure exploration may possibly be present east of the one under the Greenstone flow.

A distinct advantage in fissure exploration is that the promising zone beneath the Greenstone flow is very definitely outlined, and other areas of possible promise might be outlined with equal definiteness. The cost of exploration would be much less than in the early days, when much money was expended in promotion, in many separate organizations, and in roads, mills, and other features that could now be partly eliminated. Altogether there seems good reason to expect that a comprehensive campaign of fissure exploration would result in the development of mines that would give a moderate return for the effort. It is hardly to be expected that any great mines would be developed on fissures.

\section{GENERAL FEATURES OF EXPLORATION}

In any general plan of exploration of the fissures of Keweenaw County, there are certain features that should be considered. Among the more important are (1) significance of the gaps in the Greenstone flow; (2) significance to be attached to the character of the fissures as they are exposed in the Greenstone flow; (3) influence of thick, fragmental, well-oxidized amygdaloids on the precipitation of copper in the fissures; (4) influence of faults or barriers on the localization of copper.

1. There is little doubt that the gaps in the Greenstone flow have resulted from weakness of the rock due to faults or fissures. Definite indication of this is seen in the displacement of the rocks and in the shearing of the rock bordering some of these gaps, as the Eagle River gap and the Central gap. Two of the gaps have been prospected, the Madison and the Amygdaloid. In the Madison a fissure was exposed, but little was done on it, owing to the difficulty of drainage. In the Amygdaloid the Drexel fissure was developed by the Amygdaloid Mining Co. and yielded considerable copper. Diamond drilling across the North American, Arnold, and Central gaps has shown fissures present in each. Therefore, so far as developments have been carried in the north end of the district, there is reason to suppose that the gaps may mark the location of fissures.

On the Allouez anticline the strongest shatter zones, where they cross the Kearsarge lode, do not contain productive fissures. There are fissures in these zones, and what they contain in the belt under the Greenstone flow has not been determined.

The drilling of three of the gaps, the North American, Arnold, and Central, indicates that the gaps are due to fissuring and faulting, although in none is a wide shatter zone present. In the "road gap" at the Central mine there is a mineralized fissure; in the main gap, a fault with only a narrow fracture zone about 8 feet wide.

2. The Greenstone bluff and some of the ridges north of it are practically the only places where the fissures are naturally exposed, and it is important to know whether the character of the fissures as shown in the bluff is any indication of what is to be expected of them in the favorable zone below the Greenstone flow.

Naturally the fissures that appear largest in the Greenstone flow are the ones that have been chosen for prospecting. This prospecting has led to the development of one paying fissure mine, the Cliff; a second that would doubtless have paid under modern 
efficient management, the Phoenix; and several others that might have nearly or quite paid the cost of their development, as the St. Clair, the fissure mines at Delaware, and the Drexel. On the other hand, many of the other fissures prospected because of their prominence in the Greenstone flow have yielded little or no copper.

The most productive fissure, the Central, was not recognized where it crossed the Greenstone flow but was discovered in an outcrop about 600 feet south of this flow and in ancient pits which presumably were sunk on the outcrop of the vein. It therefore appears that too much reliance should not be placed on the appearance of a fissure in the Greenstone flow, but a more certain method and perhaps as cheap would be to drift on a favorable amygdaloid along chosen stretches of fissured ground with the idea of examining all the fissures of the area where they crossed the favorable zone.

3 . There is reason to believe that the thick fragmental, well-oxidized amygdaloids had a favorable effect on the precipitation of copper in the fissures. Such amygdaloids are present in the belt under the Greenstone flow and may or may not have been the controlling factor in making this a favorable belt. That it is a favorable belt has been well demonstrated. The practical question is therefore not so much whether the amygdaloids under the Greenstone flow have exerted a favorable influence as whether similar amygdaloids elsewhere that have not been explored have exerted such an influence. There are thick amygdaloids below this belt at about the horizon of the Osceola lode, in which fissures have been prospected but little. The Central fissure was mineralized at this general horizon, but other fissures have not been examined where they eross this belt. (See accompanying sections.)

4. A fault at the base of the Greenstone flow offsets some of the veins. Any interruption of the veins along such an inclined plane would tend to produce a barrier and concentration of solution beneath it. Such a barrier condition would favor the formation of deposits, although the evidence from the fissures that cross favorable parts of the Kearsarge, the Ashbed, and the conglomerates in the south end of the district suggests that barriers may not be essential.

\section{METHOD OF EXPLORATION}

Selected areas along a thick amygdaloid could be prospected either by sinking a shaft and drifting, or in places by driving an adit that would permit exploration near the surface. The latter method would eliminate both pumping and hoisting and would serve in the examination of long stretches of territory, but probably sufficient depth to explore under the deeper gaps could not be obtained in this way, and it would give only very shallow exploration of the promising fissures, which would then have to be examined further by shaft.
In the following paragraphs are suggested explora. tions which might determine the points outlined above and the results of which would of course influence any further consideration of the general problem.

At present all that is known about the influence of thick amygdaloids aside from that below the Green. stone flow is that the Osceola horizon where the Central fissure crossed it at depth was well mineralized and that the Vaughnsville fissure showed best in what was thought to be the Osceola amygdaloid.

It is of course possible to project any of the known mineralized fissures to the crossing of belts lower in the series and prospect at that point, but it would seem advantageous to use the information gained in prospecting the known favorable horizon in deciding how to prospect one that is little known.

\section{FISSURE MINES AND PROSPECTS OF KEWEENAW AND ONTONAGON COUNTIES}

Star.-Two miles south of Copper Harbor, in the E. $1 / 2$ sec. 9 , T. 58 N., R. 28 W., south of the Greenstone flow. Two shafts were sunk on the prineipal vein, 300 and 90 feet deep. These were connected by drifts and by an adit level for drainage. Little stoping has been done (1864). An amygdaloid belt 13 feet wide, carrying copper, was opened 150 feet east of the transverse vein. Another vein being prospected in 1864 carried rich barrel rock near the surface. D.S. Childs, the agent, reports opening two veins, one 700 feet to the west of the Star vein and one 600 feet to the east. The one to the west was opened 100 feet from the Greenstone flow, where it was 5 feet wide and well charged with copper. It was opened also 1,000 feet from the Greenstone flow, where it carried less copper. The recorded production of the Star Mining Co. is 17,938 pounds.

Clark. - South of Copper Harbor and north and west of the Star property. The veins bear N. $10^{\circ} \mathrm{W}$. and have been mined on both sides of the Greenstone flow. Two veins were opened by adit and three shafts. Small masses of copper were frequently found, enough to give encouragement but not enough to pay costs. The recorded production is 187,915 pounds.

Iron City. - Southeast of Mosquito Lake, in sec. 14, T. 58, N., R. 29 W. Two shafts were sunk 30 feet apart, No. 1 to a depth of 300 feet, and connected by levels. The vein was wide but failed to yield copper. Medora.-One mile southwest of Mosquito Lake, in the E. $1 / 2$ sec. 17 , T. 58 N., R. 29 W., immediately south of the Greenstone flow. The company was organized in 1851. Considerable work was done, bu a relatively small amount of copper was found Amygdaloid "floors" were said to be present as in the other mines.

Native Copper.- North of Delaware, in sec. 10, T $58 \mathrm{~N}$., R. $30 \mathrm{~W}$. Worked on a vein crossing the Ashbed horizon but found nothing encouraging. 
Conglomerate.-Under the names Northwest Copper Co., Pennsylvania Mining Co., Delaware Mining Co., and Conglomerate Mining Co. the veins and the Allouez conglomerate at Delaware were worked at different times. The Northwest Copper Co. began operations in 1847 and developed three fissures. To the end of 1859 it had expended $\$ 611,000$, and its copper sales had amounted to $\$ 328,000$. In 1861 the Pennsylvania Mining Co. was organized to take over the property. This company opened three additional veins and undertook extensive surface improvements, expending $\$ 126,000$, but produced no copper. In 1863 part of the territory was sold to the Delaware Mining Co., under the same management. The two companies are said to have spent nearly $\$ 2,000,000$ in the next few years but produced little copper. In 1866 the property was taken over by the bondholders. The two properties were in 1876 united as the Delaware Copper Mining Co. This company operated with little production till 1881, when it was reorganized as the Conglomerate Mining Co. The new company is said to have expended $\$ 1,300,000$ in making surface improvements and opening the Conglomerate mine. The mine at present belongs to the Calumet \& Hecla Consolidated Copper Co. Altogether more than $\$ 4,000,000$ was spent, and to 1886 a total of $7,188,000$ pounds of copper was produced. At no period in its history was the mine operated at a profit. Three fissures were developed to a considerable extent- the Stoutenberg, Delaware, and Hogan. The Stoutenberg was opened to the eighth level, the Delaware to the ninth level, and the Hogan to the fourth level. The geologic relations in all the fissures seem to have been essentially the same. The productive part of each was close under the Allouez conglomerate, though the fissures do not appear to have been mined into the Allouez conglomerate. The reports state that several amygdaloid "floors" were present in the mine and that the amygdaloids had a marked influence on the vein. The "floors" were also mined and apparently furnished a considerable part of the production. The maps show that the stoping on the amygdaloids decreased away from the fissures, indicating that the richness of the ground decreased in the same direction. Connecticut.-West of the Delaware. Owned by Amygdaloid Mining Co. Opened by three shaftsNo. 1, near Greenstone flow, 60 fathoms; No. 2, 20 fathoms; No. 3, 6 to 7 fathoms - and an adit. Adit level driven 551 feet; 10 fathoms below adit, drifted 181 feet; 20 fathoms below adit, 514 feet; 30 fathoms below adit, 147 feet. Total recorded yield 116,800 pounds of copper.

Amygdaloid.-Just west of the Delaware. Opened in 1860 and operated through 1878. No statement or map showing the amount of development has been found. Recorded production 1,541,180 pounds.

Eagle Harbor.-Explored a vein crossing the Greenstone flow, midway between the Madison and Amyg- daloid gaps. It was reported to carry good copper above the Ashbed horizon in sec. 8. It crossed the Greenstone flow in low, poorly exposed ground, and the explorations (1866) failed to locate the fissure. A vein through Madison gap was opened in the low ground. It carried some copper but was not further explored (1865) on account of the difficulty of working. A vein west of the gap was opened by a shaft and adit to a depth of 72 feet. The vein was found $31 / 2$ feet wide but was said to be in "hard rock" and unprofitable. The Essex fissure, which passes through a gap, was explored in sec. 16 by an adit. At 500 feet from the Greenstone flow a shaft 100 feet deep was sunk and a drift started north (1865?). The vein, where followed by the adit, was reported to be rich in stamp copper, but apparently further development did not reveal a valuable deposit. Another vein farther east, reported as 3 feet wide and yielding good stamp copper, was opened in 1866 . No production is recorded from these explorations.

Madison.-The Madison Mining Co. operated on three fissures--the Perkins, 2,000 feet west of Madison gap, and the East and West veins, 4,000 feet west of Madison gap. The East or main lode has three shafts and an adit level. No. 3 shaft is opened to the 20fathom level, No. 2 to the 30 -fathom, and No. 1 only to the adit level. Shafts were connected on the adit, 10 -fathom and 20-fathom levels, and some stoping was done. The West lode was opened by shafts and winzes to the 20 -fathom level with some stoping. It is reported that about $\$ 250,000$ was expended. The recorded production was 72,000 pounds. The Madison gap was not explored except for a pit that located a fissure.

Dana.-The Dana fissure, about 4,000 feet east of the Central mine, was opened by an adit 780 feet long and by three shafts, but it proved unproductive.

Copper Falls.-The Copper Falls Mining Co. was one of the earliest in the district. It conducted operations on several fissures and on the Ashbed lode. At different times tracts have been set aside from the original grant and recombinations made. At present the ground belongs to the Arnold Mining Co. Altogether the Copper Falls Co. collected $\$ 1,000,000$ from assessments and paid $\$ 100,000$ in dividends. It has the distinction of being the only mine in the north end of the district above the Greenstone flow that has paid dividends, but it evidently was not a profitable undertaking. The most prosperous period was in the late sixties, when a small but rich area in the Owl Creek vein was being mined. This vein was developed by an adit that starts near the base of the Great conglomerate and extends through the trap series, probably into the Greenstone flow. There is some uncertainty from the old records as to the relation of the ore to the different types of rock. In general it may be said that the fissure was productive only in the vicinity of the Ashbed lode. Apparently nothing 
encouraging was found from the Greenstone flow to a short distance below the Ashbed and from a short distance above the Ashbed to the Great conglomerate. According to Marvine's Eagle River section, there were no thick amygdaloids between the Greenstone flow and the Ashbed amygdaloid. Above the Ashbed are some amygdaloids but apparently none as thick as that flow. It seems logical to conclude that the Ashbed amygdaloid was a factor in the enrichment of the vein at this point. The Ashbed amygdaloid itself is mineralized and was mined for 1,000 feet or more on both sides of the fissure. No statement has been found to indicate whether it was notably richer or poorer near the fissure, though the old stope map suggests better ground near the fissure than at a distance. Datolite is abundant in the Owl Creek fissure and in the Ashbed amygdaloid. As the Ashbed was mined for part of the time the production from the fissures is not known accurately, but it is estimated as follows: Owl Creek fissure, 7,283,000 pounds; Copper Falls fissure, 731,000 pounds; Old Copper Falls fissure, 86,000 pounds; Hill fissure, 501,000 pounds; Childs fissure, 32,000 pounds. It is estimated that the Ashbed amygdaloid yielded $17,706,000$ pounds of copper.

Petherick.-The Petherick fissure is about 2,000 feet west of the Owl Creek fissure and has been developed in the same general stratigraphic horizon. It has been opened, so far as known, continuously by adit and shaft for about 2,300 feet along the strike and to a maximum depth from the outerop at No. 6 shaft to the adit level of about 225 feet. (See pl. 50.)

No accurate record is available of the stoping on this fissure. There was some stoping on the Ashbed amygdaloid adjacent to the fissure workings, of which, too, there is no record. It is therefore not known how much of the production of the Petherick Mining Co. came from the fissure and how much from the Ashbed. As indicated by the material on the dump, datolite was abundant in the fissure and in the Ashbed adjacent to the fissure. In this respect the Petherick resembles the neighboring Owl Creek fissure.

Old Copper Falls. - The Copper Falls Co. began work in 1845 on the Old Copper Falls fissure. The outcrop was exposed in the falls of the stream. The work was continued till 1850, and a depth of 267 feet was attained. Some good ground was developed, but the production was small and the operations were unprofitable.

Northwestern.-The Northwestern Mining Co. began operations in 1845 on a fissure below the Greenstone flow and worked rather continuously till 1857; some work was also done later by this company on the original fissure and on the southward extension of the Central fissure. Assessments to the amount of $\$ 228,000$ were collected, and copper to the value of about $\$ 75,000$ was produced. The workings comprised four shafts, 109, 201, 215, and 225 feet deep, an adit 1,226 feet long, and levels Nos. 10, 20, and 30, respeetively 944, 1,057, and 124 feet long. The recorded production is 313,000 pounds.

Central.-The description of the Central vein is compiled from the mine maps and from Hubbards account. The Central mine was opened in 1834 and closed in 1898. During this period it yielded $51,875,527$ pounds of copper, and the company paid about $\$ 2,130,000$ in dividends. The mine is opened on a fissure vein striking nearly at right angles to the beds and dipping very steeply to the east in the upper levels and slightly less steeply in the lower levels. There is no pronounced gap or outcrop of vein in the face of the Greenstone bluff to indicate where the fissure crosses. It may be offset by a strike fault at or near the base of the Greenstone flor. The fissure was discovered by outcrops and in ancient pits about 600 feet south of the Greenstone bluff. The productive part near the surface was close under the Greenstone flow, though the minable portion nowhere seems to have extended to or into the Allowe conglomerate. With increased depth the mineralized portion gets farther and farther from the Greenstone flow. The ore shoot has its greatest extent along the strike of the fissure at about the 100 -fathom level. Below that it narrows to about the 200 -fathom lerel, where it again expands; it continues to the Kearsarge conglomerate at about the twenty-ninth level, where the fissure is displaced by a fault. The principal structural features are the main fissure and the strike fault at the Kearsarge conglomerate. The fault cuts out the Kearsarge conglomerate and offsets the rein below the fault 284 feet to the west. The fact that the thick conglomerate is completely cut out by the strike fault suggests a large movement of which the horizontal offset of the fissure is a small component. Below the fault what is regarded as the continuation of the fissure was found to contain but little copper, though the fissure appears to be wide. No direct statement is made in Hubbard's description regarding the age of the fault relative to the period of mineralization. As the breccia along the fault is mineralized, however, it is probable that mineralization followed the faulting.

No detailed description of the character of the amygdaloids intersected by the fissure has been found. Pumpelly briefly described those in the upper part of the mine. He mentioned three soft brown amygds. loids between the Calumet \& Hecla conglomerate and the Houghton conglomerate. These are at about the horizon where the lode begins to widen out upward. The character of the amygdaloids below the Calumet \& Hecla conglomerate is not known. Central dis. mond-drill hole No. 9, west of the mine, and the one at Arnold Gap (No. 11) show thick fragmental 
amygdaloids above and below the Houghton conglomerate.

The cause for the concentration at this point is susceptible of several explanations. If the faulting preceded the mineralization, it is hardly reasonable to suppose that the mineralizing solutions rose along the fissure below the fault and then jumped across to the portion above the fault. If mineralization preceded faulting and the movement was of great magnitude, a barren part of the fissure might be brought into contact with a mineralized part. The mineralized portion of the fissure is immediately above the point where the conglomerate is cut out. This, together with the fact that the crushed portion of the Kearsarge conglomerate is mineralized, has led to the suggestion that the solutions rose along the conglomerate and escaped into the fissure where the conglomerate was cut out. The reason for the variation in mineralization along the fissure is not clear, and little information is available concerning the character either of the fissure or of the inclosing beds to give a basis for an interpretation. The map shows, however, a distinct tendency for the expansions in the shoot to extend along the bedding rather than across it. This suggests an influence of the beds in precipitating copper. The soft brown beds noted by Pumpelly at about the horizon where the upper expansion occurs may have influenced the precipitation. Whether similar beds are connected with the lower expansion is not known. The mineralization did not extend to the Greenstone flow, and so far as can be judged from the map there is little evidence of the deflecting or damming influence of this flow.

There appears to have been some mineralization of several of the amygdaloids near the fissure, and the Calumet \& Hecla conglomerate was well mineralized adjacent to the fissure at about the eighteenth level. Nowhere was commercial rock found to extend far from the fissure. In the Calumet \& Hecla conglomerate ore extended about 40 feet on each side of the fissure. The Houghton conglomerate was reported as well mineralized, but no stoping was done on it.

Winthrop.-The Winthrop Mining Co. worked several years on a fissure in the SW. $1 / 4$ sec. 23, T. 58 N., R. 31 W., west of the Central mine. No production is reported.

Eagle River.-The Babbitt vein, 1,000 feet east of the St. Clair, was opened in 1880 by the Eagle River Mining Co., which put down two shafts, 275 feet apart, one close to the Greenstone flow. The recorded production is 49,678 pounds.

St. Clair (acquired by the Phoenix Consolidated Copper Co.).- The St. Clair vein is east of the Eagle River gap, and the mine is immediately under the Greenstone flow. A fault or "slide" branches from the Greenstone flow contact about 150 feet below the outcrop. It dips more steeply than the contact and thus diverges from it with increasing depth. At the 10th level the stratigraphic distance between the Greenstone flow and the fault is about 350 feet. Practically all the stoping has been done between the Greenstone flow and the fault. The stopes seem to extend up to the flow and in places cross the fau't but have extended only a short distance below it. The mine was opened to the twelfth level. The vein is said to have been rich, carrying 2 to 3 per cent of copper, but it was narrow, and the mineralized area was relatively small. Under the conditions of operation it evidently did not pay.

Bay State.-The Bay State Co. operated on the Phoenix or Bay State fissure, south of the Phoenix mine, and was later absorbed by the Phoenix Co.

Phoenix.-The Phoenix Copper Co., now absorbed by the Keweenaw Copper Co., was organized in 1844 and was one of the earliest companies in the district. It operated on numerous veins and on the Ashbed amygdaloid. The total assessments by the old Phoenix and the Phoenix Consolidated are given by Stevens as $\$ 2,385,500$, and the dividends as $\$ 20,000$. The only really profitable operations seem to have been conducted for a few years in the early seventies on the Phoenix fissure.

Phoenix fissure.-The only description found of the rocks under the Greenstone flow in the Phoenix mine is that by Marvine. This description does not give the impression of any particularly thick amygdaloids in the mine. There is a belt of thin flows, but the amygdaloids are apparently small. The Allouez conglomerate is represented by a "slide." Extensive stoping has nowhere been carried more than 1,400 feet from the Greenstone flow along the level, or about 700 feet across the beds. Nothing has been seen in the reports to indicate where the richest ground was found. The vein evidently varied in grade from place to place, but there is no statement of the conditions accompanying this variation. Neither is it stated whether or not there was a notable change in grade from the surface downward. The deepest workings on the inclined shaft are at a vertical depth of about 1,000 feet. Stevens states that the yield from 1872 to 1885 was 473 pounds per fathom, or about 1.5 per cent. No mention is made of operations on amygdaloids.

Robbins or West.-The Robbins or West vein was developed by the Phoenix Co. a short distance west of the Phoenix or Bay State vein. It has a more easterly strike than the Phoenix and cuts the beds at an acute angle. The mineralized belt, as indicated by the stope map, is 100 to 250 feet wide and 50 to 75 feet below the Allouez slide. The maps indicate but one amygdaloid belt, 300 to 350 feet below the stopes, but other amygdaloids are undoubtedly present. The mine has been opened to a vertical depth of about 600 feet. 
Some good ground was found, but as a whole it did not pay. The vein is said to have contained no mass copper, producing stamp rock only.

Old Phoenix.-A vein was encountered under the bed of Eagle River near the Ashbed crossing and followed for several hundred feet. One account of this vein describes the copper and silver as occurring with waterworn pebbles, suggesting a placer deposit. Others indicate that it is a vein that has been followed by the river. A few thousand pounds of copper and some silver was taken from this vein. It apparently was never developed at depth except where the Ashbed drift crossed its downward extension. There it is a thick calcite vein with some copper but not in commercial quantities.

Vaughnsville.-The Cliff Copper Co. opened the Vaughnsville fissure, nearly a mile south of the Greenstone flow. The strongest mineralization was found at the intersection of an amygdaloid supposed to be the Osceola.

Cliff.-The Cliff mine, on the Cliff fissure, was the first large copper producer of the Lake Superior region. Production began in 1845, when it yielded about 20,000 pounds of copper. The mine was operated, with the exception of an interval from 1870 to 1872 , until 1883. It was idle from 1883 until 1906, when it was reopened and some amygdaloids in the upper levels were explored adjacent to the fissure. A total of $38,207,000$ pounds of copper was produced, and the company paid $\$ 2,518,620$ in dividends.

The productive portion of the Cliff fissure lies under the Greenstone flow. At the mine the Allouez conglomerate is represented by the "slide," a few inches of clay gouge. Immediately under the slide is a series of small flows numbered in the Cliff mine upward from 1 to 13 . These have an average thickness of about 50 feet, and so far as can be judged from the old maps, from one-third to one-half of the rock in this belt is amygdaloid. The five beds next to the Calumet \& Hecla conglomerate average about 90 feet in thickness. The series of thin beds beneath the Greenstone flow form a relatively weak zone, as is indicated by the pronounced depression in the bedrock surface just south of the Greenstone bluff. The thickest amygdaloid, as indicated on the maps, is No. 13, the one immediately beneath the "slide." No. 9 is also indicated on the maps as a thick amygdaloid. No detailed description of the amygdaloids has been found, and it is therefore not known whether they are fragmental or how well they are oxidized. Examination of the dump indicates that there is at least one fragmental, well-oxidized amygdaloid. The diamonddrill section west of the fissure shows some thick fragmental amygdaloids below the Houghton conglomerate. The developments have been confined to beds above the Calumet \& Hecla conglomerate.
The Cliff fissure cuts nearly at right angles to the beds and dips steeply to the east, with local reversed of dip. It is well exposed as a wide veined and shattered zone in the face of the Greenstone bluff and has been followed from a point south of the Cliff mine workings to the lake shore. In places in the mine workings it branches. There are two "slides" noted in the mine workings - one at the horizon of the Allouez conglomerate and one that reaches the surface at about No. 2 shaft, South Cliff. Both are essentially parallel to the beds, and both have displaced the fissure but slightly. The second slide has two branches for the first few hundred feet. Just north of $\mathrm{N}_{0.3} 3$ shatt, South Cliff, the lode is crossed by a strong zone of fissuring, which is represented on the maps as vertical. Little development work has been done south of this zone.

The mineralization was in the main confined to the fissure, though there was some mineralization of the amygdaloids. Here, as in the more productive part of the mine, the amygdaloids are closely spaced, and the old maps show no close relation between masses of copper and amygdaloids. Old reports speak of rich copper in the vein associated with the ninth and thirteenth floors, and on one of the old maps special mention is made of rich ground in the fissure where it intersects the thirteenth floor (just below the slide) from the 30 -fathom to the 60 -fathom level. In the lower levels, however, mineralization does not seem to have been strong in the thirteenth floor.

Mention is also made of rich ground where the fissure splits and includes a horse of the country rock. To the north the mineralization was limited by the slide. The vein passes through the Greenstone flow but has not been found to contain commercial copper there. The North Cliff workings are at the intersection of the fissure with the Ashbed amygdaloid. Here the vein is said to be a zone of fissuring 10 feet wide, but it contained relatively little copper.

No very clear description of the distribution of the copper in the fissure south from the Allouez slide has been found. The general impression gained from the old reports is that the vein was richest close to the Greenstone flow and grew leaner toward the south, and that the distribution was irregular, the richest portions being associated with the intersections of amygdaloids

In some of the old reports the statement is made that the mineralization was eut off on the south "slide," and the maps show that very little stoping was done south of that slide. The vein may have about reached the limit of profitable working before passing the slide, and therefore it is not clear that the slide itself was an important factor in limiting the mineralization. The fissure and mineralization ver! evidently extended south of the slide. Exploration at No. 5 shaft, which is on the southern projection o 
the Cliff vein, has failed to disclose a strongly mineralized fissure.

Two possible causes for the richness of the fissure beneath the Greenstone flow have been suggested:

1. The fissure has been offset at the slide about 20 feet. If this offset occurred before mineralization, the interruption of the fissure and the presence of the gouge of the slide would form a barrier that might result in a concentration of solutions rising along it.

2. The area of greatest productivity is in a belt in which amygdaloids are very abundant, and there evidently was a relation between richness of the vein and some of the amygdaloids. The available description of the amygdaloids is too meager to judge of their character, but if there are several well-oxidized amygdaloids they might be an influential or even a controlling factor in the mineralization.

North Cliff.-The North Cliff Mining Co. w as organized in 1858 to work the extension of the Cliff fissure above the Greenstone flow on lands set apart by the Pittsburgh \& Boston Mining Co. The Cliff fissure had previously been traced by pits every few hundred feet from the most northerly Cliff shaft to the base of the Great conglomerate, a distance of 9,000 feet. In the Greenstone flow the fissure was found to be not more than 14 inches wide and to contain only a little copper. In the Ashbed lodes the vein was found broken into numerous branches for a width of 10 feet or more, and the branches were well filled with barrel and stamp copper. Three vertical shafts were sunk on the fissure near the Ashbed lode, one to the 30fathom level, and an adit was driven south for more than 1,700 feet, cutting the Ashbed. The production to March 21, 1864, was 5,657 pounds of refined copper taken from the fissures as masses. An inclined shaft was also sunk on the Ashbed in or near the Cliff fissure, and some drifting was done on that lode, but there is no record as to the results obtained.

North American.-The North American Mining Co. worked for four years on a fissure under the Greenstone flow in the E. $1 / 2$ sec. 2 , T. 57 N., R. 32 W. The workings are on the north side of the North American gap, and the bearing of the fissure, N. $58^{\circ}$ W., is such that it soon enters the gap. It was worked to a depth of 415 feet. The total yield was 445,000 pounds of refined copper. The fissure is split into three parts in the upper levels. There appears to be a difference of about $30^{\circ}$ in the trend of the fissure and that of the gap.

Albion-Manhattan.-The Albion-Manhattan Co. in 1848 sunk a shaft 115 feet through the Greenstone flow, drove an adit to connect with it, and sunk 200 feet below the adit level. The vein was $2 \frac{1}{2}$ feet wide but barren. Later a shaft sunk to a depth of 70 feet near the Greenstone flow yielded 5 tons of copper.

Mohawk.-Several arsenide fissures have been prospected in the north end of the Mohawk mine. The main mineralized area is at the crossing of the Kearsarge lode and extends for a short distance into the hanging wall of the Kearsarge. A fissure opened south of No. 6 Mohawk shaft contained some copper near the intersection with the lode. The lode is also reported as rich near the fissure.

Fulton.-The Fulton fissure was opened in 1853 in the SW. $1 / 4$ sec. 33 , T. 57 N., R. 32 W. The vein was 18 inches wide. The same fissure has been opened in the North Ahmeek mine, where some masses of copper have been found, but as it is arsenical little has been mined. What seems to be the same fissure has been opened under the Greenstone flow. The vein material on the dump contains copper, but no record of the work has been found. The recorded production from this fissure by the Forsythe Mining Co. was 1,255 pounds, and some copper has also been produced by the Mohawk and Ahmeek mining companies.

Mass. - The Mass fissure of the Ahmeek mine where it crosses the Kearsarge lode strikes about N. $20^{\circ}$ W. and dips steeply to the east. The fissure has been opened to the twenty-sixth level. Along the strike it has been developed to maximum distances of about 1,100 feet to the northwest from the Kearsarge lode and about 600 feet to the southeast. A slide fault intersects the fissure about 200 feet stratigraphically and 300 feet horizontally above the Kearsarge lode. The fissure, however, is not displaced. The fissure varies considerably in character from place to place. Commonly the fissure zone has a width of 2 to 4 feet, but it may pinch to a few inches or may spread to considerably more than the average width. Where the fissure zone is broad the rock within is sheared and brecciated.

Calcite is the most abundant vein mineral. Locally a foot or more of calcite occurs in the fissure. Quartz, epidote, prehnite, and laumontite are locally present. Copper occurs typically in large irregular more or less lenticular masses. In places there is a solid mass of copper a foot or even more in thickness in the vein. Some masses containing more than 200 tons of copper have been mined. Where the massive copper occurs the other vein minerals are usually sparsely represented. Chloritization is the most characteristic alteration of the wall rock and the breccia within the fissure, though there is some sericitization.

Most of the copper has been mined within 400 feet horizontally above and 200 feet horizontally below the Kearsarge lode. Copper is known to occur 1,000 feet from the Kearsarge lode, but the masses beyond 400 feet are small and scattering. Little copper has been mined above the ninth level. The general distribution of copper is shown in Plate 51. The Mass fissure to the end of 1925 is estimated to have yielded $11,567,000$ pounds of copper.

Arsenide.-The Arsenide fissures in the Ahmeek, Mohawk, and Seneca mines have the same general dip 
and strike as the Mass fissure. They have been developed but a short distance away from the Kearsarge lode. The principal vein minerals are quartz, calcite, ankerite, and the copper arsenides. Albite, prehnite, and laumontite are present in variable amounts. The typical rock alteration associated with the Arsenide fissures is chloritization and sericitization. In places the veins contain a foot or even more of nearly solid copper arsenides at their intersections with the Kearsarge lode, but there has been little production from these veins.

Minesota and Branch fissures and Calico lode.-The occurrence of the ore in the Calico lode of the Minesota mine is closely associated with that in the fissures, and they are therefore described together. The statements here given are based on old descriptions and company maps and records, as there was no opportunity for underground examination. The copper occurs mainly in two northward-dipping beds and in strike fissures that parallel the beds or dip more steeply than the beds and cut them. The lower bed, the Minesota conglomerate (South Branch) is about 125 feet below the Calico amygdaloid (North Branch). Striking nearly parallel with the beds is the Branch fissure (Middle Branch), which cuts both the Minesota conglomerate and the Calico amygdaloid. The Minesota fissure is represented as diverging from the Branch fissure where the latter cuts the Minesota conglomerate and as following the top of the conglomerate to the outcrop. The operations on the Minesota fissure (pl. 52) were among the earliest and have been the most profitable in Ontonagon County. No separate record of the copper from the Minesota and Branch fissures and Calico lode is available, but most of the output came from the Minesota and Branch fissures. Production began in 1848. To 1880 a total of $53,000,000$ pounds of copper was produced from the Minesota, National, and Rockland mines, and dividends of $\$ 2,140,000$ were paid.

T'The Michigan Copper Mining Co., began operations in 1899. From 1899 to 1912 the Calico lode and the Branch vein were rather extensively opened and mined. The Branch vein was apparently the most productive. A total of $17,180,000$ pounds of copper was produced. The yield from the stamp rock probably did not exceed 12 pounds to the ton, but there was much mass copper, especially on the Branch vein.

Production and dividends from Minesola and Branch fissures and Calico lode

\begin{tabular}{|c|c|c|c|c|}
\hline \multirow[b]{2}{*}{ Mine } & \multirow[b]{2}{*}{ Period } & \multirow[b]{2}{*}{$\begin{array}{l}\text { Copper produced } \\
\text { (pounds) }\end{array}$} & \multicolumn{2}{|c|}{ Dividends } \\
\hline & & & Total & $\begin{array}{l}\text { Per pound } \\
\text { of copper } \\
\text { (cents) }\end{array}$ \\
\hline $\begin{array}{l}\text { Minesota... } \\
\text { National } \\
\text { Rockland... } \\
\text { Branch } \\
\text { Calico lode. }\end{array}$ & $\begin{array}{l}1848-1885 \\
1853-1895 \\
1854-1880 \\
1902-1912 \\
1900-1913\end{array}$ & $\begin{array}{r}34,707,000 \\
11,613,000 \\
5,821,000 \\
a 9,174,000 \\
a 8,006,000 \\
\end{array}$ & $\begin{array}{r}\$ 1,820,000 \\
320,000 \\
\end{array}$ & $\begin{array}{r}5.24 \\
2.67 \\
\\
\\
\end{array}$ \\
\hline & & $69,321,000$ & $2,140,000$ & 3.00 \\
\hline
\end{tabular}

Estimated.
The Minesota conglomerate is a few hundred feet above the Evergreen and succeeding lodes, and the Calico amygdaloid is about 125 feet anove the Mine. sota conglomerate. Next above the Calico lode is the North lode, on which some development work has been done. The beds dip $47^{\circ}-50^{\circ} \mathrm{N}$., steepening slightly with increased depth and toward the south. west. Striking approximately with the beds but dipping at a steeper angle is the Branch vein or fissure. The outcrop is mainly in the hanging wall of the Calico lode except between shafts A and B. At shaft $\mathrm{B}$ the Branch vein is represented as diverging from the Calico lode above the fifth level and entering the conglomerate between the thirteenth and fourteenth levels. The dip varies considerably from place to place. At the contact with the conglomerate the Branch fissure is represented as splitting off from the South or Minesota fissure, which is shown as following the hanging wall of the conglomerate to the outcrop. There was apparently little displacement of the beds on the Branch fissure, though in places at least there seems to have been much shattering of the rock. Other fissures are mentioned in the records but do not seem to have been of great importance.

The Minesota conglomerate where seen on the out crop is a pebble to boulder conglomerate composed mainly of felsitic material and similar to the other felsitic conglomerates of the area. In some sections it is represented as 25 feet thick and underlain by nearly as much sandstone, though it doubtless varies in thickness and averages less than 25 feet.

The Calico lode is apparently a fragmental lode varying in thickness and in character from place to place, as is characteristic of the fragmental lodes in general.

The Minesota fissure follows the hanging wall of the Minesota conglomerate from the outcrop to its intersection with the Branch fissure. The copper occurred characteristically in masses, some of great size. One mass of 527 tons, the largest ever found, was taken out in 1856. The masses are said to hare occurred both in the fissure and in the underlying conglomerates. Apparently much of the copper replaced conglomerate but was closely associated with the fissure. Where seen on the dump the copperbearing conglomerate shows the bleaching by remoral of iron characteristic of conglomerate mineralization elsewhere. The Minesota fissure was productive from the surface to about the 140 -fathom level. Beyond the junction of the Branch fissure it appears to have been poor, at this junction and those of minot fissures it was apparently rich.

The developments on the Calico amygdaloid by the Michigan Copper Mining Co. showed the best groum to be at and above the intersection with the Brancl fissure, especially in shafts A and B. There was some fair ground reported below the intersection in shat 
C, but not much was stoped. The Calico lode yielded little mass copper, the output being mainly stamp rock.

The Branch fissure was mined by the Michigan Copper Mining Co. nearly to the intersection of the Minesota conglomerate between shafts $\mathrm{B}$ and $\mathrm{C}$, but at the intersection it was said to be lean. It is not clear from the descriptions whether the fissure continued on its normal dip through the conglomerate or flattened into the dip of the conglomerate. The copper occurred mainly as mass copper, but there was considerable production from stamp rock.
Norwich.-The Norwich mine, 8 to 10 miles southwest of the Victoria mine, was productive intermittently from about 1852 to about 1870 . The records show an output of 993,360 pounds of copper. The operations were mainly on fissures crossing the beds. The fissures contained some large masses of copper, but considerable rock was also milled. The fissures are described as quartz-epidote veins. The Norwich property was later explored by the Cass Copper Co., mainly by diamond drilling. Northeast of the Norwich mine there were some early operations on fissures, but apparently little copper was produced.

\section{LARGE-SCALE MAPS AND GEOLOGIC SECTIONS}

The surface maps of the district were prepared on a scale of 1 inch $=500$ feet. A small edition of these maps was published in 1925 . The cross sections were prepared on a scale of $1 \mathrm{inch}=200$ feet. Part of them were prepared on tracing cloth and can be reproduced by blue printing. It was not found feasible to publish the detailed descriptions of sections, but two copies of such records have been prepared.

The original plates of the large-scale surface maps and of the cross sections have been deposited with the Michigan School of Mines and Technology at Houghton, together with one copy of the description of geologic sections. A second copy of the description of geologic sections has been deposited in the Calumet \& Hecla library at Calumet. A few copies of the large-scale maps are available for distribution by the United States Geological Survey.

\section{ADDENDA TO BIBLIOGRAPHY}

The following entries were obtained after this report was in page proof:

Baldwin, C. Kemble.

Tailings disposal plant at the Wolverine mill: Eng. and Min. Jour., vol. 88, pp. 71-73, 1909.

Blake, William P.

The mass copper of Lake Superior mines and the method of mining it: Am. Inst. Min. Eng. Trans., vol. 4, p. $110,1876$.

Broderick, Thomas Monteith, and Hohl, C, D.

Geophysical methods applied to exploration and geologic mapping: Econ. Geology, vol. 23, pp. 489-514, 1928.

Campbell, A. C.

The copper and iron bearing rocks of Lake Superior: Eng. and Min. Jour., vol. 31, pp. 20-21, 1881.

Cooper, James B.

The history of copper smelting in the Lake Superior region: Eng. and Min. Jour., vol. 71, pp. 529-530, 1901.

Crane, W. R.

Drilling practice in the Lake Superior copper mines; Drifting and stoping at Lake Superior; Underground ore handling at Lake Superior; Shaft sinking at the Wolverine mine; Ore breaking at Lake Superior; Mine timbering at Lake Superior: Eng. and Min. Jour,, vol. 82, 1906.
Edwards, G. E.

The Quincy mine, Michigan, from stope to smelter: Min. and Eng. World, Apr. 20, 1912.

Fraser, Lee.

Practice at the Osceola mill, Lake Superior: Eng. and Min. Jour., vol. 83, pp. 1180-1183, 1907.

Hodge, Walter R.

The Ahmeek mill, Hubbell, Mich.: Eng. and Min. Jour., vol. 94 , pp. $749-571,1912$.

Hore, Reginald Edwin.

Methods of prospecting and developing deposits in Michigan: Canadian Min. Jour., Jan. 1, 1913.

Houghton, JACOB, Jr.

Early history of the mineral region of Lake Superior: Am. Min. Jour. and Railroad Gazette, vol. 1, pp. 57-59, 1847.

Lowe, Francis A.

The Silver Islet mine and its present developments: Eng. and Min. Jour., vol. 34, pp. 320-323, 1882.

Moffett, S. E.

Romances of the world's great mines, III, Calumet \& Hecla: Cosmopolitan, April, 1903.

Paine, Ralph D.

The story of a copper mine: Outing, June, 1907.

Rice, Claude T.

Baltic method of mining: Eng. and Min. Jour., vol. 93, pp. 843-847, 1912; Sinking the Hancock No. 2 shaft: Eng. and Min. Jour., vol. 95, pp. 787-791, 1913.

Rolker, Charles M.

The Allouez mine and ore dressing, as practiced in the Lake Superior copper district: Eng. and Min. Jour., vol. 23, pp. 274-275, 294-296, 314-315, 335-336, 1877.

Singewald, Joseph T., Jr.

Genetic comparison of Michigan and Bolivian copper deposits: Econ. Geology, vol. 23, No. 1, pp. 55-61, 1928; Review of "Beiträge zur Frage der Entstehung der Balimanischen Kupferzlagerstätten vom Tyrus Carico," by Bruno Geier (Neues Jahrb., Beilage-Band 58, pp. 1-42, 1927): Econ. Geology, vol. 23, pp. $583-584,1928$.

Skewes, Edward.

Electric ore-finding system: Eng. and Min. Jour., vol. 75, pp. 780-782, 1903.

Stone, Charles J.

Lode copper mining on Keweenaw Point, Michigan: Min. World, October, 1908.

Winchell, Newton Horace.

Ancient copper mines of Isle Royal: Eng. and Min. Jour., vol. 32 , pp. 184-186, 201-202, 1881. 



\section{INDEX}

Page

\section{A}

Acknowledgments for aid Adventure company, production by

Adventure mine, features of

Aetna company, production by.

Age of the rocks

Ahmeek company, dividends paid by

production by

Alaska, copper deposits in.

143-144

Albany \& Boston company, production by ............................... 77

Albion-Manhattan prospect, opening of ............................... 231

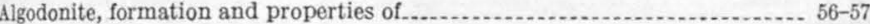

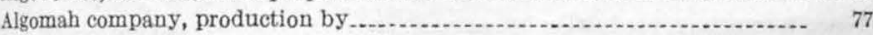

Algomah lode, features of ....................................................... 217

Allouez company, dividends paid by .................. 73

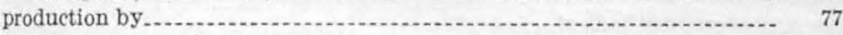

Allouez conglomerate, development on ...................................... 181-182 longitudinal sections of ..................................... Plate 37 , in pocket

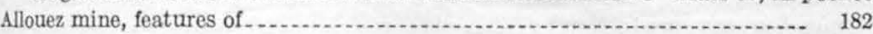

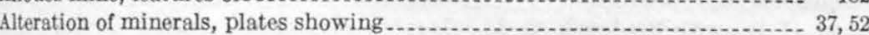

of rocks, causes and effects of

Amygdaloid company, production by ............ $77-78$

Amygdaloid lodes, bleaching of, plate showing ............................. 132

Amygdaloid mine, working of .............. 227

Amygdaloidal conglomerate, origin of

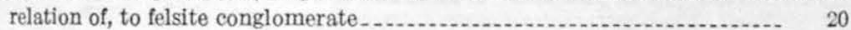

Amygdaloids, bottom layer of

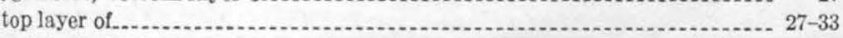

Amygdular inclusions, glaciated surface showing resistance of, plate showing.. $\quad 17$

Arcadian company, production by

Arcadian lode, features of

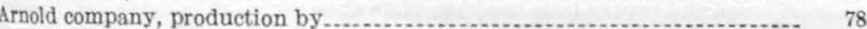

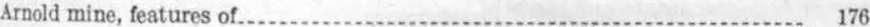

Arsenide fissures, work on ...................................................... 231-232

Arsenides, occurrence of $\quad 56-58$

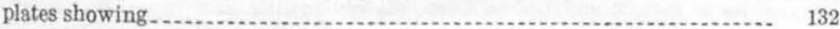

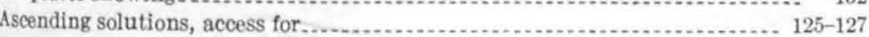

direction of movement of $\ldots$

precipitation of, by oxidation. .......................................... 129-137

by reduction......................................................... 127-129

in consequence of saturation 129

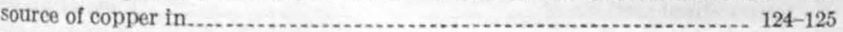

Ash, occurrence of ......................................................... 21

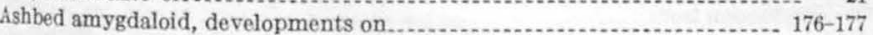

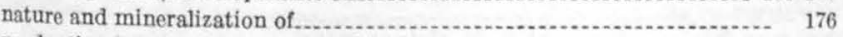

production from. 175

Ashbed company, production by.

Ashbed lode, longitudinal sections of

Atlantio company, dividends paid by production by

Atlantic mine, features and production of

Atmosphere, possibility of oxidation of iron in lava tops by

Aztec company, production by.

Plate 34, in pocket

78
73

73

78
177

42

79

\section{B}

Baltic company, dividends paid by

production by

Baltic lode, extent and correlation of longitudinqi sections of. mineralization of.

nature of rocks of.

production from

structure of

$\begin{array}{r}218-219 \\ \hline\end{array}$

$\begin{array}{ll} & 133\end{array}$

West lode, features of

longitudinal section of.

Barriers, effect of.

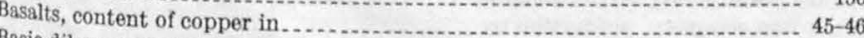

Basic dikes, occurrence of.

Bay State company, production by

Bay State prospect, work on

Belt company, production by

Bibliography on the copper deposits

addenda to . . . . 233
Bleaching, oxidation indicated by ..................................... 133-136

plate showing

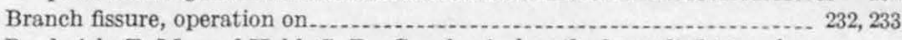

Broderick, T. M., and Hohl, C. D., Geophysical methods applied to exploration and geologic mapping.

$156-168$

Butler lode, description of

C

Caledonia company, production by ................... 79

Calico lode, operation on $\ldots \ldots \ldots \ldots+232$

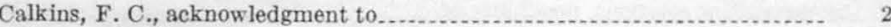

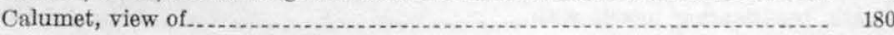

Calumet \& Hecls conglomerate lode, alteration in .

alteration in, plate showing.

composition of............................................................ 183-185, 186

content of ore at and below the surface in ............................... 112-113

longitudinal section of ..................................... Plate 38, in pecket

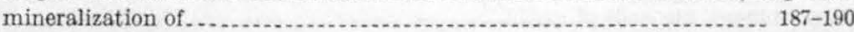

production from .............................................................. 183

structure of $186-187$

texture of

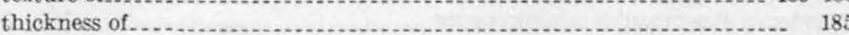

Calumet \& Hecla Consolidated Copper Co., acknowledgment to ...............

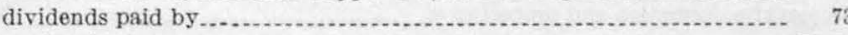

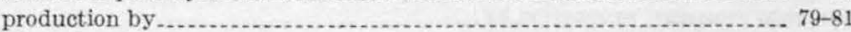

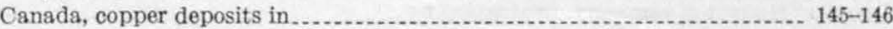

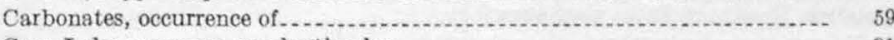

Carp Lake company, production by ..................................... 81

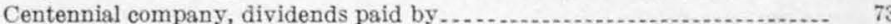

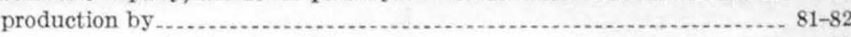

Central company, dividends paid by ...................................... 73

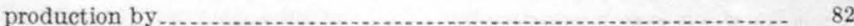

Central mine, development of $\ldots$ mineralization in . . . . 228-229

Champion company, dividends paid by .................................. 73

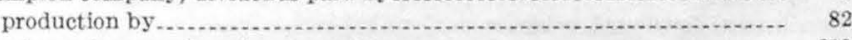

Cherokee mine, opening of .............................................. 212

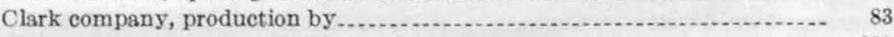

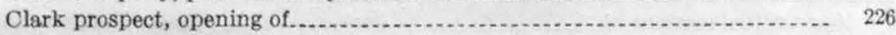

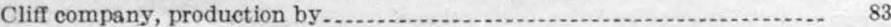

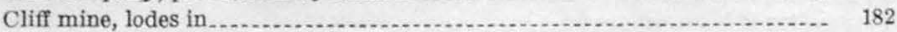
mineralization in . . .

pperation of

Climate of the district.................................. 14-15

Composition, chemical, of the rocks, influence of, on the position of ore shoots. 118

Concord company, production by ........................................ 83

Conglomerate, nature and source of .................. 18-21

Conglomerate mine, development of ....................... 227

Connecticut company, production by ........................................... 83

Connecticut mine, opening of . . . .

Contact Copper Co.'s mine, geologie sections in............. Plate $2 \delta$, in pocket

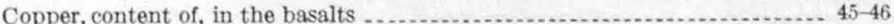

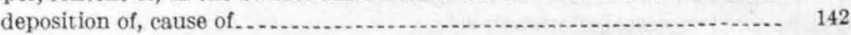

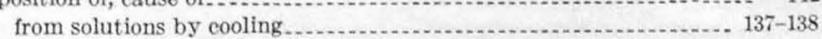
from solutions by dilution $\ldots 139$ from solutions by fractional oxidation of copper sulphide.......... 138-139 by reduction of acidity ......................................... 139-141

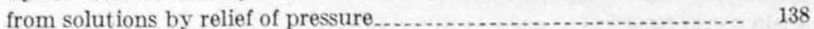

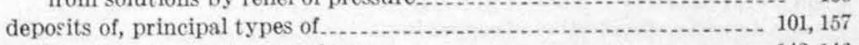

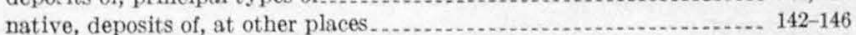

intergrowth of, with silver, plate showing.......................... 52

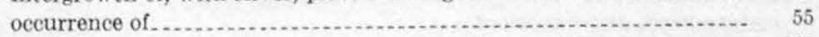

source of

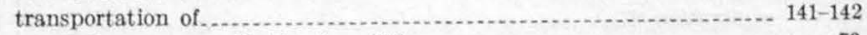

Copper Falls company, dividends paid by production by ............ 83-84

Copper Falls mine, description of
development of

Copper Range, geologic map of, from Adventure to Victoria... Plate 13, in pocket geologic map of, from Atlantic to Challenge............... Plate 10, in pocket from Challenge to Winona.............................. Plate 11, in pocket from Copper Falls to Gratiot........................... Plate 7, in pocket from Gratiot to La Salle.

Plate 8 , in pocket 
Copper Range, geologic map of, from Keweenaw Point to Mount Houghton

from La Salle to Atlantic

from Mount Houghton to Delaware

from Winons to Adventure

$$
\text { map of }
$$

stratigraphic sections of

topographic map of, from Painesdale to Cliff, Mich

Copper Range company, dividends paid by

Coro Coro, Bolivia, copper deposit at

Dans prospect, opening of.

Plate 5 , in pocket Plate 9 , in pocket Plate 6, in pocket Plate 12 , in pocket Plate 3 , in pocket Plate 15 , in pocket Plate 4, in pocket

74 142

porcelanic, inclosing copper, plate showing

mammillary surface of, plate showing

Delaware, development at.

Delaware company, production by

Denton, F. W., quoted

Deposition of copper by ascending solutions by descending solutions, possibility of.

Depth, persistence of metals with richness in relation to .

Derby company, production by

Descending solutions, precipitation from source of copper in. transportation of ....

Development, methods of

Diamond drill, use of, in exploration

Distribution, geographic, of ore deposits geologic, of ore deposits

Dividends of companies mining copper

Dolerite, texture of

Domeykite, formation and properties of

Douglass company, production by

Douglass Houghton company, production by.

Douglass Houghton Falls, plate showing...

Drill cores improperly stored, plate showing

Eagle Harbor prospect, opening of

Eagle River company, production by

Eagle River mine, work on

Elm River mine, geologic sections in. opening of

Enrichment, downward, evidence on

Evergreen Bluff company, production by

Evergreen lode, development on. longitudinal sections of

Exploration of lodes, guides for

methods of

process of

Extrusive rocks, composition of distribution and thickness of

nature of.

texture of.

Faults of the district

$48-50$

age and cause of

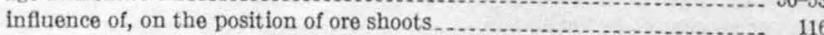

Felsite conglomerate, bed underlying.

nature and distribution of

source and deposition of.

Ferric iron, oxidizing action of

$19-20$

131-136

Field work, record of . . . . . .

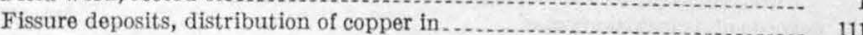

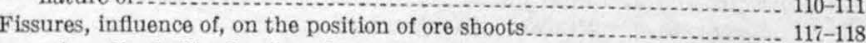
mineralized, distribution of..

distribution of copper in .......... $223-224$

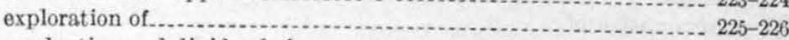

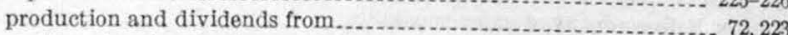

sections showing development along

Plate 50, in pocket

Flint Steel River company, production by.

Flows, thick, influence of, on the position of ore shoots

Fluorite, occurrence of
Folds of the district.

age and cause of.

influence of, on the position of ore shoots

Forest lode, description of

longitudinal sections of.

Franklin company, dividends paid by production by.

Franklin Jr, mine, features of.

Freda sandstone, occurrence of...

Fulton company, production by

Fulton mine, work on

Garden City company, production by

Geography of the district.

Geologic work, suggestions for -

Geophysies, electrical methods of exploration by

principles and use of, in exploration for copper

Grand Portage company, production by...

Gratiot company, production by.

\section{$\mathrm{H}$}

Hancock company, production by

Hancock lode, longitudinal sections of ...

Hancock mine, lodes of

Hauling of ore, methods of -

Hematite. See Ferric iron.

Hillenbrand, W. F., acknowledgment to

Hilton company, production by.

Hohl, C. D., with Broderick, T. M., Geophysical methods applied to explo-

ration and geologic mapping.

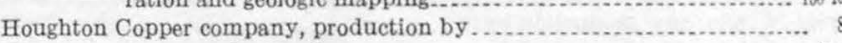

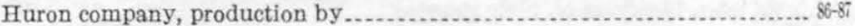

Hydrocarbon, occurrence of . . . . . . . . . . . . . . . . . .

Hydrothermal action, possibility of oxidation of iron in lava tops by ......... $41-4$ ?

Igneous rocks. See Extrusive rocks and Intrusive rocks.

Indiana company, production by.

Indians mine, felsite of

Indians, stone and copper tools used by, plate showing -

Intrusive rocks, nature and kinds of .................................... 40-4

Investigations, earlier.

Iron City prospect, opening of.

Iron oxides as seen in polished sections, plates showing.

Island company, production by.

Isle Royale company, dividends paid by production by.

Isle Royale lode, depasition of ore on

extent and correlation of.

longitudinal sections of

nature of rocks of

production from.

structure of.

Isle Royale mine, view north from, plate showing.

Isle Royale property, openings on.

Kearsarge company, dividends paid by production by

Kearsarge flow, description of

Kearsarge lode, causes of rich and poor ground on

content of ore at and below the surface in

longitudinal section of

mineralization of

nature of rocks of.

production from.

shafts on, plate showing

structure of

Kenney, H. C., acknowledgment to.

Keweenaw Copper company, production by

Keweenaw fault, age and cause of features of.

Keweenaw mine, longitudinal sections of

of ....................... Plate 37 , in pockel

Keweenawan series, subdivisions of

Knowlton company, production by

Knowlton lode, development on. longitudinal sections of.

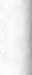
$4 i$ $2-3$ 
Page

Robbins mine, development of

Rock-forming period, formation of minerals in

Rockland company, production by

Saginew company, production by

St. Clair company, production by

St. Clair mine, development of .

Salt-water horizon, evidence on enrichment a

Scope of the report

Sections, method of showing rocks in.

Seeber, R. R., acknowledgment to

Seneca company, production by

Shelden \& Columbian compony, production

Shoots, conditions determining position of .......................

Silicates, occurrence of

Silver, intergrowth of, with copper, plate showing ............................ 52

occurrence of, in the Calumet \& Helca lode.............................. 190

Siskowit company, production by ........................................... 96

Smelting, practice in

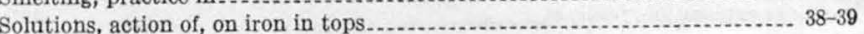

South Lake company, production by .......................................... 96

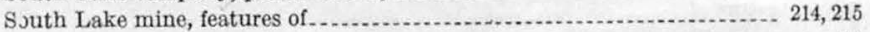

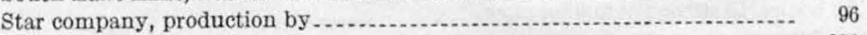

Star mine, features of ........................................................... 226

Stoping, methods used in

Structure of the district............................................ 48-53

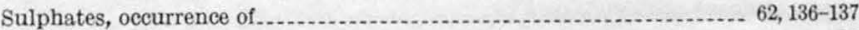

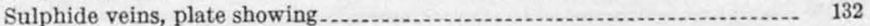

Sulphides, distribution of ................................. 55-56, 130

relation of, to other minerals, plate showing ........................... 53

Superior company (in Houghton County), dividends paid by............... 75 production by ................................................................ 96

Superior company (in Ontonagon County), production by .................. 96

Superior lodes, longitudinal sections of . Plate 48, in pocket

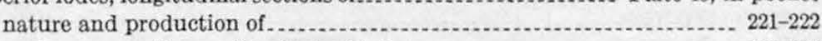

Surveying, magnetic, results obtainable by .................................. 164-168

magnetic, theory and practice of . ........................................ 162-163

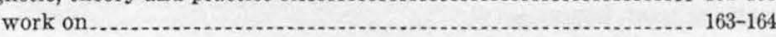

$\mathrm{T}$

T. 49 N., Rs. 40,41 , and 42 W., geologic sections in

T. 50 N., R. 39 W., geologic sections in.

Plate 31 in pocket

Tps. 50 and 51 N., R. 38 W., geologic sections in......... Plates 30 and 31 , in pocket

T. 51 N., R. 37 W., geologie sections in.

T. $52 \mathrm{~N}, \mathrm{R} .36 \mathrm{~W} .$, geologic sections in

T. 53 N., R. 35 W., geologic sections in .......... Plates 25,26 , and 27 , in pocket

T. 54 N., R. 34 W., geologic sections in........................ Plate 25, in pocket

Tps. 54 and 55 N., R. 34 W., geologic sections in ............. Plate 24, in pocket

T. 55 N., R. 34 W., geologic sections in........................... Plate 23, in pocket

Tps. 55 and 56 N., R. 33 W., geologic sections in.............. Plate 22 , in pocket

T. 56 N., R. 33 W., geologic sections in......................... Plate 21, in pocket

T. 56 N., Rs. 32 and $33 \mathrm{~W}$., geologic sections in .................. Plate 20, in pocket

Tps. 56 and 57 N., R. 32 W., geologie sections in ........... Plate 19, in pocket

Tps. 57 and 58 N., Rs. 31 and 32 W., geologic sections in ....... Plate 18, in pocket

T. $58 \mathrm{~N}$., Rs. 28 and $29 \mathrm{~W}$., geologic sections in................. Plate 16, in pocket

Tamarack company, dividends paid by .

production by
Tamarack junior company, production by

Tecumseh company, production by

Tempers ture in the mines

Texture of sedimentary rocks, as it appears in drill cores, plate showing.

Toltec company, production by

Tops, lavs, alteration of

ragmental or brecciated, character of ................................... origin of.

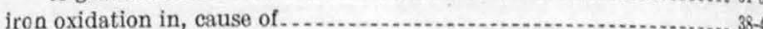

oxidation in, mineralogic features of . . . . . . . . . . . . . . . . .

reil color of.

"scoriaceous" variety of

smooth, oxidation in

structure of rough variety of

structure of smooth variety of

ture of, as seen in drill cores, plate showing ................

as seen in lodes, plate showing

as seen in specimens, plate showing

as seen in thin sections, plate showing

varieties of

Trap, alteration of

natue of.

Trimountain company, dividends paid by

production by.

$\mathrm{V}$

Vaughnsville prospect, opening of.

Veins, content of ore in

Victoris company, production by

Victoris mine, description of

Volcanis vents, location of

Vulcan company, production by

W

Washington, H. S., quoted

Water in the mines

Weathering, formation of minerals during.

possibility of oxidation of iron in lava tops by

Wells, R. C., Chemistry of the deposition of native copper from ascending solutions...

White Pine company, dividends paid by production by

White Pine Extension mine, description of

White Pine mine, description of maps of.

Whitneyite, formation and properties of

Windsor company, production by

Winona company, production by

Winona lode, deseription of. longitudinal sections of

shafts on, plate showing

Winthrop prospect, work on

Wolverine company, dividends paid by production by.

Wyandot company, production by

W yandot mine, opening of

Wyandot No. 8 lode, features of 